\title{
HYDROSTRATIGRAPHY OF THE GENERAL SEPARATIONS AREA, SAVANNAH RIVER SITE (SRS), SOUTH CAROLINA (U)
}

by R. K. Aadland

Westinghouse Savannah River Company

Savannah River Site

Aiken, South Carolina 29808

Other Authors:

M. K. Harris

(WSRC)

C. M. Lewis

(WSRC)

T.F. Gaughan

(WSRC)

T. M. Westbrook

Dames \& Moore

Atlanta, GA
WSRC-RP- $-91-013$

DE93 008499

This paper was prepared in connection with work done under Contract No. DE-AC09-89SR18035 with the U. S. Department of Energy. By acceptance of this paper, the publisher and/or recipient acknowledges the U. S. Government's right to retain a nonexclusive, royalty-free license in and to any copyright covering this paper, along with the right to reproduce and to authorize others to reproduce all or part of the copyrighted paper. 


\section{DISCLAIMER}

This report was prepared as an account of work sponsored by an agency of the United States Government. Neither the United States Government nor any agency thereof, nor any of their employees, makes any warranty, express or implied, or assumes any legal liability or responsibility for the accuracy, completeness, or usefulness of any information, apparatus, product, or process disclosed, or represents that its use would not infringe privately owned rights. Reference herein to any specific commercial product, process, or service by trade name, trademark, manufacturer, or otherwise does not necessarily constitute or imply its endorsement, recommendation, or favoring by the United States Government or any agency thereof. The views and opinions of authors expressed herein do not necessarily state or reflect those of the United States Government or any agency thereof.

This report has been reproduced directly from the best available copy.

Available to DOE and DOE contractors from the Office of Scientific and Technical Information, P.O. Box 62, Oak Ridge, TN 37831; prices available from (615) 576-8401, FTS 626-8401.

Available to the public from the National Technical Information Service, U.S. Department of Commerce, 5285 Port Royal Rd, Springfield, VA 22161. 
DOCUMENT NO. WSRC-RP-91-13

Distribution Category: UC-\#

HYDROSTRATIGRAPHY OF THE GENERAL SEPARATIONS

AREA, SAVANNAH RIVER SITE (SRS), SOUTH CAROLINA (U)

Rolf K. Aadland. Mary K. Harris, Cathy M. Lewis, Thomas F. Gaughan, and Thomas M. Westbrook

Approved by:

D.B. Moore, Section Manager

Environmental Sciences Section

Publication Date: January 1991

D.B. Moore, Section Manager

Authorized Derivative Classifier

Westinghouse Savannah River Company

Savannah River Site

Aiken, SC 29808

PREPARED FOR THE U.S. DEPARTMENT OF ENERGY UNDER CONTRACT NO. DE-AC09-89SR18035 


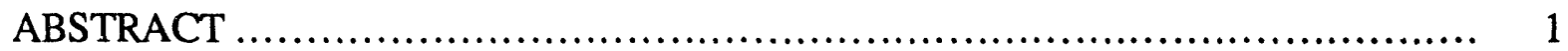

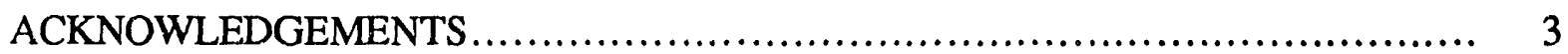

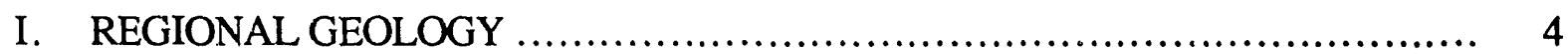

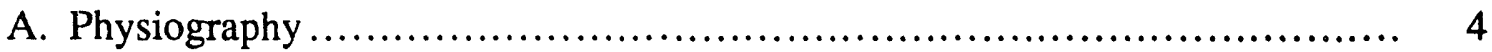

B. Geological History ........................................................ 6

C. Coastal Plain Stratigraphy, Lithology, and Structure ....................... 11

1) Cape Fear Formation ...................................................... 11

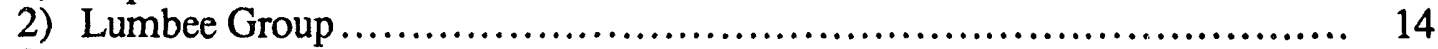

3) Paleocene-Eocene Black Mingo Group ................................ 16

4) Middle Eocene Orangeburg Group ......................................... 18

5) Late Eocene Barnwell Group.............................................. 20

6) "Upland" Unit................................................................ 21

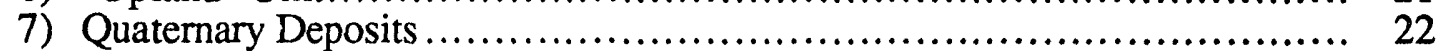

D. Faulting and Folding of Coastal Plain Sediments ............................. 22

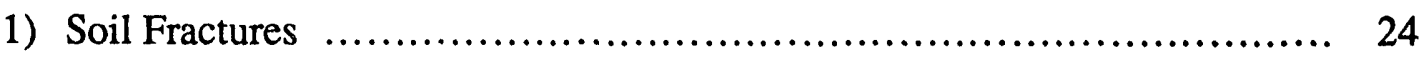

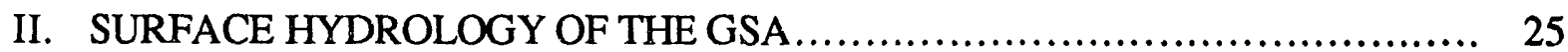

A. Upper Three Runs Creek............................................... 25

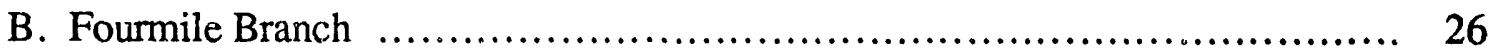

III. REGIONAL SUBSURFACE HYDROLOGY OF SRS ....................... 28

A. Geologic Setting ....................................................... 28

1) Hydrogeology of the Paleozoic Rocks ................................... 28

2) Hydrogeology of the Triassic Rocks ........................................ 29

3) Hydrogeology of Confining System I ................................... 31

4) Hydrogeology of the Coastal Plain Sediments .................................. 31

a) Hydrostratigraphic Nomenclature ....................................... 31

b) Aquifer System I ..................................................... 37

c) Aquifer System II ..................................................... 37

d) Aquifer System I/II ................................................ 38

IV. HYDROGEOLOGY OF THE GENERAL SEPARATIONS AREA ................. 38

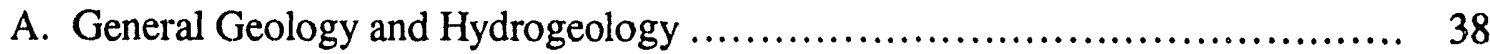


B. Methods and Procedures ............................................. 44

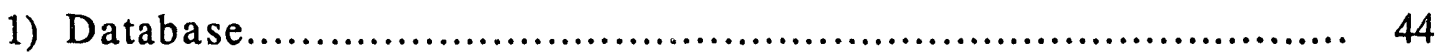

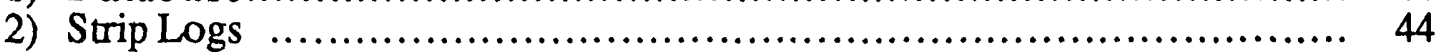

3) Cross Sections ........................................................ 45

4) Lithostratigraphic and Hydrostratigraphic and Interpretation $\ldots \ldots \ldots \ldots \ldots \ldots \ldots, 45$

C. Lithostratigraphic Sequence at the GSA ...................................... 45

1) Confining System I-II............................................. 47

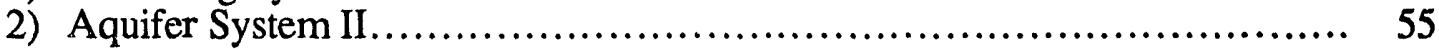

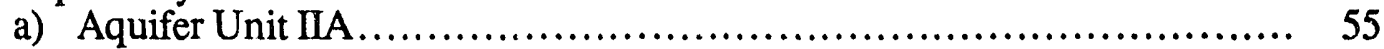

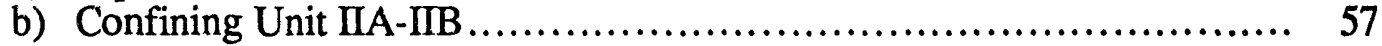

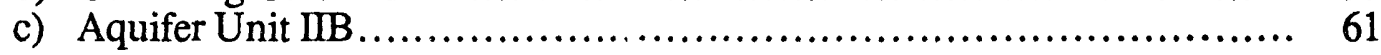

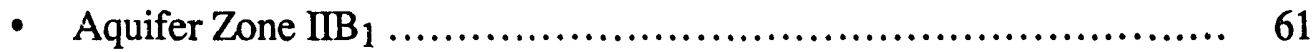

- Faulting Associated with Carbonate Buildups............................. 67

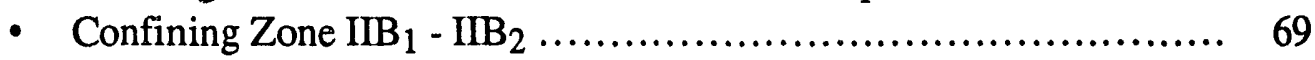

- Aquifer Zone $\mathrm{IB}_{2}$ (Water Table Aquifer) ....................... 76

V. HYDROLOGICAL CHARACTERISTICS OF THE GSA........................... 78

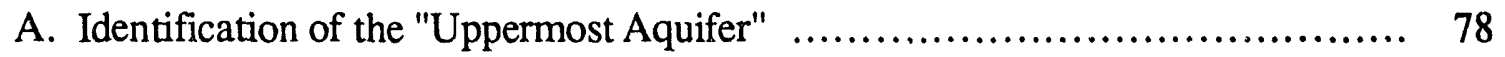

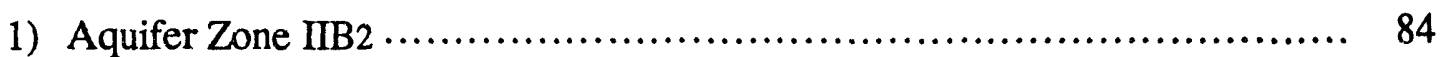

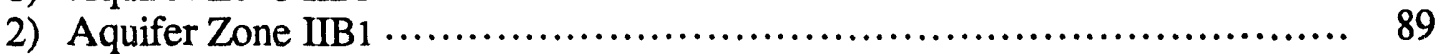

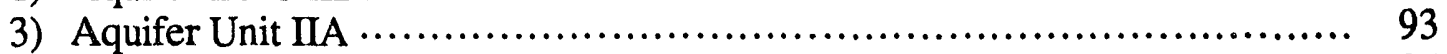

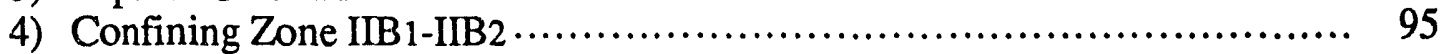

5) Confining Unit IIA-IIB ............................................. 96

6) Confining System I-II.............................................. 96

B. Ground Water Flow in Cross Section ................................ 97

1) Regional Equipotential Cross Section $1 \ldots \ldots \ldots \ldots \ldots \ldots \ldots \ldots \ldots \ldots \ldots \ldots \ldots . \ldots 7$

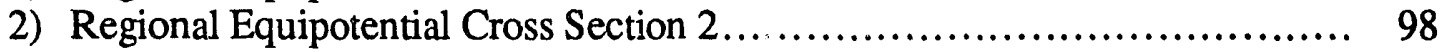

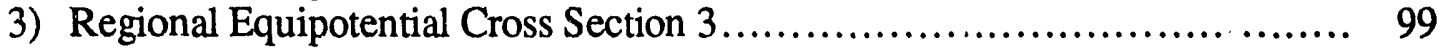

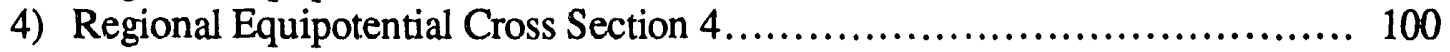

5) Regional Equipotential Cross Section 5A and 5B.......................... 101

C. Vertical Head Relationships............................................ 102

1) Head Differences Across Confining Zone IIB1-IIB2 (Tan Clay) ............ 102

2) Head Differences Across Confining Unit IIA-IIB (Green Clay)............... 104

3) Head Relationships Between the Cretaceous and Tertiary Aquifers ........... 104 


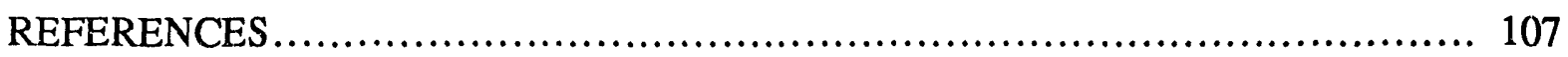

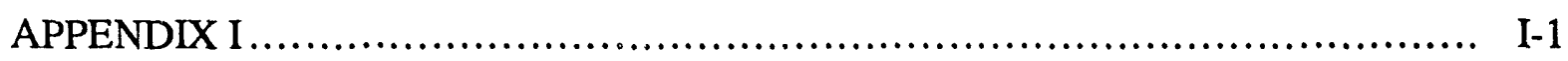

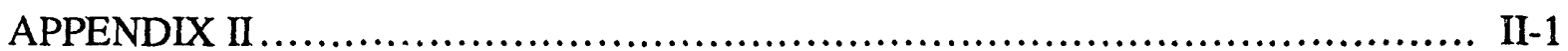

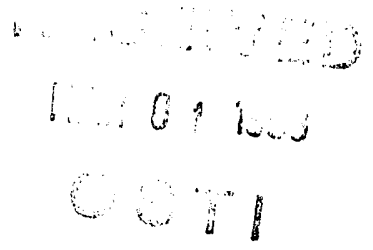


1. Physiographic Subprovinces of the S. C. Coastal Plain............................. 5

2. Location of General Separations Area.............................................. 7

3. Surface Water Drainage Map in the Vicinity of the F and H Area Seepage Basins..... 8

4. Tectonic Setting of Eastern U.S. ............................................... 9

5. Regional Stratigraphic Cross Section ............................................... 12

6. Coastal Plain Sediments at the SRS ................................................ 13

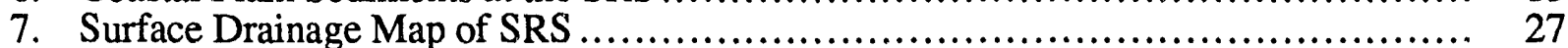

8. Comparison of Hydrostratigraphic Units Used at SRS ............................. 33

9. Hydrostratigraphic Chart ...................................................... 34

10. Schematic Hydrostratigraphic Chart............................................... 35

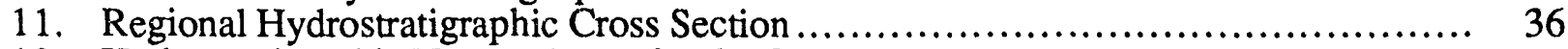

12. Hydrostratigraphic Nomenclature for the General Separations Area Savannah River Site ........................................... 40

13. Schematic Map and Cross Section of Fluvial Deposits ............................... 41

14. Generalized Marine Depositional Environments ................................. 42

15. Overriding - Delta Depositional Environments ...................................... 43

16. GSA Regional Cross Sectional Lines .......................................... 46

17. Isopach Map of the Lower Carbonate Zone of Aquifer Zone $\Pi_{3} \ldots \ldots \ldots \ldots \ldots \ldots \ldots . .48$

18. Isopach Map of the Upper Carbonate Zone of Aquifer Zone IIB $1 \ldots \ldots \ldots \ldots \ldots \ldots \ldots \ldots . . . . . . . . . .49$

19. Structure Contour Map (Top of Confining System I-I//Ellenton Clays)................ 51

20. Geophysical Characteristics of Hydrostratigraphic Units............................... 54

21. Isopach Map of Aquifer Unit IIA (Congaree Aquifer) ............................. 56

22. Isopach Map of Confining Unit IIA-IIB (Green Clay) .............................. 58

23. Structure Contour Map (Top of Confining Unit IIA-IIB) (Green Clay) ................. 59

24. Isopach Map of Aquifer Zone $\operatorname{IIB}_{1}$ (Barnwell/McBean Aquifers) $\ldots \ldots \ldots \ldots \ldots \ldots \ldots \ldots \ldots .65$

25. Geophysical Characteristics of Limestone in HSB-122 well ......................... 68

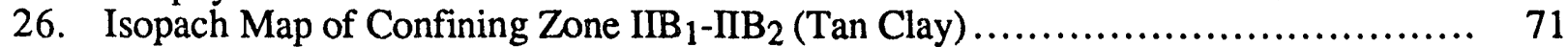

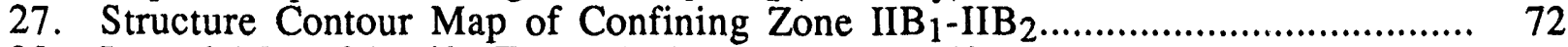

28. Isopach Map of Aquifer Zone $\mathrm{IIB}_{2}$ (Water Table Aquifer) $\ldots \ldots \ldots \ldots \ldots \ldots \ldots \ldots \ldots \ldots \ldots \ldots$

29. Potentiometric Surface Map - Aquifer Unit $\mathrm{IIB}_{2}$ (Water Table Aquifer)............... 79

30. Potentiometric Surface Map - Aquifer Zone IIB 1 (Barnwell/McBean Aquifers)........ 80

31. Potentiometric Surface Map - Aquifer Unit IIA (Congaree Aquifer) ................... 81

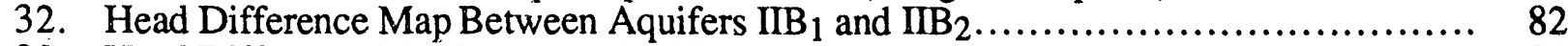

33. Head Difference Map Between Aquifers IIA and IIB $1 \ldots \ldots \ldots \ldots \ldots \ldots \ldots \ldots \ldots \ldots \ldots \ldots$

34. Head Difference Map Between Aquifer Unit IB of Aquifer System I and Aquifer IIA of Aquifer System II. 
Plate Regional Cross Sections

In Pocket

1 General Separations Hydrostratigraphic Cross Section 1

2 General Separations Hydrostratigraphic Cross Section 2

3 General Separations Hydrostratigraphic Cross Section 3

$4 \quad$ General Separations Hydrostratigraphic Cross Section 4

5A General Separations Hydrostratigraphic Cross Section 5A

5B General Separations Hydrostratigraphic Cross Section 5B

\section{Regional Equipotential Cross Sections}

6 Lines of Equipotential Cross Section 1

7 Lines of Equipotential Cross Section 2

8 Lines of Equipotential Cross Section 3

9 Lines of Equipotential Cross Section 4

10A Lines of Equipotential Cross Section 5A

10B Lines of Equipotential Cross Section 5B

\section{LIST OF TABLES}

1. Chemical Analyses of Water from Metamorphic and Triassic Rock at the Savaritah River Site

2. Thickness of the Upper and Lower Carbonate Zones for the Eeneral Separations Area ...................................

3. Elevations of Confining Unit IIA-IIB (Green Clay) and

4. Thickness of Confining Unit IIA-IIB (Green Clay)............................................. 52

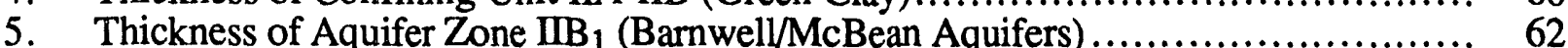

6. Thickness of Confining Unit IIB $1-\mathrm{IIB}_{2}$ (Tan Clay) and the Saturated Portion of Aquifer Zone $\mathrm{IIB}_{2}$ (Water Table Aquifer)

7. Head Difference Between Aquifer Zone IIB 2 (Water Table Aquifer) and Aquifer Zone IIB 1 (Barnwell/McBean Aquifers) ............................... 85

8. Head Difference Between Aquifer Zone IIB 1 (Barnwell/McBean Aquifers) and Aquifer Unit IIA (Congaree Aquifer) 


\title{
HYDROSTRATIGRAPHY OF THE GENERAL SEPARATIONS AREA, SAVANNAH RIVER SITE (SRS), SOUTH CAROLINA (U)
}

\author{
By Rolf K. Aadland', Mary K. Harris', Cathy M. Lewis', \\ Thomas F. Gaughan1, and Thomas M. Westbrook ${ }^{2}$
}

\author{
1 Westinghouse Savannah River Company \\ Savannah River Site \\ Aiken, SC. 29808
}

\author{
2Dames and Moore \\ 455 E. Paces Ferry Road \\ Atlanta, Ga. 30363
}

\begin{abstract}
Detailed analysis and synthesis of geophysical, core, and hydrologic data from 230 wells were used to delineate the hydrostratigraphy and aquifer characteristics of the General Separations Area at SRS. The study area is hydrologically bounded on the north and northwest by Upper Three Runs Creek (UTRC) and on the south by Fourmile Branch (FB). The Cretaceous-Tertiary sedimentary sequence underlying the study area is divided into two Aquifer Systems; in ascending order, Aquifer Systems I and II. The study concentrated on Aquifer System II, which includes all the Tertiary sediments above the Black Mingo Group (Paleocene) to the water table.
\end{abstract}

Aquifer System II is further subdivided from base upwards into Aquifers IIA and IIB, which are separated by Confining Unit IIA-IIB (informally termed the "green clay" at SRS). Aquifer IIB is further subdivided from the base upwards into Aquifer zones $\mathrm{IIB}_{1}$ and $\mathrm{IIB}_{2}$, separated by Confining zone $\mathrm{IIB}_{1}-\mathrm{IIB}_{2}$ (informally termed the "tan clay" at SRS). Aquifer IIA is incised by 
Upper Three Runs Creek to the northwest and Aquifer zone IIB 1 is incised by Fourmile Branch to the south.

Aquifer zone $\mathrm{IIB}_{2}$ is variable in thickness and hydraulically discharges groundwater towards the south in Fourmile Branch. Aquifer zone $\mathrm{IIB}_{2}$ has a downward flow potential into Aquifer zone $\mathrm{IB}_{1}$. Aquifer zone $\mathrm{IIB}_{1}$ (generally $60^{\prime}-70^{\prime}$ thick) has a potentiometric surface above its Confining zone $\mathrm{IIB}_{1}-\mathrm{IIB}_{2}$, with groundwater flow generally to the south to southeast, also discharging into Fourmile Branch. The zone has downward flow potential into Aquifer IIA.

The waters in Aquifer IIA (generally 40'-50' thick) are artesian and rise $30^{\prime}$ to $40^{\prime}$ above its Confining Unit IIA-IIB. Groundwater flow is towards UTRC to the north, generally opposite or transverse to the flow direction in the overlying aquifer zones. Carbonate buildups that truncate and/or offset the confining clay beds are interspersed in Confining Unit IIA-IIB. The buildups are potential pathways for the downward movement of water from Aquifer IIB into Aquifer IIA.

In general, the presure (head) relationships are downward from Aquifer zone IIB $_{2}$ to Aquifer zone $\mathrm{IB}_{1}$, down to Aquifer Unit IIA. Between Aquifer Unit IIA and Aquifer Unit IB of Aquifer System I, however, an upward pressure gradient is recognized across Confining System I-II throughout the GSA.

A series of lithostratigraphic cross-sections, piezometric gradient profiles, head ratio contour maps, aquifer isopach maps, and potentiometric surface maps illustrate the aquifer characteristics of the study area. 


\section{ACKNOWLEDGMENTS}

This report is the result of a combined effort by representatives of the Environmental Sciences Section of SRL and the Environmental Restoration Division. The report is a compilation and distillation of the vast amount of data assembled and organized for the Applications for Hazardous Waste Part B Post-Closure Care Permits for the F and H Area Seepage Basins. The study was an equal effort by all the authors. 


\section{REGIONAL GEOLOGY}

\section{A. Physiography}

The SRS is located on the Upper Atlantic Coastal Plain about 20 miles southeast of the Fall Line (Figure 1). The Atlantic Coastal Plain is underlain by a seaward-dipping wedge of unconsolidated and consolidated sediments that extend from the contact with the crystalline Piedmont province at the Fall Line to the edge of the continental shelf. Sediment thickness increases from zero at the Fall Line to approximately 1000 feet near the General Separations Area (GSA) to more than 4000 feet at the South Carolina coastline (Colquhoun et al., 1983). The sequence ranges in age from early Late Cretaceous (Cenomanian) to Recent (Hazel, et al., 1977).

Colquhoun and Johnson (1968) divided 's South Carolina Coastal Plain into three physiographic belts: Upper, Middle, and Lower Coastal Pisin (Figure 1). The Upper Coastal Plain slopes from a maximum elevation of $u 50$ feet $\mathrm{msl}$ at the Fall Line to about 250 feet msl on its southeastern boundary. Primary depositional topography of the Upper Coastal Plain has been obliterated by fluvial erosion. The Upper Coastal Plain is separated from the Middle Coastal Plain by the Orangeburg scarp, which has a relief of approximately 100 feet over a distance of a few miles.

Siple (1967) and Cooke (1936) previously divided the Upper Coastal Plain of South Carolina into the Aiken Plateau and Congaree Sand Hills (Figure 1). The Aiken Plateau, where the SRS is located, is bounded by the Savannah and Congaree rivers and extends from the Fall Line to the Orangeburg scarp. Its highly dissected surface is characterized by broad interfluvial areas with narrow, steep-sided valleys. Local relief is as much as 300 feet (Siple, 1967). The plateau is generally well drained, although many poorly drained sinks and depressions exist, especially 
Figure 1. Physiographic Subprovinces of the S. C. Coastal Plain 
on the topographica": y high (above 250 feet msl) "Upland" unit. Some depressions represent original depositionai topography, whereas others may be related to solution of underlying calcareous sediment (Siple, 1967; U.S. Army Corps of Engineers, 1952).

The General Separations Area (GSA) is an approximately 15-square-mile area near geographic center of the SRS (Figure 2) and includes the Hazardous Waste Management Facilities (IIWMF): the F-Area Seepage Basins, the H-Area Seepage Basins, and the Mixed Waste Management Facility (MWMF). The area is located on the Aiken Plateau within the Coastal in province at an elevation of approximately 300 feet above msl. A major surface water divide runs through the GSA between Upper Three Rinns Creek (UTRC) and Fourmile Branch (Figure 3). Plant north is used to describe locations in this report.

\section{B . Geological History}

The Coastal Plain sedimentary sequence at SRS is underlain by Precambrian to Permian aged metasedimentary and metaigneous rocks in the northern two thirds of the site, and by Late Triassic aged clastic sediments in the southern third of the site. The Paleozoic rocks are predominantly gneisses and schists with lesser amounts of quartzite (Klitgord and Behrendt, 1979) that have been folded, faulted, and intruded by predominantly granitic plutons. This deformation and metamorphism resulted from the accretion of Piedmont exotic terrains to North America. Accretion occurred during the Taconic, Acadian, and Alleghenian orogenies, which culminated about 265 million years ago at the close of the Paleozoic Era (Figure 4). At that time, Africa collided with North America, and the crystalline basement rocks beneath the SRS were emplaced in their present position. 
Figure 2. Location of General Separations Area 
Figure 3. Surface Water Drainage Map in the Vicinity of the $F$ and H-Area Seepage Basins 
Figure 4. Tectonic Setting of Eastern U. S. 
Early in the Mesozoic Era (about 240 million years ago), the supercontinent Pangaea, which resulted from Paleozoic collisions, began to break up. The present Atlantic Ocean was created by diachronous rifting between North and South America on the west and Africa and Eurasia on the east, beginning in the north and progressing to the south. Rift basins that accumulated thick (1-3 miles) sequences of sediments in the Late Triassic (approximately 225 million years ago) formed along the east coast of North America .

The Dunbarton basin, which underlies the southeastern one-third of the SRS, is typical of these rift basins (grabens) filled with sediments of Triassic age. The basin is contained within the Paleozoic metamorphic rock beneath about 1200 feet of Coastal Plain sediments in the southeastern part of the SRS. The Triassic sediments consist of poorly sorted, consolidated gravel, sand, silt, and clay. The coarser material is found near the northwest margin where fanglomerates are abundant. By analogy with other East Coast Triassic basins in the Atlantic Coastal Plain, sand, silt, and clay predominate near the center of the basin. The sorting is extremely poor (Hazel, et al., 1977), resulting in extremely low primary permeability in the Triassic rocks. The lithology of the clasts in the sedimentary rock indicates that they were derived from the crystalline metamorphic rock to the northwest of the Dunbarton basin. Many of the sands are arkosic, indicating little transport and/or rapid burial.

Rifting of the continental crust ceased in Early Jurassic time (approximately 190 million years ago), at which time deposition in the basins ceased. Since then both the Paleozoic and Triassic rocks were leveled by erosion and eventually uncomformably overlain by the unconsolidated to semiconsolidated Coastal Plain sedimentary sequence. This erosional surface dips approximately $35 \mathrm{feet} /$ mile to the southeast (Klitgord and Behrendt, 1979).

Formation of the Coastal Plain sedimentary sequence at the SRS began with deposition of Late Cretaceous (Austinian/Turonian-Coniacian) aged fluvial and deltaic sediments on the crystalline 
basement and Triassic sedimentary wedge. The Coastal Plain sediments began to accumulate at this time, when sea level had risen $650-980$ feet above the present level, and the basement complex was being downwarped to the southeast to compensate for sediment loading on the more seaward portions of the continental margin. Deposition of sediments in fluvial and deltaic environments continued into the Early Eocene. During Middle and Late Eocene time, deposition of Coastal Plain sediments at the SRS occurred in shallow marine environments. Deposition was interrupted several times during this period because of drops in sea level.

Sea level fell following the deposition of the Eocene sediments, and except for the deposition of the "Upland" unit, erosion has prevailed on the Coastal Plain since. At present, the "Upland" unit was deposited by streams as they cut down into the underlying strata. At present, the only sedimentation on this portion of the Coastal Plain occurs locally in floodplains.

\section{Coastal Plain Stratigraphy, Lithology, and Structure}

The sediments of the Atlantic Coastal Plain in South Carolina are stratified sand, clay, limestone, and gravel that dip gently seaward and range in age from Late Cretaceous to Recent. The sedimentary sequence thickens from essentially zero thickness at the Fall Line to approximately 1000 feet at the GSA, to more than 4000 feet at the coast. (Figure 5). Regional dip is to the southeast.

\section{1) Cape Fear Formation}

The Cape Fear Formation (Figure 6) at the SRS is composed of poorly sorted, silty-to-clayey quartz sands and interbedded clays. The Cape Fear Formation sediments are more indurated than 
Figure 5. Regional Stratigraphic Cross Section 
Figure 6. Coastal Plain Sediments at the SRS 
the other Cretaceous formations because of their high clay content and abundance of cristobalite in the matrix. The environment of deposition has been interpreted as upper delta plain (Prowell, 1985a). The Cape Fear Formation is about 30 feet thick at the northwestern SRS boundary and thickens to more than 180 feet near the southeastern boundary. Correlation of the basal Cretaceous at the SRS with the type section of the Cape Fear Formation is uncertain. Future correlation studies may reveal that the lowest Cretaceous unit at the SRS should have a different name, and the term is used provisionally in this report.

\section{2) Lumbee Group}

The Lumbee Group comprises, from oldest to youngest, the Middendorf, the Black Creek, and the Peedee Formations (Figure 6). The time-equivalent units of these three formations are present at the SRS. The lower two units are lithologically similar to the formations at their type localities in northern South Carolina and southern North Carolina. However, the Peedee Formation equivalent at the SRS is dissimilar to the type Peedee Formation. These Cretaceous formations have been referred to collectively as the "Tuscaloosa Formation" in past studies.

The Lumbee Group strata outcrop between the Fall Line and the SRS. The dip of the upper surface of the Lumbee Group is to the southeast at approximately $21 \mathrm{feet} / \mathrm{mile}$ across the SRS. Thickness varies across the SRS from 380 feet in the northwestern part of the site to more than 740 feet near the southeastern boundary. In general, Lumbee Group deposits are variably colored sands and clays, but become calcareous downdip from the SRS. At the coast the group is more than 1500 feet thick (Colquhoun, et al., 1983).

The Middendorf Formation, the basal formation of the Lumbee Group, is composed mostly of quartz sand, and unconformably overlies the Cape Fear Formation with a sharp, distinct contact. 
The sediments of the Middendorf Formation at the SRS probably were deposited in fluvial and deltaic environments. In the subsurface, the formation is approximately 130 feet thick near the northwestern boundary of the SRS and thickens to more than 180 feet near the southeastern boundary. The Middendorf has been assigned a Late Austinian (Late Santonian) age in the SRS area (Prowell, et al., 1985a).

The Black Creek Formation consists of quartz sands, silts, and clays. It is generally darker and more micaceous and lignitic than the other Cretaceous units. The middle section of the formation is mostly shale, while the lower and upper sections consist of silty micaceous sands in much of the SRS area. In the northwestern part of the SRS, however, the lower portion of the Black Creek Formation is mostly light colored.

Lithofacies suggest a lower deltaic plain environment for the Black Creek Formation, except the light-colored sand in the northwestern part of the SRS. Here the lithofacies suggests an upper deltaic plain environment. The Black Creek is about 110 feet thick at the northwestern boundary (Prowell, et al., 1985a) of the SRS and thickens to more than 250 feet near the southeastern boundary. The Black Creek in South Carolina is assigned a Tayloran and Early Navarroan (Campanian and Early Maastrichtian) age.

The Peedee Formation is composed of light-colored sands and highly colored clays. Because of the difference in lithology between the type Peedee Formation and the laterally equivalent sediments in southwestern South Carolina (Colquhoun, et al., 1983), the deposits in the vicinity of the SRS will be referred to as the "Steel Creek Member" of the Peedee Formation. The lower part of the Steel Creek Member is sandy with a pebble-rich zone at its base, suggesting a basal unconformity. The upper part of the Steel Creek Member is a clay that varies from more than 50 feet to less than 3 feet in thickness at the SRS. Fining upward sands are interbedded with the clay in some areas. Lithofacies suggest an upper delta plain environment in the southwest portion of 
SRS and a lower delta plain in the northeast. Dinoflagellates indicate some marine influence in parts of the Steel Creek Member. It is about 110 feet thick at the northwestern SRS boundary and 130 feet thick at the southeastern boundary. The Peedee Formation in South Carolina is Middle and Late Navarroan (Middle and Late Maastrichtian) in age (Prowell, et al., 1985a).

\section{3) Paleocene-Eocene Black Mingo Group}

In southwestern South Carolina, the Black Mingo Group consists of the Midwayan (Danian-Early Thanetian/Early Paleocene) Rhems Formation, the Early and Middle Sabinian (Middle Thanetian/Late Paleocene) Williamsburg Formation (Colquhoun, et al., 1983) (Figure 6), and the Late Sabinian (Late Thanetian/Early Eocene) Fishburne Formation (Gohn, et al., 1983). These, with the possible exception of the Fishburne, have been traced updip in the subsurface from their type localities in the lower Coastal Plain of South Carolina to the SRS (Figure 1). The upper surface of the group dips approximately $15 \mathrm{feet} / \mathrm{mile}$ to the southeast; the group is about 70 feet thick at the northwestern plant boundary, thickens to about 150 feet near the southeastern boundary, and is about 700 feet thick at the coast (Colquhoun, et al., 1983).

The stratigraphic interval that includes the Rhems Formation was named the "Ellenton Formation" and described from well cuttings at the SRS by Siple (1967). At the time, Siple (1967) thought that the age was either Cretaceous or Paleocene. The formation was later dated as Midwayan (Danian to Early Thanetian) and equivalent to the Rhems Formation (Prowell, et al., 1985b). Because it is lithologically different from the type Rhems Formation, the formation is designated as the "Ellenton Member" of the Rhems Formation at SRS. The interval has been informally referred to as the "Ellenton Clays" in previous SRS reports. The Ellenton Member lies unconformably on the Cretaceous sediments and consists mostly of gray, poorly sorted, micaceous, lignitic, silty and clayey quartz sand interbedded with gray clays. 
Upper delta plain deposits composed of light-colored, moderately to poorly sorted, micaceous quartz sands are common in the northwestern part of the SRS, with darker, poorly sorted, micaceous, lignitic lower deltaic plain facies becoming dominant in the southeastern part. The Ellenton Member is approximately 40 feet thick at the northwestern boundary of the SRS and thickens to about 100 feet near the southeastern boundary. The Midwayan (Danian to Early Thanetian) section is about 250 feet thick and calcareous at the coast (Colquhoun, et al., 1983).

The deposits near the SRS that are time equivalent to the Sabinian (Mid-Late Thanetian) Williamsburg Formation differ from the type Williamsburg and are designated as the "Snapp Member" of the Williamsburg Formation (Figure 9). The unit is encountered in well P-22 in the southeastern part of the SRS near Snapp Station. The sediments are typically silty, medium- to coarse-grained quartz sand interbedded with clay. Dark, micaceous, lignitic sand also occurs. In the northwest part of the SRS, the Snapp Member is less silty and better sorted, with thinner clay interbeds. The Snapp Member changes from an upper deltaic plain facies in the northeast to a lower deltaic plain facies in the southeastern part of the SRS. The basal contact is probably unconformable. The Snapp Member appears to pinch out in the northwestern portion of SRS and thickens to about 50 feet near the southeastern boundary of the site. The Williamsburg Formation (Colquhoun, et al., 1983) is about 350 feet thick and calcareous near the coast.

Overlying the Williamsburg Formation is the basal Eocene Unit; approximately 30 feet $(9 \mathrm{~m})$ thick, mostly tan, yellow orange, and green, moderately sorted sand, with clay beds a few feet thick in the middle and at the top in places. Early Eocene ages, from palynological assemblages, indicate its equivalence to the Fishburne Formation (Gohn et al., 1983), a calcareous unit which occurs down dip near the coast; thus the name Fourmile Member of the Fishburne. 
Overlying the Fourmile is 30 feet $(9 \mathrm{~m})$ of sands very similar to the Fourmile. Occasional dinoflagellate assemblages indicate that the sands are correlative with the Congaree Formation. Because of the difficulty in distinguishing the Fishburne from the Congaree Formation, the entire 60 foot section has been assigned to the Congaree in previous SRS reports.

\section{4) Middle Eocene Orangeburg Group}

The Claibornian (Lutetian-Bartonian) Orangeburg Group consists of the lower Middle Eocene Congaree Formation (Tallahatta equivalent) and the upper Middle Eocene Santee Limestone Formation (Lisbon equivalent) (Figure 6). Here we are not distinguishing the Congaree Formation from the underlying Fishburne Formaton. The group is exposed at lower elevations in many places in the vicinity of and at the SRS. The sediments thicken from approximately 100 feet at the northwestern SRS boundary to about 160 feet near the southeastern boundary. Dip of the upper surface is about $12 \mathrm{feet} / \mathrm{mile}$ to the southeast across the plant. Downdip at the coast, the Orangeburg Group is about 325 feet thick (Colquhoun, et al., 1983).

The early Middle Eocene Congaree Formation has been traced from the Congaree valley in eastcentral South Carolina into the SRS area. At the SRS the formation consists of yellow, orange, tan, gray, and gresnish gray, well-sorted, fine-to-coarse quartz sands. Thin clay laminae occurs throughout the section, and pebbly layers, clay clasts, and glauconite are present in places. The base of the formation is unconformable.

The Congaree is a shallow marine deposit. The equivalent of the Congaree northwest of the SRS has been mapped as the Huber Formation where it occurs at low elevations (Nystrom and Willoughby, 1982). At these locations it becomes more micaceous and poorly sorted, indicating deposition in fluvial and deltaic environments. The Congaree is about 60 feet thick at the 
northwestern boundary of the SRS and about 85 feet thick near the southeastern boundary. The lower Middle Eocene deposits become increasingly calcareous between the SRS and the coast (Colquhoun, et al., 1983).

The late Middle Eocene deposits in the vicinity of the SRS, consisting of carbonates, calcareous quartz sands, glauconitic sands and clays, are designated as the Santee Formation in this report. "McBean Formation" and "Lisbon Formation" have been applied in the past to these sediments. Often the "McBear Fo mation" of previous SRS reports consists largely of sediments that are now known to be Late Eocene (Dry Branch Formation).

Fine-grained, of cen glauconitic sands that occur in many places at the SRS at and near the base of the Santee Limestone Formation are referred to as the "Warley Hill Member of the Santee Limestone" in this report, and the green clay beds in the interval are assigned to the "Caw Caw Member of the Santee Limestone". Both the Warley Hill and the Caw Caw lithologies occur at or near the base of the Santee Limestone Formation at the SRS and are the "green clay" beds referred to in many previous SRS reports.

The remainder of the Santee Limestone Formation is assigned to the McBean Member, which is made up of micritic, calcarenitic, and shelly limestone, calcareous quartz sand, and noncalcareous, generally fine-grained quartz sand. The McBean member of the Santee is the dommiant member of the formaton. Calcareous components of the McBean Member are rare in the northwestern part of the SRS, but are locally more abundant in central portions of the site. To the southeast they are widespread and thick. The McBean Member Carbonates form the lower Carbonate Zone noted in this report.

All three members of the Santee Limestone occur at the surface in the northern areas of SRS, where they are expo.ed along stream channels. The formation is approximately 40 feet thick at the 
northwestern boundary of the SRS and thickens to more than 80 feet near the southeastern boundary.

\section{5) Late Eocene Barnwell Group}

Upper Eocene deposits lie unconformably on the Santee Limestone. Huddleston and Hetrick (1985) have recently revised the Upper Eocene stratigraphy of the Georgia Coastal Plain, and their approach has been extended into South Carolina (Nystrom and Willoughby, 1982; Nystrom et al., 1986). These authors elevated the Eocene (Jacksonian-Priabonian) "Barnwell Formation" to the "Barnwell Group", which in Burke County, GA, includes (from oldest to youngest) the Clinchfield, Dry Branch, and Tobacco Road Formations (Figure 6).

The Clinchfield Formation is sandy and contains some clay and siliceous sponge spicules. It can be identified at SRS only when the contrasting carbonates of the Griffins Landing Member of the Dry Branch Formation and the McBean Member of the Santee Limestone are present, with the sand sandwiched between them. It has been identified as being up to 25 feet thick at three localities within the SRS, but cannot be mapped with the available data.

The overlying Dry Branch Formation, which outcrops in many places around and within the SRS, is about 50 feet thick near the northwestern plant boundary and about 80 feet thick near the southeastern boundary. The Dry Branch Formation includes the Twiggs Clay Member, the Irwinton Sand Member, and the Griffins Landing Member, which contains carbonate. The Twiggs Clay Member does not appear to be mappable at SRS, but clay that is lithologically similar to the Twiggs Clay Member is present at various stratigraphic levels within the Dry Branch Formation. This clay lithofacies, which is tan, light gray, and brown, varies up to 12 feet thick in the SRS wells, but is not continuous over long distances. It has been called the "Tan Clay" in 
previous SRS reports. The Irwinton Sand Member is composed of tan, yellow, and orange, moderately sorted quartz sand, with interlaminated clays abundant in places. The upper, noncalcareous part of the "McBean Formation" of previous SRS reports is the Irwinton Sand Member.

Previous reports of the SRS geology have assigned all carbonate to the Middle Eocene "McBean Formation." The carbonate of the Griffins Landing Member of the Dry Branch Formation occurs sporadically at the SRS. It is not known to be present northwest of Tinker Creek and Upper Three Runs Creek within the plant boundaries. The Griffins Landing carbonate ranges from 0 to 45 feet thick in the southeastern part of the SRS. The Griffins Landing Member formed in a shallow marine or lagoonal environment. The unit is referred to as the upper carbonate zone in this report. The Tobacco Road Formation, the youngest unit of the Barnwell Group, is probably the typical "Barnwell" of the older literature.

\section{6) "Upland" Unit}

The "Upland" unit is an informal stratigraphic term applied to fluvial deposits that occur at higher elevations (260 ft above msl at SRS) in many locations in the southwestern South Carolina Coastal Plain (Nystrom and Willoughby, 1982; Nystrom et al., 1985). The sediments are poorly sorted, clayey-to-silty sands, with lenses and layers of conglomerates, pebbly sands, and clays. The lower surface is irregular because of erosion of the underlying deposits that occurred prior to or during deposition of the "Upland". At higher elevations the "Upland" unit occurs at the surface in many places around and within the SRS, but is not present at all higher elevations (Figure 5). The precise age of the "Upland" unit is not known. Pliocene and Miocene ages have been assigned to the unit (Siple, 1967; Doering, 1960; Colquhoun and Steele, 1985; Cooke and MacNeil, 1952; Huddleston and Hetrick, 1979; and McCartan, et al., 1984). 


\section{7) Quaternary Deposits}

Cooke (1936) identified seven marine terraces in the site region, although the highest three are extensively eroded and are not easily recognized (Siple, 1967). The terrace deposits are a few tens-of-feet thick, and their origin is problematic. Recent alluvium occurs in the main and tributary channels of the Savannah River and other streams in the vicinity of the SRS.

\section{Faulting and Folding of Coastal Plain Sediments}

The Atlantic continental margin has been tectonically quiescent since late Cretaceous time, and has been characterized by gentle subsidence and relatively uniform sedimentation rates. Faulting has been documented in the sedimentary sequence, however, in both South Carolina and Georgia. Subsurface faulting of sediments as young as Oligocene have been recognized in the Atlantic Coastal Plain province of South Carolina (Higgins, et al., 1978). Isopach and structure-contour maps of Oligocene rocks suggest subsurface faulting in the Atlantic Coastal Plain province of Georgia (Cramer and Arden, 1978). Small-scale faulting and folding through Middle Eocene time have been recognized in shallow sediments of the Atlantic Coastal Plain province near Langley, SC. There, normal faulting is associated with a small graben in the Eocene Barnwell Group (Inden and Zupan, 1975). The Paleozoic Carolina Slate belt argillites and Late Cretaceous sediments of the Middendorf Formation are folded and faulted near Cheraw, SC (Howell and Zupan, 1974).

Reactivation of basement faults associated with the northern flank of the Dunbarton Basin (Pen Branch fault) during the Cretaceous has been documented at SRS (Stieve, Stevenson and Aadland, 1991). Basement related (reactivated) faulting similar to the Pen Branch fault is probably responsible for the offset observed in the Tertiary section between the P-27 well and the HPC-1 well in the GSA (Plate 2). Shallow offsets other than the fault between the P-27 well and the 
HPC-1 well are documented in the GSA in this study (Plates 1-10). These offsets are apparently related to slumping of the sediments that overlie and flank carbonate buildups that possibly underwent dissolution and collapse (see p. 66).

Preliminary results from correlation of core and downhole geophysical data from numerous wells used in Phase I of the Pen Branch fault study (Stieve, Stevenson and Aadland, 1991) indicates that the Upland Unit post-dates movement on the Pen Branch fault. Two on going studies: 1) Phase II of the Pen Branch fault study; and 2) the three year multi-disciplined Upland Unit study, are designed in part to precisely date and determine the youngest sediments involved in the most recent movement on the Pen Branch fault, and any other faults documented at depth. In addition, the precise age and most recent movement on the shallow slump features observed in the GSA is not well documented and awaits the results of the Upland Unit study and Phase II of the Pen Branch fault study. Until the results of the two studies are known, the upper or shallow portions of the slump features that underlie the areas at higher evaluations in the GSA, which are capped by the Upland Unit, are dashed (Plates 2, 5A, 5B, 7, 10A, 10B). The slump features in the valleys and hill sides are not dashed since they penetrate to the surface due to recent erosion.

The Phase II study of the Pen Branch fault includes high resolution shallow seismic surveys and the addition of numerous boreholes that straddle the Pen Branch fault trace. All are designed to precisely date the most recent movement on the fault by analyzing in detail any and all cross cutting relationships and offsets observed in the shallow strata.

The three year multi-disciplined Upland Unit study is designed to determine the geometry, age, stratigraphic and possible structural relationships between the Upland Unit and underlying units throughout the SRS region. The study involves field mapping, shallow high resolution seismic surveys, paleontological age dating of the Upland Unit and underlying units as well as analysis of sediments from numerous auger holes. The results of the study will determine if and/or where 
faulting and/or slump features have involved Upland or younger sediments.

\section{1) Soil Fractures}

Road cuts and excavations on interstream areas near the SRS commonly expose a deeply developed soil profile (Newell, et al., 1980). The "A" horizon may be up to 10 feet thick and typically consists of buff to nearly white, structureless, fine- to medium-grained quartz sand. The "B" horizon varies from 2 to 10 feet in thickness and contains iron and aluminum compounds leached from the overlying material. Reticulate mottling of this plinthic horizon is a salient feature.

Weathering effects extend to depths of at least 25 feet. At that depth in the "Upland" unit, feldspar in the originally arkosic unit is weathered completely, and some quartz cobbles are soft enough to crush manually.

In some areas, the intense chemical weathering has produced tensional soil fractures as a result of volume reduction. There has been no vertical displacement along these fractures. They are dominant features in shallow exposures, such as roadside embankments and drainage ditches. At depth they typically terminate as colored bands in the less weathered, parent sedimentary material. These soil fractures have been called "clastic dikes" in earlier reports. This misnomer is unfortunate, because true clastic dikes are caused by episodic earth movements powerful enough to cause liquefaction and upward injection of water-saturated sand through a more brittle overlying stratum. Johnson and Heron (1965) also describe soil fractures resulting from volume changes as "clastic dikes." No true clastic dikes have been observed at the SRS. 


\section{SURFACE HYDROLOGY OF THE GSA}

The SRS is located on the Aiken Plateau (Figure 1). The plateau slopes southeastward approximately $5 \mathrm{feet} / \mathrm{mile}$ and is dissected by creeks that drain into the Savannah River. The major tributaries that occur on the SRS are Upper Three Runs Creek, Fourmile Branch, Tinker Creek, Pen Branch, Indian Grave Creek, Steel Creek, and Lower Three Runs Creek (Figure 7). The interstream upland area is flat to gently rolling and characterized by gently dipping units of sand, sandy clay, and clayey sand. The GSA lies between UTRC and Fourmile Branch (Figure 2).

\section{A. Upper Three Runs Creek}

The Upper Three Runs Creek watershed drains about $200 \mathrm{mi}^{2}$ of the Upper Coastal Plain northeast of the Savannah River. Significant tributaries to Upper Three Runs Creek are Tinker Creek, a relatively lengthy headwaters branch, and Tims Branch, which receives industrial wastes and wastewater from the Fuel Fabrication facilities (SRS M-Area) and the Savannah River Laboratory (SRL). The drainage basin consists principally of forest land and farmland and has no significant lakes or flow control structures.

The Upper Three Runs Creek stream channel has a low gradient and is meandering, especially in the lower reaches. Its floodplain ranges in width from 0.25 to 1 mile and contains extensive stands (about 98 percent) of bottom land hardwood forest (Faye and Prowell, 1982). Within the SRS the Upper Three Runs Creek valley is asymmetrical, having a steep southeastern side and a gently sloping northwestern side. 


\section{B . Fourmile Branch}

Fourmile Branch drains about $23 \mathrm{mi}^{2}$ within the SRS, including much of $\mathrm{F}$ and $\mathrm{H}$-Areas and CArea. The creek flows to the southwest into the Savannah River Swamp and then into the Savannah River. The valley is V-shaped, with the sides varying from fairly steep to gently sloping. The floodplain is up to 1000 feet wide. Fourmile Branch receives effluents from $\mathrm{F}$ and H-Areas and, until June 1985, received large volumes of cooling water from the production reactor in C-Area. The creek valley has been modified by the cooling water discharge, which has created a delta into the Savannah River Swamp. 
Figure 7. Surface Drainage Map of SRS 


\section{REGIONAL SUBSURFACE HYDROLOGY OF SRS}

\section{A. Geologic Setting}

Three distinct geologic provinces occur in the subsurface benerth the Savannah River Site: 1) Paleozoic Metamorphic and igneous rocks; 2) lithified mudstones, sandstones, and conglomerates of Triassic age; and 3) the unconsolidated Coastal Plain sediments of Late Cretaceous and Tertiary age.

\section{1) Hydrogeology of the Paleozoic Rocks}

The Paleozoic and Triassic rocks comprise the Basement Hydrologic System (Figure 8). The hydrogeology of these deeply buried rocks was studied intensively to assess the safety and feasibility of deep storage of radioactive wastes in these rocks. Water injection and removal tests on packed-off sections of the sequence indicate that two kinds of fractures exist in the Paleozoic bedrock (Siple, 1967). The first consists of minute fractures that pervade the entire rock mass but transmit water slowly. Rocks containing only this kind of fracture are called "virtually impermeable rocks". The second kind of fractures have larger openings that transmit water more quickly. The fractures are generally vertically restricted but can often be traced laterally. Rocks containing these kinds of fractures are called "hydraulically transmissive rocks".

Marine (1979) reported representative hydraulic conductivity values of $3 \times 10^{-4}$ gal per day per square foot $\left(\mathrm{gpd} / \mathrm{ft}^{2}\right)$ for the virtually impermeable rocks and $0.8 \mathrm{gpd} / \mathrm{ft}^{2}$ for the hydraulically transmissive rocks. Analysis of a two-well tracer test indicated a porosity of 0.08 percent in the 
hydraulically transmissive fracture zone. Laboratory analyses of cores indicated an average intergranular porosity of 0.13 percent (U.S. Army Corps of Engineers, 1952).

The Paleozoic bedrock is not pumped at the SRS except for testing programs. Immediately south of the Fall Line and to the north of it in the Piedmont province, the Paleozoic metamorphic and igneous rocks are domestic aquifers.

Because of the large amount of fresh ground water in the prolific aquifers of the overlying Coastal Plain sediments, the Paleozoic bedrock will remain an unexploited water source at the SRS. It is also unlikely that the status of the hydrologic regime of the metamorphic and igneous rocks at SRS would change appreciably for many decades. Chemical analyses of ground water from the Paleozoic crystalline rocks are listed in Table 1. The water has a total dissolved solids (TDS) content of about $6000 \mathrm{mg} / 1$; dissolved solids are mainly calcium $(500 \mathrm{mg} / \mathrm{L})$, sodium $(1300 \mathrm{mg} / \mathrm{L})$, sulfate $(2500 \mathrm{mg} / \mathrm{L})$, and chloride $(1100 \mathrm{mg} / \mathrm{L})$.

\section{2) Hydrogeology of the Triassic Rocks}

Ground water occurs in the primary porosity of the Triassic clastic rocks. However, the hydraulic conductivı. is extremely low, and water movement is almost nonexistent. The hydraulic conductivity of the Triassic sequence, as determined from field tests, ranged from $10^{-4}$ to $10^{-7}$ $\mathrm{gpd} / \mathrm{ft}^{2}$ (Cooke, 1936). The average total porosity was 8.0 percent for sandstones and 3.3 percent for mudstones. Average effective porosity was 7.0 percent for sandstones and 0.53 percent for mudstones.

Water is not pumped from the Triassic rocks in the Dunbarton Basin, nor is there likely to be any development in the future, because of the poor water quality and low permeability of the rocks. 
Table 1 
Table 1 includes chemical analyses of water samples from the Dunbarton Basin. Samples from the deeper wells near the center of the basin have TDS (Total Dissolved Solids) concentrations between 12,000 and $18,000 \mathrm{mg} / \mathrm{L}$, predominantly $\mathrm{NaCl}$ (Marine, 1974).

\section{3) Hydrogeology of Confining System I}

Overlying the Paleozoic - Triassic Basement Hydrologic System is Confining System I (Figure 8), composed mostly of clayey silty sandstones and gravels of the Cape Fear Formation. Two clayrich zones at the base of the system form an effective seal that separates the ground water in the Coastal Plain sediments above from the water in the underlying crystalline Paleozoic bedrock and the Triassic Basin. The first zone is a residual clayey material (saprolite) that immediately overlies the bedrock. The second zone is the clay-rich silty sands of the basal Cretaceous-age Cape Fear Formation, which occurs above the saprolite.

\section{4) Hydrogeology of the Coastal Plain Sediments}

\section{a) Hydrostratigraphic Nomenclature}

The Coastal Plain sedimentary sequence overlies Confining System I and constitutes a multilayer hydrologic system in which retarding beds are interspersed with beds that transmit water more readily. Ground water flow paths and flow velocities for each of these units are governed by the hydraulic properties, the geometry of the individual units, and the distribution of recharge and discharge areas. 
Siple (1967) devised the first code for naming hydrostratigraphic units at the SRS. Since that time additional codes have been devised and used in various reports at the SRS (Figure 8). Thus, a generally accepted code has not existed for naming hydrostratigraphic units sitewide. Consequently, this report will use the new hydrostratigraphic nomenclature system proposed by Aadland and Bledsoe (1990) (Figures 9,10). The new hydrostratigraphic code provides a systematic classification scheme applicable to the entire SRS (Figure 11).

The classification scheme divides the Coastal Plain sediments at the SRS into two Aquifer systems. Within these aquifer systems are individual aquifer units, which may be further subdivided into zones. Aquifer systems, aquifer units, and zones do not necessarily coincide with stratigraphic boundaries (Figures 9 and 10).

The aquifer units used in this report are defined on the basis of their hydraulic properties relative to the hydraulic properties in the overlying and underlying confining units. The aquifer and confining units are mapped, however, on the basis of the thickness, areal distribution, and continuity of the lithologies of the units (Aadland and Bledsoe, 1990). A summary of the lithologic and hydraulic properties of the new hydrostratigraphic nomenclature is provided in the SRS Baseline Hydrogeologic Investigations Summary Report (Bledsoe, Aadland, and Sargent, 1990). The proposed nomenclature follows criteria suggested by the South Carolina Hydrostratigraphic Subcommittee for naming aquifers and aquifer systems in South Carolina. Geographic names for the aquifers have not been formally agreed upon by the subcommittee. At present, an interim alpha-numeric hydrostratigraphic nomenclature is used to define and address the regional hydrogeologic characteristics of the SRS aquifers. Geographic names for the aquifers will replace the alpha numeric system when the suivcommittee formally agrees on the nomenclature. 
Figure 8. Comparison of Hydrostratigraphic Units Used at SRS 
Figure 9. Hydrostratigraphic Chart 
Figure 10. Schematic Hydrostratigraphic Chart 
Figure 11. Regional Hydrostratigraphic Cross Section 


\section{b) Aquifer System I}

Aquifer System I overlies Confining System I throughout SRS. Stratigraphically, Aquifer System I includes the majority of the Upper Cretaceous age sediments of the Lumbee Group (Figure 6). In the main body of the SRS, including the GSA, Aquifer System I is divided into Aquifer Units IA and IB. These units are separated by Confining Unit IA-IB (Figures 9 and 10). Aquifer Unit IA includes the sands of the Middendorf Formation and lower third of the Black Creek Formation. Aquifer Unit IB includes the sands in the upper third of the Black Creek Formation and the Peedee Formation. Stratigraphically, Confining Unit IA-IB correlates with confining beds in the middle third of the Black Creek Formation (Aadland and Bledsoe, 1990).

Aquifer System I is overlain by Confining System I-II, which is often referred to as the Ellenton Clays in previous reports. Stratigraphically, the system includes the Paleocene Black Mingo Group and the confining beds of the upper Peedee Formation (Figures 8, 9, 10) (Aadland and Bledsoe, 1990).

In general, Aquifer Unit IB of Aquifer System I is persistent throughout the SRS. However, Confining System I-II to the north of UTRC ceases to be completely effective and Aquifer Unit IB and Aquifer System II are locally in communication (Figure 10). Here Aquifer System I/II is defined, and Aquifer Unit 1B is designated as Aquifer Unit I/IIB of Aquifer System I/II (Aadland and Bledsoe, 1990) (Figure 9).

\section{c) Aquifer System II}

Aquifer System II overlies Confining System I-II throughout the lower two-thirds of the SRS, including the GSA. Stratigraphically, it includes the Tertiary sedimentary sequence. The system is 
divided into two aquifers, Aquifer Units IIA and IIB, separated by Confining Unit IIA-IIB (Figure 10). Aquifer Unit IIA, usually referred to as the Congaree Aquifer in previous reports, includes the sands of the Congaree Formation, the Four Mile Member of the Fishburne Formation, and locally the Warley Hill Member of the Santee Formation (Aadland and Bledsoe, 1990). Confining Unit IIA-IIB consists of the glauconitic clay beds of the Caw Caw Member located at and near the base of the Santee Formation. The Caw Caw Member is informally termed the "green clay" in previous reports. Aquifer Unit IIB consists of the sandy beds of the Santee Formation and the heterogeneous sedimentary sequences comprising the overlying Barnwell Group.

\section{d) Aquifer System I/II}

Aquifer System I/II is not present in the General Separations Area (GSA) at SRS and a discussion of it is not pertinent to this report. For a review of the System, the reader is referred to Aadland and Bledsoe, 1990.

\section{HYDROGEOLOGY OF THE GENERAL SEPARATIONS AREA}

\section{A. General Geology and Hydrogeology}

The GSA is underlain by unconsolidated sediments occurring with isolated zones of consolidated sediments that range in age from Late Cretaceous to Holocene. This sedimentary sequence is approximately 1000 feet thick in the GSA and is underlain by Paleozoic crystalline basement. The sedimentary sequence strikes northeast and dips to the southeast towards the coast. 
Aquifer Systems I and II are present under the GSA (Figure 9). The major ground water producing aquifers are Aquifer Units IA and IB (Middendorf and Black Creek Aquifers of previous reports) and Aquifer Unit IIA (Congaree Aquifer). Major confining beds under the GSA are Confining System I (Cape Fear) and Confining System I-II (Ellenton Clays). Minor confining beds in Aquifer System II are Confining Unit IIA-IIB (Green Clay) and Confining zone IIB 1 -IIB 2 (Tan Clay) (Figure 10). This report will be limited to a hydrogeological discussion of the Tertiaryage sediments of Aquifer System II in the GSA.

The Tertiary sediments underlying the GSA are composed of sand, silt, and clay beds, as well as calcareous sediments. The sequence is complex, with abrupt changes in lithology occurring rapidly over short distances. This reflects the alternating nonmarine and marine characteristics typical of near-shore environments. Depositional environments consist of three major types: fluvial, deltaic and marine (Figures 13, 14, and 15).

Depositional environments affect the hydrologic properties of the sediments. Good aquifers consist of the coarsest and/or the most well-sorted sediments. Examples include channel and point bar deposits of both upper and lower delta plains; lower delta plain barrier islands, tidal channels, and beach deposits; and shallow siliclastic shelf sand deposits. Limestones associated with both siliclastic and carbonate shelf deposition can also act as good aquifers. Confining beds occur where the finest grained, least permeable sediments are deposited. Examples are interdistributarybay and overbank flood deposits on the upper and lower delta plain; swamp and marsh deposits of the lower delta plain; and silt, clay, and marl of the delta front, prodelta, and deep siliclastic shelf deposits. 
Figure 12. Hydrostratigraphic Nomenclature for the General Separations Area Savannah River Site 
Figure 13. Schematic Map and Cross Section of Fluvial Deposits 
Figure 14. Generalized Marine Depositional Environment 
Figure 15. Overriding - Delta Depositional Environment 


\section{B. Methods and Procedures}

1) Database

The subsurface data used in the report comes largely from the F and H-Area Seepage Basins and the Mixed Waste Management Facility (MWMF) and represents the primary source of subsurface information for the GSA hydrostratigraphic interpretations. Subsurface data sources also include interim status wells, deep rock borings, baseline hydrogeological wells ( $\mathrm{P}$-wells), and production wells. Data types include geophysical logs (natural gamma, self-potential, resistivity, and caliper), geologist and driller field logs, detailed core logs, well construction data, slug tests, and sieve analyses. A master data list of all well data for the GSA is presented as Appendix I.

\section{2) Strip Logs}

For each well with a geophysical gamma $\log$, a hand drawn strip log of the lithologies encountered in the well was constructed as the initial step in the geological in:e $i_{i}$ station of the data. All the strip logs are documented and available in the F and H Area Seepage Basins Part B Closure Permit Applications. Over 160 strip logs were constructed in this process, all at the vertical scale of $1 "=$ 10 . The core logging descriptive data were given first priority in the lithologic descriptions, with lithologies interpreted from the gamma curves used as a secondary source of comparison. This required the review of the field log and occasional visits to the core repository for more detailed information. The strip logs represented a uniform interpretation of the combined inputs of all of the available subsurface data from the cored and geophysically logged borings. They are maintained in a central repository at SRS. 


\section{3) Cross Sections}

Six regional cross sections were constructed within the GSA (Figure 16). The six cross sections illustrate the lithostratigraphy and hydrostratigraphy of the region. Detailed descriptions of the lithofacies and thicknesses of the aquifer units observed on the six cross-sections are available in Apjendix II. The regional cross sections will provide a database for ongoing and future hydrostratigraphic interpretations within individual facilities in the GSA.

\section{4) Lithostratigraphic and Hydrostratigraphic Maps and Interpretation}

A base map of the GSA at a scale of $1 "=1000^{\prime}$ was used. At this scale adequate areal coverage of the entire GSA was obtained, while an effective level of detail for the interpretations was maintained. All structure contour maps, isopach maps, potentiometric maps, and head difference maps for the GSA were also constructed at this scale.

\section{Lithostratigraphic Sequence at the GSA}

The lithostratigraphic sequence at the GSA is composed mostly of terrigenous clastics interspersed with carbonate-rich clastics and limestones. The clastic facies consist of gravel and/or pebble sands, clayey sands, silt, clay, and sandy clay. The calcareous facies consist of calcareous sand, calcareous mud, limestone, sandy limestone, and sandy and muddy limestone. The clastic lithofacies are dominant throughout the GSA and occur within all hydrostratigraphic units. Beds thicken and thin abruptly, pinching out and intertonguing rapidly over short distances. 
Figure 16. GSA Regional Cross Sectional Lines 
The calcareous lithofacies is discontinuous, but confined to two distinct horizons. The lower horizon (zone) occurs in three separate areas in the GSA along a northeast-southwest trend. The lower horizon is equivalent to the McBean Member of the Santee Formation located near the base of the formation (Figure 10). This horizon thickens and thins rapidly (Table 2 and Figure 17). Slump faulting observed on the various cross-sections typically occurs on the flanks of these carbonate zones, suggesting displacement of overlying sediment due to dissolution and compaction of the limestone horizon. The upper zone is very discontinuous and occurs at two locations in the GSA (Table 2 and Figure 18). This zone ccurs within the upper portions of Aquifer zone $\mathrm{IIB}_{1}$ (Barnwell/McBean Aquifers) and Confining zone $\mathrm{IIB}_{1}-\mathrm{IIB}_{2}$ (Tan Clay) and is equivalent to the Griffins Landing Member of the Dry Branch Formation (Figure 10).

\section{1) Confining System I-II}

Confining System I-II is informally referred to as the "Ellenton Clays" at the SRS. This system attains a thickness of over 100 feet in the GSA. A structure contour map was constructed on the top of the Confining System (Figure 19), with elevations tabulated in Table 3. This system consists predominantly of clays and silts, with interbeds of sandy clay, clayey sands, and sands. Individual layers of clays, silts, and sandy clays range in thickness from 2 to 22 feet. Individual layers of clayey sands and sands range in thickness from 1 to 15 feet.

The clay and silt lenses of Confining System I-II consist of buff and light gray to black clay and sandy clay. The clay is generally very fissile, highly micaceous, and often carbonaceous or lignitic. The interbeds of clayey sands and sands are generally fine to coarse grained and range from moderate to very poorly sorted. Grains are sub-angular to angular. According to Dennehy and others, 1989, the predominant clay minerals forming the matrix of the clays, sandy clays, and clayey sands are kaolinitic. The quartz that is present consists predominantly of cristobalite. The high mica content of the Confining System I-Il sediments result in uniformily distinct, naturai 
Figure 17. Isopach Map of the Lower Carbonate Zone of Aquifer Zone $\mathrm{IIB}_{2}$ 
Figure 18. Isopach Map of the Upper Carbonate Zone of Aquifer Zone IIB 1 
TABLE 2

\section{THICKNESS OF UPPER AND LOWER CARBONATE ZONES FOR THE \\ GENERAL SEPARATIONS AREA}

\begin{tabular}{|c|c|c|c|}
\hline Well & $\begin{array}{c}\text { Top } \\
\text { Elevation }(\mathrm{ft})\end{array}$ & $\begin{array}{c}\text { Bottom } \\
\text { Elevation (ft) }\end{array}$ & $\begin{array}{c}\text { Thickness } \\
(\mathrm{ft})^{* * *}\end{array}$ \\
\hline $\begin{array}{l}\text { BGO 6A* } \\
\text { BGO 8A* } \\
\text { BGO 10A* } \\
\text { BGO 14A* } \\
\text { BGO 16A* } \\
\text { BGO 18A* } \\
\text { BGO 25A* } \\
\text { BGO 26A* } \\
\text { BGO 27C* } \\
\text { FSB 100A* } \\
\text { FSB 106C* } \\
\text { FSB TA* } \\
\text { HPT 1A* } \\
\text { HPT 2A* } \\
\text { HSB 65A* } \\
\text { HSB 68A* } \\
\text { HSB 85A* } \\
\text { HSB 118A* } \\
\text { HSB 120A* } \\
\text { HSB 121A* } \\
\text { HSB 122A* } \\
\text { HSB 123A* } \\
\text { HSB 124A* } \\
\text { HSB 127C* } \\
\text { HSB 134C* } \\
\text { HSB TB* } \\
\text { P18 TA** } \\
\text { BGO 26C** } \\
\text { HSB 126C** }\end{array}$ & $\begin{array}{l}175.8 \\
172.3 \\
169.1 \\
179.2 \\
158.8 \\
153.9 \\
178.7 \\
177.1 \\
156.9 \\
149.8 \\
152.0 \\
160.4 \\
152.9 \\
154.7 \\
160.7 \\
160.4 \\
160.1 \\
145.0 \\
101.0 \\
147.3 \\
149.4 \\
154.3 \\
138.9 \\
157.4 \\
144.1 \\
156.1 \\
170.7 \\
101.1 \\
182.3\end{array}$ & $\begin{array}{r}123.8 \\
125.3 \\
128.1 \\
136.2 \\
151.8 \\
142.9 \\
150.7 \\
159.1 \\
145.9 \\
131.8 \\
143.0 \\
129.4 \\
141.9 \\
124.7 \\
88.7 \\
120.4 \\
132.1 \\
140.0 \\
99.0 \\
128.3 \\
123.4 \\
113.3 \\
130.9 \\
136.4 \\
141.1 \\
108.1 \\
129.7 \\
99.1 \\
170.3\end{array}$ & $\begin{array}{r}52 \\
47 \\
41 \\
43 \\
6 \\
11 \\
28 \\
18 \\
11 \\
18 \\
11 \\
31 \\
11 \\
20 \\
62 \\
40 \\
32 \\
5 \\
2 \\
19 \\
26 \\
41 \\
8 \\
21 \\
3 \\
48 \\
41 \\
2 \\
12\end{array}$ \\
\hline \multicolumn{4}{|l|}{ NOTES: } \\
\hline $\begin{array}{ll}\text { 1. } & * \\
\text { 2. } & * * \\
\text { 3. } & * * *\end{array}$ & $\begin{array}{l}\text { Lower carbonate zone } \\
\text { Upper carbonate zone } \\
\text { Rounded to the nearest whole foot }\end{array}$ & & \\
\hline
\end{tabular}


Figure 19. Structure Contour Map (Top of Confining Systems I-II/Ellenton Clays) 
TABLE 3

\section{ELEVATIONS OF CONFINING UNIT IIA-IIB (GREEN CLAY) AND \\ CONFINING SYSTEM I-II (ELLENTON CLAYS)}

\begin{tabular}{|c|c|c|c|}
\hline Well & $\begin{array}{c}\text { Elevation } \\
\text { Bottom of } \\
\text { Confining Unit } \\
\text { IIA-IIB } \\
\text { (Green Clay) }\end{array}$ & $\begin{array}{c}\text { Elevation } \\
\text { Top of } \\
\text { Confining System } \\
\text { I-II } \\
\text { (Ellenton Clays) }\end{array}$ & $\begin{array}{l}\text { Thickness of } \\
\text { Aquifer Unit IIA } \\
\text { (Congaree) }\end{array}$ \\
\hline BGO 6A & 108.8 & $\ldots$ & $\ldots$ \\
\hline $\mathrm{BGO} 8 \mathrm{~A}$ & 120.3 & - & $\ldots$ \\
\hline BGO 10A & 119.1 & $\cdots$ & - \\
\hline BGO 12A & 119.4 & $\ldots$ & - \\
\hline $\mathrm{BGO} 14 \mathrm{~A}$ & 115.2 & $\ldots$ & - - \\
\hline $\mathrm{BGO} 16 \mathrm{~A}$ & 123.8 & - & -- \\
\hline $\mathrm{BGO} 18 \mathrm{~A}$ & 124.9 & $\ldots$ & -- \\
\hline $\mathrm{BGO} 25 \mathrm{~A}$ & 111.7 & $\ldots$ & $\ldots$ \\
\hline BGO 26A & 111.1 & $\ldots$ & -- \\
\hline BGO 29A & 120.1 & $\ldots$ & -- \\
\hline DRB 4 & 111.0 & 44.0 & 67 \\
\hline FSB 76A & 115.5 & 29.5 & 86 \\
\hline FSB 78A & 102.5 & - & -- \\
\hline FSB 79A & 102.1 & 20.0 & 82 \\
\hline FSB $87 \mathrm{~A}$ & 110.6 & $\ldots$ & $\cdots$ \\
\hline FSB 96A & 103.7 & $\ldots$ & - \\
\hline FSB 97A & 106.8 & .. & - - \\
\hline FSB $98 A$ & 107.7 & - & - \\
\hline FSB 99A & 112.3 & $\cdots$ & $\cdots$ \\
\hline $\mathrm{FSB} 100 \mathrm{~A}$ & 115.8 & $\ldots$ & - \\
\hline FSB $101 \mathrm{~A}$ & 116.9 & - & $\ldots$ \\
\hline FSB TA & 116.4 & 43.5 & 73 \\
\hline HPT 1A & 117.9 & 52.0 & 62 \\
\hline HPT 2A & 117.7 & 56.0 & 62 \\
\hline $\mathrm{HPC} 1$ & 109.5 & 46.5 & 63 \\
\hline HSB $65 A$ & 110.7 & - & $\therefore$ \\
\hline HSB $68 \mathrm{~A}$ & 111.4 & $\ldots$ & -- \\
\hline HSB 69A & 111.1 & $\ldots$ & $\ldots$ \\
\hline HSB $83 A$ & 105.9 & $\ldots$ & - - \\
\hline HSB 84A & 110.4 & .. & - - \\
\hline HSB 85A & 115.1 & 52.0 & 63 \\
\hline HSB 86A & 110.0 & 58.0 & 52 \\
\hline HSB $117 \mathrm{~A}$ & 114.1 & -. & - \\
\hline HSB $118 \mathrm{~A}$ & 113.0 & $\ldots$ & - \\
\hline HSB $119 \mathrm{~A}$ & 109.8 & $\ldots$ & - \\
\hline
\end{tabular}


TABLE 3

\section{ELEVATIONS OF CONFINING UNIT IIA-IIB (GREEN CLAY) AND \\ CONFINING SYSTEM I-II (ELLENTON CLAYS) \\ (Continued)}

\begin{tabular}{lccc}
\hline & $\begin{array}{c}\text { Elevation } \\
\text { Bottom of } \\
\text { Confining Unit } \\
\text { IIA-IIB } \\
\text { (Green Clay) }\end{array}$ & $\begin{array}{c}\text { Elevation } \\
\text { Top of } \\
\text { Confining System } \\
\text { I-II }\end{array}$ & $\begin{array}{c}\text { Thickness of } \\
\text { Aquifer Unit IIA } \\
\text { (Congare) }\end{array}$ \\
\hline HSB 120A & 109.0 & -- & - \\
HSB 121A & 109.3 & -- & - \\
HSB 122A & 107.4 & -- & - \\
HSB 123A & 104.3 & -- & - \\
HSB 124A & 114.9 & - & - \\
HSB 139A & 113.0 & 54.0 & 52 \\
HSB TB & 106.1 & 28.0 & 98 \\
IDL 3 & 126.4 & 7.0 & 107 \\
P18 TA & 113.7 & 48.5 & 79 \\
P27 TA & 127.1 & 59.0 & 58 \\
P28 TA & 117.2 & & \\
& & & - \\
\hline
\end{tabular}

NOTES:

1. - Data not available 
Figure 20. Geophysical Characteristics of Hydrostratigraphic Units 
gamma ray curve spikes typical of clays (Figure 20). These spikes are very conspicuous in the borings that penetrate Confining System I-II in the GSA.

\section{2) Aquifer System II}

Aquifer System II is subdivided into Aquifer Unit IIA (Congaree Aquifer), Confining Unit IIA-IIB (Green Clay), and Aquifer Unit IIB. Aquifer Unit IIB is further subdivided into Aquifer zone IIB $_{1}$ (Barnwell/McBean Aquifers), Confining zone $\mathrm{IIB}_{1}-\mathrm{IIB}_{2}$ (Tan Clay), and Aquifer zone IIB 2 (Water Table Aquifer) (Figure 12).

a) Aquifer Unit IIA

Aquifer Unit IIA is commonly referred to as the Congaree Aquifer in previous reports at SRS. This unit ranges in thickness from 52 to 107 feet within the GSA (Table 3). An isopach of this unit is presented in Figure 21. The isopach map indicates a thickening of the unit in the western portion of the GSA, a minor thickening to the southeast, and a minor thinning of this aquifer under the MWMF.

Aquifer Unit IIA consists predominantly of sands and clayey sands with thin interbeds of sandy clays, clays, and calcareous sands. Sands and clayey sands range in thickness from 2 to 84 feet. Sandy clays and clays range in thickness from 1 to 9 feet. Calcareous sands range in thickness from 2 to 3 feet. The sands and clayey sands of Aquifer Unit IIA are largely yellow to orange in color and consist of fine to coarse grained, subangular to subrounded quartz. The sands vary from 
Figure 21. Isopach Map of Aquifer Unit IIA (Congaree Aquifer) 
well to poorly sorted. Relatively small quantities of heavy minerals were noted. The assemblage consists of sillimanite, ilmenite, staurolite, rutile, garnet, and magnetite (Dennehy, et al., 1989).

Aquifer Unit IIA (Congaree Aquifer) typically exhibits a natural gamma ray curve normally associated with clean sands (Figure 20). The contact between the base of Aquifer Unit IIA and the underlying Confining System I-II is readily apparent where the transition occurs from clean sands to clayey/silty sediments.

\section{b) Confining Unit IIA-IIB}

Confining Unit IIA-IIB (Caw Caw member of the Santee Formtion) is commonly referred to as the "Green Clay" in previous reports at SRS. Previous investigators illustrated this unit as one vertically and horizontally continuous clay zone. The current study has revealed that the "Green Clay" consists of several clay lenses that thicken, thin, and pinch out abruptly.

Confining Unit IIA-IIB ranges in thickness (Table 4) from 2 to 30 feet (Figure 22). The unit is thin to the west and southeast, becoming thicker to the north. A structure contour map of the top of the unit (Figure 23) indicates a southeastern dip with localized lows near the H-Area Seepage Basins and on the northern boundary of the MWMF. These structural lows tend to correspond with the thickest accumulations of the carbonates (Figure 17). In addition, the clays of the confining unit generally thin here or are truncated at the periphery of the carbonate buildups.

Confining Unit IIA-IIB consists predominantly of clays, sandy clays, and clayey sands. Locally, beds of calcareous mud contribute significant thickness to the unit. Minor interbeds of sands are also present. Clay and sandy clay lenses range in thickness from 2 to 12 feet. Clayey sand beds 
Figure 22. Isopach Map of Confining Unit IIA-IIB (Green Clay) 
Figure 23. Structure Contour Map (Top of Confining Unit IIA-IIB) (Green Clay) 
TABLE 4

THICKNESS OF CONFINING UNIT IIA-IIB (GREEN CLAY)

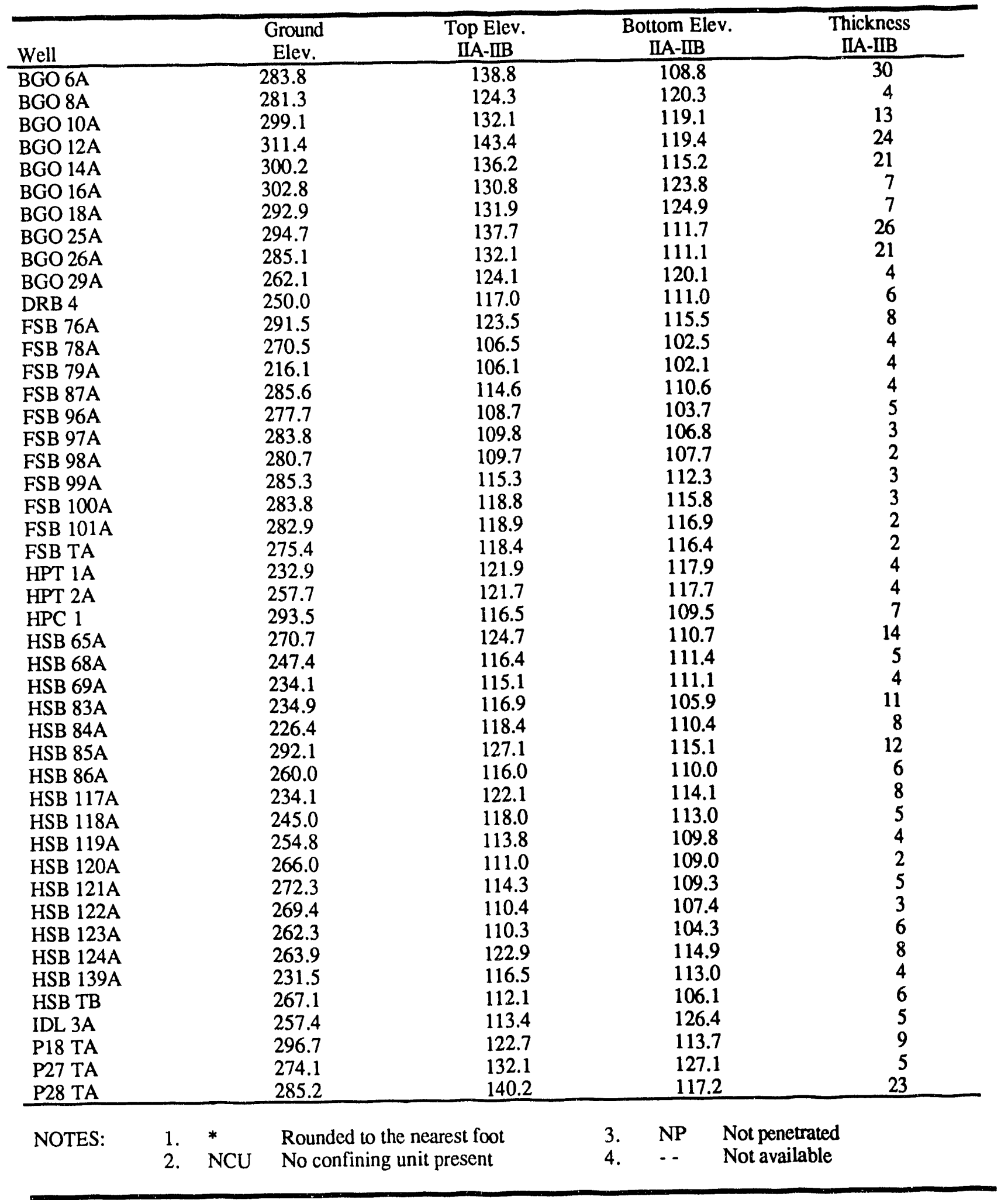


range in thickness from 1 to 14 feet. Calcareous muds range in thickness from 3 to 11 feet and the sand beds range in thickness from 1 to 6 feet.

The clay minerals that constitute the matrix of the units described above consist of illite and smectite according to Dennehy and others, 1989. R. Strom (personal communication) notes that smectite, illite, and kaolinite occur in the unit in that order of abundance. The clays, sandy clays, and clayey sands generally have a distinct dark green color due to the accessory mineral glauconite. The calcareous muds tend to be light green in color. The clayey sands are generally moderately to poorly sorted, with grain sizes ranging from medium to very coarse. They can be consolidated locally within the GSA and are light tan to orange in color, fine to very fine grained, and well sorted. Grains are usually subangular and cemented with silica. The dark green clay facies exhibits a distinct natural gamma ray signature (Figure 20). A large spike on the gamma curve makes this unit easily distinguishable from sediments above and below the horizon.

\section{c) Aquifer Unit IIB}

Aquifer Unit IIB is divided from the base upwards into Aquifer zones $\mathrm{IIB}_{1}$ and $\mathrm{IIB}_{2}$, separated by Confining zone $\mathrm{IIB}_{1}-\mathrm{IIB}_{2}$.

- Aquifer Zone IIB 1 Aquifer zone IIB $_{1}$ has been referred to as the "Barnwell/McBean" Aquifer in previous reports. This zone ranges in thickness from 39 to 91 feet (Table 5). The isopach of the unit indicates thinning of the aquifer towards the west near the F-Area Seepage Basins (Figure 24). Thickening of the aquifer occurs to the southeast near the H-Area Seepage Basins. 
TABLE 5

THICKNESS OF

AQUIFER ZONE IIB 1

(BARNWELL/MCBEAN AQUIFERS)

\begin{tabular}{|c|c|c|c|}
\hline Well & $\begin{array}{c}\text { Elevation } \\
\text { Bottom of } \\
\text { Confining Zone } \\
\text { IIB }_{1}-\mathrm{IBB}_{2}^{\mathrm{a}} \\
\text { (Tan Clay) }\end{array}$ & $\begin{array}{c}\text { Elevation } \\
\text { Top of } \\
\text { Confining Zone } \\
\text { IIA-IIB } \\
\text { (Green Clay) }\end{array}$ & $\begin{array}{c}\text { Thickness of } \\
\text { Aquifer Zone } \\
\text { IIB }_{1} \\
\text { (Barnwell/ } \\
\text { McBean) }\end{array}$ \\
\hline BGO 1D & -- & $\cdots$ & $\cdots$ \\
\hline BGO 3D & $\cdots$ & $\cdots$ & -- \\
\hline $\begin{array}{l}\text { BGO 5C } \\
\text { BGO 6A }\end{array}$ & 215.2 & - & z \\
\hline $\begin{array}{l}\text { BGO 6A } \\
\text { BGO 8A }\end{array}$ & 194.6 & 138.8 & 56 \\
\hline $\begin{array}{l}\text { BGO 8A } \\
\text { BGO 10A }\end{array}$ & 197.3 & 124.3 & 73 \\
\hline BGO 10A & 199.1 & 132.1 & 67 \\
\hline $\begin{array}{l}\text { BGO 12A } \\
\text { BGO 14A }\end{array}$ & 215.4 & 143.4 & 72 \\
\hline $\begin{array}{l}\text { BGO 14A } \\
\text { BGO 16A }\end{array}$ & 209.2 & 136.2 & 73 \\
\hline $\begin{array}{l}\text { BGO 16A } \\
\text { BGO 18A }\end{array}$ & 187.8 & 130.8 & 57 \\
\hline $\begin{array}{l}\text { BGO 18A } \\
\text { BGO 21D }\end{array}$ & 198.9 & 131.9 & 67 \\
\hline $\begin{array}{l}\text { BGO 21D } \\
\text { BGO 23D }\end{array}$ & 199.0 & - - & - \\
\hline $\begin{array}{l}\text { BGO 23D } \\
\text { BGO 25A }\end{array}$ & -- & -- & $-\overline{7}$ \\
\hline $\begin{array}{l}\text { BGO 25A } \\
\text { BGO 26A }\end{array}$ & 204.7 & 137.7 & 67 \\
\hline $\begin{array}{l}\text { BGO 26A } \\
\text { BGO 27C }\end{array}$ & 198.1 & 132.1 & 66 \\
\hline $\begin{array}{l}\text { BGO 27C } \\
\text { BGO 29A }\end{array}$ & 190.9 & -- & -- \\
\hline BGO 29A & 188.1 & 124.1 & 64 \\
\hline $\begin{array}{l}\text { BGO 30C } \\
\text { BGO } 31 \mathrm{C}\end{array}$ & 190.6 & -- & $\cdots$ \\
\hline $\begin{array}{l}\text { BGO 31C } \\
\text { BGO 33C }\end{array}$ & 185.1 & $\cdots$ & $\cdots$ \\
\hline $\begin{array}{l}\text { BGO 33C } \\
\text { BGO 35C }\end{array}$ & 193.4 & $\cdots$ & -- \\
\hline $\begin{array}{l}\text { BGO 35C } \\
\text { BGO 37C }\end{array}$ & 194.4 & $\cdots$ & $\cdots$ \\
\hline $\begin{array}{l}\text { BGO 37C } \\
\text { DRB } 4\end{array}$ & 192.3 & 1170 & $\overline{73}$ \\
\hline $\begin{array}{l}\text { DRB } 4 \\
\text { FSB 76A }\end{array}$ & 190.0 & $\begin{array}{l}117.0 \\
123.5\end{array}$ & \\
\hline $\begin{array}{l}\text { FSB 76A } \\
\text { FSB 78A }\end{array}$ & 182.5 & 123.5 & $\begin{array}{l}59 \\
39\end{array}$ \\
\hline $\begin{array}{l}\text { FSB 78A } \\
\text { FSB 79A }\end{array}$ & 145.5 & 106.5 & \\
\hline $\begin{array}{l}\text { FSB 79A } \\
\text { FSB 87A }\end{array}$ & 163.1 & $\begin{array}{l}106.1 \\
114.6\end{array}$ & $\begin{array}{l}51 \\
62\end{array}$ \\
\hline $\begin{array}{l}\text { FSB 87A } \\
\text { FSB 88C }\end{array}$ & 176.6 & $\begin{array}{r}114.6 \\
\ldots\end{array}$ & -- \\
\hline $\begin{array}{l}\text { FSB 88C } \\
\text { FSB 89C }\end{array}$ & 180.4 & $\cdots$ & -- \\
\hline $\begin{array}{l}\text { FSB 89C } \\
\text { FSB 90C }\end{array}$ & $\begin{array}{l}179.1 \\
178.1\end{array}$ & $\ldots$ & -- \\
\hline $\begin{array}{l}\text { FSB 90C } \\
\text { FSB 91C }\end{array}$ & $\begin{array}{l}178.1 \\
162.0\end{array}$ & $\ldots$ & - \\
\hline $\begin{array}{l}\text { FSB 91C } \\
\text { FSB 92D }\end{array}$ & 142.6 & - & -- \\
\hline FSB 93C & 155.0 & -- & - \\
\hline FSB 94C & 151.8 & - & $\cdots$ \\
\hline FSB 95C & 156.8 & - & -- \\
\hline FSB 96A & 160.7 & 108.7 & 52 \\
\hline FSB 97A & 152.8 & 109.8 & 43 \\
\hline FSB 98A & 161.7 & 109.7 & 52 \\
\hline FSB 99A & 175.3 & 115.3 & 60 \\
\hline
\end{tabular}


TABLE 5

\section{THICKNESS OF} AQUIFER ZONE IIB 1

(BARNWELL/MCBEAN AQUIFERS)

(Continued)

\begin{tabular}{|c|c|c|c|}
\hline Well & $\begin{array}{c}\text { Elevation } \\
\text { Bottom of } \\
\text { Confining Zone } \\
\text { IB }_{1} \text {-IIB } 2 \\
\text { (Tan Clay) }\end{array}$ & $\begin{array}{c}\text { Elevation } \\
\text { Top of } \\
\text { Confining Zone } \\
\text { IIA-IIB } \\
\text { (Green Clay) }\end{array}$ & $\begin{array}{c}\text { Thickness of } \\
\text { Aquifer Zone } \\
\text { IB }_{1} \\
\text { (Barnwell } \\
\text { McBean) }\end{array}$ \\
\hline $\begin{array}{l}\text { FSB } 100 A \\
\text { FSB } 101 A\end{array}$ & $\begin{array}{l}181.8 \\
184.9\end{array}$ & $\begin{array}{l}118.8 \\
1189\end{array}$ & $\begin{array}{l}63 \\
66\end{array}$ \\
\hline FSB $102 \mathrm{C}$ & $\begin{array}{r}104.9 \\
\ldots\end{array}$ & 110. & 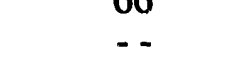 \\
\hline FSB $103 C$ & 159.1 & $\ldots$ & $\ldots$ \\
\hline FSB $104 C$ & 170.7 & $\ldots$ & - \\
\hline FSB $105 \mathrm{C}$ & 162.5 & $\cdots$ & - \\
\hline FSB $106 \mathrm{C}$ & 173.0 & $\ldots$ & - \\
\hline FSB 107C & 166.8 & $\ldots$ & $\ldots$ \\
\hline FSB $111 \mathrm{C}$ & 175.0 & $\ldots$ & $\ldots$ \\
\hline FSB TA & 186.4 & 118.4 & 68 \\
\hline $\mathrm{HC} 12 \mathrm{~A}$ & 190.3 & - & - \\
\hline HPT $1 \mathrm{~A}$ & NCU & 121.9 & $\ldots$ \\
\hline HPT $2 A$ & $\mathrm{NCU}$ & 121.7 & $\ldots$ \\
\hline $\mathrm{HPC} 1$ & 186.5 & 116.5 & 70 \\
\hline HSB $65 \mathrm{~A}$ & 203.7 & 124.7 & 79 \\
\hline HSB 68A & 189.4 & 116.4 & 73 \\
\hline HSB $69 A$ & 181.1 & 115.1 & 66 \\
\hline HSB $70 \mathrm{C}$ & 173.9 & - & $\ldots$ \\
\hline HSB $71 \mathrm{C}$ & 180.4 & $\ldots$ & - - \\
\hline HSB 83A & 188.9 & 116.9 & 72 \\
\hline HSB 84A & 182.4 & 118.4 & 64 \\
\hline HSB 85A & 197.1 & 127.1 & 70 \\
\hline HSB $86 A$ & 185.4 & 116.0 & 69 \\
\hline $\mathrm{HSB} 100 \mathrm{C}$ & 193.0 & - & $\ldots$ \\
\hline HSB $101 \mathrm{C}$ & 189.3 & $\ldots$ & $\ldots$ \\
\hline HSB $102 \mathrm{C}$ & 180.7 & -- & - \\
\hline HSB $103 C$ & 181.2 & - & $-\infty$ \\
\hline HSB $104 C$ & 183.5 & - & $\cdots$ \\
\hline HSB $105 \mathrm{C}$ & 176.2 & $\cdots$ & - \\
\hline HSB $106 \mathrm{C}$ & 177.7 & -- & -- \\
\hline HSB $107 \mathrm{C}$ & 182.3 & $\ldots$ & - \\
\hline HSB $108 \mathrm{C}$ & 202.9 & $\ldots$ & - \\
\hline HSB $109 \mathrm{C}$ & 189.4 & $\ldots$ & $\ldots$ \\
\hline HSB $110 \mathrm{C}$ & 188.4 & - & - \\
\hline HSB $111 \mathrm{C}$ & 171.7 & - & $\ldots$ \\
\hline HSB $112 \mathrm{C}$ & 180.6 & -- & $\ldots$ \\
\hline HSB $113 \mathrm{C}$ & 173.7 & $\ldots$ & - \\
\hline
\end{tabular}


TABLE 5

THICKNESS OF

AQUIFER ZONE IIB 1

(BARNWELL/MCBEAN AQUIFERS)

(Continued)

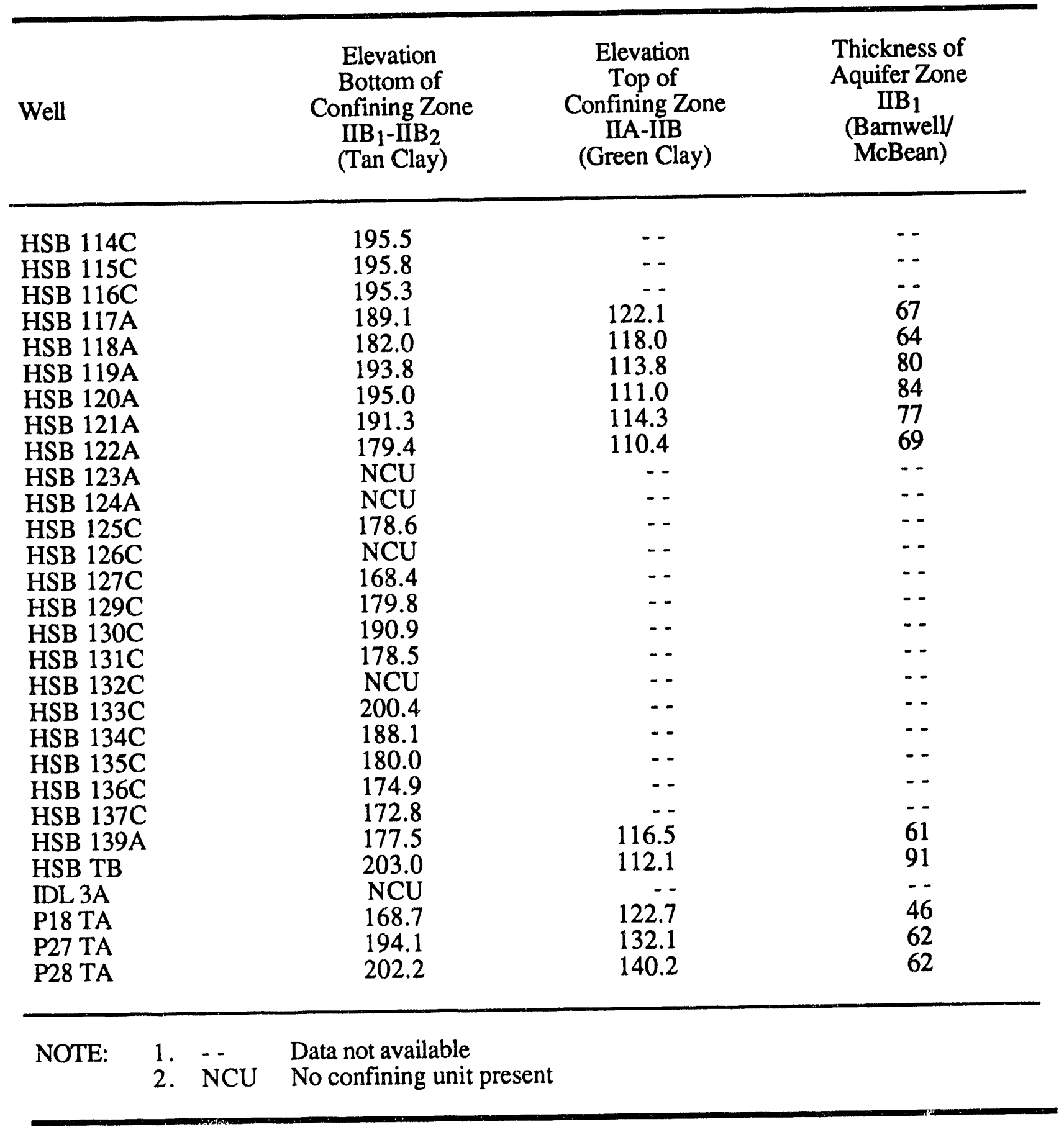


Figure 24. Isopach Map of Aquifer Zone IIB 1 (Barnwell/McBean Aquifers) 
This aquifer zone consists predominantly of sand and clayey sand sequences with localized zones of abundant calcareous sands, sandy and muddy limestones, and limestones. Minor interbeds of clay and sandy clay are also present. Sands and clayey sands range in thickness from 2 to 60 feet. Calcareous sands range in thickness from 2 to 33 feet. Sandy and muddy limestones and limestones range in thickness from 3 to 30 feet. Figure 18 illustrates the thickness of the two calcareous units in this zone. Figure 24 illustrates the thickness of the entire Aquifer zone IIB 1 . Clay and sandy clays range in thickness from 1 to 16 feet. The sand and clayey sand beds are generally yellow to tan, occasionally greenish brown to light brown. The sand is fine to coarse grained, moderately to well sorted, and generally subangular.

The calcareous sands are white to buff in color and contain up to 50 percent calcareous materials. Shell fragments (gastropods, pelecypods, echinoderms, bryozoans, and barnacles) and whole foraminifera are common in the sands. The sand is quartz rich and is generally fine grained, subangular, and well to moderately sorted. Small percentages of glauconite are common.

The sandy and muddy limestones and limestones are white to buff in color and contain greater than 80 percent calcareous material. Glauconite is common in this unit. Many of the limestones are partially to fully consolidated with abundant moldic porosity from fossil molds. Shells are dominantly pelecypods and gastropods. Unconsolidated limestones are generally a "coquina" type shell hash consisting of shell fragments of pelecypods, gastropods, echinoderms, bryozoans, and barnacles. Small silicified layers of this shell hash $(<0.5$ feet) are occasionally observed in this unit.

The fossiliferous limestones are typical of bioherms observed on the shallow marine shelf. Modern analogues are found in Florida Bay near the Keys (Baars, 1963), where shell mounds are commonly observed surrounded by the silty clayey sands of the shallow shelf. The carbonate 
buildups in the GSA are oriented northwest-southeast, paralleling the strike of the shoreline at that time.

The interbeds of clays and sandy clays in this unit are light tan to orange in color. According to Dennehy, et al., (1989) the clay minerals are illite/smectite. The sand is quartz, fine to medium grained, subangular, and well to moderately sorted.

The calcareous sands and limestones contained in this unit are generally not recognizable on natural gamma curves in the GSA. Occasionally, a limestone with good moldic porosity will be distinct on the electric resistivity curve (Figure 25). The clastic lithofacies of Aquifer zone $\mathrm{IB}_{1}$ are not easily distinguishable on natural gamma curves alone. Correlation in this zone requires careful examination and interpretation of both core and geophysical data.

- Faulting Associated With Carbonate Buildups. A prominent feature on Cross Section \#3 (Plate 3) is the offset of beds between FSB-91 and FSB-100. The beds are down thrown approximately 12 feet to the south. The offset between the wells is typical of the shallow "faulting" observed in the GSA. Most often the areas where offset has occurred are related to the flanks of the carbonate buildups found at and near the base of Aquifer zone IIB 1 . Geophysical and core data both corroborate the offset in Aquifer zone $\mathrm{IIB}_{1}$, Confining zone $\mathrm{IIB}_{1},-\mathrm{IIB}_{2}$, and Aquifer zone $\mathrm{IIB}_{2}$, but offset below the carbonate buildups in Aquifer IIA cannot be demonstrated. The precise age and most recent movement on the shallow offsets is not well documented and awaits the results of the Upland Unit study and Phase II of the Pen Branch fault study (see p.23). Until the results of the two studies are known, the upper or shallow portions of the offsets that underlie the areas at higher evaluations in the GSA have been dashed (Plates 2, 5A, 5B, 7, 10A, 10B). The slump features in the valleys and hill sides are not dashed since they penetrate to the surface due to recent erosion. 
Figure 25. Geophysical Characteristics of Limestone in HSB-122 
Siple (1967) speculated that dissolution of calcareous material in the Santee Limestone has occurred at the SRS and caused subsidence of overlying beds and the formation of depressions. He noted that voids and loosely compacted sediments were encountered during well drilling and mentioned that large amounts of cement grout were used to stabilize the subsurface before construction of heavy structures. Slump features have been recognized in the coastal plain calcareous sediments by Johnson and Heron (1965). In all probability the shallow offsets noted at the GSA are due to slumping of the section above the carbonate buildups due to carbonate dissolution. However, soft sediment deformation such as deltaic slumping is another feasible explanation for the offset (McDowell and Houser, 1983).The localized steepening of dip observed near borings FSB-106, FSB-91, and FSB-100 in the Aquifer zone IIB 1 interval could be caused by the proposed slumping due to carbonate dissolution. Alternately, the overlying clastic sediments may simply be draped over the flanks of the carbonate mounds.

A similar feature on Cross Section \#5B (Plate 5B) is the offset beds between FSB-97 and FSB-98. The feature exhibits normal offset, and beds are downthrown to the west with a throw of approximately 9 feet in Aquifer zone $\mathrm{IB}_{2}$. Throw decreases to around 3 feet in Confining zone $\mathrm{IIB}_{1}-\mathrm{IIB}_{2}$ and Aquifer zone $\mathrm{IIB}_{1}$. The offset apparently does not penetrate Confining Unit IIAIIB. The offset cuts FSB-97 at 121 feet above msl. Geophysical and core data both corraborate this offset. Again, there is a good possibility of slumping associated with carbonate dissolution as previously discussed. Due to the close proximity of calcareous beds in the nearby boring FSB100 , there is a strong possibility that borings FSB-97 and FSB-98 once contained carbonate beds, and post-depositional carbonate dissolution is a reasonable explanation for the offset observed between FSB-97 and FSB-98.

- Confining Zone IIB I -IIB $\underline{Z}_{2}$ (Tan Clay). Confining zone $\mathrm{IIB}_{1}-\mathrm{IIB}_{2}$ is commonly referred to as the "Tan Clay" in previous reports at SRS. This zone consists of multiple lenses of clay that thicken, thin, and pinch out abruptly and within very short distances. This zone ranges in 
thickness from 0 to 33 feet (Table 6 and Figure 26). As indicated, no confining zone was encountered in a group of wells east of the MWMF and in an area west of the F-Area Seepage Basins. At the H-Area Seepage Basins there are three small areas where no confining zone within this interval was identified. Elsewhere within the GSA the zone thickens and thins abruptly. Figure 27 is a structure contour map on top of the confining zone. The structure contours suggest that the thinning of the zone at the H-Area Seepage Basins may be a result of post-depositional erosion.

Confining zone $\mathrm{IIB}_{1}-\mathrm{IIB}_{2}$ consists predominantly of clays and sandy clays, with minor to equal interbeds of clayey sands and sands. One occurrence of a 2 foot thick calcareous sand was encountered at wells monitoring the MWMF. Clays and sandy clays range in thickness from 1 to 11 feet. Clayey sands and sands range in thickness from 1 to 8 feet.

Clays and sandy clays are light tan to light green tan in color. According to Dennehy and others (1989), the clay is predominantly composed of kaolinite and tends to be sticky and plastic. The quartz sand is angular to subangular and contains mica and dark heavy minerals. The heavy mineral suite is brown ilmenite, zircon, brown hornblende, staurolite, sillimanite, kyanite, and magneite. Clay bedding exhibits thin, irregular laminae.

Clayey sands and sands are light tan to light orange in color. The clay matrix in the sand is predominantly kaolinite (Dennehy, et al., 1989). The quartz sands are predominantly medium to coarse grained, with a moderate degree of sorting. Grain size tends to coarsen upward.

The calcareous sand is composed of shell fragments and quartz sand in a clay matrix. The quartz sand is fine grained and subrounded. The thicker clays within the confining zone exhibit a natural gamma spike typical of clays. However, natural gamma spikes may also be related to concentrations of heavy minerals. 
Figure 26. Isopach Map for Confining Zone $\mathrm{IIB}_{1}$ - IIB 2 (Tan Clay) 
Figure 27. Structure Contour Map for Confining Zone IIB 1 - IIB 2 
TABLE 6

DETAILS OF CONFINING UNIT IIB 1 -IIB 2 (TAN CLAY) AND THE SATURATED PORTION OF AQUIFER ZONE IIB 2 (WATER TABLE AQUIFER)

\begin{tabular}{|c|c|c|c|c|c|c|}
\hline Well & $\begin{array}{l}\text { Ground } \\
\text { Elev. }\end{array}$ & $\begin{array}{l}\text { Water Elev. } \\
\qquad \mathrm{IIB}_{2}{ }^{\mathrm{a}}\end{array}$ & $\begin{array}{l}\text { Elev. } \\
\text { Top Of } \\
\text { Confining } \\
\text { Zone } \\
\mathrm{IIB}_{1}-\mathrm{IIB}_{2} \mathrm{~b}\end{array}$ & $\begin{array}{c}\text { Elev. } \\
\text { Bottom of } \\
\text { Confining } \\
\text { Zone } \\
\text { IIB }_{1}-\mathrm{IIB}_{2} \mathrm{~b}\end{array}$ & $\begin{array}{l}\text { Thickness of } \\
\text { Confining } \\
\text { Zone } \\
\mathrm{IIB}_{1}-\mathrm{IIB}_{2} \mathrm{b,d}\end{array}$ & $\begin{array}{c}\text { Saturated } \\
\text { Thickness } \\
\mathrm{IIB}_{2} \mathrm{c}\end{array}$ \\
\hline BGO 1D & 293.0 & 237.5 & NP & NP & $\ldots$ & .. \\
\hline BGO 3D & 290.8 & 235.4 & NP & NP & $\cdots$ & - \\
\hline BGO 5C & 294.2 & 231.3 & 218.2 & 215.2 & 3 & 13.1 \\
\hline BGO 6A & 283.8 & 231.4 & 209.6 & 194.6 & 15 & 21.8 \\
\hline BGO 8A & 281.3 & 231.7 & 213.3 & 197.3 & 16 & 18.4 \\
\hline BGO 10A & 299.1 & DRY & 218.1 & 199.1 & 19 & - \\
\hline BGO 12A & 311.4 & 229.4 & 226.4 & 215.4 & 11 & 3.0 \\
\hline BGO 14A & 300.2 & DRY & 223.2 & 209.2 & 14 & $\ldots$ \\
\hline BGO 16A & 302.8 & 229.7 & 214.8 & 187.8 & 27 & 14.9 \\
\hline BGO 18A & 292.9 & 231.0 & 204.9 & 198.9 & 6 & 26.1 \\
\hline BGO 21D & 283.0 & 233.9 & 212.0 & 199.0 & 13 & 21.9 \\
\hline BGO 23D & 287.0 & 235.3 & NP & NP & - & -. \\
\hline BGO 25A & 294.7 & -. & 214.7 & 204.7 & 10 & - \\
\hline BGO 26A & 285.1 & 225.7 & 214.1 & 198.1 & 16 & 11.6 \\
\hline BGO 27C & 273.9 & 225.5 & 197.9 & 190.9 & 7 & 27.6 \\
\hline BGO 29A & 262.1 & $\ldots$ & 197.1 & 188.1 & 9 & - \\
\hline BGO 30C & 272.6 & 223.6 & 200.6 & 190.6 & 10 & 23.0 \\
\hline BGO 31C & 271.1 & 224.6 & 195.1 & 185.1 & 10 & 29.5 \\
\hline BGO 33C & 277.4 & 227.9 & 201.4 & 193.4 & 8 & 26.5 \\
\hline BGO 35C & 271.4 & 232.2 & 213.4 & 194.4 & 19 & 18.8 \\
\hline BGO 37C & 284.3 & 235.1 & 201.3 & 192.3 & 9 & 33.8 \\
\hline DRB 4 & 250.0 & - & 204.0 & 190.0 & 14 & - \\
\hline FSB 76A & 291.5 & .. & 192.5 & 182.5 & 20 & .- \\
\hline FSB 78A & 270.5 & 207.4 & 162.5 & 145.5 & 17 & 44.9 \\
\hline FSB 79A & 216.1 & 201.6 & 173.1 & 163.1 & 10 & 28.5 \\
\hline FSB $87 \mathrm{~A}$ & 285.6 & .. & 175.6 & 176.6 & 3 & - \\
\hline FSB $88 \mathrm{C}$ & 280.4 & - - & 188.4 & 180.4 & 8 & - \\
\hline FSB 89C & 279.1 & 213.0 & 186.1 & 179.1 & 7 & 26.9 \\
\hline FSB 90C & 276.1 & 212.0 & 185.1 & 178.1 & 7 & 26.9 \\
\hline FSB 91C & 277.0 & 211.2 & 169.0 & 162.0 & 7 & 42.2 \\
\hline FSB 92D & 273.6 & 210.0 & 167.6 & 142.6 & 25 & 42.4 \\
\hline FSB 93C & 274.0 & 209.1 & 169.0 & 155.0 & 14 & 40.1 \\
\hline FSB 94C & 278.8 & $\cdots$ & 173.8 & 151.8 & 22 & -. \\
\hline FSB 95C & 281.8 & 208.3 & 172.8 & 156.8 & 16 & 35.5 \\
\hline FSB 96A & 277.7 & $\cdots$ & 169.7 & 160.7 & 9 & .. \\
\hline FSB 97A & 283.8 & 209.0 & 165.8 & 152.8 & 13 & 43.2 \\
\hline FSB 98A & 280.7 & 209.9 & 174.7 & 161.7 & 13 & 35.2 \\
\hline FSB 99A & 285.3 & 210.8 & 180.3 & 175.3 & 5 & 30.5 \\
\hline FSB $100 \mathrm{~A}$ & 283.8 & - & 184.8 & 181.8 & 3 & $\ldots$ \\
\hline FSB 101A & 282.9 & .. & 191.9 & 184.9 & 7 & .- \\
\hline FSB $102 C$ & 198.9 & - & NP & NP & .. & .- \\
\hline FSB $103 C$ & 240.1 & -. & 173.1 & 159.1 & 14 & $\ldots$ \\
\hline
\end{tabular}


TABLE 6

THICKNESS OF CONFINING UNIT IIB 1 -IIB 2 (TAN CLAY) AND THE SATURATED PORTION OF AQUIFER ZONE IIB 2 (WATER TABLE AQUIFER)

(Continued)

\begin{tabular}{|c|c|c|c|c|c|c|}
\hline Well & $\begin{array}{l}\text { Ground } \\
\text { Elev. }\end{array}$ & $\begin{array}{c}\text { Water Elev. } \\
\mathrm{IIB}_{2}{ }^{\mathrm{a}}\end{array}$ & $\begin{array}{c}\text { Elev. } \\
\text { Top Of } \\
\text { Confining } \\
\text { Zone } \\
\mathrm{IIB}_{1}-\mathrm{IIB}_{2}{ }^{\mathrm{b}} \\
\end{array}$ & $\begin{array}{c}\text { Elev. } \\
\text { Bottom of } \\
\text { Confining } \\
\text { Zone } \\
\text { IIB }_{1}-\text { IIB }_{2}{ }^{b} \\
\end{array}$ & $\begin{array}{l}\text { Thickness of } \\
\text { Confining } \\
\text { Zone } \\
\text { IIB }_{1-\mathrm{IIB}_{2}} \mathrm{b,d}\end{array}$ & $\begin{array}{c}\text { Saturated } \\
\text { Thickness } \\
\mathrm{IIB}_{2}{ }^{\mathrm{c}}\end{array}$ \\
\hline FSB $104 C$ & 216.7 & 203.1 & 172.7 & 170.7 & 2 & 30.4 \\
\hline FSB $105 C$ & 283.5 & 208.5 & 173.5 & 162.5 & 11 & 35.0 \\
\hline FSB 106C & 233.0 & $\cdots$ & 179.5 & 173.0 & 7 & - \\
\hline FSB 107C & 268.8 & 211.5 & 180.8 & 166.8 & 14 & 30.7 \\
\hline FSB 111C & 274.0 & 212.9 & 186.0 & 175.0 & 11 & 26.9 \\
\hline FSB TA & 275.4 & - & 190.4 & 186.4 & 4 & - \\
\hline $\mathrm{HC} 12 \mathrm{~A}$ & 287.3 & $\cdots$ & 205.3 & 190.3 & 15 & - \\
\hline HPT 1A & 232.9 & $\cdots$ & NCU & $\mathrm{NCU}$ & 0 & - \\
\hline HPT 2A & 257.7 & $\cdots$ & $\mathrm{NCU}$ & $\mathrm{NCU}$ & 0 & - \\
\hline HPC 1 & 293.5 & $\cdots$ & 192.5 & 186.5 & 6 & - \\
\hline HSB 65A & 270.7 & 231.0 & 208.7 & 203.7 & 5 & 22.3 \\
\hline HSB 68A & 247.4 & 218.0 & 200.4 & 189.4 & 11 & 18.2 \\
\hline HSB 69A & 234.1 & 219.6 & 187.1 & 181.1 & 6 & 32.5 \\
\hline HSB $70 \mathrm{C}$ & 240.9 & - & 190.9 & 173.9 & 17 & $\cdots$ \\
\hline HSB 71C & 239.4 & 225.1 & 193.4 & 180.4 & 13 & 31.7 \\
\hline HSB 83A & 234.9 & 226.0 & 196.9 & 188.9 & 8 & 29.1 \\
\hline HSB 84A & 226.4 & 219.0 & 204.4 & 182.4 & 22 & 14.6 \\
\hline HSB 85A & 292.1 & 237.5 & 207.1 & 197.1 & 10 & 30.4 \\
\hline HSB 86A & 260.0 & 223.9 & 211.4 & 185.4 & 26 & 12.5 \\
\hline HSB $100 C$ & 258.0 & $\cdots$ & 199.0 & 193.0 & 6 & -- \\
\hline HSB 101C & 256.3 & 229.5 & 195.3 & 189.3 & 6 & 34.2 \\
\hline HSB $102 C$ & 256.7 & 228.0 & 192.7 & 180.7 & 12 & 35.3 \\
\hline HSB 103C & 245.2 & 225.4 & 195.2 & 181.2 & 14 & 30.2 \\
\hline HSB $104 C$ & 245.5 & $\cdots$ & 194.5 & 183.5 & 11 & -- \\
\hline HSB $105 C$ & 247.2 & 225.4 & 191.2 & 176.2 & 15 & 34.2 \\
\hline HSB $106 C$ & 250.7 & $\cdots$ & 193.7 & 177.7 & 16 & - \\
\hline HSB 107C & 258.3 & $\cdots$ & 199.3 & 182.3 & 17 & -- \\
\hline HSB 108C & 263.9 & - & 212.9 & 202.9 & 10 & - \\
\hline HSB $109 \mathrm{C}$ & 259.4 & $\cdots$ & 203.4 & 189.4 & 14 & - \\
\hline HSB $110 C$ & 253.4 & $\cdots$ & 203.4 & 188.4 & 15 & - \\
\hline HSB 111C & 253.7 & $\cdots$ & 186.7 & 171.7 & 15 & - \\
\hline HSB 112C & 252.6 & - & 189.6 & 180.6 & 9 & -- \\
\hline HSB 113C & 258.7 & $\cdots$ & 187.7 & 173.7 & 14 & - \\
\hline HSB 114C & 261.5 & 215.0 & 208.5 & 195.5 & 13 & 15.0 \\
\hline HSB $115 C$ & 266.8 & -. & 210.8 & 195.8 & 15 & -. \\
\hline HSB $116 C$ & 255.3 & 216.4 & 209.3 & 195.3 & 14 & 16.4 \\
\hline HSB 117A & 234.1 & - & 215.1 & 189.1 & 26 & - \\
\hline HSB 118A & 245.0 & $\cdots$ & 214.0 & 182.0 & 32 & -- \\
\hline HSB 119A & 254.8 & $\ldots$ & 212.8 & 193.8 & 18 & - \\
\hline HSB 120A & 266.0 & - & 213.0 & 195.0 & 18 & -- \\
\hline HSB 121A & 272.3 & - & 197.3 & 191.3 & 6 & -- \\
\hline HSB 122A & 269.4 & $\cdots$ & 194.4 & 179.4 & 15 & .. \\
\hline
\end{tabular}


TABLE 6

THICKNESS OF CONFINING UNIT IIB 1 -IIB 2 (TAN CLAY)

AND THE SATURATED PORTION OF AQUIFER ZONE IIB 2 (WATER TABLE AQUIFER) (Continued)

\begin{tabular}{|c|c|c|c|c|c|c|}
\hline Well & $\begin{array}{l}\text { Ground } \\
\text { Elev. }\end{array}$ & $\begin{array}{c}\text { Water Elev. } \\
\mathrm{IIB}_{2}{ }^{\mathrm{a}}\end{array}$ & $\begin{array}{l}\text { Elev. } \\
\text { Top of } \\
\text { Confining } \\
\text { Zone } \\
\mathrm{IBB}_{1}-\mathrm{IIB}_{2}{ }^{\mathrm{b}}\end{array}$ & $\begin{array}{c}\text { Elev. } \\
\text { Bottom of } \\
\text { Confining } \\
\text { Zone } \\
\mathrm{IIB}_{1}-\mathrm{IIB}_{2}{ }^{\mathrm{b}}\end{array}$ & $\begin{array}{l}\text { Thickness of } \\
\text { Confining } \\
\text { Zone } \\
\mathrm{IB}_{1}-\mathrm{IIB}_{2} \mathrm{~b}, \mathrm{~d}\end{array}$ & $\begin{array}{c}\text { Saturated } \\
\text { Thickness } \\
\qquad \mathrm{IIB}_{2}{ }^{\mathrm{c}}\end{array}$ \\
\hline HSB 123A & 262.3 & $\ldots$ & $\mathrm{NCU}$ & $\mathrm{NCU}$ & 0 & -. \\
\hline HSB $124 \mathrm{~A}$ & 263.9 & - & $\mathrm{NCU}$ & $\mathrm{NCU}$ & 0 & - \\
\hline HSB $125 \mathrm{C}$ & 229.6 & - - & 193.6 & 178.6 & 15 & -. \\
\hline HSB $126 C$ & 210.3 & 205.7 & $\mathrm{NCU}$ & $\mathrm{NCU}$ & 0 & 0 \\
\hline HSB $127 \mathrm{C}$ & 223.4 & - & 190.4 & 168.4 & 22 & - - \\
\hline HSB $129 \mathrm{C}$ & 212.8 & 208.7 & 199.8 & 179.8 & 20 & 8.9 \\
\hline HSB $130 C$ & 215.9 & 199.5 & 215.9 & 190.9 & 25 & 0 \\
\hline HSB $131 \mathrm{C}$ & 209.5 & 205.9 & 193.5 & 178.5 & 15 & 12.4 \\
\hline HSB $132 C$ & 238.3 & $\ldots$ & NCU & NCU & 0 & $\ldots$ \\
\hline HSB $133 C$ & 253.4 & 223.4 & 204.4 & 200.4 & 4 & 19.0 \\
\hline HSB $134 \mathrm{C}$ & 236.1 & 221.9 & 194.1 & 188.1 & 6 & 27.8 \\
\hline HSB $135 \mathrm{C}$ & 229.8 & - & 197.0 & 180.0 & 17 & $\cdots$ \\
\hline HSB $136 \mathrm{C}$ & 225.6 & 220.8 & 197.9 & 174.9 & 23 & 22.9 \\
\hline HSB $137 \mathrm{C}$ & 233.8 & 222.6 & 205.8 & 172.8 & 33 & 16.8 \\
\hline HSB 139A & 231.5 & - & 188.5 & 177.5 & 11 & $\ldots$ \\
\hline HSB TB & 267.1 & - & 207.1 & 203.1 & 4 & -. \\
\hline IDL 3A & 257.4 & - & NCU & $\mathrm{NCU}$ & 0 & - \\
\hline P18 TA & 296.7 & 218.9 & 185.7 & 168.7 & 17 & 33.2 \\
\hline P27 TA & 274.1 & 265.9 & 200.1 & 194.1 & 6 & 65.8 \\
\hline P28 TA & 285.2 & 222.0 & 215.2 & 202.2 & 13 & 0 \\
\hline
\end{tabular}

NOTES:
1. $\quad-$.
Not applicable
2. $a$
Water Elevation of Aquifer zone $\mathrm{IIB}_{2}$ (Water Table Aquifer)
3. b
Elevation and thickness of Confining Zone IIB 1 - IIB 2 (Tan Clay)
4. c
Thickness of the saturated portion of Aquifer zone $\mathrm{IIB}_{2}$
5. $\mathrm{d}$
(Water Table Aquifer)
6. NCU
Rounded to the nearest whole foot
7. DRY
No confining unit present
8. NP
Dry well
Not penetrated 
- Aquifer Zone IIB2 Aquifer zone $\mathrm{IIB}_{2}$ represents the "water table aquifer". The total thickness of the lithologies of this zone range from 0 feet at Fourmile Branch to 110 feet (Table 6). An isopach of the saturated portion of this zone is presented in Figure 28.

This zone consists predominantly of sands and clayey sands with lesser or equal amounts of clay and sandy clay. Gravel and pebble layers occur locally. Sands and clayey sands range in thickness from 2 to 107 feet. Clays and sandy clays range in thickness from 1 to 18 feet. Gravel and pebble layers range in thickness from 1 to 5 feet. Sands and clayey sands are tan to red to purple and are often highly variegated in color. Sands are fine to very coarse, subangular to angular, and moderately to poorly sorted. Clays and sandy clays are composed predominantly of kaolinite (Dennehy, et al., 1989). Sands are fine to very coarse and subangular to angular. Clay clasts, mica, and dark heavy minerals are also present in the quartz sand. Brown ilmenite and sillimanite are very abundant in the typical heavy mineral assemblage along with zircon, rutile, brown hornblende, and staurolite (Dennehy, et al., 1989).

Clasts within the gravel and pebble beds range in diameter from 0.5 up to 4 inches and are generally well rounded. Gravels are usually found in a matrix of fine to very coarse clayey quartz sand containing abundant mica and white clay balls. The quartz sand is generally coarse and angular to subangular.

The unit is difficult to correlate on geophysical data alone. As in Confining zone $\mathrm{IIB}_{1}-\mathrm{IIB}_{2}$ (Tan Clay), the natural gamma spikes resembling clays may be attributed to concentrations of potassium-rich heavy minerals. Core and geophysical data were both carefully analyzed in the interpretation and correlations of Aquifer Unit IIB 2 . 
Figure 28. Isopach Map of Aquifer Zone $\mathrm{IIB}_{2}$ (Water Table Aquifer) 


\section{HYDROLOGIC.AL CHARACTERISTICS OF THE GSA}

\section{A. Identification of the "Uppermost Aquifer"}

All of the aquifers and confining units above Confining System I-II are included in the "uppermost aquifer" (Figure 12). The RCRA Ground Water Monitoring Technical Enforcement Guidance Document (TEGD) defines the "uppermost aquifer" as "the geologic formation, group of formations, or part of a formation that is the aquifer nearest to the ground surface and is capable of yielding significant amount of ground water to wells or springs" (Chapter 1, Section 1.4, p. 35). The TEGD emphasizes that identification of the lower confining layer (or / boundary) is essential to the proper definition of the "uppermost aquifer". The TEGD also notes that the degree of hydraulic interconnection between the "uppermost aquifer" and lower aquifers must be limited. Using this guidance, the "uppermost aquifer" beneath the GSA includes all the hydrostratigraphic units which lie between the Aquifer zone $\mathrm{IIB}_{2}$ and the base of Aquifer Unit IIA (Figure 12). Aquifer Unit IIA is the basal hydrostratigraphic unit in the "uppermost aquifer". There are three aquifer units separated by two confining units within the "uppermost aquifer". The Principal Confining Unit which underlies Aquifer Unit IIA is Confining System I-II.

Potentiometric maps were prepared for each of the three aquifer units in the GSA (Figures 29, 30, and 31 ) at a scale of $1 "=1000$ '. Vertical flow potential across the confining units in the area are illustrated on hydraulic head difference maps in Figures 32 and 33. Water elevation measurements used to produce these maps were taken during the fourth quarter of 1989. 
Figure 29. Potentiometric Surface MapAquifer Unit $\mathrm{IIB}_{2}$ (Water Table Aquifer) 
Figure 30. Potentiometric Surface Map. Aquifer Zone IIB 1 (Barnwell/McBean Aquifers) 
Figure 31. Potentiometric Surface Map Aquifer Unit IIA (Congaree Aquifer) 
Figure 32. Head Difference Between Aquifers $\mathrm{IIB}_{1}$ and $\mathrm{IIB}_{2}$ 
Figure 33. Head Difference Between Aquifers IIA and IIB 1 


\section{1) Aquifer Zone IIB 2}

Aquifer zone $\mathrm{IIB}_{2}$ consists of all the saturated strata which lie between the water table and Confining zone $\mathrm{IB}_{1}-\mathrm{IIB}_{2}$. This aquifer is included in the "uppermost aquifer" because it is the first hydrostratigraphic unit which lies beneath the GSA. This zone has a general downward potential into the lower aquifer units. A "water table" map is depicted in Figure 29. A ground water divide occurs at the westerly trending topographic high crossing the MWMF (Figure 3). Ground water to the north of the divide flows toward Upper Three Runs Creek. To the south of the divide, ground water flows south toward Fourmile Branch. The F and H Area Seepage Basins are located south of the ground water divide. Horizontal flow in Aquifer Zone $\mathrm{IIB}_{2}$ at the seepage basins flows toward and outcrops into Fourmile Branch and the wetlands adjacent to the creek. Water table elevations in the GSA range from 199.5 feet near Fourmile Branch to 266 feet above msl at well P-27 (Figure 29). Natural recharge to the water table is from percolation of rainwater. Mounding resulting from excessive local recharge due to water in the seepage basins is evident beneath the basins in both $\mathrm{F}$ and $\mathrm{H}$ Areas. The steepest hydraulic gradients in the water table are observed between H Area Seepage Basins and Fourmile Branch.

The vertical component for the flow of water in the water table is downward across Confining Zone IIB 1 -IIB 2 into Aquifer Zone IIB 1 (Table 7). Confining Zone IIB 1 -IIB 2 is a leaky aquitard. The degree of leakage across the confining zone is variable. Leakage depends on the magnitude of the head difference accoss the confining zone and the local competency of the confining unit. Figure 32 indicates the head differences across the Coniining Zone $\mathrm{IIB}_{1}-\mathrm{IIB}_{2}$. The lateral variability in the sediments that make up the confiring zone and offset from faulting which breaches the confining unit at both the $\mathrm{F}$ and $\mathrm{H}$ Area Seepage Basins, provide the preferential pathways for the vertical migration of water and chemical constituents. 
TABLE 7

HEAD DIFFERENCE BETWEEN

AQUIFER ZONE IIB 2 (WATER TABLE AQUIFER) AND AQUIFER ZONE IIB 1 (BARNWELL/MCBEAN AQUIFERS)

\begin{tabular}{|c|c|c|c|}
\hline $\begin{array}{l}\text { Well } \\
\text { Cluster }\end{array}$ & $\begin{array}{c}\text { Water } \\
\text { Elevation } \\
{\text { IIB } 2^{2}} \\
\text { (Water Table) }\end{array}$ & $\begin{array}{c}\text { Potentiometric } \\
\text { Surface } \\
\text { IIB }_{1}^{\mathrm{b}} \\
\text { (Barnwell/McBean) }\end{array}$ & $\begin{array}{c}\text { Head } \\
\text { Difference* }\end{array}$ \\
\hline BGO 1D & 237.5 & $\ldots$ & .. \\
\hline BGO 3D & 235.4 & $\ldots$ & $\ldots$ \\
\hline BGO 5C & 231.3 & 215.8 & 15.5 \\
\hline BGO 6A & 231.4 & 219.5 & 11.9 \\
\hline BGO 8A & 231.7 & 222.3 & 9.4 \\
\hline BGO 10 & DRY & .. & $\ldots$ \\
\hline BGO 12 & 229.4 & 219.7 & 9.7 \\
\hline BGO 14 & DRY & -- & $\cdots$ \\
\hline BGO 16 & 229.7 & $\cdots$ & $\ldots$ \\
\hline BGO 18 & 231.0 & - & $\ldots$ \\
\hline BGO 21 & 233.9 & $\ldots$ & $\ldots$ \\
\hline BGO 23 & 235.3 & -- & -- \\
\hline BGO 25 & $\cdots$ & -- & - - \\
\hline BGO 26 & 225.7 & -- & - \\
\hline BGO 27 & 225.5 & $\cdots$ & - \\
\hline BGO 29 & $\cdots$ & - & - \\
\hline BGO 30 & 223.6 & 219.1 & 4.5 \\
\hline BGO 31 & 224.6 & - & $\cdots$ \\
\hline BGO 33 & 227.9 & 223.5 & 4.4 \\
\hline BGO 35 & 232.2 & 227.6 & 4.6 \\
\hline BGO 37 & 235.1 & 228.8 & 6.3 \\
\hline DRB 4 & - & -. & $\ldots$ \\
\hline FSB 76 & $\cdots$ & 211.1 & -- \\
\hline FSB 77 & 211.0 & $\cdots$ & $\ldots$ \\
\hline FSB 78 & 207.4 & 206.3 & 1.1 \\
\hline FSB 79 & 201.6 & 196.4 & 5.2 \\
\hline FSB 87 & $\cdots$ & 207.0 & $\ldots$ \\
\hline FSB 88 & 214.0 & 210.5 & 3.5 \\
\hline FSB 89 & 213.0 & 209.3 & 3.7 \\
\hline FSB 90 & 212.0 & 208.8 & 3.2 \\
\hline FSB 91 & 211.2 & 208.8 & 2.4 \\
\hline FSB 92 & 210.0 & $\cdots$ & $\cdots$ \\
\hline FSB 93 & 209.1 & 206.9 & 2.2 \\
\hline FSB 94 & & $\cdots$ & $\cdots$ \\
\hline FSB 95 & 208.3 & 205.3 & 3.0 \\
\hline FSB 96 & - & $\ldots$ & $\ldots$ \\
\hline FSB 97 & 209.0 & 206.2 & 2.8 \\
\hline FSB 98 & 209.9 & 206.7 & 3.2 \\
\hline FSB 99 & 2108 & 207.4 & 3.4 \\
\hline FSB 100 & $\ldots$ & - & $\ldots$ \\
\hline FSB 101 & - - & - & $\ldots$ \\
\hline FSB 102 & - & 195.0 & $\ldots$ \\
\hline FSB 103 & - & 201.2 & $\ldots$ \\
\hline
\end{tabular}


TABLE 7

HEAD DIFFERENCE BETWEEN

AQUIFER ZONE IIB 2 (WATER TABLE AQUIFER)

AND AQUIFER ZONE IIB 1 (BARNWELL/MCBEAN AQUIFERS) (Continued)

\begin{tabular}{|c|c|c|c|}
\hline $\begin{array}{l}\text { Well } \\
\text { Cluster }\end{array}$ & $\begin{array}{c}\text { Water } \\
\text { Elevation } \\
\operatorname{IIB}_{2}{ }^{\mathrm{a}} \\
\text { (Water Table) }\end{array}$ & $\begin{array}{c}\text { Potentiometric } \\
\text { Surface } \\
\text { IIB }_{1}{ }^{b} \\
\text { (Barnwell/McBean) }\end{array}$ & $\begin{array}{c}\text { Head } \\
\text { Difference* }\end{array}$ \\
\hline FSB 104 & 203.1 & 199.5 & 3.6 \\
\hline FSB 105 & 208.5 & 205.3 & 3.2 \\
\hline FSB 106 & -. & 201.0 & 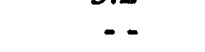 \\
\hline FSB 107 & 211.5 & 208.5 & 3.0 \\
\hline FSB 108 & 215.0 & -. & $\therefore$ \\
\hline FSB 109 & 211.3 & $\ldots$ & . \\
\hline FSB 110 & 204.2 & 200.3 & 3.9 \\
\hline FSB 111 & 212.9 & 210.1 & 2.8 \\
\hline FSB TA & - & - & $\ldots$ \\
\hline $\mathrm{HC} 12 \mathrm{~A}$ & - & $\ldots$ & $\ldots$ \\
\hline HPT 1A & $\ldots$ & $\ldots$ & $\ldots$ \\
\hline HPT $2 A$ & $\cdots$ & $\cdots$ & .. \\
\hline HPC 1 & - & $\ldots$ & - \\
\hline HSB 65 & $\ldots$ & - & - \\
\hline HSB 66 & $\ldots$ & - & - \\
\hline HSB 67 & 224.5 & - & - \\
\hline HSB 68 & - & 217.4 & $\ldots$ \\
\hline HSB 69 & 219.6 & - & $\ldots$ \\
\hline HSB 70 & 225.4 & 224.0 & 1.4 \\
\hline HSB 71 & 225.1 & 223.0 & 2.1 \\
\hline HSB 83 & 226.0 & 224.0 & 2.0 \\
\hline HSB 84 & 219.0 & 213.7 & 5.3 \\
\hline HSB 85 & - & 237.5 & $\ldots$ \\
\hline HSB 86 & - - & -. & - \\
\hline HSB 100 & 232.2 & 226.0 & 6.6 \\
\hline HSB 101 & 229.5 & 224.4 & 5.1 \\
\hline HSB 102 & 228.0 & 223.5 & 4.5 \\
\hline HSB 103 & 225.4 & 223.0 & 2.4 \\
\hline HSB 104 & 225.5 & 220.0 & 5.5 \\
\hline HSB 105 & 225.4 & 219.2 & 6.2 \\
\hline HSB 106 & 225.4 & 221.1 & 4.3 \\
\hline HSB 107 & 224.2 & 219.2 & 5.0 \\
\hline HSB 108 & 223.1 & 218.0 & 5.1 \\
\hline HSB 109 & 222.4 & 218.3 & 4.1 \\
\hline HSB 110 & 222.0 & 219.0 & 3.0 \\
\hline HSB 111 & 221.9 & 220.1 & 1.8 \\
\hline HSB 112 & 221.8 & 221.5 & 0.3 \\
\hline HSB 113 & 222.7 & 221.8 & 0.9 \\
\hline HSB 114 & 223.5 & 223.5 & $\therefore$ \\
\hline HSB 115 & 224.0 & 224.0 & - \\
\hline HSB 116 & 225.7 & 225.2 & 0.5 \\
\hline
\end{tabular}

TABLE 7 


\section{HEAD DIFFERENCE BETWEEN \\ AQUIFER ZONE IIB 2 (WATER TABLE AQUIFER) \\ AND AQUIFER ZONE IIB 1 (BARNWELL/McBEAN AQUIFERS) (Continued)}

\begin{tabular}{|c|c|c|c|}
\hline $\begin{array}{l}\text { Well } \\
\text { Cluster }\end{array}$ & $\begin{array}{c}\text { Water } \\
\text { Elevation } \\
\text { IIB }_{2}{ }^{\mathrm{a}} \\
\text { (Water Table) }\end{array}$ & $\begin{array}{c}\text { Potentiometric } \\
\text { Surface } \\
\text { IIB }_{1}^{\mathbf{b}} \\
\text { (Barnwell/McBean) }\end{array}$ & $\begin{array}{c}\text { Head } \\
\text { Difference* }\end{array}$ \\
\hline HSB 117 & 225.0 & 221.7 & 3.3 \\
\hline HSB 118 & - & -. & $\ldots$ \\
\hline HSB 119 & $\cdots$ & $\cdots$ & -- \\
\hline HSB 120 & $\ldots$ & $\ldots$ & -. \\
\hline HSB 121 & $\cdots$ & $\cdots$ & $\cdots$ \\
\hline HSB 122 & $\ldots$ & - & $\ldots$ \\
\hline HSB 123 & - - & $\ldots$ & - - \\
\hline HSB 124 & $\cdots$ & - & $\cdots$ \\
\hline HSB 125 & $\ldots$ & $\ldots$ & $\ldots$ \\
\hline HSB 126 & 205.7 & 203.6 & 2.1 \\
\hline HSB 127 & 218.6 & 209.7 & 8.9 \\
\hline HSB 129 & 208.7 & 205.5 & 3.2 \\
\hline HSB 130 & 200.0 & $\ldots$ & $\ldots$ \\
\hline HSB 131 & 206.0 & 203.2 & 2.8 \\
\hline HSB 132 & $\ldots$ & -. & $\ldots$ \\
\hline HSB 133 & 234.0 & 229.3 & 1.7 \\
\hline HSB 134 & 222.0 & 220.3 & 1.7 \\
\hline HSB 135 & 218.1 & 206.0 & 12.1 \\
\hline HSB 136 & 220.8 & 217.1 & 3.7 \\
\hline HSB 137 & 222.6 & 220.5 & 2.1 \\
\hline HSB 138 & 223.3 & $\cdots$ & $\ldots$ \\
\hline HSB 139 & 223.3 & 214.2 & 9.1 \\
\hline ISB TB & -. & - & $\ldots$ \\
\hline IDL 3A & - & - & $\ldots$ \\
\hline P18 TA & 219.0 & . - & $\ldots$ \\
\hline P27 TA & 265.9 & 240.0 & 25.9 \\
\hline $\mathrm{P} 28 \mathrm{TA}$ & 222.0 & 213.6 & 8.4 \\
\hline
\end{tabular}

NOTES:

$\begin{array}{lll}\text { 1. } & \text { DRY } & \text { Dry weii } \\ \text { 2. } & -- & \text { Not applicable } \\ \text { 3. } & * & \text { Head difference calculated from fourth quarter } 1989 \text { data } \\ \text { 4. a } & \text { Elevation of Aquifer zone } \mathrm{IB}_{2} \text { (Water Table Aquifer) } \\ \text { 5. } & \text { b } & \begin{array}{l}\text { Potentiometric surface of Aquifer zone } \mathrm{IIB}_{1} \\ \text { (Barnwell/McBean Aquifers) }\end{array}\end{array}$


Hydraulic conductivity estimates for this aquifer zone are based on slug tests, sieve analyses, and pumping tests. Slug tests have been performed on many of the water table wells installed since 1986. The values for the 60 slug tests performed range from a high of 45.40 to a low 0.05 feet per day. The arithmetic means were calculated at each of the three areas: MWMF, F Area Basins, and H Area Basins. The calculated hydraulic conductivities are:

1. MWMF -2.35 feet/day, $n=17$. Range: 0.10 to 15.15 feet/day.

2. F Area Seepage Basins -2.78 feet/day, $n=15$. Range: 0.05 to 23.11 feet/day.

3. H Area Seepage Basins $-10.64 \mathrm{feet} / \mathrm{day}, \mathrm{n}=28$. Range 0.08 to $45.40 \mathrm{feet} / \mathrm{day}$.

The arithmetic mean for the complete dataset (60 values) is $5.26 \mathrm{feet} /$ day.

Two series of single well pumping tests have been performed on Aquifer zone IIB 2 . Parizek and Root (1986) conducted thirty-eight single well pump tests in the vicinity of the GSA. Hydraulic conductivity values calculated from these tests were reported to range from 0.30 to $3.6 \mathrm{feet} /$ day with a median value of 0.61 feet/day. A more recent series of tests were performed by Evans (work in progress) which produced values much higher than the highest value of 3.6 feet/day from the Parizek and Root study of 1986.

Sieve analyses are routinely performed on samples of materials nbtained from the screened zones of the wells installed for RCRA monitoring. The grain-size analyses have been used to estimate hydraulic conductivity with the Beard and Weyl method, 1973. The values were compiled and arithmetic means were calculated at each of the three areas: MWMF, F Area Basins, and H Area Basins. he means and basis for the calculations are presented by facility as follows: 
1. $M W M F-123$ feet/day, $n=5$. Range: 27 to 315 feet/day.

2. F Area Seepage Basins -163 feet/day, $n=7$. Range: 55 to 479 feet/day.

3. H Area Seepage Basins -84 feet/day, $n=8$. Range 13 to 149 feet/day.

The mean of the complete dataset is 123 feet/day, $n=20$, the values range from 13 to 479 feet/day (Thayer, et al., 1990). The method gives elevated estimates of hydraulic conductivity, eg. slug test results for the interval range from .05-45 ft/day, the pump tests $.3-3.6 \mathrm{ft} /$ day.

\section{2) Aquifer Zone IIB}

Aquifer zone IIB 1 consists of all saturated strata which lie between Confining zone $\mathrm{IIB}_{1}-\mathrm{IIB}_{2}$ and Confining Unit IIA-IIB. This zone is poorly confined and included in the "uppermost aquifer" because it is recharged primarily by downward flow from Aquifer zone $\mathrm{IB}_{2}$ above.

The groundwater divide also exists in Aquifer zone $\mathrm{IIB}_{1}$. Horizontal flow in this aquifer zone is south toward Fourmile Branch in the vicinity of the F and H Area Seepage Basins (Figure 30). Measured water elevations in the GSA range from 195 to 240 feet above mean sea level (msl). The hydraulic gradient in this zone is steepest between the $\mathrm{H}$ Area Seepage Basins and Fourmile Branch. The recharge to this unit is from leakage through Confining zone $\mathrm{IBB}_{1}-\mathrm{IIB}_{2}$.

The vertical component of flow in Aquifer zone IIB $_{1}$ is downward across the Confining Unit IIAIIB into Aquifer Unit IIA. Confining Unit IIA-IIB is more competent than Confining Zone IIB 1$\mathrm{IIB}_{2}$, but there is evidence of leakage where the clay beds thin and are discontinous and where the clays have been breached by slump features. Head differences across Confining Unit IIA-IIB are illustrated on Figure 33 and Table 8. 
Hydraulic conductivity estimates for Aquifer zone $\Pi_{1} B_{1}$ are based on slug tests, sieve analyses, and pumping tests. The range in the values for the 46 slug tests performed is from a high of 136.0 to a low of 0.13 feet per day (Sirrine, 1987, 1988; S\&ME, 1988 a,b). The arithmetic means were calculated at each of the three areas: MWMF, F Area Seepage Basins, and H Area Seepage Basins. Arithmetic means of the test results were calculated and are presented by facility as follows:

1. MWMF - 1.01 feet/day, $n=3$. Range: 0.13 to 1.51 feet/day.

2. F Area Seepage Basins $-3.97 \mathrm{feet} /$ day, $n=16$. Range: 0.14 to 24.03 feet/day.

3. H Area Seepage Basins -12.92 feet/day, $n=27$. Range 0.25 to 136.10 feet/day.

Parizek and Root (1986) conducted a series of 51 single-well pump tests from wells screened in Aquifer zone $\mathrm{IIB}_{1}$ in and around the GSA. Hydraulic conductivity values as reported from the tests range from 0.17 feet/day to 2.6 feet/day with a median value of 0.90 feet/day.

Sieve analyses are routinely performed on samples of materials obtained from the screened zones of the wells installed for RCRA monitoring. The grain-size analyses have been used to estimate hydraulic conductivity using the Beard and Weyl Method, 1973. The values were compiled and arithmetic means were calculated at each of the three areas: MWMF, F Area Seepage Basins, and $\mathrm{H}$ Area Seepage Basins. The means and basis for the calculations are presented by facility as follows:

1. MWMF - 110 feet/day, $n=4$. Range: 37 to 192 feet/day.

2. F Area Seepage Basins - 199 feet/day, $n=11$. Range: 90 to 397 feet/day.

3. H Area Seepage Basins - 271 feet/day, $n=2$. Range 185 to 357 feet/day. 
TABLE 8

HEAD DIFFERENCE BETWEEN

AQUIFER ZONE IIB 1 (BARNWELL/MCBEAN AQUIFERS) AND AQUIFER UNIT IIA (CONGAREE AQUIFER)

\begin{tabular}{|c|c|c|c|}
\hline $\begin{array}{l}\text { Well } \\
\text { Cluster }\end{array}$ & $\begin{array}{c}\text { Potentiometric } \\
\text { Surface } \\
\text { Aquifer Zone IIB } 1 \\
\text { (Barnwell/McBean) }\end{array}$ & $\begin{array}{l}\text { Potentiometric } \\
\text { Surface } \\
\text { Aquifer Unit IIA } \\
\text { (Congaree) }\end{array}$ & $\begin{array}{c}\text { Head } \\
\text { Difference* }\end{array}$ \\
\hline BGO 6 & 219.5 & 158.1 & 61.4 \\
\hline BGO 8 & 222.3 & 160.5 & 61.8 \\
\hline BGO 10 & 219.3 & 168.5 & 50.8 \\
\hline BGO 12 & 219.7 & 180.0 & 39.7 \\
\hline BGO 14 & 221.7 & 157.3 & 64.4 \\
\hline BGO 16 & - & 159.6 & - \\
\hline BGO 18 & - & 159.7 & $\ldots$ \\
\hline BGO 25 & - & 158.8 & $\cdots$ \\
\hline BGO 26 & - & - & $\cdots$ \\
\hline BGO 29 & $\ldots$ & $\cdots$ & -- \\
\hline DRB 4 & $\ldots$ & - & $\cdots$ \\
\hline FSB 76 & 214.7 & 154.3 & 60.4 \\
\hline FSB 78 & 208.1 & 155.1 & 53.0 \\
\hline FSB 79 & 196.2 & 156.4 & 39.8 \\
\hline FSB 87 & 209.7 & 152.9 & 56.8 \\
\hline FSB 96 & - & 152.3 & $=$ \\
\hline FSB 97 & 206.2 & 151.1 & 55.1 \\
\hline FSB 98 & 206.7 & 150.3 & 56.4 \\
\hline FSB 99 & 207.4 & 149.7 & 57.7 \\
\hline FSB 100 & - & 150.6 & $\cdots$ \\
\hline FSB 101 & -- & 150.8 & $\ldots$ \\
\hline FSB TA & - & - & -- \\
\hline HPT $1 \mathrm{~A}$ & - & $\cdots$ & -- \\
\hline HPT $2 A$ & $\ldots$ & - & -- \\
\hline HPC 1 & -. & - & - \\
\hline HSB 65 & 231.3 & 169.8 & 61.5 \\
\hline HSB 68 & 217.4 & 169.9 & 47.5 \\
\hline HSB 69 & -- & 170.3 & - \\
\hline HSB 83 & 226.0 & 171.4 & 54.6 \\
\hline HSB 84 & 220.8 & 170.1 & 50.7 \\
\hline HSB 85 & 207.6 & 167.3 & 40.3 \\
\hline HSB 86 & 231.6 & 166.8 & 64.8 \\
\hline HSB 117 & 221.7 & 164.6 & 57.1 \\
\hline HSB 118 & - & 166.0 & - \\
\hline HSB 119 & - & 165.2 & - \\
\hline
\end{tabular}


TABLE 8

HEAD DIFFERENCE BETWEEN

AQUIFER ZONE IIB 1 (BARNWELL/MCBEAN AQUIFERS)

AND AQUIFER UNIT IIA (CONGAREE AQUIFER) (Continued)

\begin{tabular}{|c|c|c|c|c|}
\hline $\begin{array}{l}\text { Well } \\
\text { Cluster }\end{array}$ & & $\begin{array}{l}\text { Potentiometric } \\
\text { Surface } \\
\text { Aquifer Zone IIB } 1 \\
\text { (Barnwell/McBean) }\end{array}$ & $\begin{array}{l}\text { Potentiometric } \\
\text { Surface } \\
\text { Aquifer Unit IIA } \\
\text { (Congaree) }\end{array}$ & $\begin{array}{c}\text { Head } \\
\text { Difference* }\end{array}$ \\
\hline $\begin{array}{l}\text { HSB } 120 \\
\text { HSB } 121 \\
\text { HSB } 122 \\
\text { HSB } 123 \\
\text { HSB } 124 \\
\text { HSB } 139 \\
\text { HSB TB } \\
\text { IDL 3 } \\
\text { P18 TA } \\
\text { P27 TA } \\
\text { P28 TA }\end{array}$ & & $\begin{array}{r}-- \\
-- \\
-- \\
-- \\
-- \\
214.5 \\
-- \\
-- \\
-- \\
-- \\
--\end{array}$ & $\begin{array}{r}164.7 \\
170.0 \\
169.7 \\
169.8 \\
192.0 \\
171.7 \\
-- \\
-- \\
-- \\
-- \\
--\end{array}$ & $\begin{array}{r}- \\
- \\
-- \\
- \\
-- \\
42.8 \\
-- \\
-- \\
-- \\
-- \\
-\end{array}$ \\
\hline NOTES: & $\begin{array}{ll}1 . & * \\
2 . & --\end{array}$ & \multicolumn{3}{|c|}{$\begin{array}{l}\text { Head difference calculated from fourth quarter } 1989 \text { data } \\
\text { Not Applicable }\end{array}$} \\
\hline
\end{tabular}


The mean of the overall dataset is 193 feet/day, $n=17$. The values range from a low of 37 to a high of 397 feet/day (Thayer, et al., 1990).

\section{3) Aquifer Unit IIA}

Aquifer Unit IIA consists of all the saturated strata which lie between Confining Unit IIA-IIIB and the Principal Confining Unit, Confining System I-II in the GSA (Figure 12). Aquifer Unit IIA is semi-confined and included in the "uppermost aquifer" because a downward potential from Aquifer zone $\mathrm{IB}_{1}$ exists, providing recharge and indicating interconnection.

Ground water flow in Aquifer Unit IIA is northwest toward Upper Three Runs Creek as depicted in the potentiometric surface map (Figure 31). Fourmile Branch to the south does not incise Confining Unit IIA-IIB and therefore does not influence flow in the underlying Aquifer IIA . Recharge into Aquifer Unit IIA occurs primarily from leakage through Confining Unit IIA-IIB but also from updip flow.

In places where the confining unit is breached by faulting, this recharge may be locally increased. Evidence of this can be seen south of the $\mathrm{H}$ Area Seepage Basins. Perturbations in the equipotential surface (170' contour) of Aquifer Unit IIA (Figure 31) coincide with those in the overlying Aquifer zone $\mathrm{IIB}_{1}$ (Figure 30) and with the location of slumps features, which breach the Confining Unit IIA-IIB. A marked break in the contours of head difference across Confining Unit IIA-IIB in the vicinity of these slump features (Plate 3, Figure 33) is further evidence of localized zones of increased recharge which are controlled by geologic features. Downward flow of water into Aquifer Unit IIA is locally increased. 
Discharge is to Upper Three Runs Creek. Any downward component of flow out of this aquifer unit is believed to be minimal. In most of the GSA, an upward flow potential exists between Aquifer Unit IIA and Aquifer System I across the Confining System I-II.

Hydraulic conductivity estimates for this aquifer unit are based on slug tests, sieve analyses, and pump tests. The range in the values for the 8 slug tests performed is from a high of 12.0 to a low of 0.16 feet per day. Arithmetic means of the slug test results were calculated and are presented by facility as follows:

1. $\mathrm{MWMF}-4.42$ feet/day, $n=3$. Range: 0.50 to 11.98 feet/day.

2. F Area Seepage Basins -0.59 feet/day, $n=2$. Range: 0.33 to 0.85 feet/day.

3. H Area Seepage Basins $-6.98 \mathrm{feet} / \mathrm{day}, \mathrm{n}=3$. Range 0.16 to $12.00 \mathrm{feet} /$ day.

The overall mean of the dataset is 4.42 feet/day, $n=8$ (Sirrine, 1987, $1988 \mathrm{a} \& b ;$ S\&ME, 1988).

Aquifer tests have been performed on wells screened in this unit in many locations on the SRS. The aquifer properties discerned from these tests were compiled by Geotrans (1989). Based upon this review, a high degree of variability was noted in the deduced hydraulic conductivity values. Many of the reported ranges of values were taken from transmissivity estimates obtained from small scale pump tests. The variability is therefore more likely attributable to a variable aquifer thickness than in widely ranging permeability differences.

Values (Geotrans, 1989) used for calibrating a GSA area-wide model (38 feet/day) were in the range of the hydraulic conductivity deduced from a recent pumping test performed on well HSB84A. This test was conducted to gain data relating to aquifer characteristics and ground water chemistry. The test results indicate a range of 30 to $60 \mathrm{feet/day}$ for permeability, and leakage across the Confining System IIA-IIB in this vicinity was suggested (Albenesius, et al., 1990). 
A long duration, multiple well test was conducted for the Aquifer Unit IIA in April 1989 (CH2M Hill, 1989). This test employed a fully penetrating pumping well and multiple observation wells screened in the Aquifer Unit IIA and in the overlying Aquifer zone IIB 1 . The data indicated that in the vicinity of HPT-2A, Aquifer Unit IIA has a transmissivity of $2290 \mathrm{ft}^{2} /$ day and exhibits a barometric efficiency of 25 percent. The permeability is approximately 37.5 feet/day, utilizing an aquifer thickness of 61 feet. The value agrees with the HSB-84 and HSB-84A pump test. However, a greater permeability is suggested in the HSB-84 vicinity as a result of a thinner aquifer. Transmissivities were very similar. Leakage across the Confining Unit IIA-IIB was suggested in both pumping tests.

Sieve analyses were performed on 17 wells screened in Aquifer Unit IIA within the GSA. Estimates of hydraulic conductivity were made fiom the sieve data. The overall arithmetic mean for the dataset is $130 \mathrm{feet} / \mathrm{day}, \mathrm{n}=17$. Arithmetic means were also calculated for each of the HWMF facilities.

1. MWMF - 91 feet/day, $n=7$. Range: 22 to 205 feet/day.

2. F Area Seepage Basins $-176 \mathrm{feet} / \mathrm{day}, \mathrm{n}=5$. Range: 10 to $479 \mathrm{feet} / \mathrm{day}$.

3. H Area Seepage Basins $-106 \mathrm{feet} /$ day, $\mathrm{n}=5$. Range 82 to $167 \mathrm{feet} / \mathrm{day}$.

\section{4) Confining Zone $\mathrm{IIB}_{1}-\mathrm{IB}_{2}$}

Confining zone $\mathrm{IIB}_{1}-\mathrm{IIB}_{2}$ separates Aquifer zone $\mathrm{IB}_{2}$ from Aquifer zone $\mathrm{IIB}_{1}$. This zone is a leaky confining zone. Laboratory analyses of vertical and horizontal permeability were performed on representative undisturbed samples from this zone. The range in the reported vertical permeability measurements is from a low value of $1.9 \times 10^{-5}$ feet/day to a high value of 0.12 
feet/day (Bledsoe, et al., 1990; Atlanta Testing and Engineering, 1987, 1988). The unit weights of these samples varied from a low of $66.1 \mathrm{pcf}$ (pounds per cubic foot) to a high of $106.6 \mathrm{pcf}$. The lower unit weights are indicative of a silty and sandy nature.

\section{5) Confining Unit IIA-IIB}

Confining Unit IIA-IIB separates Aquifer zone IIB $_{1}$ from Aquifer Unit IIA. This unit is more competent that Confining zone $\mathrm{IB}_{1}-\mathrm{IB}_{2}$ but still exhibits leakage. Laboratory analyses of physical characteristics, including horizontal and vertical permeability, were performed on representative undisturbed samples of the clayey portions of Confining Unit IIA-IIB. Nine analyses were performed from wells completed in the GSA. The range in values is from a low of $3.8 \times 10^{-8}$ feet/day to a high of $2.7 \times 10^{-3}$ feet/day. The dry unit weights range from $50.9 \mathrm{pcf}$ to 106.3 pcf. In general, the higher unit weights indicate that Confining Unit IIA-IIB is a dense and compact clay. The lower values result from lighter organic material in some samples of the clay.

\section{6) Confining System I-II}

Confining System I-II, the principal confining unit in the GSA, separates the basal hydrostratigraphic unit, Aquifer Unit IIA of Aquifer System II, from Aquifer System I (Figures 9 and 12). Confining System I-II was penetrated in 15 borings within the study area. The system attains a thickness of over 100 feet in the GSA. (Figure 19). No streams in the study area incise the system.

Vertical and horizontal hydraulic conductivities of the clay and silt beds are very similar in the GSA. Vertical hydraulic conductivities for Confining System I-II range from $7.7 \times 10^{-5}$ feet/day to 
$2.9 \times 10^{-4}$ feet/day. Horizontal hydraulic conductivities from $1.0 \times 10^{-4}$ feet/day to $1.1 \times 10^{-4}$ feet/day (Bledsoe, Aadland, and Sargent, 1990). The consistency of the low conductivity values (vertical and horizontal) support the confining capabilities of this system.

Lithological and geophysical data add additional support to the confining capabilities of this system. Clays and silts are generally very fissile and highly micaceous. The gamma ray curve is very distinct with spikes typical of clays. Resistivity curves support high clay content with a significant drop in resistivity associated with the gamma spikes (Figure 20). The lithological and geophysical characteristics of Confining System I-II are correlative over the entire study area, as illustrated in Cross Sections 1, 2, 3, 4, 5A, and 5B (Plates 1 through 5B).

\section{B. Ground Water Flow in Cross Section}

In order to interpret the effect of lithologic variation on ground water flow in the GSA, equipotential lines were plotted on the GSA regional cross sections (Plates 1 through 5B) and are included in this report as Plates 7, 8, 9, 10A, 10B. Water level data are from the fourth quarter 1989. Flow direction on each cross section is described with respect to plant North.

\section{1) Regional Equipotential Cross Section 1}

Cross Section 1 (Plate 6) represents the 2.4-mile line of section from north of the MWMF to southeast of the $\mathrm{H}$ Area Seepage Basins. The section generally follows the ground water divide noted in the water table surface plan view and Aquifer Zone $\Pi_{1} B_{1}$ (Figure 3). The water table surface slopes from 265 to 230 feet above msl along the length of the section. The slope of the equipotential lines indicates a strong tendency for downward movement. 
The local change in the slope of the equipotential lines in the vicinity of HSB-85 and BGO-6 is due to the orientation of the line of section; the equipotential lines are more perpendicular to flow at this location. Flow potential is downward with a moderate component of lateral flow. This is in response to the maximum 20 feet of head drop observed along the section in the wells screened just above Confining Unit IIA-IIB. Recharge is indicated all along the line of section with a major influence of the primary recharge exhibited in the area between wells P-27 and HC-12.

Ground water flow in the underlying Aquifer Unit IIA is generally east to west; the total head drop along the section length is approximately 15 feet. The line of section roughly parallels the flow in Aquifer Unit IIA. Wells BGO-8A and BGO-10A were not included in this interpretation. These well have been identified as having been improperly constructed; they have yielded anomalous water levels since their installation and are currently being replaced.

\section{2) Regional Equipotential Cross Section 2}

Cross Section 2 (Plate 7) represents the 3.6-mile line of section from north of the F Area Seepage Basins to east-southeast of the H Area Seepage Basins. This is essentially along the regional dip of the GSA and subparallel to the ground water divide through the MWMF. This section line is generally downgradient from the ground water divide evident in the shallow system. Recharge is indicated as occurring primarily from the east to the west with a strong downward potential all along the length of the section. Lateral flow is illustrated, however, in the shallower portions of Aquifer zone $\mathrm{IIB}_{2}$ and the equipotential lines "open" somewhat between HSB-117 and DRB-4, possibly in response to some additional recharge. The ground water mound depicted in the thickness of the saturated water table (Figure 29) apparently corresponds to the recharge. Overall, 
the Aquifer zone $\mathrm{IB}_{1}$ and $\mathrm{IB}_{2}$ reveal strong recharge from the vicinity of $\mathrm{P}-27$, with a predominant downward flow potential and an indication of a prevalent lateral tendency for flow further to the west.

Underlying the shallow Aquifer zone $\mathrm{IIB}_{1}$ and $\mathrm{IIB}_{2}$ is Aquifer Unit IIA. It reveals lateral flow from east to west with a total drop in head from 175 feet to 155 feet above msl. Toward the west beneath the F Area Seepage Basins the lines of equipotential in Aquifer Unit ILA bend in response to an upward potential for flow observed between the upper and lower portions of the aquifer. This tendency has been observed in the historical water level record in limited areas within the GSA, generally in close proximity to Upper Three Runs Creek. The upward tendency may be attributed to the head or pressure relief in UTRC or to localized permeability differences.

\section{3) Regional Equipotential Cross Section 3}

Cross Section 3 (Plate 8) represents the 2.7-mile line of section from northeast of the F Arca Seepage Basins to south-southwest of the basins. The section roughly follows the regional strike. Recharge is indicated all along the line of section. Ground water flow is indicated to have a stronger lateral component for Aquifer zone $\mathrm{IIB}_{2}$ than in the underlying Aquifer zone $\mathrm{IIB}_{1}$. The subtle mound can be discerned around the 210-foot equipotential line that is likely attributable to some residual recharge from the inactive seepage basins. The equipotential lines become more closely spaced from FSB-91 to the south, as Fourmile Branch (the discharge point for the Water Table Aquifer) is approached. No apparent effects of the offset drawn between the wells FSB-100 and FSB-91 is perceived in the equipotential lines in this orientation and scale.

Beneath Confining Unit IIA-IIB, Aquifer Unit IIA is flowing generally updip in a northwesterly direction towards UTRC. The stronger component of flow in Aquifer Unit IIA illustrated in this 
section, is perpendicular to the regional strike of the section. The equipotential line, 155 feet above msl, is contorted in response to the upward potential for flow existing between the upper and lower portions of Aquifer Unit IIA in this portion of the GSA.

\section{4) Regional Equipotential Cross Section 4}

Cross Section 4 (Plate 9) represents the 1.3-mile line of section from northeast of the MWMF to the south-southeast of the H Area Seepage Basins. The section roughly follows the regional strike. Similar to the orientation of Cross Section 3, recharge is occurring all along the line of section with potential for ground water flow from the north to south. Between BGO-6 and BGO35 , the line of cross section parallels the equipotential lines and is therefore perpendicular to the direction of ground water flow. In this part of the se tion a dominant tendency for vertical flow can be discerned. From BGO-35 to the south, the vis. section line crosses the equipotential lines (in plan view) and becomes parallel to the ground water flow direction. Here, the equipotential lines indicate a stronger tendency for lateral flow. In the vicinity of HSB-116, HSB-115, and HSB-86, each of the wells screened above and below the Confining zone $\mathrm{IIB}_{1}-\mathrm{IIB}_{2}$ have essentially identical pressures. No head difference is present and lateral flow tendencies predominate in this area. Moving south towards Fourmile Branch, the shallower water table zone equipotentials are affected $b$ proximiting to the creek, causing pressure relief and flow towards the creek. The underlying Aquifer zone $\mathrm{IIB}_{1}$ appears only slightly affected by the proximity of the creek, and the possibility of some localized underflow is indicated within the floodplain.

Beneath Confining Unit IIA-IIB, water in Aquifer Unit IIA is flowing generally transverse to this line of the section west to northwest towards UTRC. However, the pressure drop is exhibited as lateral flow occurring generally in a north to northwest direction (Figure 31). 


\section{5) Regional Equipotential Cross Sections 5A anc' iB}

Cross Sections 5A and 5B (Plates 10A and 10B) represent the 2.3-mile long east-west line of section from east of the MWMF to the western edge of the F Area Seepage Basins. The discussion of the equipotential lines for these sections will be treated as one single line of section. Recharging conditions are indicated all along the $5 \mathrm{~A} / 5 \mathrm{~B}$ line of cross section. The $5 \mathrm{~A}$ portion of the sectional line is located just to the north of the ground water divide through the GSA and therefore downgradient of the divide on the north side (Figure 3). Little control is available for the construction of equipotentials further to the east of BGO-5 along Cross Section 5A, but there appears to be a change in the pressure relationship associated with the line of offset depicted near

BGO-5. The offset is a single fault essentially parallel to the line of cross section (Figure 16). The bend in the line of Cross Section 5A causes the line of section to intersect the fault twice. Generally the equipotentials in this area indicate recharging conditions. Although the potential for lateral flow is evident, the major component of flow is perpendicular to the line of section, i.e., to the north and northwest.

BGO-14 and BGO-25 represent the midpoint of the line of cross section (Figure 16). The orientation of the equipotentials in this area remains fairly constant indicating recharging conditions with a prevalent vertical potential. As the transition is made from the high ground in the MWMF (along the northeast side of Cross Section 5B) the equipotentials curve more toward the vertical, indicating a stronger component of lateral flow. At the southwest end of Cross Section 5B, the 210-foot line of equipotential bends in response to an area of increased recharge. This recharge is apparently caused by the F Area Seepage Basins. Along the length of Cross Section 5B the drop in head in a westerly to southwesterly direction is slightly more than 15 feet.

In the underlying Aquifer Unit IIA the initial portions of the Cross Section 5A proceeding from east to west are actually found to fall between the contoured piezometric levels of 155 to 160 feet 
above msl. Additionally, thize of the wells screened in this zone (BGO-8A, BGD-10A, and BGO12A) produce anomalous warter levels and were not incorporated into the dataset. As a result, no equipotential lines are produced for the $5 \mathrm{~A}$ portion of Cross Section 5 for Aquifer Unit IIA.

Near the matchline between Cross Sections 5A and 5B, the line of section turns to the south the resulting water levels, in profile, are subparallel to the potentiometric lines, and the flow is therefore perpendicular to the cross sectional line or to the north towards UTRC. Approaching the F Area Seepage Basins to the west, equipotentials indicate lateral flow towards the west $d$ directly beneath the Seepage Basin F-3. Near FSB-99 the equipotential lines strongly converge, indicating lateral flow to the north-ncxtheast towards UTRC.

\section{Vertical Head Relationships}

The uppermost aquifers beneath the GSA are comprised of three waterbearing units separated by two leaky aquitards. The shallowest waterbearing zone, Aquifer zone $\mathrm{IIB}_{2}$, overlies the poorly confined Aquifer zone $\Pi_{1}$, which in turn overlies Aquifer Unit $\Pi A$. The pressure relationships in general are downward from Aquifer zone $\mathrm{IIB}_{2}$ to Aquifer zone $\mathrm{IIB}_{1}$ down into Aquifer Unit IIA. Maps of the pressure differences were prepared on a scale where $1 "=1000$ feet for the GSA. These differences were then contoured in order to evaluate the pressure relationships throughout the GSA.

1) Head Differences Across Confining $Z_{\text {one }} \Pi_{1 B}{ }_{1} I_{1 B}$

The differences in the elevations of the water table surface and the potentiometric surface of Aquifer zone IIB 1 were plotted spatially and contoured utilizing a 5-foot contour interval (Figure 32). Confining zone $\mathrm{IIB}_{1}-\mathrm{IIB}_{2}$ supports an average head difference of 5 to 10 feet. The overall 
study area contains localized areas of more than 25 feet of head difference to areas of no head difference. The head difference indicates that Aquifer Zones $\mathrm{IIB}_{1}$ and $\mathrm{IIB}_{2}$ are not in complete hydraulic communication. However, the zones are considered generally connected and the head difference is dow riward from Aquifer Zone $\mathrm{IIB}_{2}$ to Aquifer Zone $\mathrm{IIB}_{1}$.

The areas contoured with average head differences ( 5 to 10 feet) attest to the general low permeability of the confining materials and the evidence of the response to recharge to the water table. The map illustrates two large areas of no head difference. These areas are located just east of the MWMF and northwest of the F Area Seepage Basins. These areas are associated with an absence of Confining zone $\mathrm{IIB}_{1}-\mathrm{IIB}_{2}$ as previously discussed. Additionally, the area with no observed head difference near IDL-3 is also associated with a large roadcut and valley slope down to Upper Three Runs Creek.

No zones of "0" head difference are evident around the F Area Seepage Basins. However, in the vicinity of H Area Seepage Basins, four localized areas of no head difference are observed. Of these four areas, only the one found near HSB-124 and HSB-123 appears to be related to the absence of the underlying confining unit. Just south (downgradient) of the Basin H-4 a small area of high head difference which may be related to the offset in the sediments observed is noted.

In the subsurface database, 46 points were available for the determination of the difference in head across the Confining $\mathrm{Zone}_{\mathrm{IIB}}-\mathrm{IIB}_{2}$. At these locations the thickness of the confining unit is also known. The head difference divided by the thickness of the unit produces a gradient in feet of head difference per foot of clay, which can be used to further evaluate the head differentials. The arithmetic mean of the gradient calculation is 0.5 feet per foot. The coefficient of variation of these values is high, approaching 120 percent, indicating an extreme range in the values. This occurrence is primarily due to the range of the head differences and the variable thickness of the confining unit. 


\section{2) Head Differences Across Confining Zone IIA-IIB}

A map of the differences in head observed from the wells in the GSA completed above and below Confining Unit IIf. - IIB was prepared in a fashion similar to the head difference map for Confining Zone $\mathrm{IB}_{1}-\mathrm{IIB}_{2}$ (Figure 33). The map illustrates a ridge of maximum head difference across the GSA trending in an east-west direction. The largest head difference ( $66.2 \mathrm{feet})$ is noted at the northwest boundary of the study area at cluster FC-1. The lowest head difference was 39.8 feet occurring at cluster FSB-79. The lines of equal head difference, as contoured in the vicinity of the $\mathrm{H}$ Basins, indicate an increase beneath the basins tending in a general north-south direction. This area corresponds to the largest calcareous body situated in the lower calcareous zone. The response may be related to the localized high permeability suspected for these materials based on the drilling notes and slug tests values.

The differences in head at each cluster location were divided by the associated thickness of the Confining Unit IIA-IIB. The resulting value is a gradient calculated in feet per foot of the loss in pressure across the clay materials comprising the confining unit. This value is a reasonable estimate of the confining capability of the unit expressed in a relative sense throughout the GSA. The subsurface database contains 20 values available for analysis of the relative head loss across this clay boundary. The mean of the data is 9.4 feet per foot with a coefficient of variation of 71 percent, indicating that the data are very consistent throughout the GSA.

\section{3) Head Relationships Between the Cretaceous and Tertiary Aquifers}

The contact of the Confining System I-II with the underlying unit (Aquifer System I) is marked by an erosional unconformity representing Cretaceous-age sediments overlain with Tertiary-age sediments. In the GSA the ground water in the Cretaceous sediments is under higher pressure than 
in Aquifer Unit IIA that overlies Confining System I-II. This was first discovered from prelimiriary subsurface reconnaissance work undertaken by the Corps of Engineers (1952).

The upward pressure gradient across the Tertiary/Cretaceous boundary has been recognized in the GSA since the 1960s with the maps prepared by Reichart (1969). Later, Marine (1983) plotted water elevations of the aquifers above and below Confining System I-II and concluded that the underlying upper Cretaceous Aquifer (Aquifer Unit IB) in this report (Figure 15) has a potentiometric surface some 10 feet above the potentiometric surface of the Tertiary-age Aquifer Unit IIA within some portions of the SRS.

Since 1981 ground water development on the SRS has increased as many facilities converted from surface water to ground water and additional facilities have been constructed. Ground water usage has almost doubled (Stephenson and Steele, 1988). These demands, coupled with increased offtake from downdip municipal pumpa re, has produced a measurable effect of the head relationships between Aquifer System $1:$ Aquifer Unit IIA on site. Although the upward pressure gradient has been observed to decline and the unity line between the aquifers has wandered somewhat with time, the upward pressure gradien has been found to be persistent beneath the $\mathrm{F}$ and $\mathrm{H}$ Area Seepage Basins.

Within the GSA the upward pressure gradient ranges from 0 to $20+$ feet. An updated version of the pressure gradien map between Aquifer System I and Aquifer System II has been prepared from fourth quarter 1989 data and is presented as Figure 34 (Bledsoe, personal communication, 1990). Historical data indicate that the upward pressure gradien has remained essentially constant since 1988. 
Figure 34. Head Difference Between Aquifer Unit IB of Aquifer System I and Aquifer II of Aquifer System II 


\section{REFERENCES}

Aadland, R. K., and H. W. Bledsoe, "Classification of Hydrostratigraphic Units at Savannah River Site, South Carolina." Savannah River Laboratory, WSRC-RP-90-987, Westinghouse Savannah River Company, Aiken, S.C. (1990).

Albenesius, P. W., M. B. Amidon, and T. F. Gaughan, "HSB 84A Pumping Test." Waste Management Technology, WSRC-TR-90-313, Westinghouss Savannah River Company, Aiken, S. C. (1990).

Baars, D. L., 1963, Petrology of Carbonate Rocks: in. Bass, R. O. ed., Shelf Carbonates of the Paradox Basin; A Symposium: Fourth Field Conference: Four Corners Geological Society, pp. 101-129.

Beard, D. C., and P. K. Weyl. "Influence of Texture on Porosity and Permeability of Unconsolidated Sand." American Association of Petroleum Geologists; Vol. 57 No. 2. (1973).

Bledsoe, H. W., R. K. Aadland, and K. S. Sargent, "SRS Baseline Hydrogeologic Investigations Summary Report." Savarnah River Site, Savannah River Laboratory, WSRC-RP-90-1010Westinghouse Savannah River Company, Aiken, S. C. (1990).

Bledsoe, H. W., Personal Communication, (1990).

$\mathrm{CH}_{2} \mathrm{M}$ Hill, "Congaree Aquifer Test." Savannah River Site, (1989).

Colquhoun, D. J., I. D. Woollen, D. S. Van Nieuwenhuise, G. G. Padgett, R. W. Oldham, D. C. Boylan, J. W. Bishop, and P. D. Howell. "Surface and Subsurface Stratigraphy, Structure and 
Aquifers of the South Carolina Coastal Plain." Report for Department of Health and Environmental Control, Ground Water Protection Division, published through the Office of the Governor, State of South Carolina, Columbia (1983).

Christensen, E. J. and D. E. Gordon, "Technical Summary of Groundwater Quality Protection Psogram at Savannah River Plant." Vol. I, Site Geohydrology and Solid and Hazardous Wastes; DPST-83-929. E. I. du Pont de Nemours \& Company, Savannah River Laboratory, Aiken, S. C. (1983).

Colquhoun, D. J., and H. S. Johnson, Jr. "Tertiary Sea-Level Fluctuation in South Carolina." Palaeogeography, Palaeoclimatology, Palaeoecology, v. 5, pp. 105-126 (1968).

Colquhoun, D. J., and K. B. Steele, "Chronostratigraphy and hydrostratigraphy of the northwestern South Carolina Coastal Plain": Project No: G868-05, Annual Cooperative Grant Agreement Nol 13040 R-83-591, Interim Technical Report to Water Resources Research Institute, Clemson University, Clemson, South Carolina, 15 p (1985).

Cooke, C. Wr. "Geology of the Coastal Plain of South Carolina." U. S. Geological Survey Bulletin 867 (1936).

Cooke, C. W., and F. S. MacNeil, "Tertiary Stratigraphy of South Carolina": U.S. Geological Survey Progessional Paper 243-B, p. 19-29 (1952).

Cramer, H. R., and D. D. Arden, Jr. "Faults in Oligocene Rocks of the Georgia Coastal Plain." Geological Society of America Abstracts with Programs, Southeast Section, v. 10, p. 166 (1978). 
Dennehy, K. F., D. C. Prowell, and P. B. McMahon "Reconnaissance Hydrogeologic Investigation of the Defense Waste Processing Facility and Vicinity." Savannah River Flant South Carolina, U. S. Geological Survey, Water Resources Investigations Report 88-4221, 74 pp (1989).

Doering, J. A. "Quaternary Surface Formations of Southern Part of Atlantic Coastal Plain." Journal of Geology, v. 68, pp. 182-202 (1960).

Faye, R. E., and D. C. Prowell. "Effects of Late Cretaceous and Cenozoic Faulting on the Geology and Hydrology of the Coastal Plain Near the Savannah River, Georgia, and South Carolina." U. S. Geological Survey Open File Report 82-156 (1982).

Geotrans, Inc. "Characterization of Groundwater Flow and Transport in General Separations Area. Savannah River Plant, Effluents of Closure Options on Groundwater Flow at H-Area Seepage Basins (1989).

Geotrans, Inc. "Characterization of Ground Water Flow and Transport in the General Separations Area, Savannah River Plan, Effects of Closure Options on Groundwater Flow at the F-Area Seepage Basins" (1988).

Gohn, F. S., J. E. Hazel, L M. Bybell, and L. E. Edwards. "The Fishburne Formation (Lower Eocene), a Newly Defined Subsurface Unit in the South Carolina Coastal Plain." U. S. Geological Survey Bulletin 1537-C, pp. 1-16 (1983).

Hazel, J. E., L. M. Bybell, R. A. Christopher, N. O. Frederiksen, F. E. May, D. M. McLean, R. Z. Poore, C. C. Smith, N. F. Sohl, P. C. Valentine, and R. J. Witmer. "Biostratigraphy of the Deep Corehole (Clubhouse Crossroads Corehole 1) near Charleston, South Carolina," Studies 
Related to the Charleston, South Carolina, Earthquake of 1886 -- A Preliminary report, ed., D. W. Rankin, U. S. Geological Survey Professional Paper 1028, pp 71-89 (1977).

Higgins, B. B., G. S. Gohn, and L. M. Bybell. "Subsurface Geologic Evidence for Normal Faults in the South Carolina Coastal Plain Near Charleston." Geological Society of America Abstracts with Programs, Southeast Section, v. 10, p. 171 (1978).

Howell, D. E., and A. W. Zupan. "Evidence for Post-Cretaceous Tectonic Activity in the Westfield Creek Area, North of Cheraw, South Carolina." South Carolina State Development Board, Division of Geology, Geologic Notes, v. 18, pp. 98-105 (1974).

Huddlestun, P. F., and J. H. Hetrick. "Upper Eocene Stratigraphy of Central and Eastern Georgia." Georgia Geologic Survey Bulletin 95, p. 78 (1985).

Inden, R. F., and A. W. Zupan. "Normal Faulting of Upper Coastal Plain Sediments, Ideal Kaolin Mine, Langley, South Carolina." South Carolina State Development Board, Division of Geology, Geologic Notes, v. 19, pp. 159-165 (1975).

Johnson, H. S., Jr., and S. D. Heron, Jr. "Slump Features in the McBean Formation and Younger Beds, Riley Cut, Calhoun County, South Carolina." South Carolina State Development Board, Division of Geology, Geologic Notes, v. 9, pp. 37-44 (1965).

Klitgord, K. D., and J. C. Behrendt. "Basin Structure of the U. S. Atlantic Margin." Geological and Geophysical Investigations of Continental Margins. American Association of Petroleum Geologists Memoir 29, eds., J. S. Watkins, L. Montadert, and P. W. Dickerson, pp. 85-112 (1979). 
Marine, I. W., and G. E. Siple. "Buried Triassic Basin in the Central Savannah River Area, South Carolina and Georgia." Geological Society of America Bulletin, v. 85, pp. 311-320 (1974).

Marine, I. W., "Hydrology of Buried Crystalline Roch at Savannah River Plant Near Aiken, South Carolina" DOE/SR-WM-79-2. 220 pp., 9(1979).

Marine, I. W., "Geohydrology of a Buried Triassic Basin at Savannah River Plant, South Carolina." American Association of Petroleum Geologists Bulletin, v. 58, pp. 1825-1837 (1974).

McCartan, Lucy, E. M. Lemon, Jr., and R. E. Weems, "Geologic Map of the Area Between Charleston and Orangeburg, South Carolina": U.S. Geological Survey Miscellaneous Investigations Series Map I-1472, scale 1:250,000.

McDowell, R. C. and B. B. Houser. "Distribution of Small - Scale Deformation Structures Upper Coastal Plain, South Carolina and Georgia." U. S. Geological Survey Map MF-1538 (1983).

Newell, W. L., M. H. Pavich, D. C. Prowell, and H. W. Markewich. "Surficial Deposits, Weathering Processes, and Evolution of an Inner Coastal Plain Landscape, Augusta, Georgia." Excursions in Southeastern Geology; Guidebook, ed., R. W. Frey, Geological Society of America 1980 Annual Meeting, Atlanta, Georgia, American Geological Institute, Guidebook, v. 2, pp. 527544 (1980).

Nystrom, P. G., Jr., R. H. Willoughby, and L. E. Kite. "Cretaceous-Tertiary Stratigraphy of the Upper Edge of the Coastal Plain Between North Augusta and Lexington, South Carolina." Carolina Geological Society Field Trip Guidebook, South Carolina Geological Survey (1986). 
Nystrom, P. G., Jr., and R. H. Willoughby. "Geological Investigations Related to the Stratigraphy in the Kaolin Mining District, Aiken County, South Carolina." Carolina Geological Society Field Trip Guidebook, South Carolina Geological Survey, p. 183 (1982).

Parizek, R. R., and R. W. Root, "Development of a Ground Water Velocity Model for the Radioactive Waste Management Facility, Savannah River Plant, Aiken, South Carolina." DPST86-658, E. I. du Pont de Nemours \& Company, Savannah River Laboratory, Aiken, South Carolina (1986).

Prowell, D. C., R. A. Christopher, L. E. Edwards, L. M. Bybell, and H. E. Gill. "Geologic Section of the Undip Coastal Plain from Central Georgia to Western South Carolina." U. S. Geological Survey, Text with Map MF-1737, p. 11 (1985a).

Prowell, D. C., Edwards, L. E., and Frederiksen, N. O.; "The Ellenton Formation in South Carolina-A revised age designation from Cretaceous to Paleocene: U. S. Geological Survey Bulletin 1605-A. pp. A63-A69, (1985b).

Reichart, S.O., "Flow of Groundwater in Tertiary Sediments at the Savannah River Plant, Near Aiken, South Carolina." Draft Report, Savannah River Plant, Aiken, S. C. (1969).

S\&ME Inc. "Borehole Permeability Analysis F-Area Assessment Wells at the Savannah River Plant, Aiken, SC." (1988B).

S\&ME Inc. "Borehole Permeability Analysis for Burial Ground Parameter Wells at the Savannah River Plant, Aiken, SC." (1988A). 
Siple, G. E. "Geology and Ground Water of the Savannah River Plant and Vicinity, South Carolina." U. S. Geological Survey Water-Supply Paper 1841 (1967).

Sirrine Environmental Consultants. "Field Permeability Tests H-Area Seepage Basins Savannah River Plant." (1988A).

Sirrine Environmental Consultants. "Field Permeability Tests H-Area Seepage Basin Plume Assessment Well Savannah River Plant." (1988B).

Sirrine Environmental Consultants. "F-Area Compliance Monitoring Program Field Permeability Tests." (1987).

Stephenson, D. E., and J. E. Steele, "New Production Wells and Head Reversal in the Separations Areas of the Savannah River Plant (SRP)." Savannah River Laboratory, DPST-88-473, E. I. du Pont de Nemours \& Company, Aiken, S. C. (1988).

Stieve, A. L., Stephenson, D. E. and R. K. Aadland; "Pen Branch Fault Prograrn: Consolidated Report on the Seismic Reflection Surveys and the Shallow Drilling (U)"; U.S. DOE Report WSRC-TR-91-87; Westinghouse Savannah River Co, Aiken S.C. 26 pp. (1991).

Strom, R. N., 1991, Personal Communication.

Thayer et al, 1990, Personal Communication

U. S. Army Corps of Engineers, Charleston District. Geologic-Engineering Investigations, Savannah River Plant. DPWR-52, E. I. du Pont de Nemours and Company, Savannah River Plant, Aiken, SC (1952). 
Veatch, Otto, and L. W. Stephenson, "Preliminary Report on the Geology of the Coastal Plain of Georgia": Georgia Geologic Survey Bulletin 23, pp. 237-296 (1911). 


\section{APPENDIX I}

\section{MASTER LIST OF WELLS}

GENERAL SEPARATIONS AREA 


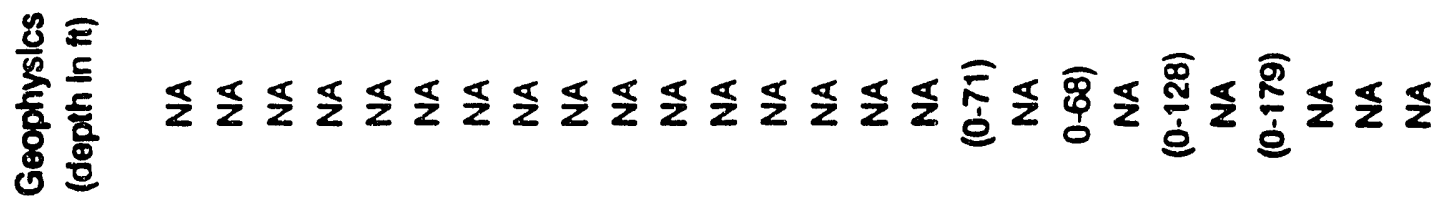

II

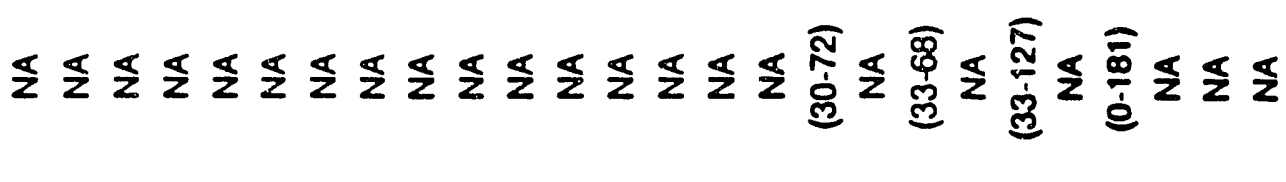

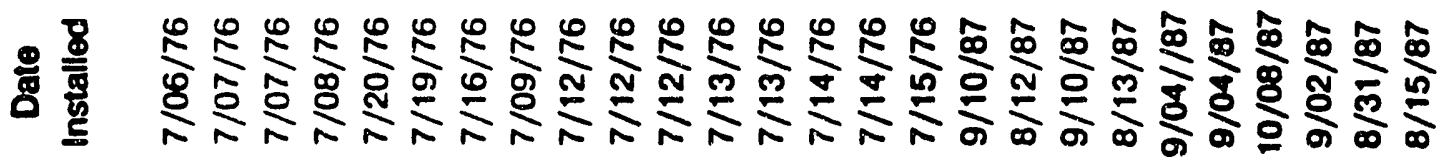

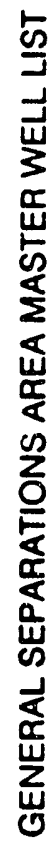

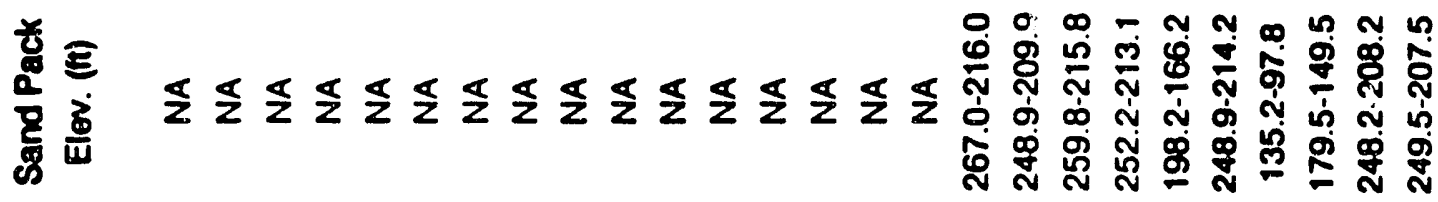

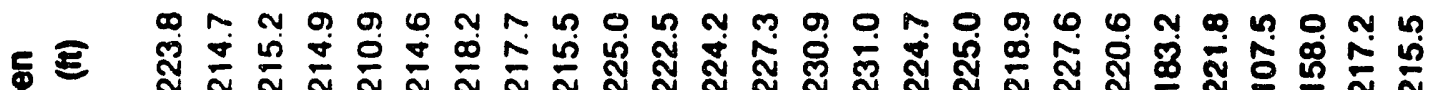

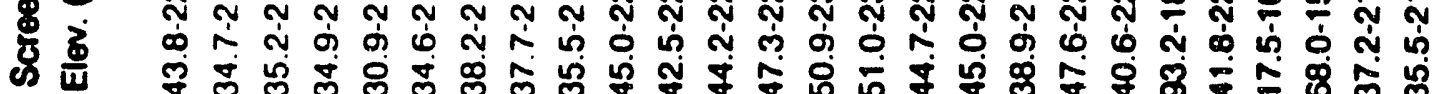

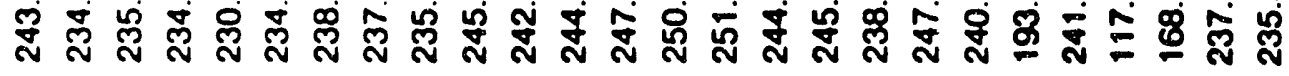

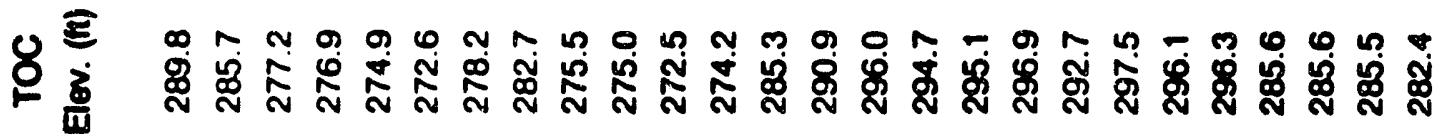

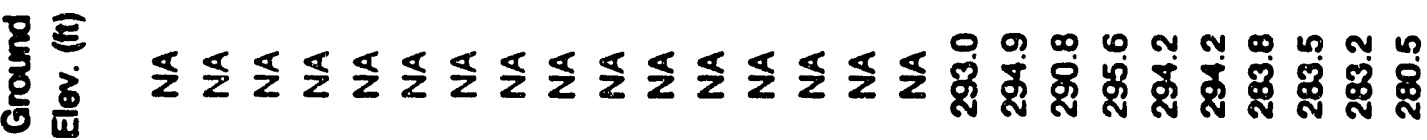

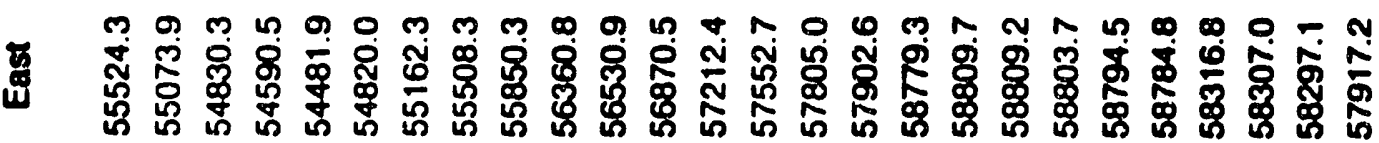

จ

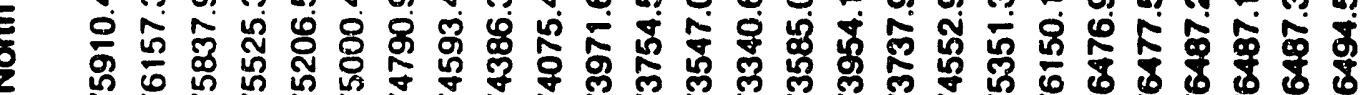

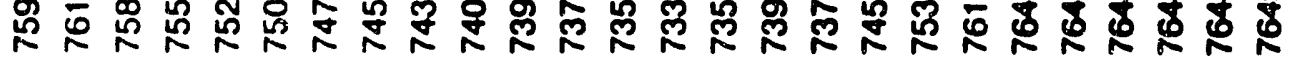

숭 กิ 岛 
II

II

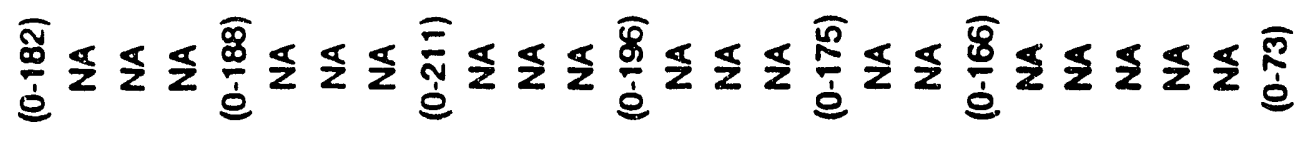

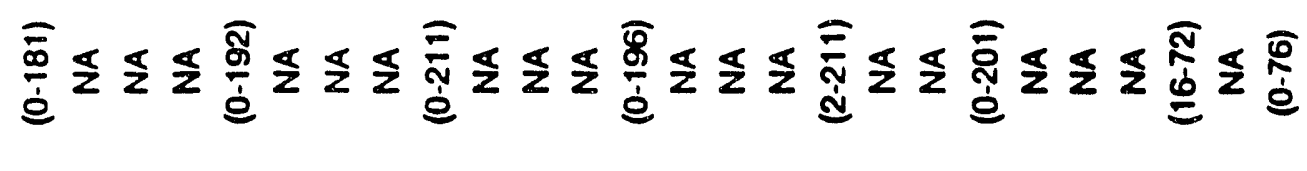

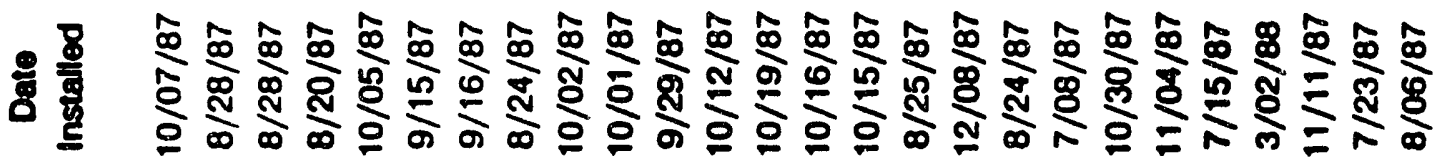

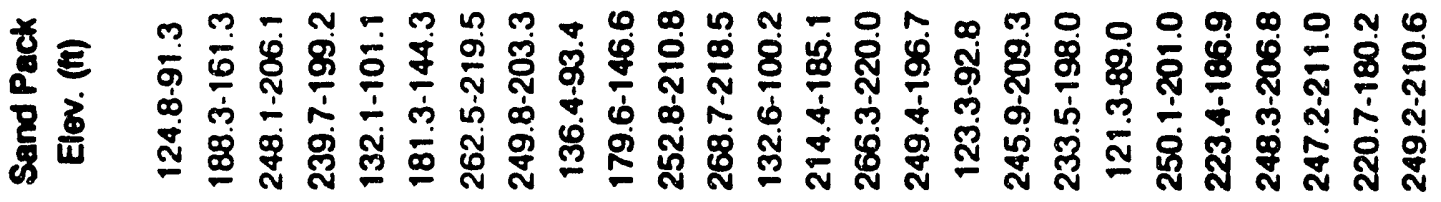

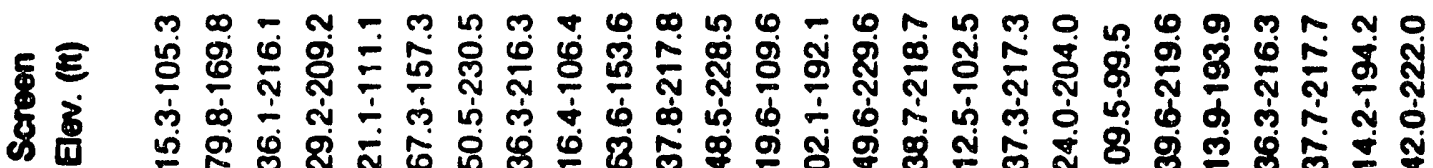

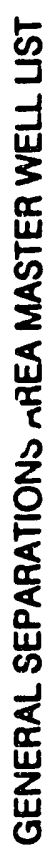

พ - พ -

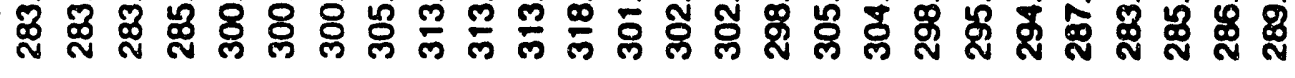

m

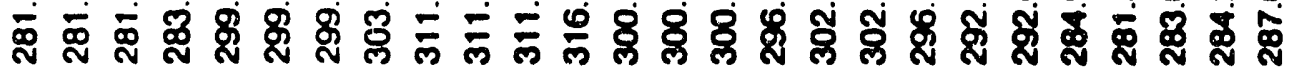

m 0 0 000 m 0 -

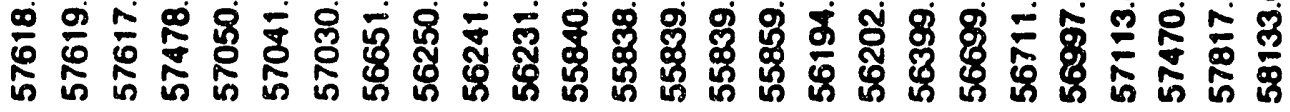

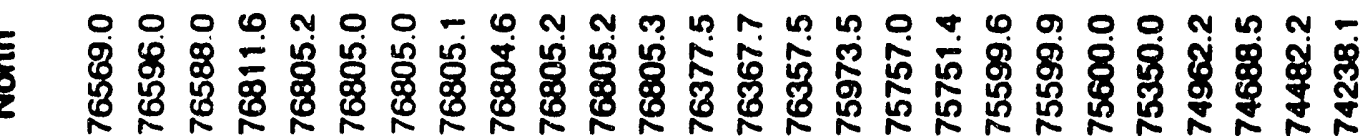

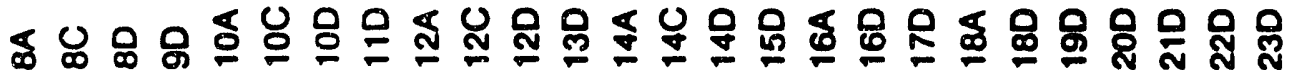

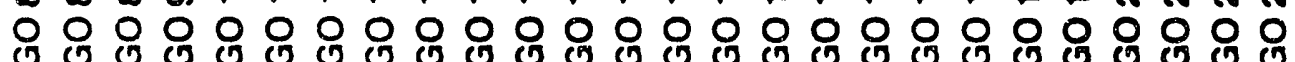

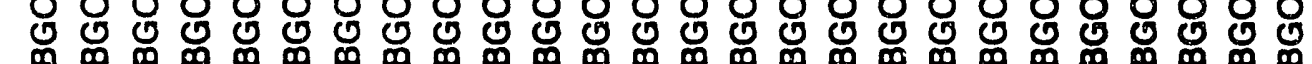




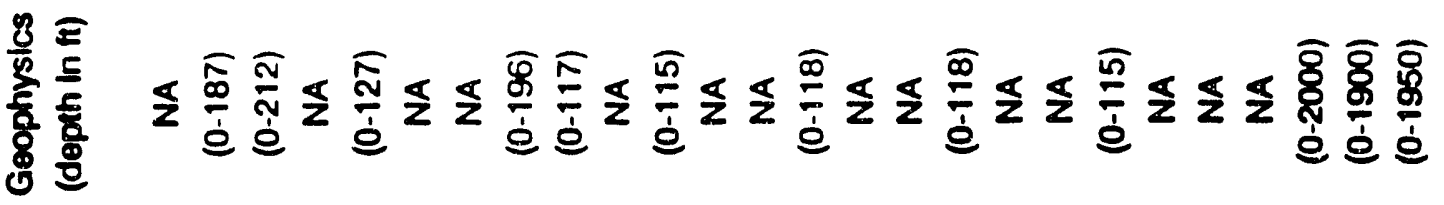

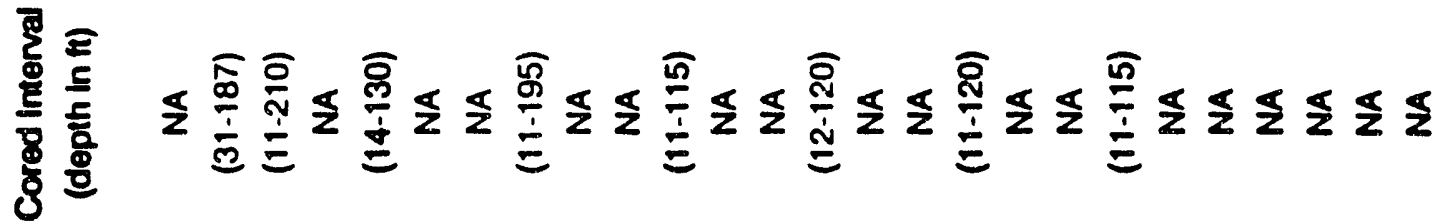

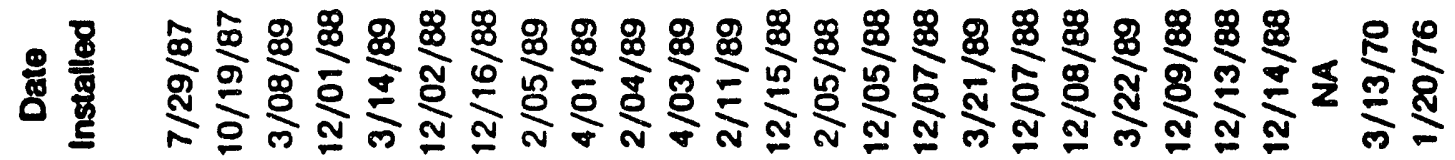

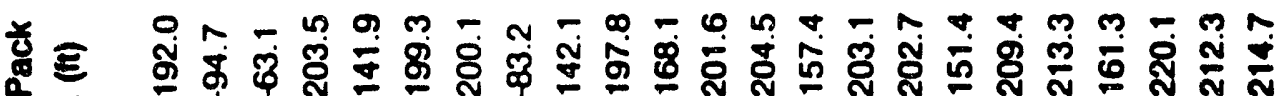

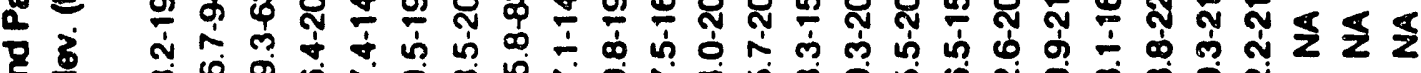

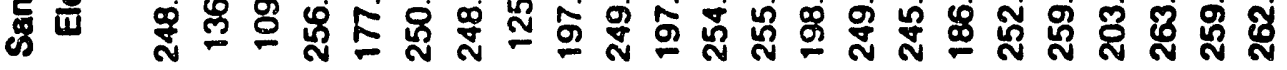

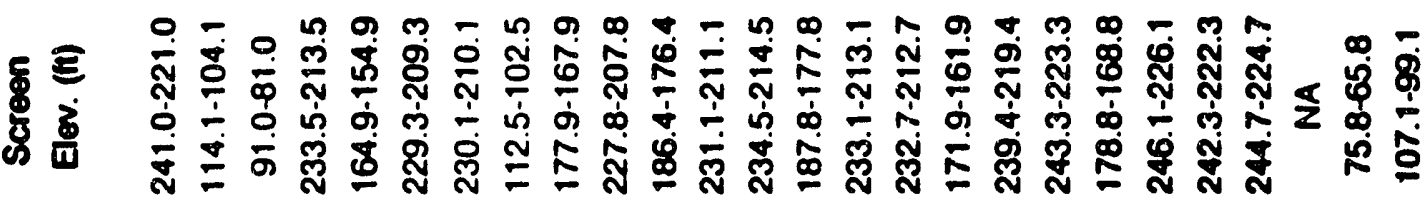

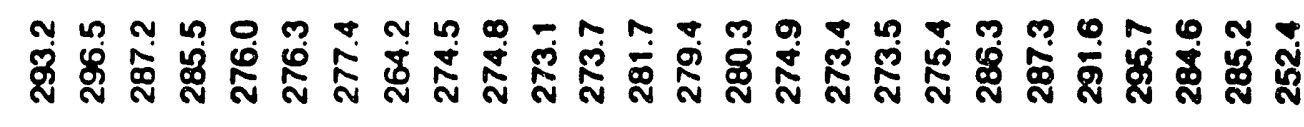

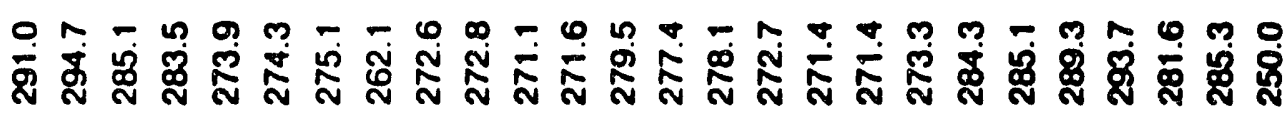

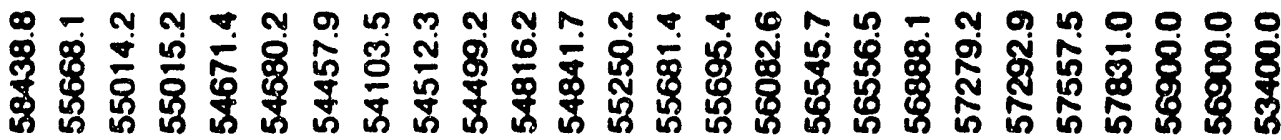

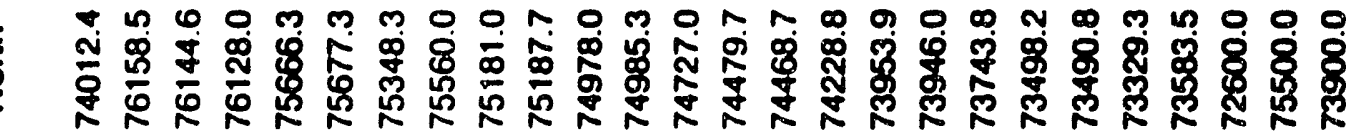

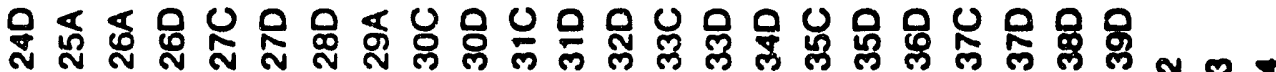

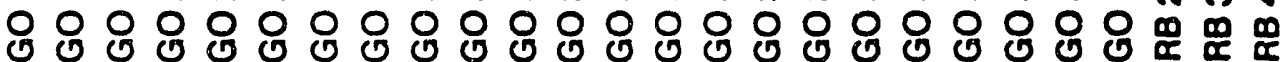

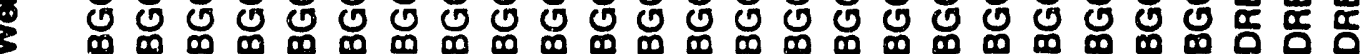




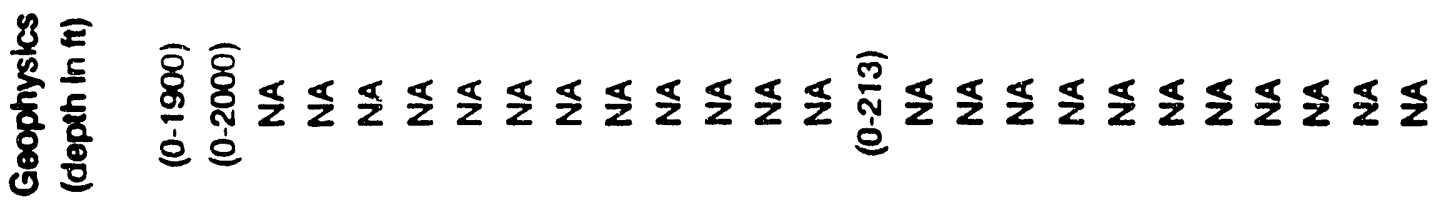
II

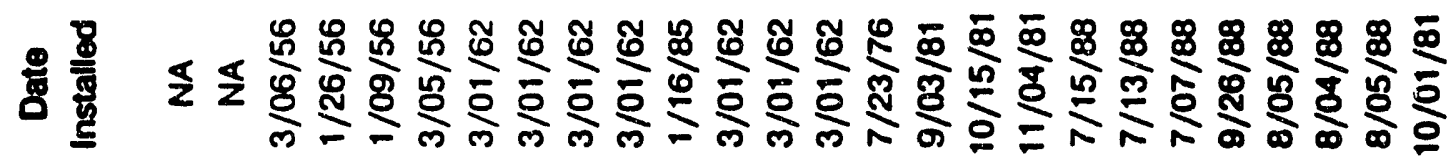

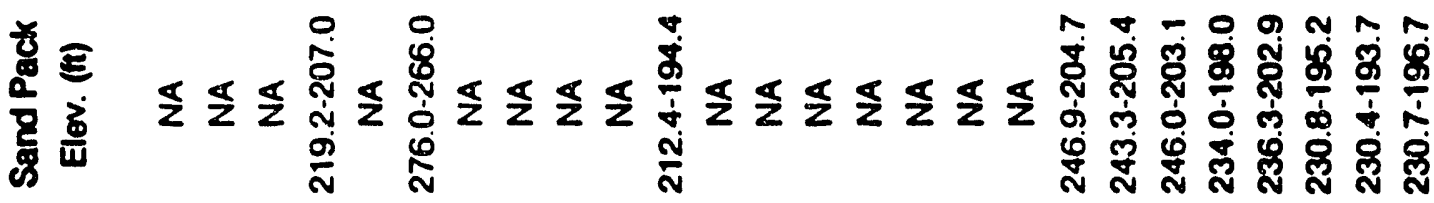

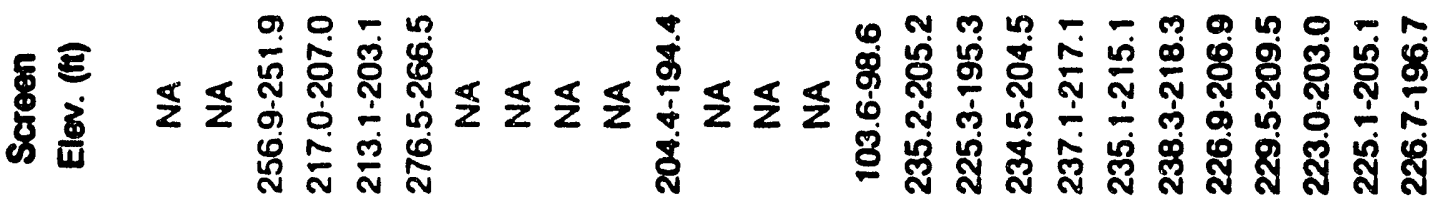

ๆ

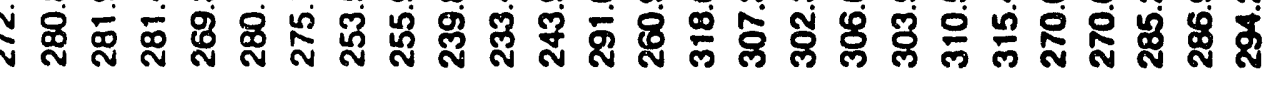

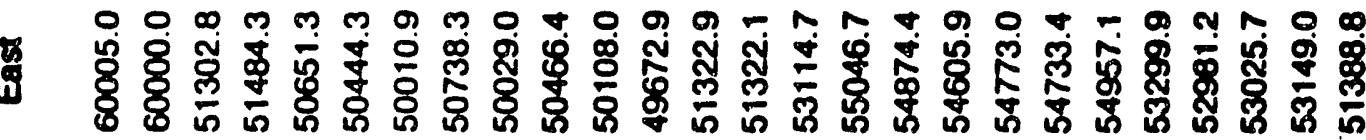

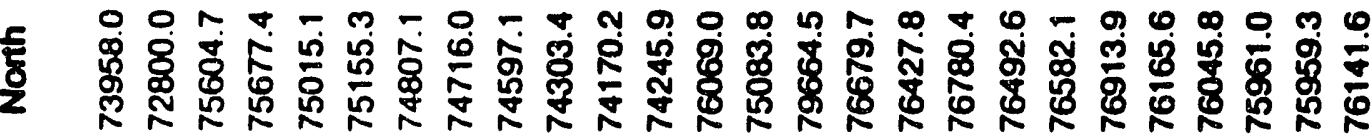

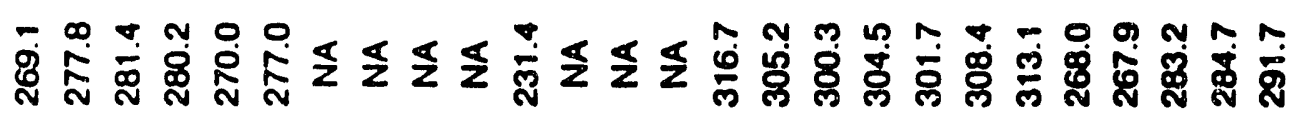

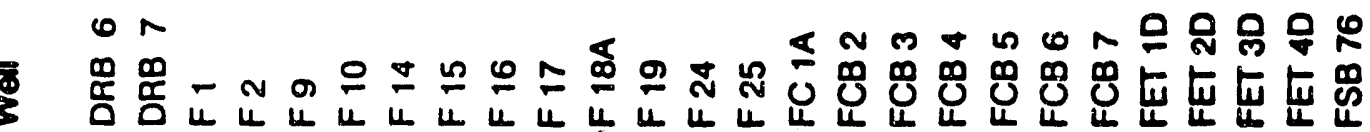




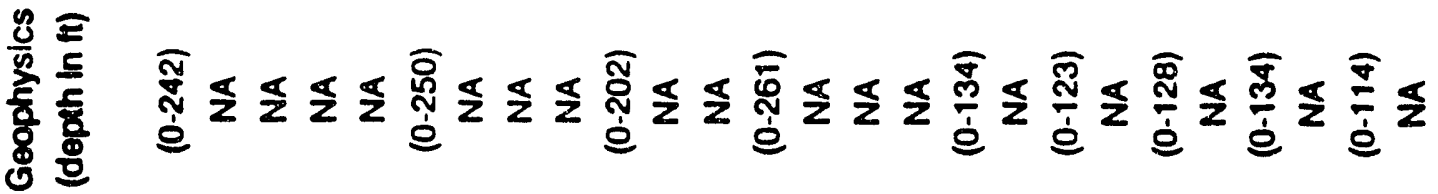

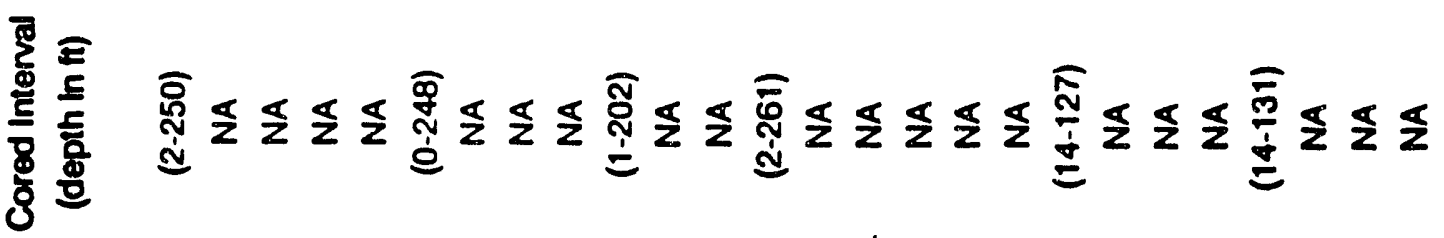

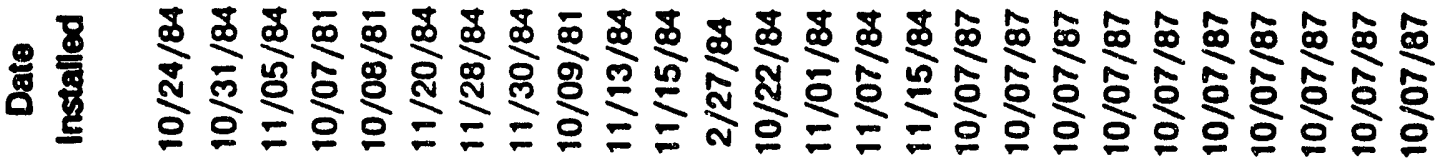

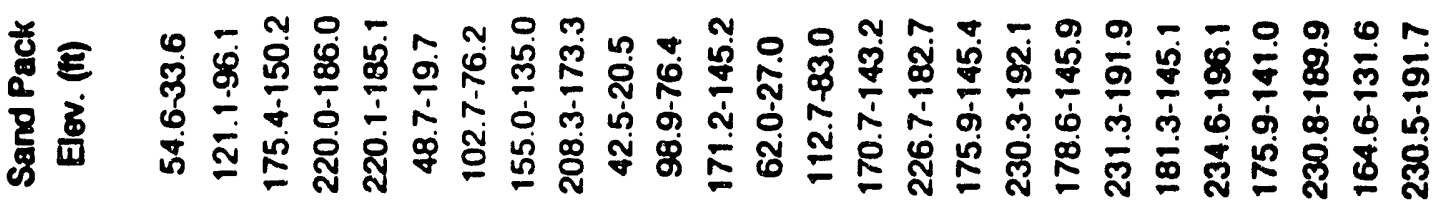

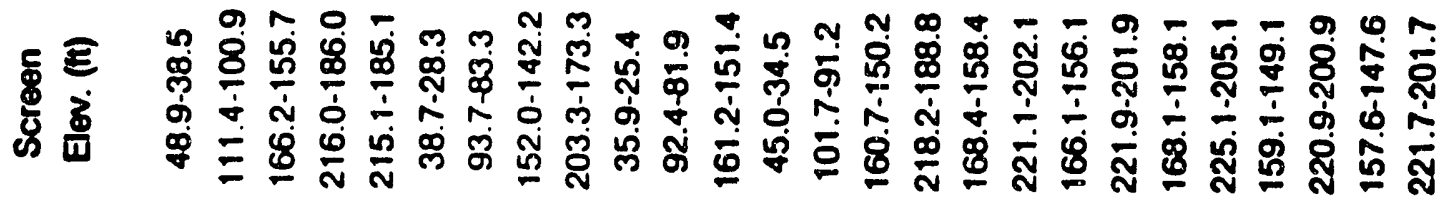

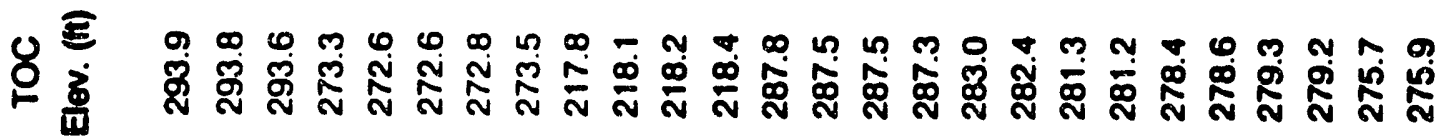

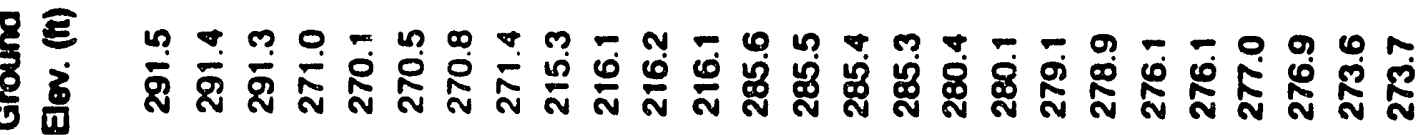

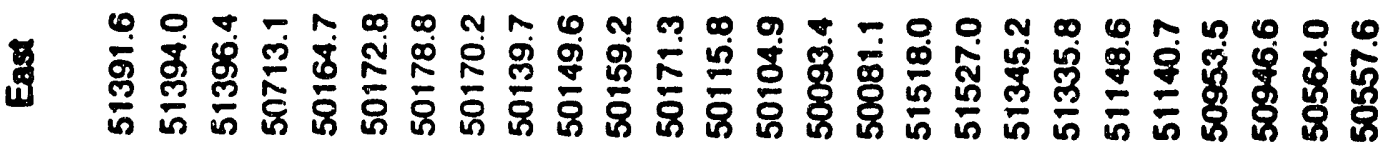

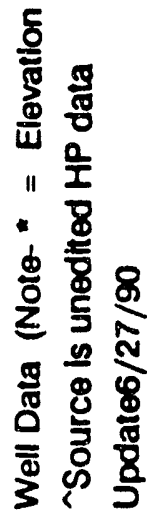

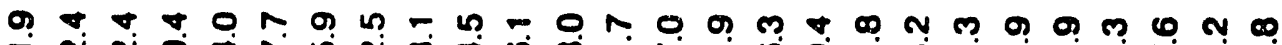
的 స

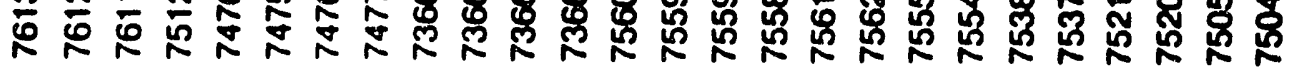

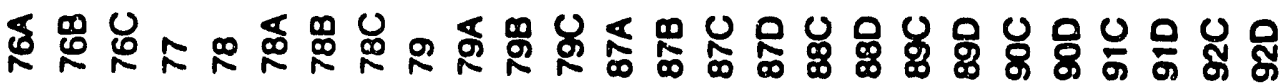

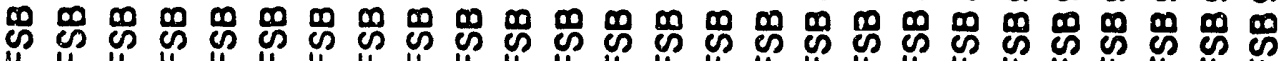




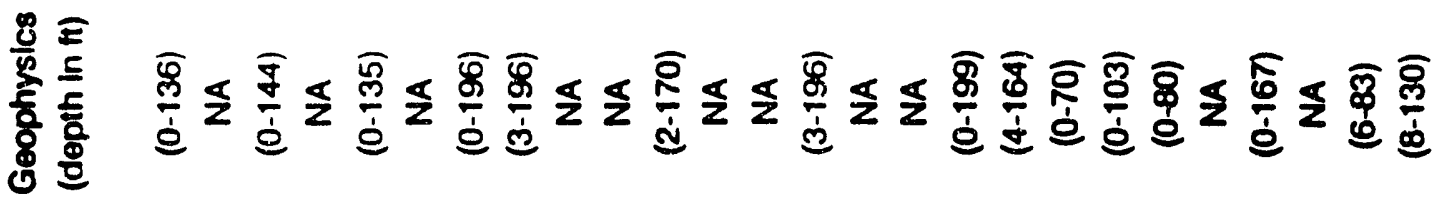

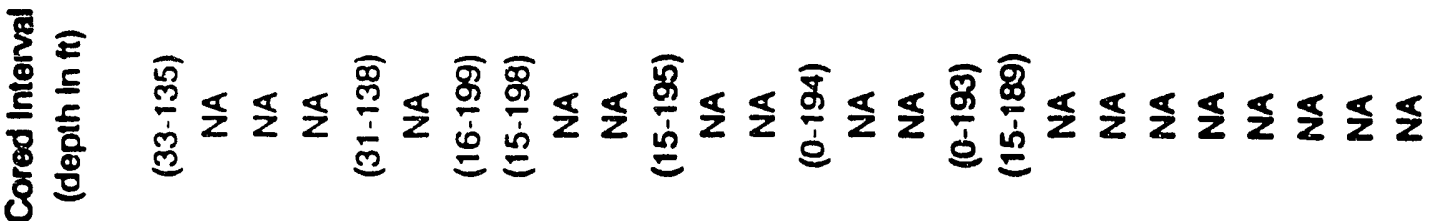

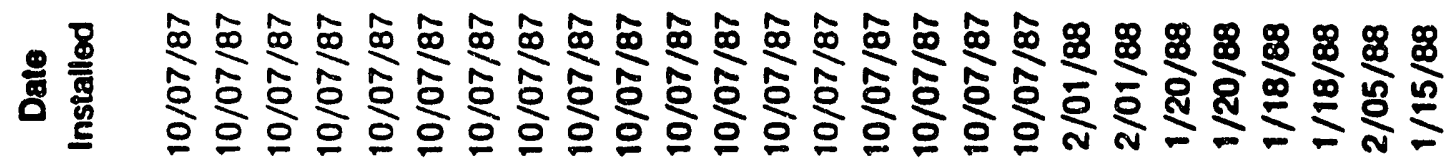
政

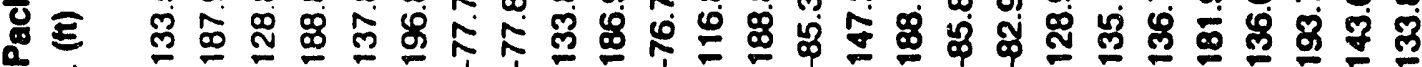

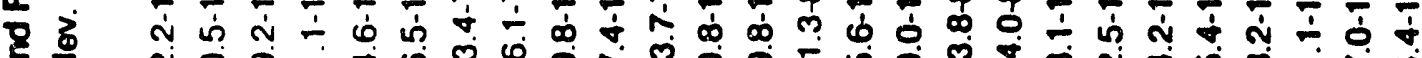

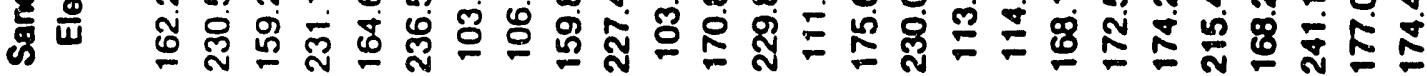

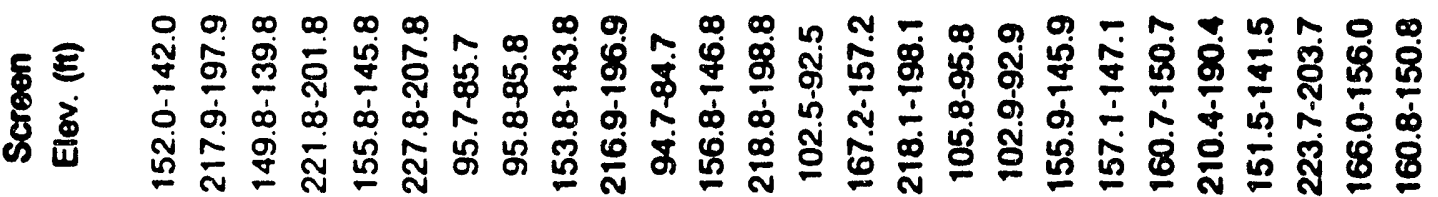

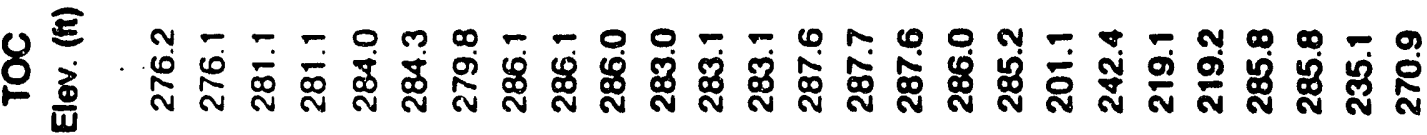

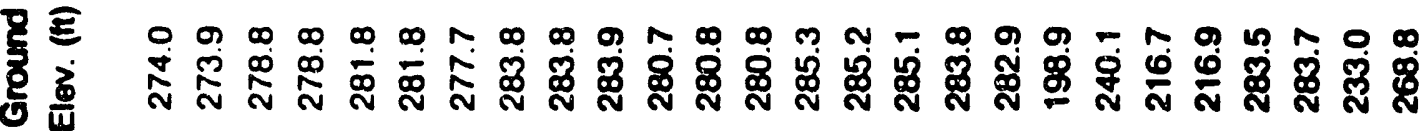

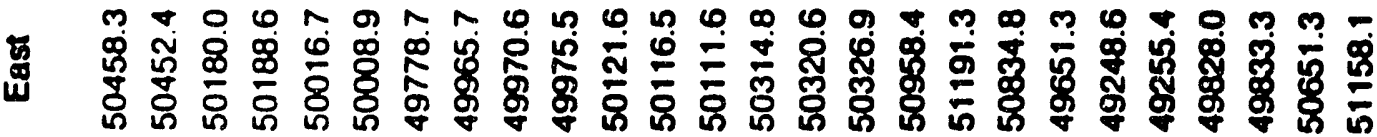

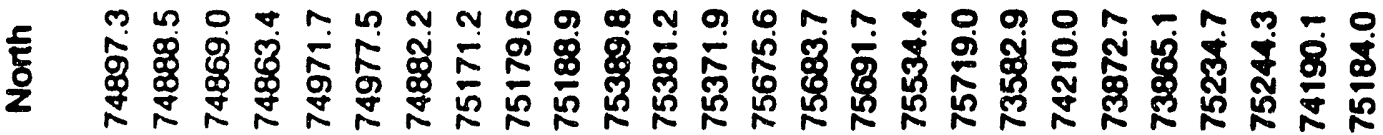

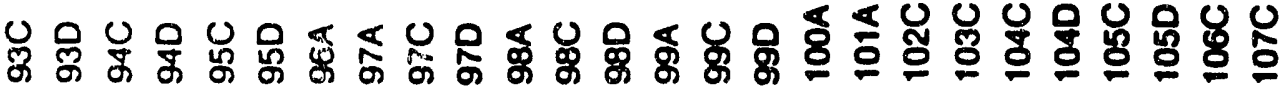

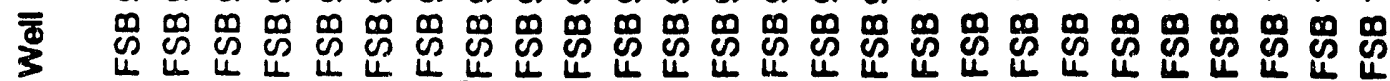




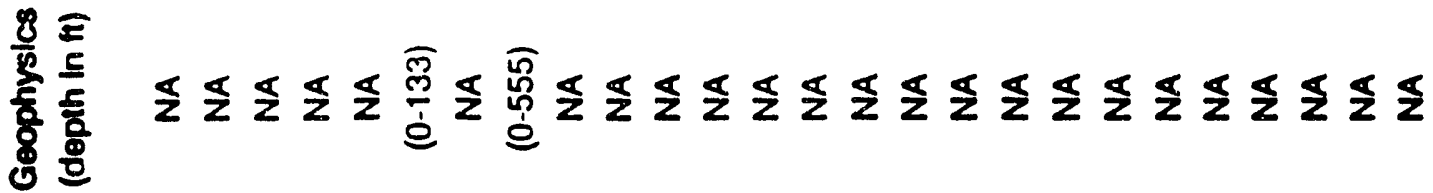
㿣

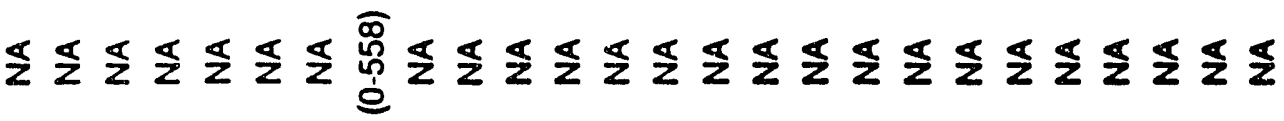

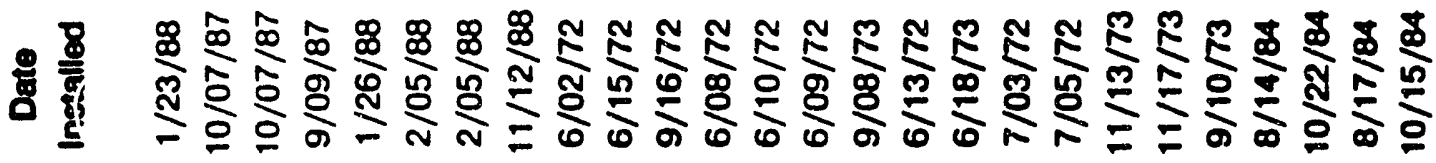

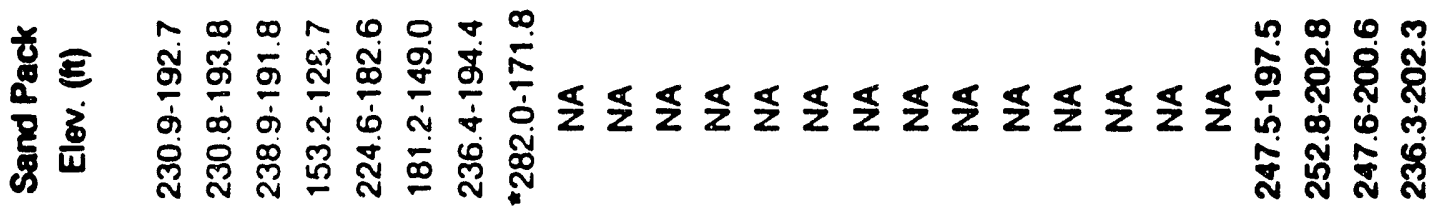

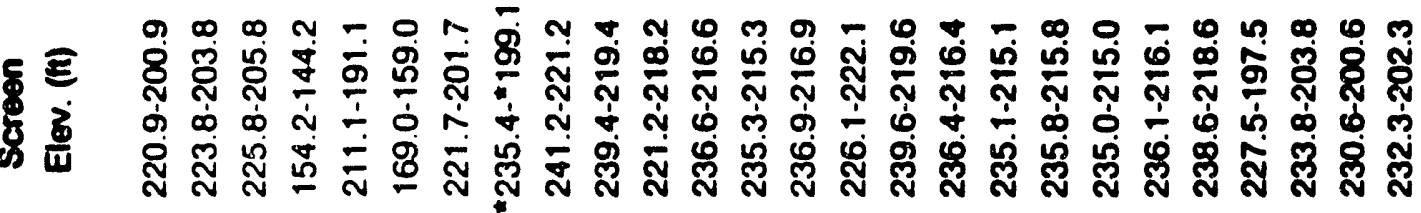

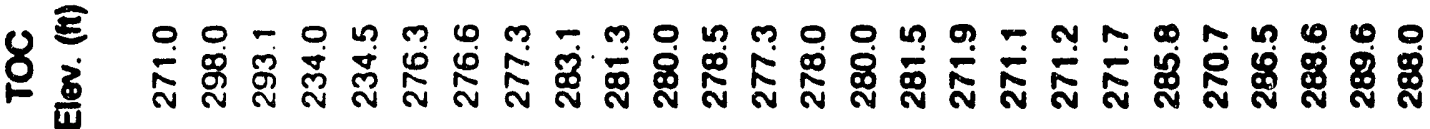

Z E

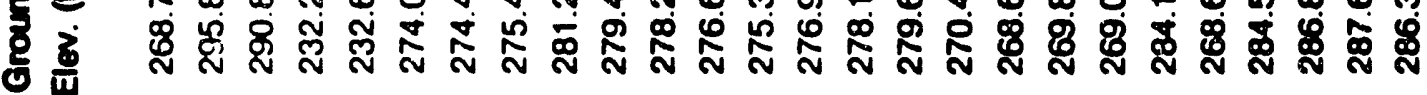

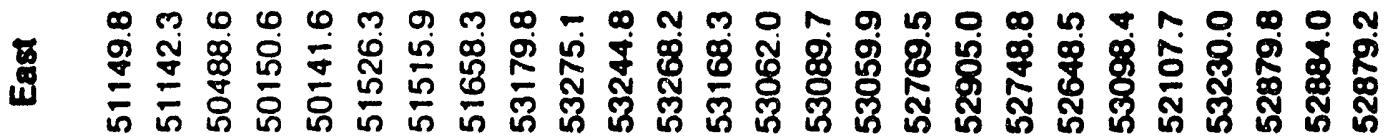

ง

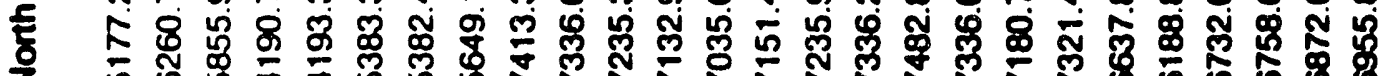

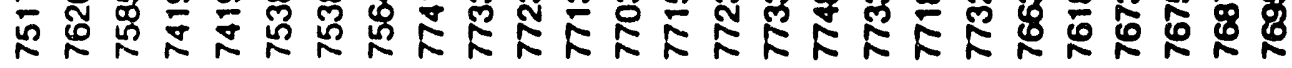

옹용ㅇㅇ으은

으음ㅌㄷㄷㄴ

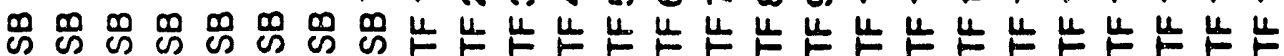

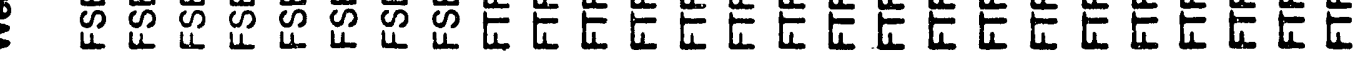




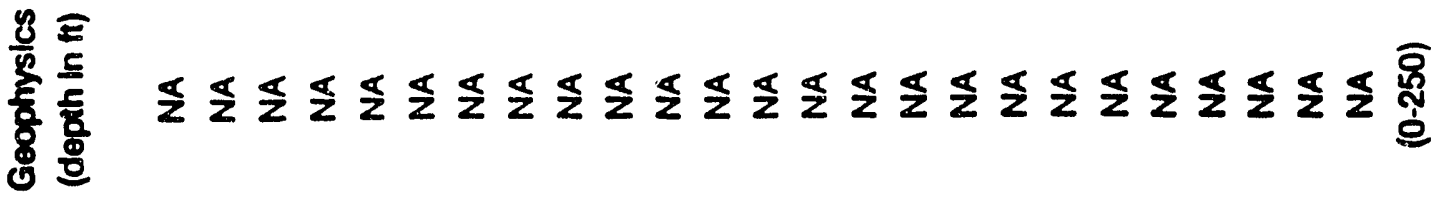

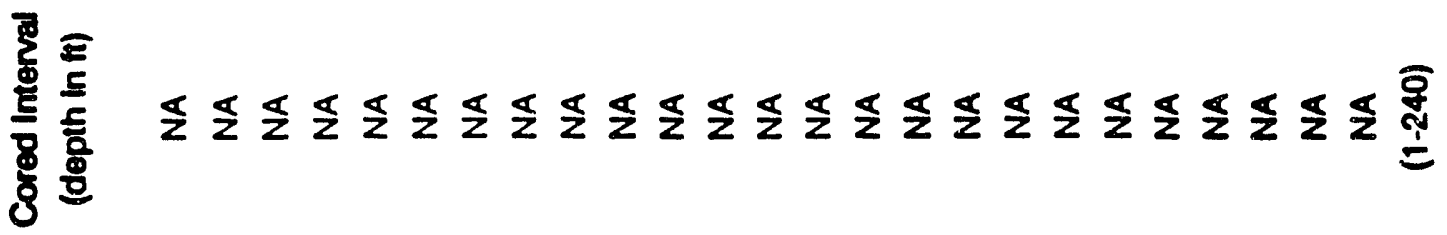

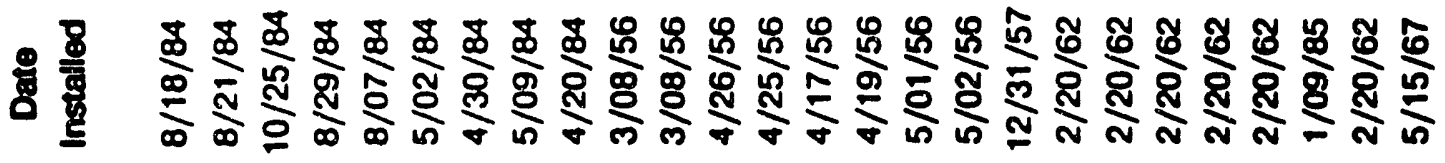

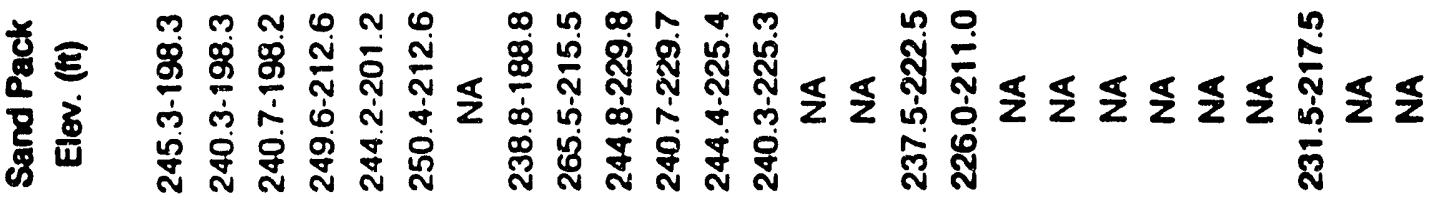

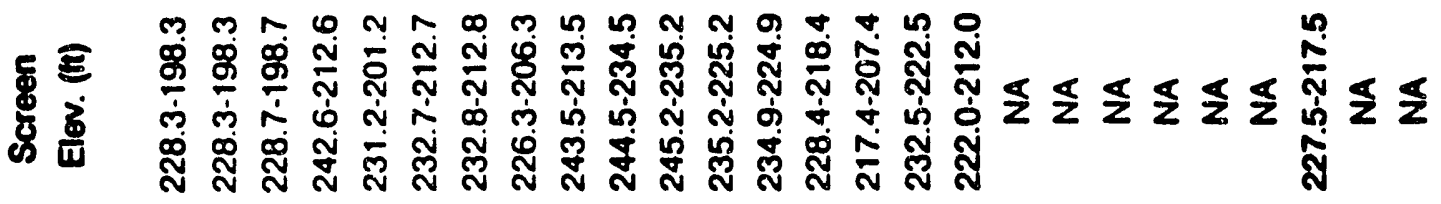
$n-m \infty \circ m$ - n

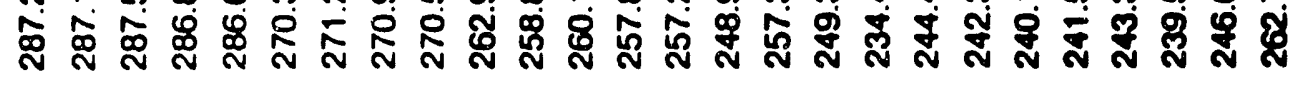

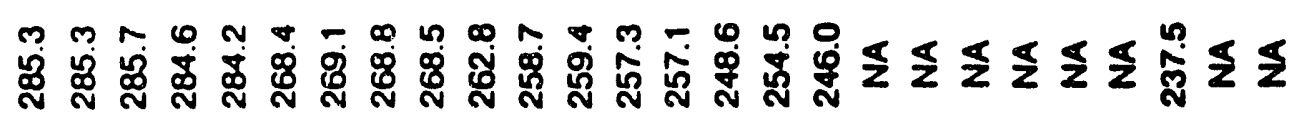

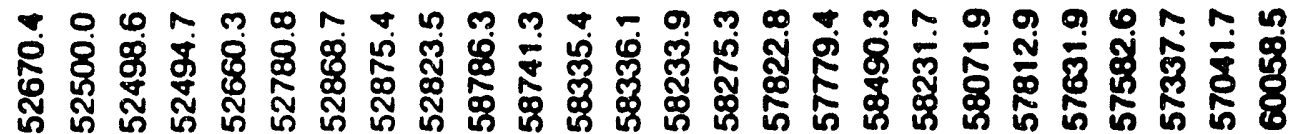

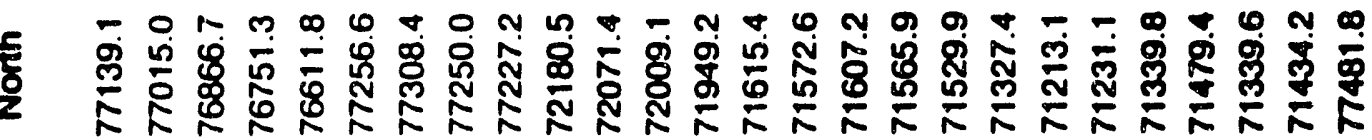
오ำ ส

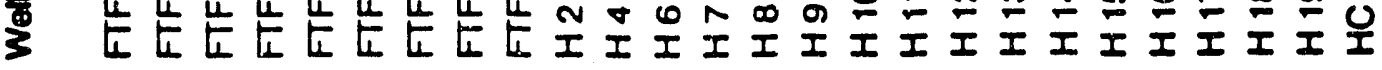




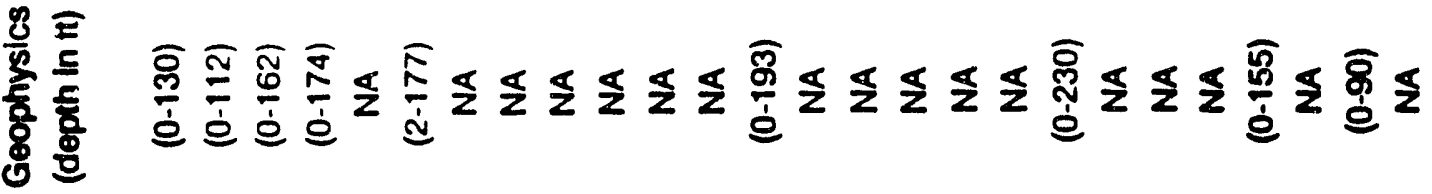

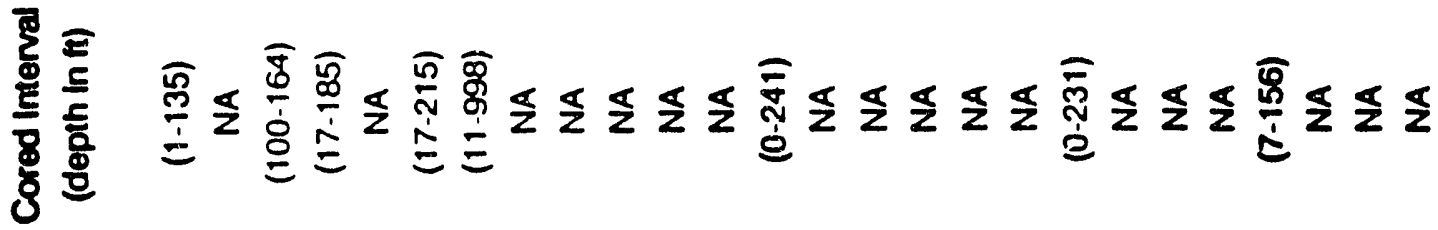

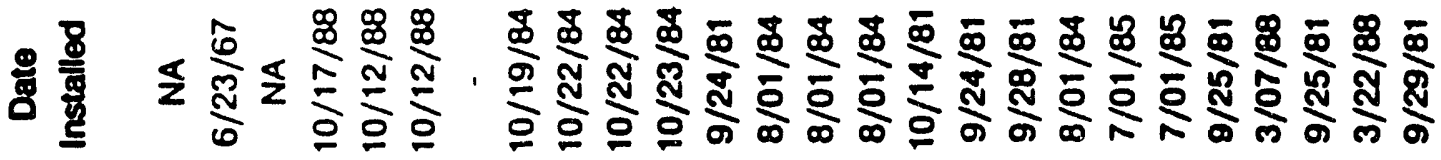

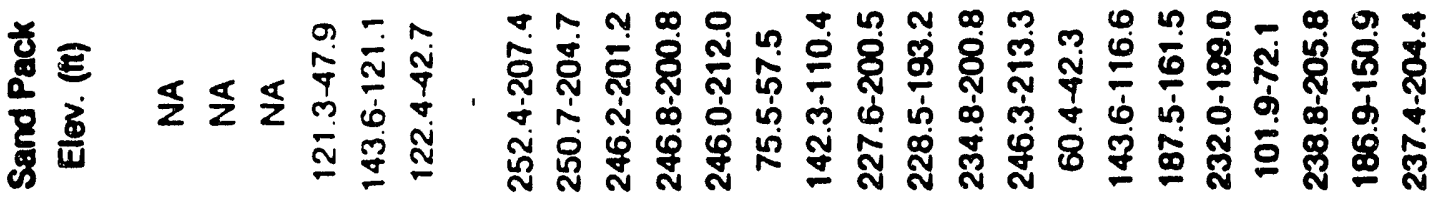

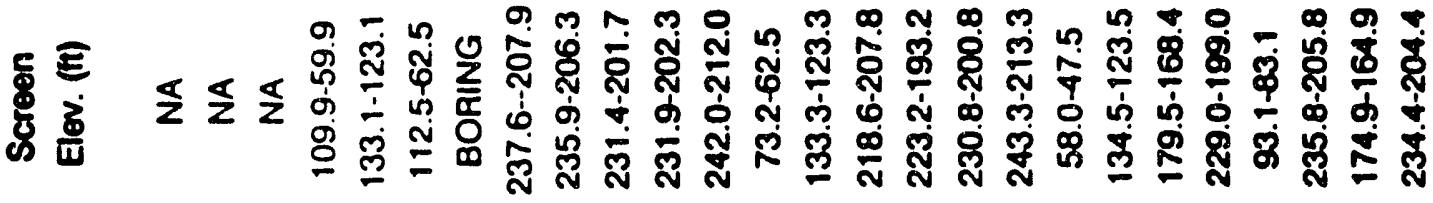

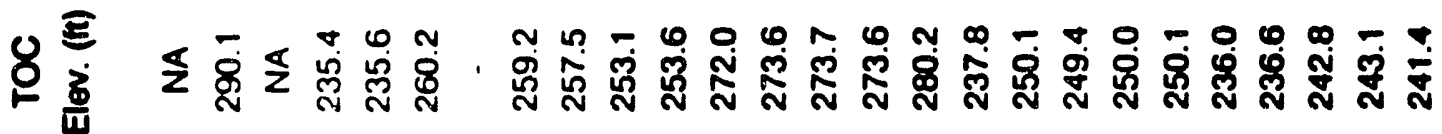

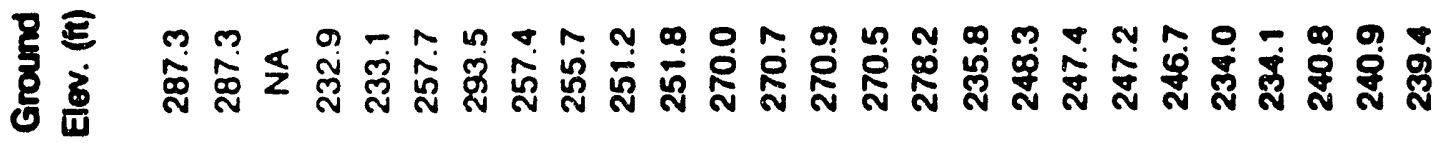

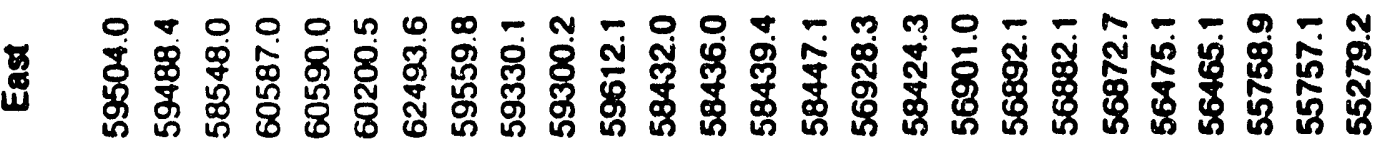
○

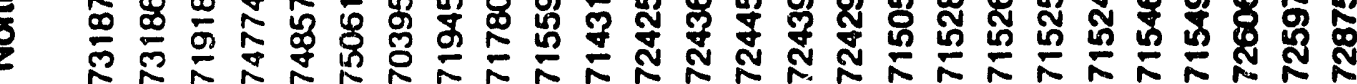

只 곤 


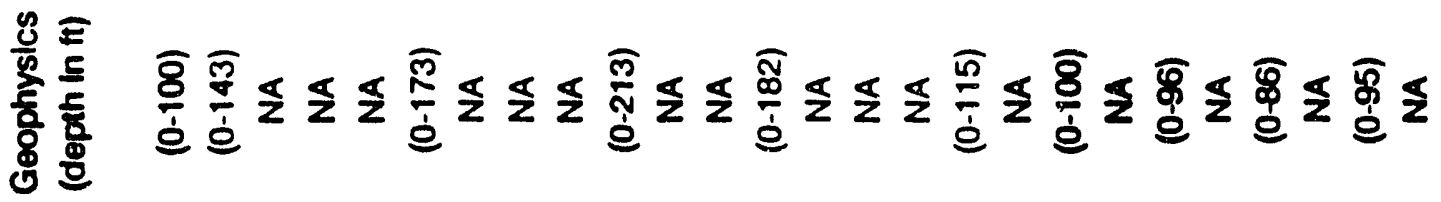

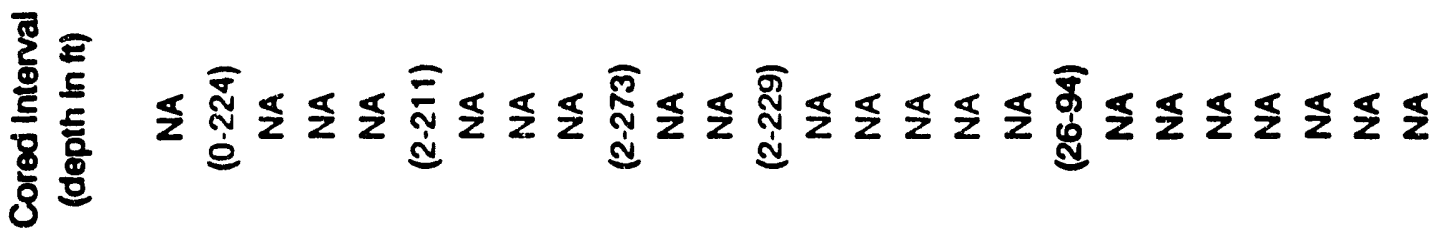

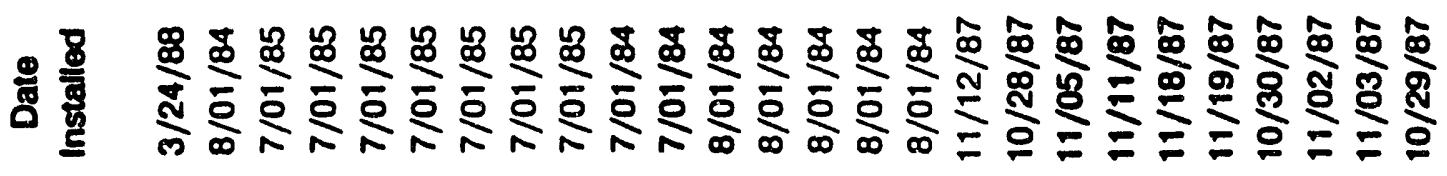

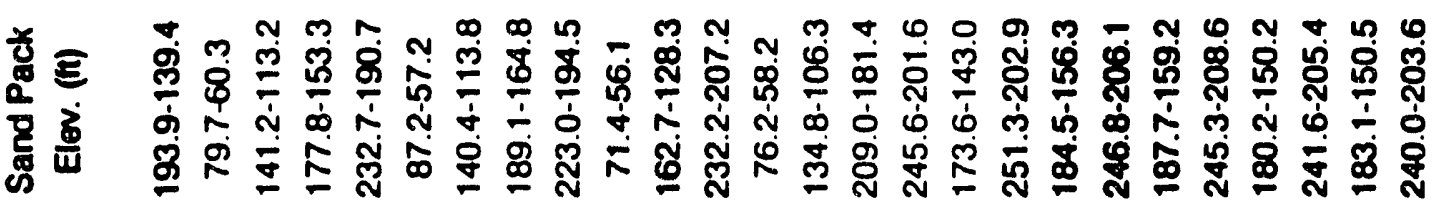

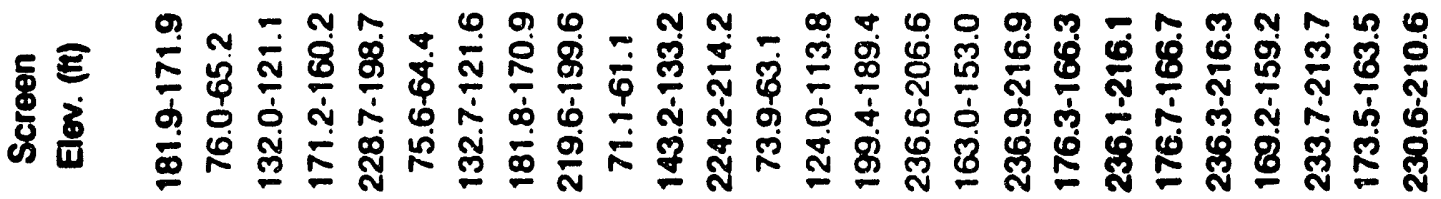

$\varphi$ ๘ 茫 代 N

\%

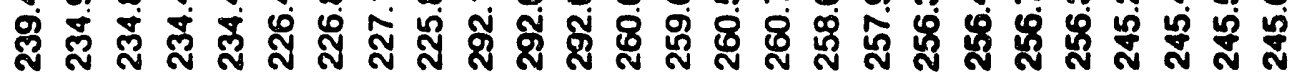

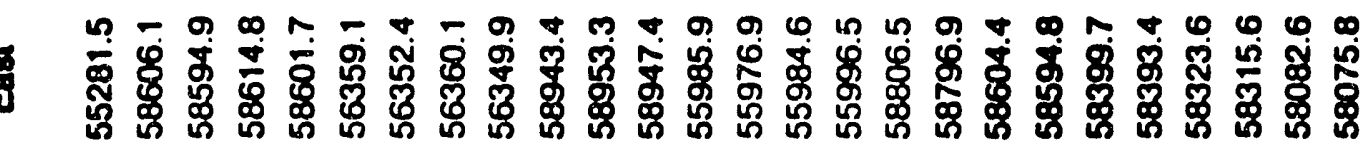

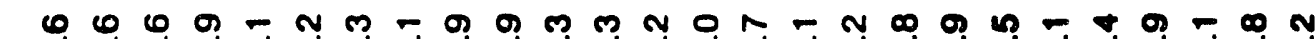
\&

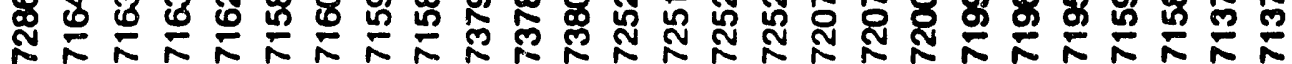
놇 ஐ ம

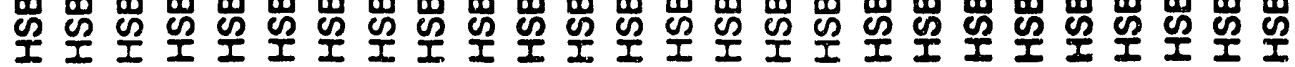




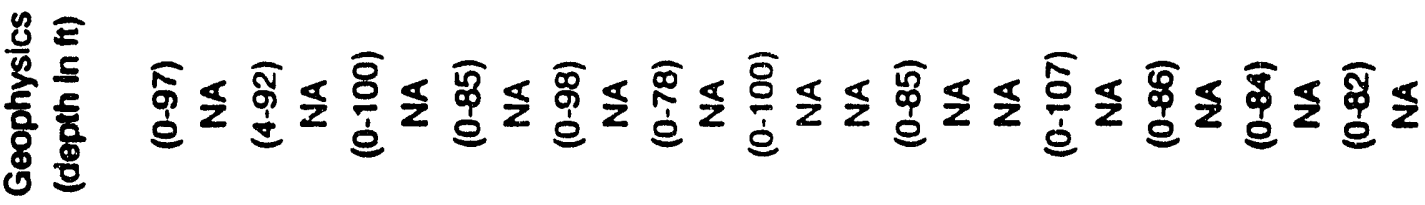

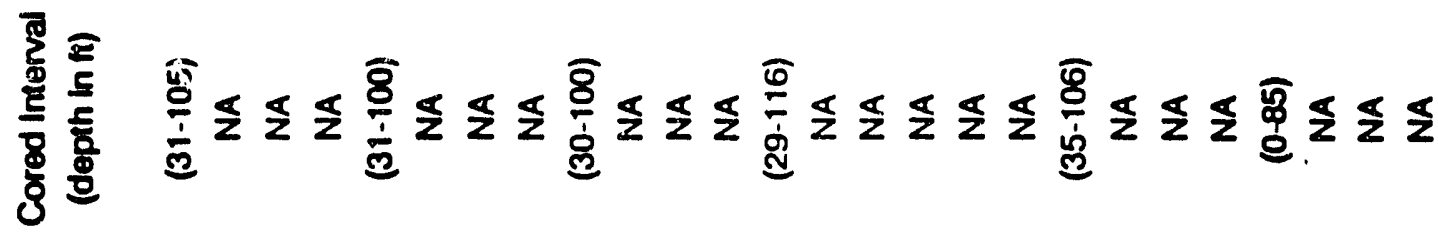

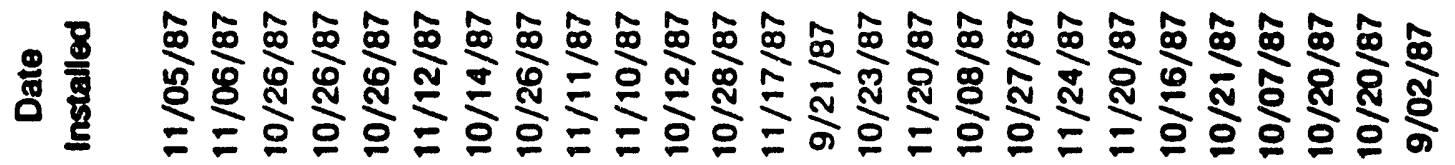

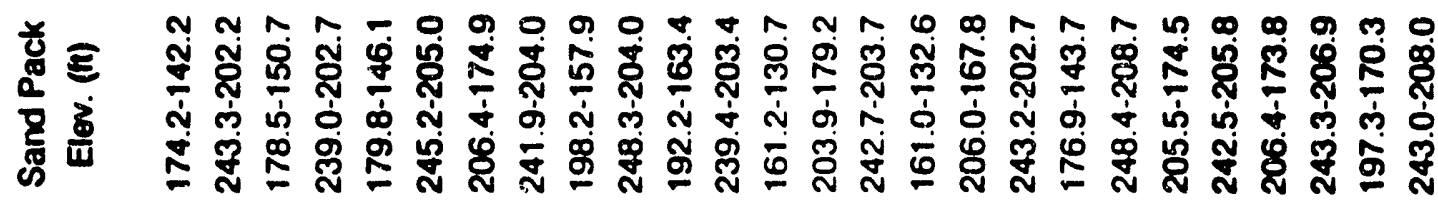

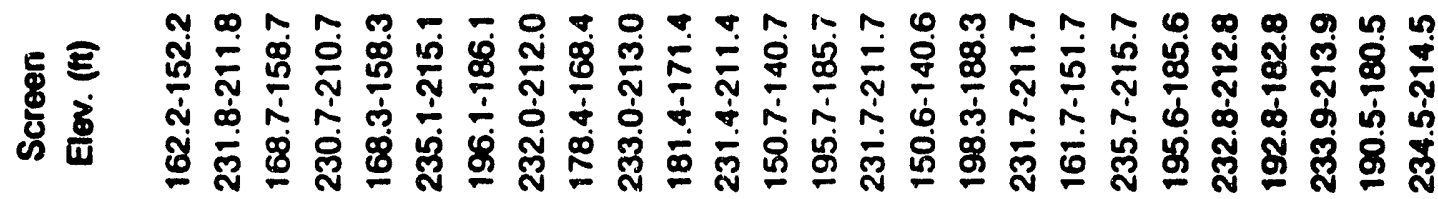

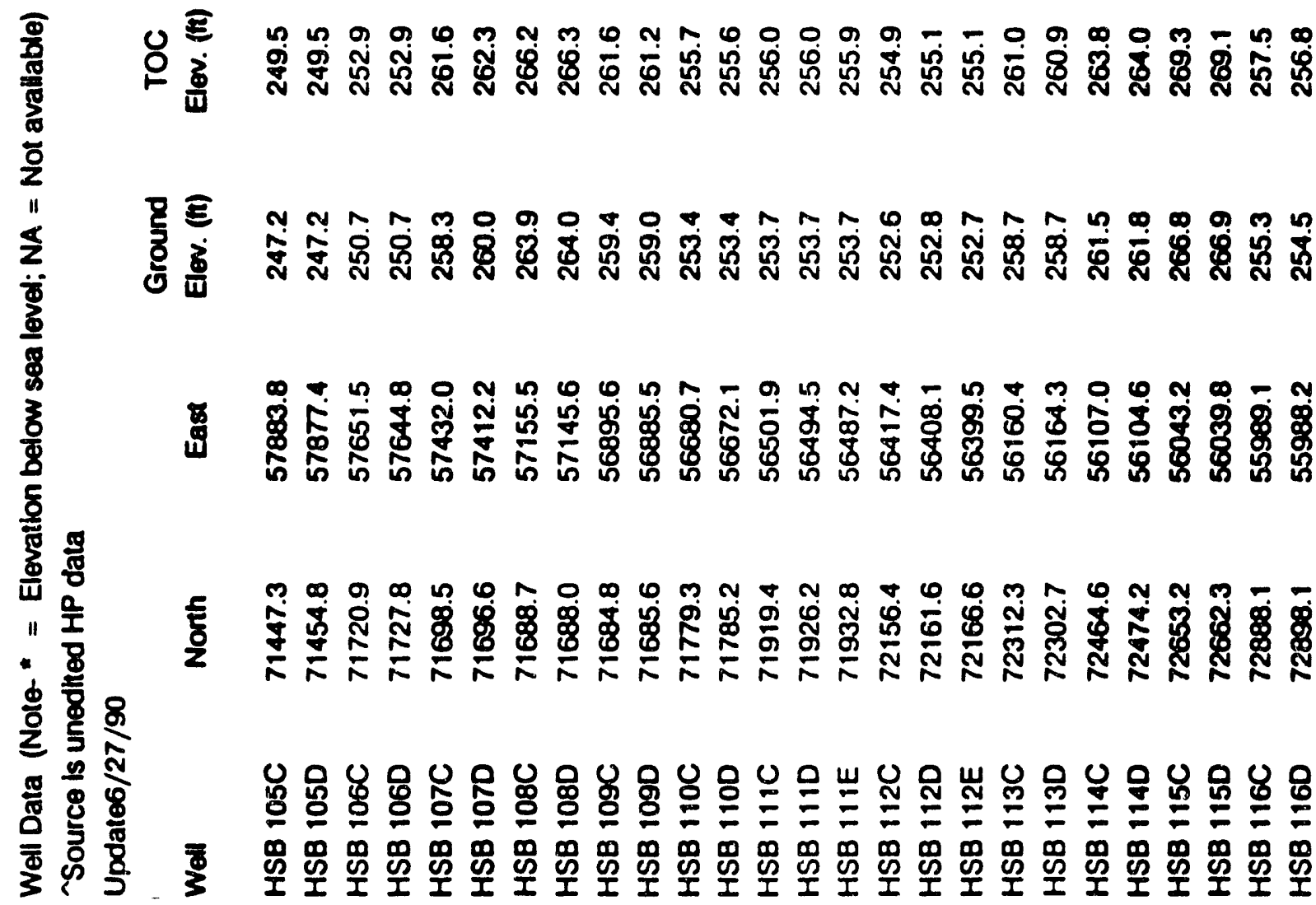




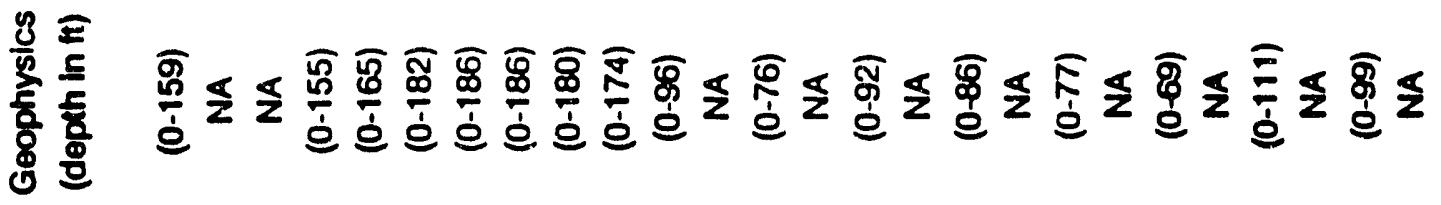

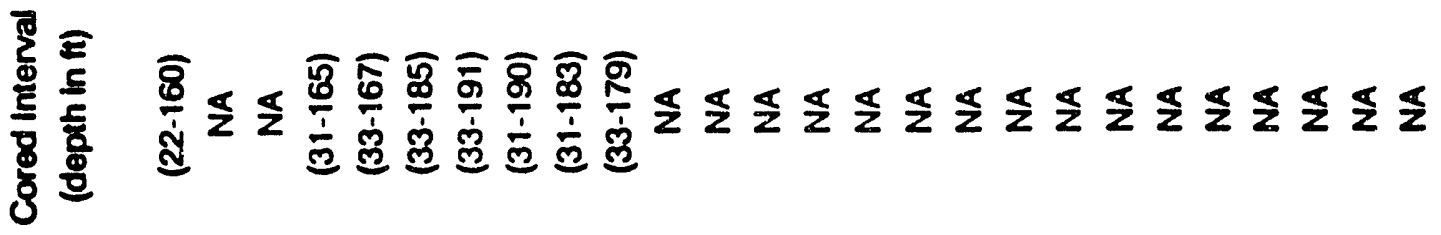

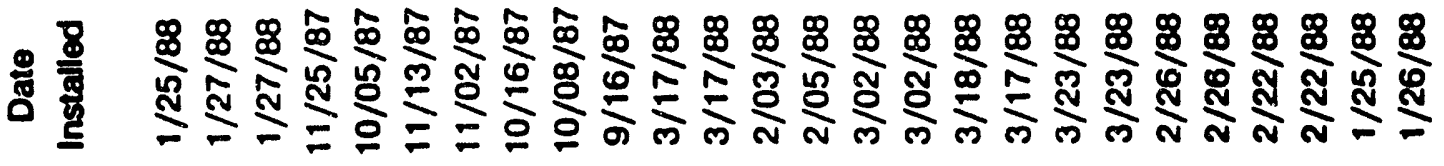

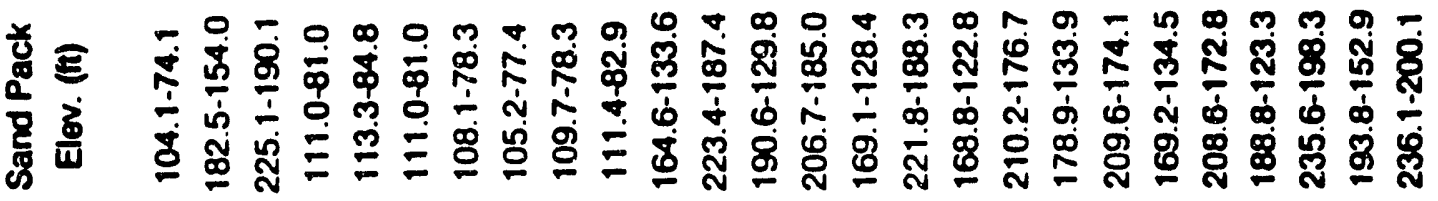

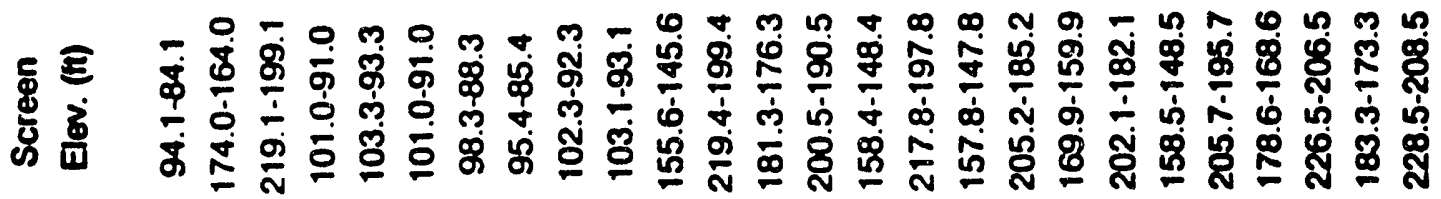




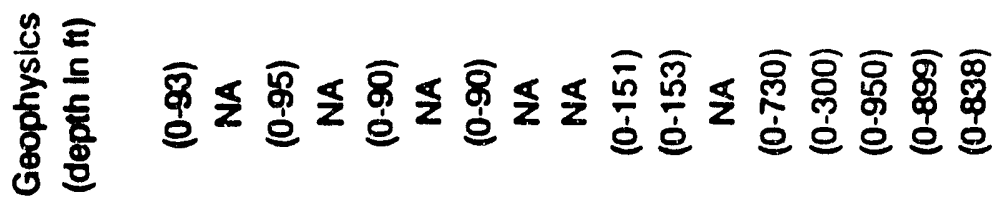

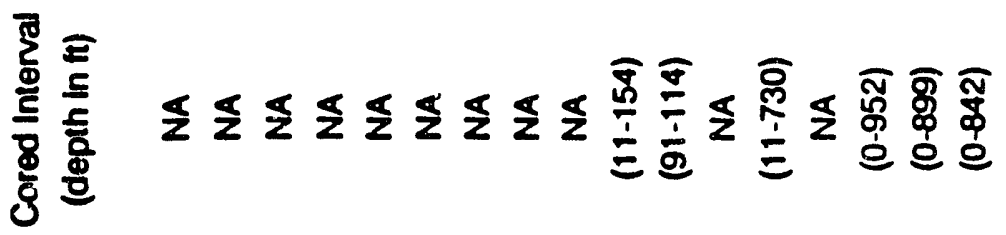

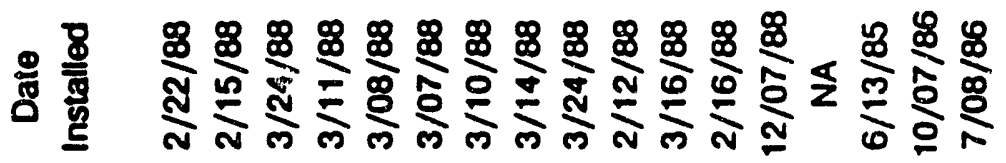

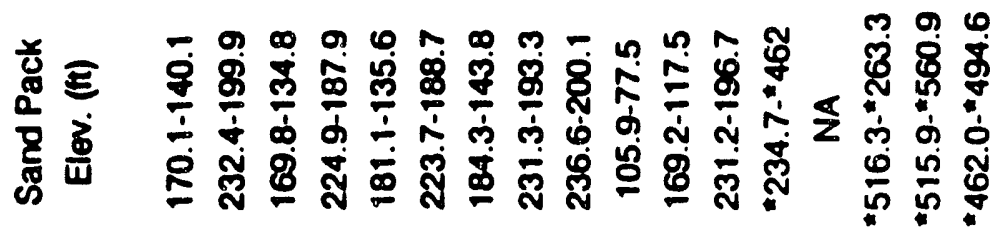

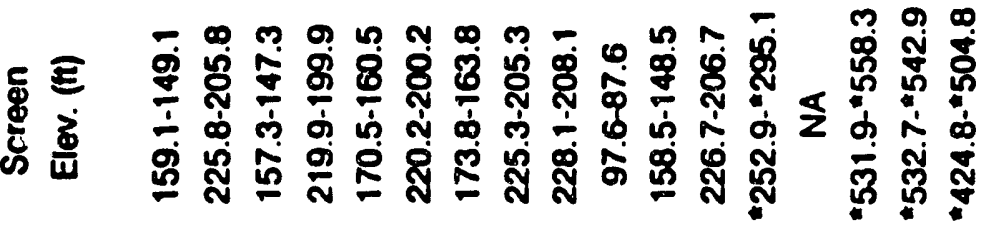

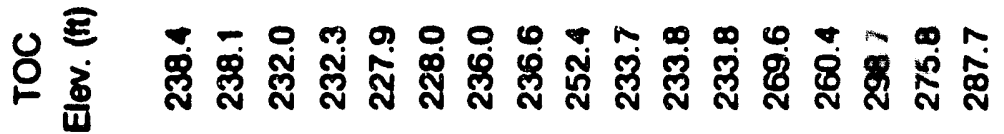

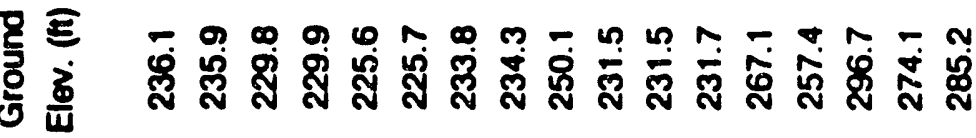

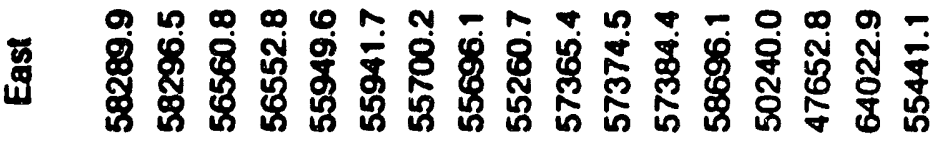

8

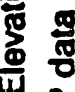

"녹

- 8

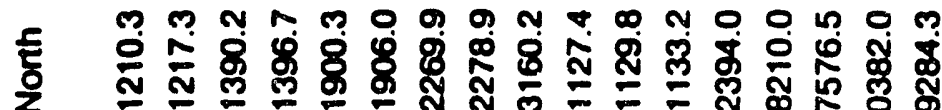

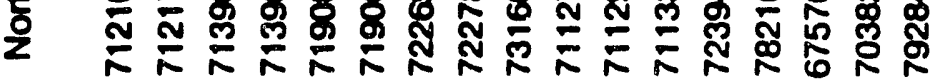

을 \&

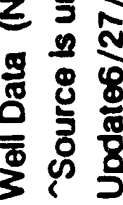

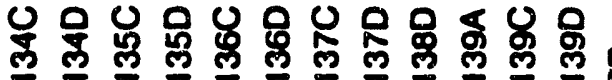




\section{APPENDIX II}

\section{DETAILED DESCRIPTIONS OF THE LITHOFACIES OF THE HYDROLOGIC UNITS ON REGIONAL CROSS SECTIONS}

\section{Cross Section \#1}

Cross Section \#1 (Plate 1) represents a 2.4-mile line of section from north of the MWMF to southeast of H-Area Seepage Basins. The section follows the southeast regional dip of the GSA. Topography is relatively flat with elevations ranging from 270 to 292 feet above msl. The depression between borings P-28 and BGO-10 is an unnamed stream that drains into UTRC. The bedding is essentially flat.

Cross Section \#1 illustrates all of the hydrostratigraphic unit, proviously described. Confining System I-II was penetrated in borings P-28, HSB-85, and P-27, attaining a thickness of over 100 feet in P-28 ard P-27. Little data are available in the vicinity of HSB-65. The dashed line represents where the top of the confining system would be located based on stratigraphic position.

Aquifer Unit IIA was not fully penetrated in borings BGO-10, BGO-8 and BGO-6. Where the unit was fully penetrated it consists of approximately 55 to 75 feet of clean sand with minor interbeds of clayey sand. Confining Unit IIA-IIB is interpreted to thicken and thin rapidly on Cross Section \#1. The unit is approximately 20 feet thick in P-28 to the northeast. At the MWMF the unit thickens to 30 feet in BGO-6 and thins to 5 feet to the southeast at P-27. The units between HSB-85 and P-27 consist of two separate lenses of clay. The dashed line represents where the lenses would meet based on available data. The lithofacies of Confining Unit IIA-IIB consists predominantly of clays and sandy clays with minor interbeds of calcareous muds. 
The thickness of Aquifer zone IIB 1 varies from 60 to 75 feet. The calcareous sands, mud, and limestone beds in the zone attain a thickness of 45 feet to the northeast, but thin to approximately 25 feet to the southeast. Clastic interbeds observed within the calcareous facies near BGO-6 are not uncommon. Generally, lithofacies vary quickly and abruptly within short distances. This could be indicative of local changes in the depositional environment such as water depth. Clastic lithologies may have been calcareous at the time of deposition with post-depositional ground water movement possibly removing the calcareous material within localized areas.

Confining zone $\mathrm{IIB}_{1}-\mathrm{IIB}_{2}$ is a series of thin clay beds, sandy clay beds, and clayey sand beds attaining of thickness of 20 feet to the northwest. To the southeast it thins to 5 feet and becomes a clay of intermediate thickness between HC-12 and P-27.

Aquifer zone $\mathrm{IIB}_{2}$ has an average thickness ranging from 70 to 80 feet. The zone becomes slightly aicker to the southeast attaining a thickness of 90 feet. To the northeast this $z$ nne becomes very clay-rich in borings P-28, HC-12 and P-27. At other locations this zone is predominantly clayey said with few beds of clean sand. The dip of the beds steepens between HSB-85 and HC-12 within Confining zone $\mathrm{IIB}_{1}-\mathrm{II}_{2}$ and Aquifer zone $\mathrm{IIB}_{2}$. This is interpreted to be a local facies change or a localized post-depositional erosional surface.

\section{2) Cross Section \#2}

Cross Section \#2 (Plate 2) represents a 3.6-mile line of section from north of F-Area Seepage Basins to east-southeast of H-Area Seepage Basins. This is essentially along the regional dip. Topography is undulating with elevations ranging from 304 to 208 feet above msl. An unnamed 
tributary of Fourmile Branch exists between HSB-TB, HSB-133 and HPC-1. The incised area between DRB-4 and HSB-117 is an effluent stream for the F-Area facility to the north. The bedding is essentially flat lying.

A prominent structural feature on Cross Section \#2 is the normal fault between HPC-1 and P-27. This fault is downthrown to the east with a throw of approximately 20 feet. Data accumulated in the Pen Branch Fault investigation suggests the offset may actually be an anticlinal flexure overlying and controlled by deeper seated faulting associated with reactivation of basement faults. Thus this feature is considered to be structurally controlled.

All of the hydrostratigraphic units are illustrated on this cross section. Confining System I-II attains a thickness of approximately 100 feet in DRB-4. The geophysical and core data provide good correlation for this system. At the H-Area Seepage Basins the system was not fully penetrated. The dashed line represents where the top of Confining System I-II would be located based on stratigraphic position. Confining System I-II consists predominantly of clay/silts, sandy clay/silts, and clayey sands of equal thicknesses. Few clean sands are present.

Aquifer Unit IIA was not fully penetrated in HSB-117, HSB-119, HSB-65, or HSB-123. Where the unit was fully penetrated it consists predominantly of sands and clayey sands. The unit becomes clayey at FSB-76 and FSB-TA. HSB-65 and contains a 20-foot thick calcareous sand bed. Both the clay and calcareous sand beds are attributed to local facies change.

Aquifer Unit IIA thins considerably to the east-southeast. In the northeast the unit attains a thickness of around 100 feet thinning to 50 to 65 feet in the east-southeast area. The thickening to the northeast may be related to the absence of carbonate sediments that tend to dominate in the vicinity of the H-Area Seepage Basins. To the northwest the clay beds of Confining Unit IIA-IIB tend to be stratigraphically higher than in the areas of carbonate buildup. The clay beds of the 
confining unit underlie the carbonates and are stratigraphically lower in the section. Aquifer Unit IIA is thinnest in these areas.

Confining Unit IIA-IIB is relatively thin throughout Cross Section \#2, attaining a maximum thickness of 15 feet in HSB-65. Elsewhere the unit is approximately 5 feet thick. Cross Section \#2 illustrates the separate lenses of green clays that thicken and thin, and pinch out abruptly. The clay lens in IDL-3 pinches out before meeting a lower clay lens in FSB-76. This upper clay lens appears downdip at HPC-1 and truncates abruptly into a limestone lithofacies in Aquifer zone IIB 1 . No lower clay lenses are present at HPC-1.

Aquifer zone $\mathrm{IIB}_{1}$ thins to around 50 feet in the north of the F-Area Seepage Basins, thickens to about 90 feet in the H-Area Seepage Basins and thins again to around 65 feet east-southeast of the basins. This fluctuation in thickness is attributed to the thick carbonate sequence present near the H-Area Seepage Basins. The isolated carbonate section in FSB-TA was interpreted to be carbonate, based on the daily detailed drilling report. Lost circulation and cuttings data all indicate the presence of a calcareous zone.

Aquifer zone $\mathrm{IBB}_{1}$ consists predominantly of clayey sand beds. Several clean sand beds are scattered throughout this zone. The calcareous facies of Aquifer zone $\mathrm{IIB}_{1}$ consists mainly of limestones and sandy limestones beds. A few thin clastic beds are intertonguing with the calcareous beds. This is attributed to a local facies change or carbonate dissolution within the clastic beds, reducing the percentage of carbonate.

Confining zone $\mathrm{IIB}_{1}-\mathrm{IIB}_{2}$ thickens and thins very abruptly on Cross Section \#2, ranging in thickness from 0 to 25 feet. No confining zone was encountered in the vicinity of IDL-3 and HSB-123. Between HSB-133 and HPC-1 the clays of the confining zone are interpreted to be discontinuous and, based on available data, may or may not be interconnected. 
Aquifer zone $\mathrm{IIB}_{2}$ thickens and thins in response to the topography along the cross section. This zone becomes thin in the vicinity of HSB-117 with a thickness of approximately 40 feet and increases to the north and east-southeast to a thickness of 90 to 100 feet. Clayey sediments dominate this zone with the exception of FSB-TA and IDL-3. FSB-TA may possibly represent a sand infilled channel.

\section{Cross Section \#3}

Cross Section \#3 (Plate 3) represents a 2.7-mile line of section from northeast of the F-Area Seepage Basins to south-southwest of the F-Area Basins. The section roughly follows the regional strike. Topography is undulating with elevations ranging from 180 feet above msl at Fourmile Branch to 297 feet at P-18. The beds are essentially flat lying with the exception of the northeast area between P-28 and FSB-76 where Confining zone IIB 1 -IIB 2 and Aquifer zone $\mathrm{IIB}_{2}$ show a slight steepening of the beds to the southwest. Within this area Confining zone $\mathrm{IIB}_{1}-\mathrm{IIB}_{2}$ could be a post-depositional erosional surface resulting in a change of dip.

A prominent feature on Cross Section \#3 is the offset of beds between FSB-91 and FSB-100. Beds are downthrown approximately 12 feet to the south. This feature is possibly structurally controlled or sedimentalogically controlled. Often areas of offset are related to carbonate buildups. There is the strong possibility of slumping associated with carbonate dissolution. Slump features were recognized in the coastal plain calcareous sediments by Johnson and Heron (1965). Features of this type are also discussed by McDowell and Houser (1983). The offset has been projected to the top of Confining System I-II however, this interpretation is based on the limited data available. Geophysical and core data both corroborate the offset in Aquifer zone $\mathrm{IIB}_{1}$, Confining zone IIB - $^{-}$ $\mathrm{IIB}_{2}$, and Aquifer zone $\mathrm{IIB}_{2}$. 
A localized steepening of dip is observed in borings FSB-106, FSB-91, and FSB-100 within Aquifer zone $\mathrm{IB}_{1}$, in association with the area of offset. The steepening could be caused by the proposed slumping due to carbonate dissolution. Another possibility is clastic sediments draped over the flanks of the carbonate mounds.

Confining System I-II is represented by four borings on Cross Section \#3 (Plate 3). In P-28 the system attains a thickness of approximately 100 feet; in P-18, a thickness of around 50 feet; and in FSB-79 and FSB-76, only the very top (approximately 10 feet) was penetrated. The dashed line represents where the top of the confining system would be located based on stratigraphic position for borings FSB-91, FSB-100, and FSB-101.

At the northeast end of the section at P-28 Aquifer Unit IIA reaches a thickness of approximately 55 feet, thickening to the south-southwest to 105 feet at P-18. The thickening and thinning of this unit and its relation to the top of Confining System I-II is well illustrated in Figures 19 and 21. The structure contours on Confining System I-II reveal a regional dip to the south-southeast while the isopach of Aquifer Unit IIA illustrates a thickening in the same direction. This supports the interpretation of channel erosion into the Ellenton Clays of Confining System I-II infilled by sands of Aquifer Unit IIA (Congaree Aquifer) deposited on the erosional unconformity. Aquifer Unit IIA is composed predominantly of sands and clayey sands. Minor interbeds of clay and sandy clay are present. A thin stringer of calcareous sand is present in P-18.

Confining Unit IIA-IIB consists of three separate lenses in the southwest between P-18 and FSB79. Only the thinner lower lens continues through the F-Area Seepage Basins. The unit thickens around FSB-76, and continues to thicken, and becomes two distinct clay lenses to the northeast. Generally, the unit consists of clay and sandy clay beds with minor clayey sand and sand beds. 
Aquifer zone $\mathrm{IIB}_{1}$ is relatively uniform in thickness varying from 45 to 60 feet throughout Cross Section \#3. The zone is predominantly calcareous to the southwest near P-18, becoming less calcareous at the F-Area Seepage Basins. To the northeast only clastic lithofacies are found. The zone is primarily clayey sand beds with a few thick, clean sand beds.

Confining zone $\mathrm{IIB}_{1}-\mathrm{IIB}_{2}$ is about 17 feet thick to the southwest at $\mathrm{P}-18$. The zone thins to 2 to 3 feet thick in the vicinity of FSB-91 and FSB-100 and thickens again to about 12 feet at P-28 to the northeast. The lithofacies are primarily clay with minor interbeds of clayey sand.

Aquifer zone $\mathrm{IIB}_{2}$ becomes very thin around Fourmile Branch. Thicknesses range to over 100 feet to the northeast and southwest. The lithofacies are quite clayey to the northeast at P-28 and FSB76. Around the F-Area Seepage Basins sands and clayey sands dominate the lithofacies. To the southwest at P-18 the section includes equally thick beds of sand, clays, clayey sands, and sandy clay.

\section{Cross Section \#4}

Cross Section \#4 (Plate 4) represents a 1.3 mile line of section from northeast of the HWMF to the south-southeast of H-Area Seepage Basins. The section roughly follows the regional strike. This section intersects Cross Section \#1, Cross Section \#2 and Cross Section \#5A. Topography is relatively flat with the steepness increasing near Fourmile Branch. Elevations range from 284 feet at BGO-6 to 192 feet at Fourmile Branch. The bedding is essentially flat lying.

Confining System I-II was only penetrated at HSB-86 on Cross Section \#4. Approximately 30 feet of sandy clay, silt, and clayey sand beds of equal thickness are present at this location. The 
dashed line indicates where the top of the confining system would be located based on its stratigraphic position at HSB-129 and HSB-130.

Aquifer Unit IIA was fully penetrated at HSB-86 and partially penetrated at HSB-119 and HSB120. The unit attains a thickness of 50 feet at HSB-86. The unit is composed of thick sand and clayey sand beds. One calcareous sand stringer was encountered at HSB-120. The dashed iine indicates where the top of Aquifer Unit IIA would be located based on stratigraphic position.

Confining Unit ILA-IIB consists of a relatively thin, sandy clay to the south at HSB-86. The unit becomes progressively thinner at HSB-120, having a thickness of only 2 feet. To the northeast the unit thickens and is composed of four separate lenses of clay and calcareous mud with minor interbeds of clayey sand. The confining unit attains a thickness of 30 feet at BGO-6.

Aquifer zone $\mathrm{IBB}_{1}$ is variable in thickness. To the south-southeast the zone is approximately 60 feet thick. In the vicinity of the H-Area Seepage Basins the zone thickens to around 80 feet. To the northeast at BGO-6 the zone thins to approximately 60 feet. The zone consists predominantly of sands and clayey sands with minor interbeds of thin clays. One muddy limestone is present at BGO-6.

Confining zone $\mathrm{IIB}_{1}-\mathrm{IIB}_{2}$ is very variable in thickness on Cross Section \#4. The zone attains a maximum thickness of 32 feet to the south-southeast at HSB-137 and a minimum thickness of 9 feet to the south where it is incised by Fourmile Branch. The confining zone consists predominantly of clay and sandy clay beds 1 to 13 feet thick interbedded with clay sand and sand beds 2 to 8 feet thick.

Aquifer zone $\mathrm{IIB}_{2}$ is truncated by Fourmile Branch. The zone attains a maximum thickness of approximately 75 feet to the northeast between BGO-21 and BGO-6. The lithofacies are very 
slayey throughout the zone. Interbeds of clayey sands and sands intertongue with the clayey sediments throughout Cross Section \#4. Occasional pebble and gravel beds are present to the northeast.

\section{5) Cross Sections \#5A and \#5B}

Cross Sections \#5A and \#5B (Plates \#5A and \#5B) represent an east-west 2.3-mile line of section from east of the MWMF to the western edge of the F-Area Seepage Basins. There are 18 borings represented on these two sections. This section was split into "A" and "B" for the ease of handling. A match line is provided for correlation. Topography is undulating with elevations ranging from 311 above msl at BGO-12 to 233 feet above msl at HPT-1. HPT-1 and HPT-2 are near the flanks of an unnamed tributary of UTRC. Beds are essentially flat lying on the outer edges of the cross sections. Around the MWMF the dip steepens in Aquifer zone $\mathrm{IIB}_{1}$, Confining zone $\mathrm{IIB}_{1}-\mathrm{IIB}_{2}$, and Aquifer zone $\mathrm{IIB}_{2}$.

The dip could be the result of clastic deposits draped over the flanks of carbonate mounds. Localized post-depositional erosional surfaces could also change the dip. An example of this would be the beds between BGO-12 and BGO-10. Here dissolution of the carbonate beds in Aquifer zone $\mathrm{IIB}_{1}$ could result in slumping of the overlying sediments.

A prominent feature on Cross Section \#5B is the offset beds between FSB-97 and FSB-98. The feature exhibits normal offset, and beds are downthrown to the west with a throw of approximately 9 feet in Aquifer zone IIB 2 . Throw decreases to around 3 feet in Confining zone IIB $_{1}-$ IIB $_{2}$ and Aquifer zone IIB 1 . The offset apparently does not penetrate Confining Unit IIA-IIB. The offset cuts FSB-97 at 121 feet above msl. Geophysical and core data both corroborate this offset. This feature is either structurally or sedimentalogically controlled. There is a good possibility of slumping associated with carbonate dissolution as previously discussed. Due to the close 
proximity of calcareous beds in the nearby boring FSB-100, there is a strong possibility that borings FSB-97 and FSB-98 once contained carbonate beds and post-depositional carbonate dissolution is a reasonable explanation for the offset observed between FSB-97 and FSB-98. Slump features were recognized in the calcareous sediments described by Johnson and Heron (1965). Soft sediment deformation such as deltaic slumping is another feasible explanation for the offset. Features of this type are discussed in detail by McDowell and Houser (1983).

An offset of beds is also on Cross Section \#5B. A normal down to the south feature is represented on the Cross Section between borings BGO-6 and BGO-5 and HPT-2. The line of section intersects the offset so that the offset is displayed twice. Well BGO-5 is on the upthrown side of the offset and wells BGO-6 and HPT-2 are on the downthrown side. The offset has a throw of 5 to 7 feet in Aquifer $\mathrm{IIB}_{2}$ and Confining zone $\mathrm{IIB}_{1}-\mathrm{IIB}_{2}$. The throw increases to approximately 10 feet in Aquifer zone $\mathrm{IIB}_{1}$. The offset possibly dies out in Aquifer zone $\mathrm{IIB}_{1}$, but data is limited in this area. Again the offset may be due to slumping of the younger sediments overlying the area where carbonate dissolution had occurred.

Confining System I-II was only penetrated at FSB-TA to the west and at HPT-1 and HPT-2 to the east. The dashed line indicates the confining system's stratigraphic position. Where the system is observed it consists of clays/silts and sandy clays with interbeds of clayey sands and sands.

Aquifer Unit IIA was only fully penetrated at FSB-TA to the west and at HPT-1 and HPT-2 to the east. Total thickness ranges from 60 to 70 feet at these locations. The unit is composed predominantly of clean sand beds with minor interbeds of clayey sand and sand beds. A thinning of the unit is inferred beneath BGO-6 and BGO-5 due to the thickening of the Confining Unit IIAIIB that overlies Aquifer Unit IIA. 
Confining Unit IIA-IIB is thin from the western edge of the F-Area Seepage Basins and becomes very thin on the southwestern edge of the MWMF. Thicknesses range from 3 to 5 feet at these locations. On the southern edge of the MWMF the unit thickens to 25 feet and remains thick until borings HPT-1 and HPT-? are reached to the west. Here the unit is 4 to 5 feet thick. The confining unit is predominantly a clay and sandy clay until it reaches the southern edge of the MWMF at BGO-25, BGO-14, and BGO-12. The unit thickens and contains clays and clayey sands with interbedded sands. The clayey sand and sand lithofacies were included in the confining zone because this lithofacies is predominantly consolidated indurated sandstone in this area, where it is a very fine to fine sand sized and tightly cemented with silica cement.

West of BGO-12 the unit contains calcareous muds, clay, and clayey sands thinning back to a clay at BGO-8. At BGO-6 the unit thickens to 30 feet. The clays separate into four separate lenses and become calcareous at the top of the unit. Interbeds of clayey sand are included in this confining unit (Confining Unit IIA-IIB). Due to limited data this unit is dashed with question marks between BGO-8 and HPT-2. To the east the unit becomes a clay and sandy clay thinning to 5 feet.

Aquifer zone $\mathrm{IIB}_{1}$ is variable in thickness. At the western edge of the F-Area Seepage Basins the thickness is approximately 45 feet. To the west and at the MWMF the zone thickens to 95 feet. From the F-Area Seepage Basins the zone is predominantly composed of clastic lithofacies with calcareous lithofacies present on the eastern edge of the basins near FSB-100 and FSBTA. Clastic lithofacies are composed of relatively thick sands (up to 20 feet thick) with minor interbeds of clayey sands, clays, and sandy clays. Calcareous lithofacies consist of calcareous sands and muddy and sandy limestones. The limestone in FSB-TA is based on daily detail drilling reports compiled by the drilling and oversight personnel. Lost circulation and cuttings data all indicate the presence of a calcareous zone. 
Aquifer zone $\mathrm{IIB}_{1}$ is predominantly a calcareous lithofacies under the MWMF with the exception of BGO-12 and BGO-6. Well BGO-12 contains no calcareous sediments. Based on the isopach of the lower carbonate zone (see Figure 17) it is possible that the carbonate deposition was absent at this location. However, another possibility is the previously discussed carbonate dissolution of the sediments. The overlying steeply dipping clastic beds in BGO-12 could be a result of slumping from carbonate dissolution of calcareous beds.

The calcareous lithofacies under the MWMF are composed predominantly of calcareous sands, muddy limestone, and sandy limestones with minor interbeds of calcareous muds. The clastic lithofacies in this area includes interbeds of sands and clayey sands with minor interbeds of clay and sandy clay of equal thicknesses.

To the east Aquifer zone IIB 1 in HPT-1 and HPT-2 consists predominantly of clastic lithofacies with minor interbeds of calcareous sands in the lower portion. The clastic lithofacies include interbeds of equal thickness of sands and clayey sands. Minor clays and sandy clays are also present.

Confining zone $\mathrm{IIB}_{1}-\mathrm{IIB}_{2}$ varies in thickness throughout Cross Sections \#5A and \#5B. Thicknesses range from 5 to 20 feet. Lithofacies are predominantly clastic. One thin stringer of calcareous sand is present at BGO-25 at the southwestern edge of the MWMF. Clastic lithofacies are predominantly clay and sandy clay with minor interbeds of clayey sand and sand from the western edge of the F-Area Seepage Basins to the southwestern edge of the MWMF. At this location the clay beds become a series of thin lenses with interbeds of clayey sand and sands. At the very eastern edge of Cross Section \#5A Confining zone IIB $1-\mathrm{IIB}_{2}$ was not encountered at HPT-1 and HPT-2. This is illustrated in the isopach map of Confining zone $\mathrm{IIB}_{1}-\mathrm{IIB}_{2}$ (Tan Clay) (see Figure 26). 
Confining zone $\mathrm{IIB}_{1}-\mathrm{IIB}_{2}$ is variable in thickness due to topographic undulations. Lithological thickness is approximately 100 feet at FSB-TA and 23 feet at HPT-1. The zone is composed entirely of clastic lithofacies; predominantly sands and clayey sands. This zone becomes very sandy at the F Area Seepage Basins and in the vicinity of BGO-8. Elsewhere abundant lenses of clay are present. 


\section{PHYSIOGRAPHIC SUBPROVINCES OF THE SOUTH CAROLINA COASTAL PLAIN}

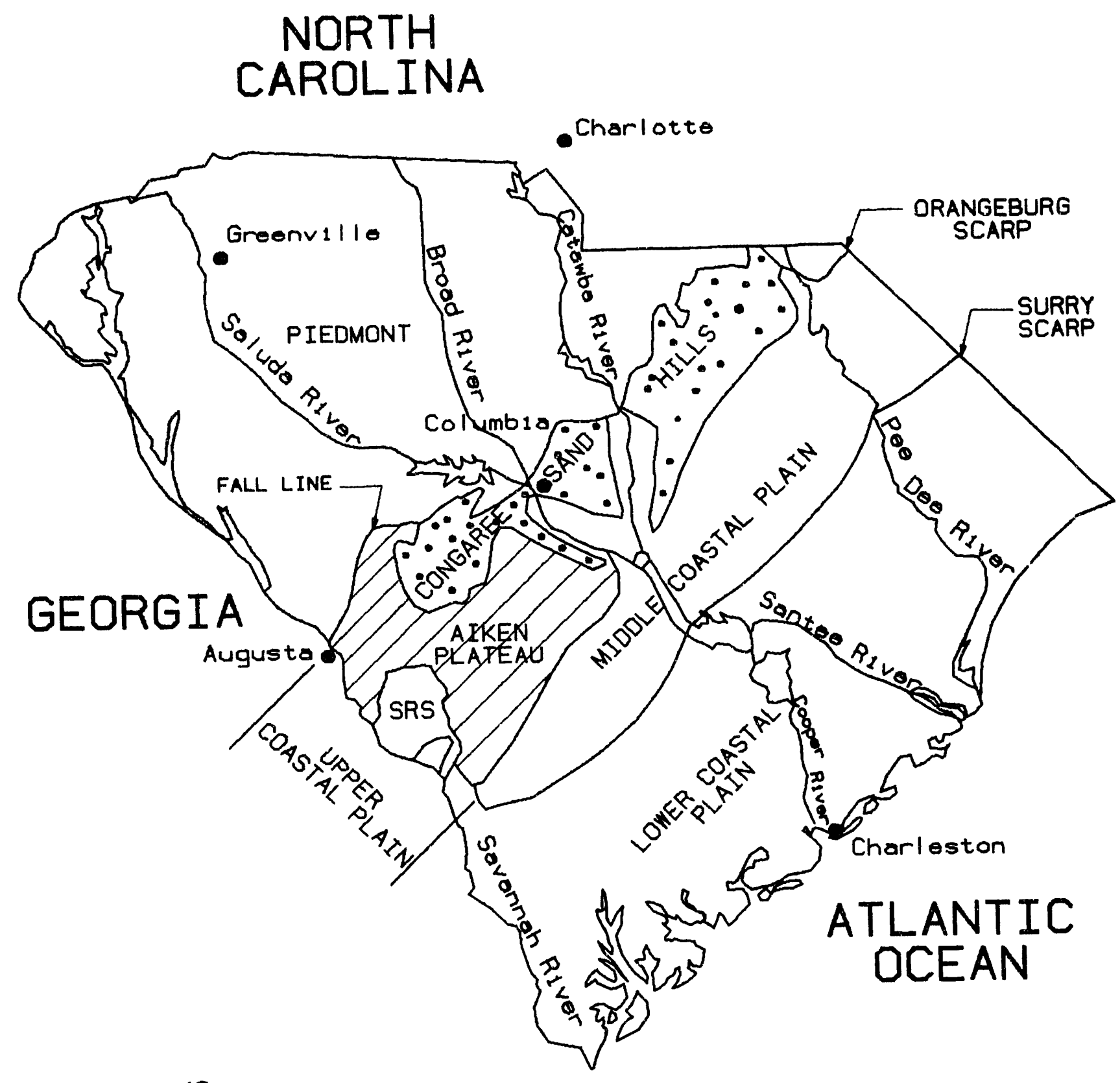

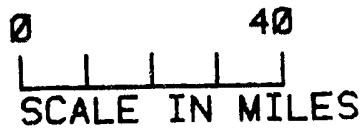




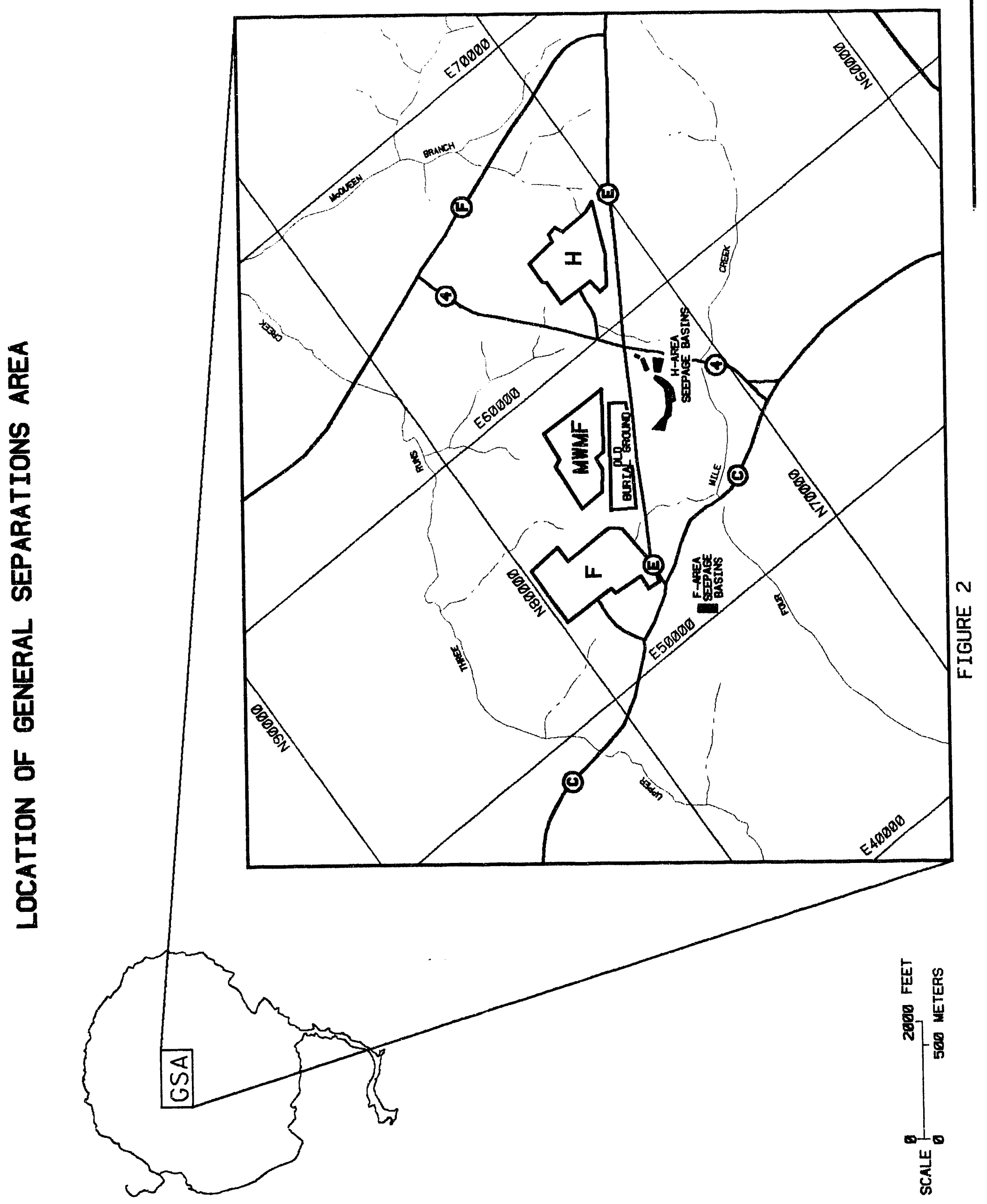




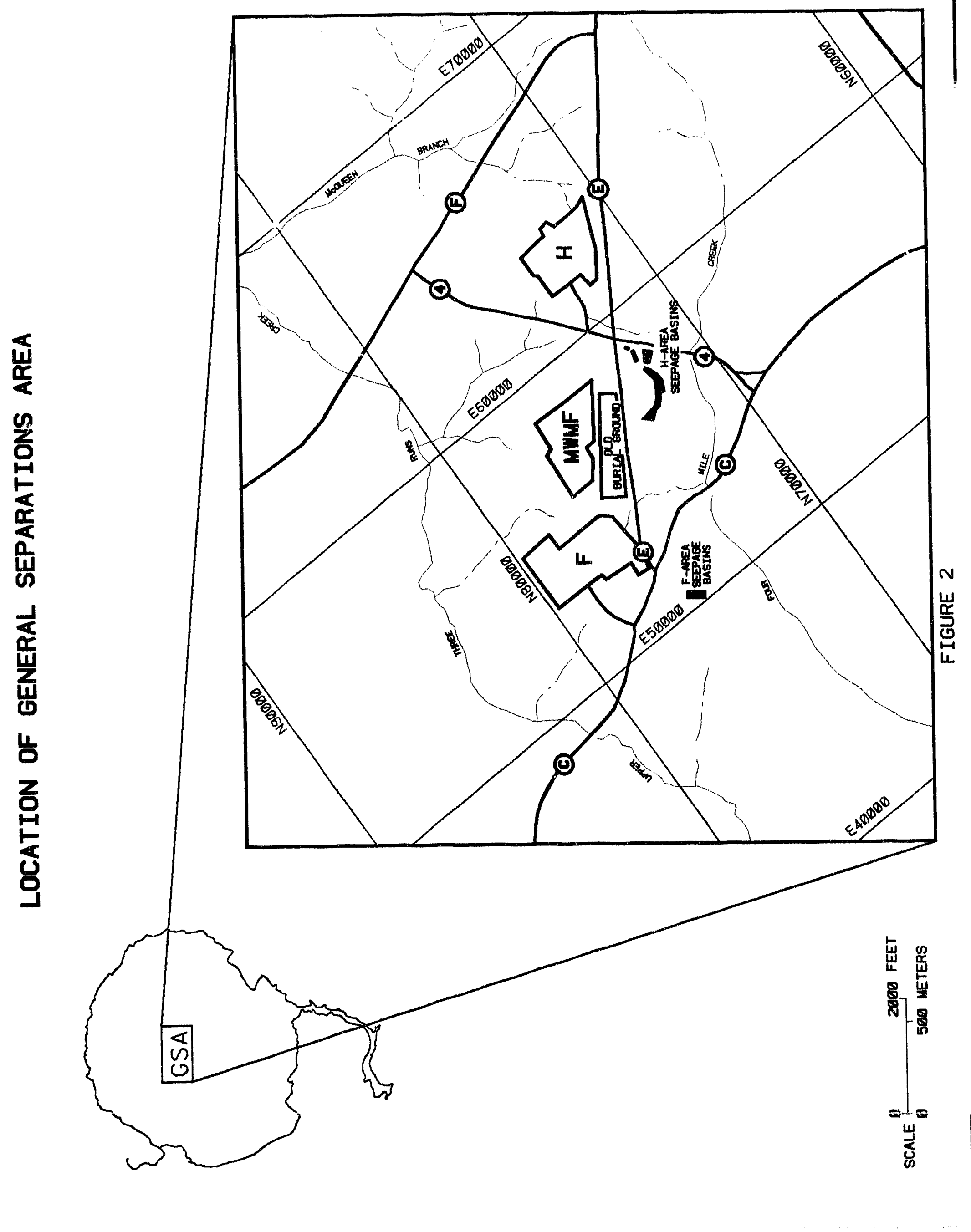




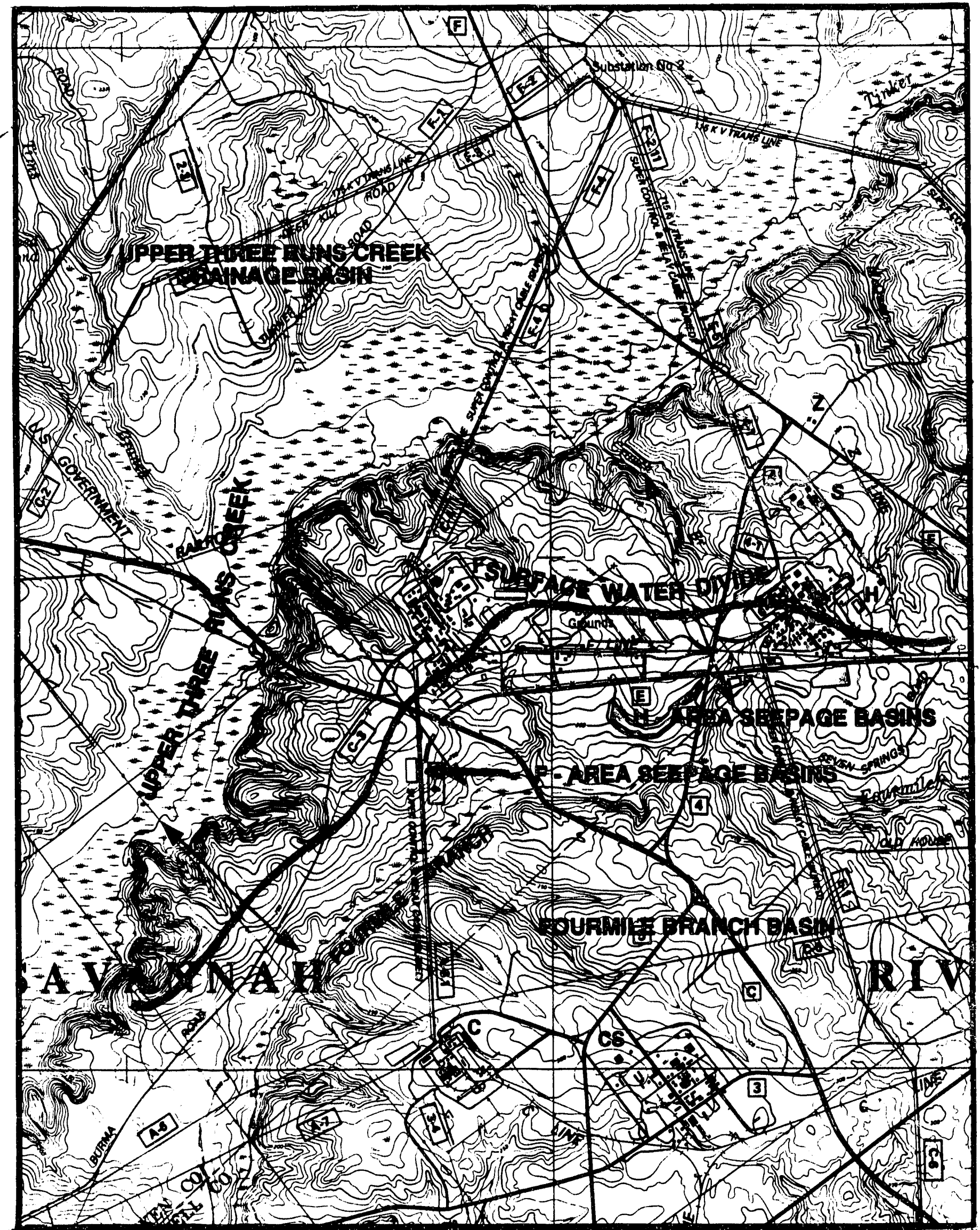




\section{TECTONIC SETTING OF EASTERN UNITED STATES}

\section{LATE PRECAMBRIAN EXTENSION}

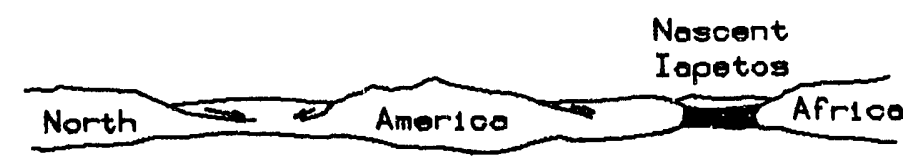

\section{LATE PRECAMBRIAN SPREADING}

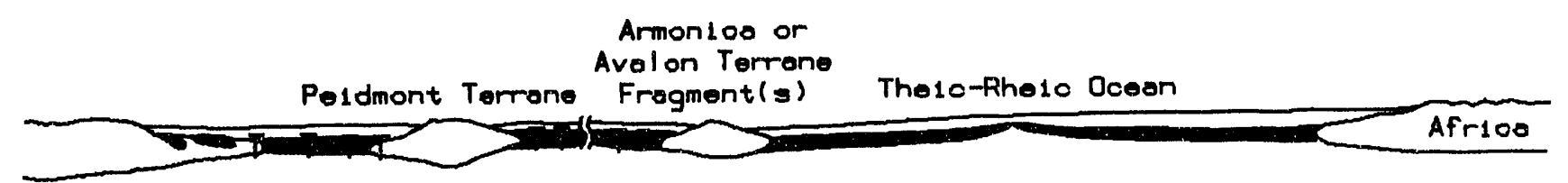

\section{LATE PRECAMBRIAN - EARLY CAMBRIAN}

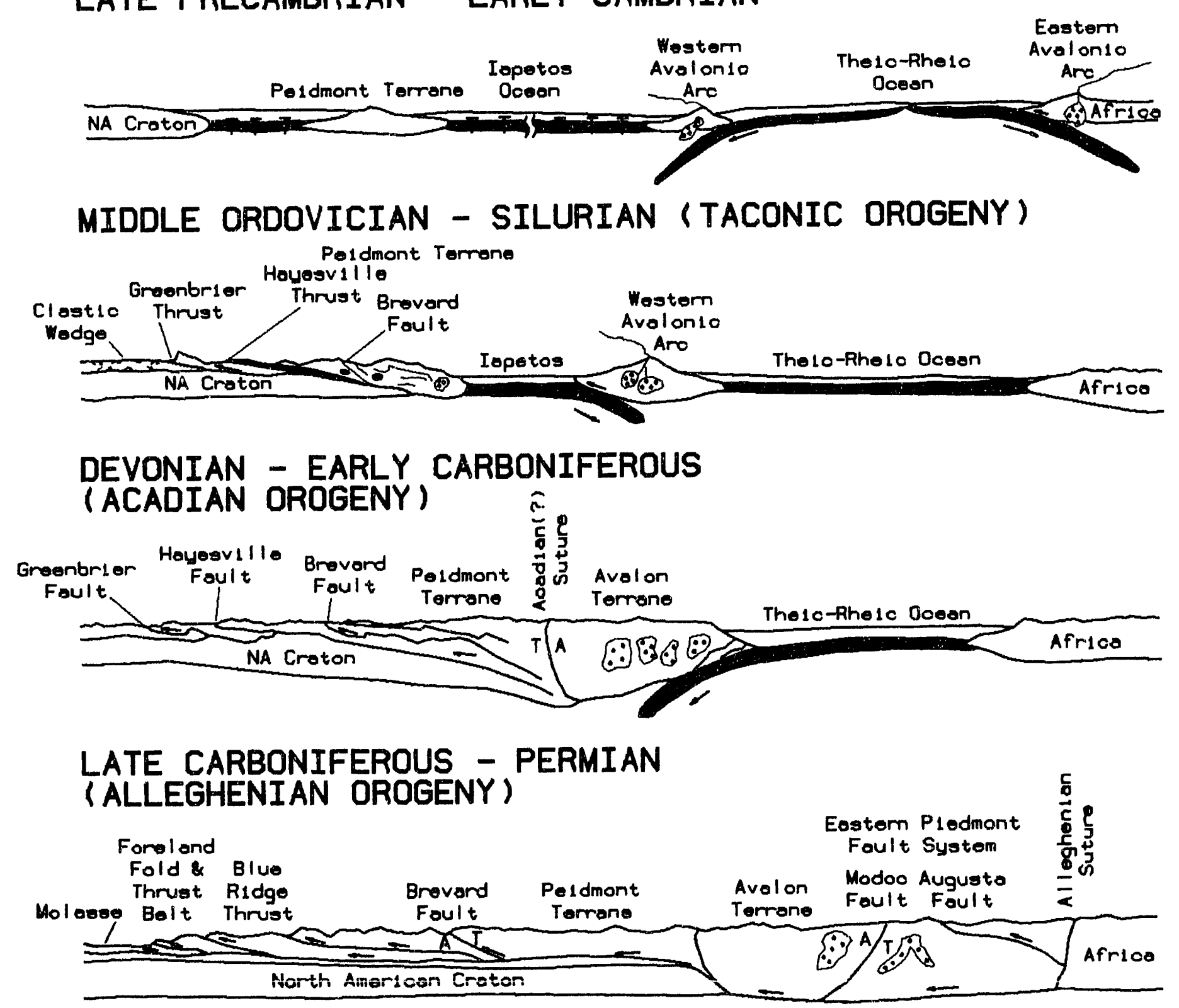

SOURCE, URANIUM SOLDIFICATION FACILITY SITE CHARACTERISTICS, APPENDICES 3A, 3B, 3C, OCTOBER, 1989. 
PREPARED OY: ROLF $K$. AMO DRAN GY: ROD A. 1 MODIF IED FROU D. COLOHAT

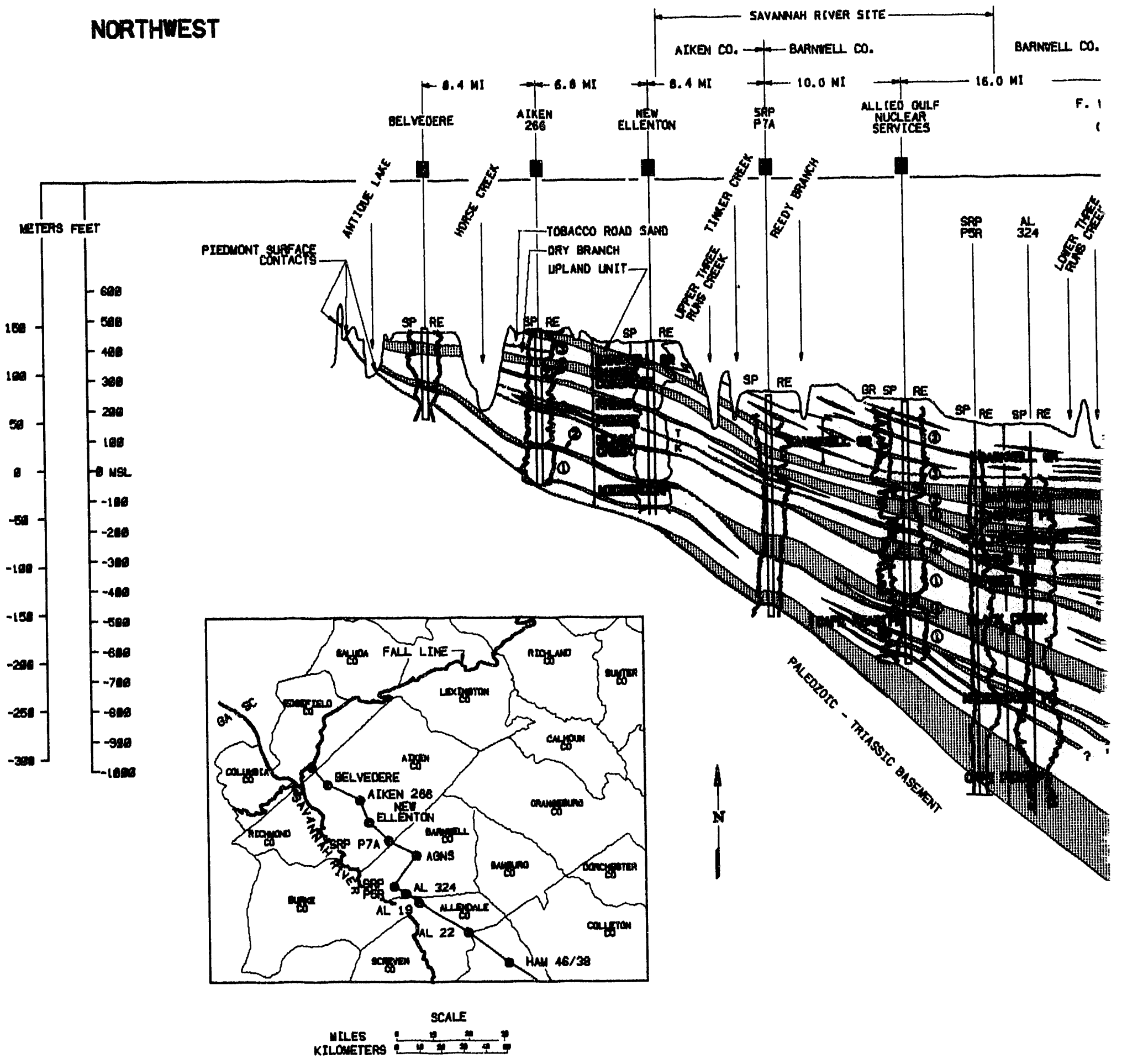




\title{
: CROSS-SECTION
}

\author{
I. 1989 \\ T \\ ETAL. 1583
}

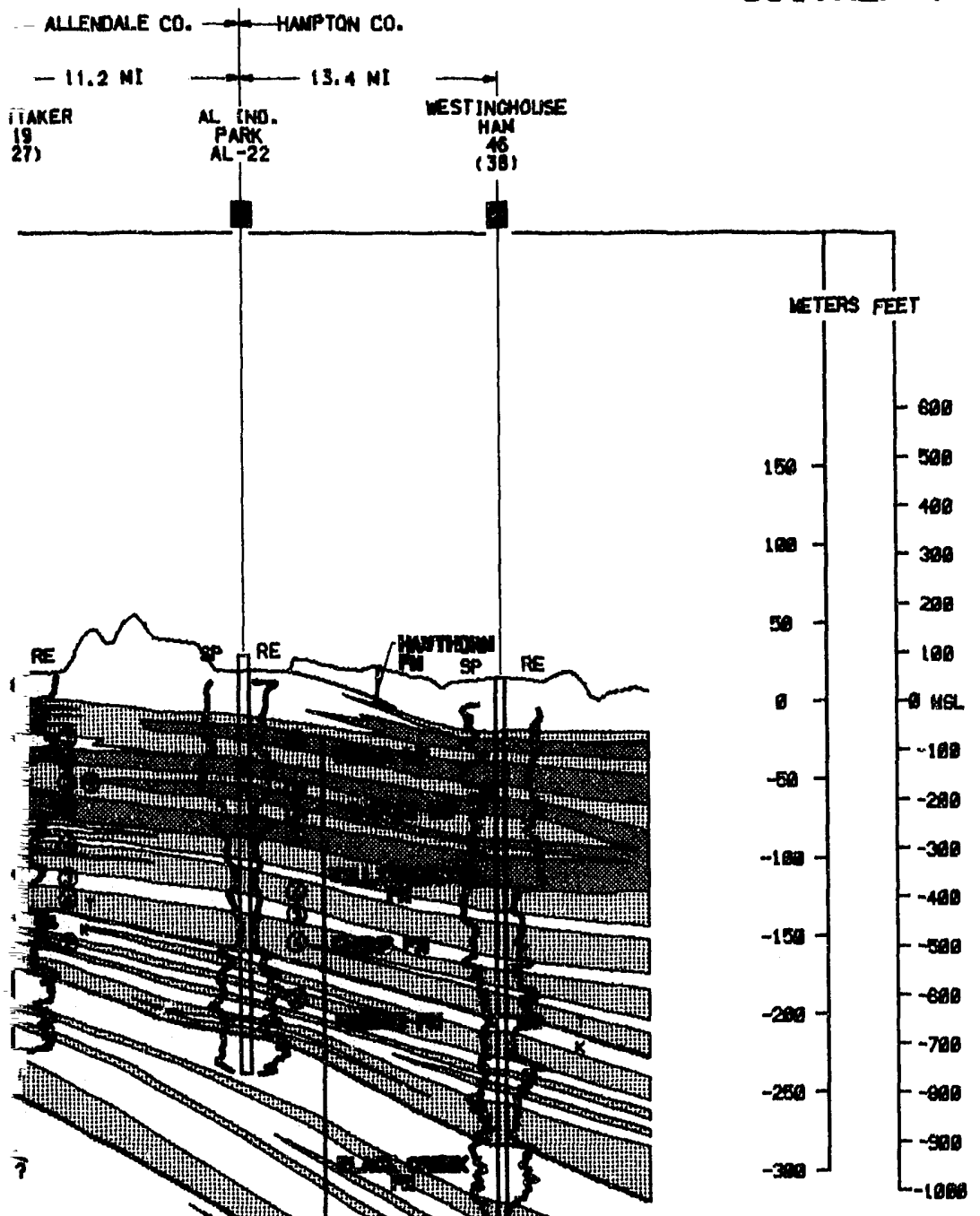

\section{SOUTHEAST}

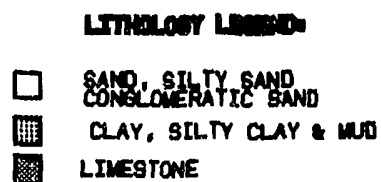

PEOIONAL EROSIONAL LACONFOFAITY

CORFGLATION

- LITHOFACLES CORRG_ATLOA

$\frac{T}{K}$ TERTIARY CORTACEOUS CONTACT

(1) UPPER DELTA PLAIN DEPOSTTIOML UNIT ABSOCLATLON

(2) LOUER DELTA PLAIN DEPOSITIONAL UNIT AgSOCLatton

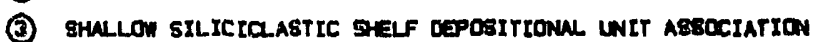

(4) DEEP SILICICLASTIC SHELF DEPOSITIONAL WNIT ASSOCIATION

(6) CARBONATE SHELF DEPOSITIONAL LNIT ASSOCIATION

SP SPONTANEOUS POTENTIAL LOS

RE REgISTIVITY LOG

CP GAme RAY LOO

Dino. No. 


\section{COASTAL PLAIN SEDIMENTS AT THE SRS}

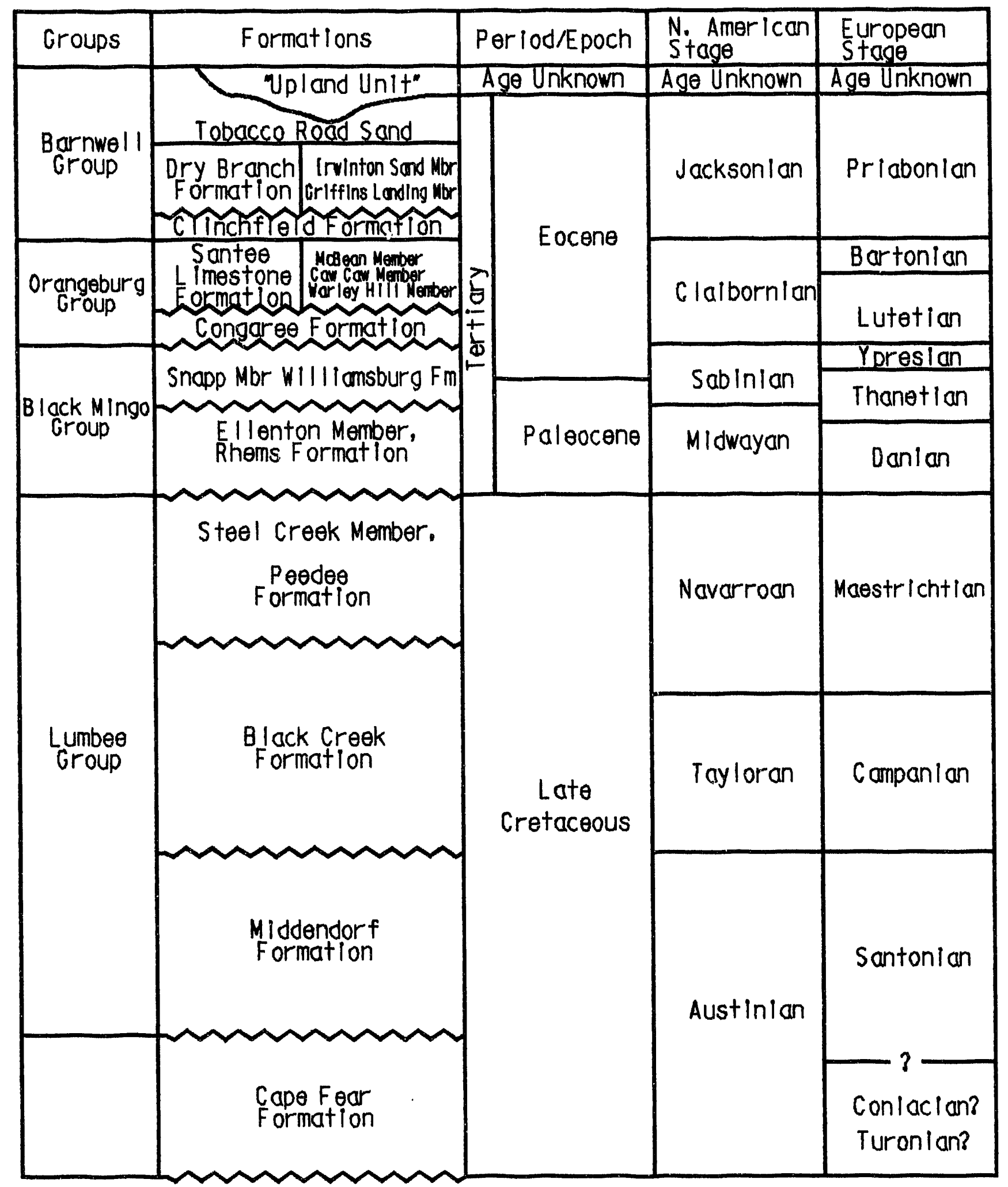

Crystalline Trlassic Basement Trlassic or Paleozolc or Precombrian Newark Supergroup 


\section{SURPACE DRARAGE MAP OP THE SAVANNAH RIVER SITE}

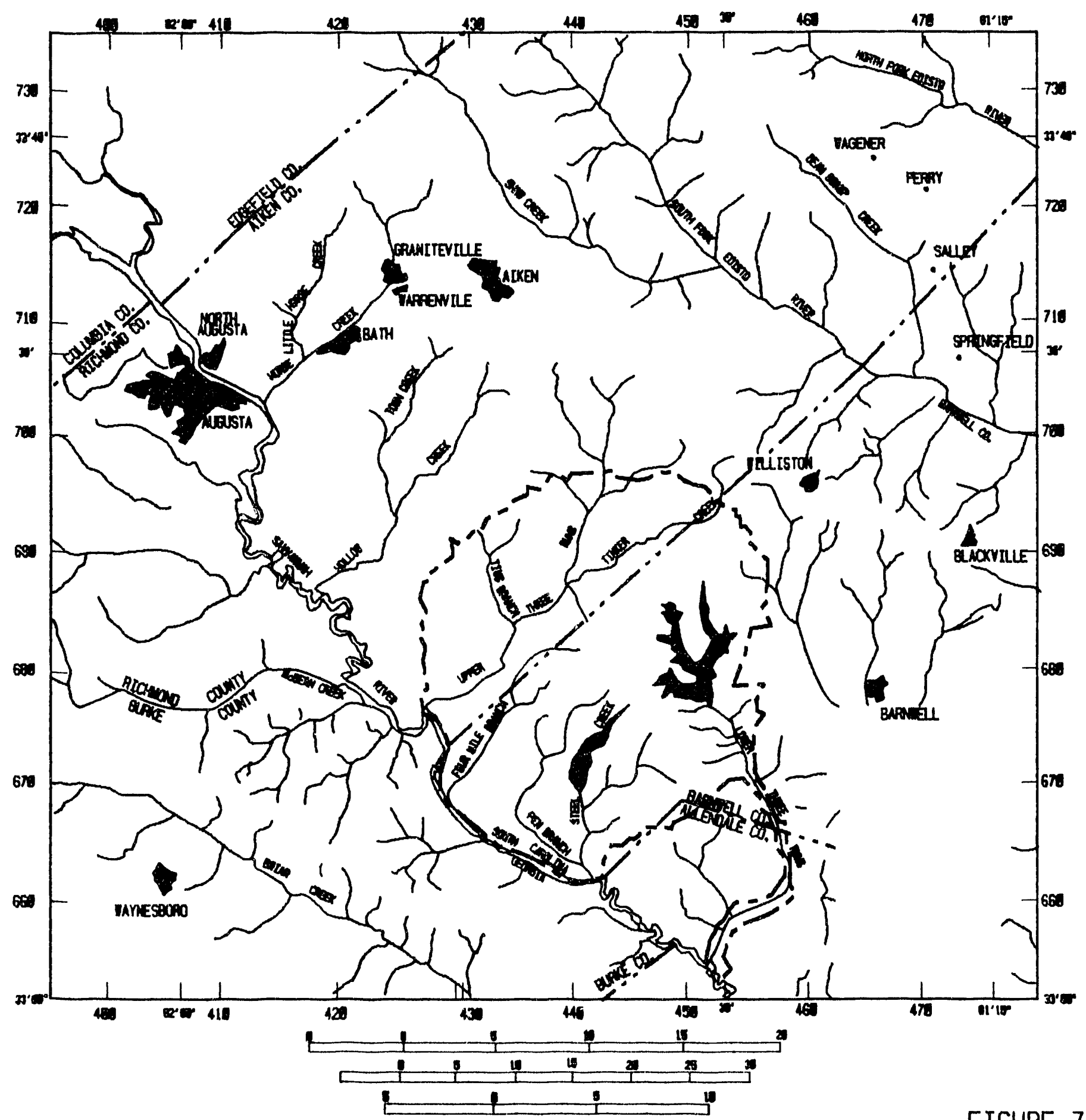

FIGURE 7

SOURCEI URANIUM SOLIDIFICATION FACILITY SITE CHARACTERISTICS, APPENDICES 3A, 3B, 3C: OCTOBER, 1989. 


\begin{tabular}{|c|c|c|c|c|}
\hline \multirow{2}{*}{ 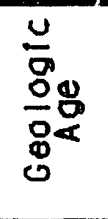 } & & & \multicolumn{2}{|c|}{ COAPARISON OF $\mathrm{H}$} \\
\hline & SIplo (1967) & $\begin{array}{l}\text { SRP Baseline } \\
\text { Hydrogeologlc study }\end{array}$ & GeoTrans (1989) & Auc \\
\hline \multirow{7}{*}{$\begin{array}{l}\frac{T}{\sigma} \\
\frac{1}{ \pm} \\
上\end{array}$} & Hawthorn Aqul fer & Upland Unit & \multirow{4}{*}{ Aquilfer 4} & \multirow{5}{*}{ Tert } \\
\hline & \multirow{2}{*}{ Barnwell Aqulfer } & \begin{tabular}{l|l}
$\overline{\bar{d}}$ & Tobacco Rd FM
\end{tabular} & & \\
\hline & & Dry Branch FM & & \\
\hline & $\begin{array}{l}\text { Mobean Aquitard } \\
\text { Green Clay }\end{array}$ & $\begin{array}{l}\text { McBean Formation } \\
\text { Groen Clay }\end{array}$ & & \\
\hline & Congaree Aqul fer & Congaree & Aquifer 3 & \\
\hline & & Villlamsburg Formation & & \\
\hline & EIIERTOO AQUITOIO & Ellenton Formation & Aquitard 2 & Confl \\
\hline & $\begin{array}{l}\text { Upper Tuscaloosa } \\
\text { Aquil fer }\end{array}$ & Peedee Formation & Aqulfer 2 & Bis \\
\hline 号 & $\begin{array}{l}\text { Mid Tuscaloosa } \\
\text { Clay Aqultard }\end{array}$ & B lack Creok Formation & Aquiltard I & Coni \\
\hline 造 & $\begin{array}{l}\text { Lower Tuscaloosa } \\
\text { Aquifer }\end{array}$ & Middendorf Formation & Aqulfer 1 & MI \\
\hline & $\begin{array}{l}\text { Basal Clay } \\
\text { Aquitard }\end{array}$ & Cape Feor Formation & Base of Model & Conf 1 \\
\hline
\end{tabular}

Trlassic or Paleozolc Basement

\section{NOTE :}

(1) Included within the different units can be individual zones SAVAN
of relatively higher or lower permeability.

(2) Hydrostratloraphlc boundarles do not necessarlly Aad colncide with stratigraphlc boundarles. 


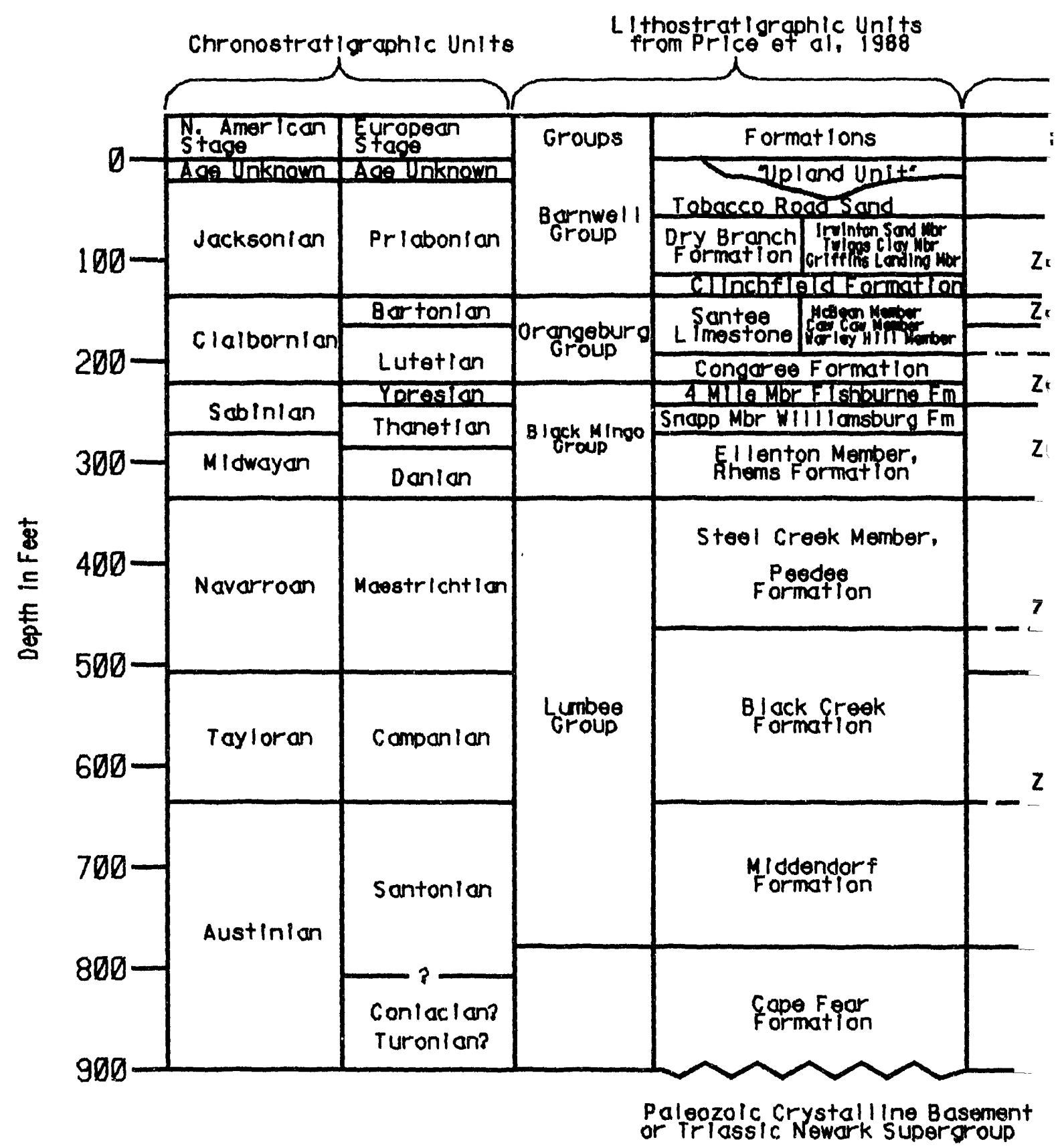

HYDROS 
Hydrostrat I graphic Units i

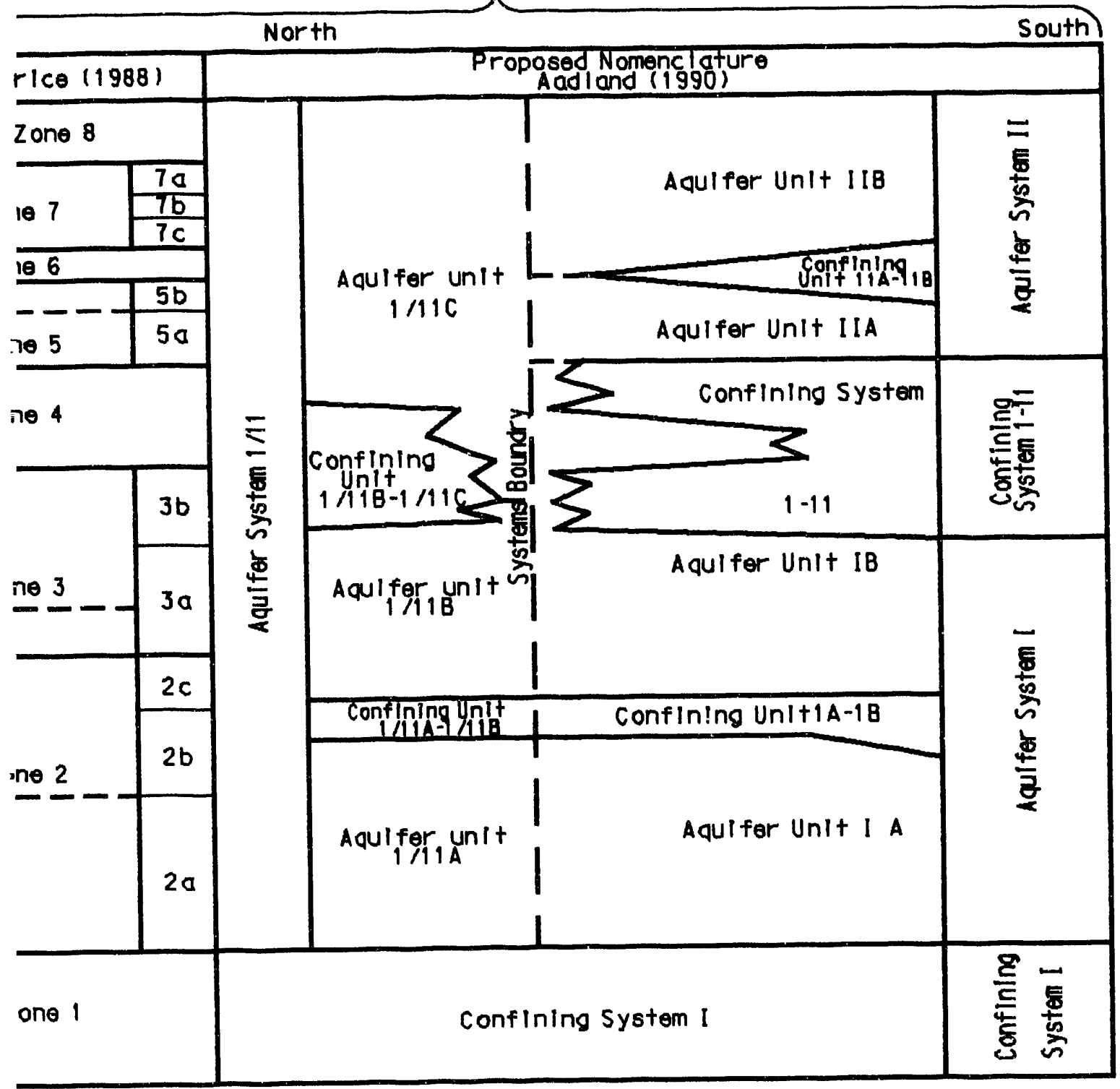

Palogzolc - Trlasslc

Basement

Hydrologic System

\section{RATIGRAPHIC CHART}

innah River Site

$\because$ Rolf $K$. Aadland

SS-SRL $10 / 26 / 89$ 


\begin{tabular}{|c|c|c|c|c|}
\hline $\begin{array}{l}\text { N. Amerlcan } \\
\text { Stage }\end{array}$ & $\begin{array}{l}\text { European } \\
\text { Stape }\end{array}$ & Groups & $\begin{array}{l}\text { Formations } \\
\text { (Price otal. 1988) }\end{array}$ & \\
\hline Ane Unknown & AOe Unknown & \multirow{4}{*}{$\begin{array}{l}\text { Barnwell } \\
\text { Group }\end{array}$} & Ipland Unit: & \multirow{14}{*}{ 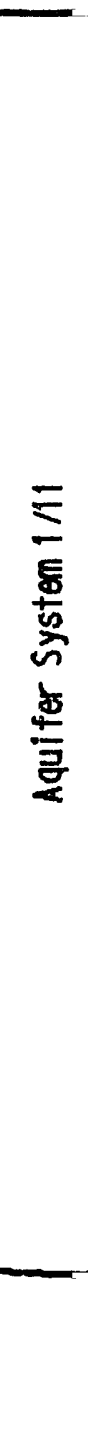 } \\
\hline \multirow{3}{*}{ Jacksonian } & \multirow{3}{*}{ Prlabonian } & & Iobacco Road Sand & \\
\hline & & & 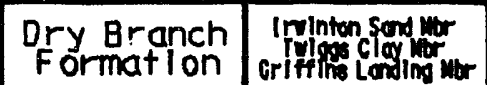 & \\
\hline & & & CTInchfleld formation & \\
\hline \multirow{3}{*}{ Claibornian } & Bartonian & \multirow{3}{*}{$\begin{array}{l}\text { Orangeburg } \\
\text { Group }\end{array}$} & Sant $\theta \theta$ Mesen henter & \\
\hline & \multirow[b]{2}{*}{ Lutetian } & & Limestone 5orloy Hilitionoer & \\
\hline & & & Congaree Formation & \\
\hline & YPreston & \multirow{3}{*}{ B I gck MIngo } & 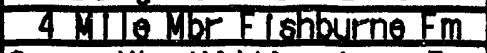 & \\
\hline Sabinlan & Thanetian & & Snopp Mbr WIIIl ansburg Fm & \\
\hline Midwayan & Danian & & $\begin{array}{l}\text { Ellenton Member, } \\
\text { Rhems Formation }\end{array}$ & \\
\hline Navarroan & Maestrichtian & \multirow{4}{*}{$\underset{\text { Group }}{\text { Lumbe日 }}$} & $\begin{array}{c}\text { Steel Creek Member. } \\
\text { Peedee } \\
\text { Formation }\end{array}$ & \\
\hline Tayloran & Companian & & $\begin{array}{l}\text { Black Creok } \\
\text { Formation }\end{array}$ & \\
\hline \multirow{2}{*}{ Austinian } & Sentonian & & $\begin{array}{l}\text { Middendorf } \\
\text { Formation }\end{array}$ & \\
\hline & $\begin{array}{l}\text { Conlaclan? } \\
\text { Turontan? }\end{array}$ & & $\begin{array}{l}\text { Cape Fear } \\
\text { Formation }\end{array}$ & \\
\hline
\end{tabular}

Paleozolc Crystal line Basement Trlasslc Nework Supergroup

SCHEMATIC HYDROS OF THE SAVANN Aadland \&: 


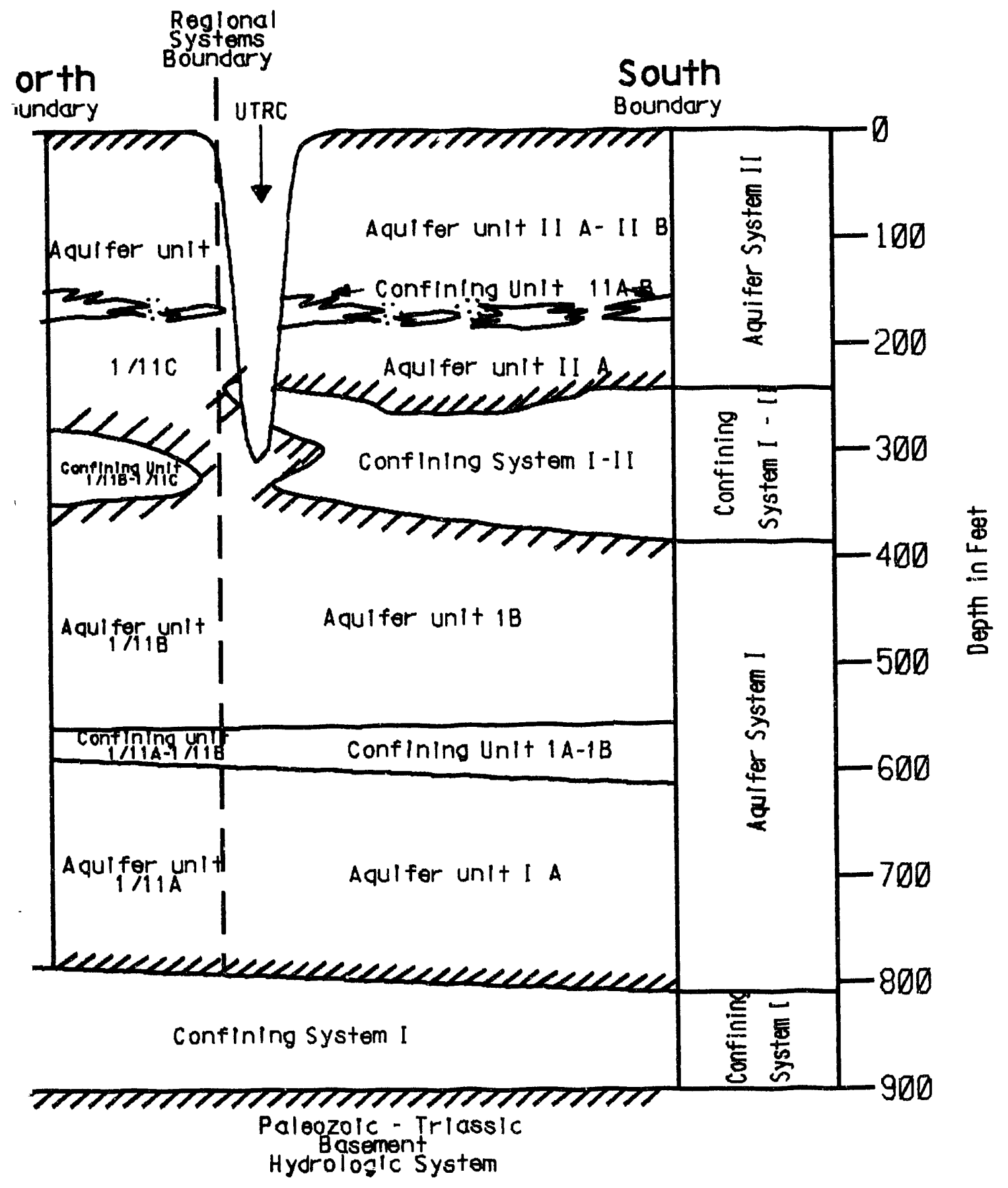

\section{PATIGRAPHIC CHART}

.H RIVER SITE 


\section{REGIONAL HYDROSTRATICRA}

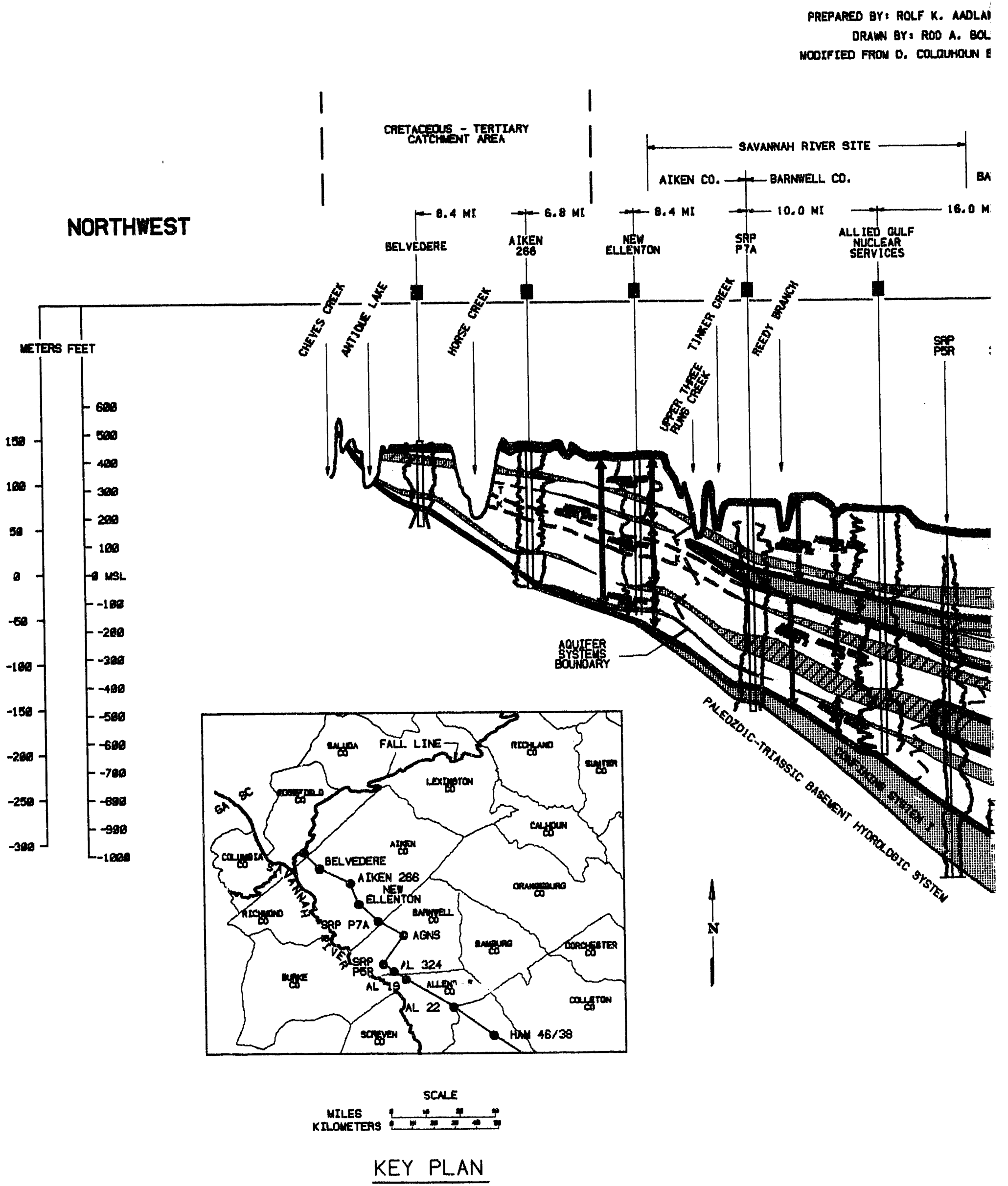




\section{HIC CROSS-SECTION}

1999

- 1933

il CO. - 1 - NLLENONE CO. -

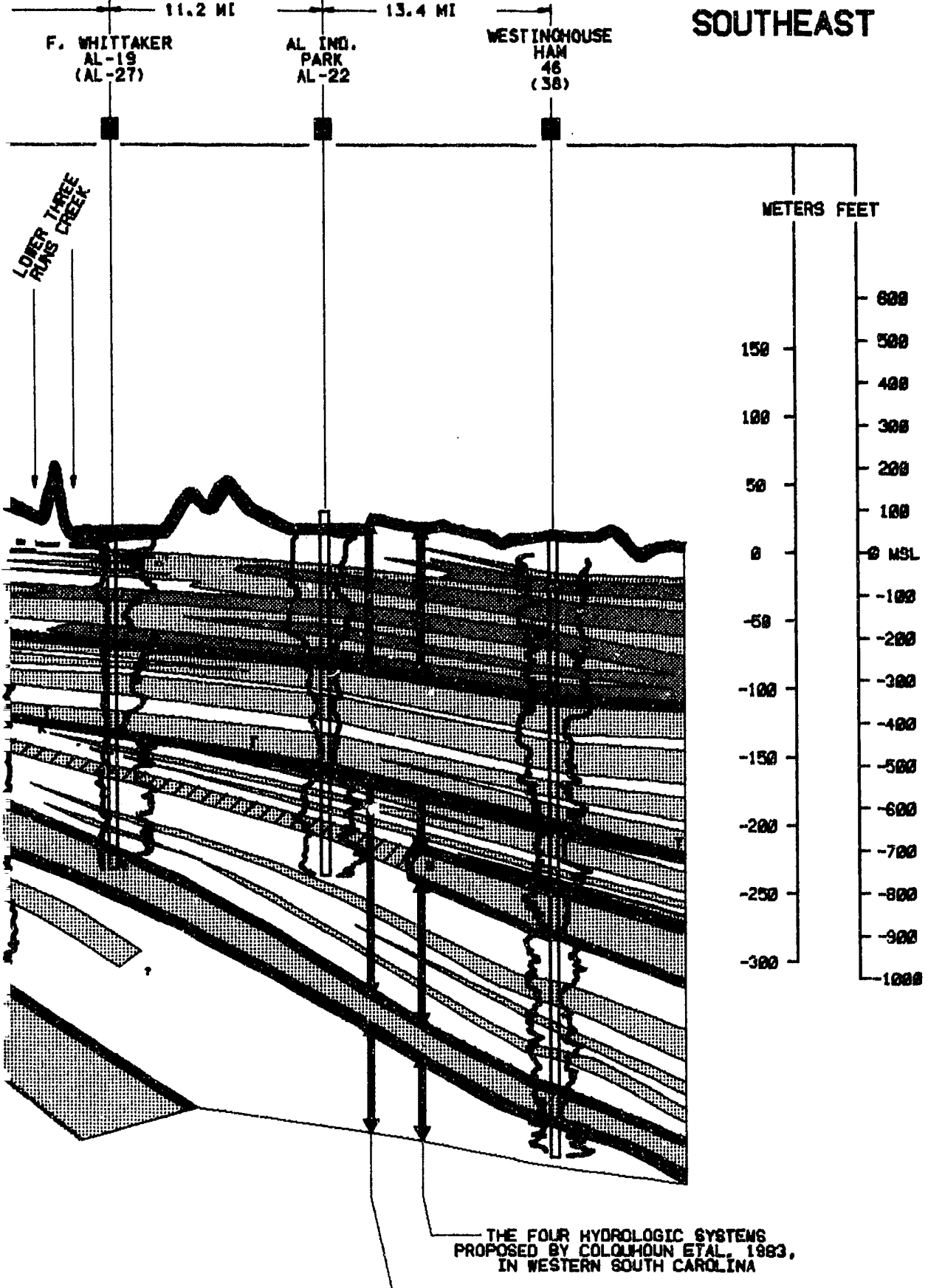

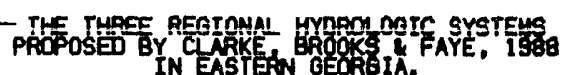

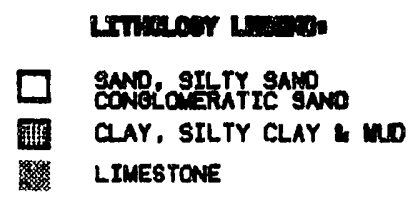

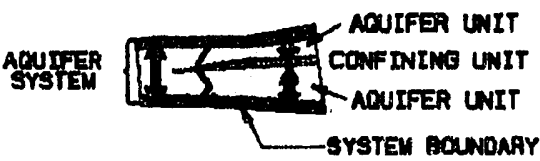

- COAAELATION

$\frac{T}{K}$ TERTLAFY / CFETACENUS BOUNOANY

* RE UPOIP LIMIT OF THESE CONFTNINQ

ISEA SEALFE CONFINING UNIT

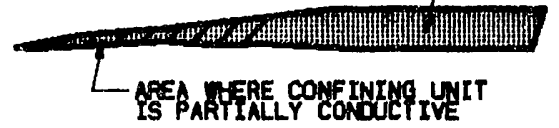




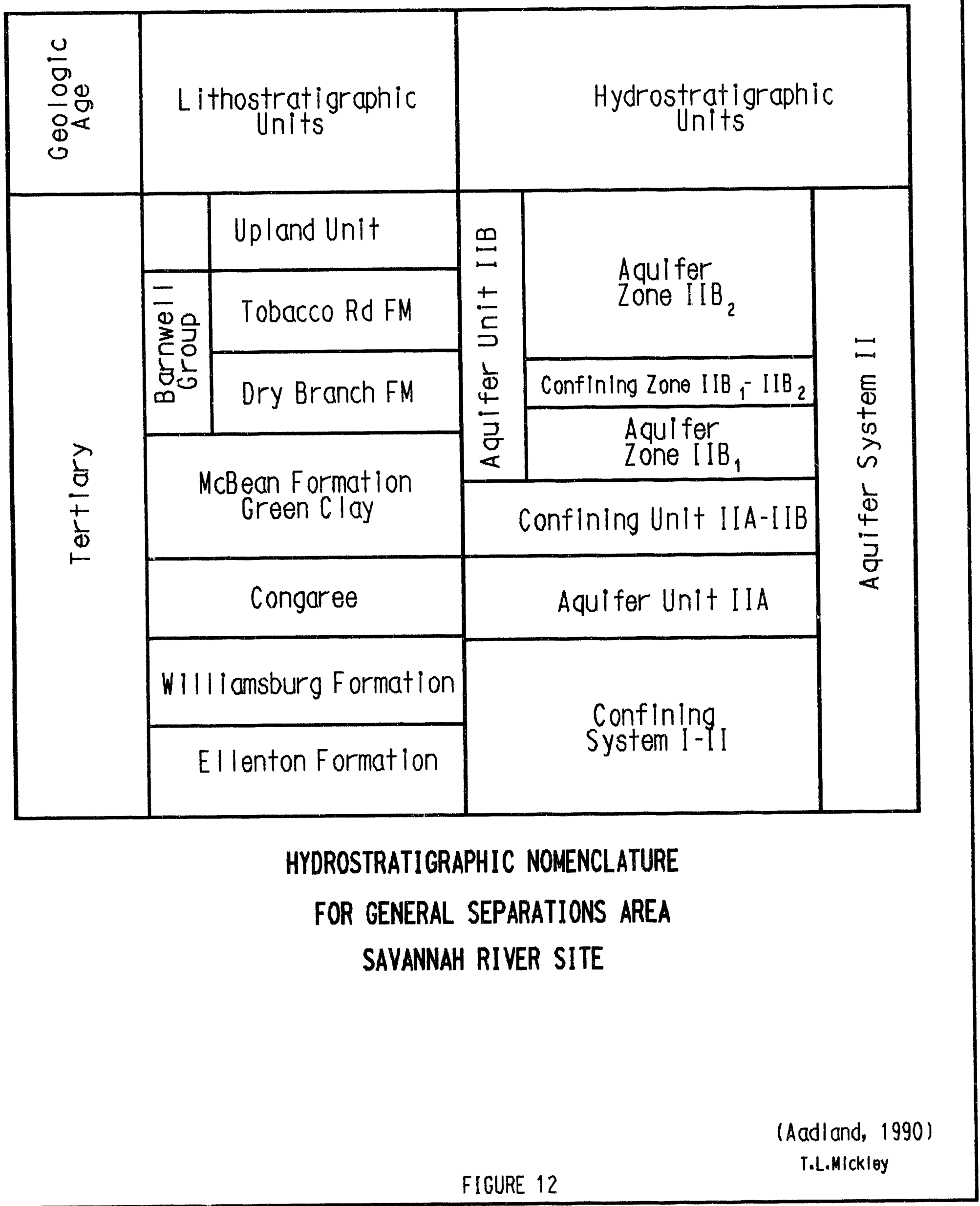




\section{SCHEMATIC MAP AND CROSS SECTION OF FLUVIAL-ENVIROMENT DEPOSITS}

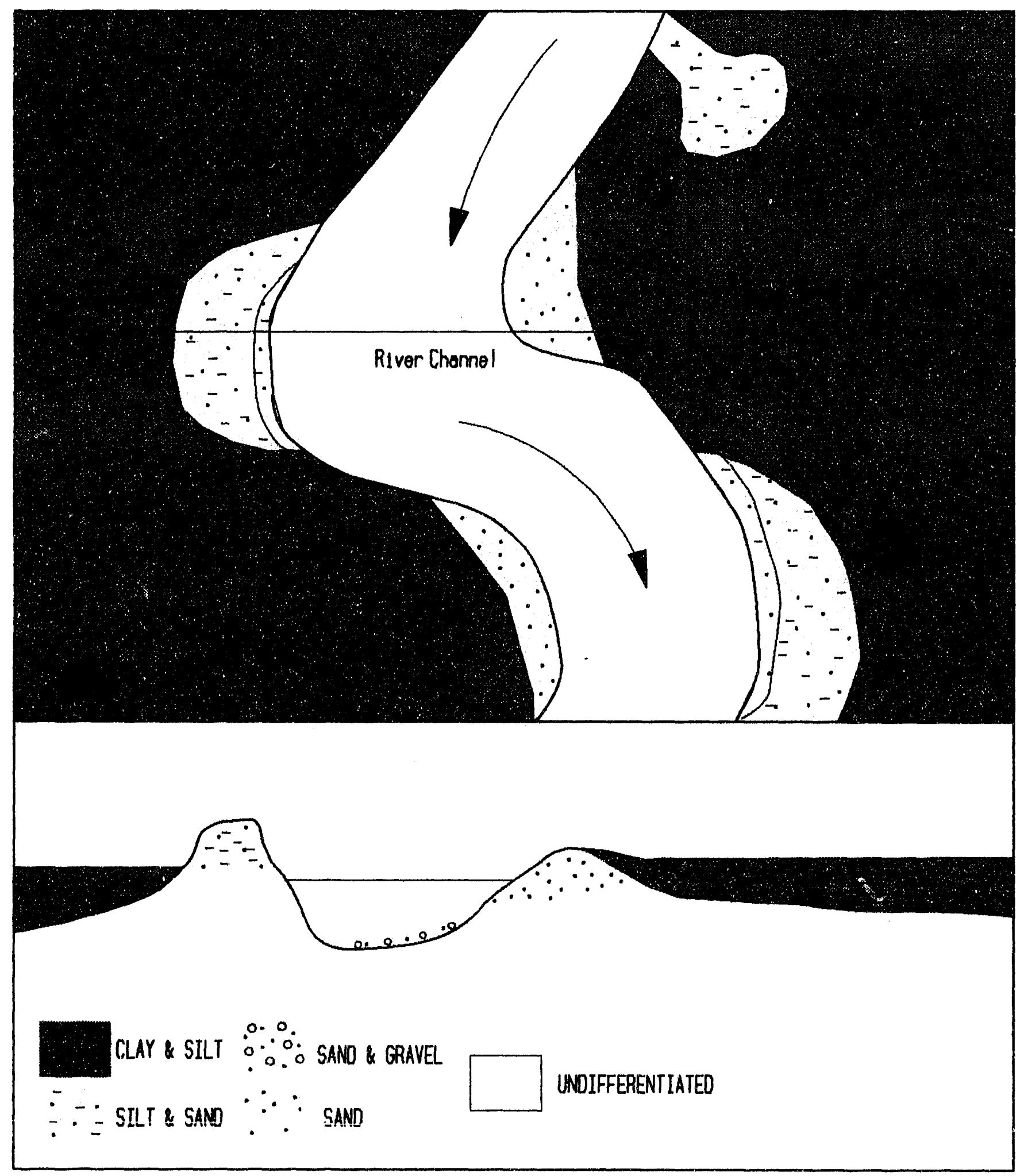




\section{GENERALIZATION OF MARINE DEPOSITIONAL ENVIRONMENT}
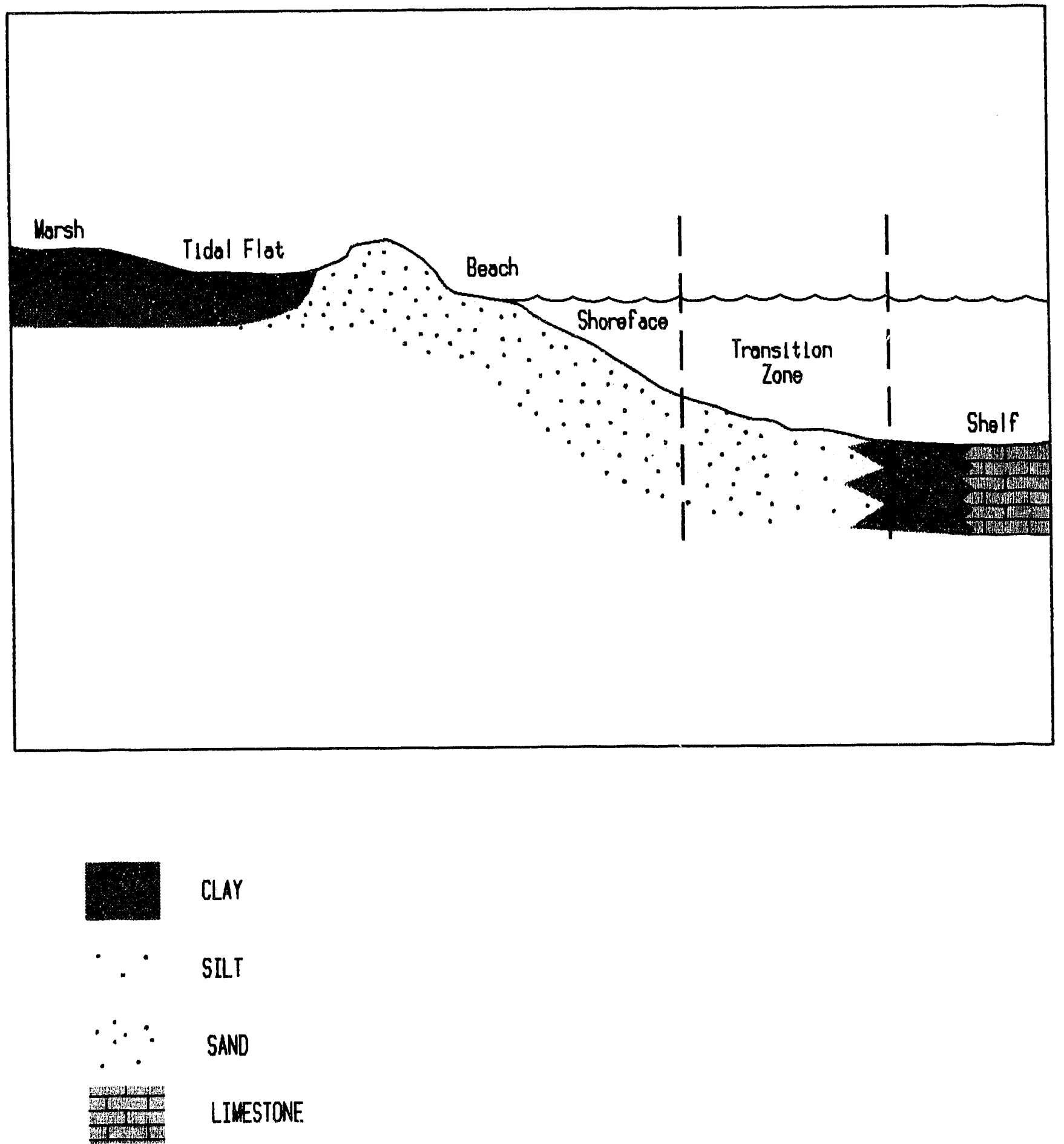


\section{OVERRIDING-DELTA DEPOSITIONAL ENVIRONMENT}
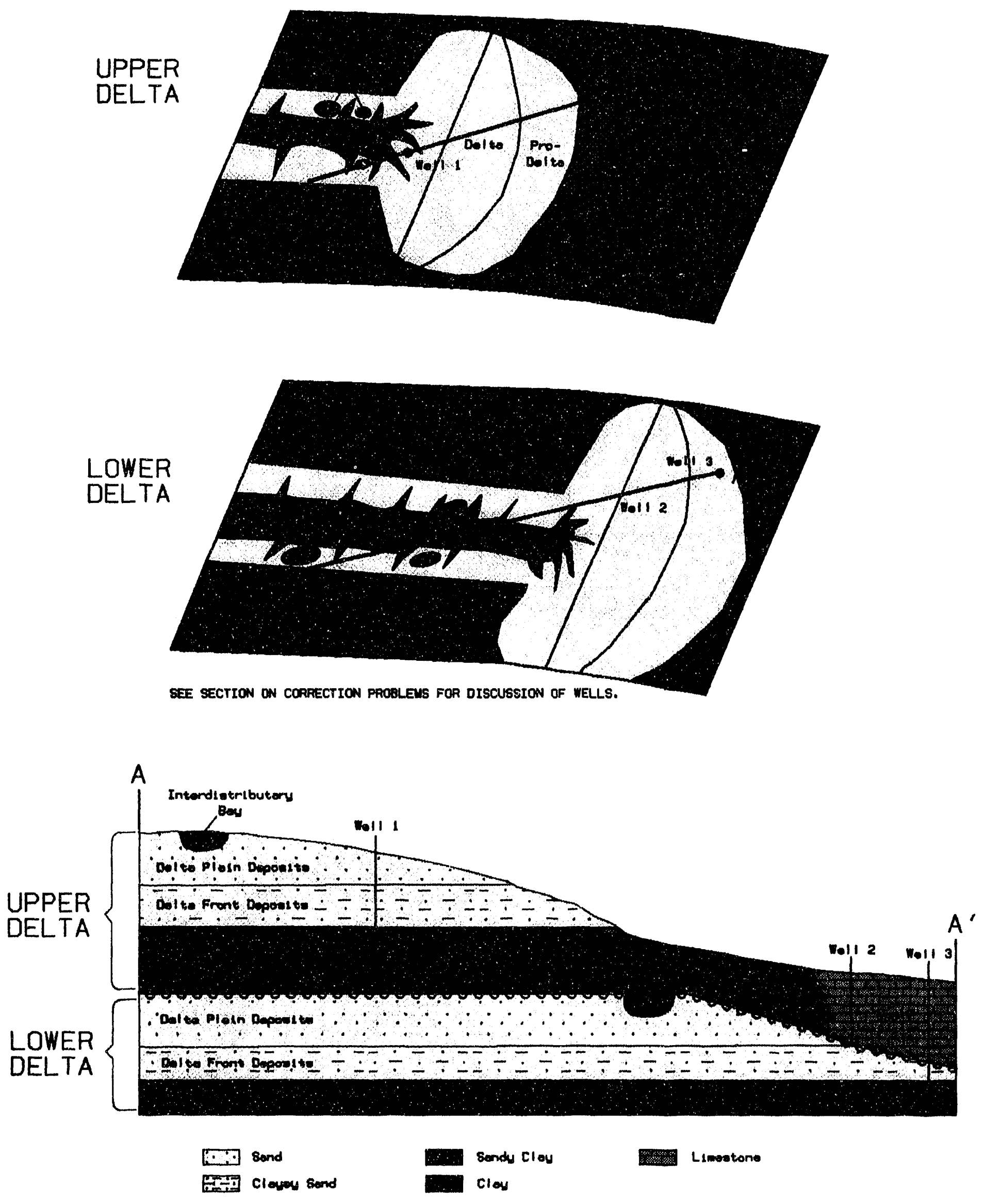

SOUACE, WATER FESOURCE COMMISION REPORT, MUMBER 155, 1999. 


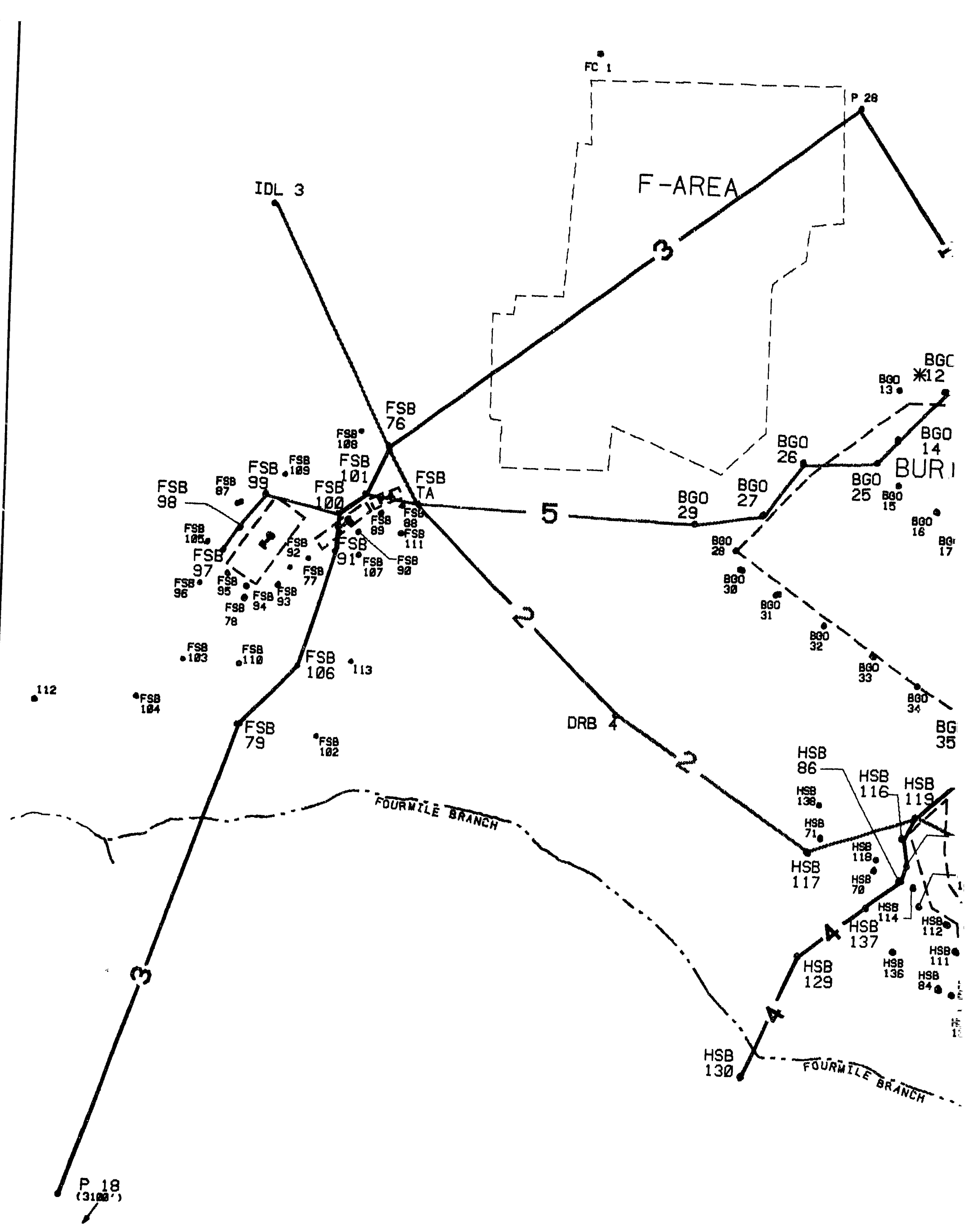




\begin{tabular}{|c|c|c|}
\hline \multicolumn{3}{|c|}{ SAVANNAH RIVER SITE } \\
\hline 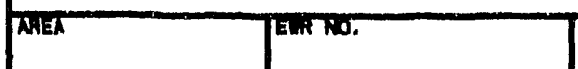 & & \\
\hline \multirow{4}{*}{$\begin{array}{l}\text { GENERAL SEPARATIONS } \\
\text { AREA REGIONAL } \\
\text { CROSS-SECTIONAL LINES }\end{array}$} & 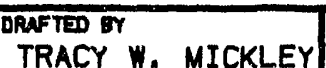 & \\
\hline & 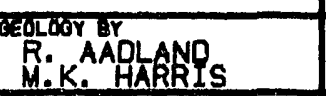 & \\
\hline & T. WESTBRODK & \\
\hline & PRAVING 56416116 & \\
\hline
\end{tabular}

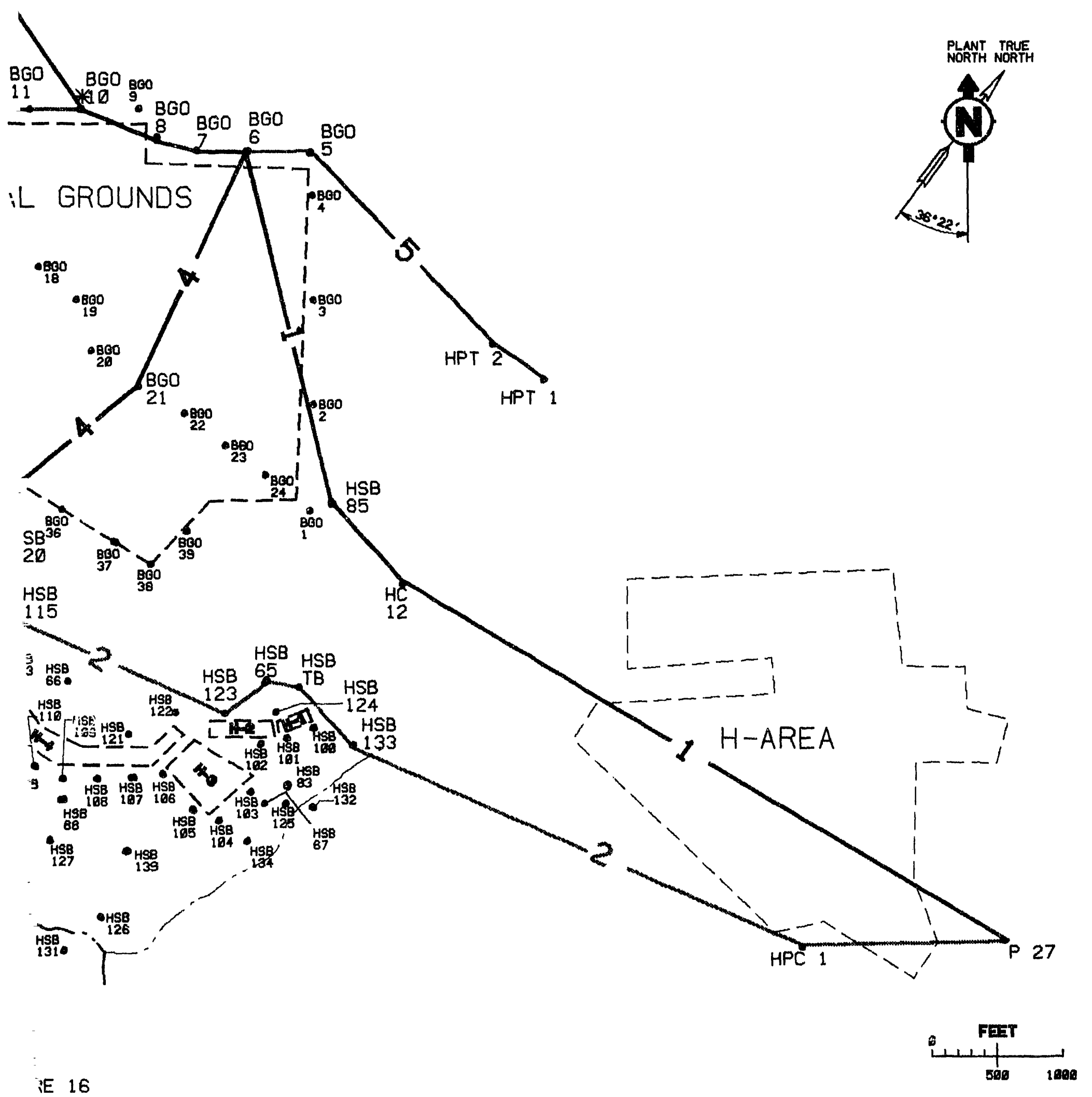


FC 1

P 28

IR
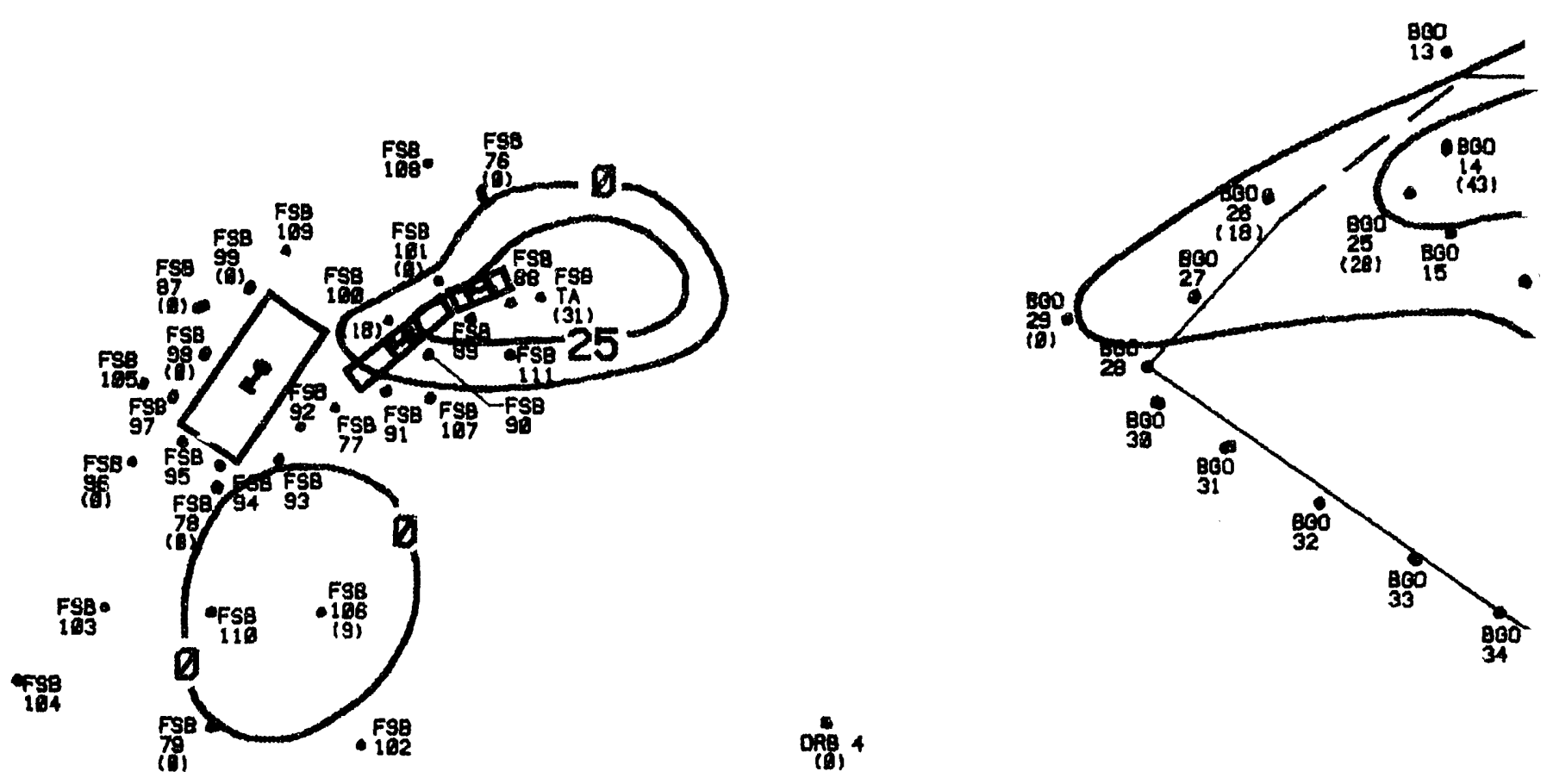

ofg 4

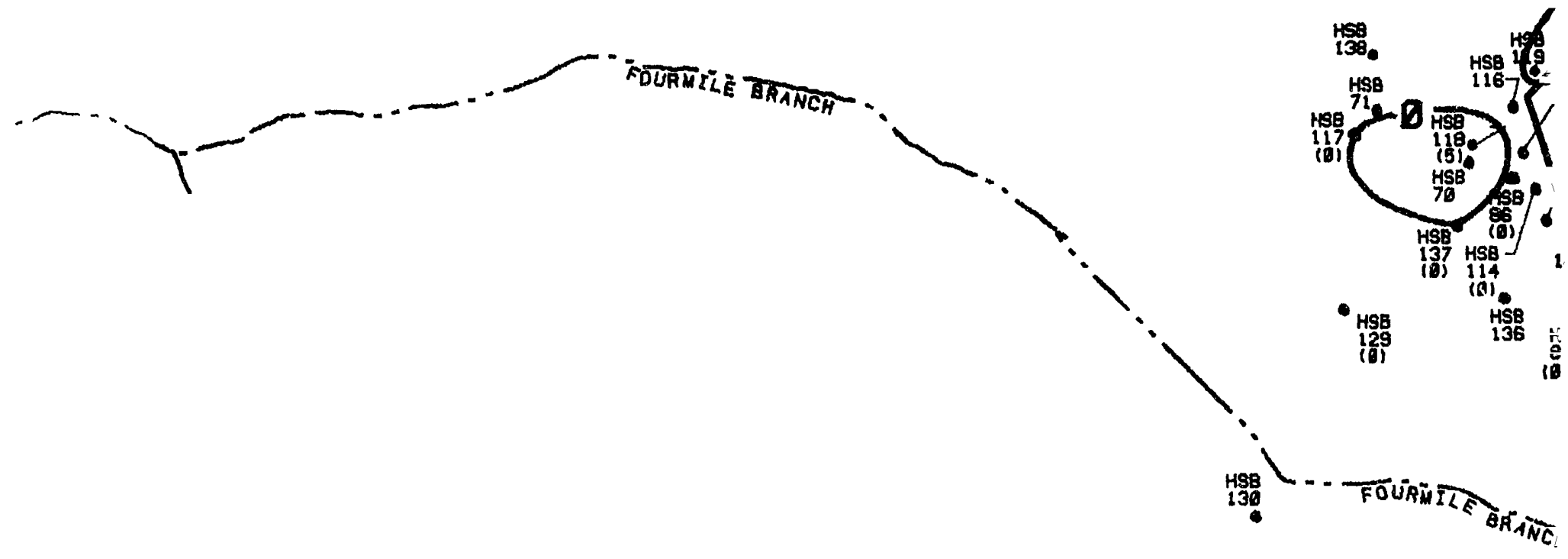




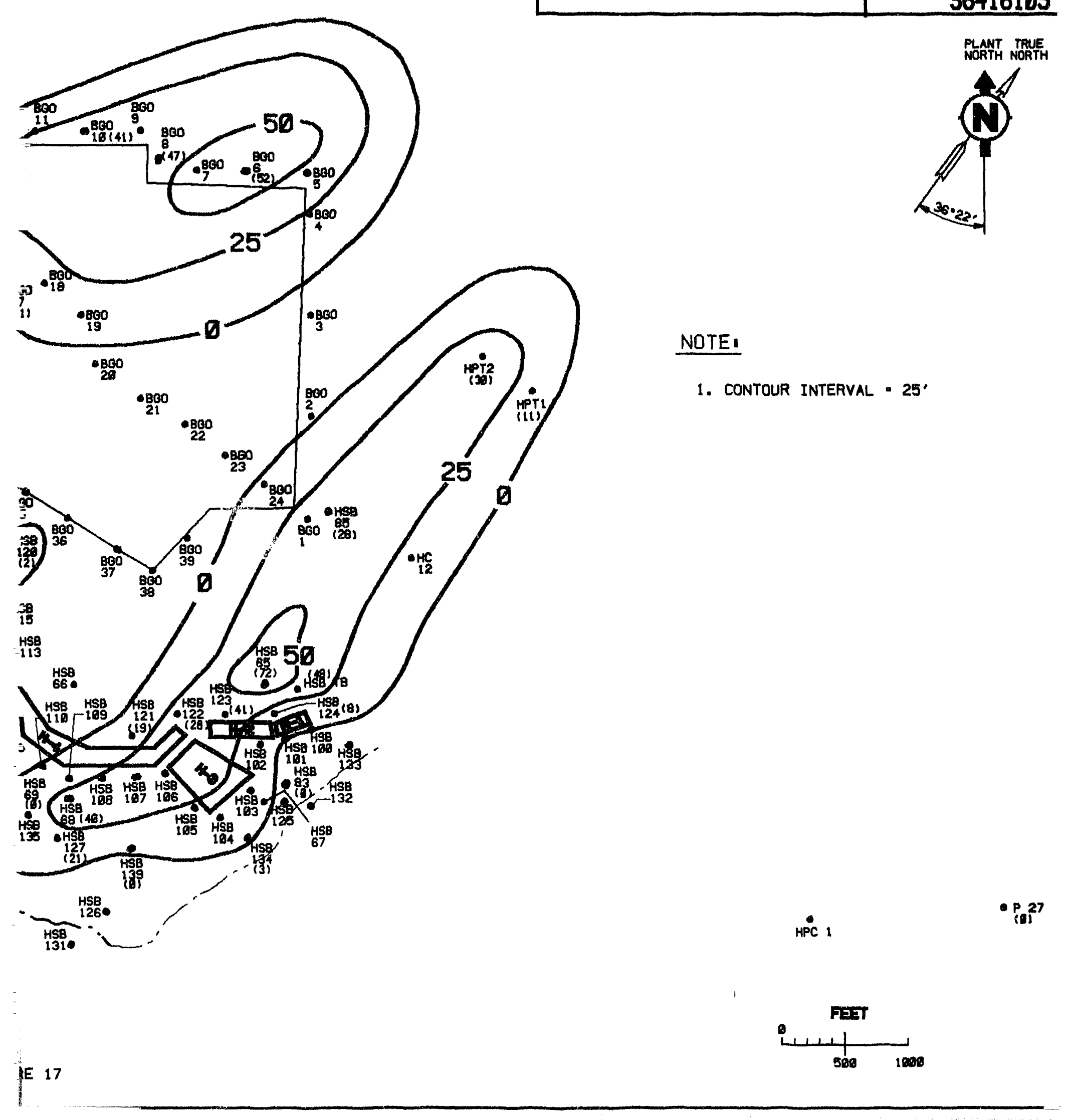


FC 1

P 28

ID 3
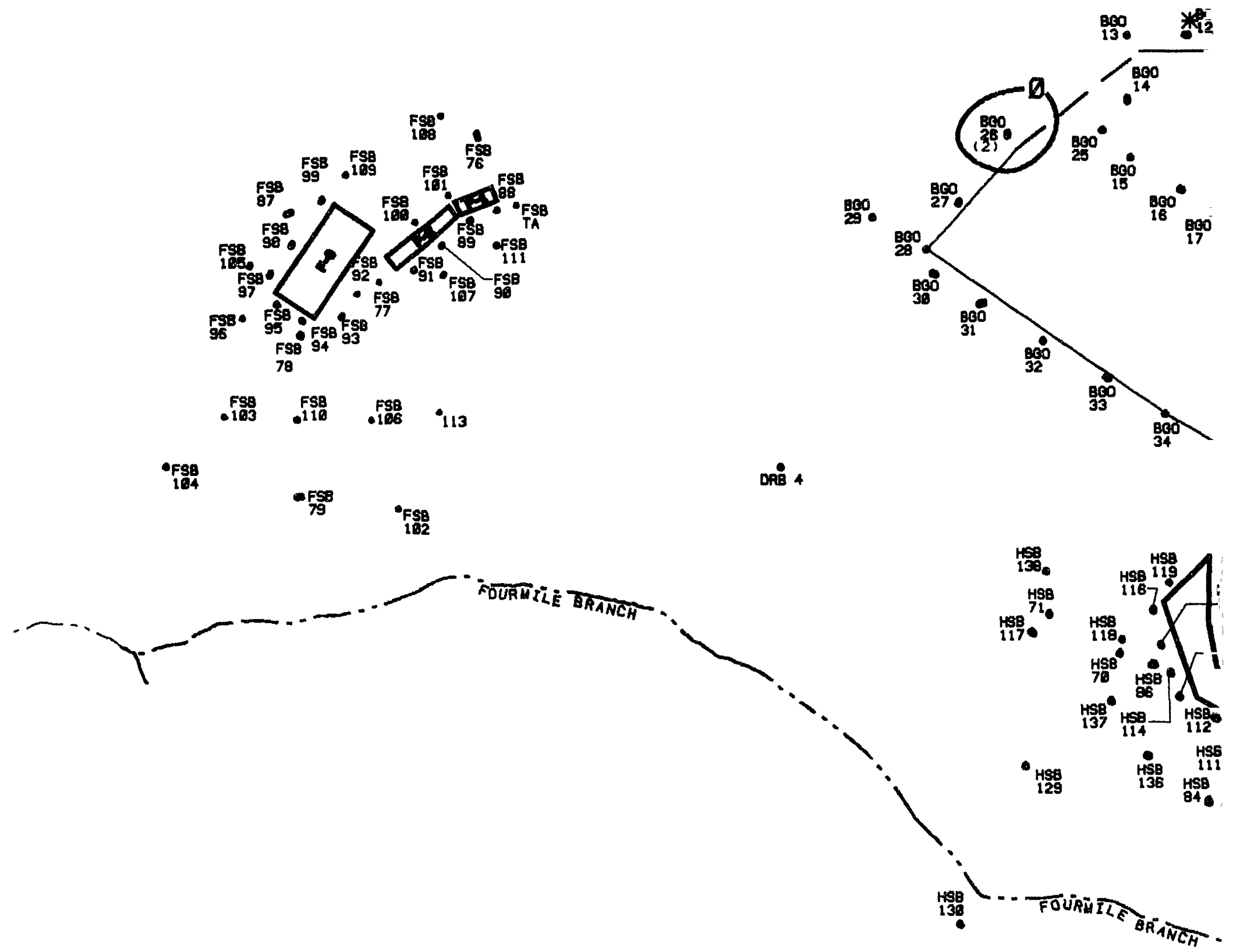


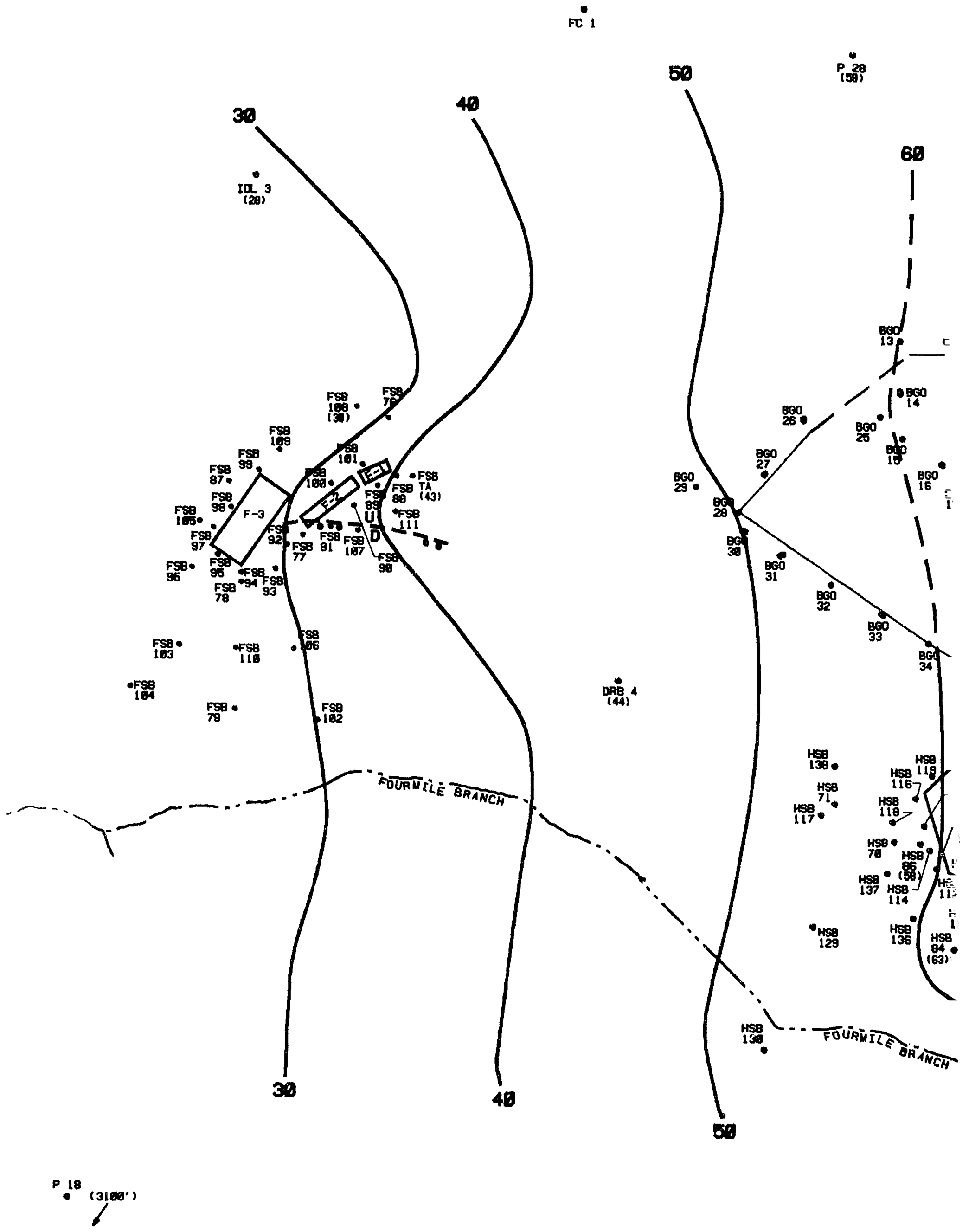




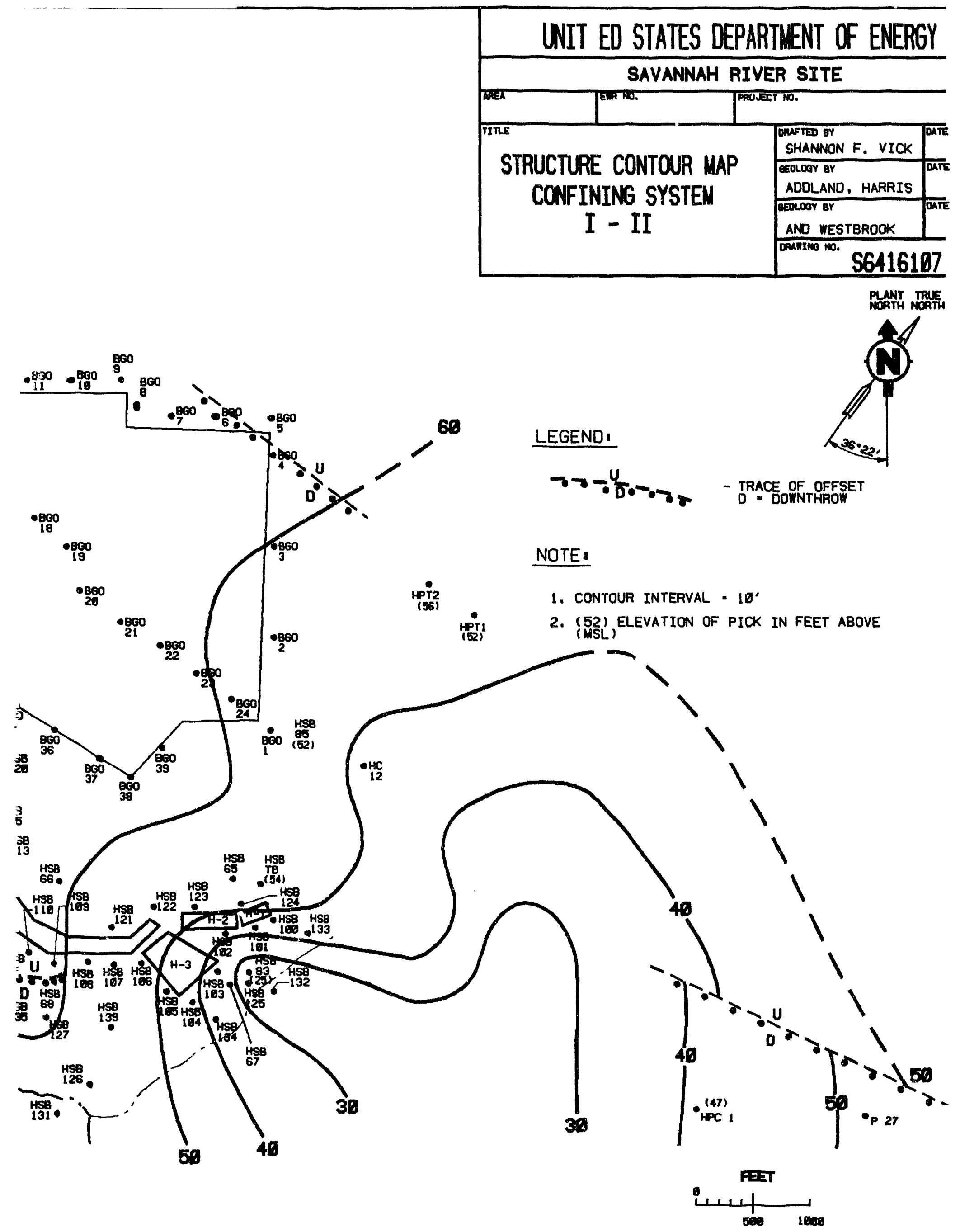




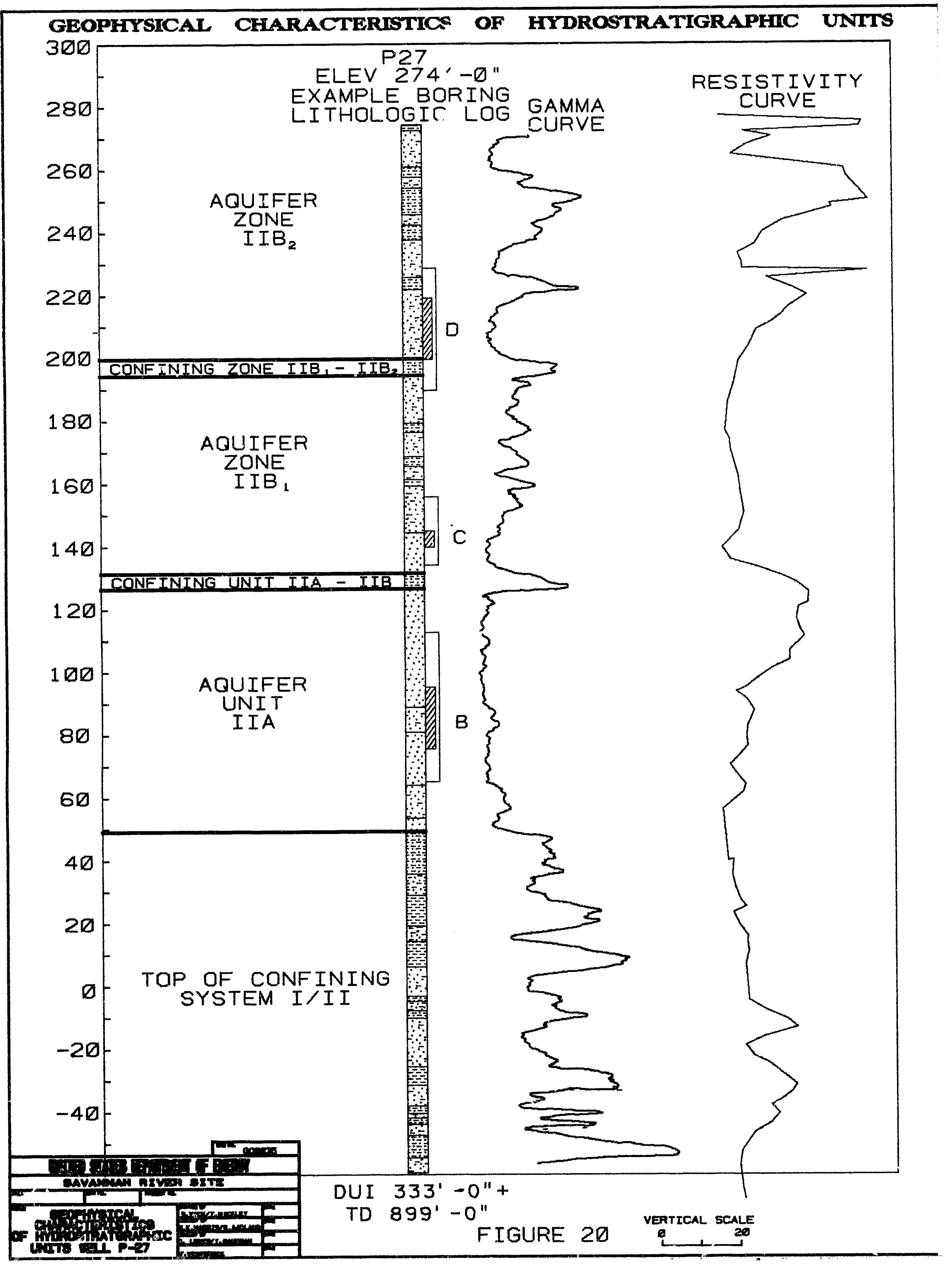




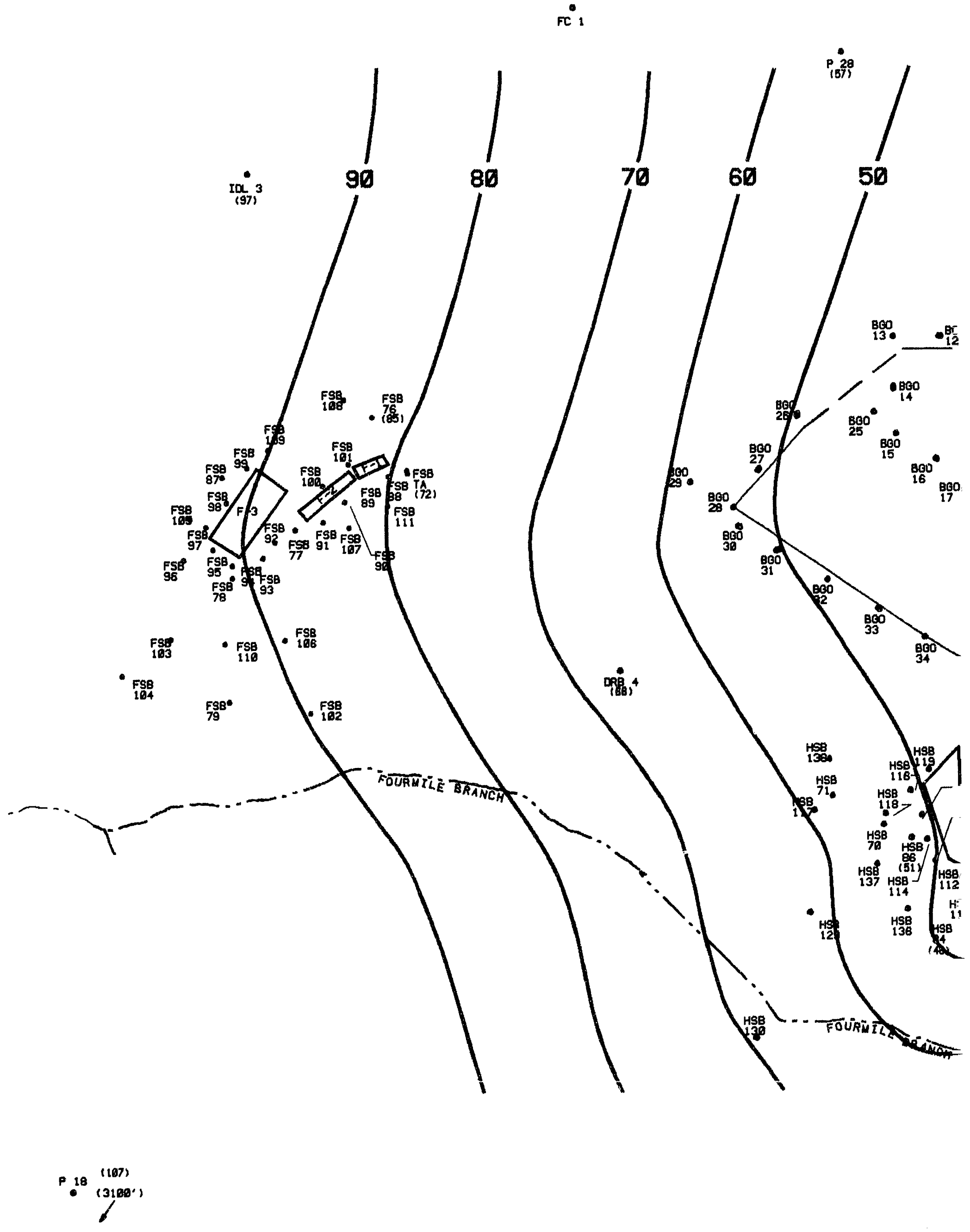




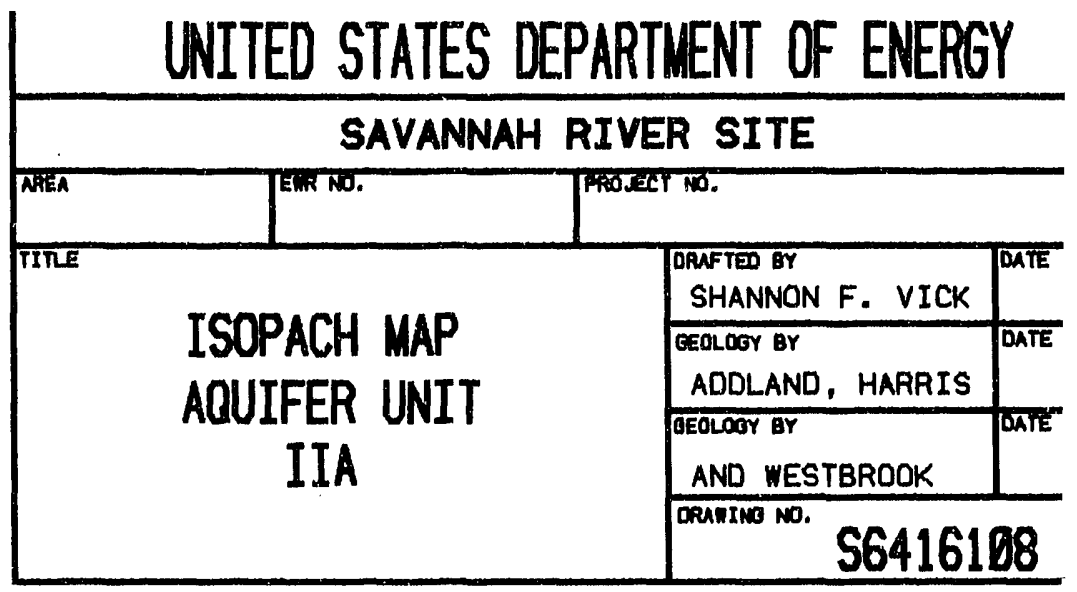
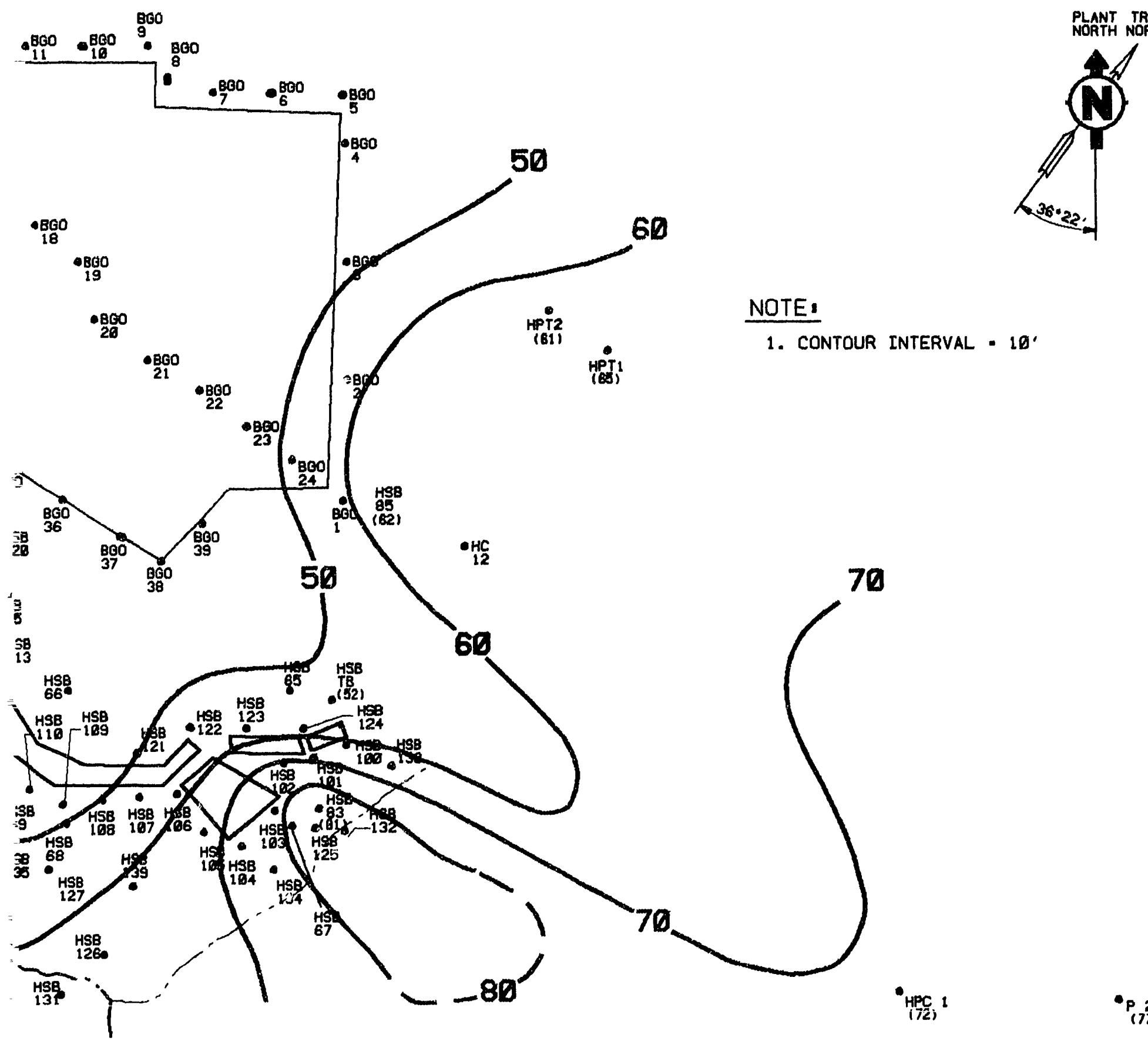

NOTE

1. CONTOUR INTERVAL - $10^{\circ}$
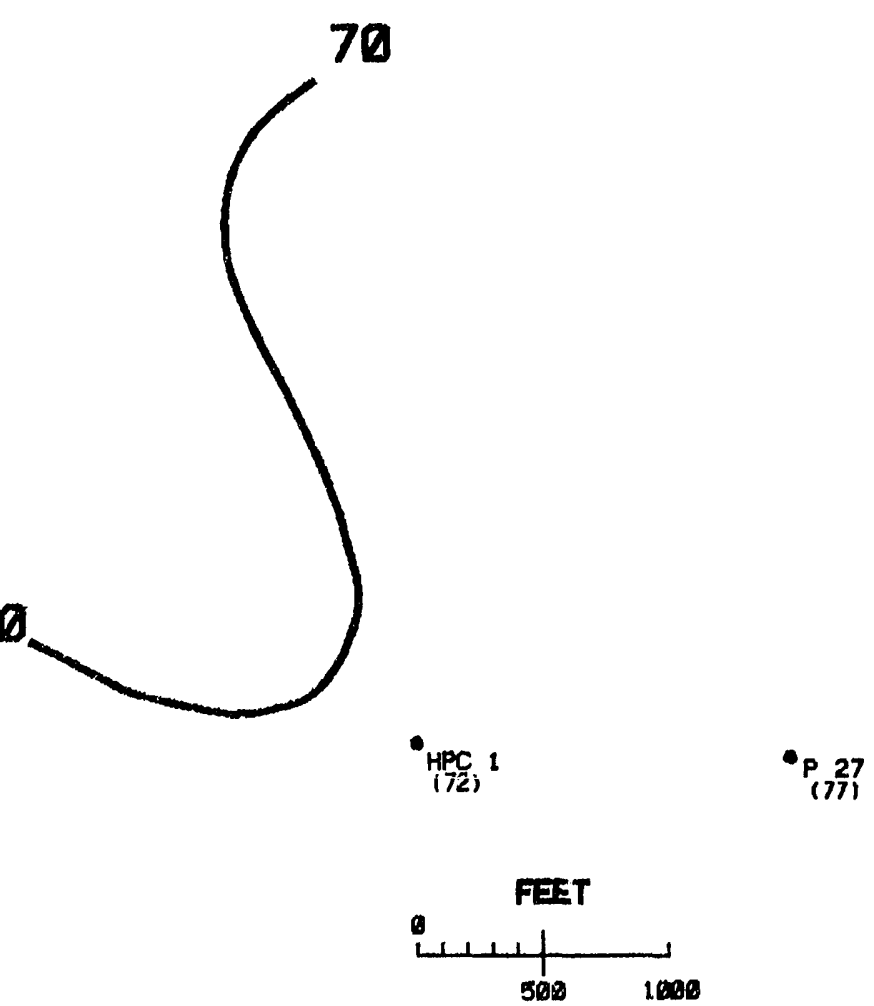


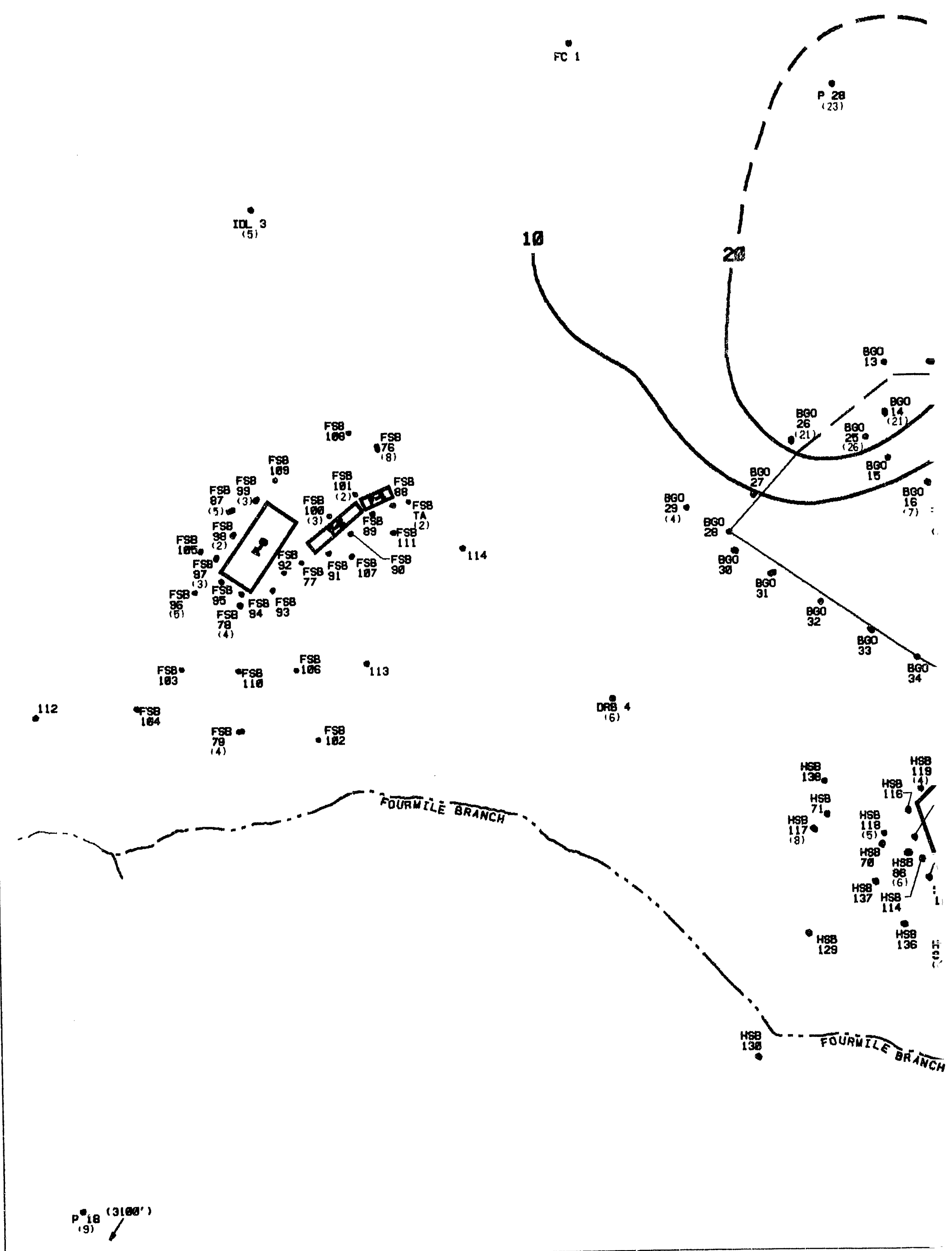



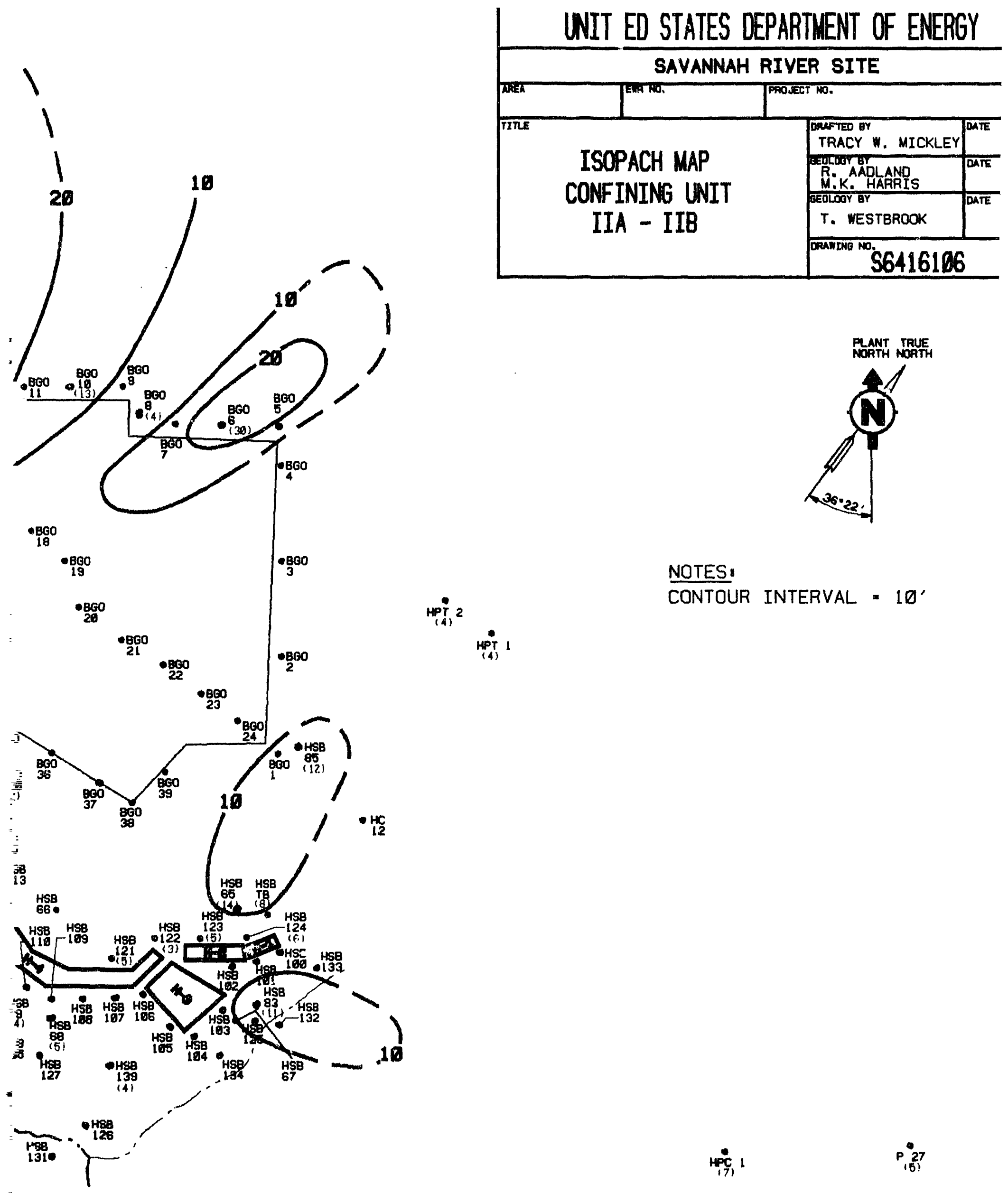

NOTES

${ }_{(4)}^{+0} 2$

CONTOUR INTERVAL $=10^{\circ}$

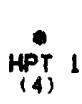

HP $_{171}$

0
$P .27$
$15 !$

IGURE 22

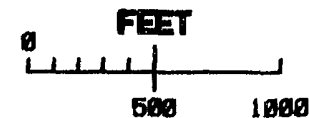




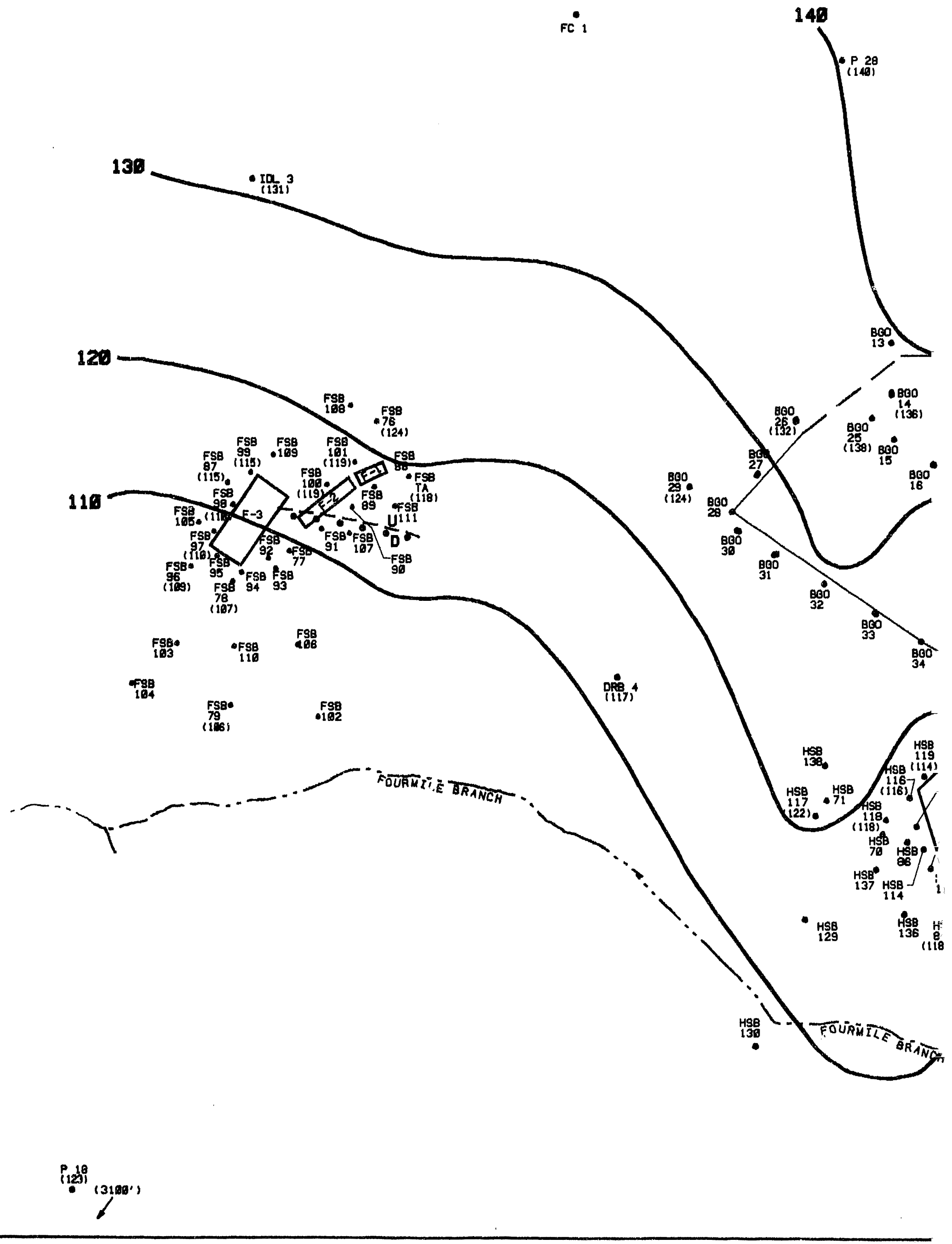




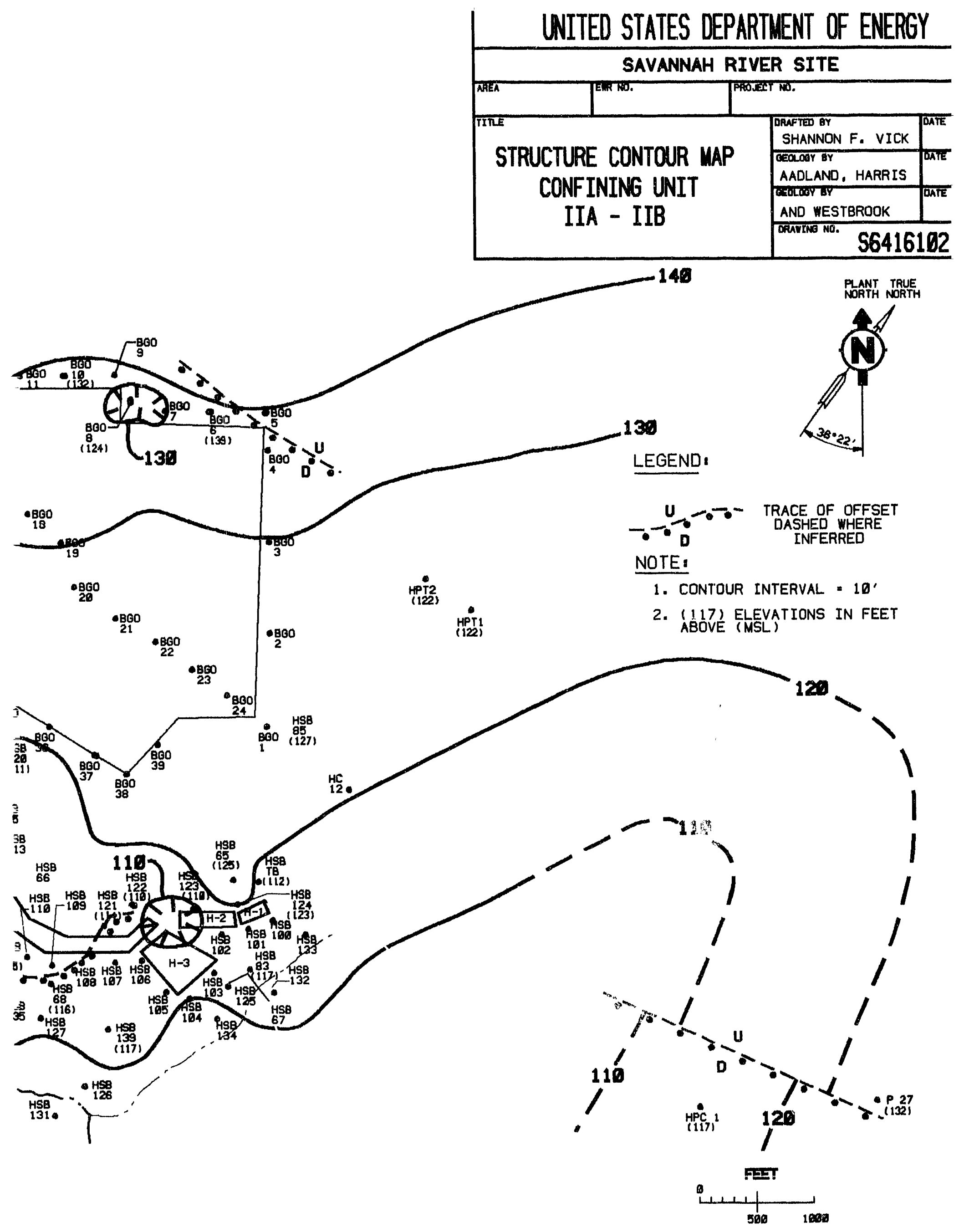


FC 1

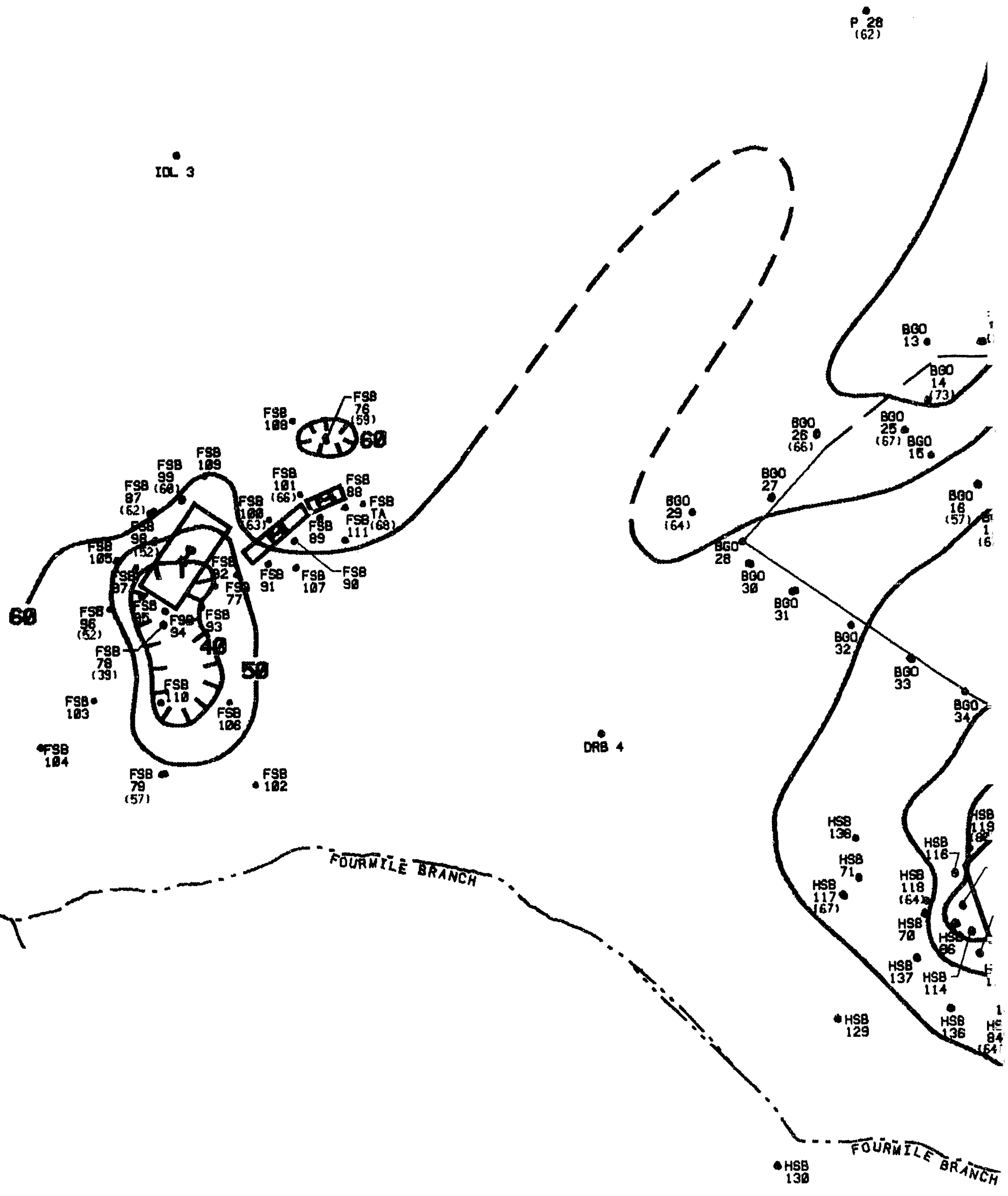

$\int_{\text {(16) }}^{18}$ (3100) 


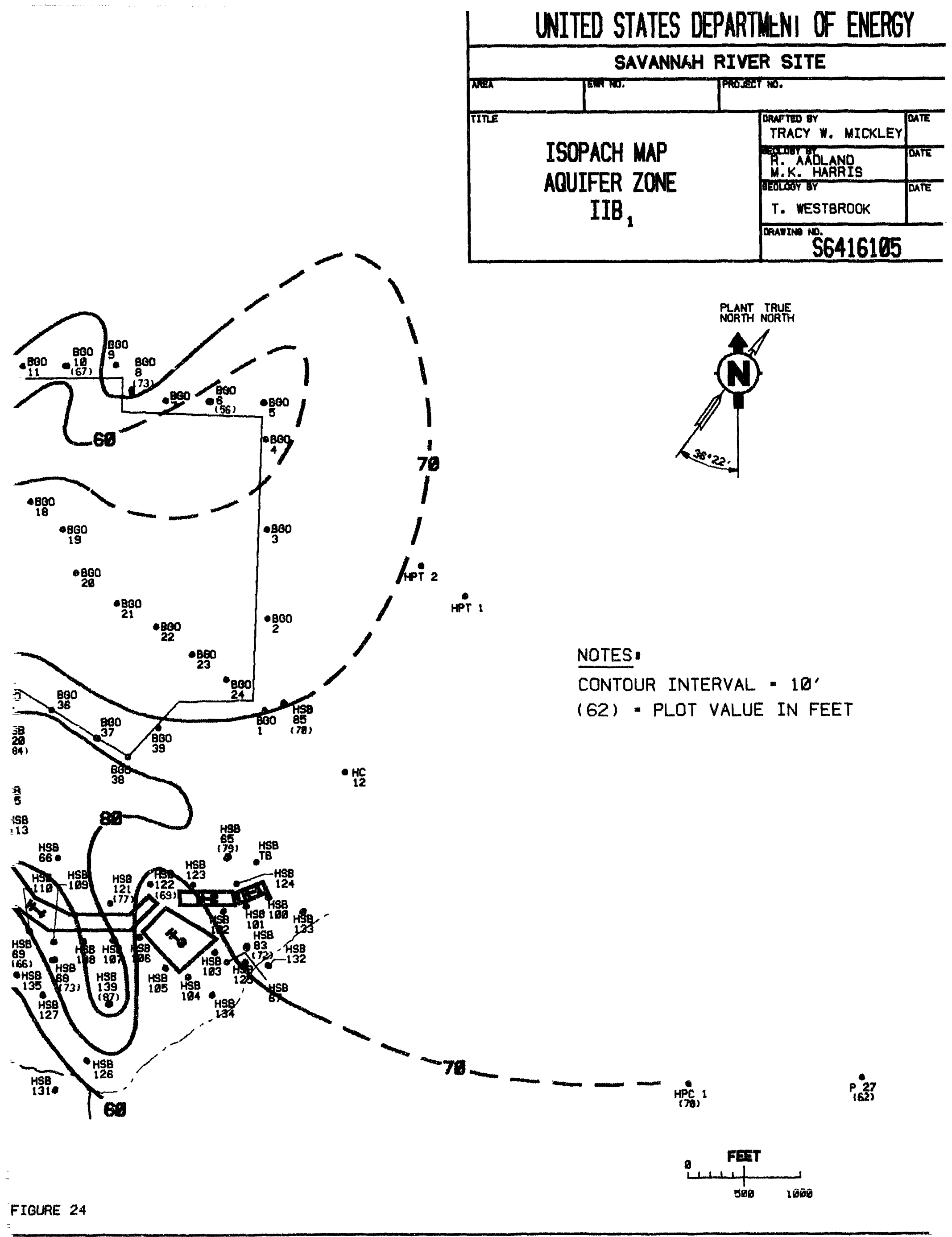




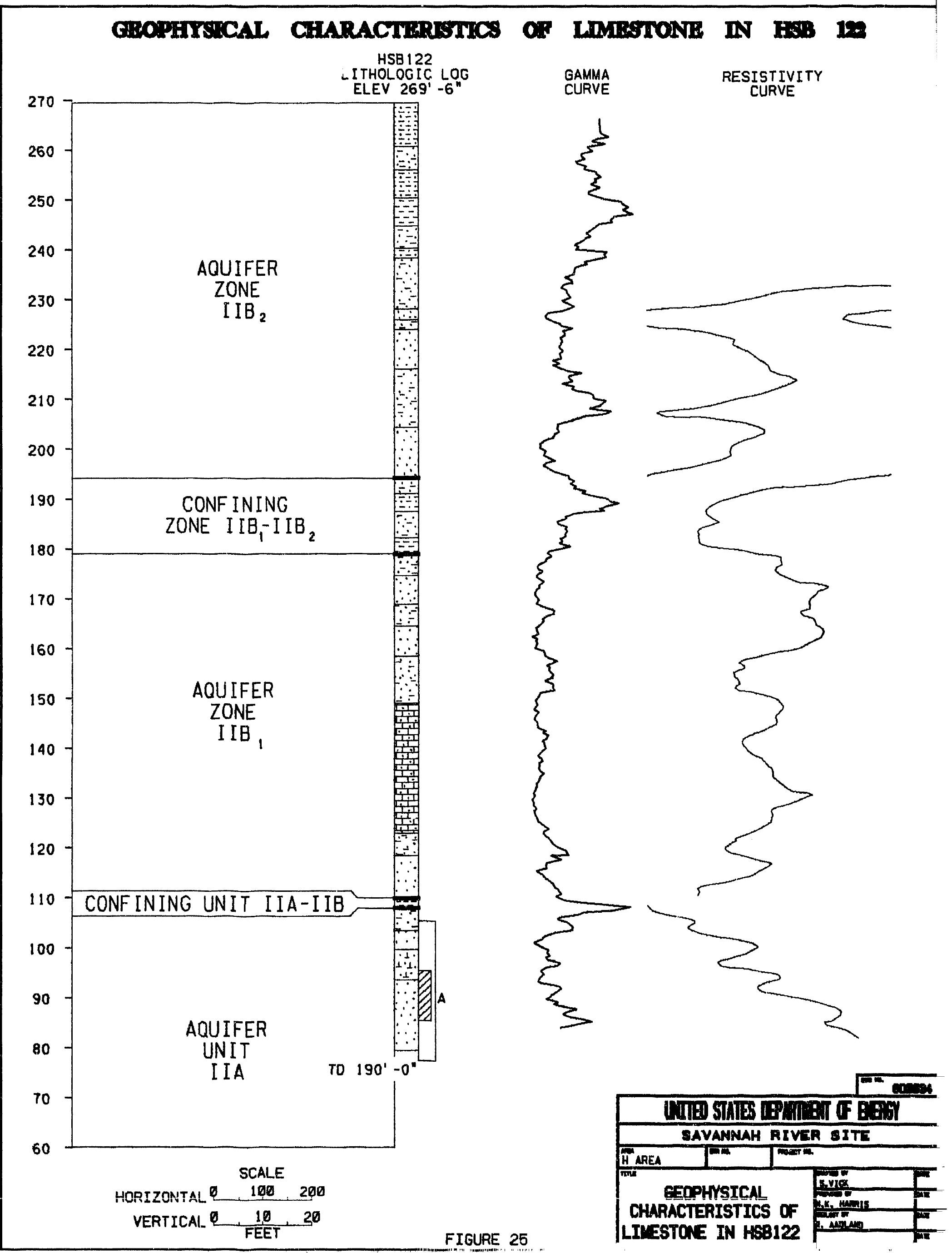




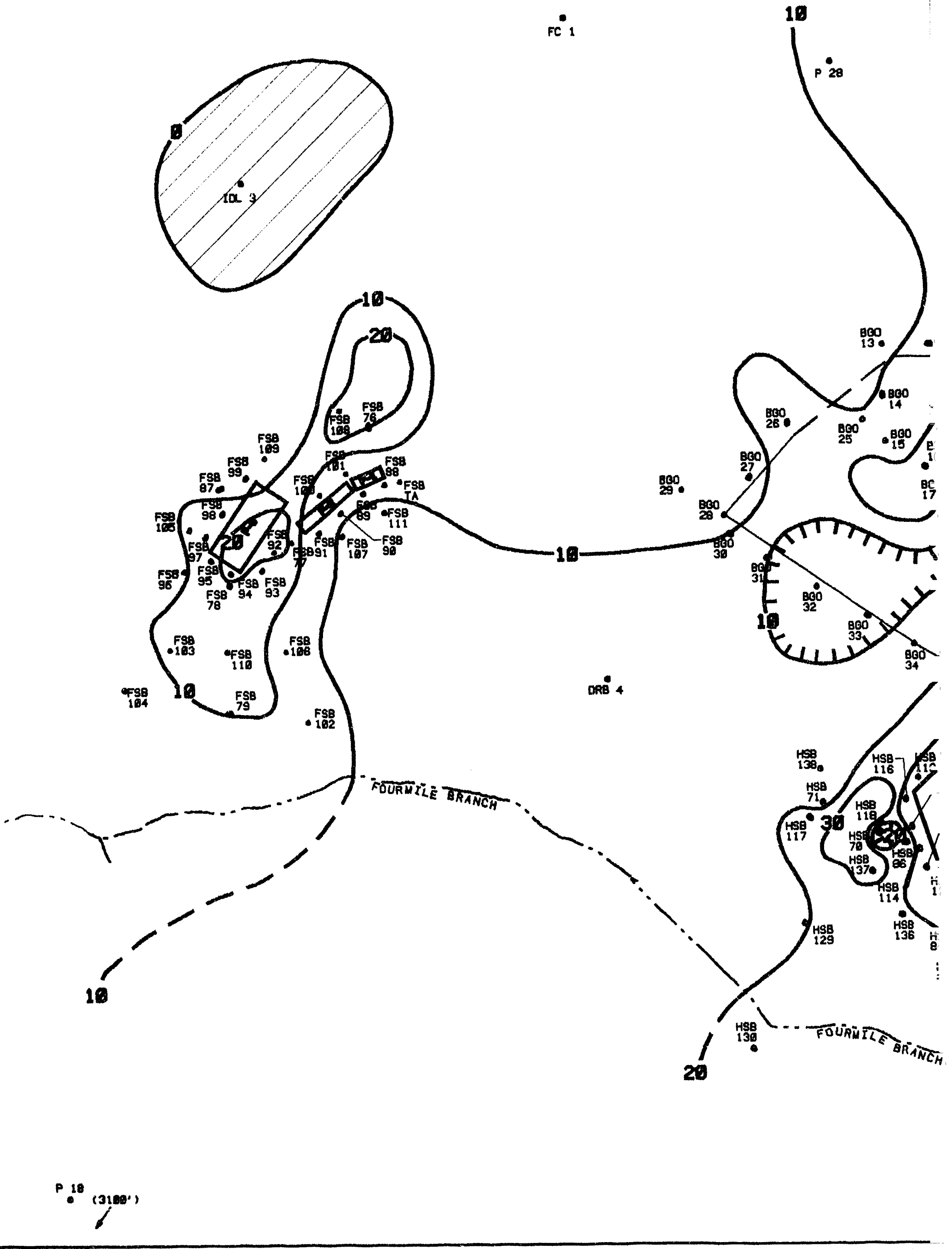


10

1

1
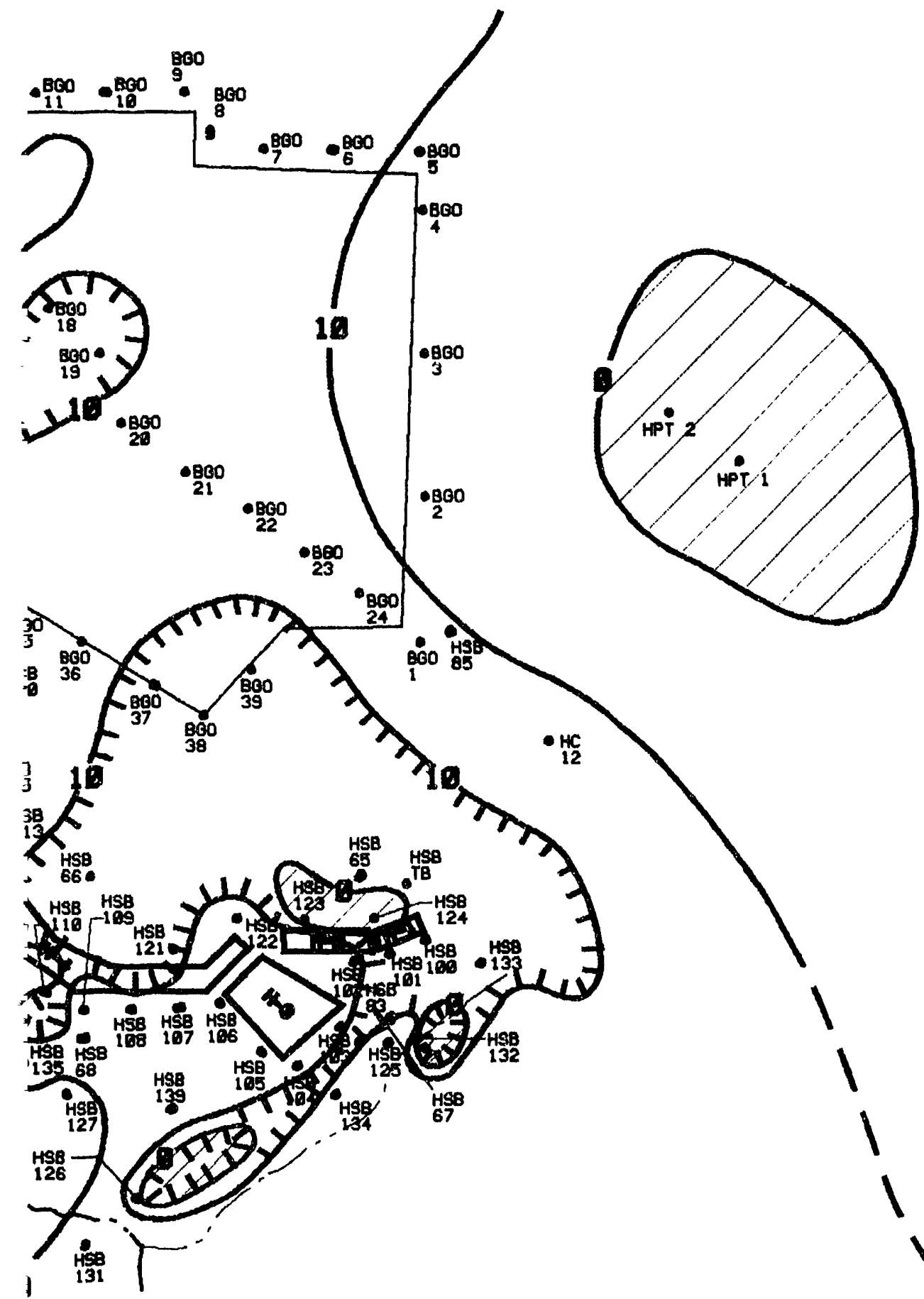

ISOPACH MAP

CONFINING ZONE

IIB $_{1}-$ IIB $_{2}$

SAVANNAH RIVER SITE

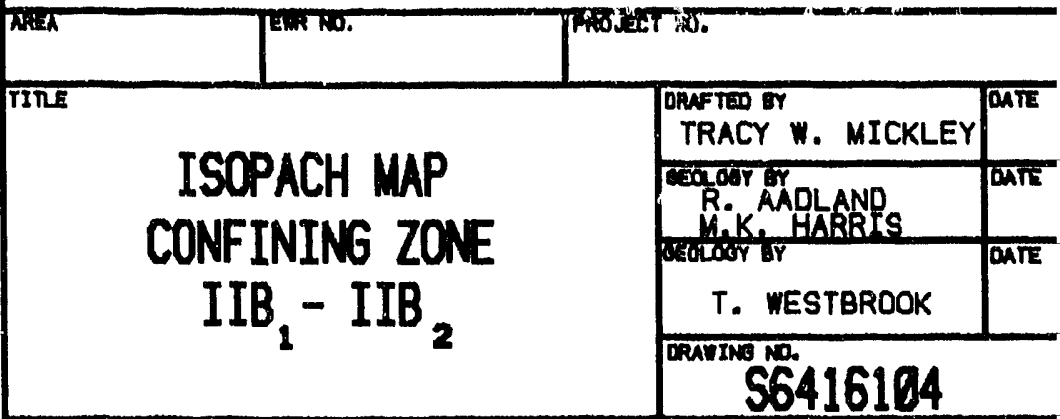

56416104
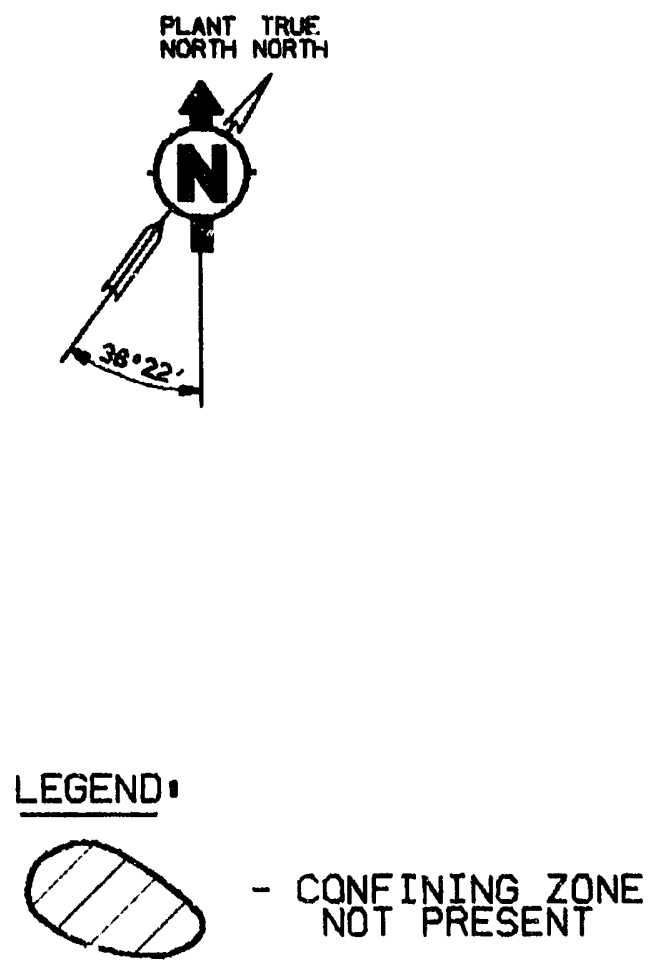

NOTES,

CONTOUR INTERVAL $=10^{\prime}$

MPC

$p: 27$

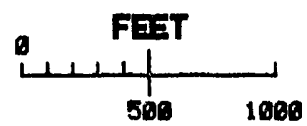


F 1

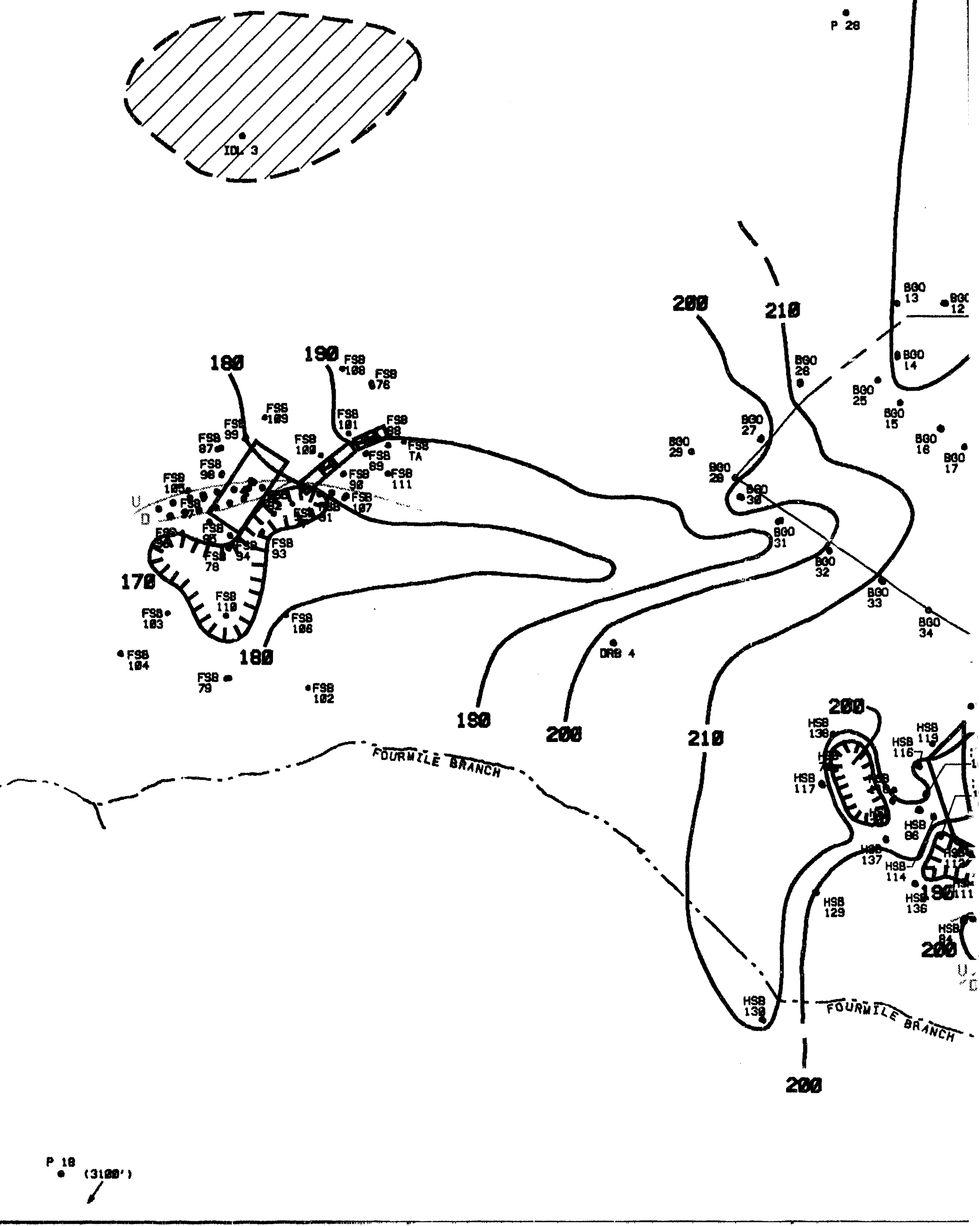

$P \bullet$ 


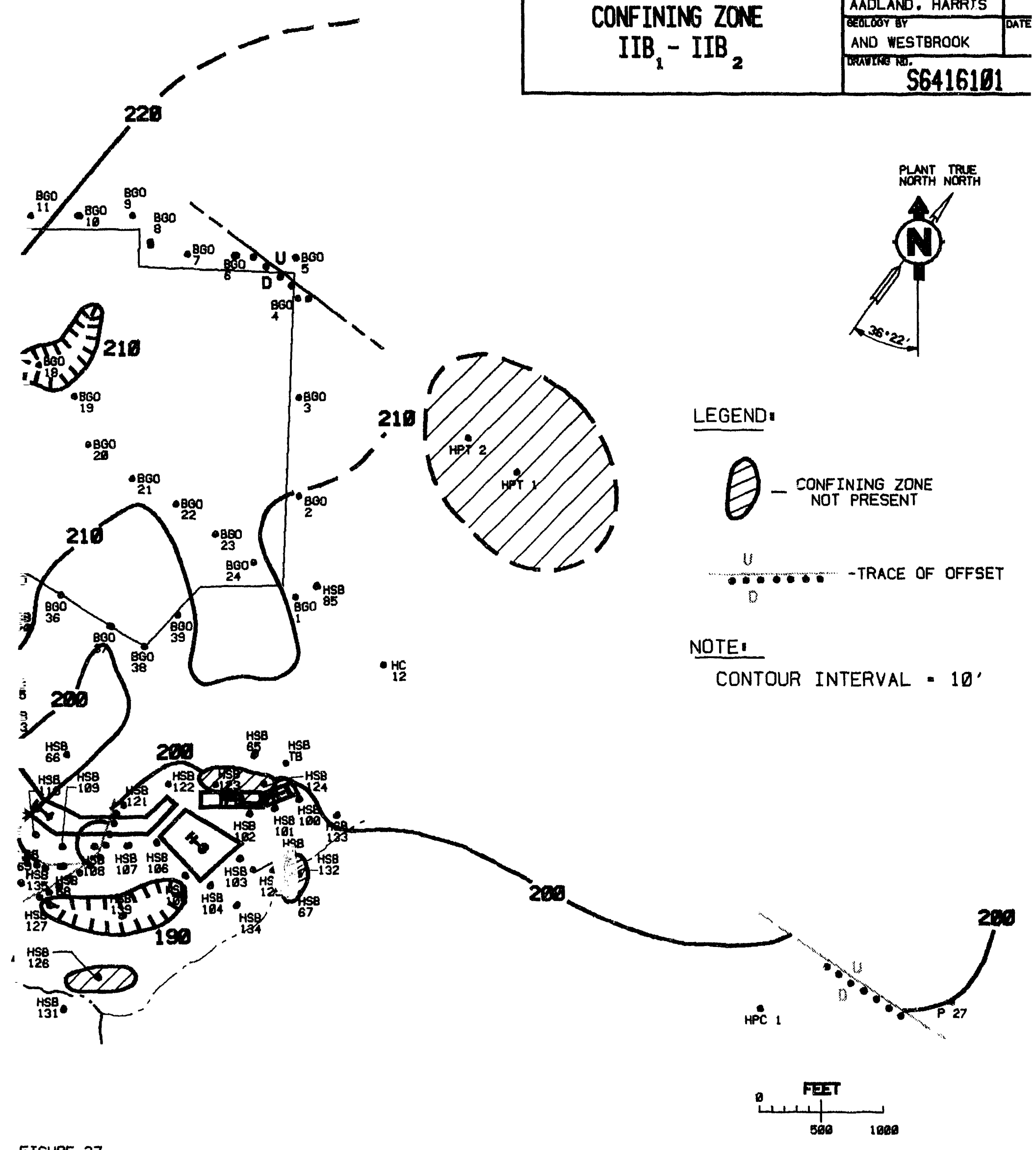


FC 1

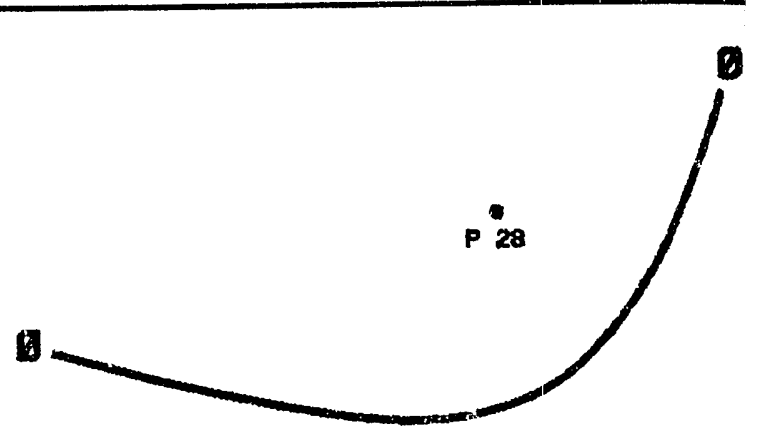

I0 3

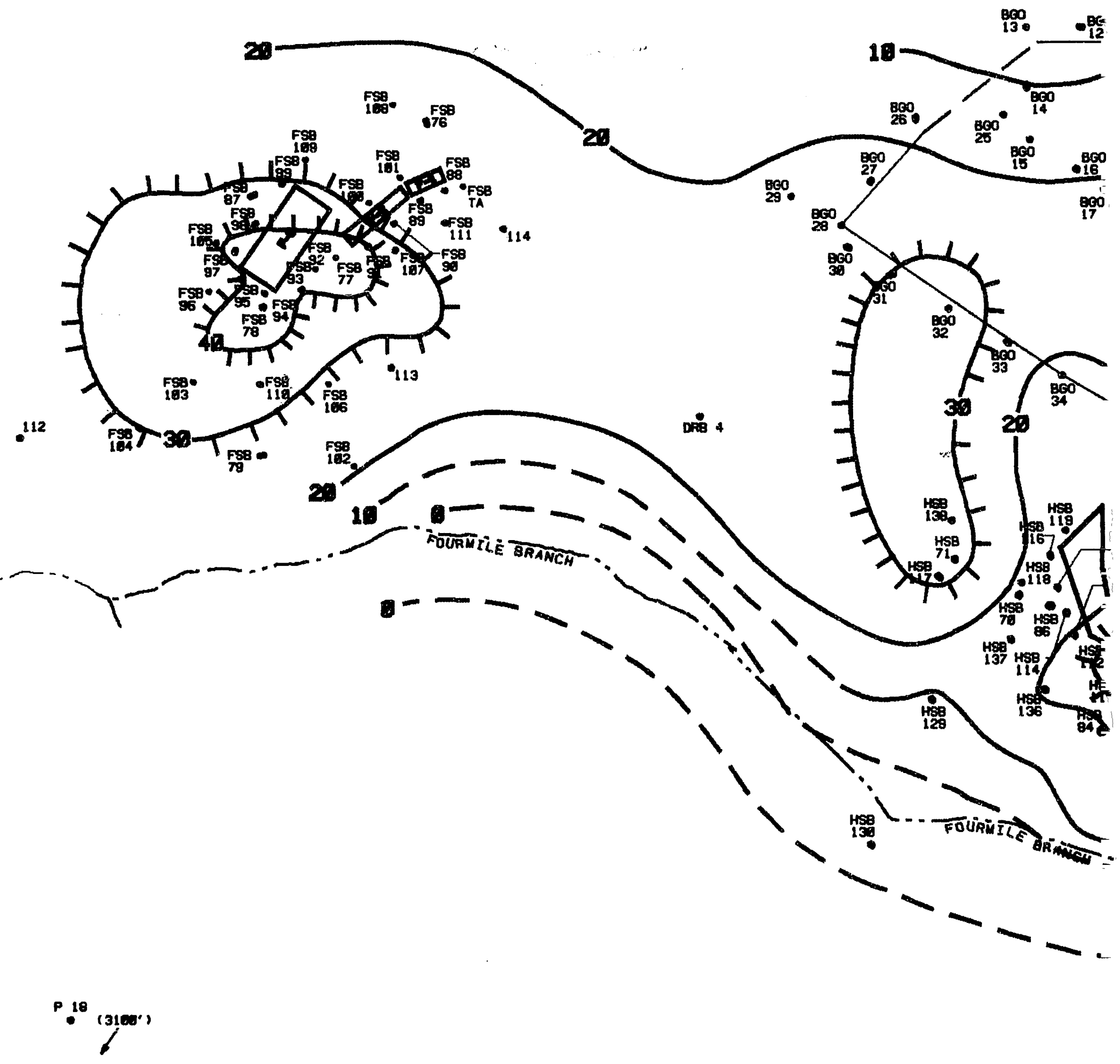




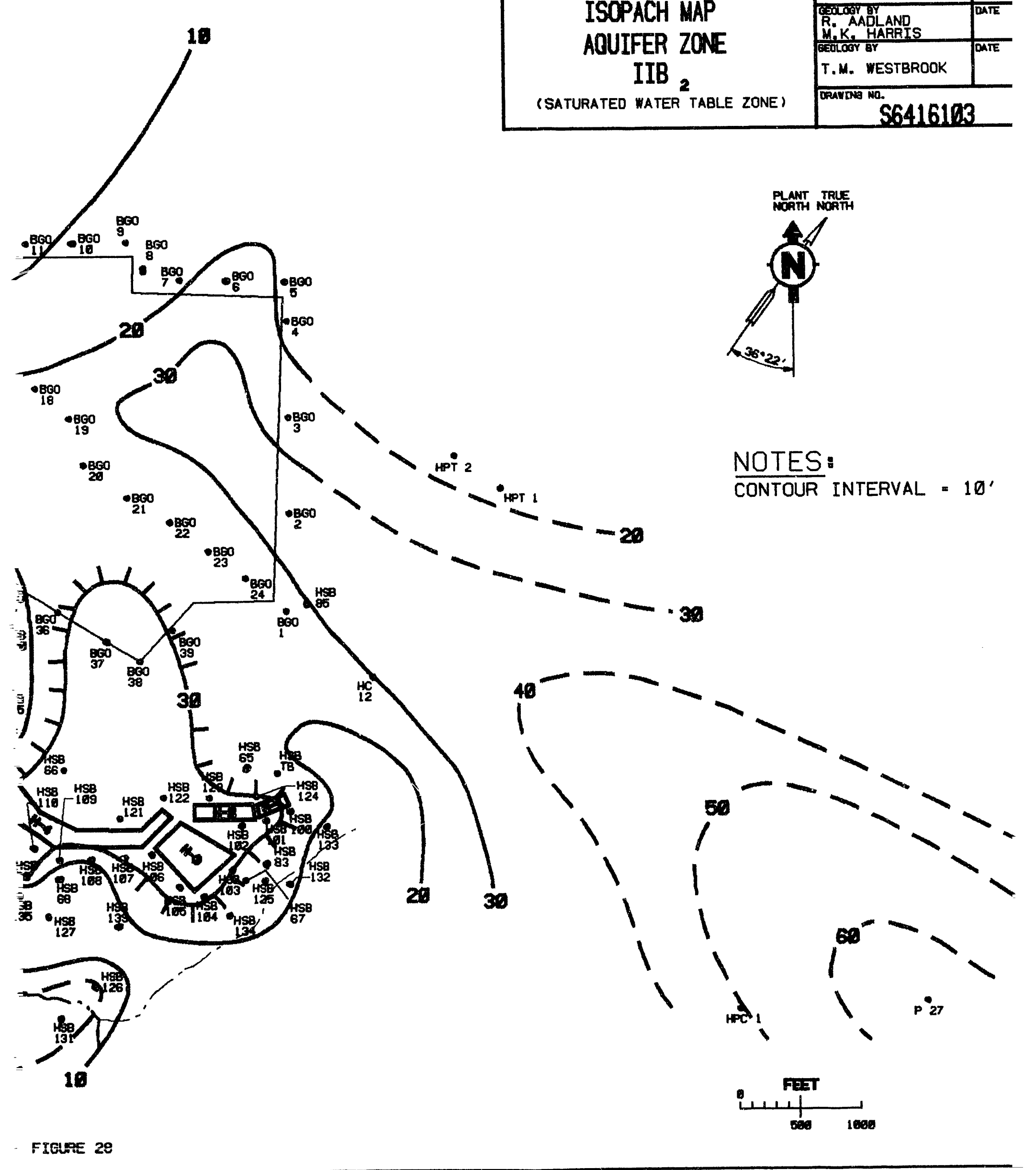


IR 3

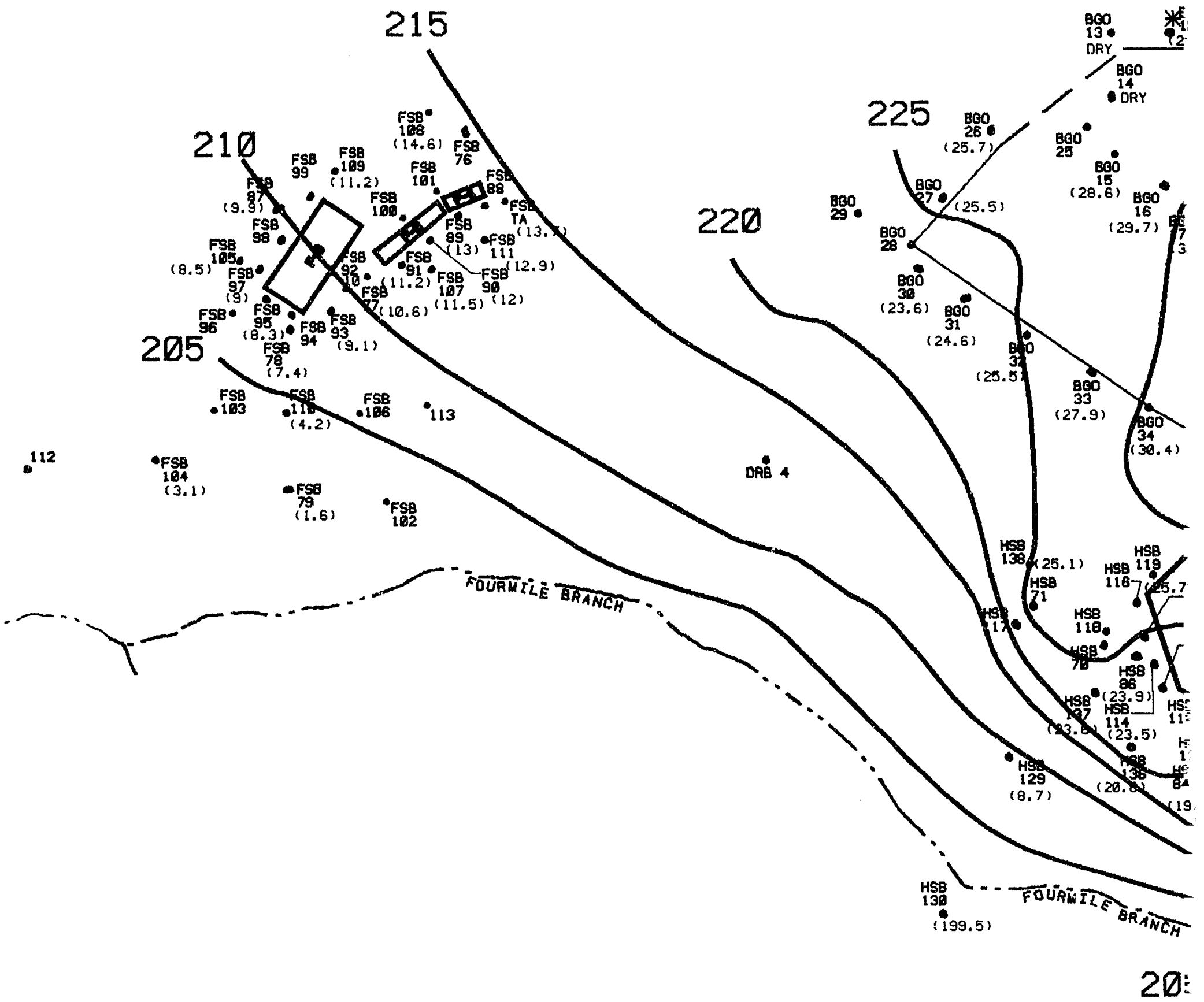




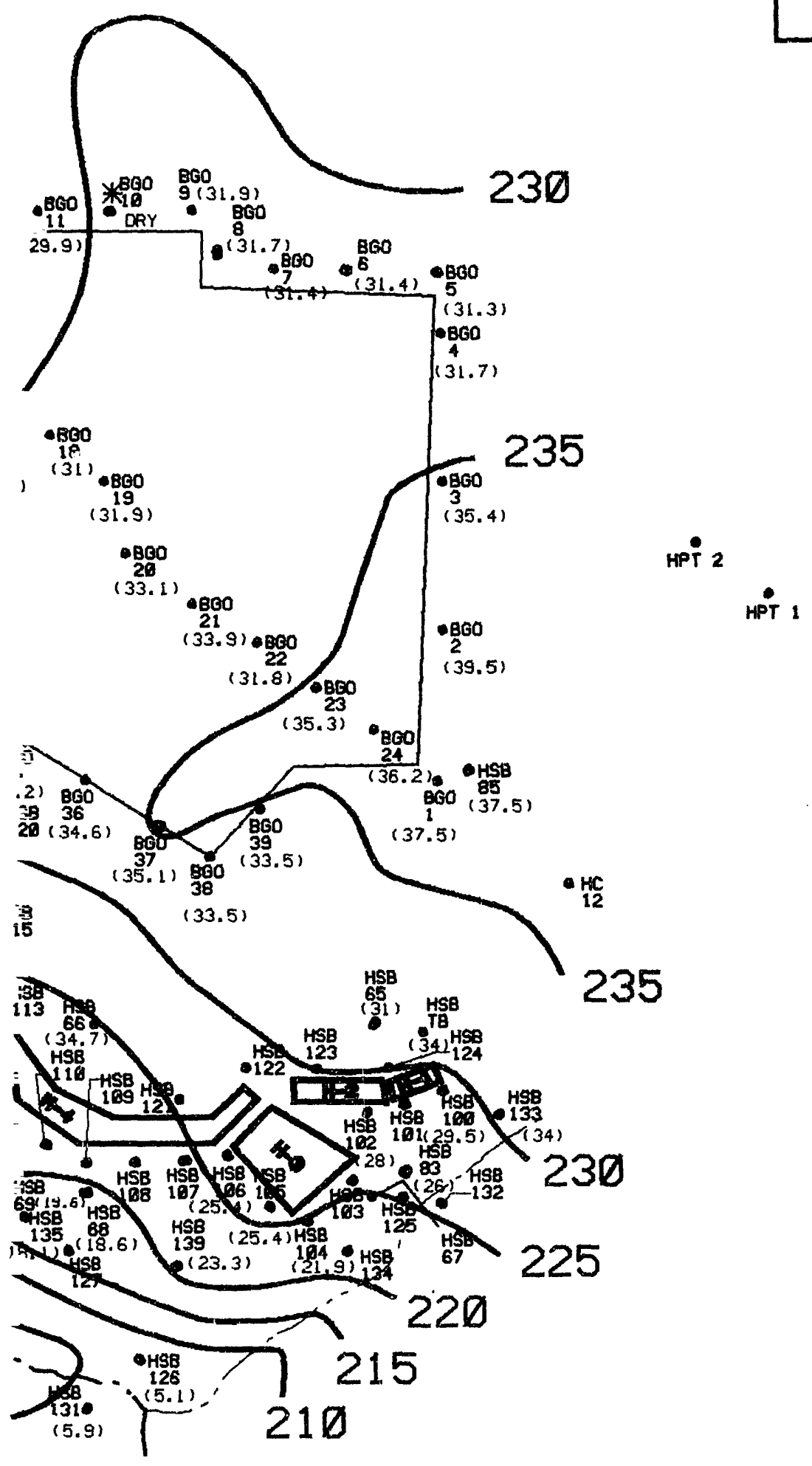

$\frac{\text { NOTES, }}{\text { CONTOUR INTERVAL }=5^{\prime}}$

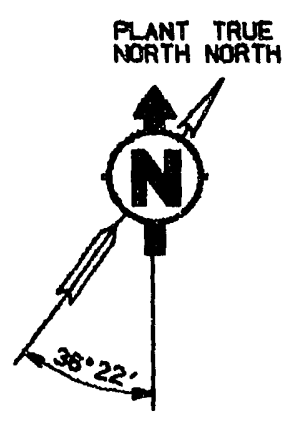




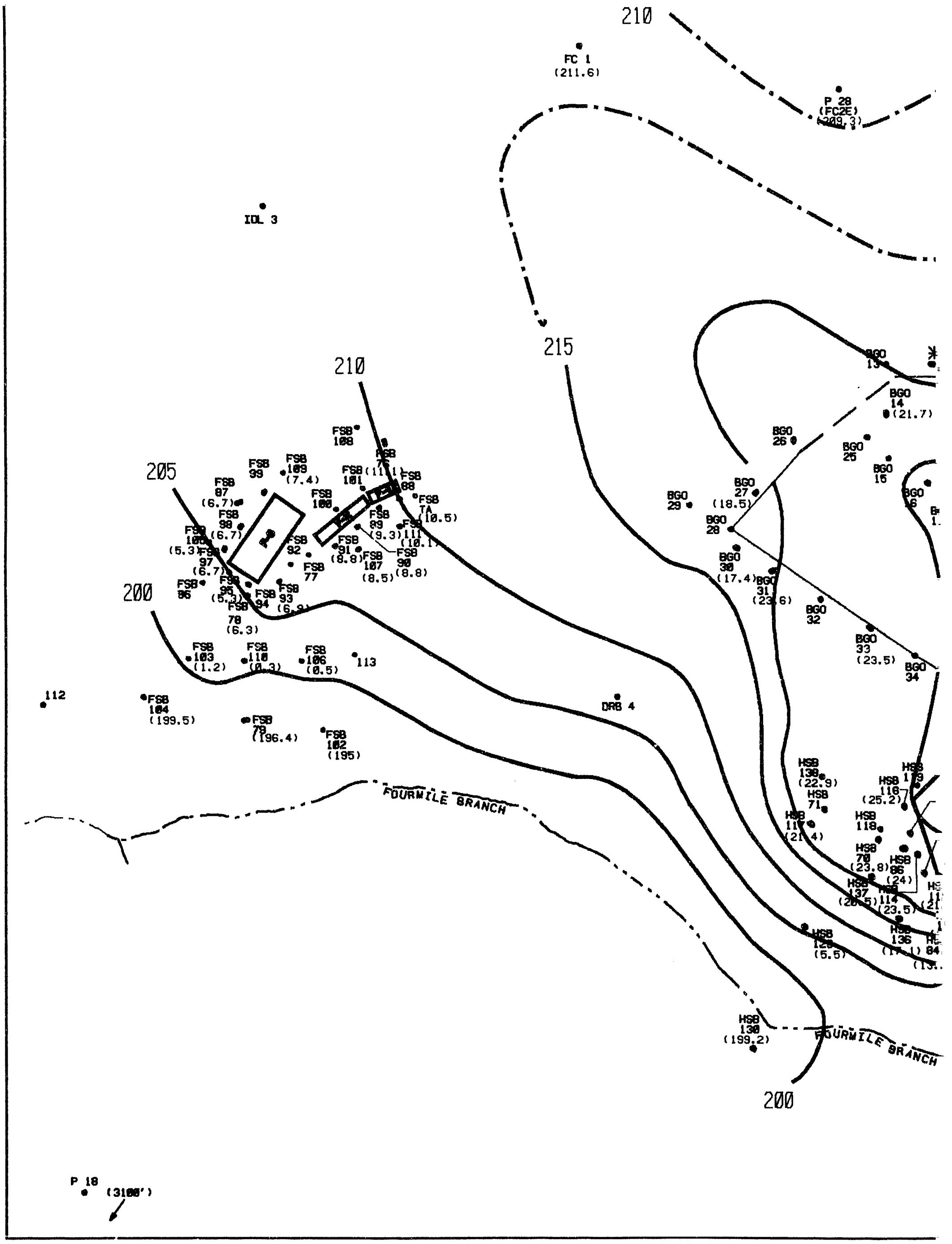



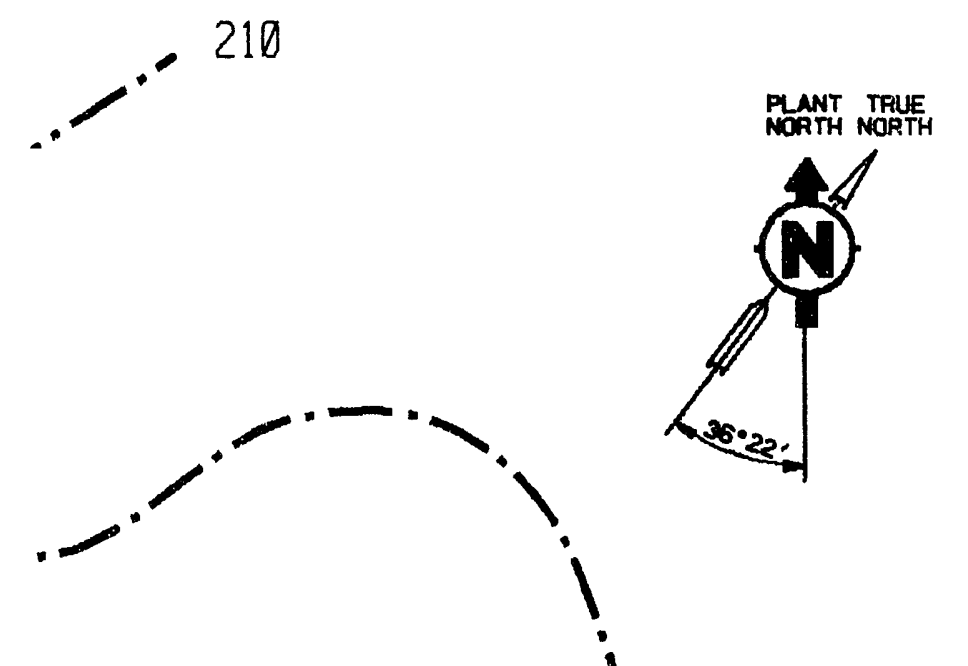

215
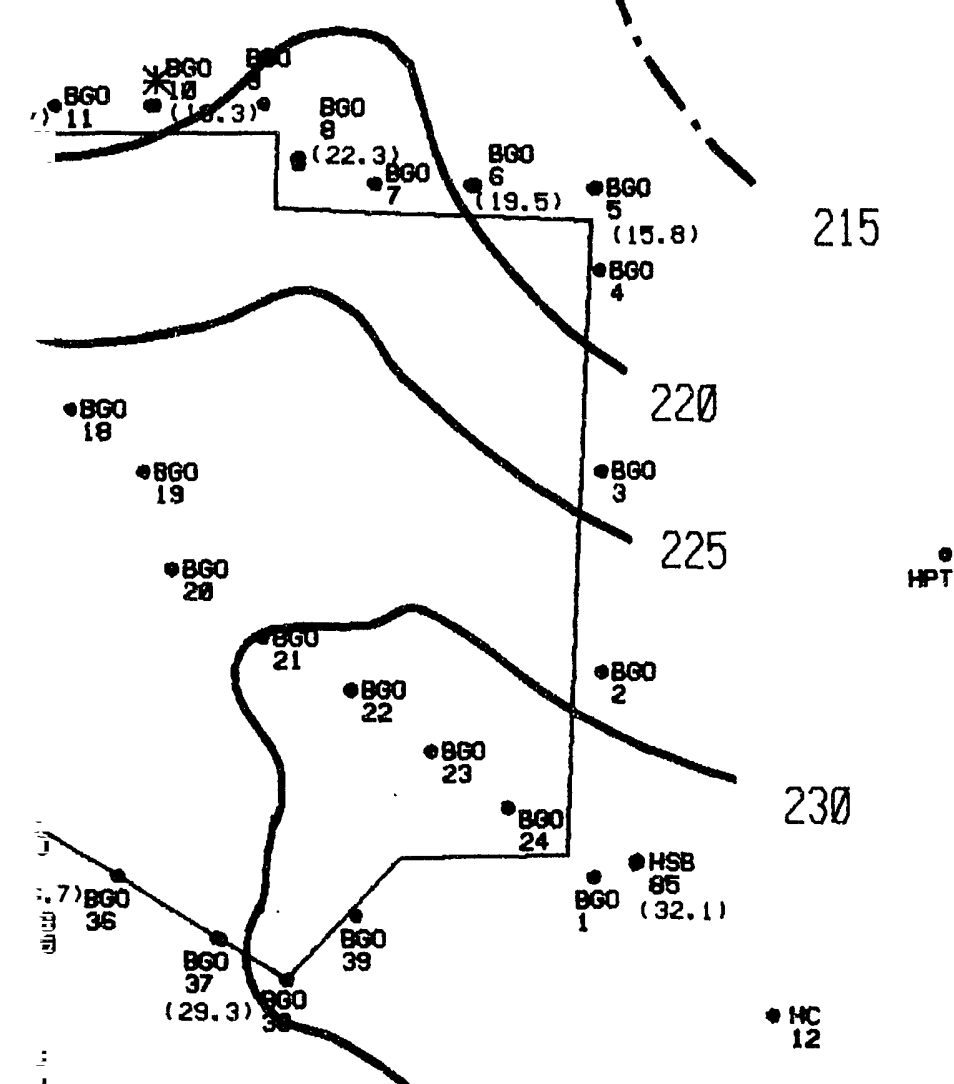

$\vdots$

.

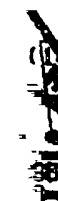

\section{(}

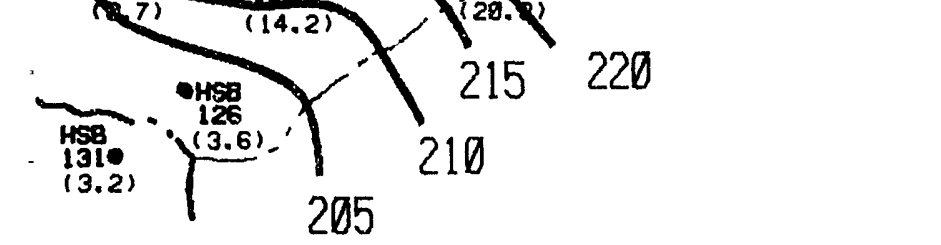




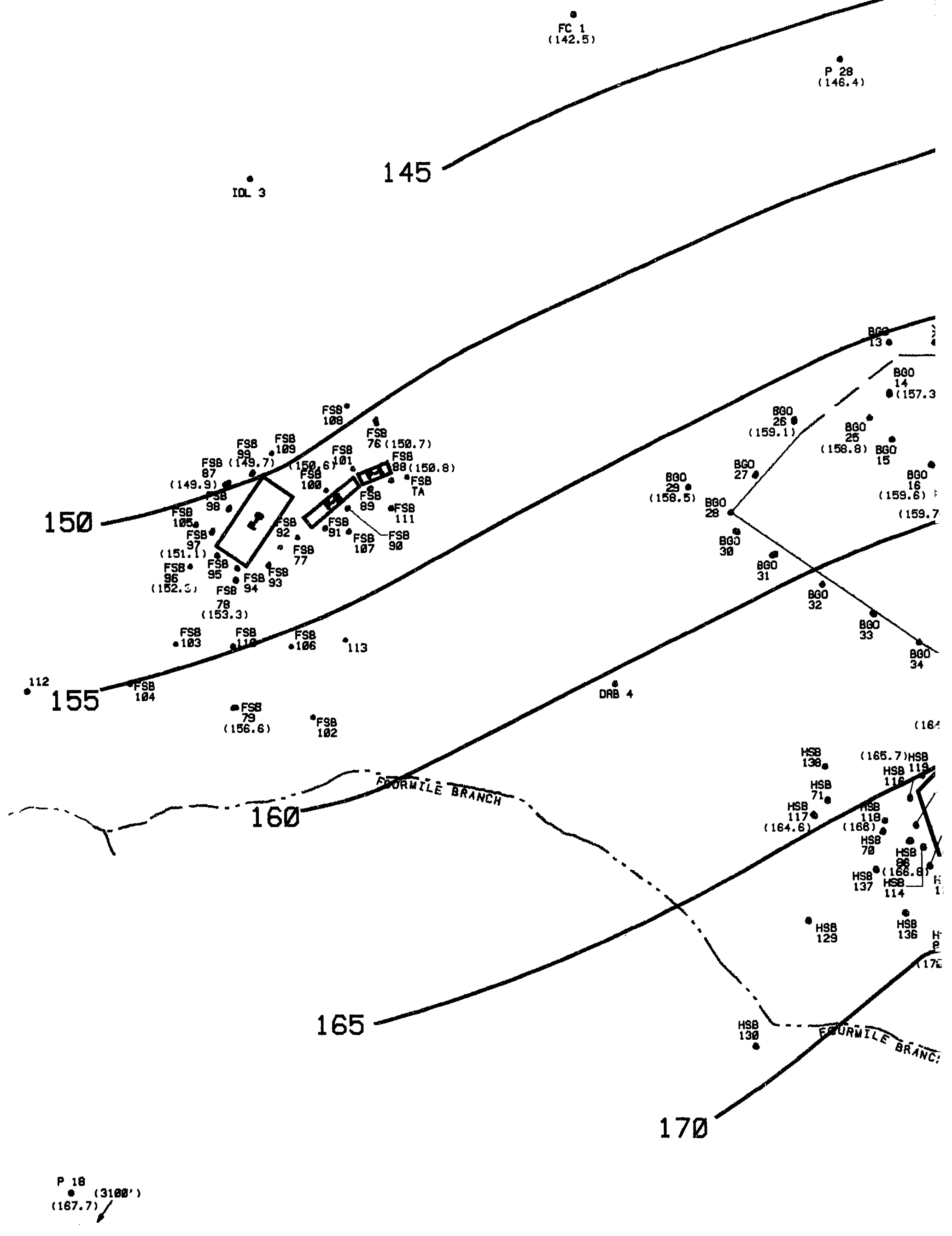

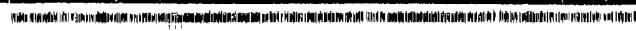



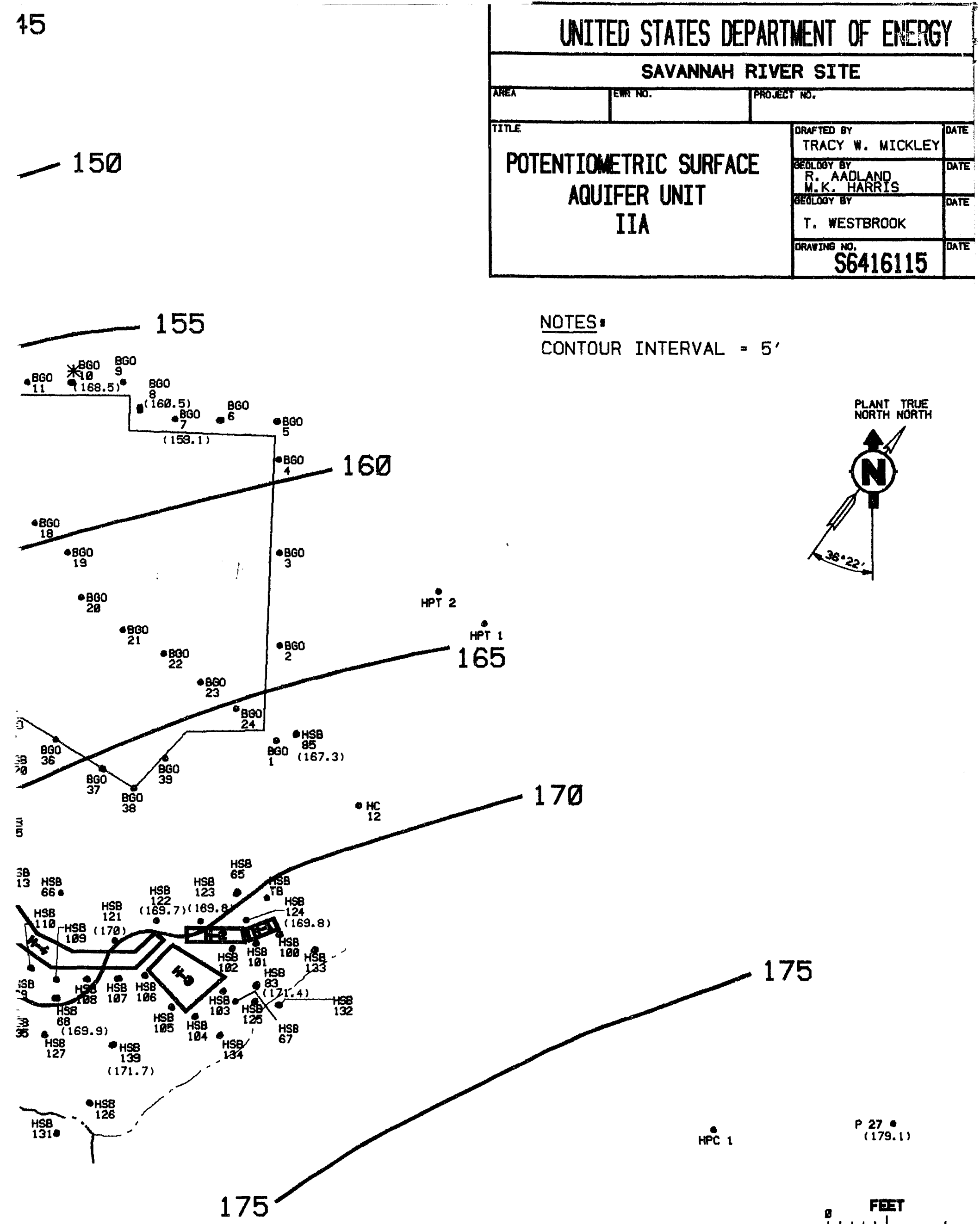


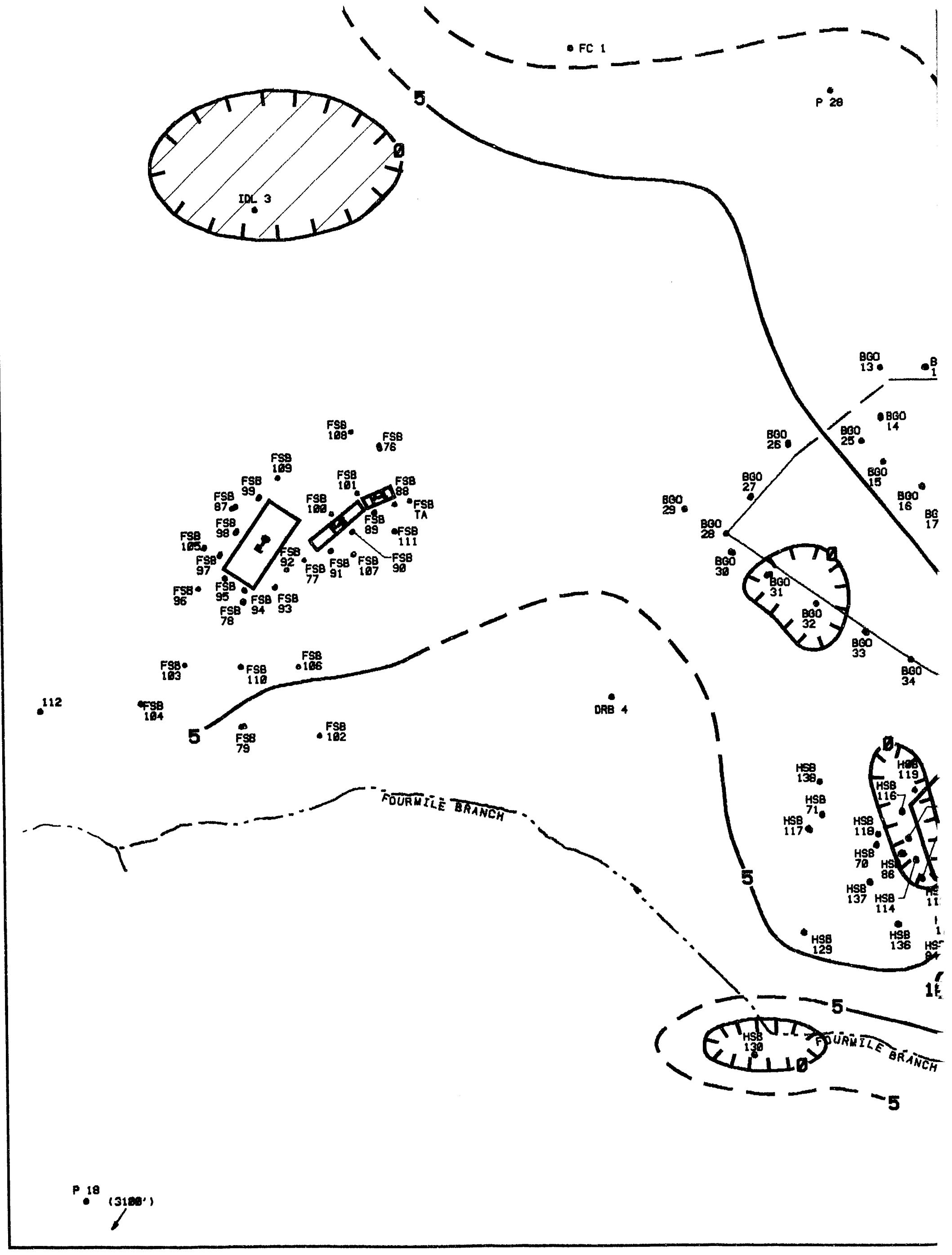




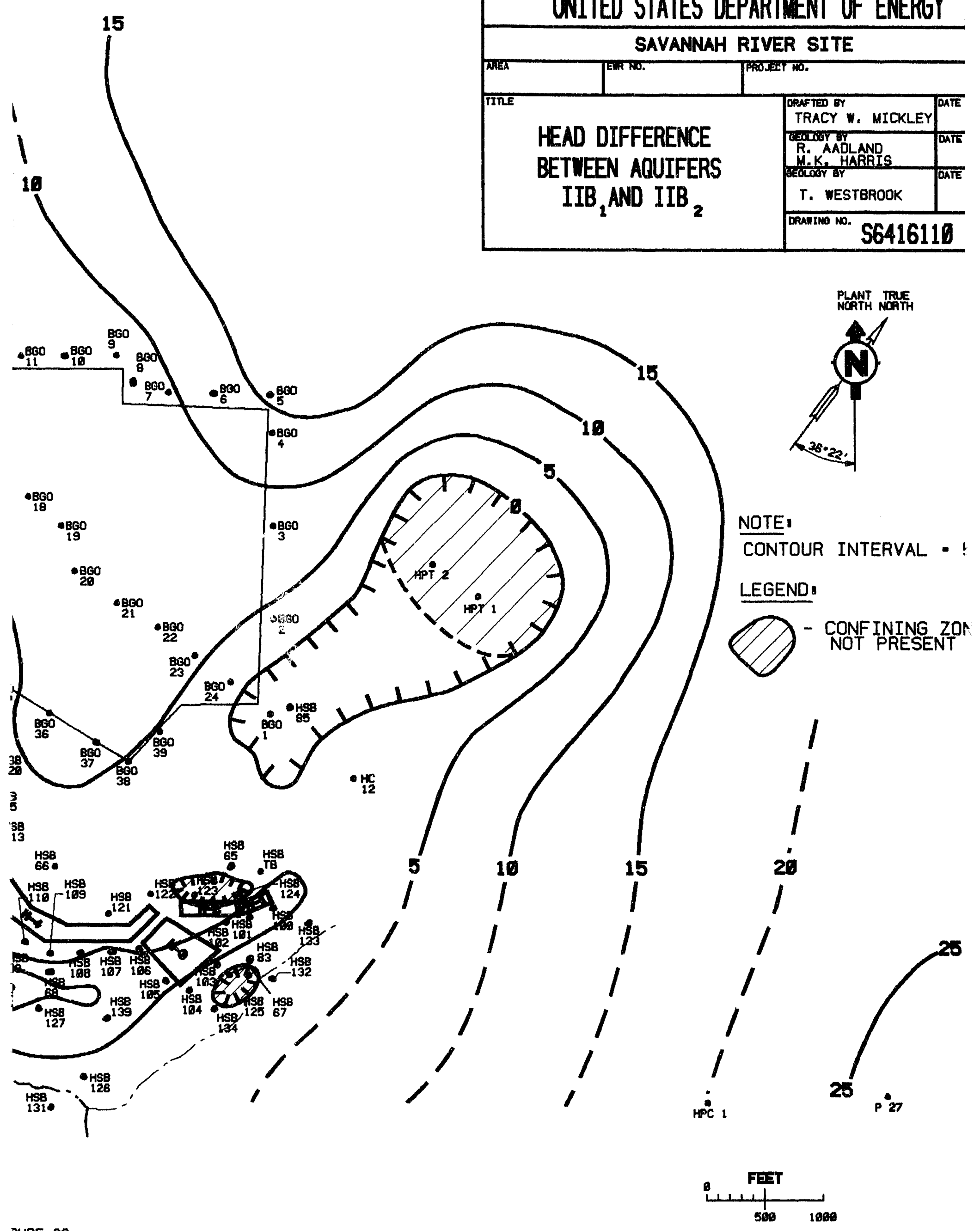




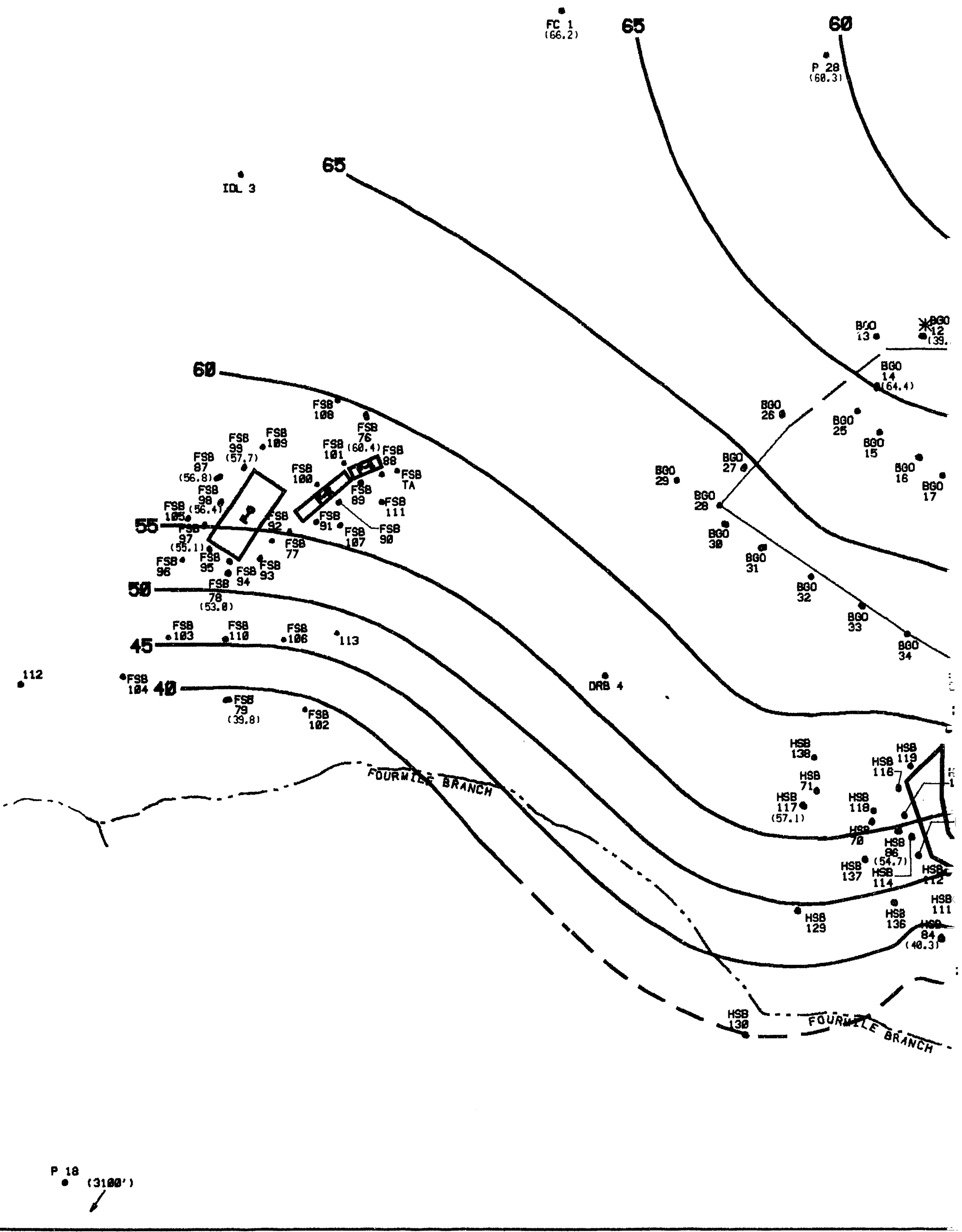




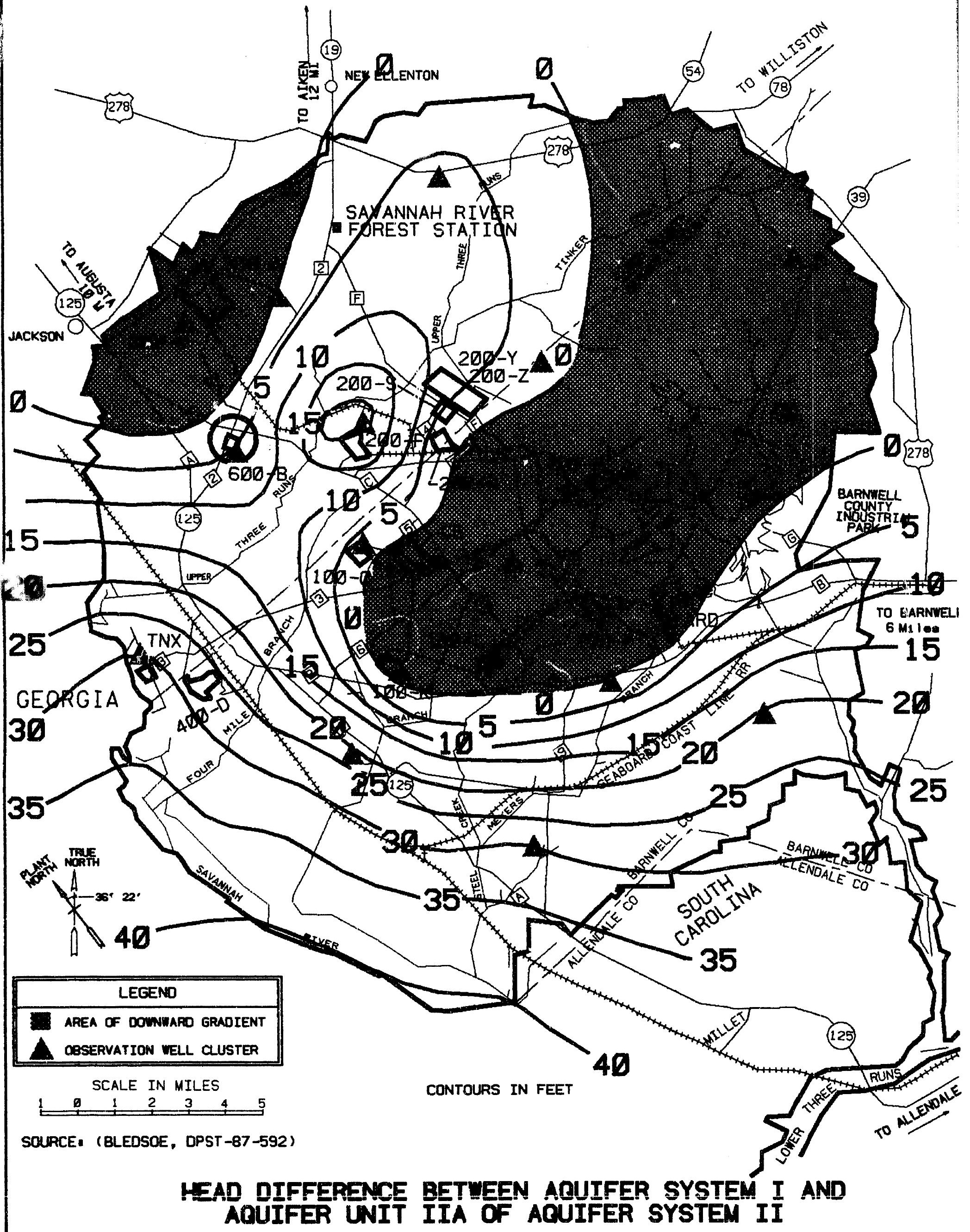




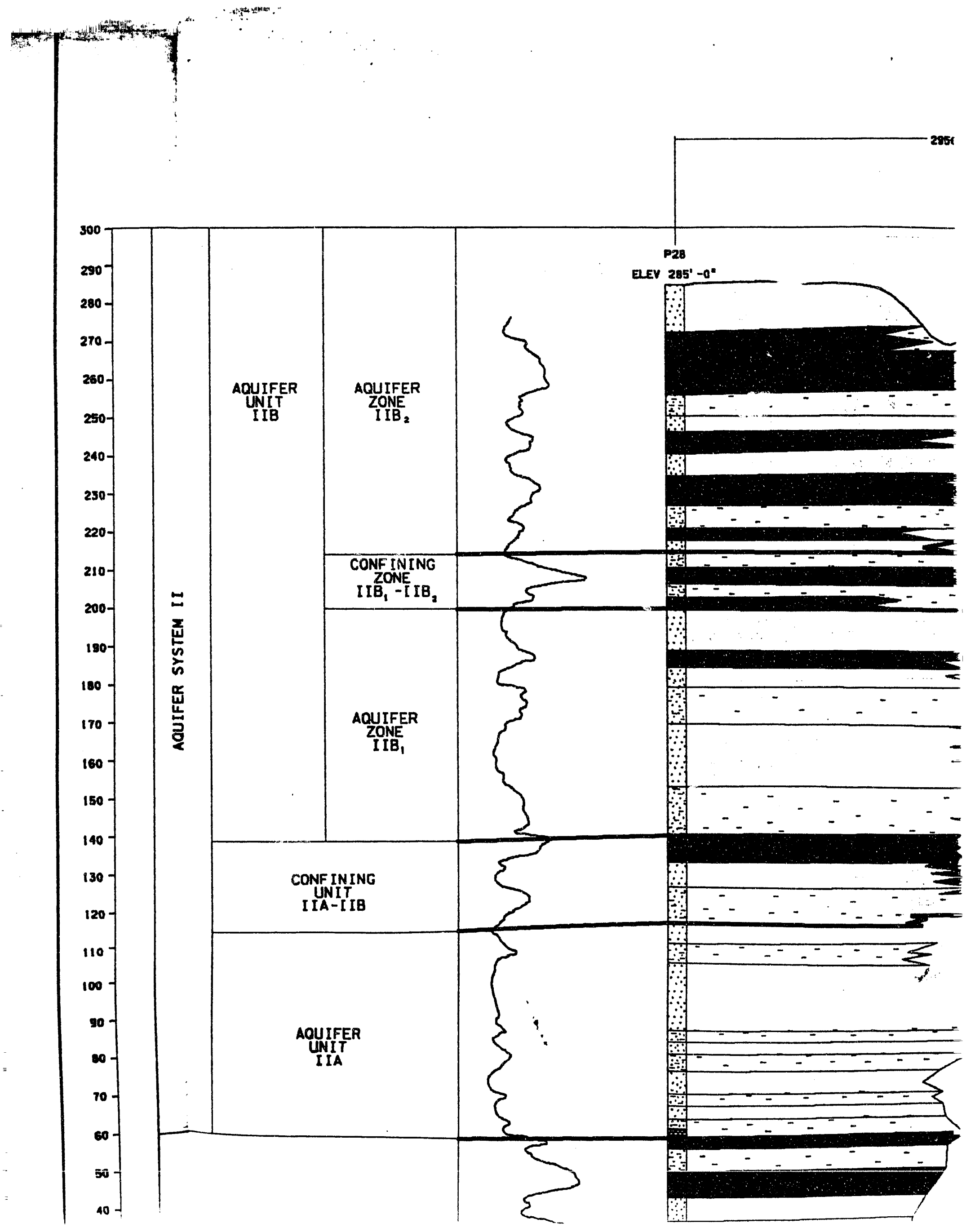




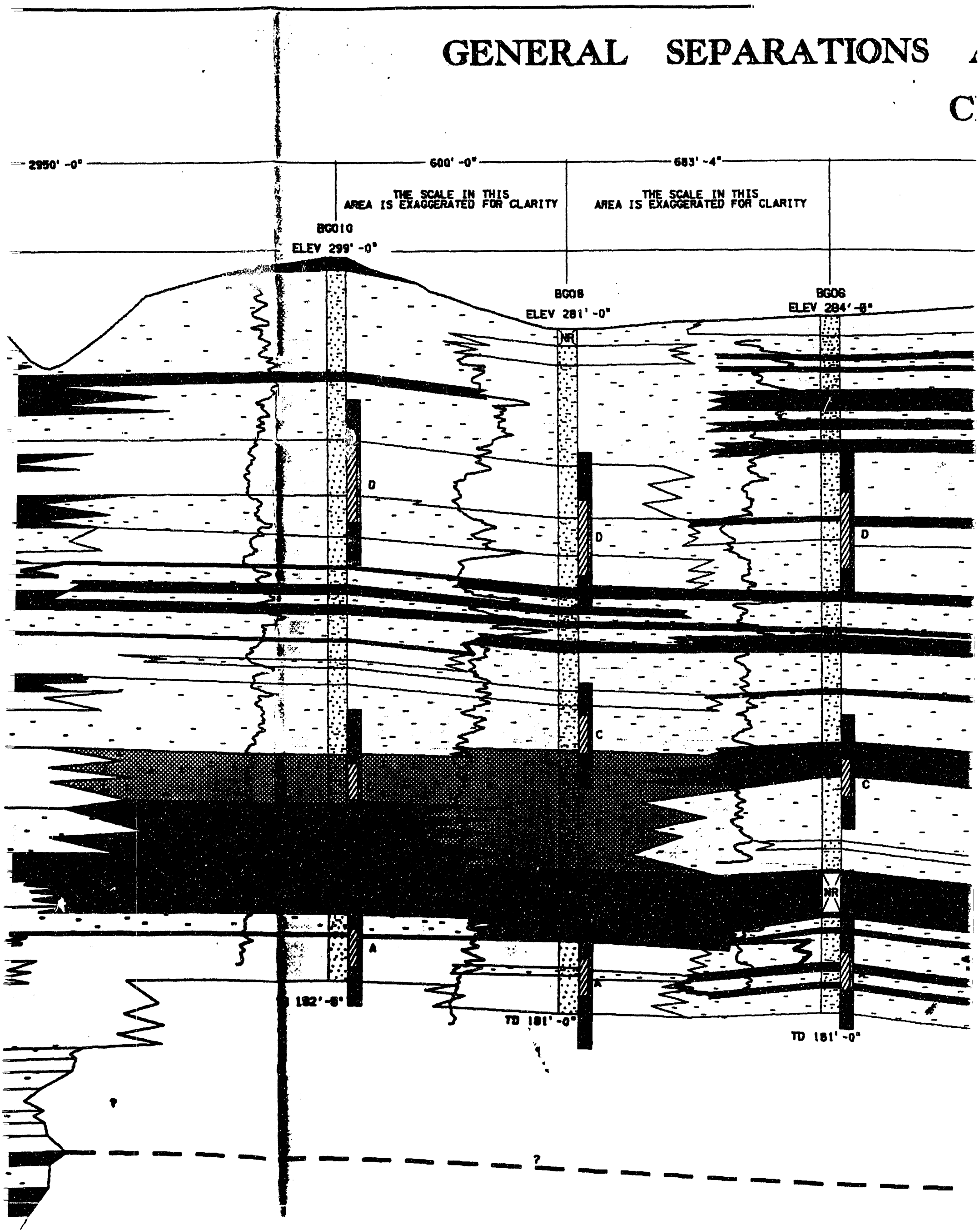




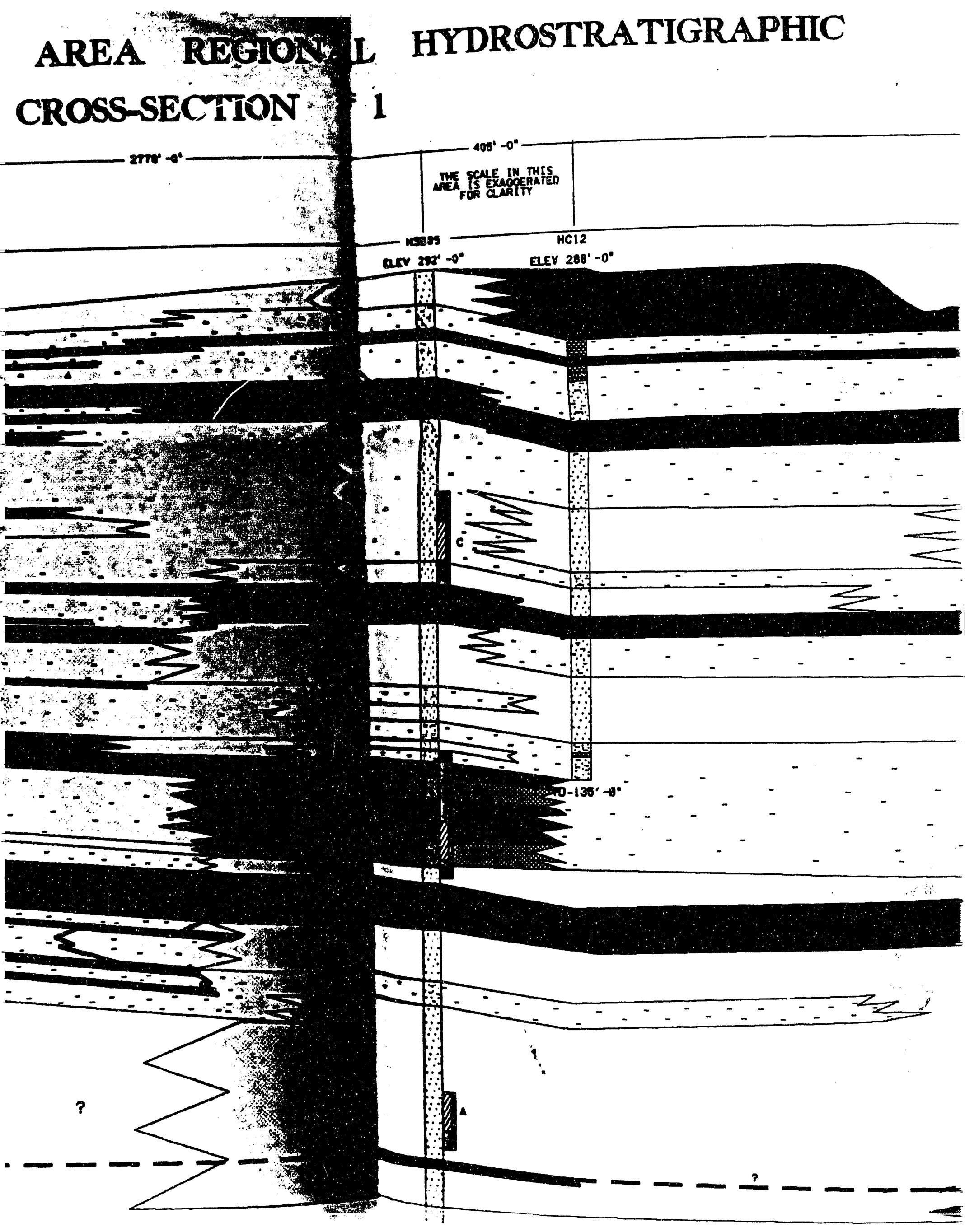




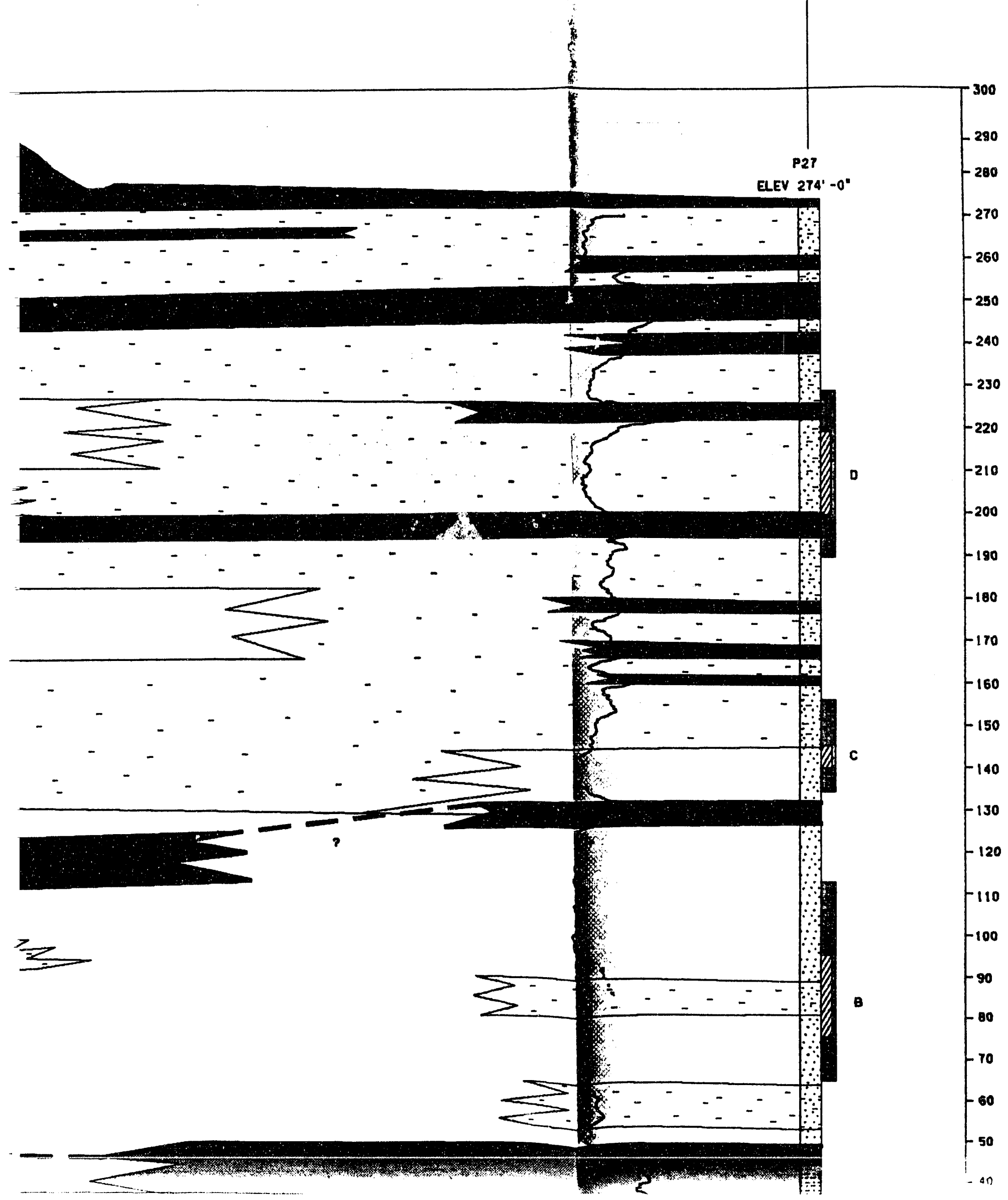



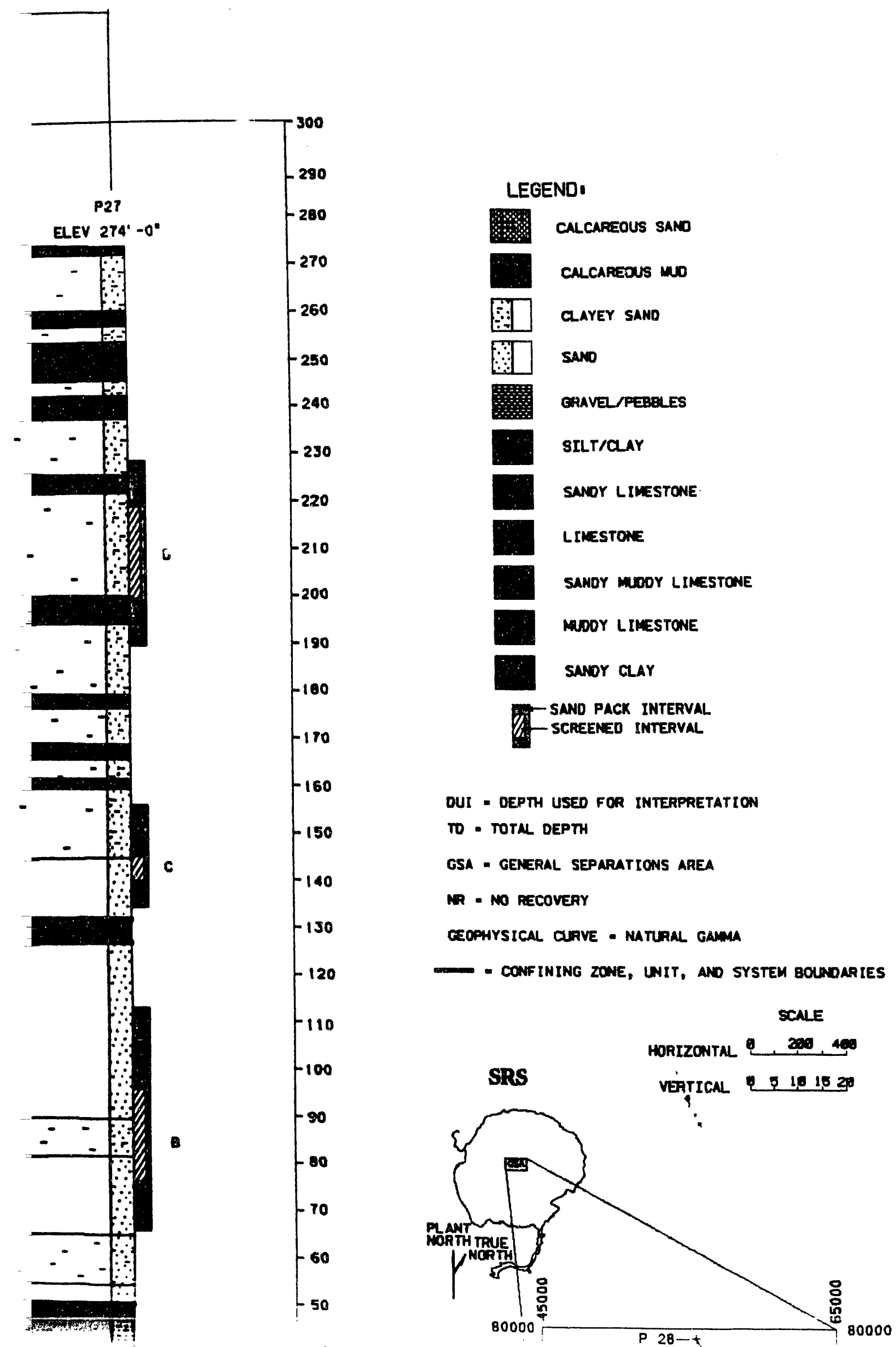


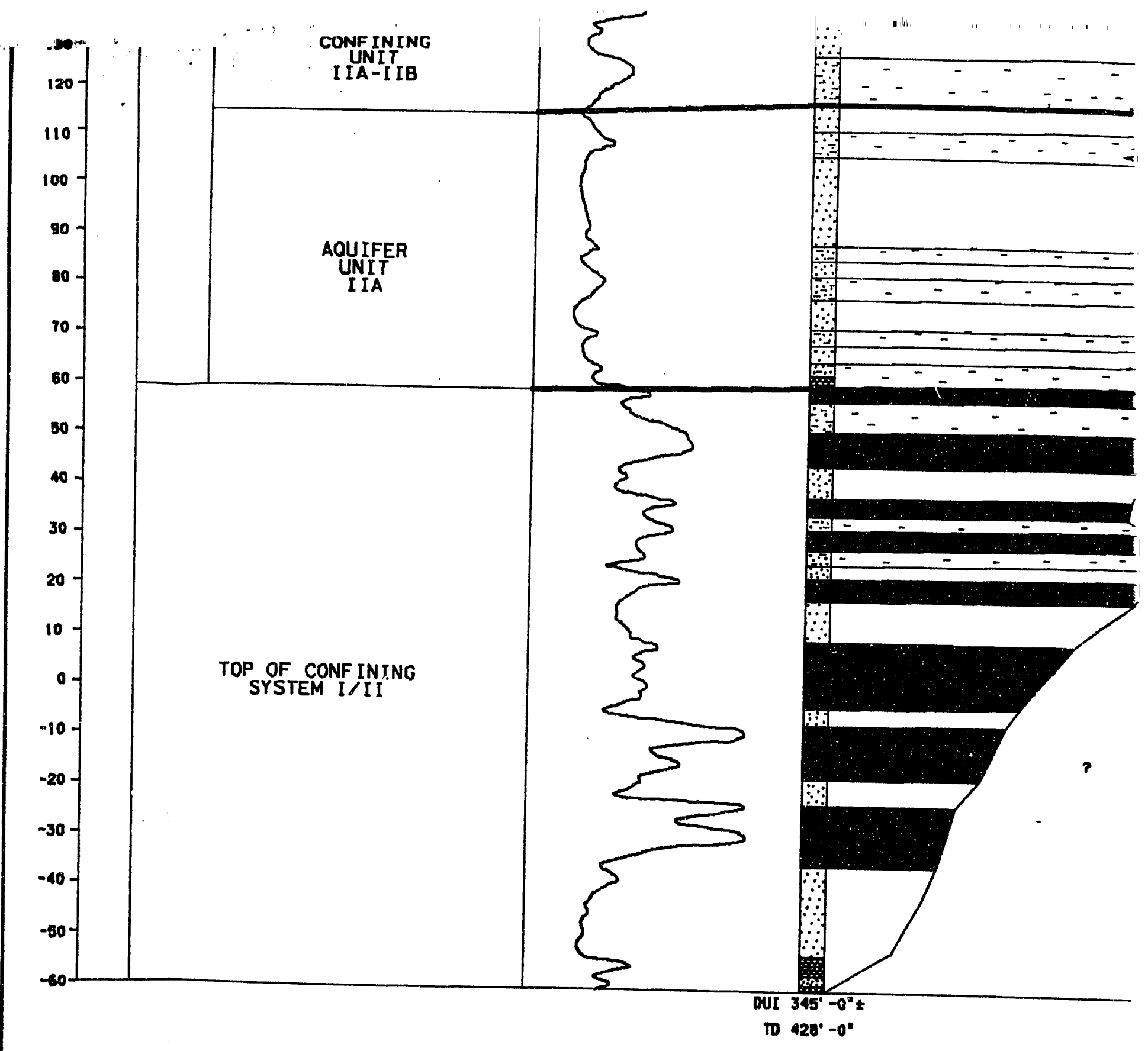




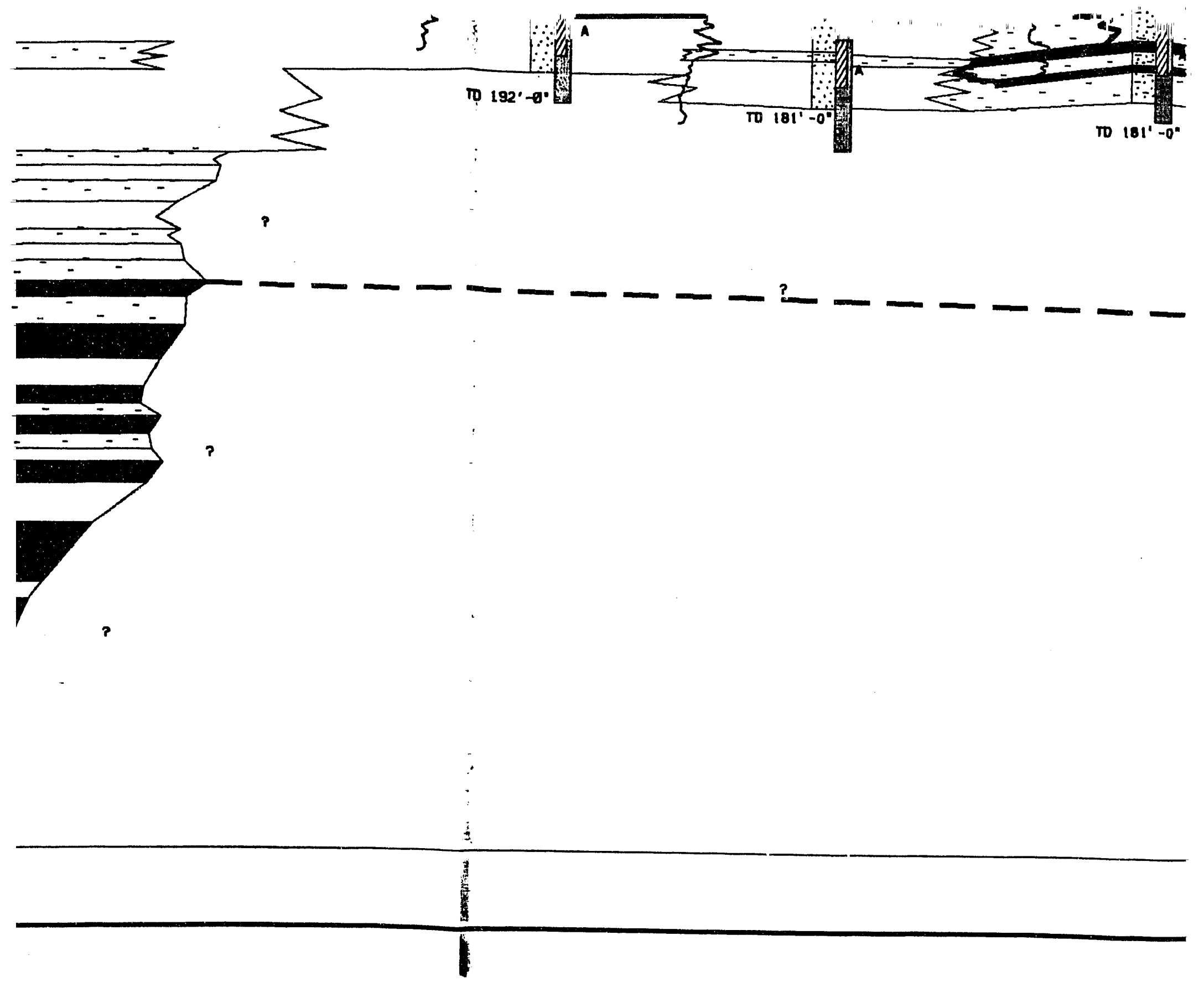




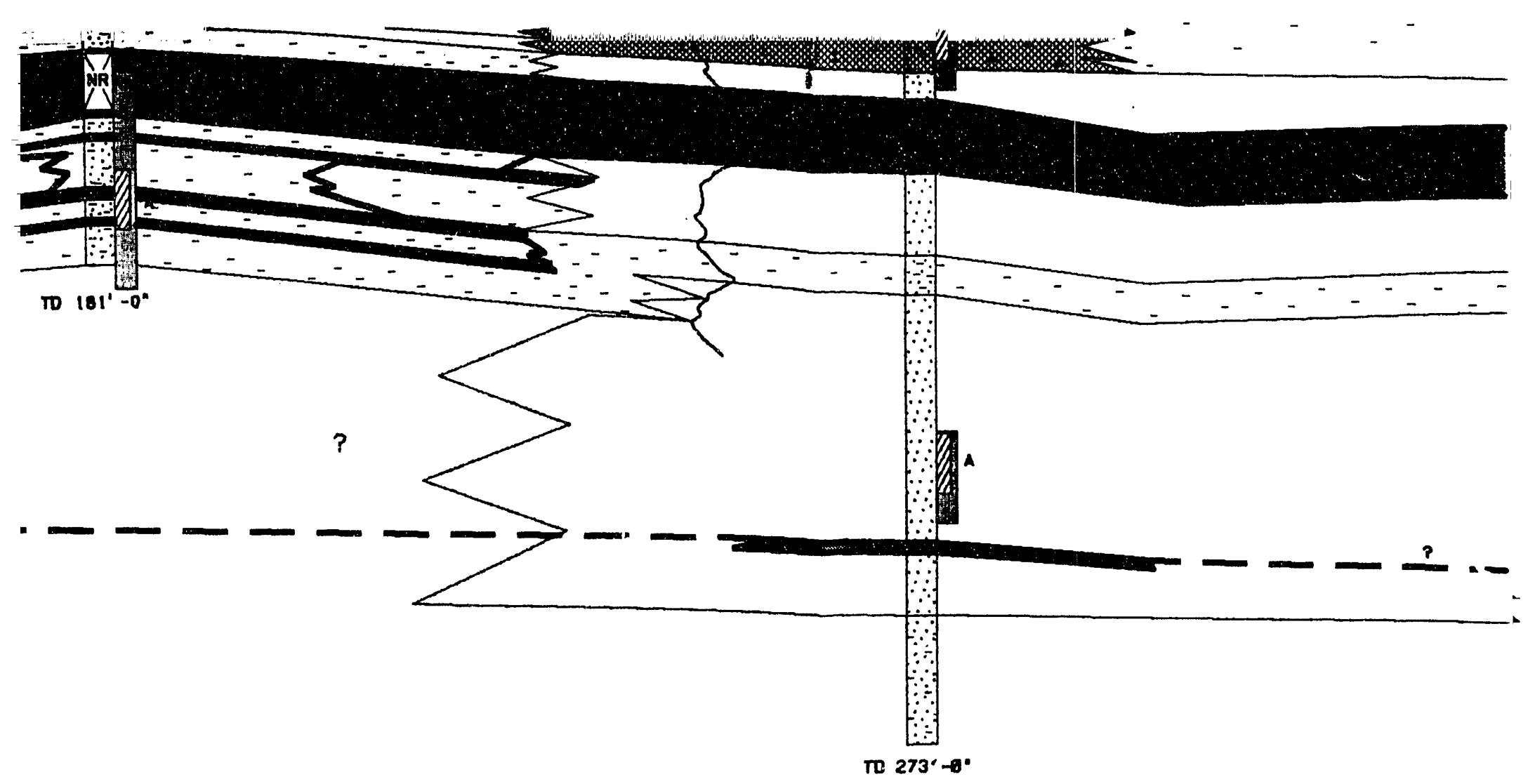




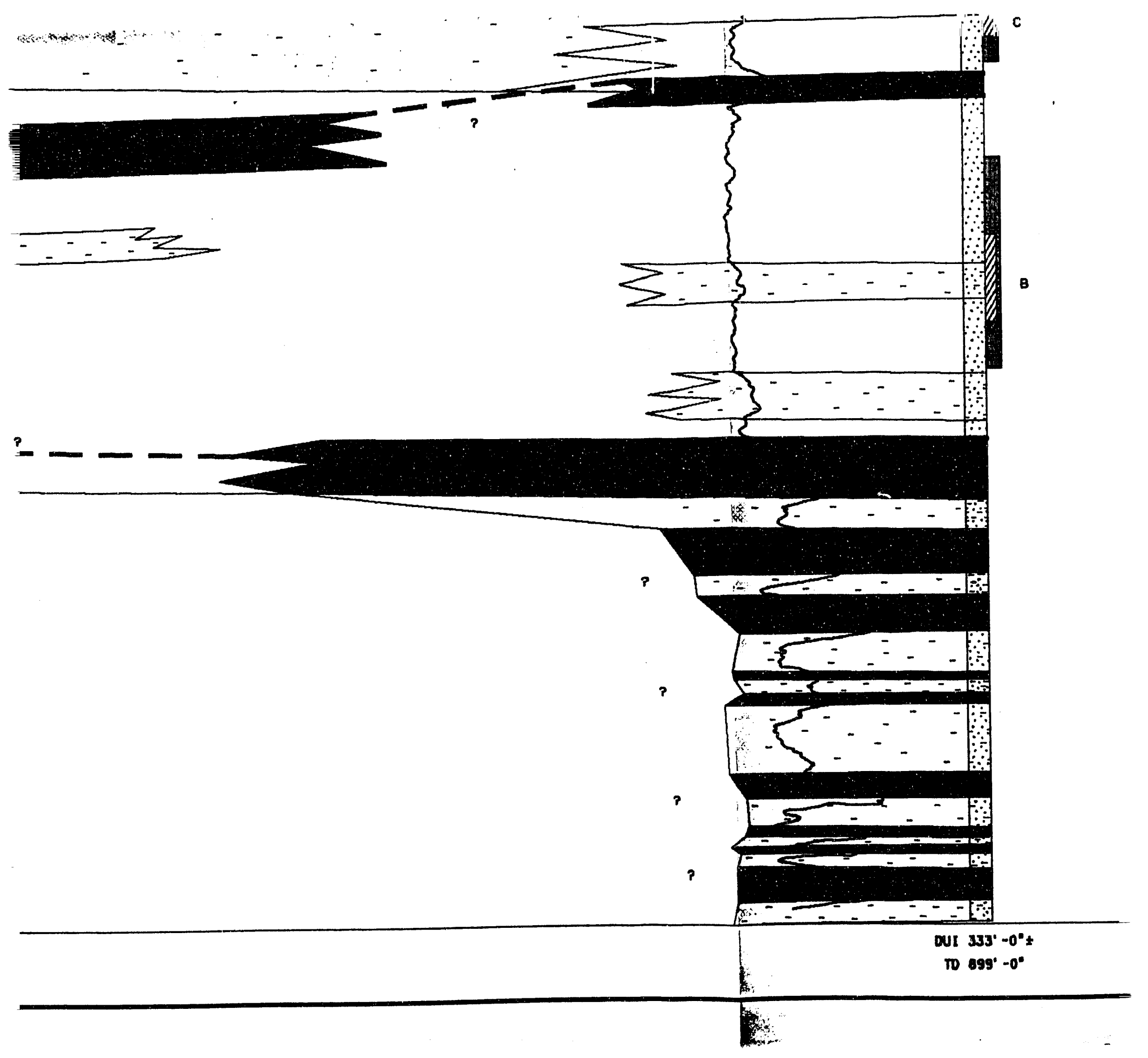




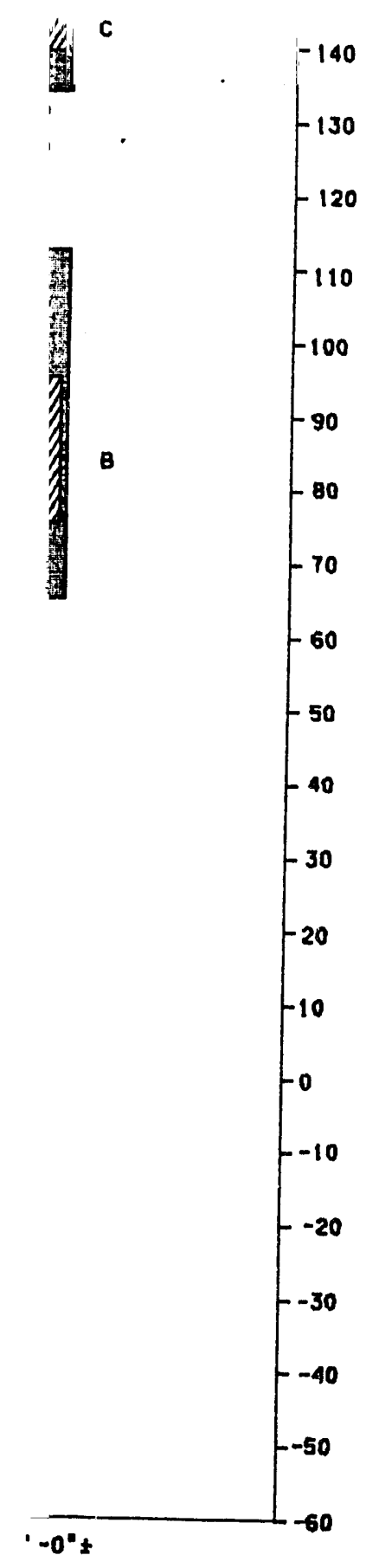

To $899^{\circ}-0^{\circ}$
GSA - general separatrons area

NR - NO RECOVERY

CEOPHYSICAL CLPVE - NATUAAL GAMMA

- CONFINING ZONE, UNIT, AND SYSTEM BOUNOARIES

SCALE

HORIZONTAL

SRS

VEATICAL 5101520

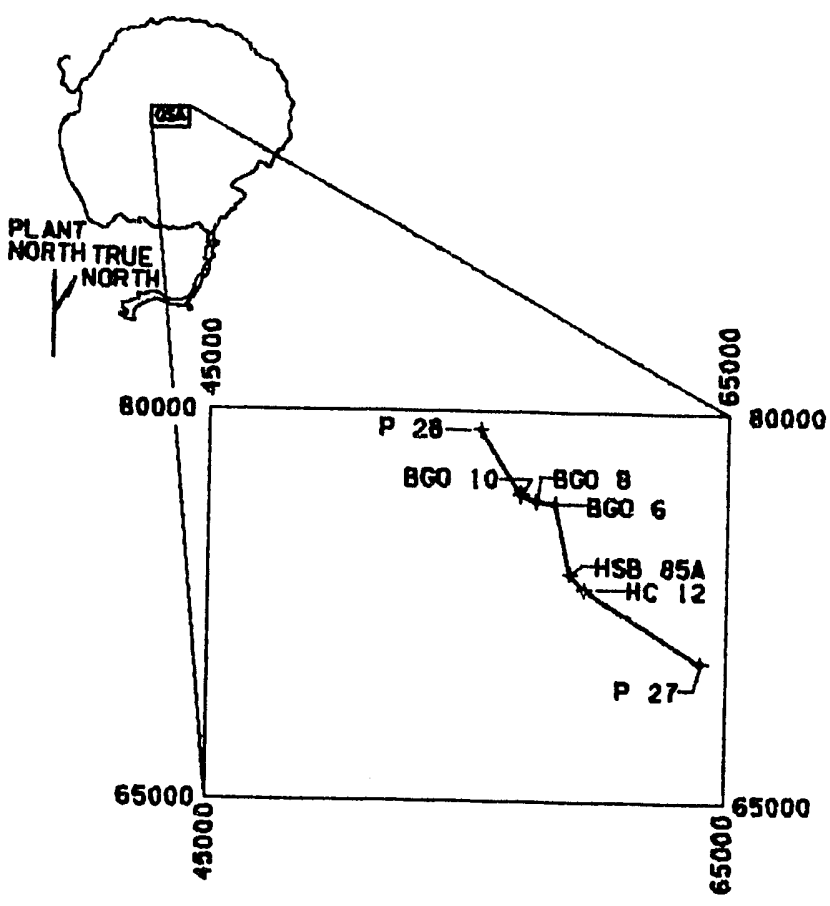

PLATE 1

min sams SAVANNAH RIVER SITE

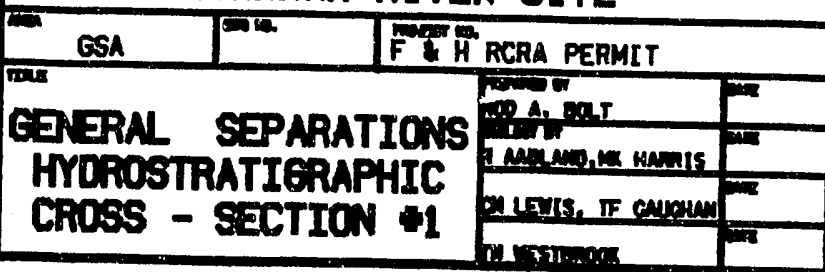




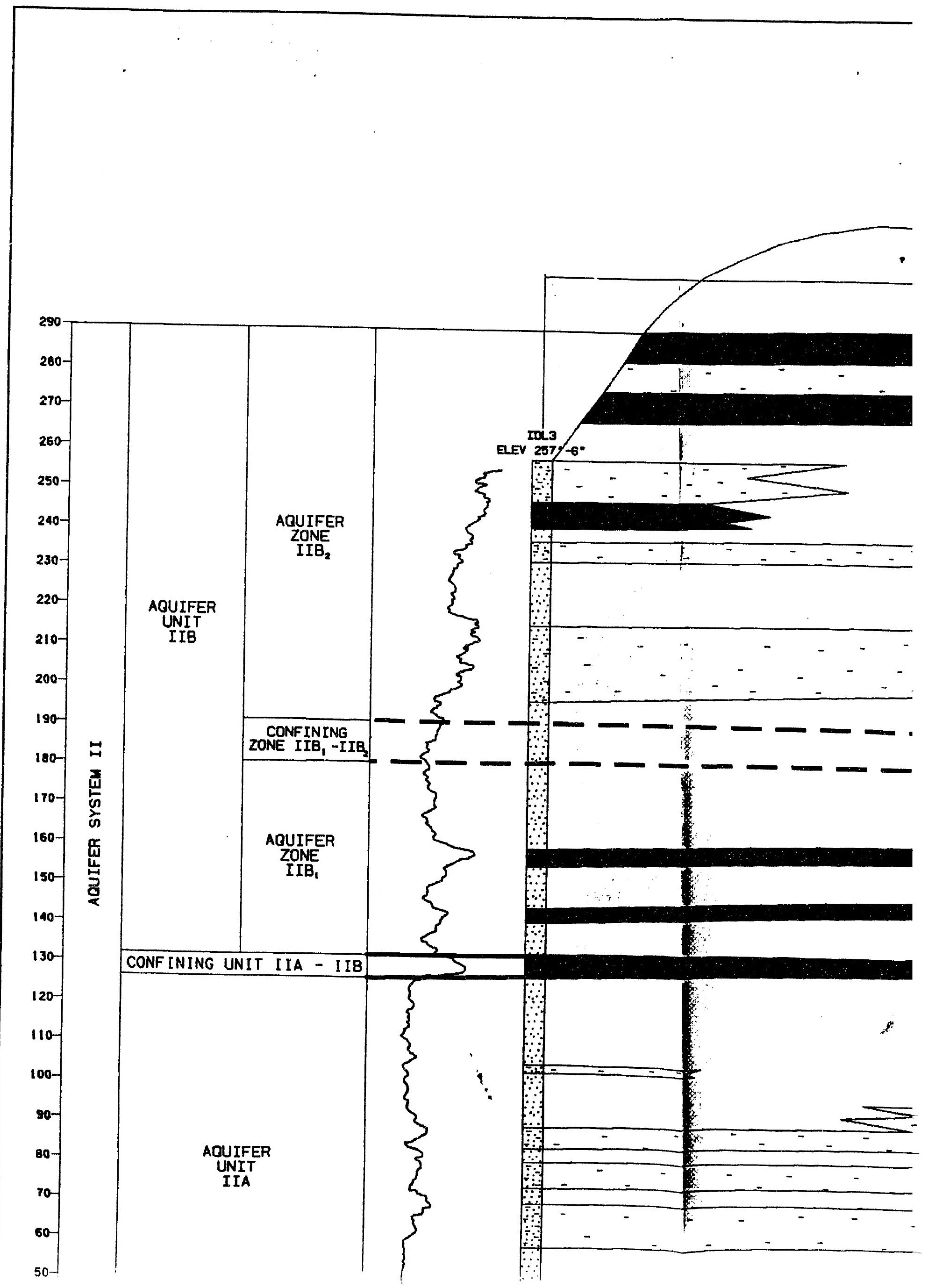


G

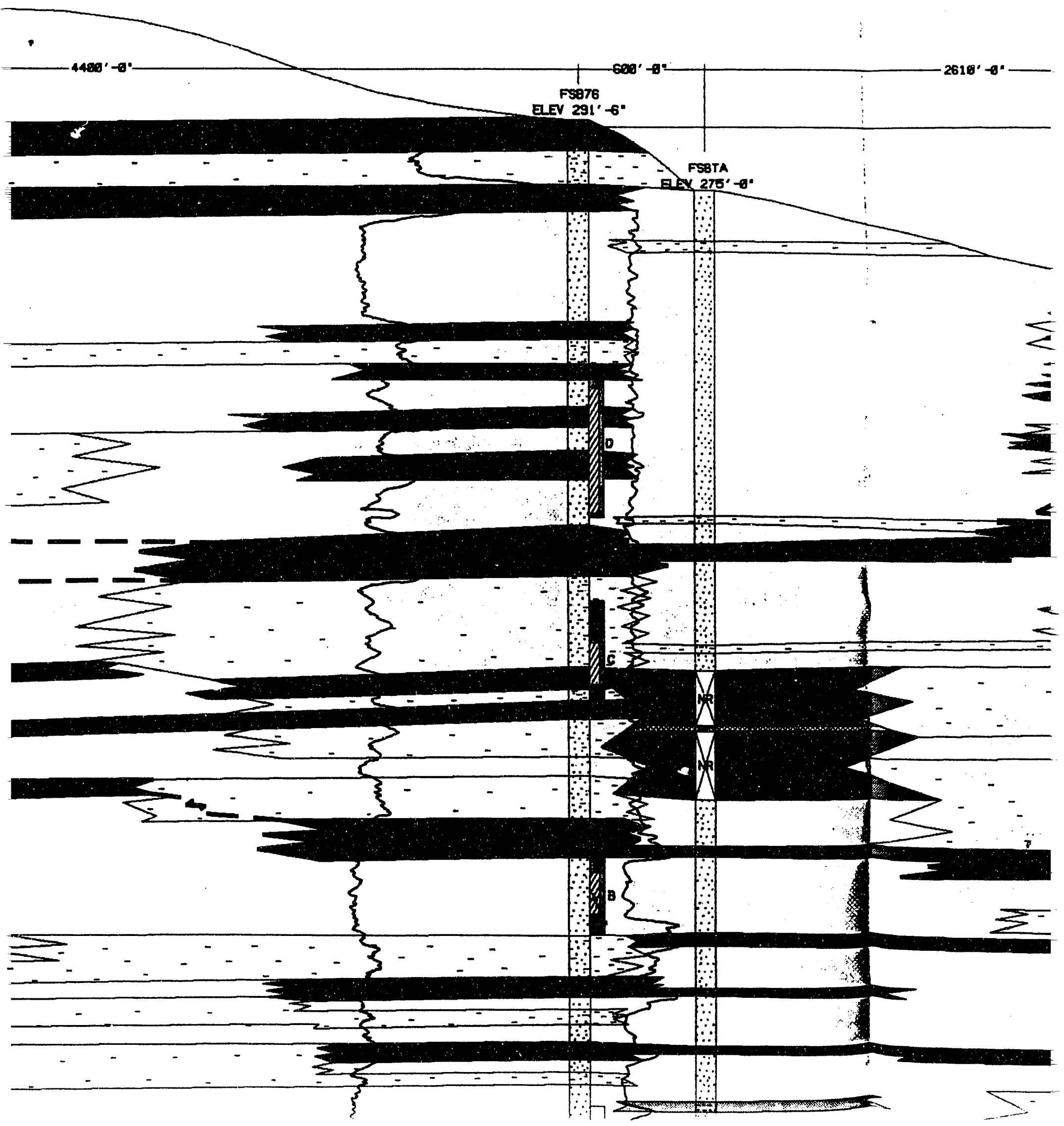




\section{GENERAL SEPARATIONS AREA REGIONAL H CROSS-SECTION \#

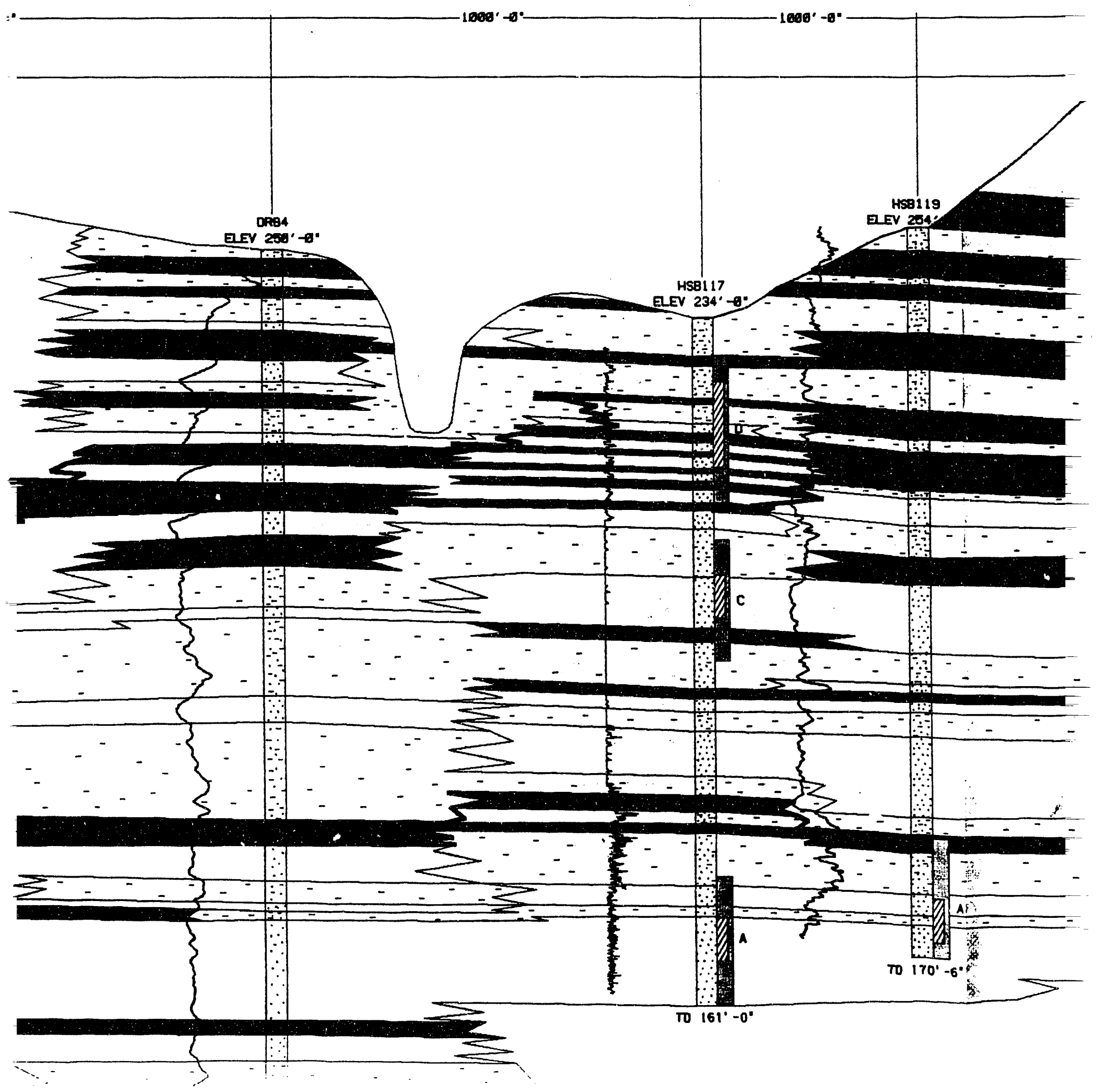




\section{HYDROSTRATIGRAPHIC}

2

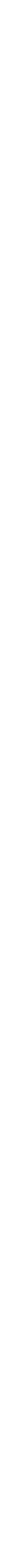




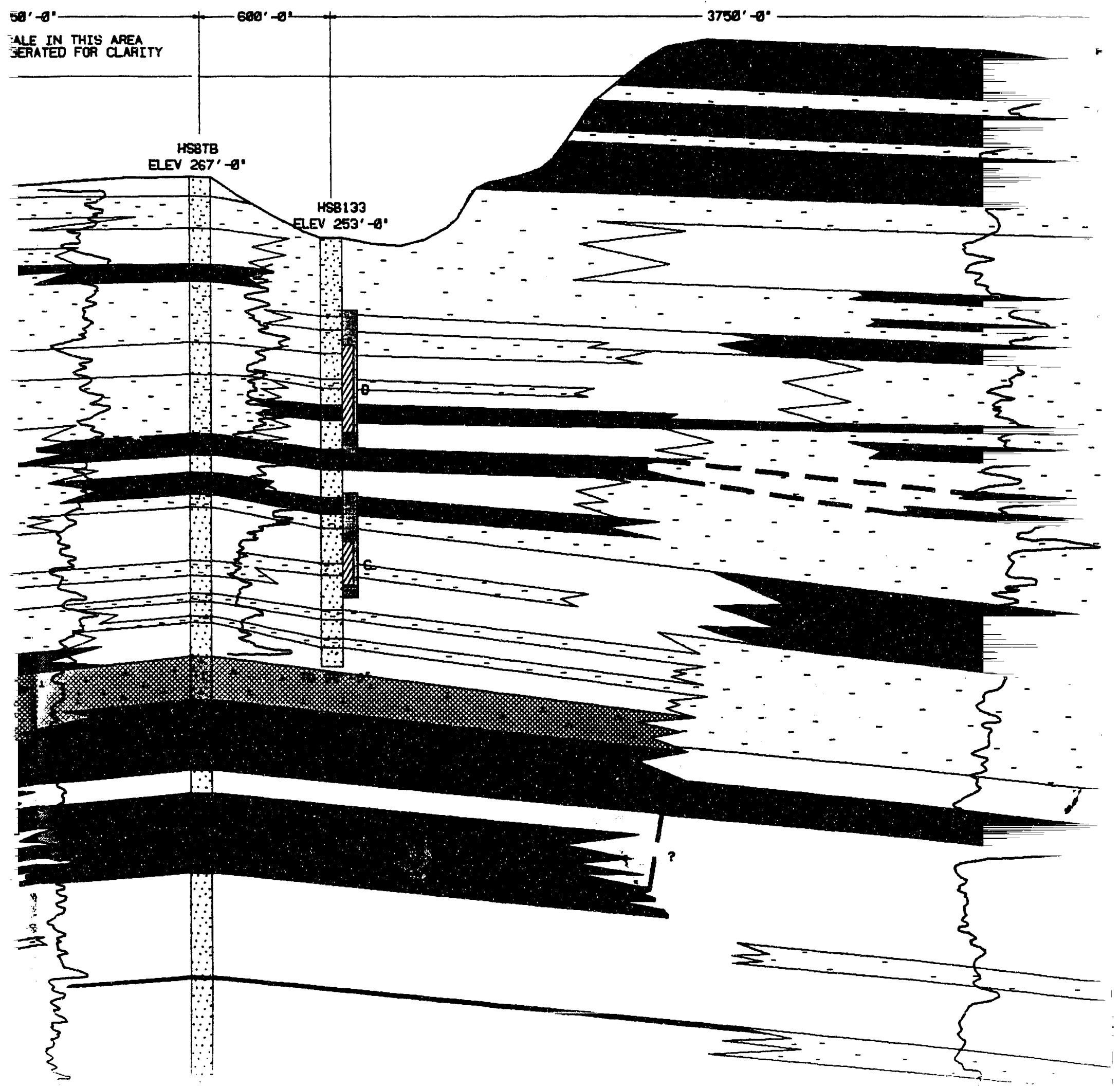




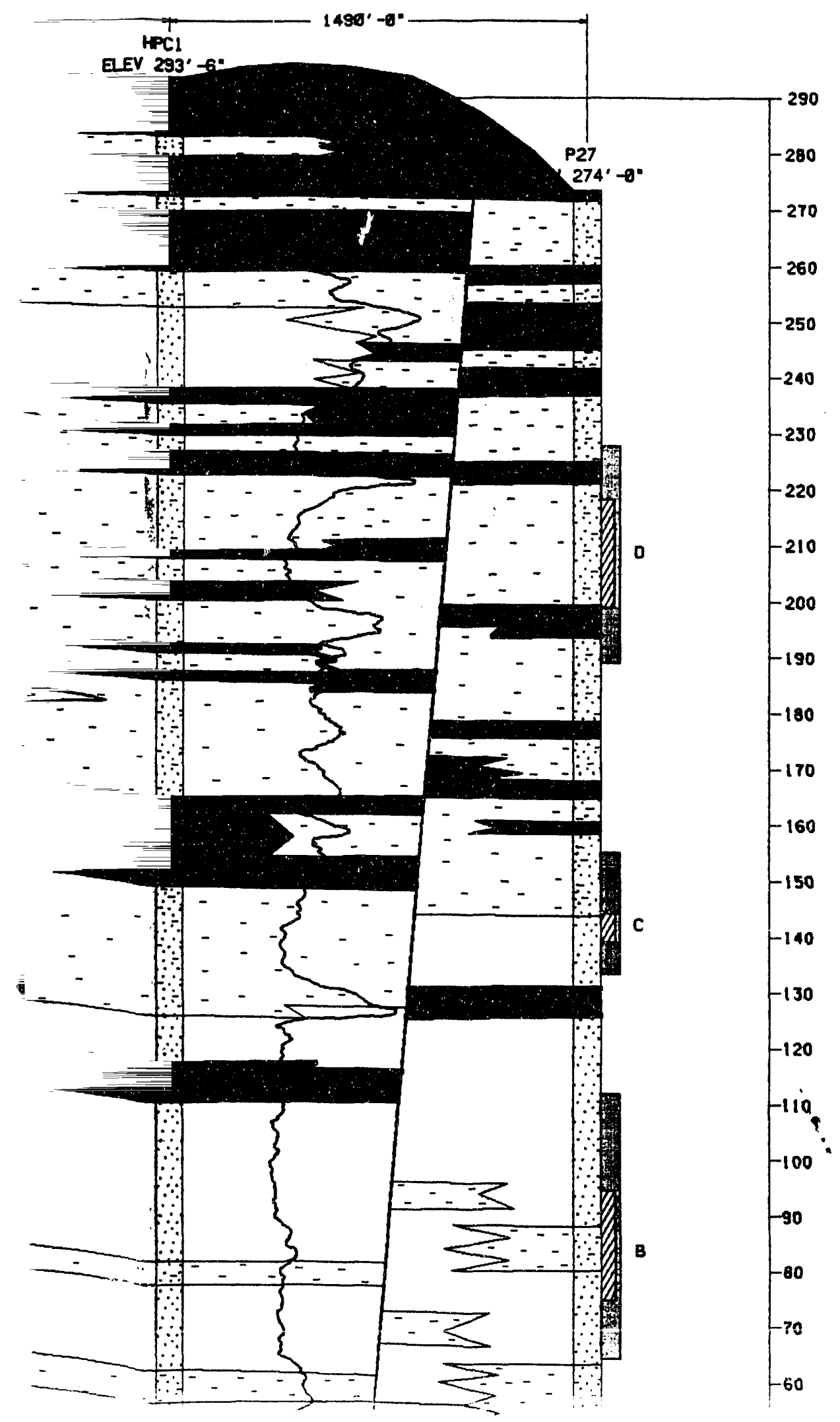

\section{LEGEND,}

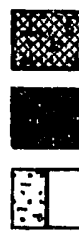

CALCAREOUS SAND

CALCAREOUS MUD

QAYEY SAND

$\therefore$

SAND

GRAVEL/PEBQLES

SILT/CLAY

SANOY LIMESTONE

LIMESTONE

SANDY MUDY LIMESTONE

MUOOY LIMESTONE

SAMOY CLAY

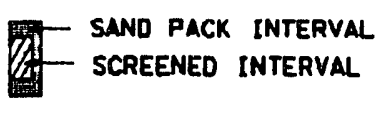

TO - TOTAL DEPTH

GSA - GENERAL SEPARATIONS AREA

NR - NO RECOVERY

DUI - OEPTH USED FOR INTERPRETATION

gEOPHYSICAL CURVE - MATUPAL GAMMA

- CONFINING zONE, UNIT, ANO SYSTEZ BOUNDARIES
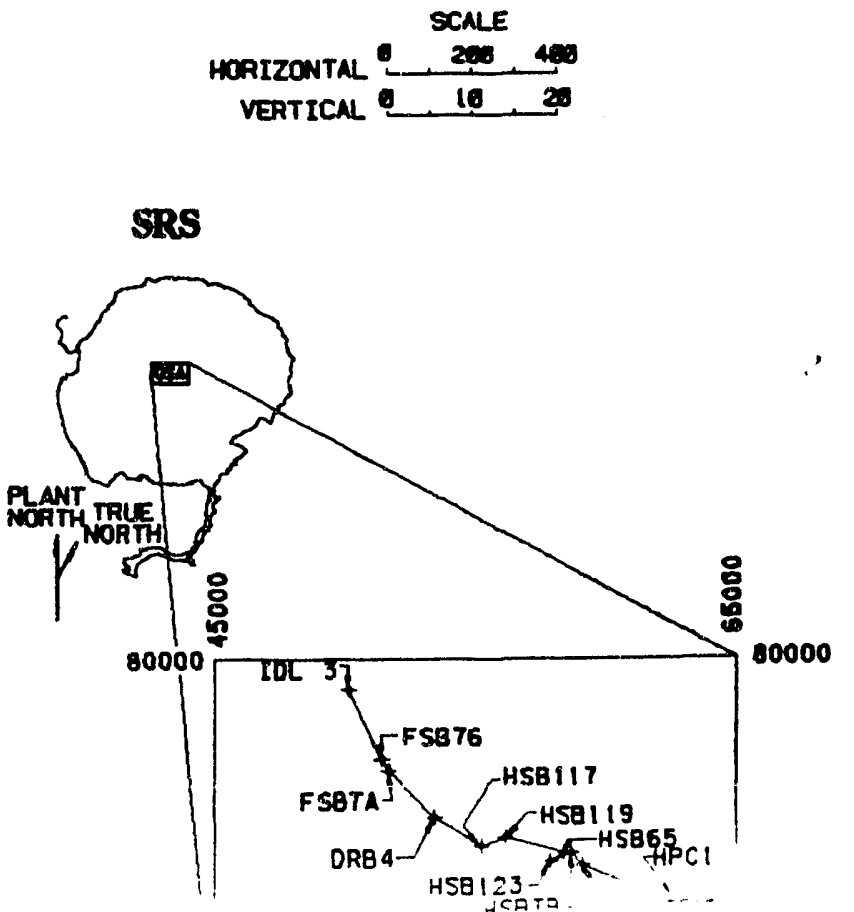


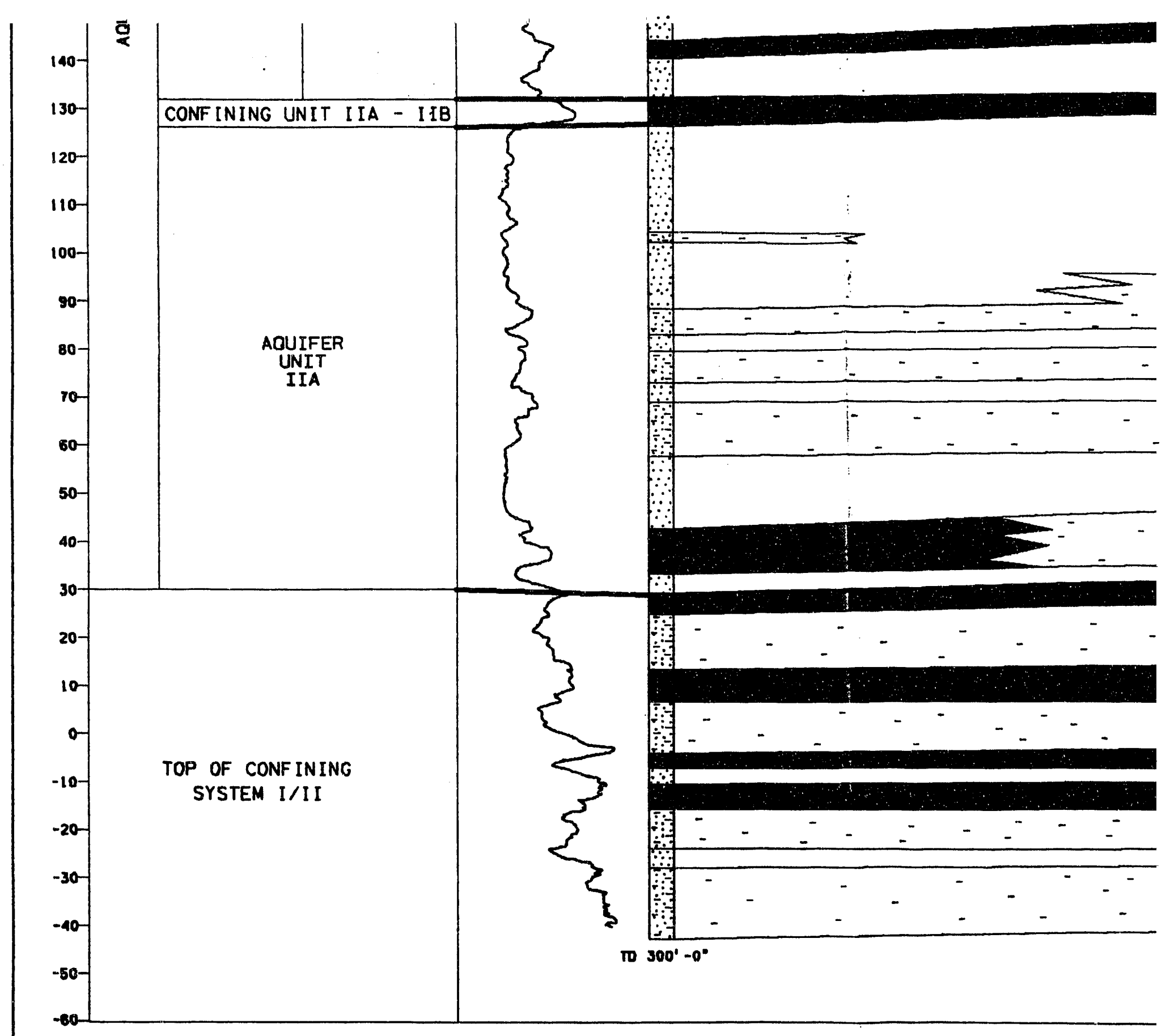




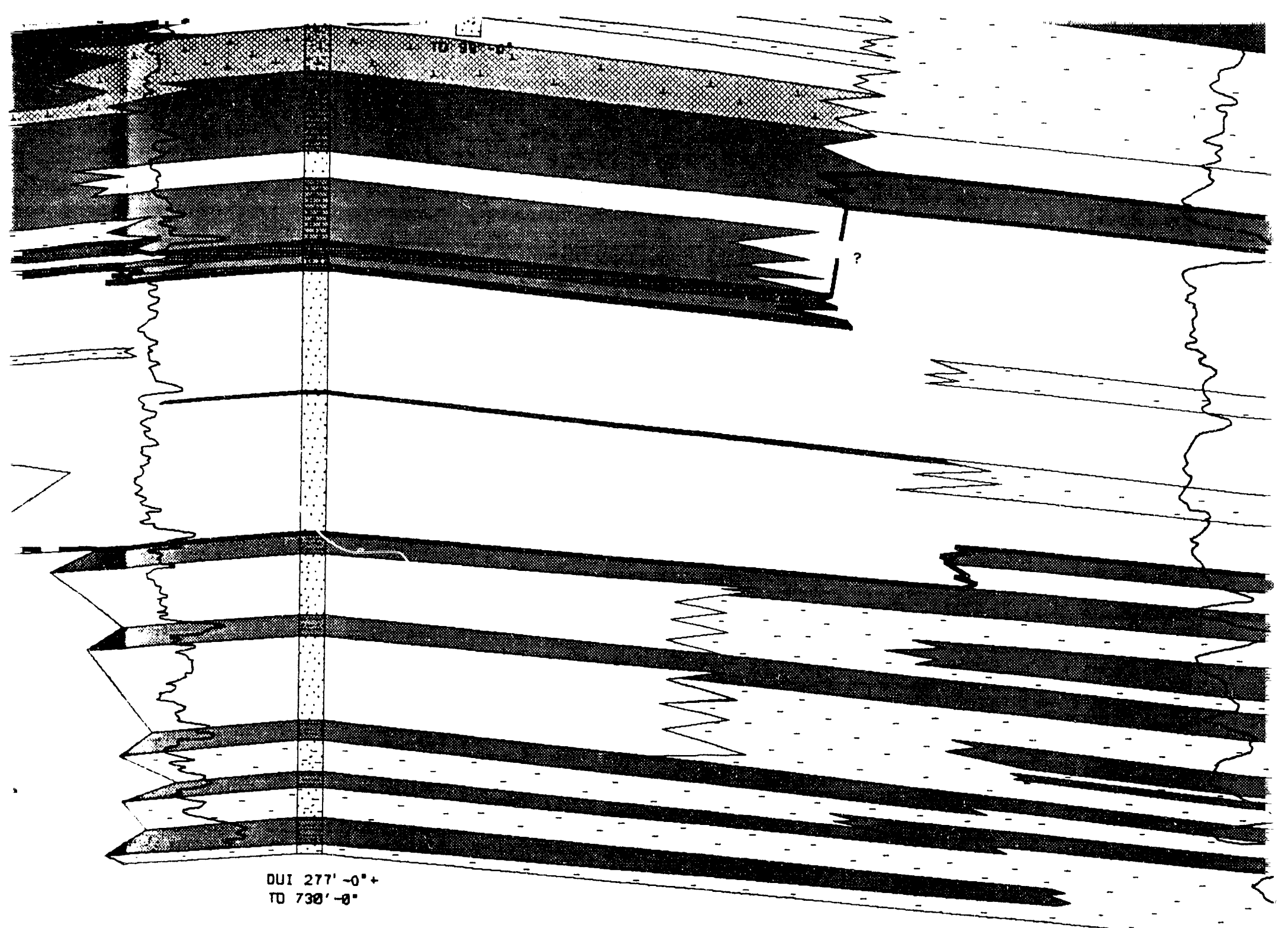




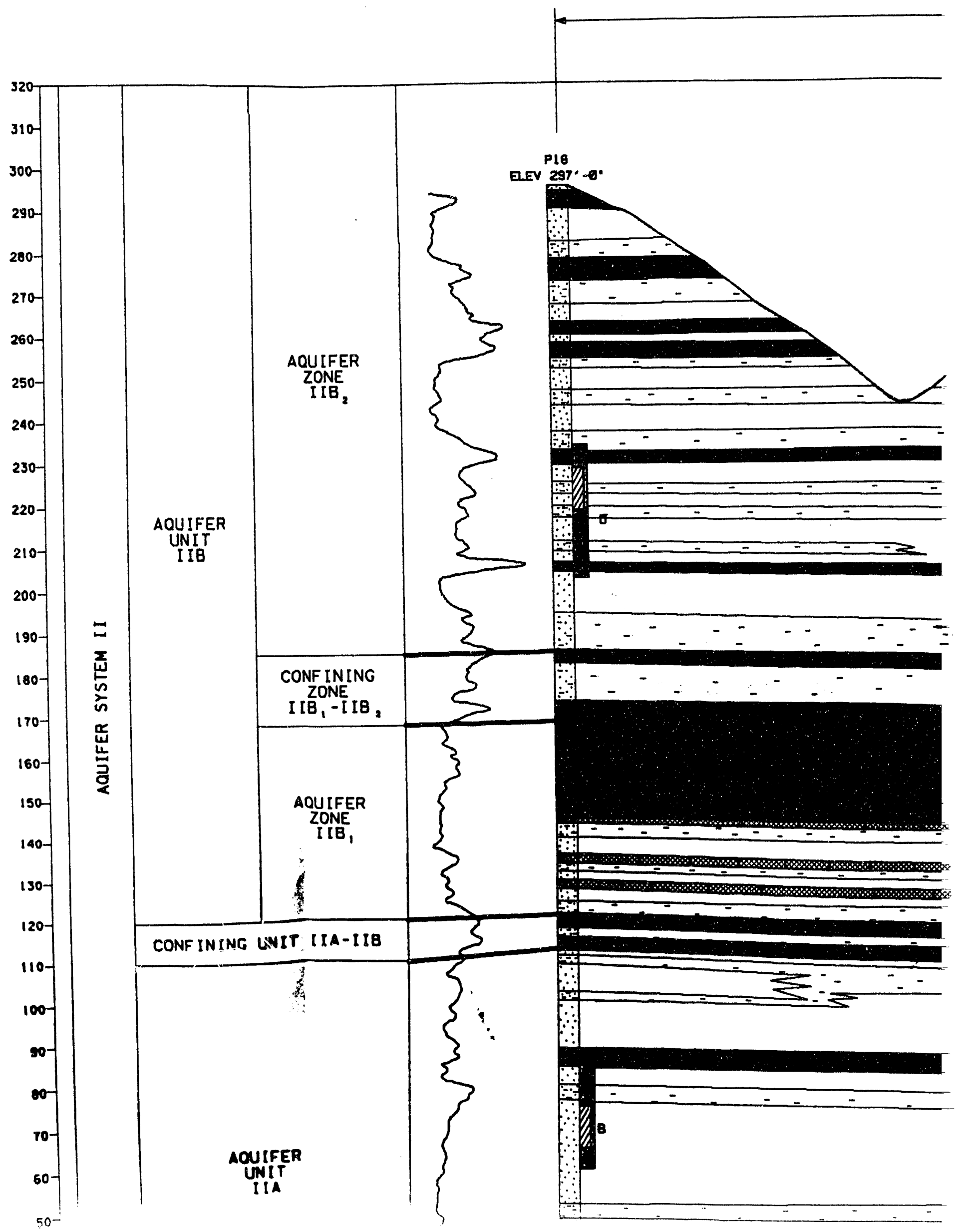




\section{GENERAL SEPARATIONS}

CI

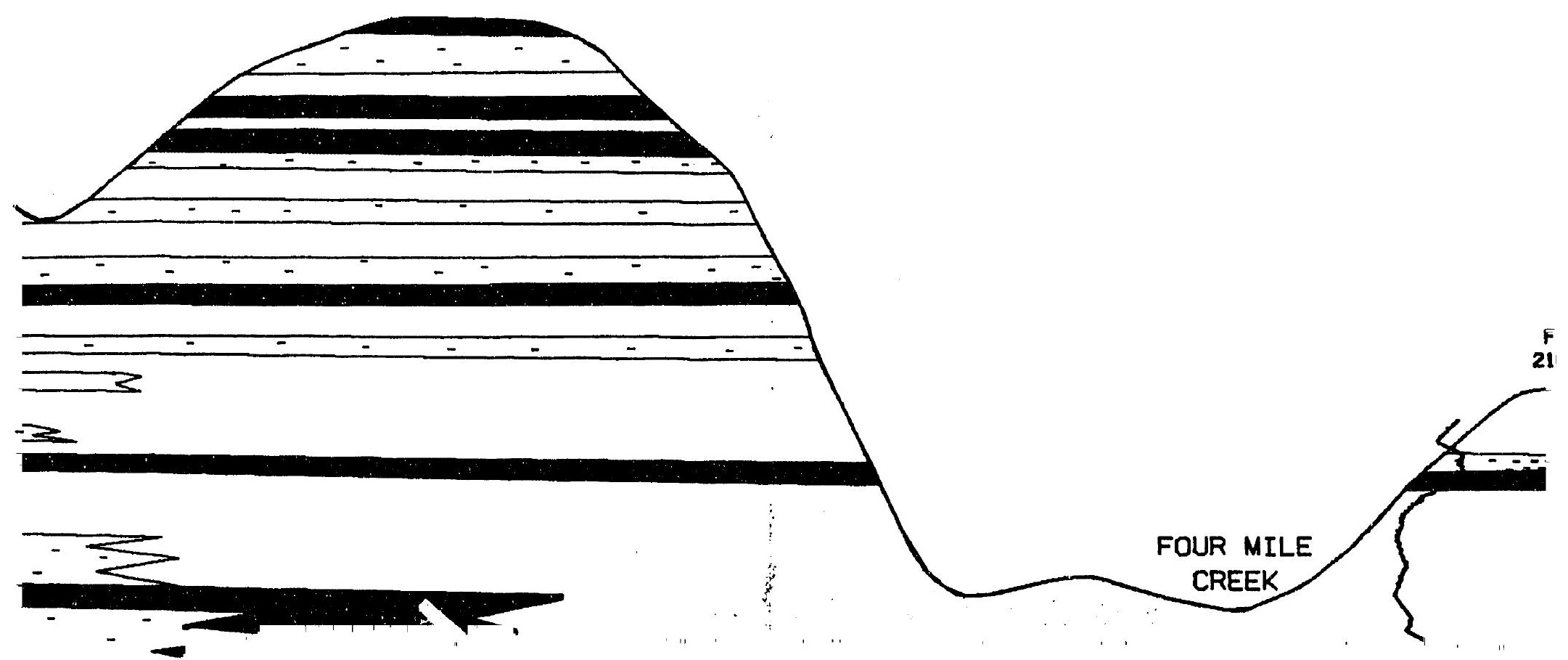




\section{IS AREA REGIONAIL HYDROSTRATIGRAPHIC}

\section{CROSS-SECTION \# 3}

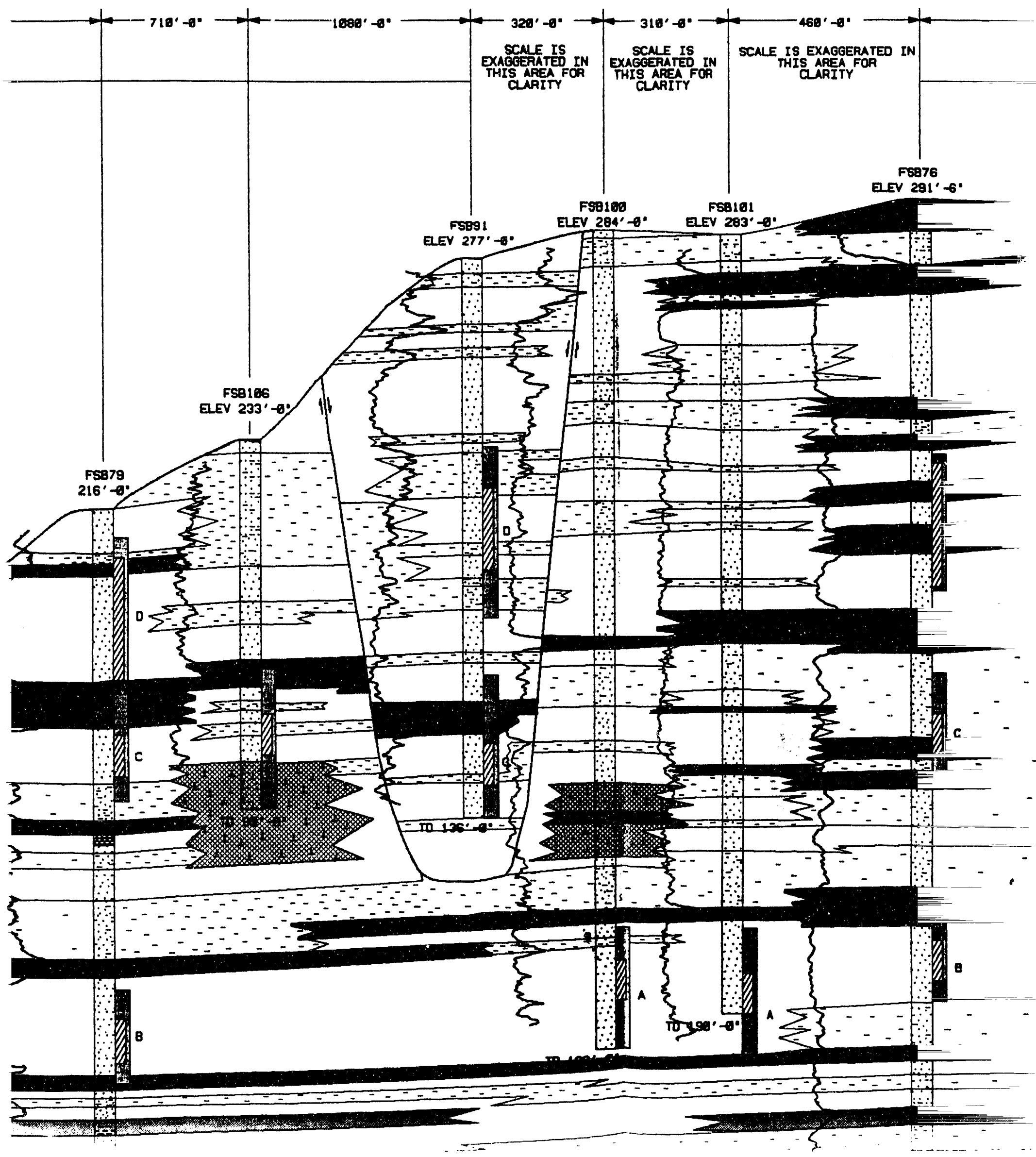



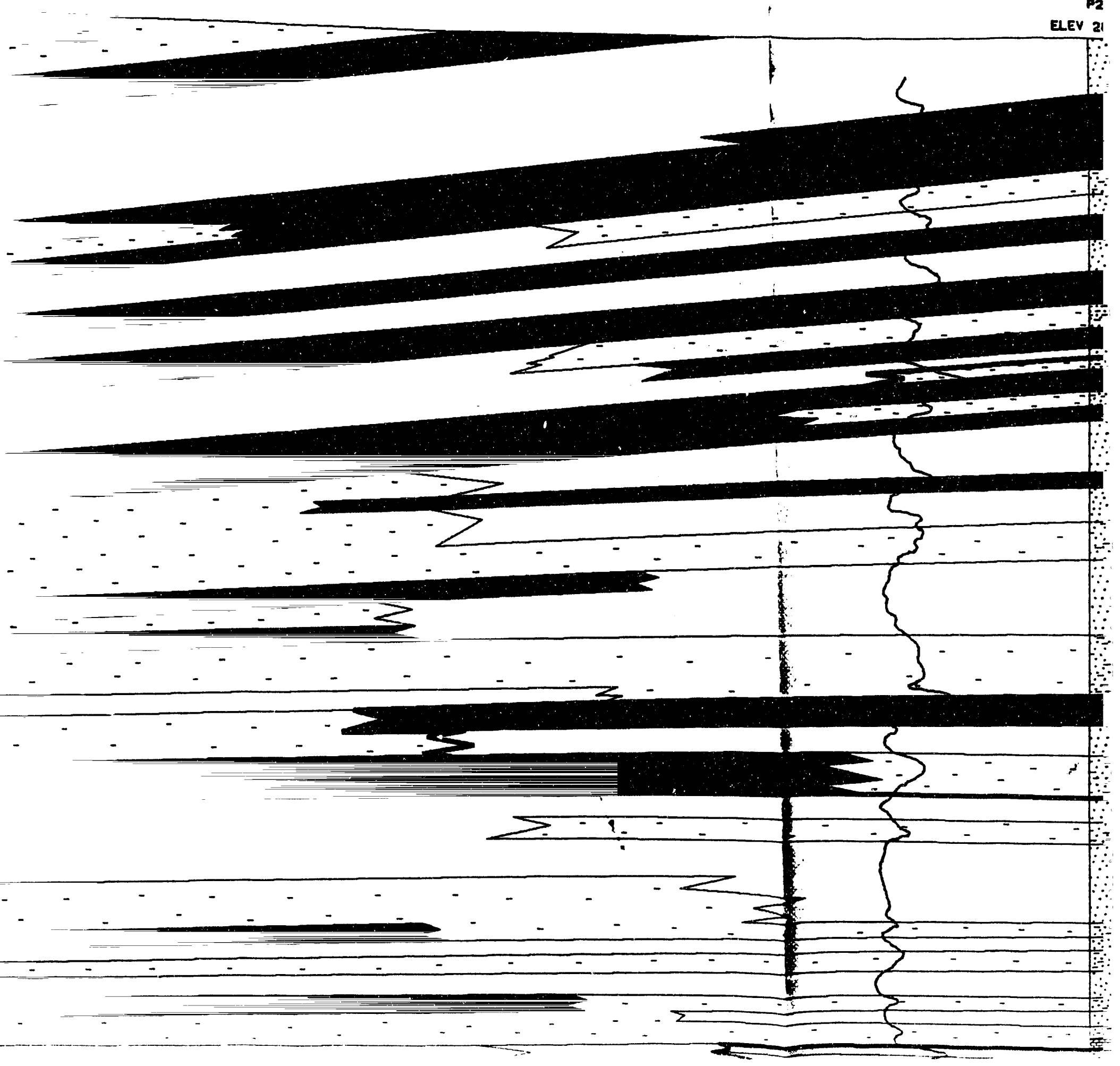


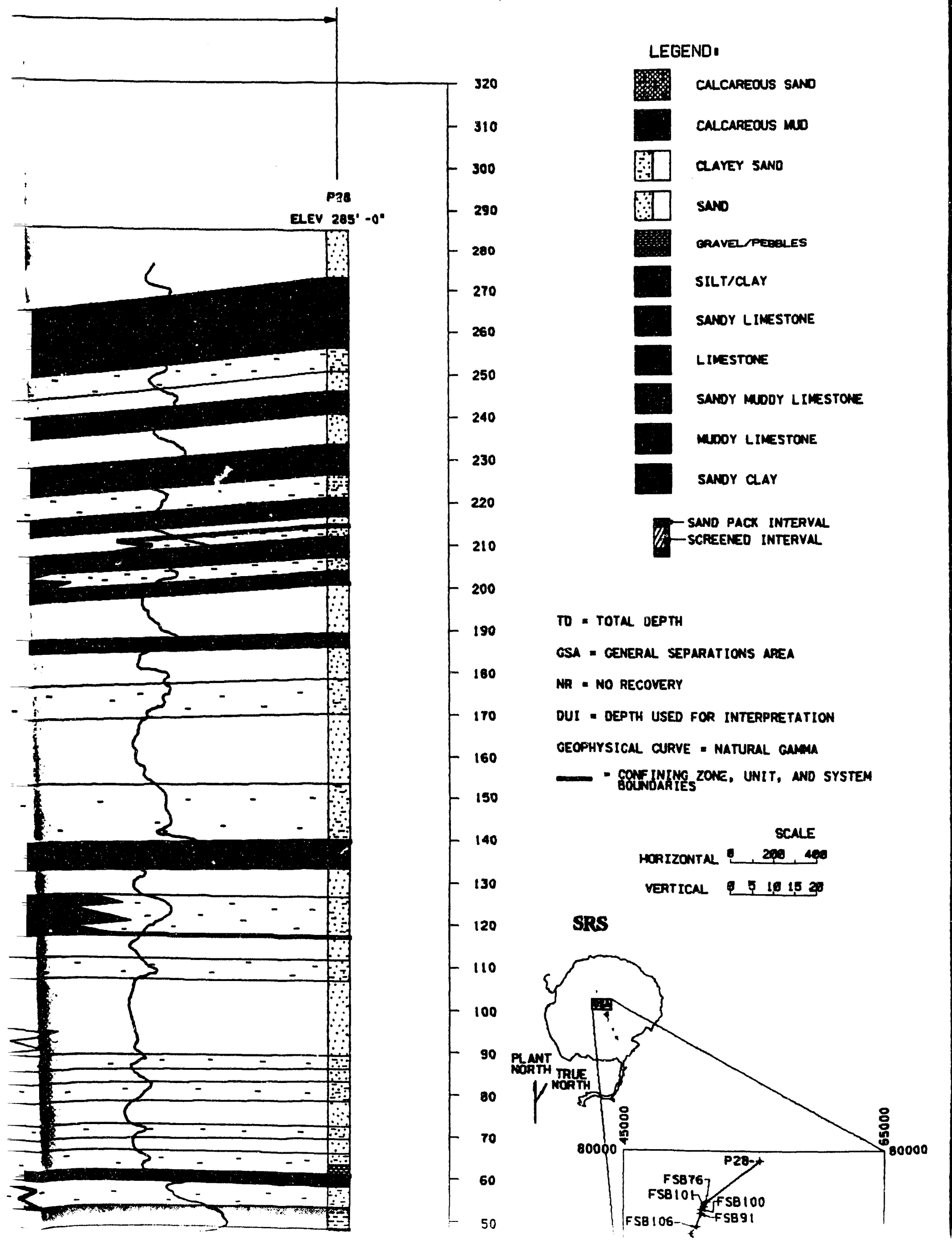




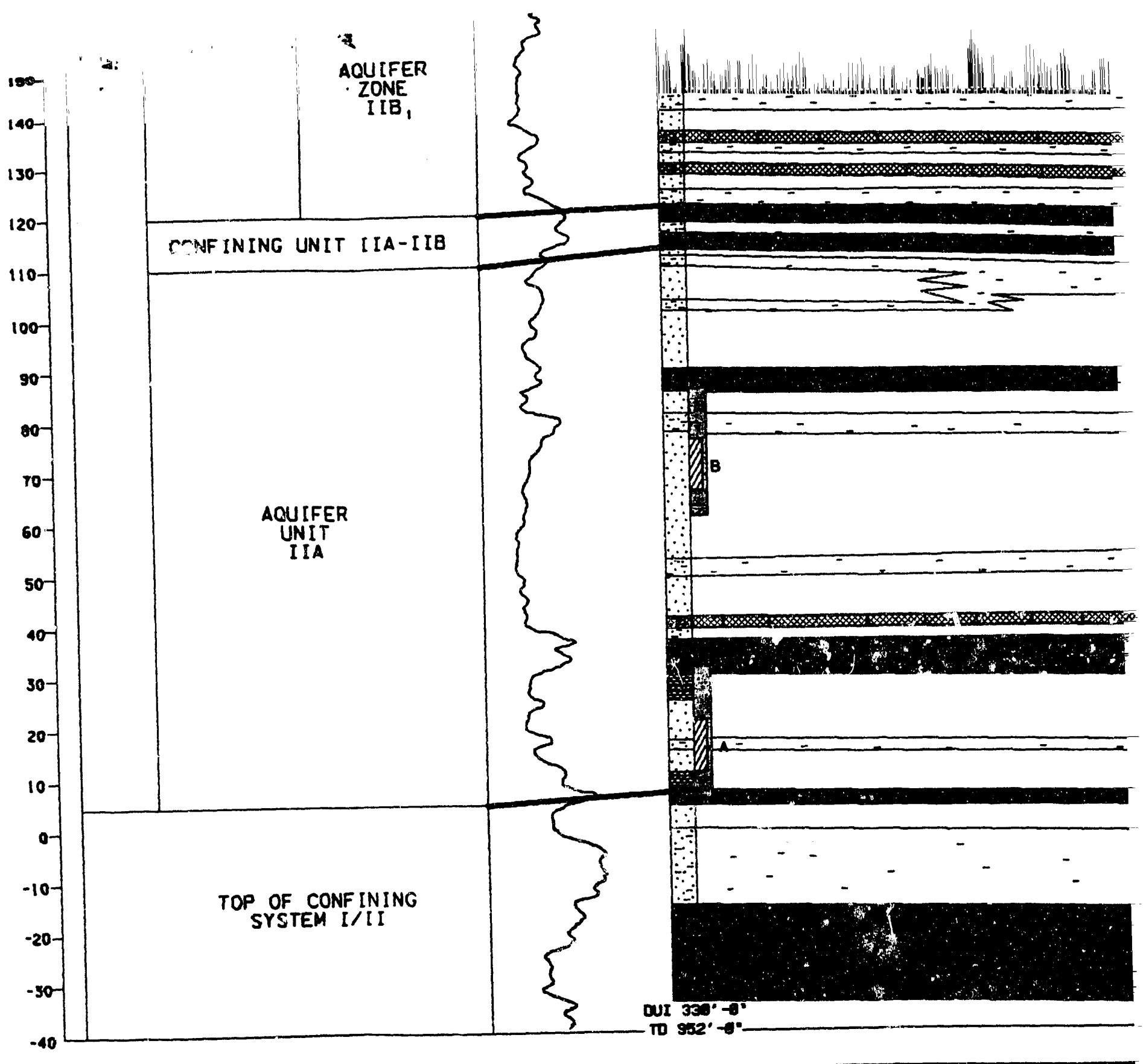




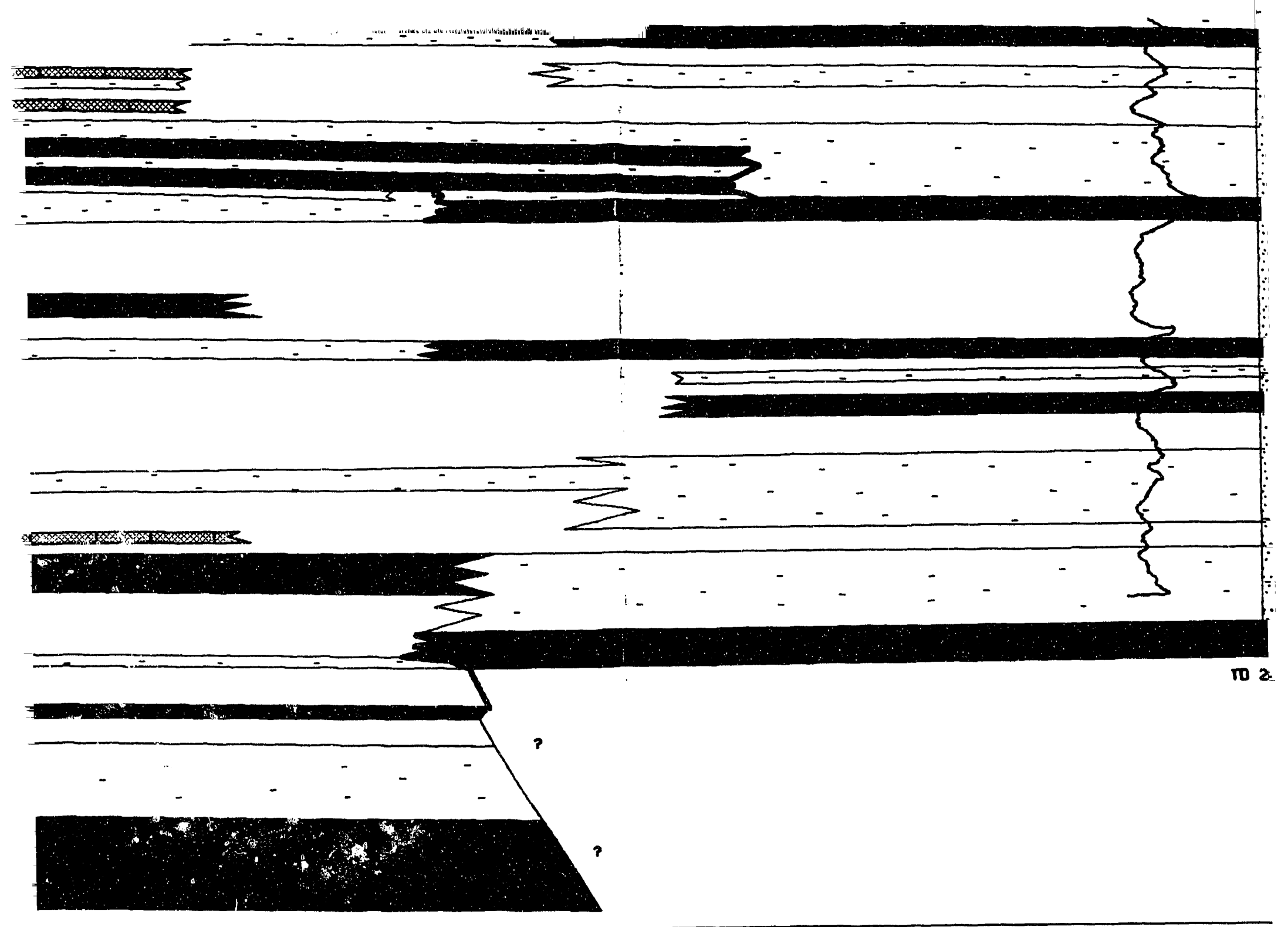




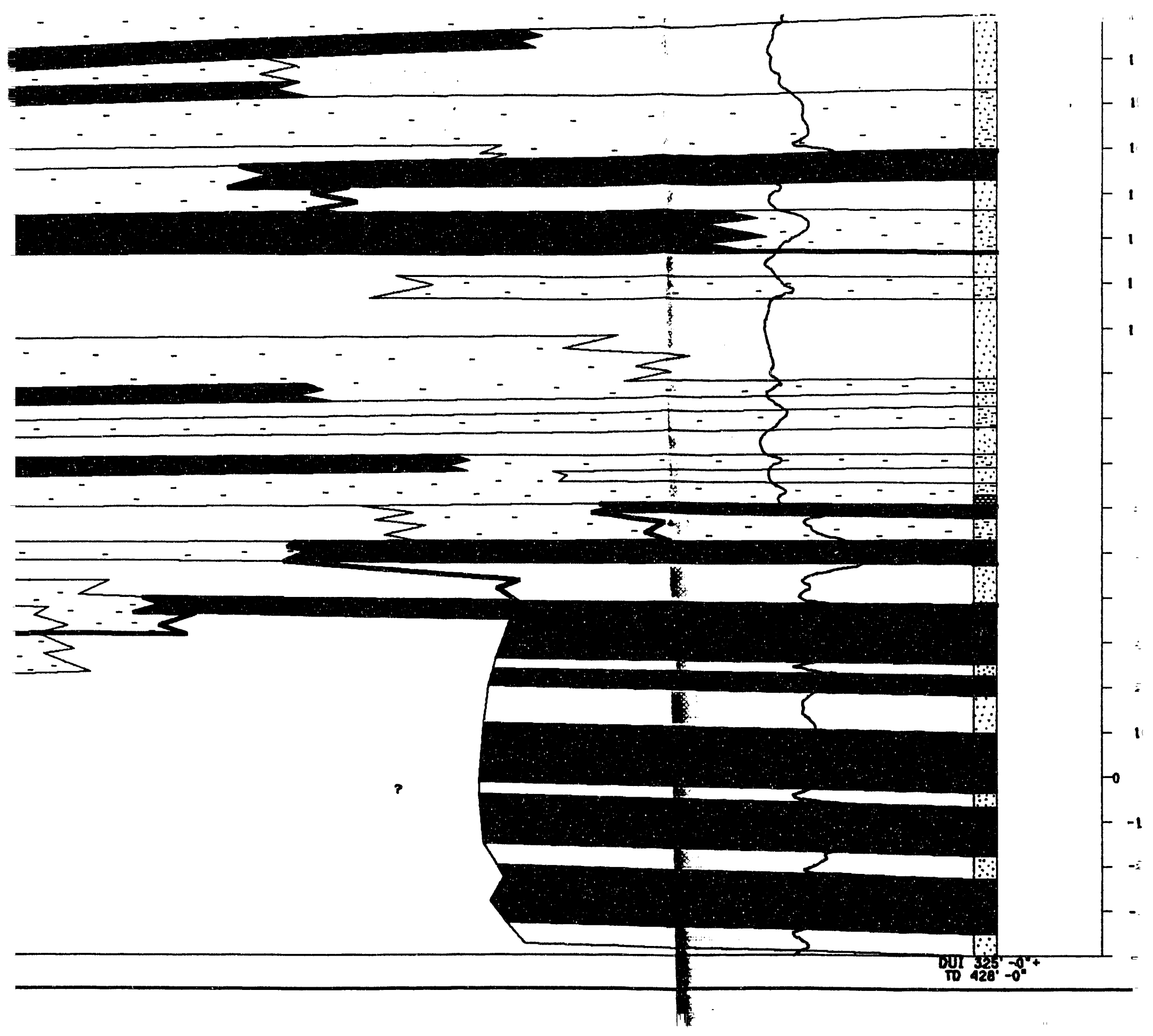




$$
\bar{e}
$$


GE

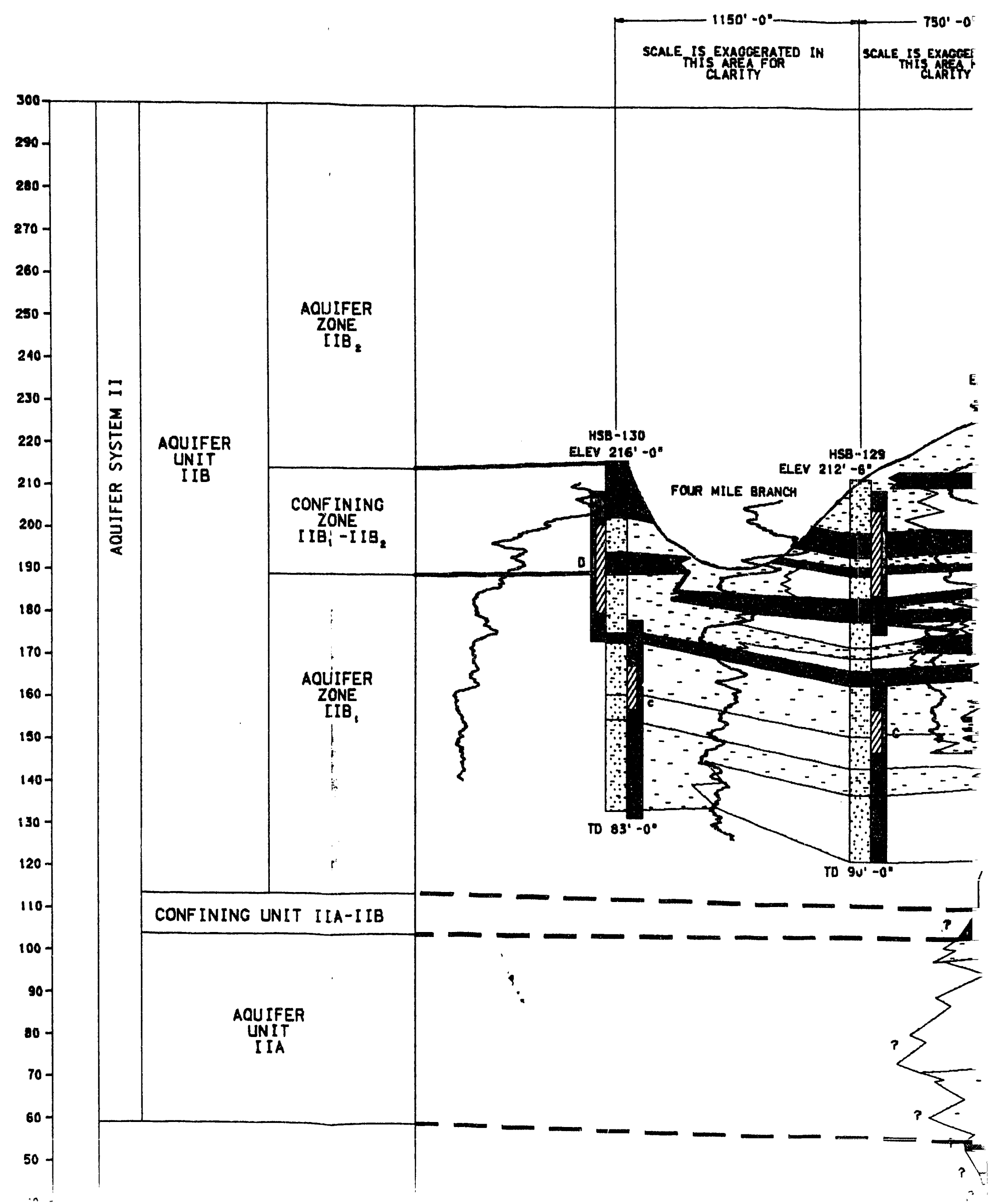




\section{GENERAL SEPARATIONS AREA REGIONAL
CROSS-SECTION \#}

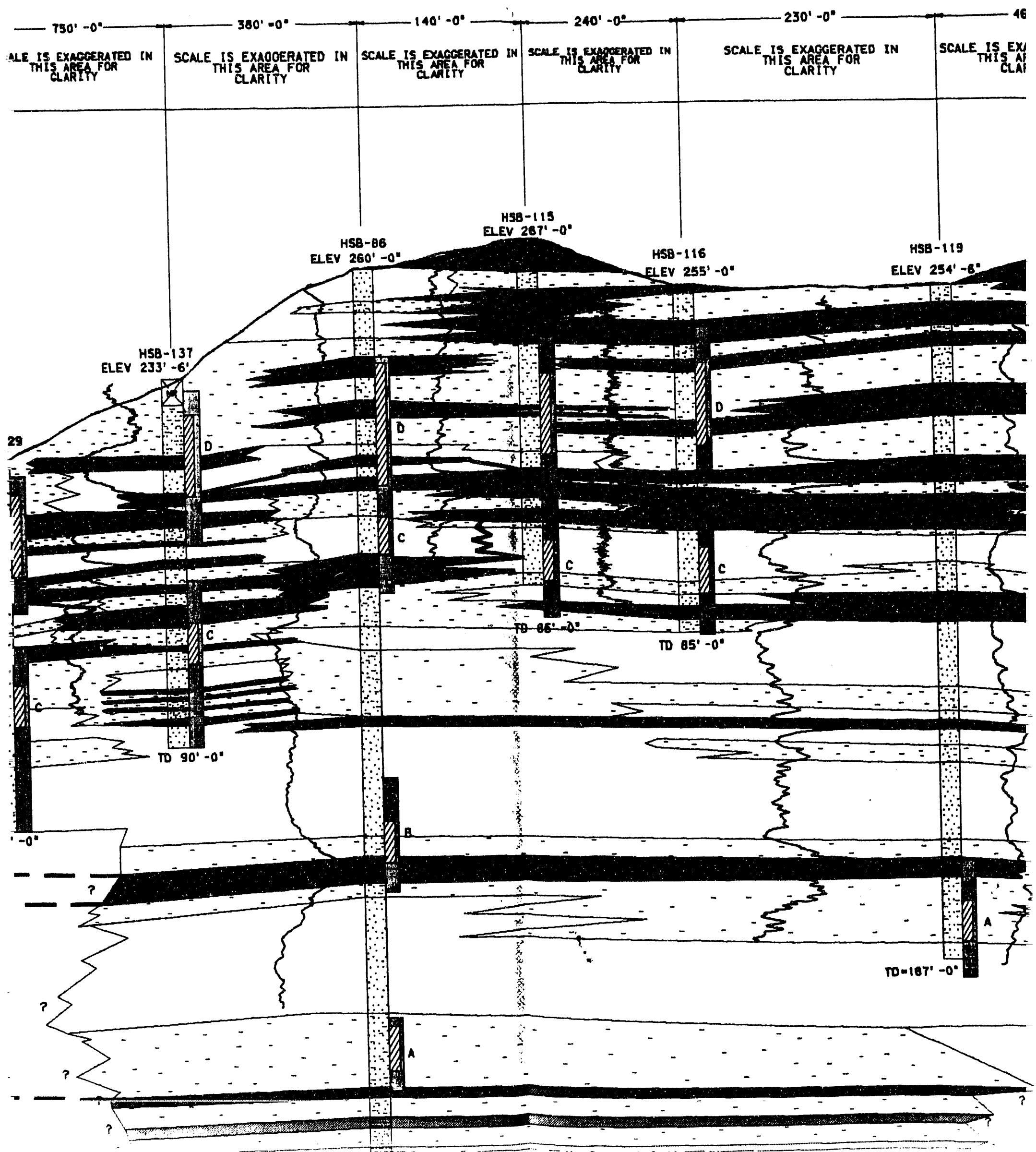




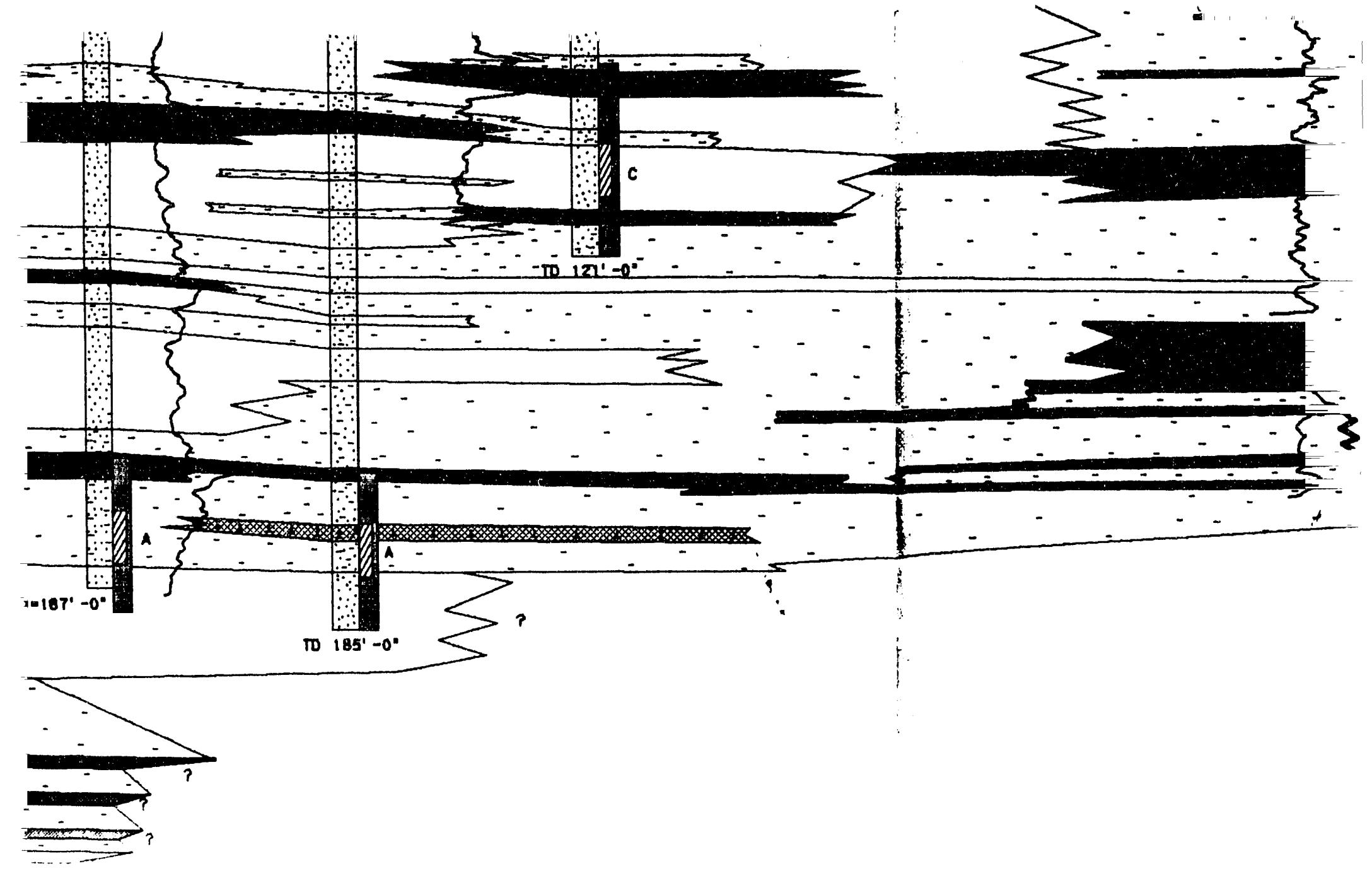



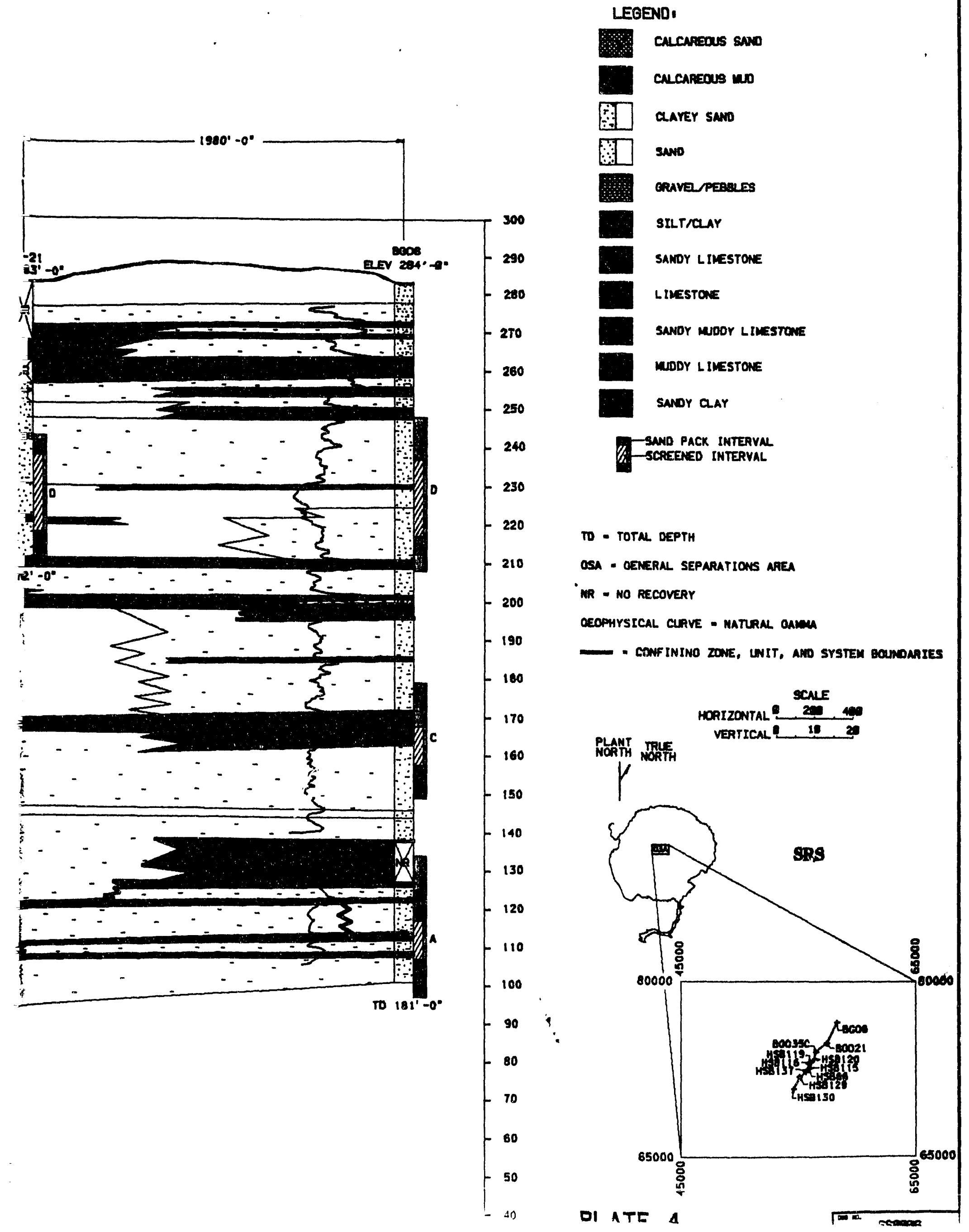


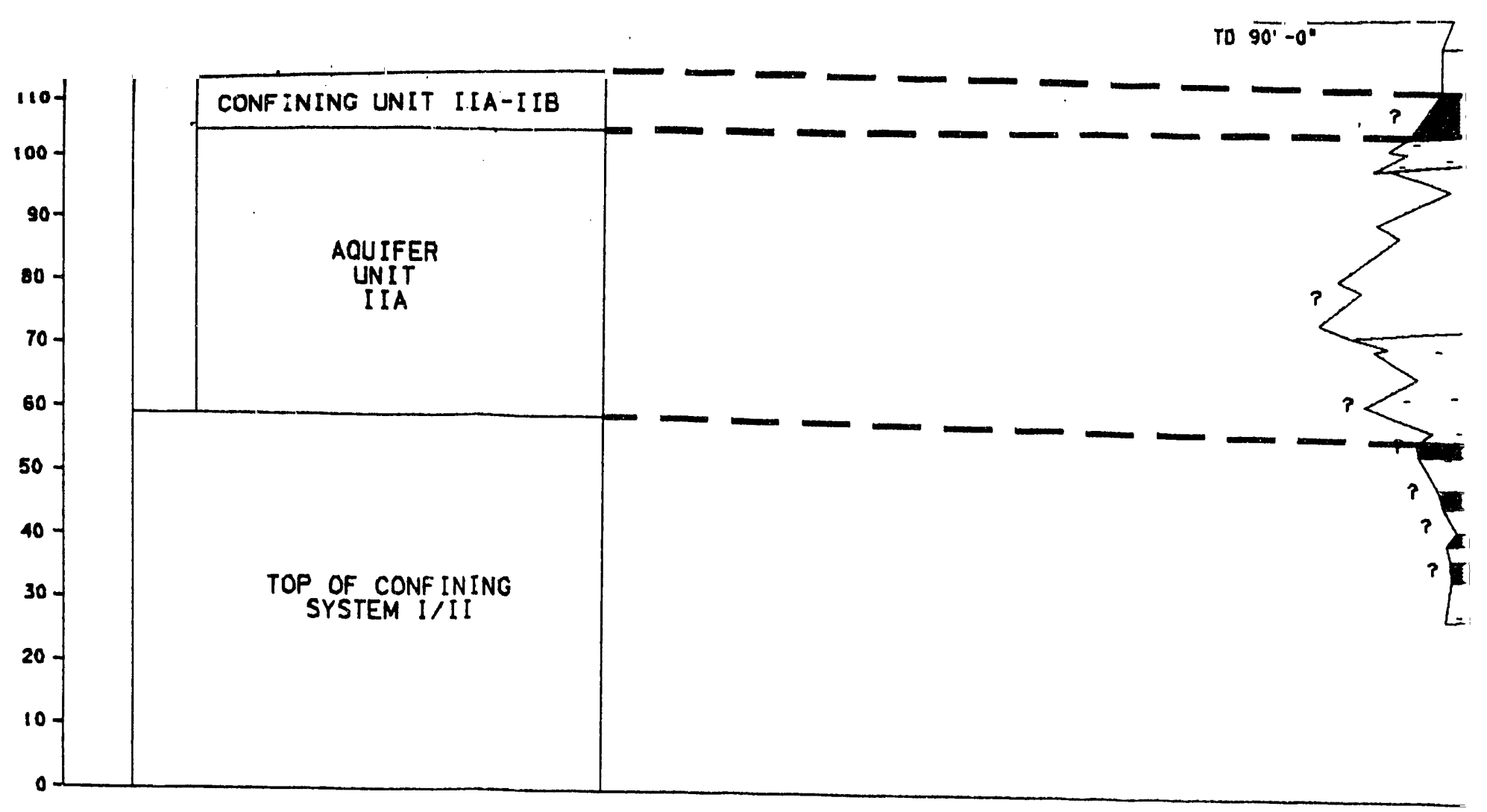




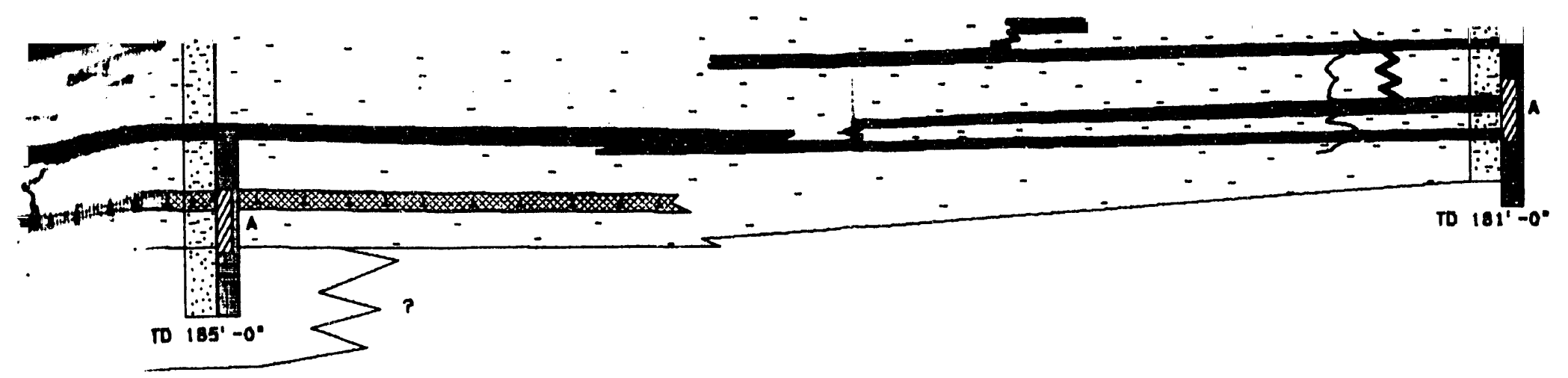



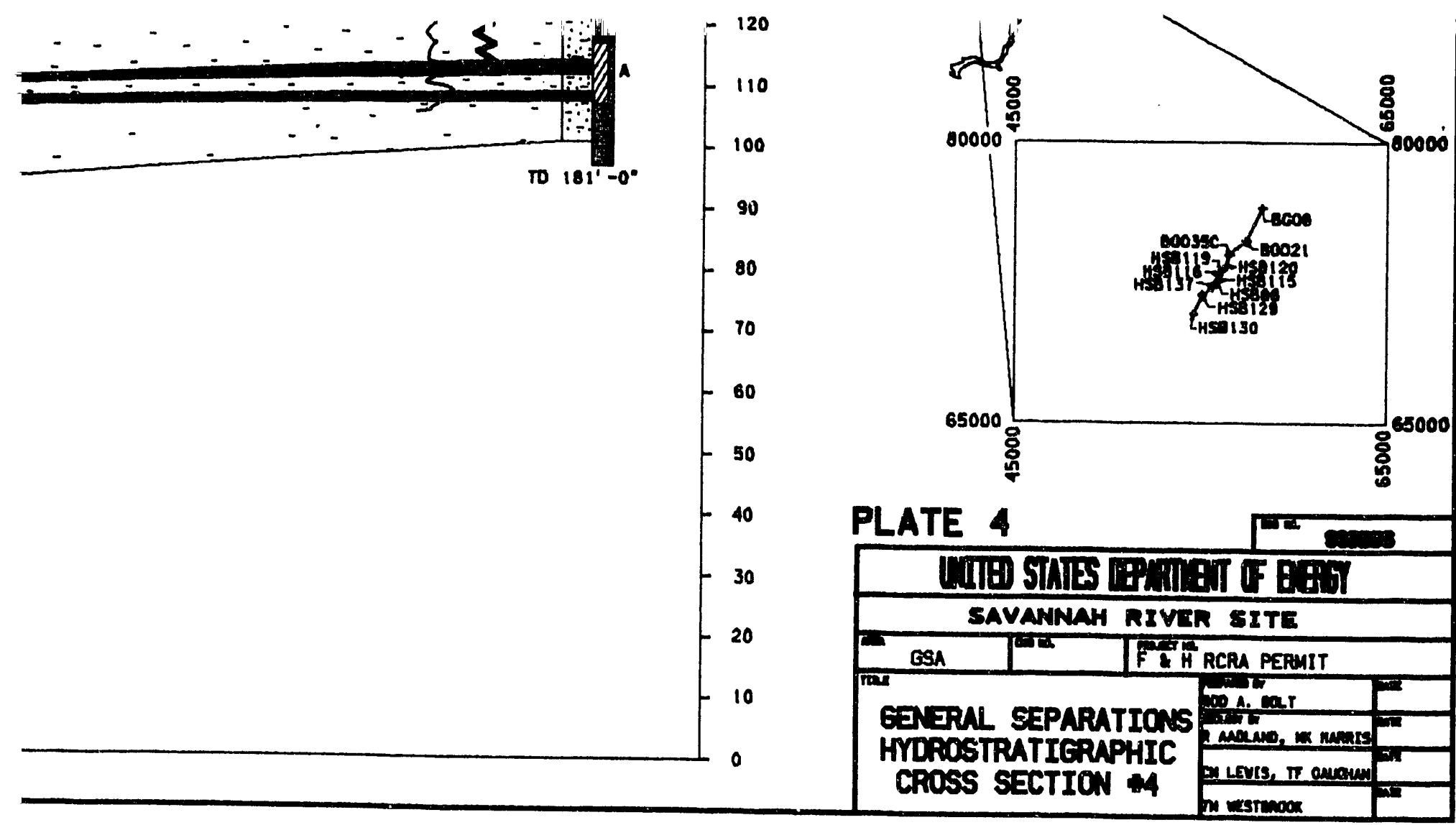


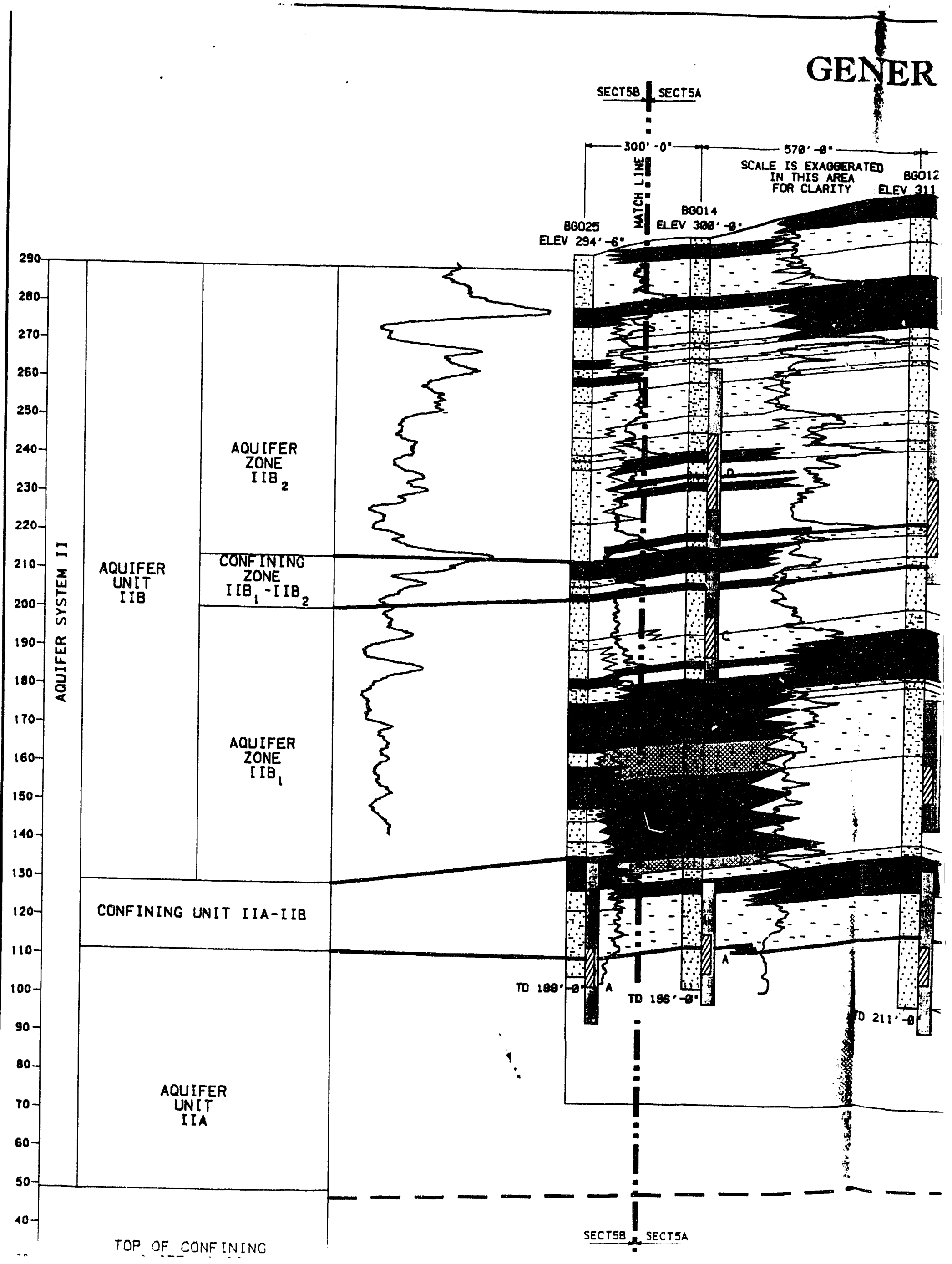




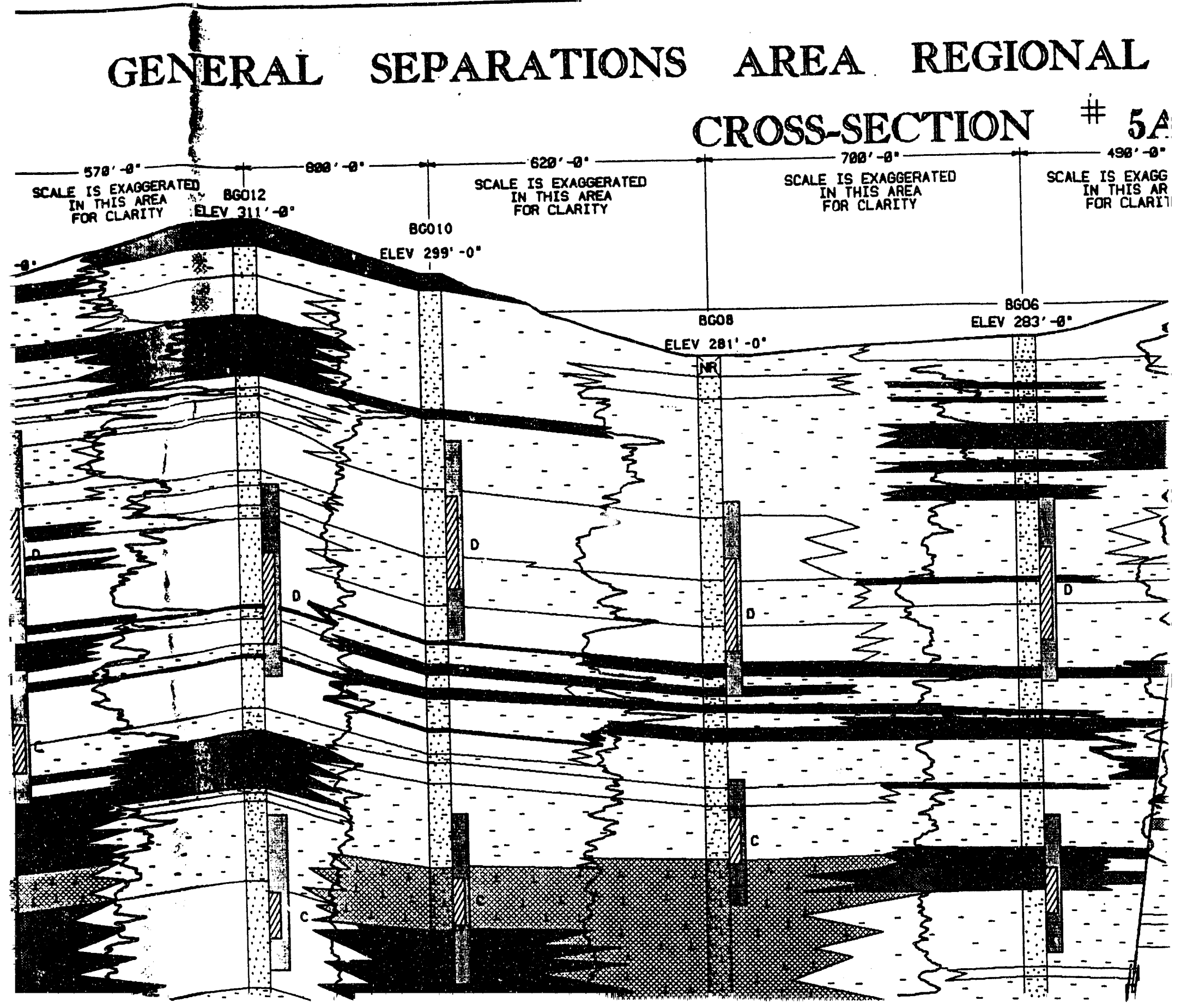




\section{DAL HYDROSTRATIGRAPHIC}

\# 5 A

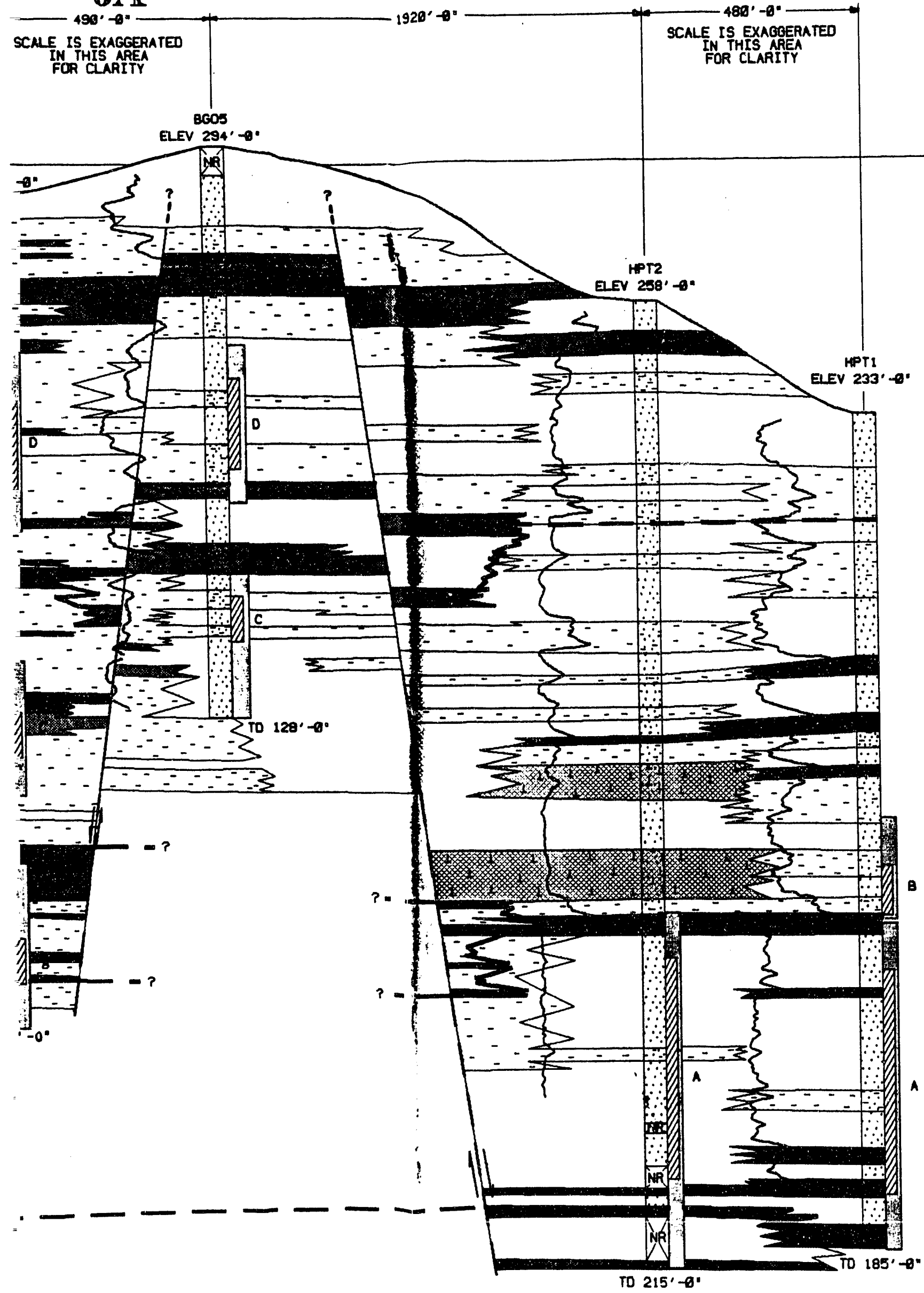




\section{RAPHIC}

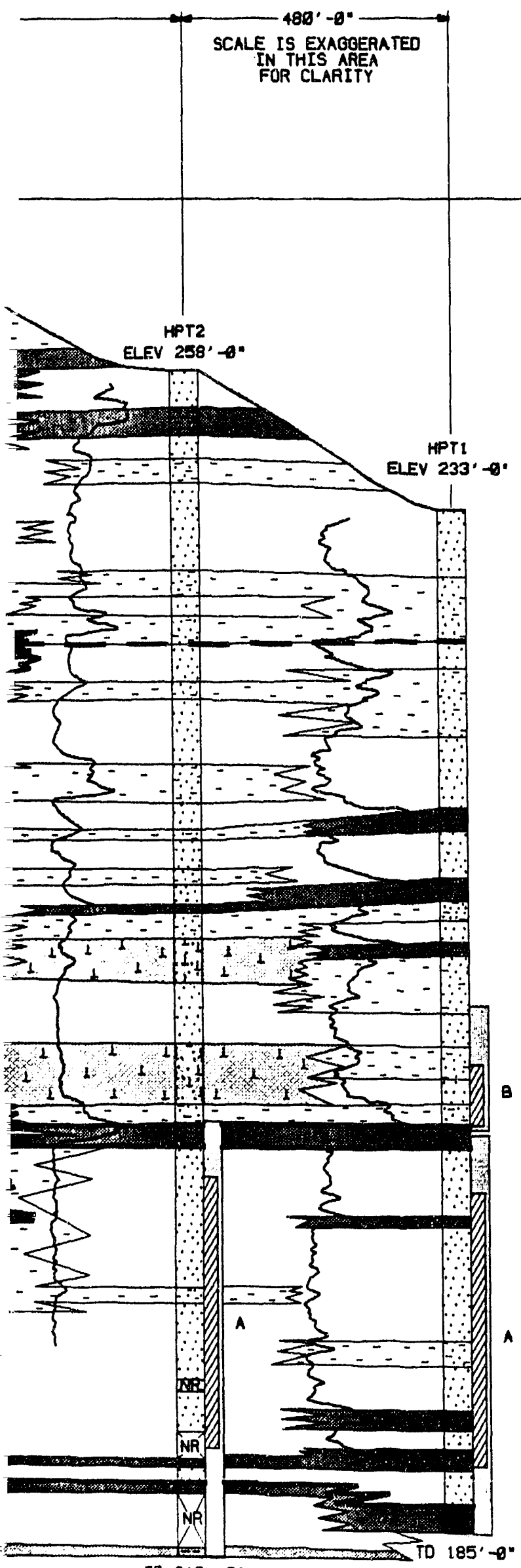

LEGEND:

YIX CALCAREOUS SAND

CALCAREOUS MUO

$\therefore$ CLAYEY SAND

290

$\because$ SAND

$-280$

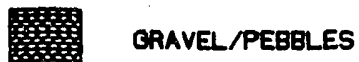

$-270^{\circ}$

SILT/CLAY

260

SANDY LIMESTONE

250

LIMESTONE

$-240$

SANOY MUDDY LIMESTONE

$-230$

$-220$

$-210$

MUDOY LIMESTONE

SANDY CLAY

TI SAND PACK INTERVAL

- SCREENEO INTERVAL

$-200$

TD = TOTAL DEPTH

GSA = GENERAL SEPARATLONS AREA

$-190$

NR - NO RECOVERY

- CONF INING ZONE, LNIT, AND SYSTEM BUUUUNDRARIES. GEOPHYSICAL CURVE - NATURAL GAMMA DUI = DEPTH USED FOR INTERPRETATION

HORIZONTAL 2 SCALE

$-160$

VERTICAL 5101520

\section{$-150$}

$-140$

$-130$

$-130$

$-120$

$-110$

$-100$

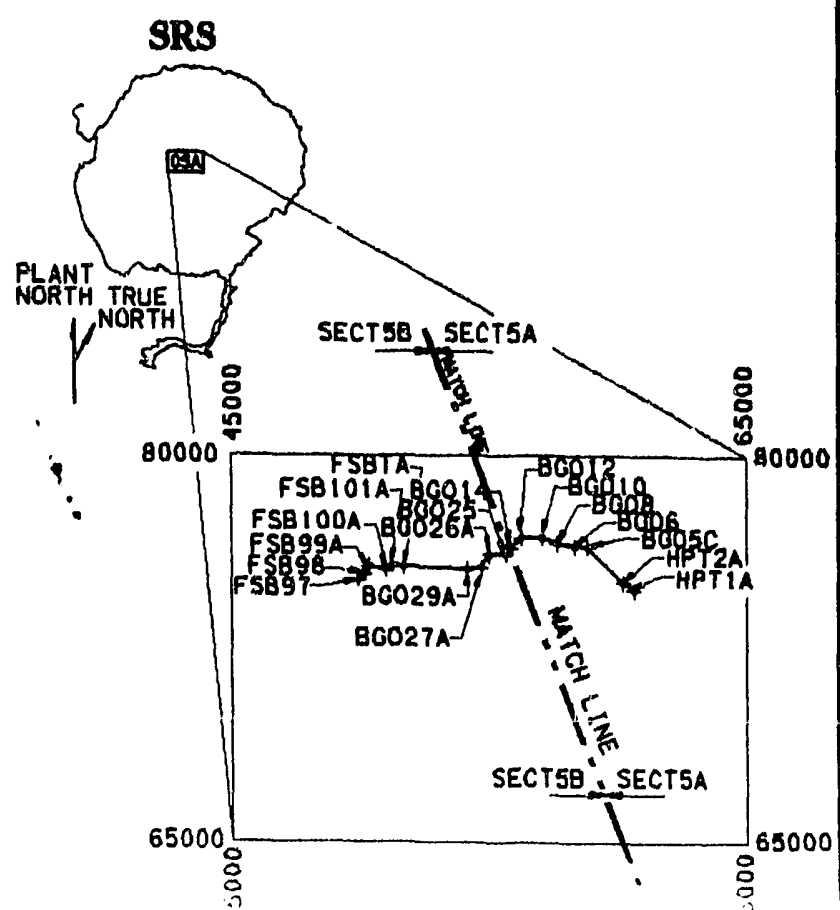




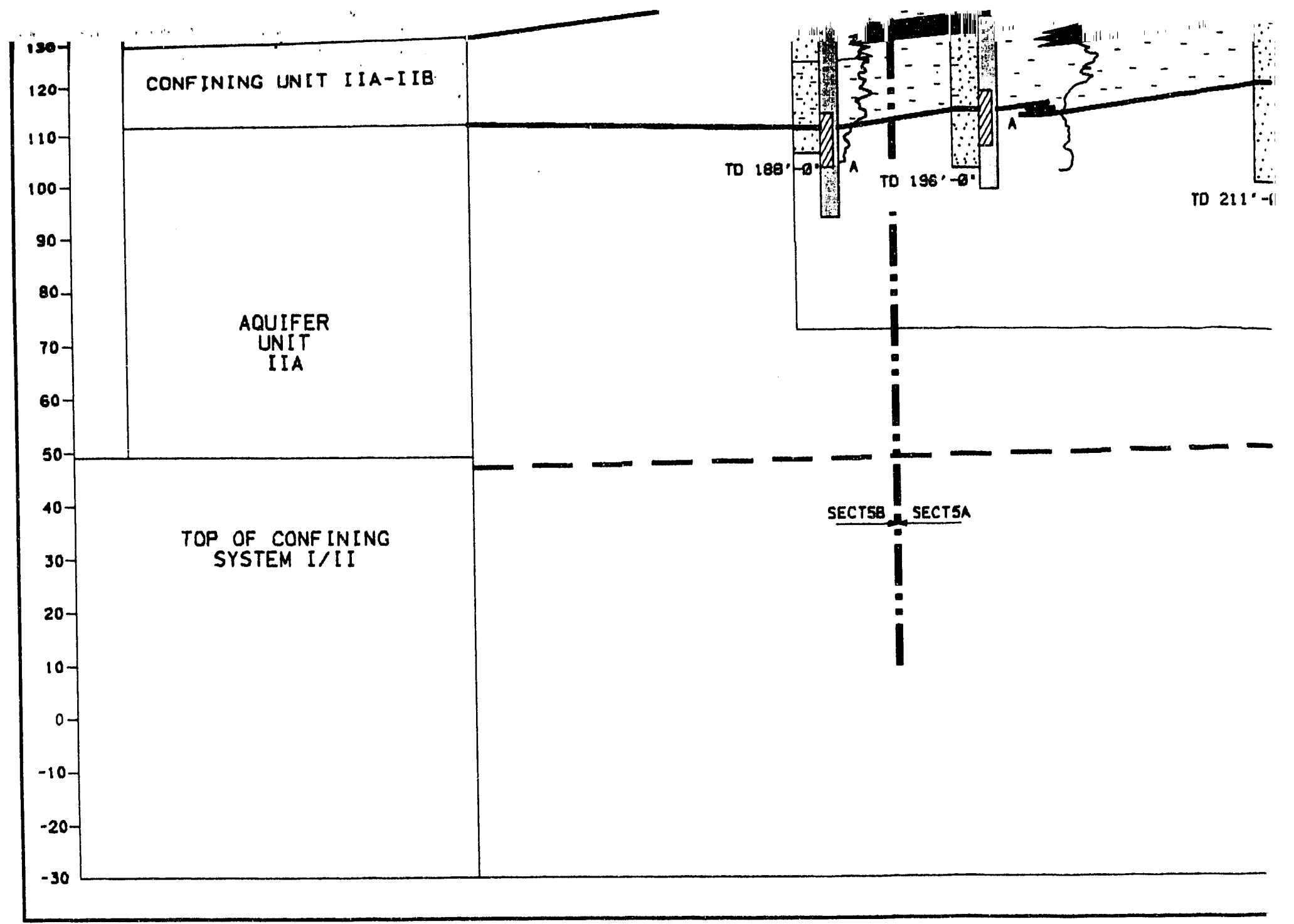




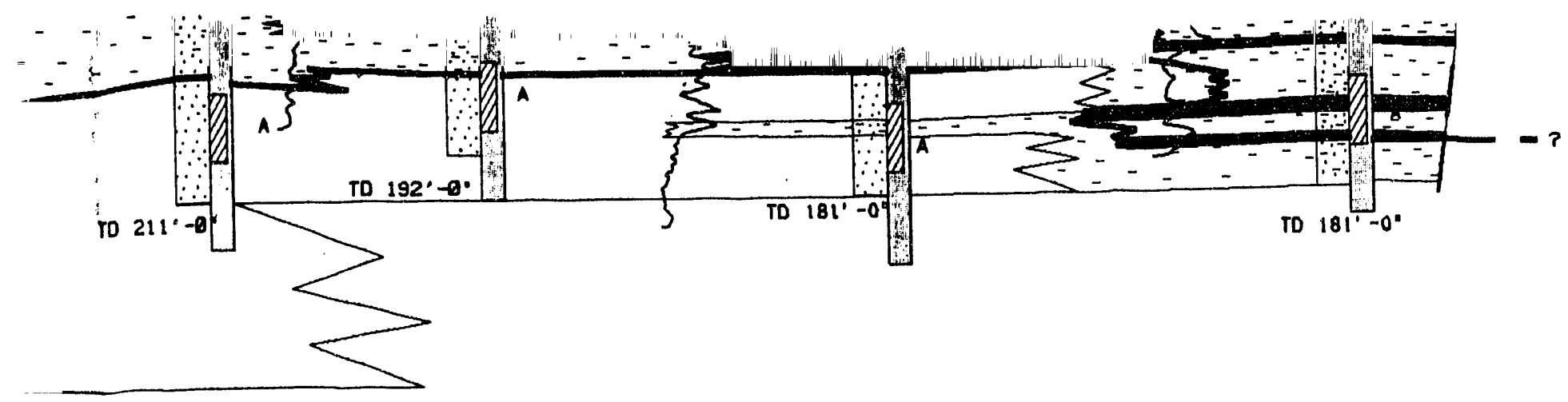



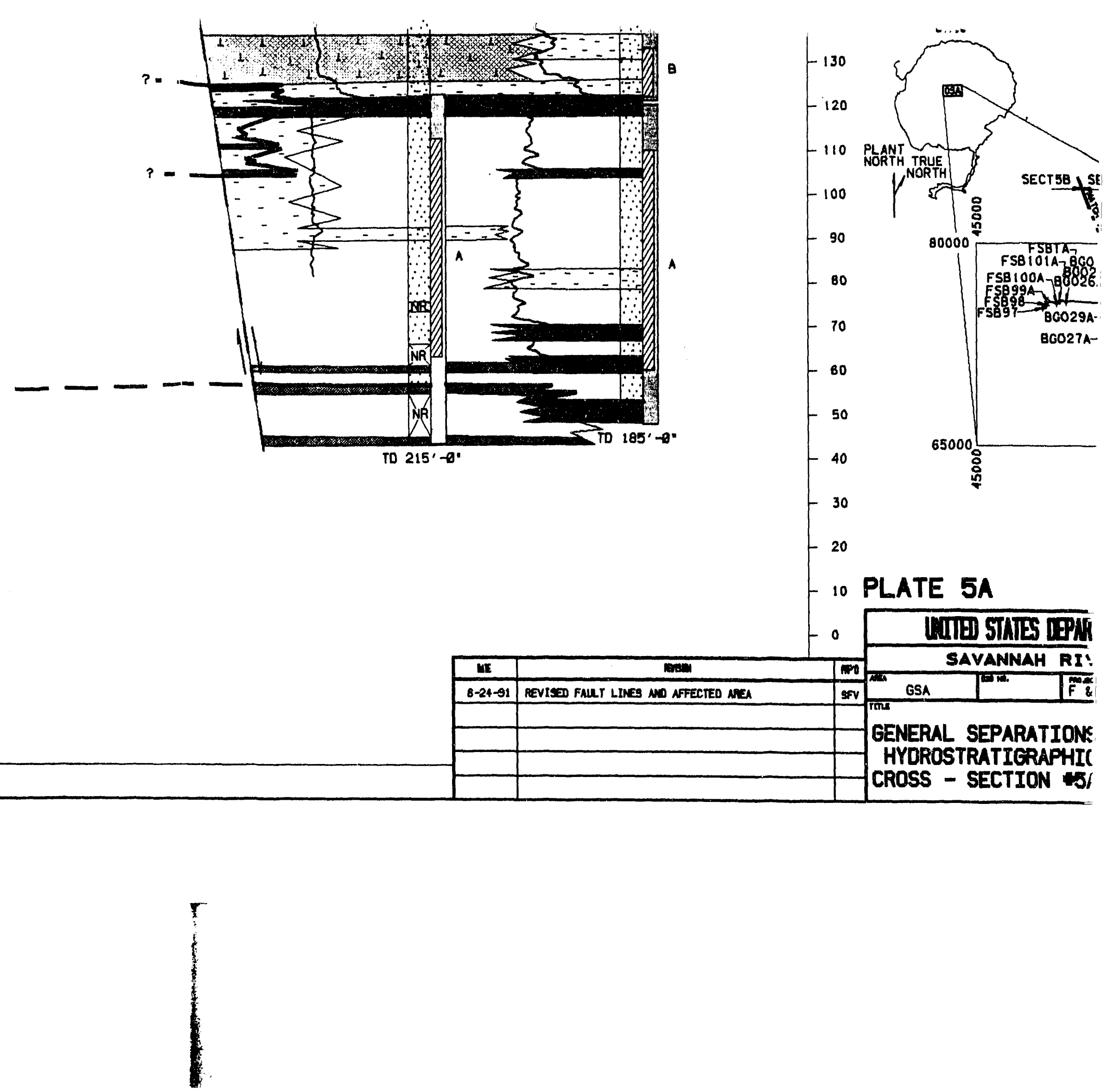


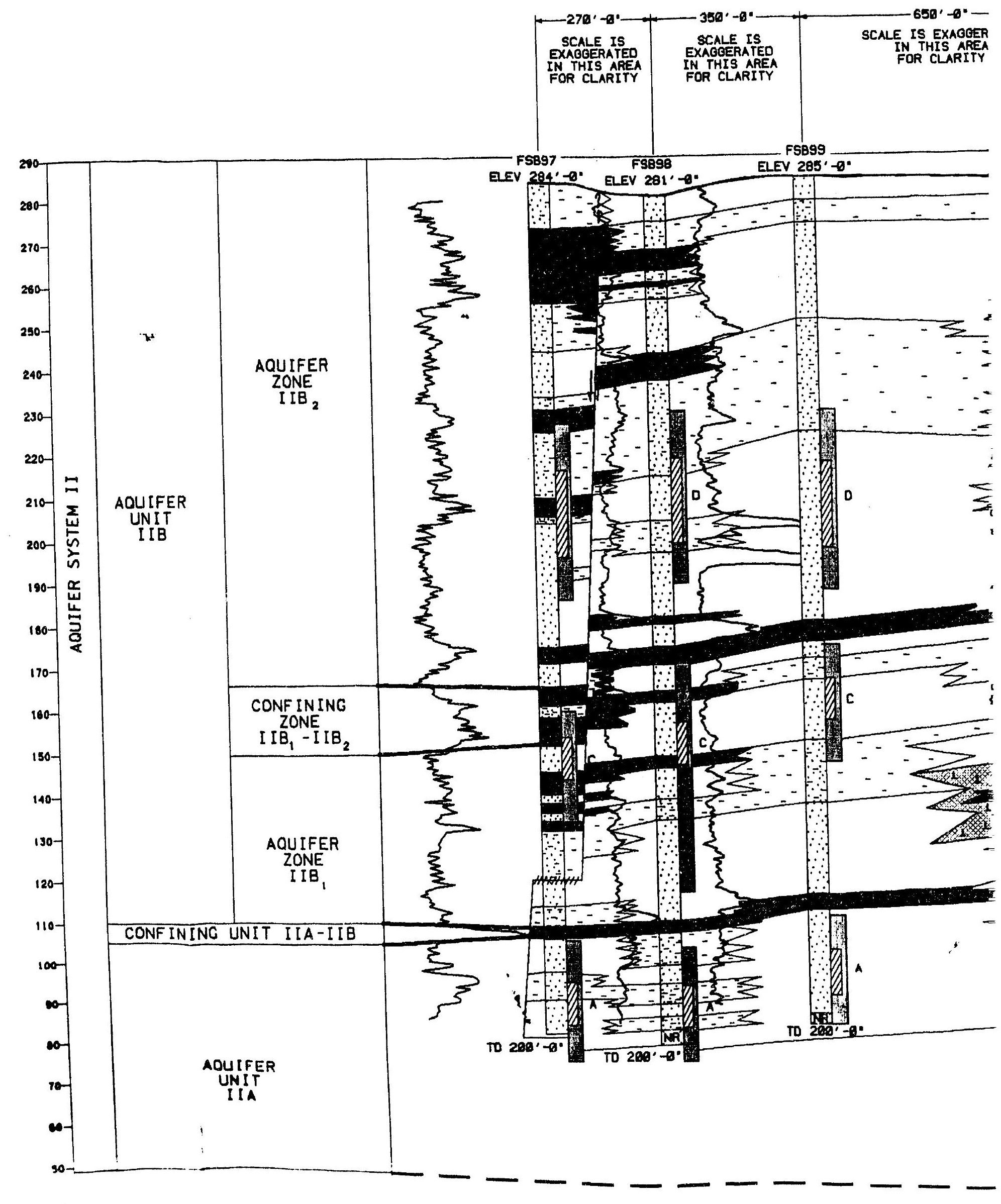




\section{ROSTRA TIGRAPHIC}
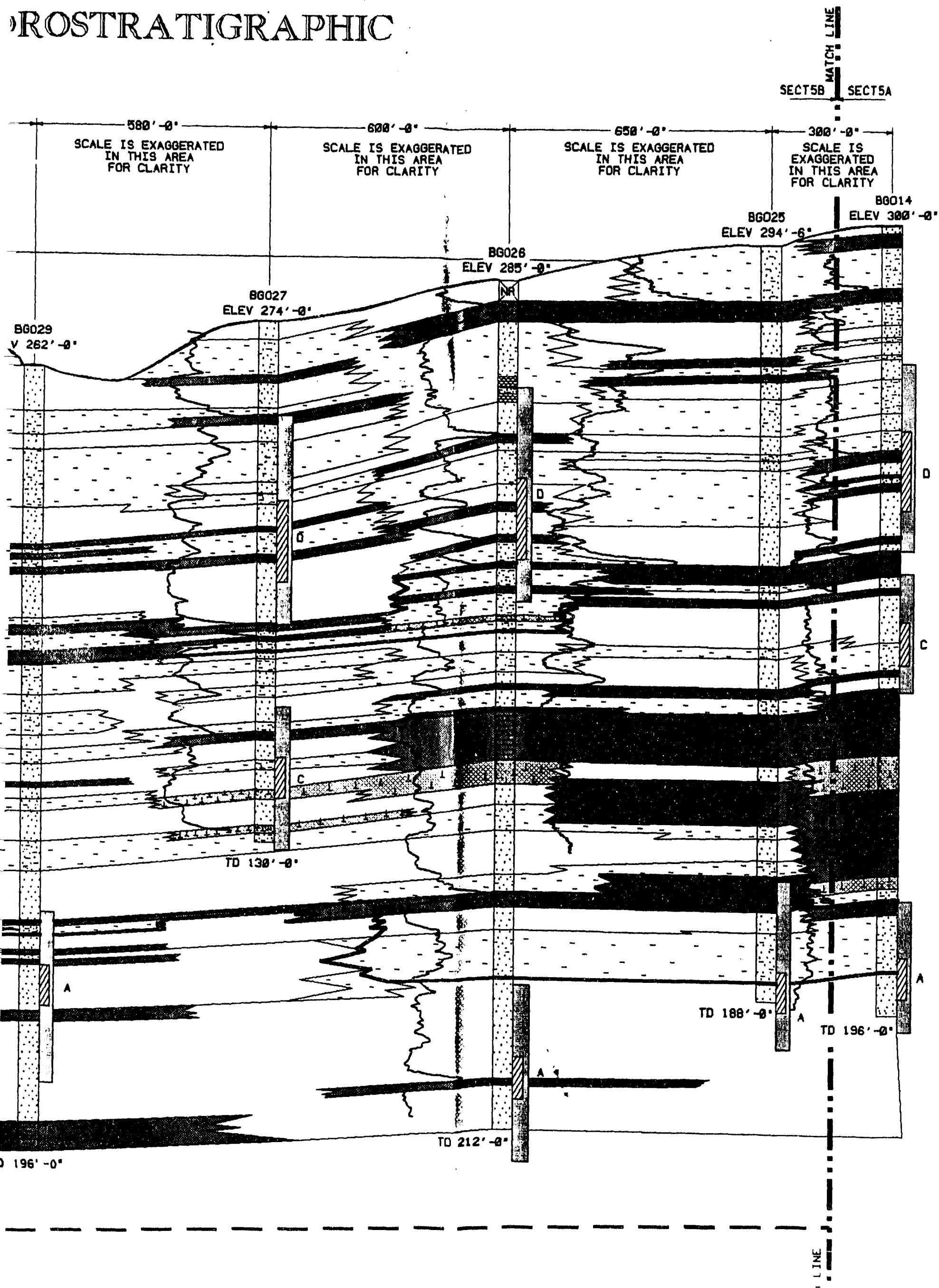


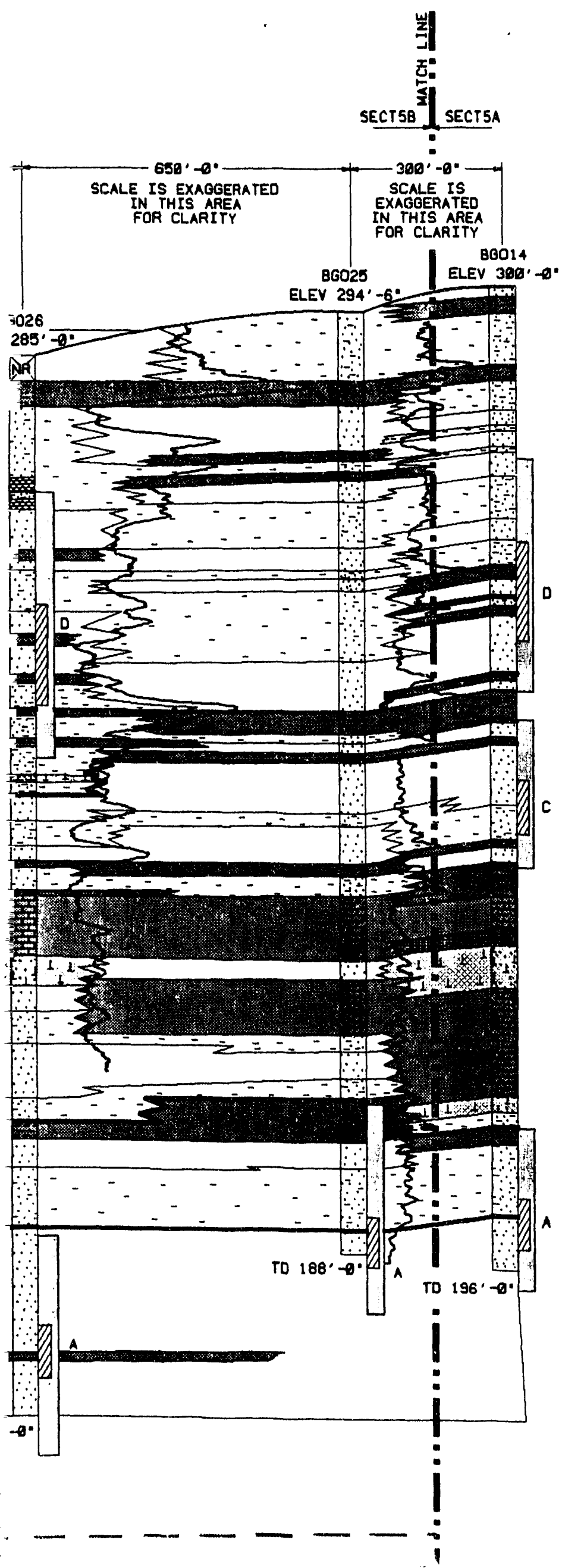

\section{LEGEND:}

CALCAREOUS SAND
CALCAREOUS MUD
$\square$ CLAYEY SAND
$\square$ SAND

GRAVEL/PEBBLES

-

SILT/CLAY

SANOY LIMESTONE

LIMESTONE

SANOY MUDY LIMESTONE

M MUDOY LIMESTONE

SANDY CLAY

TAND PACK INTERVAL SCREENED INTERVAL

TO - TOTAL DEPTH

oSA - general separations area

NR - NO AECOVERY

- CONFININO ZONE, LNIT, AND SYSTEM GOUNDRARIES.

GEOPHYSICAL CURVE - NaTURAL GAMMA

DUI = DEPTH USED FOR INTERPRETATION
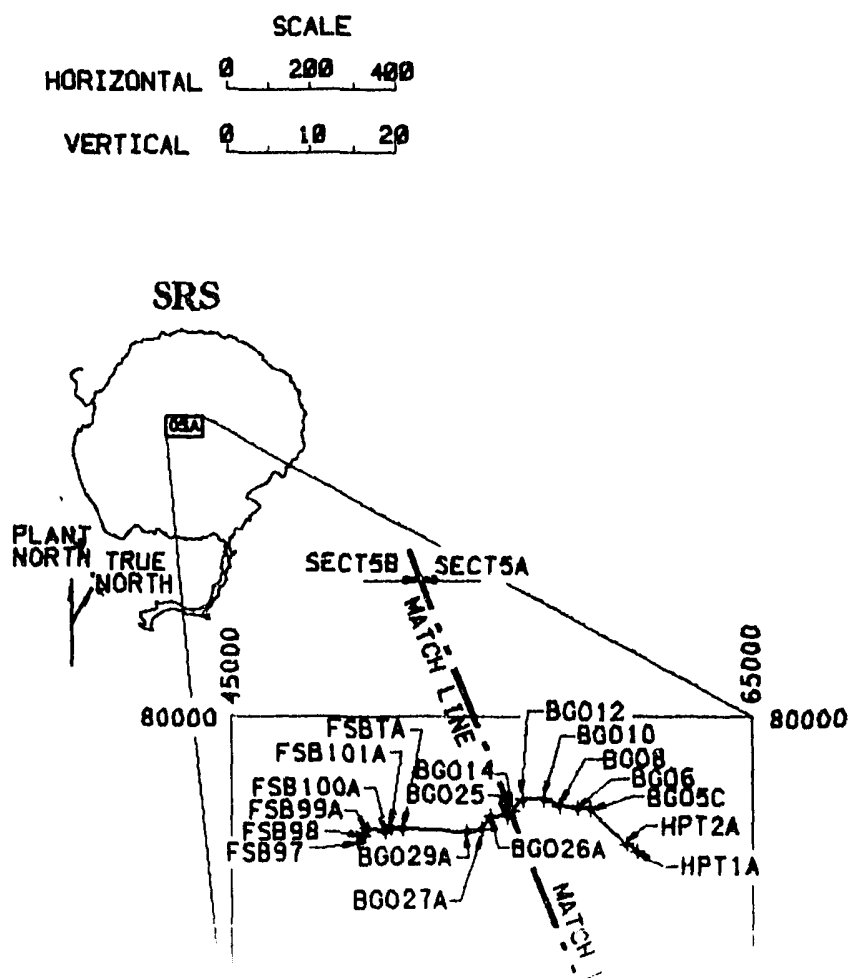


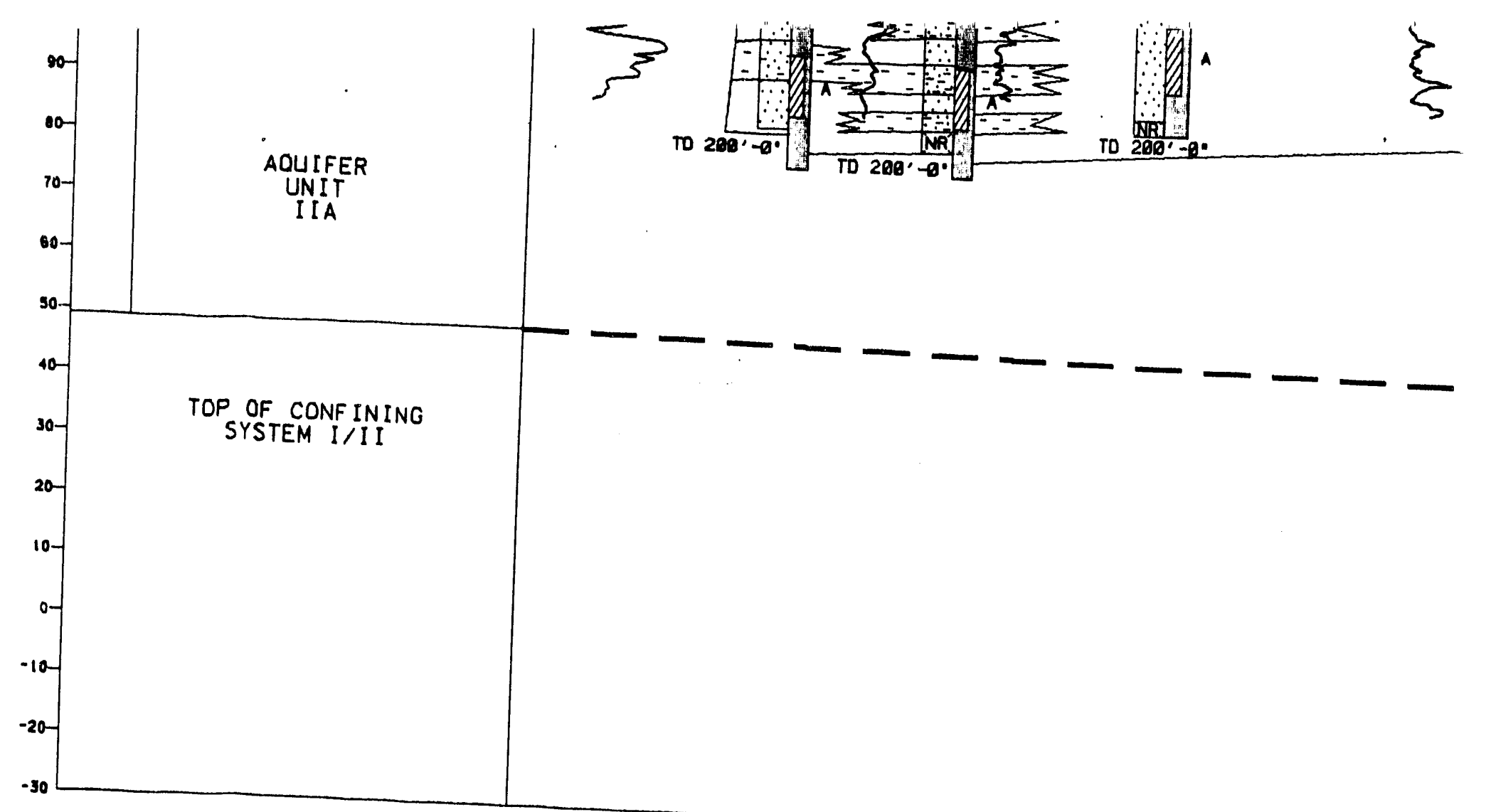




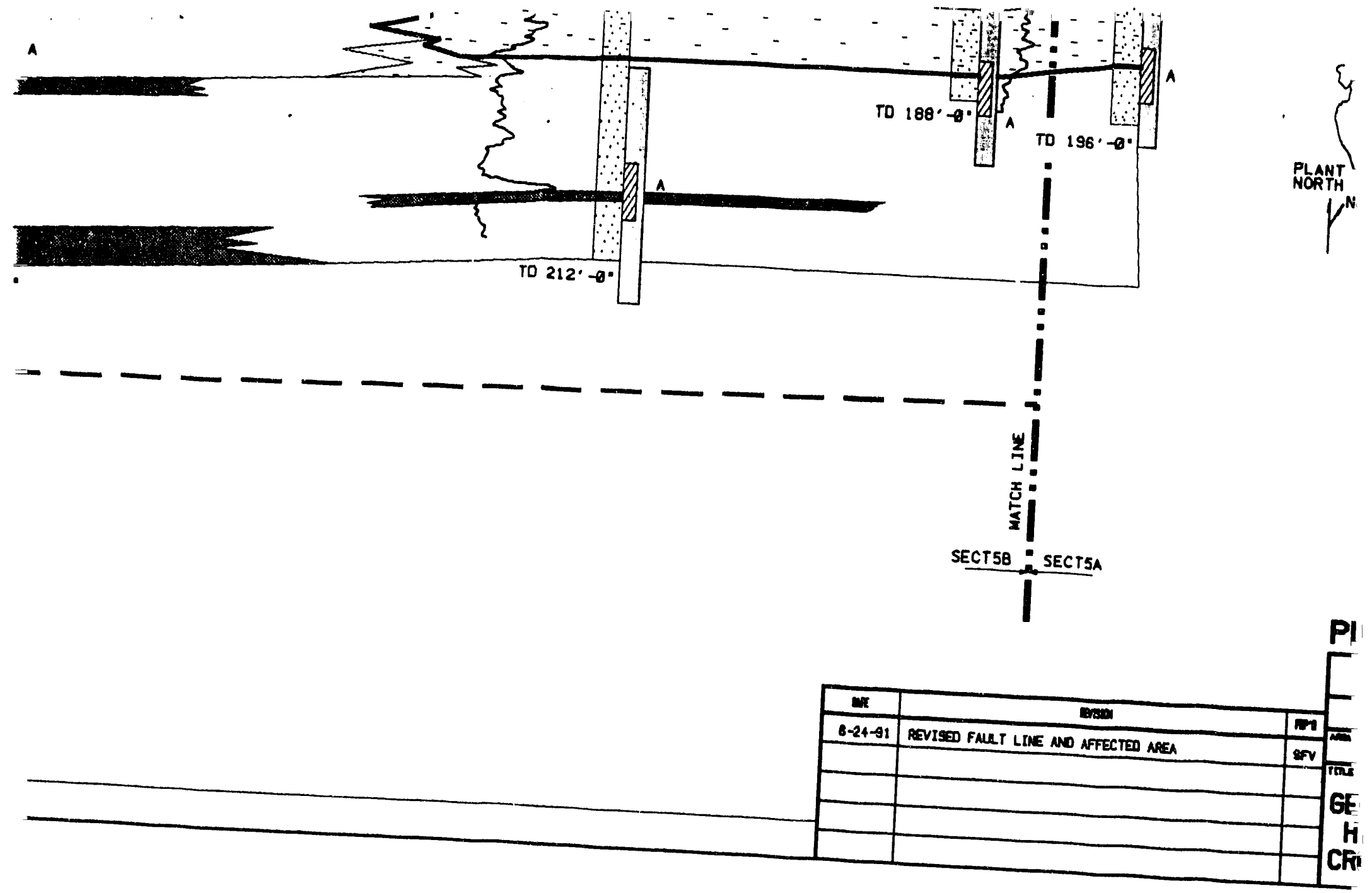




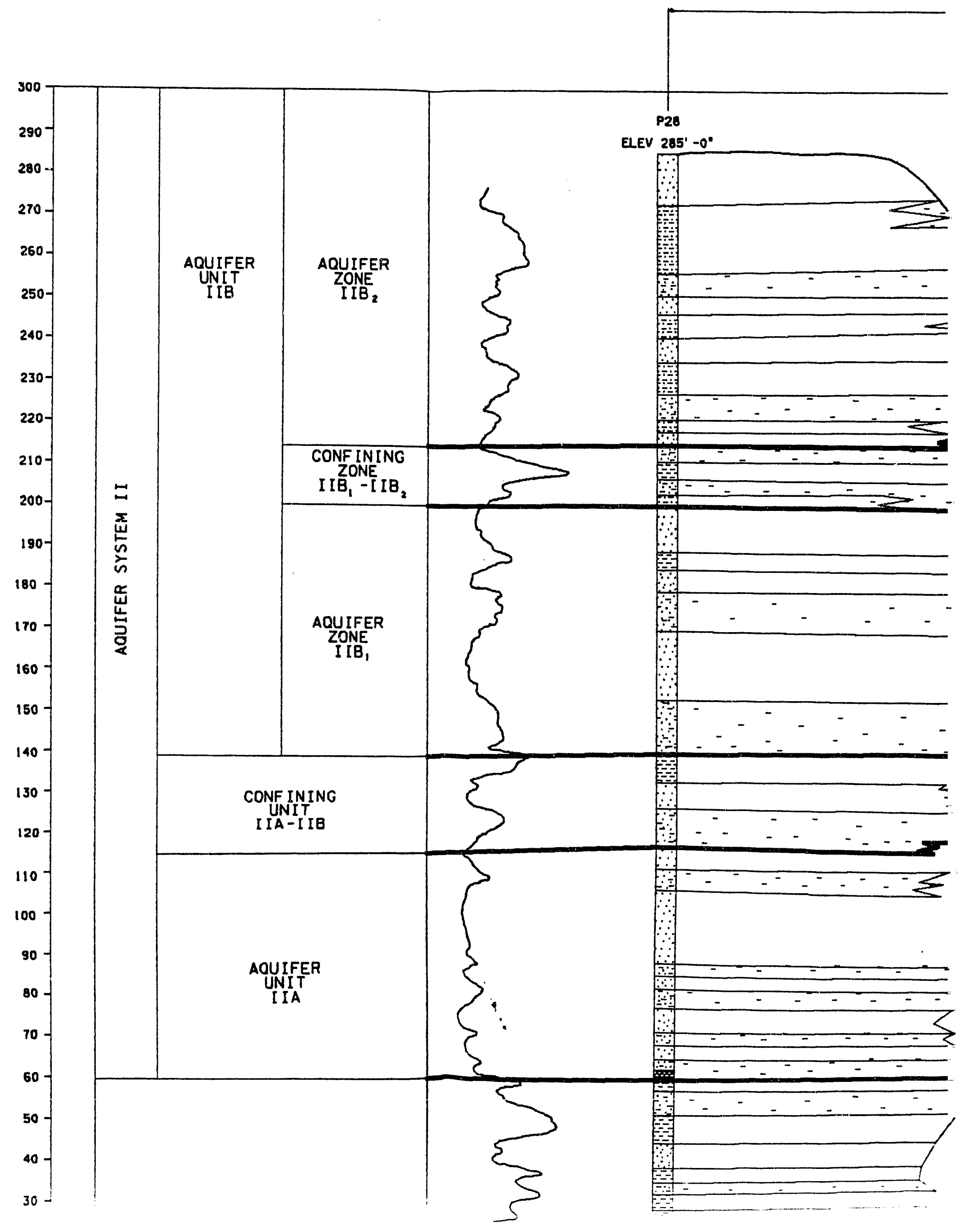




\section{GLNEIRAL SEPARA}

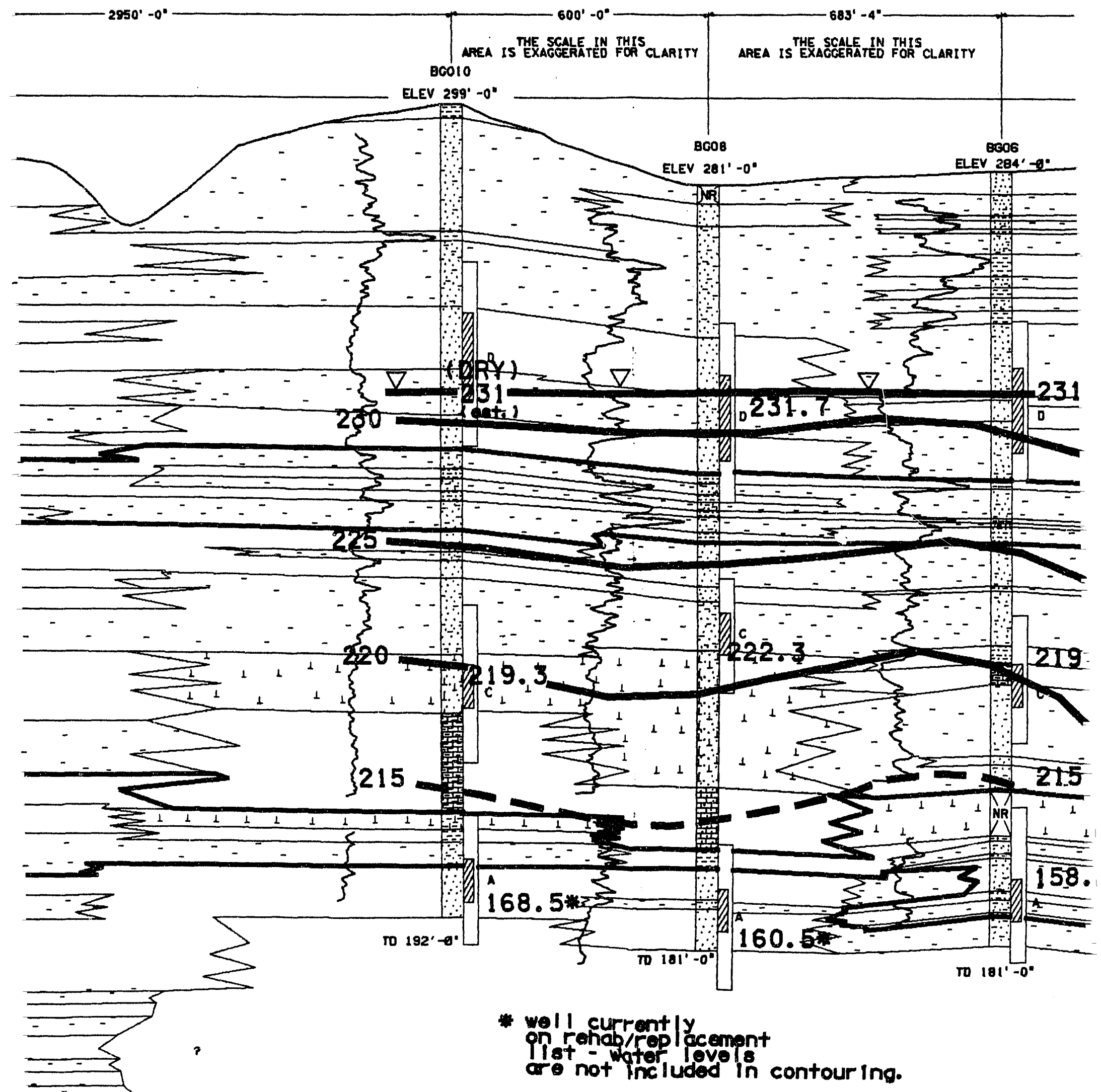




\section{OSTRATIGRAPHIC}

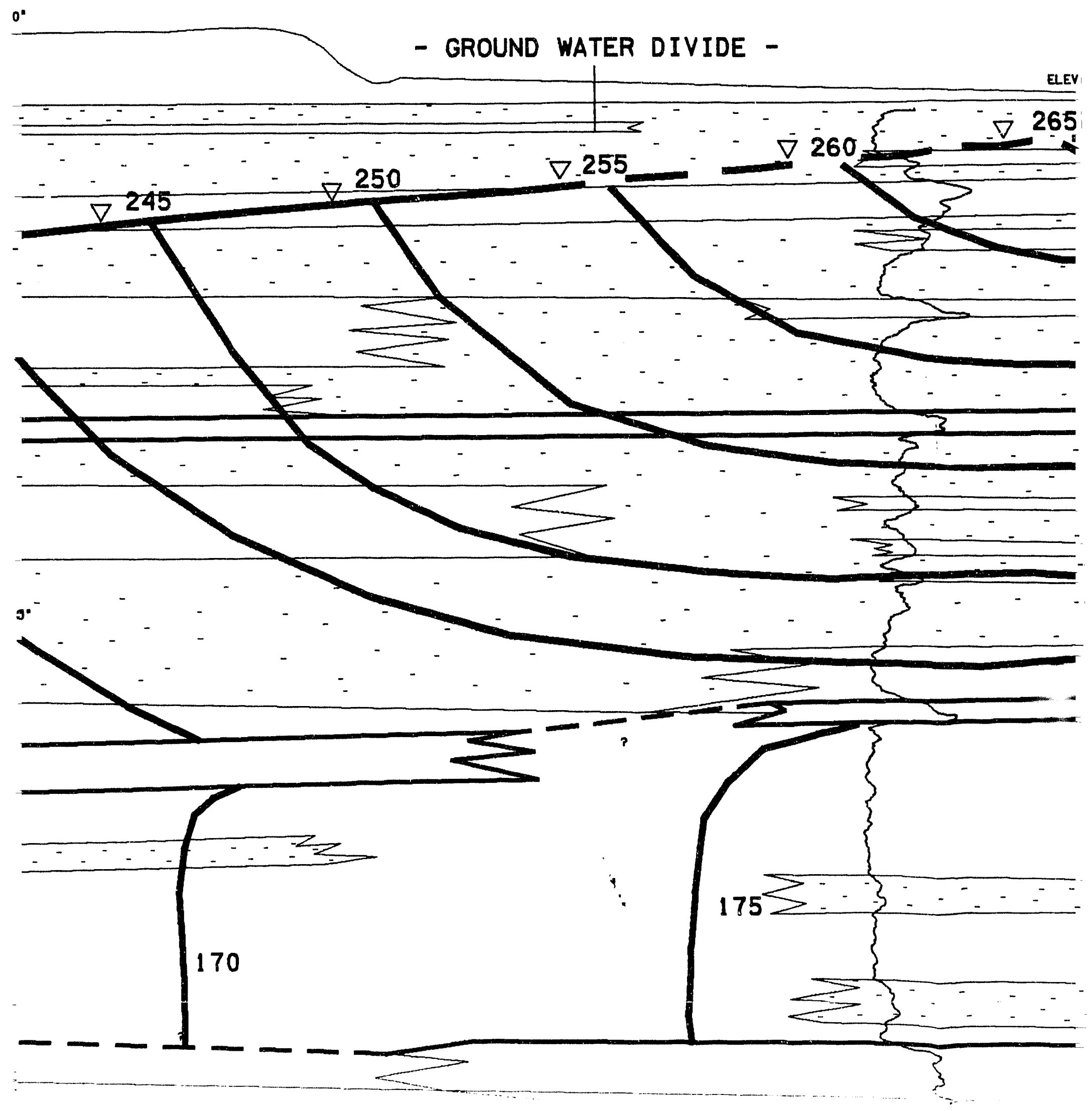




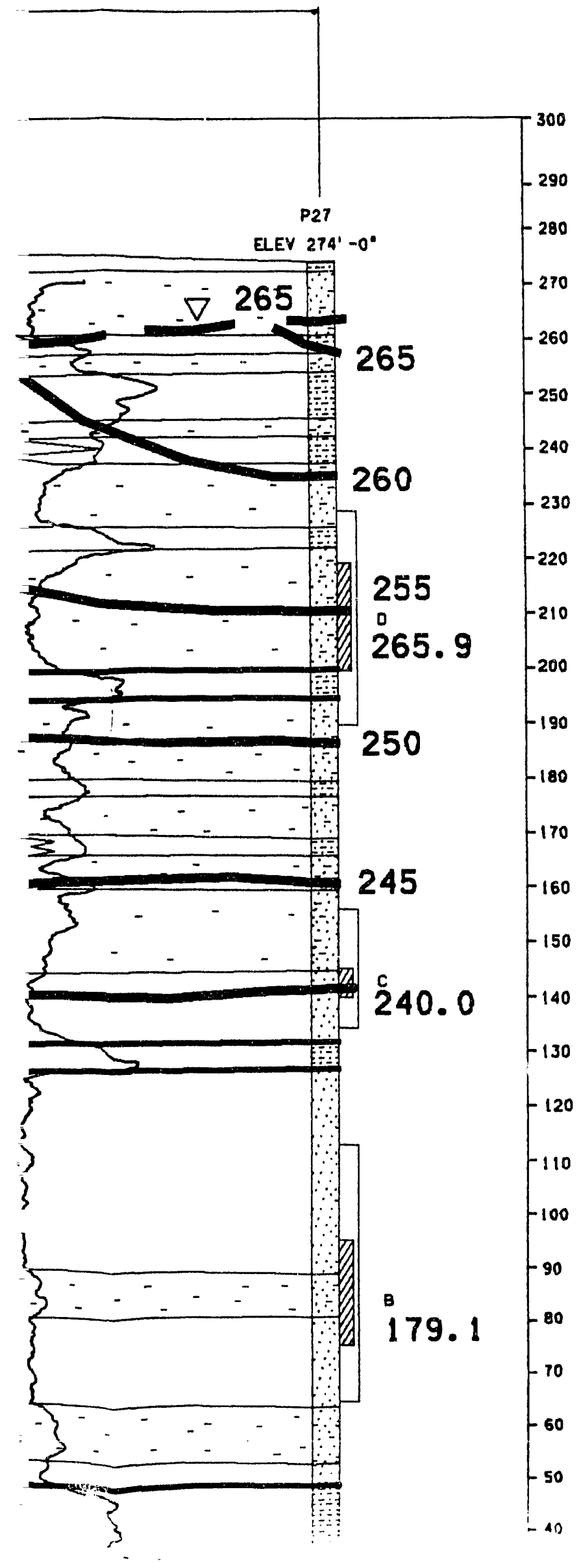

\section{LEGEND, \\ Oי CALCAREOUS SAND \\ $1-1$
$-1^{-}+1$ Calcaredus MUD \\ $\because$ Clayey sand \\ SAND

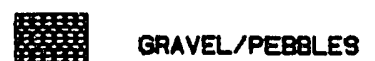

SILT/CLAY

SANDY LIMESTONE

LIMESTONE

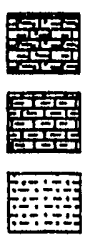

SANOY MUDOY LIMESTONE

MUDDY LIMESTONE

SANOY CLAY

- SAND PACK INTERVAL

20 SCREENEO INTERVAL.

DUI - DEPTH USED FOR INTERPRETATION

TD - TOTA DEPTH

GSA - general separations area

NR - NO RECOVERY

GEOPHYSICAL CLAVE - MATURAL GAMMa

- CONFINING zONE, UNIT, aNO SYSTEM BOUNOARIES

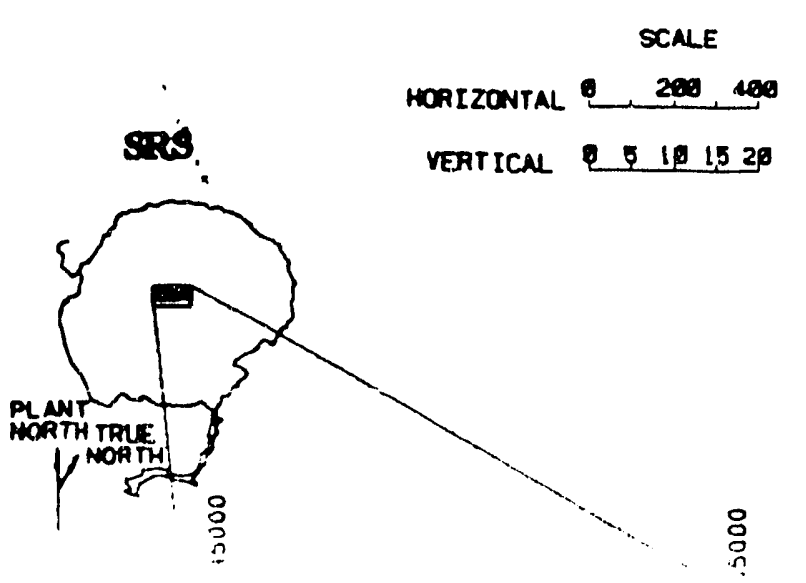




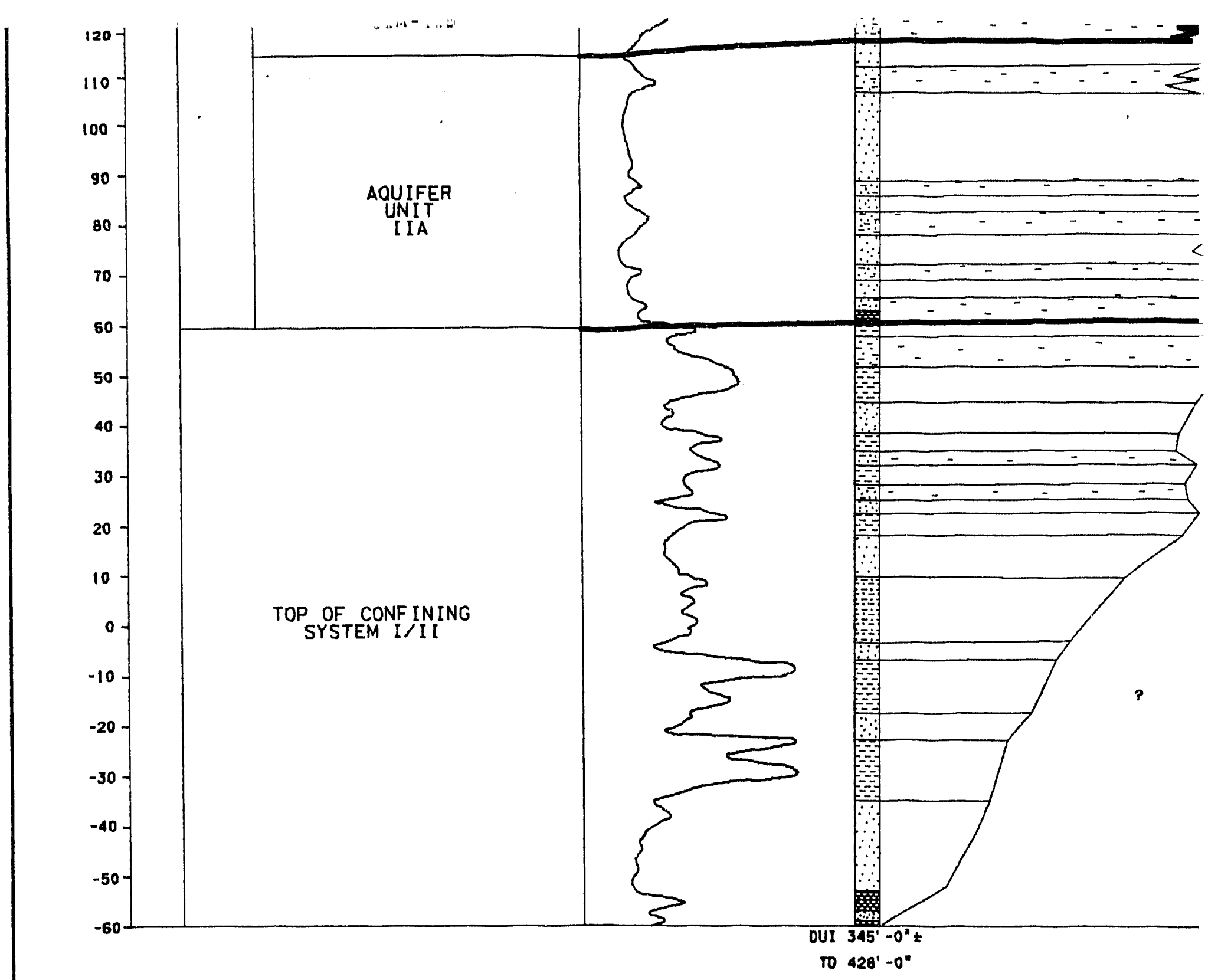




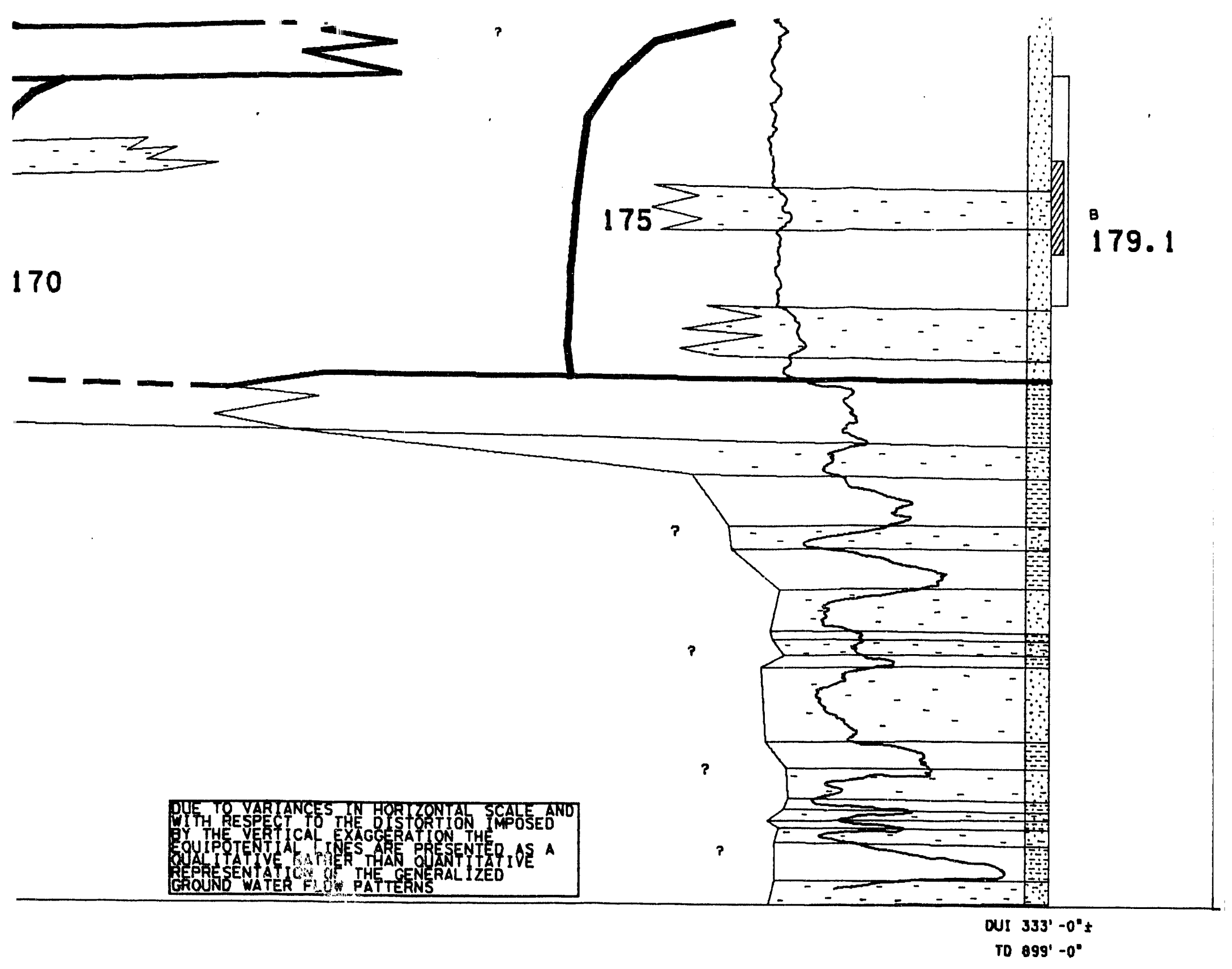




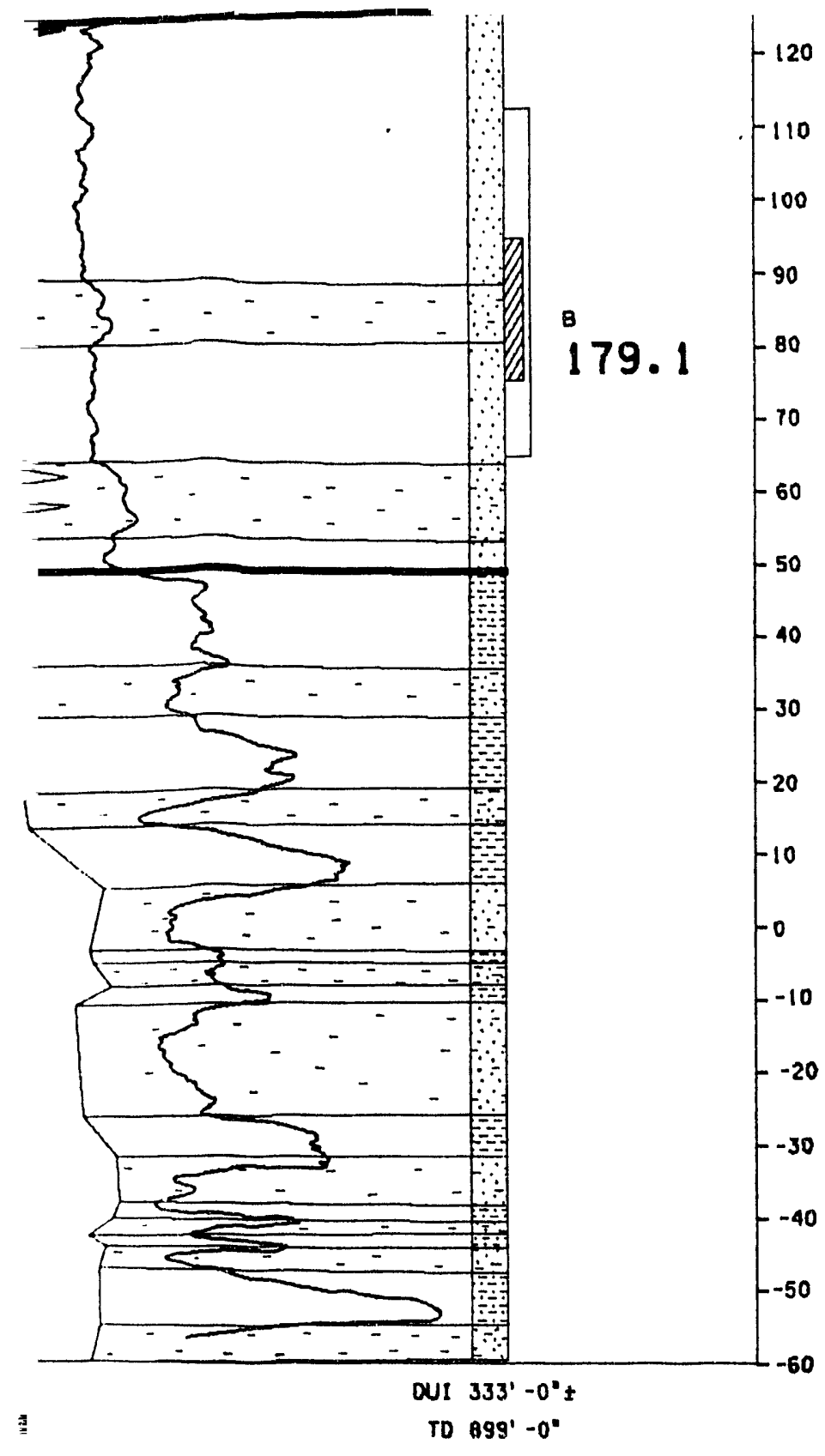

(11) $=4$

SRS

SCALE

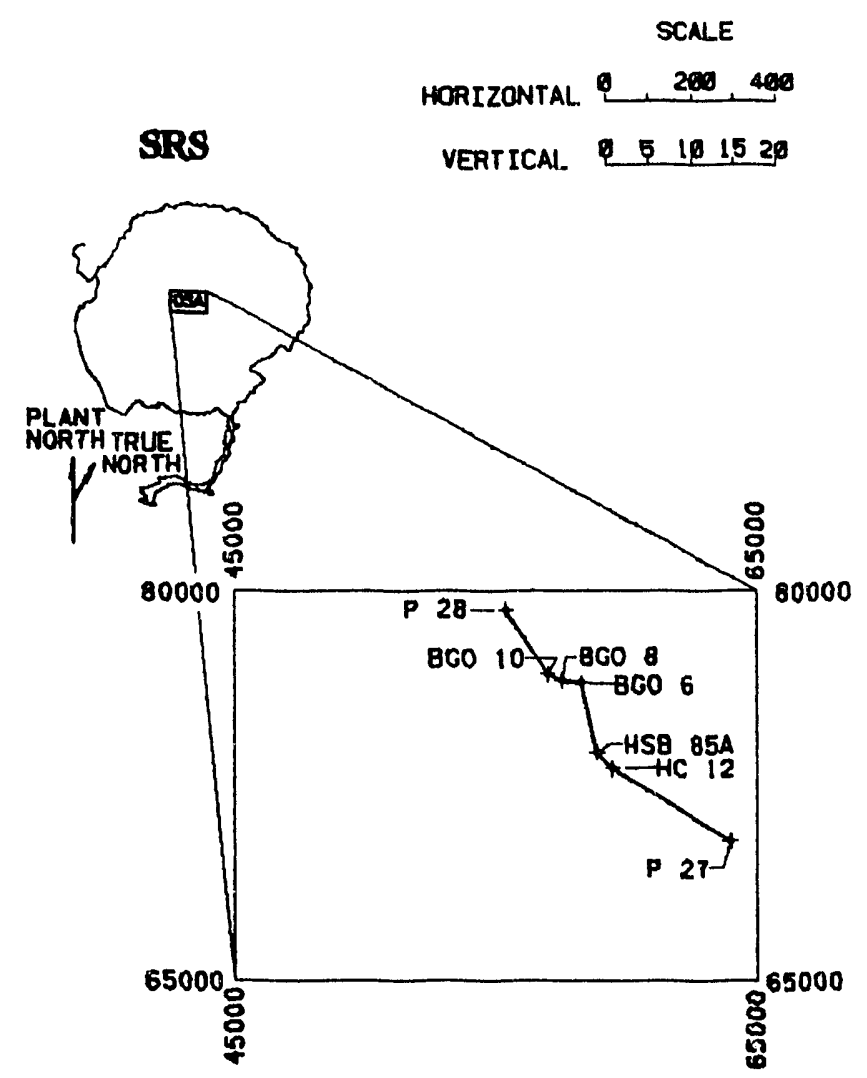

PLATE 6

W

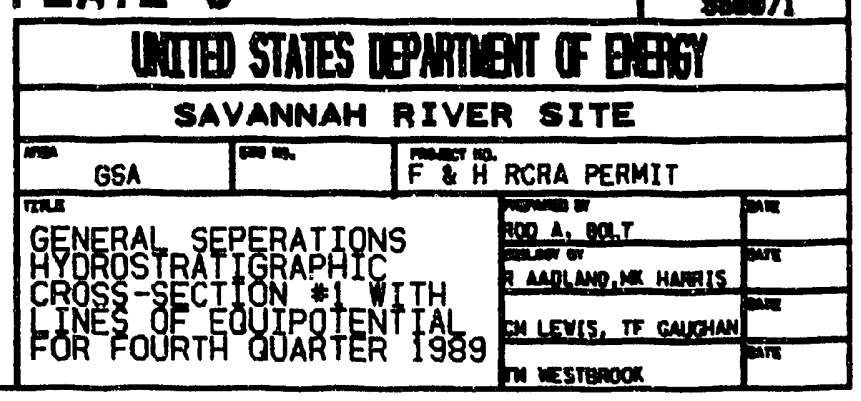




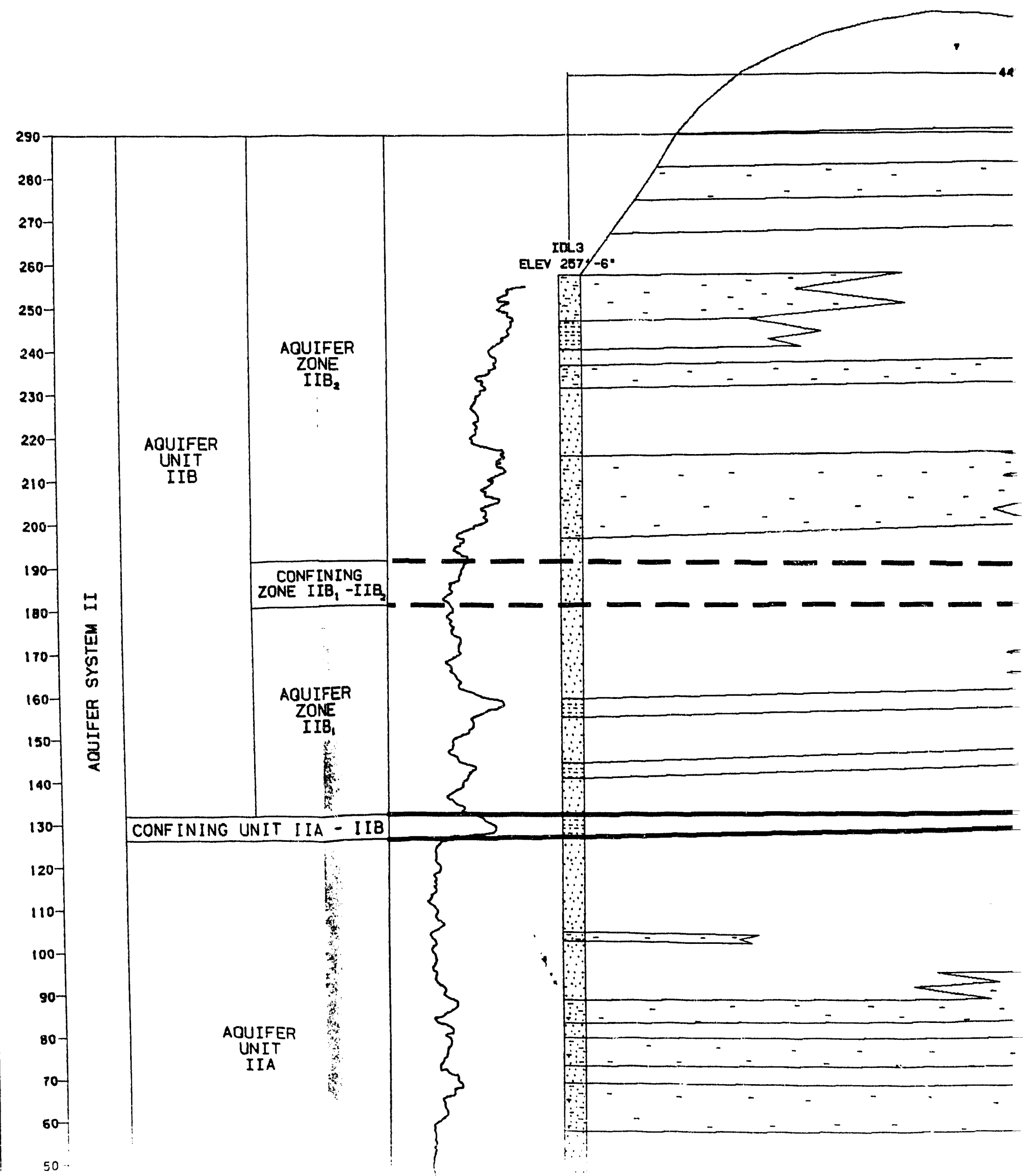




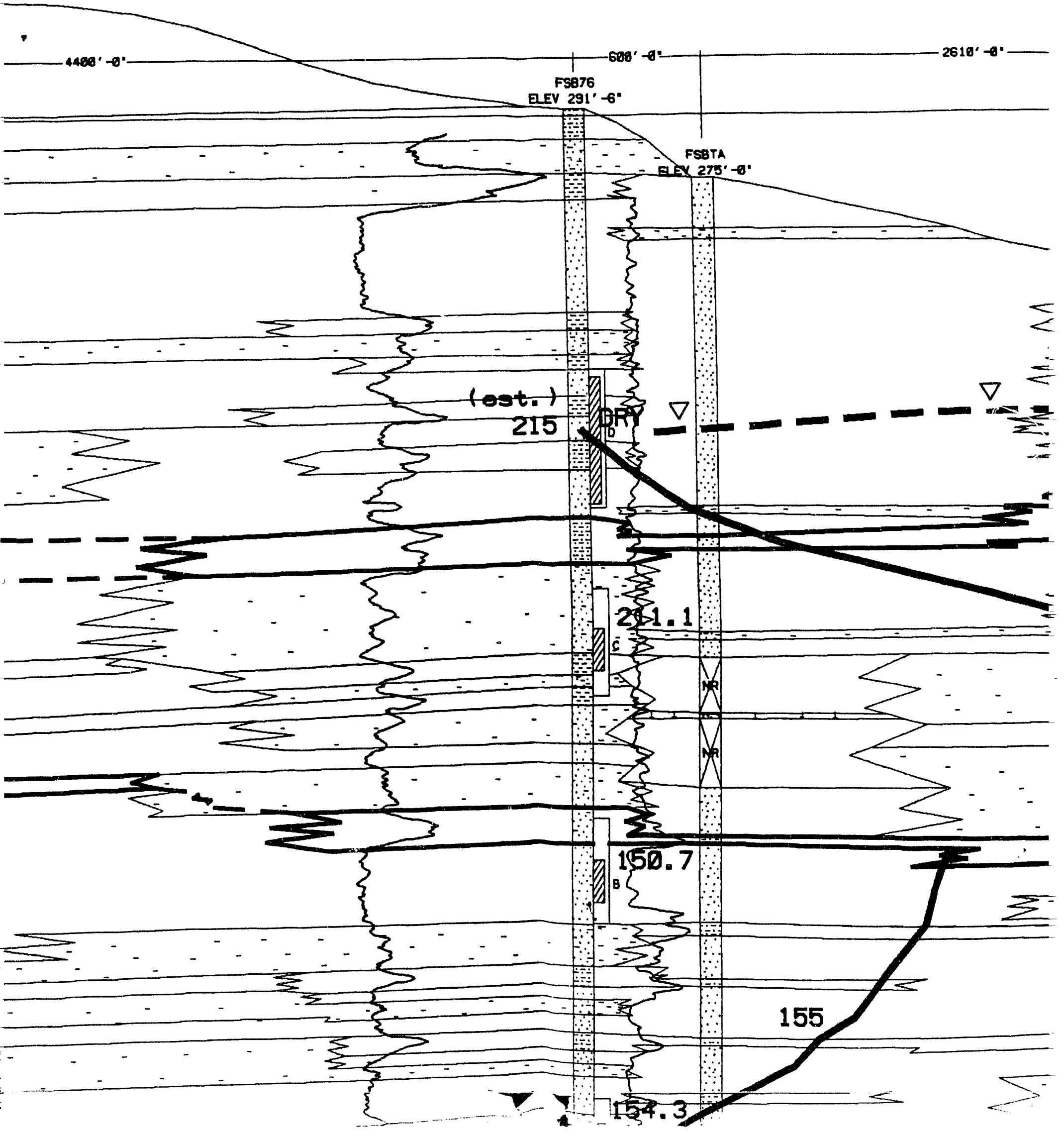




\section{GENERAL SEPARATIONS AREA REGIONAI CROSS-SECTION \#}

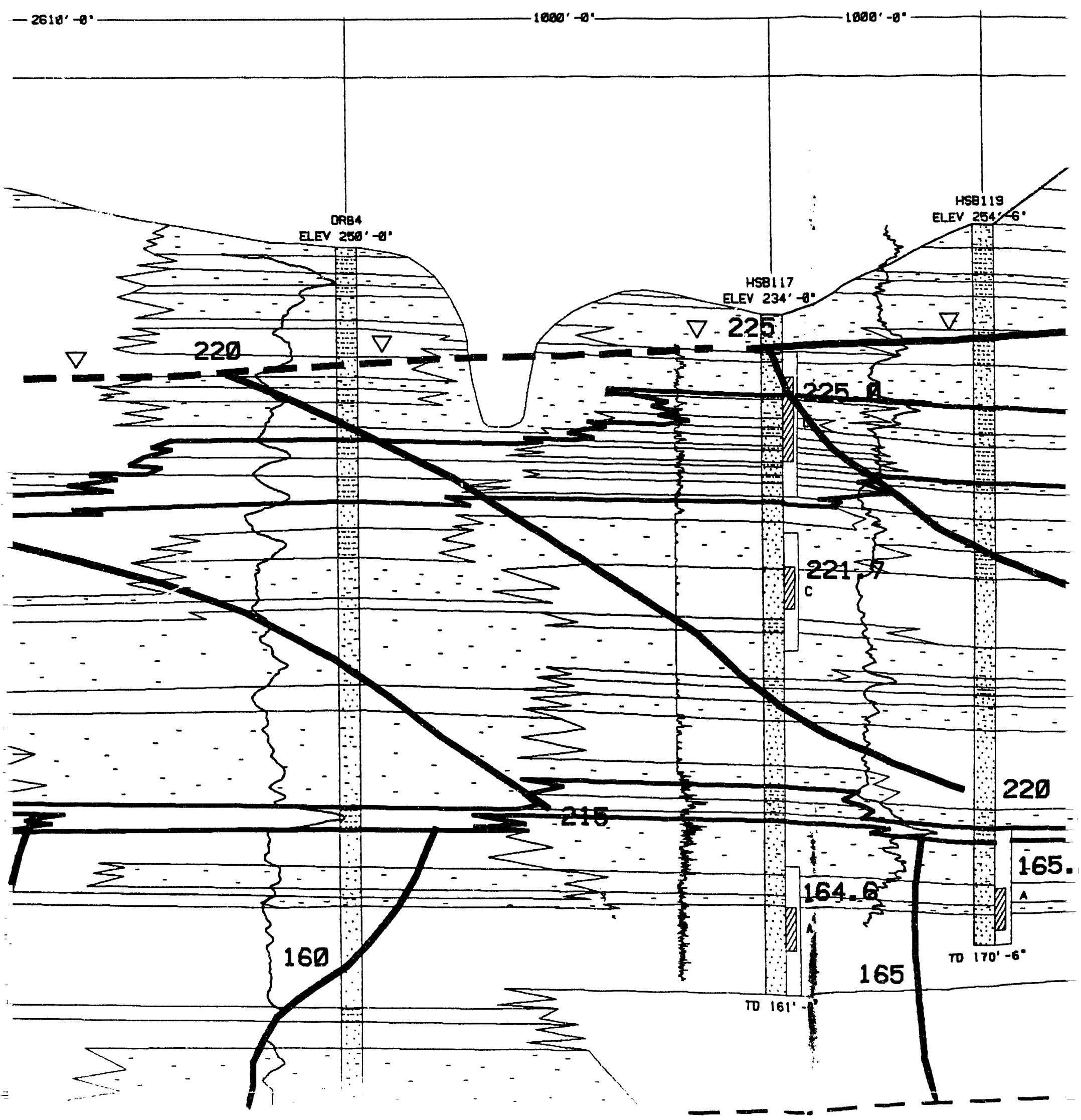




\section{DNAL HYDROSTRATIGRAPHIC}

\section{I \# 2}

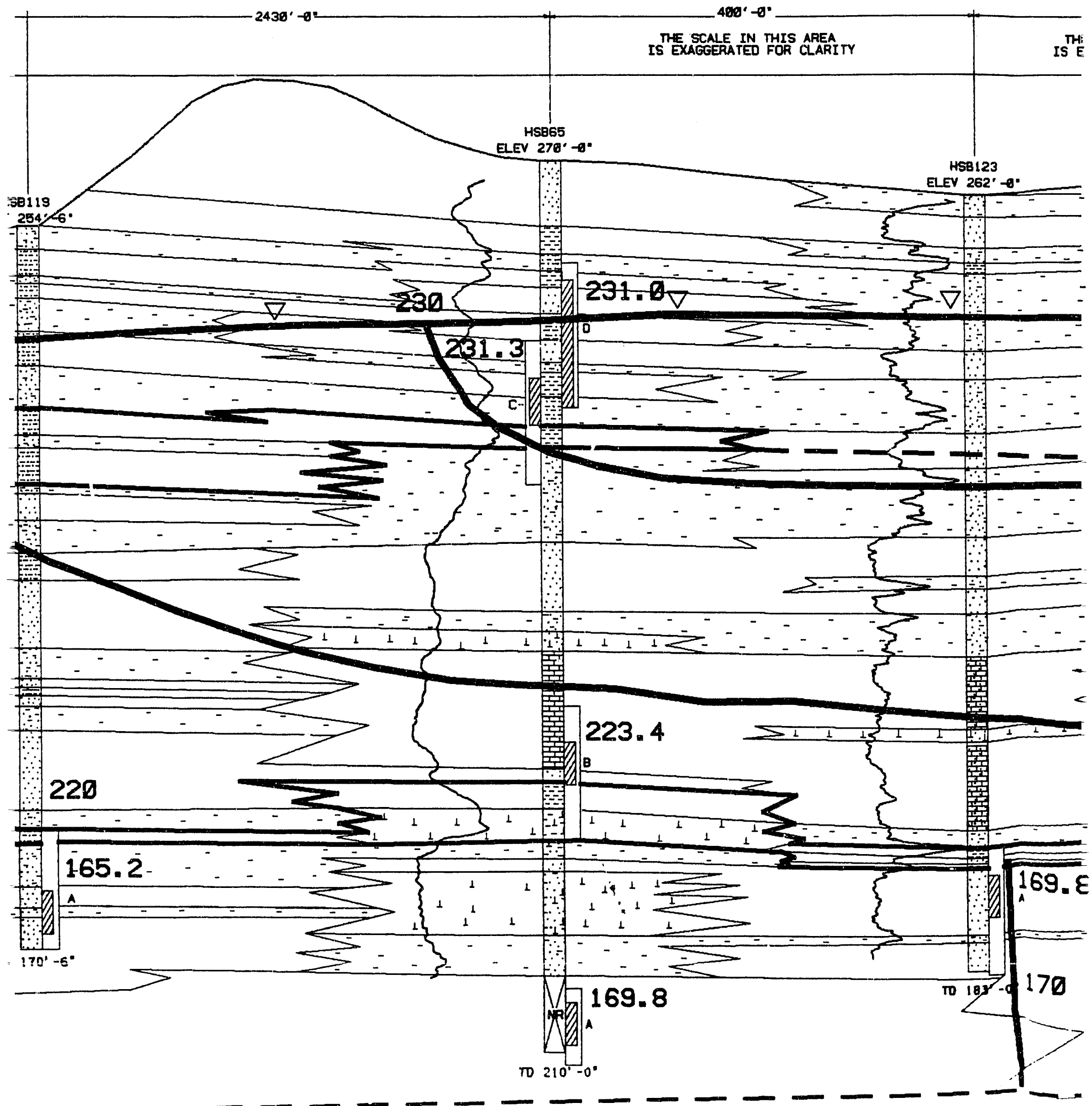




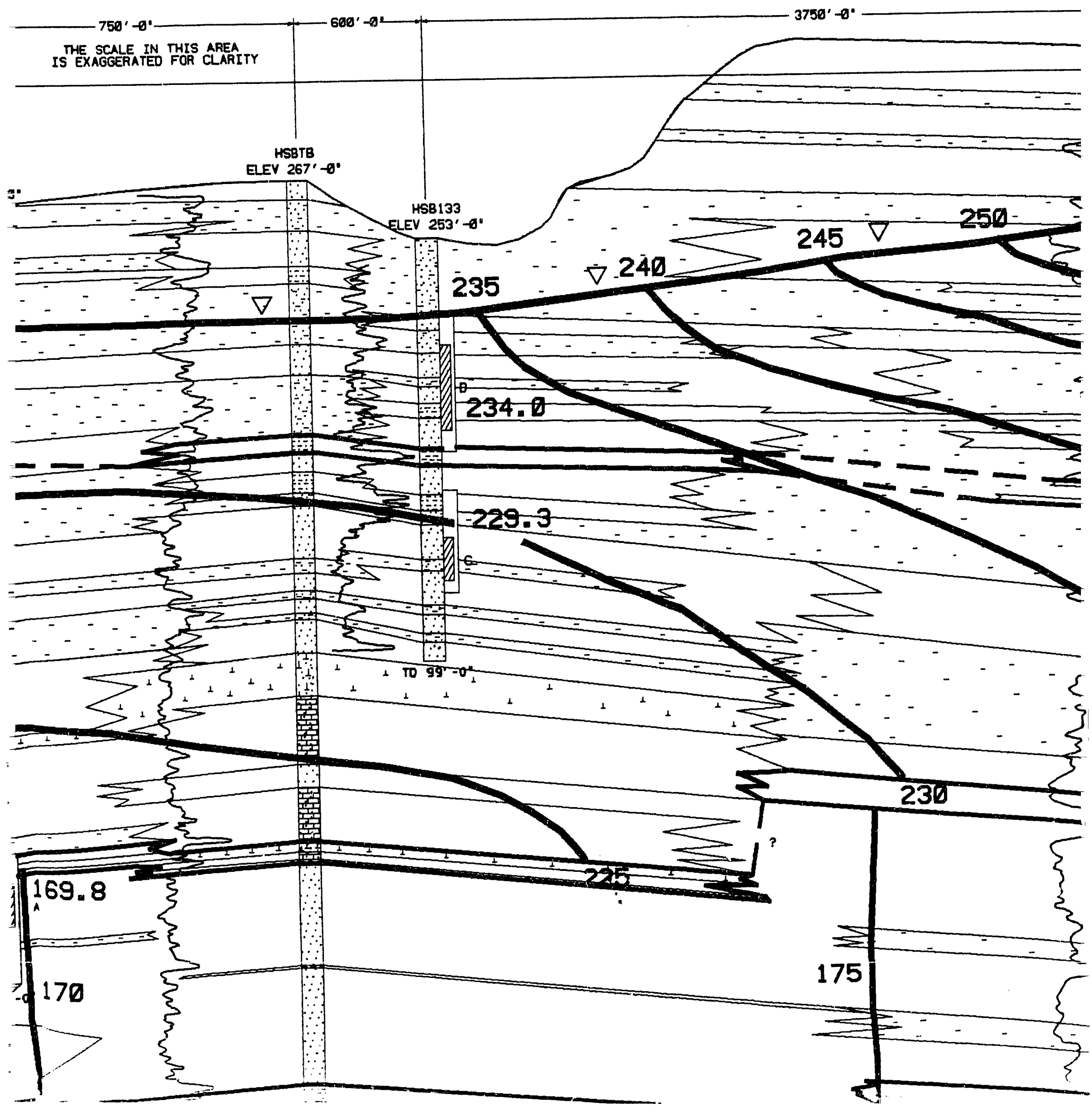



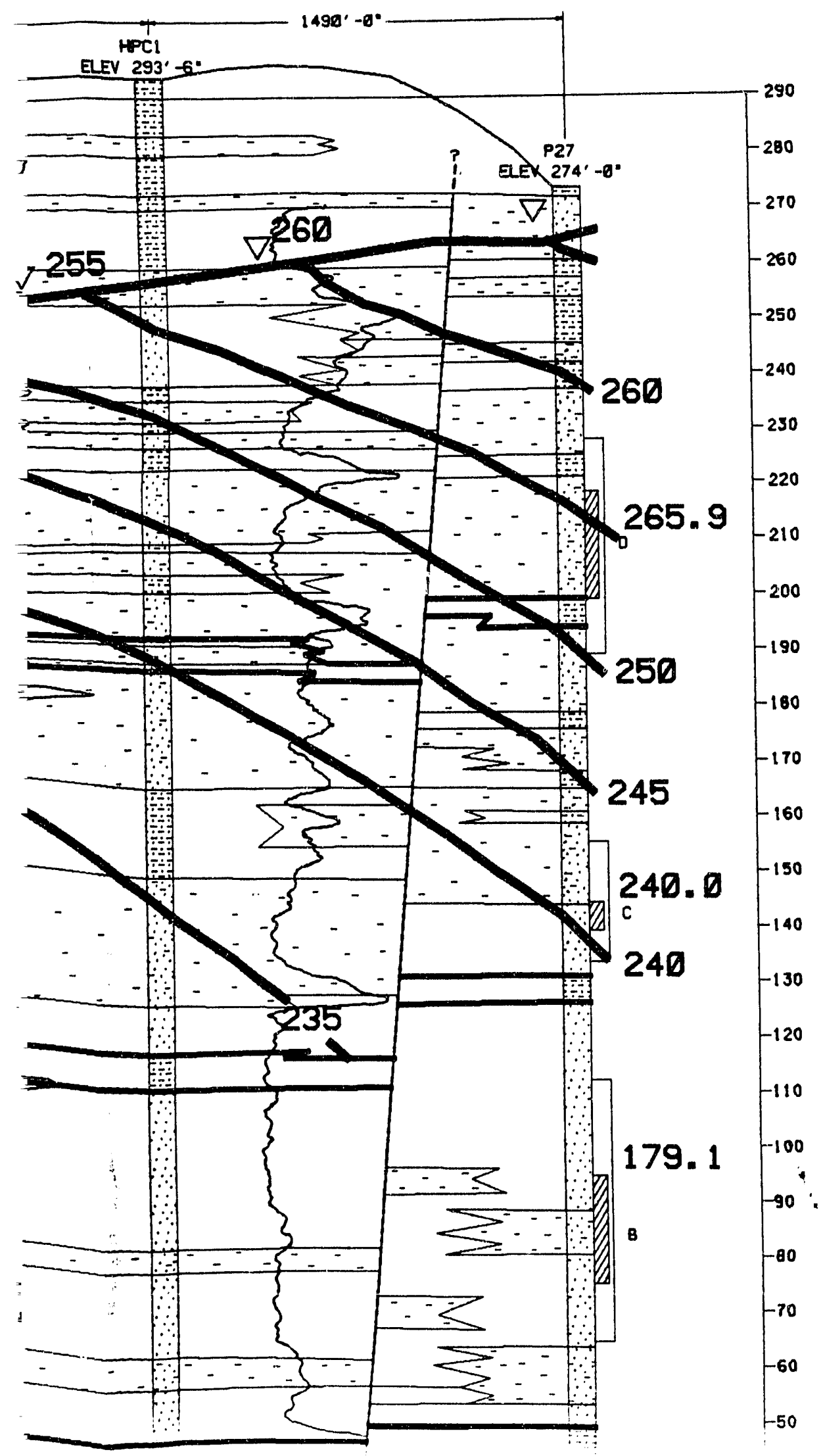

LEGEND,

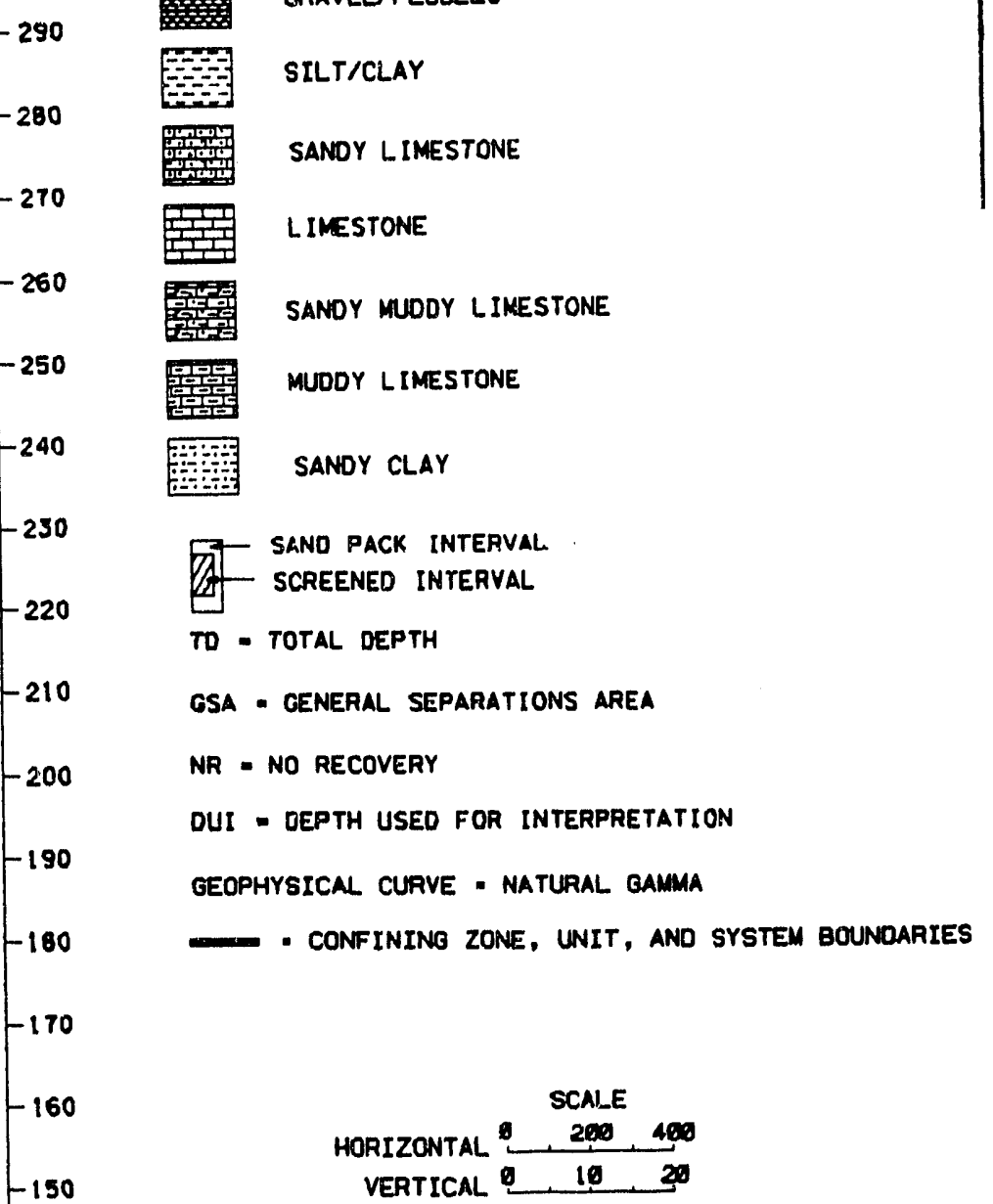

tiit

圈

1

諲琵

瑟

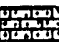

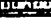

空

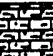

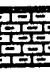

䁌

CLAYEY SAND

SAND

GRAVEL/PEBBLES

SILT/CLAY

SANOY LIMESTONE

INESTONE

SANDY MUDDY LIMESTONE

VERTICAL $0,10,20$

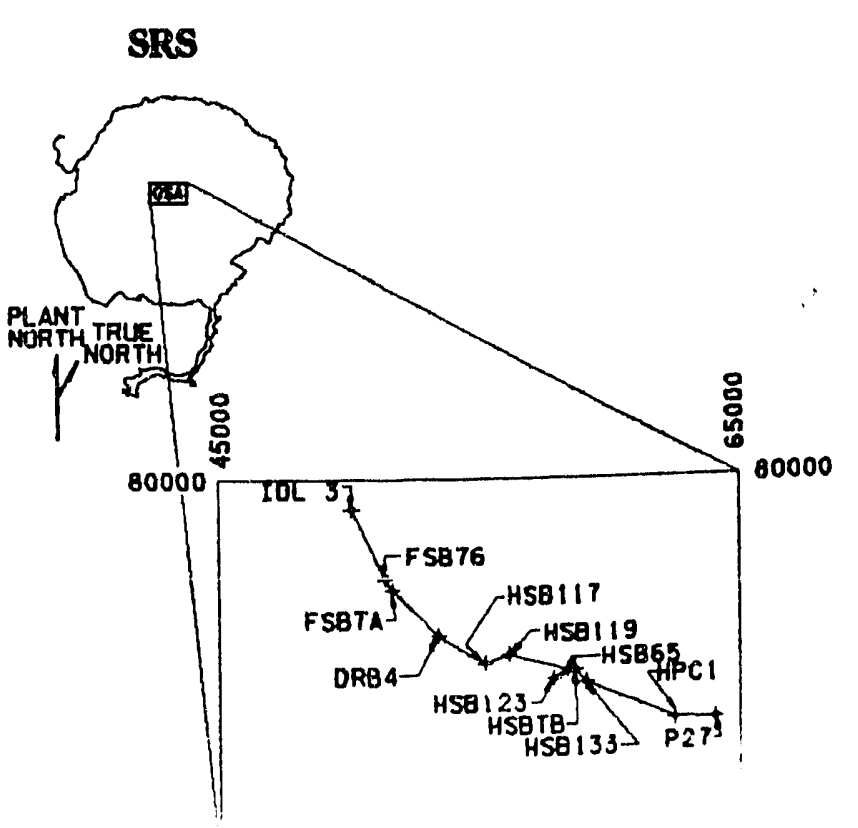




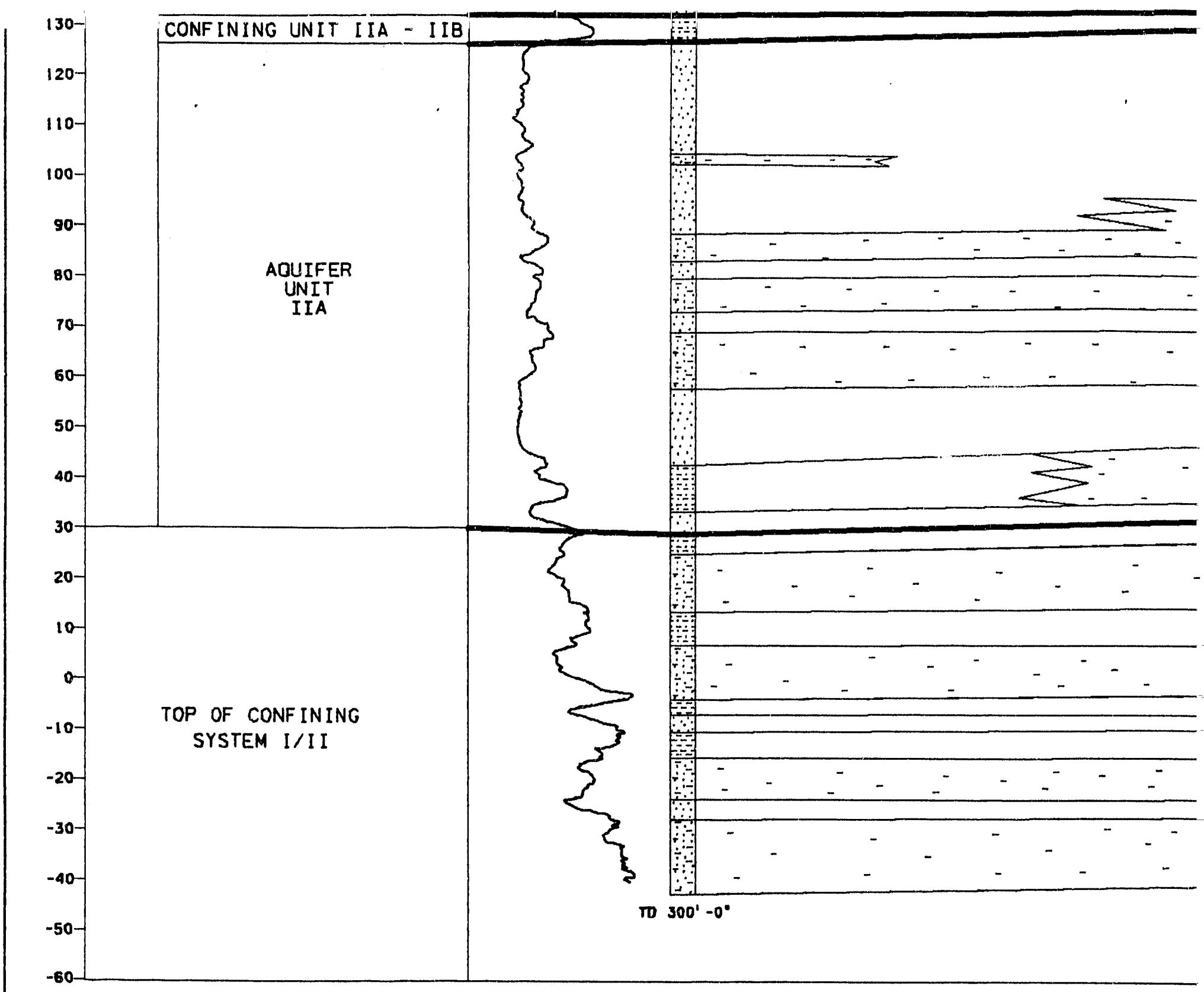




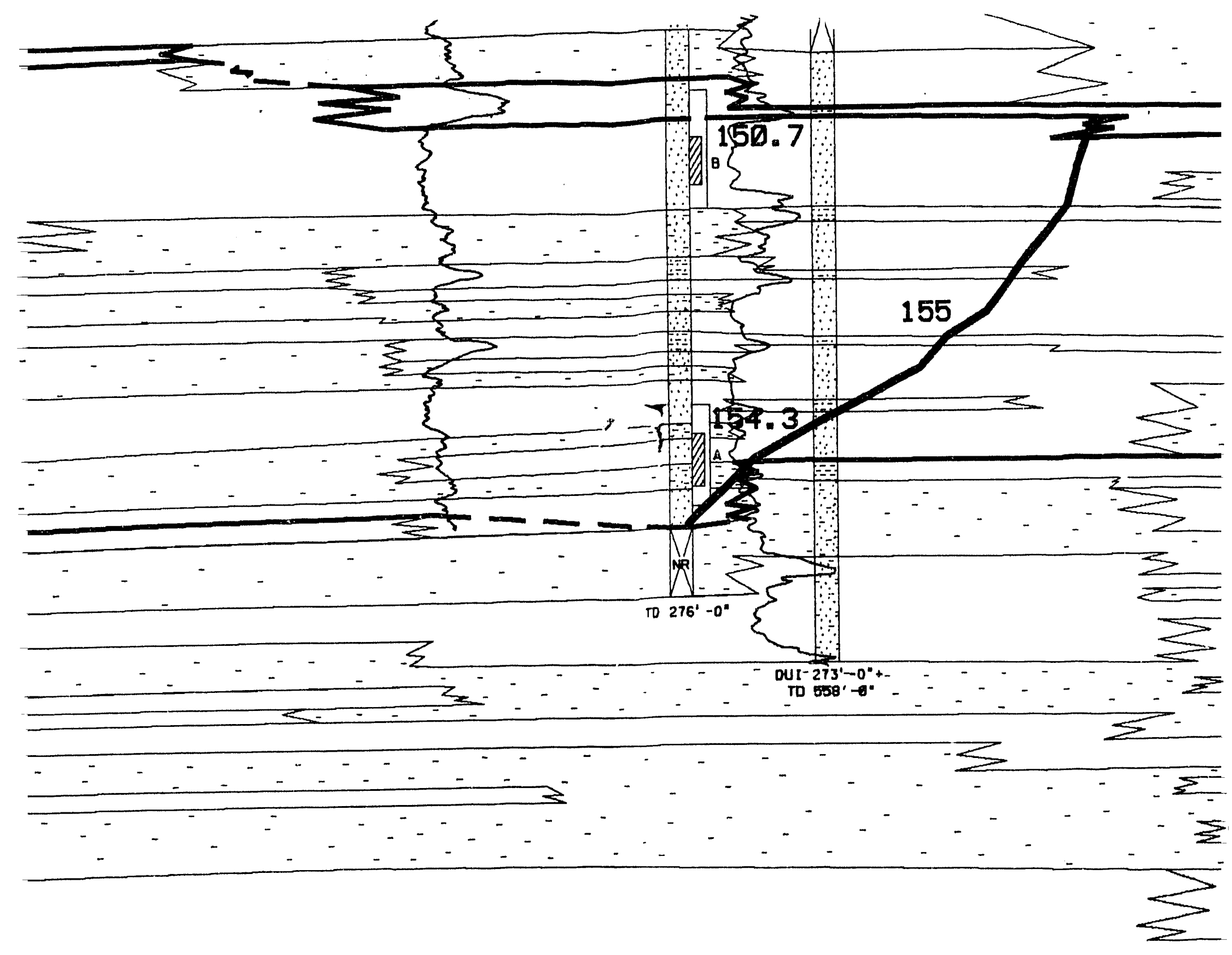




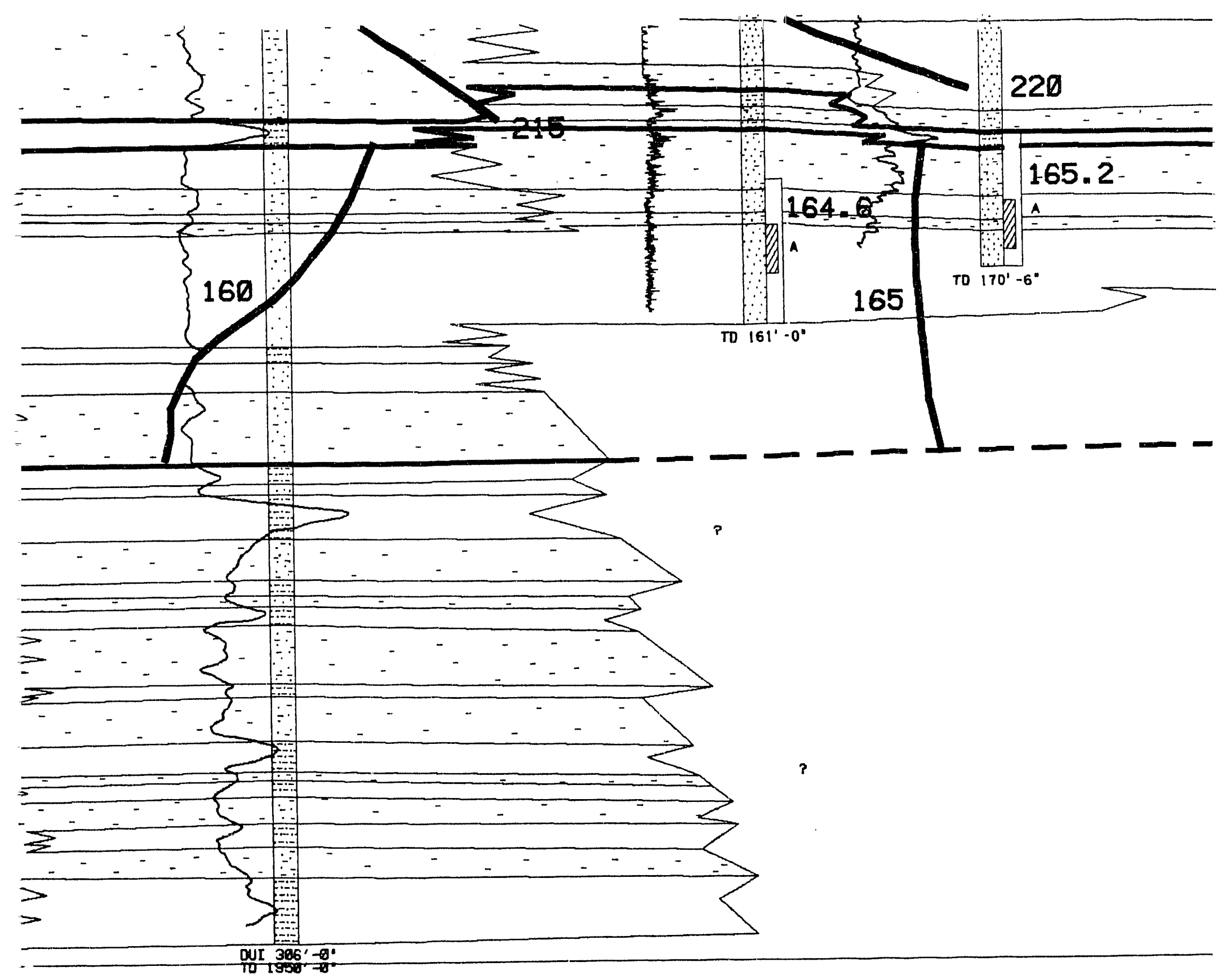




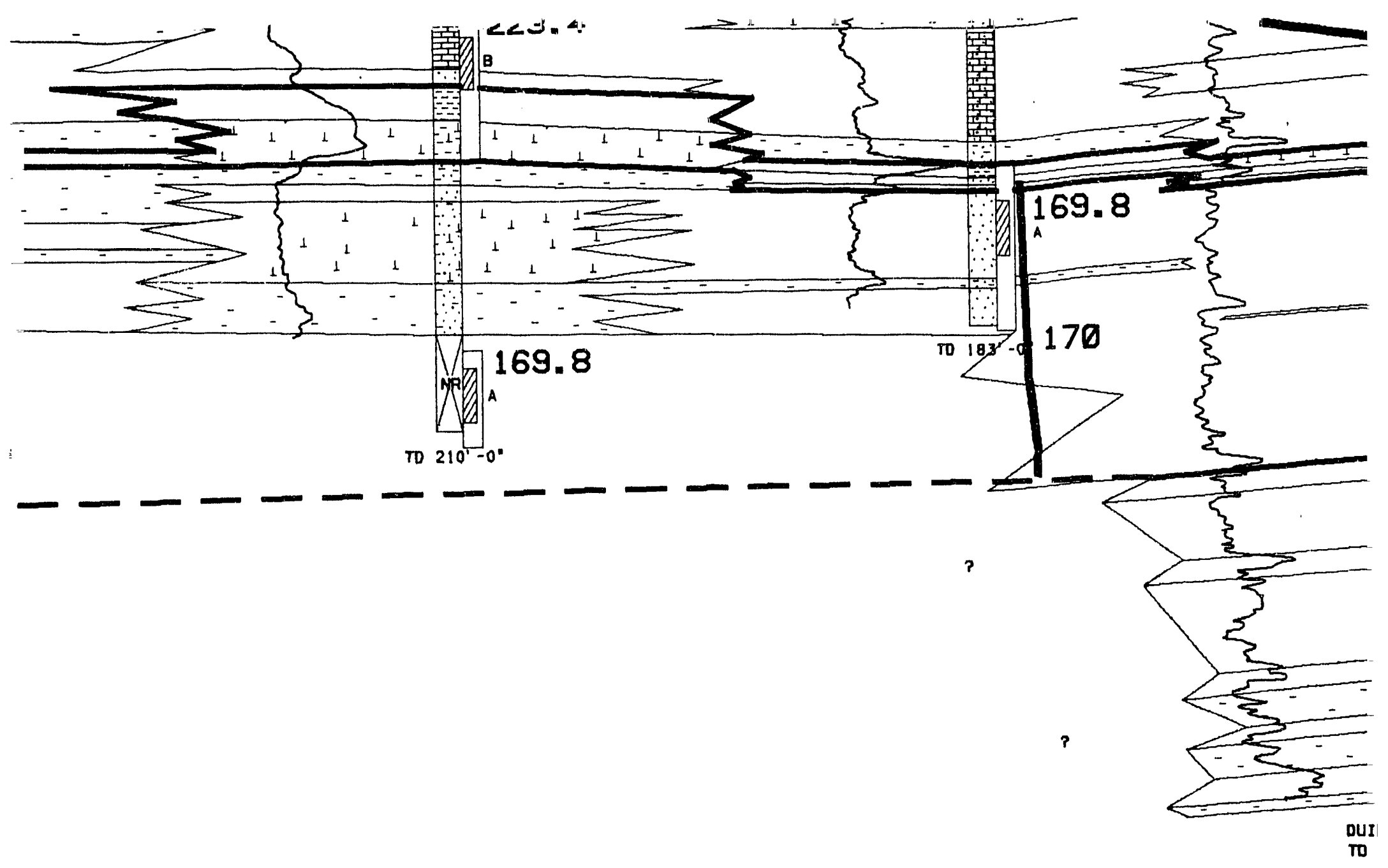




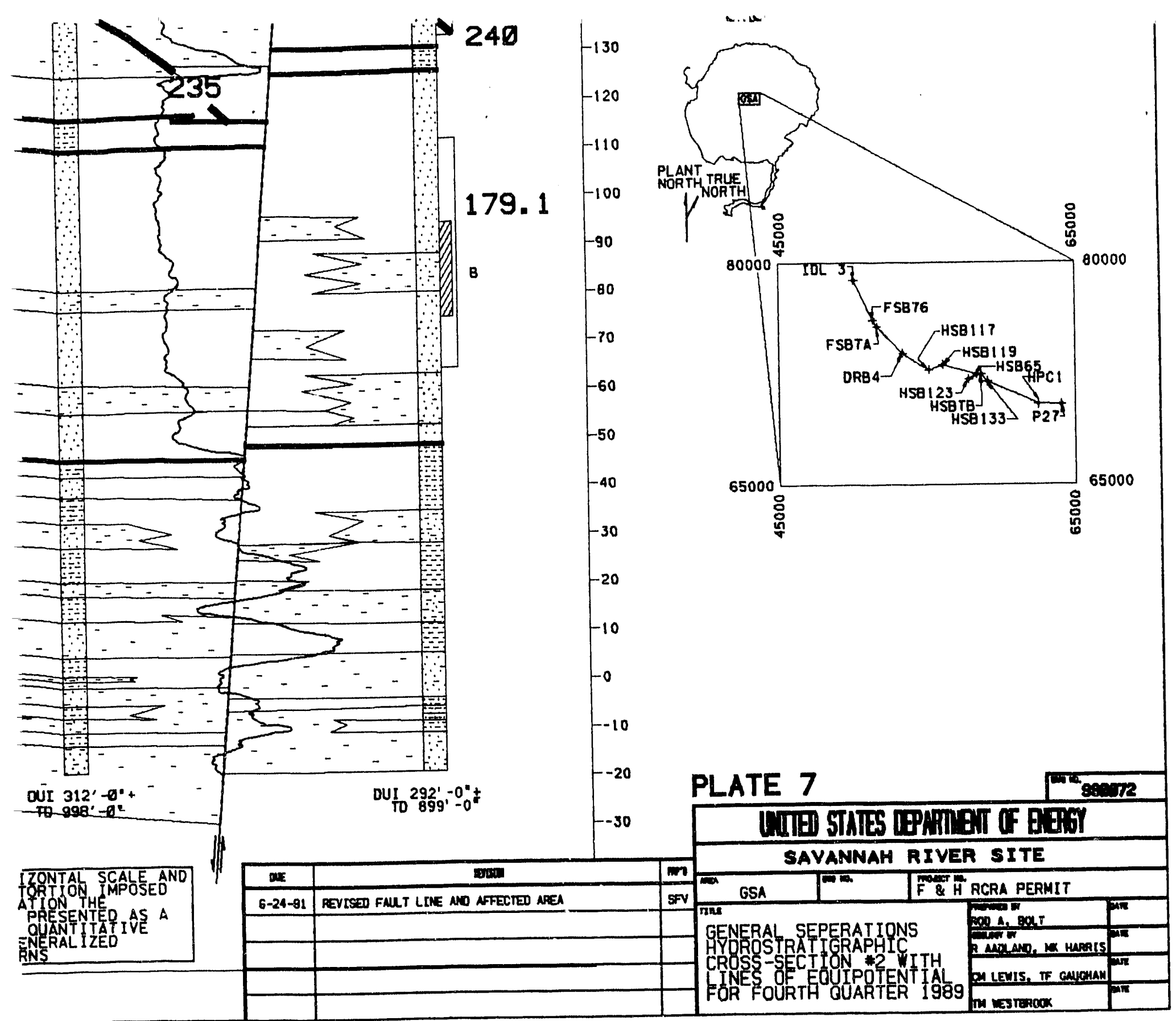




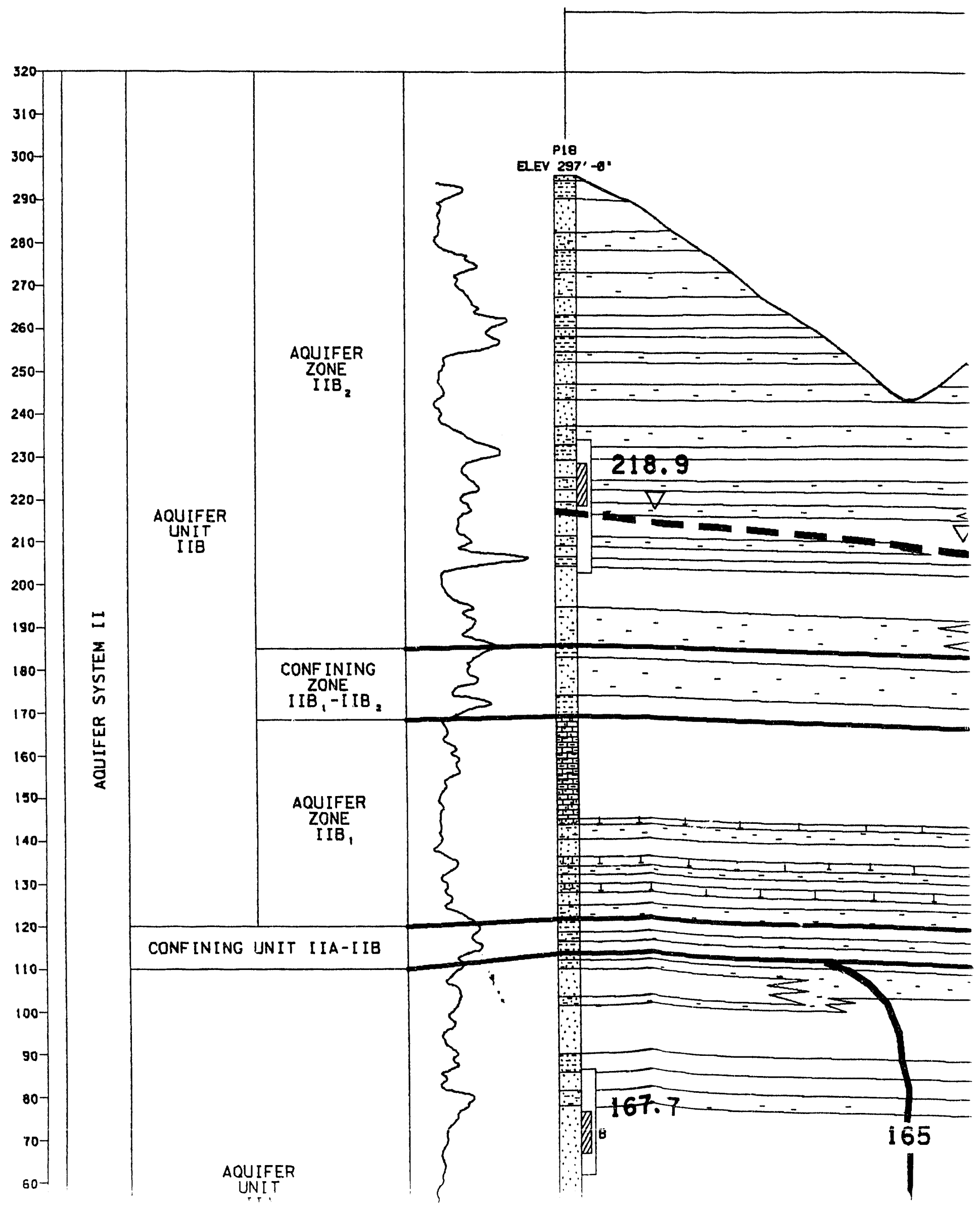




\section{GENERAL SEPARATIONS}

CI

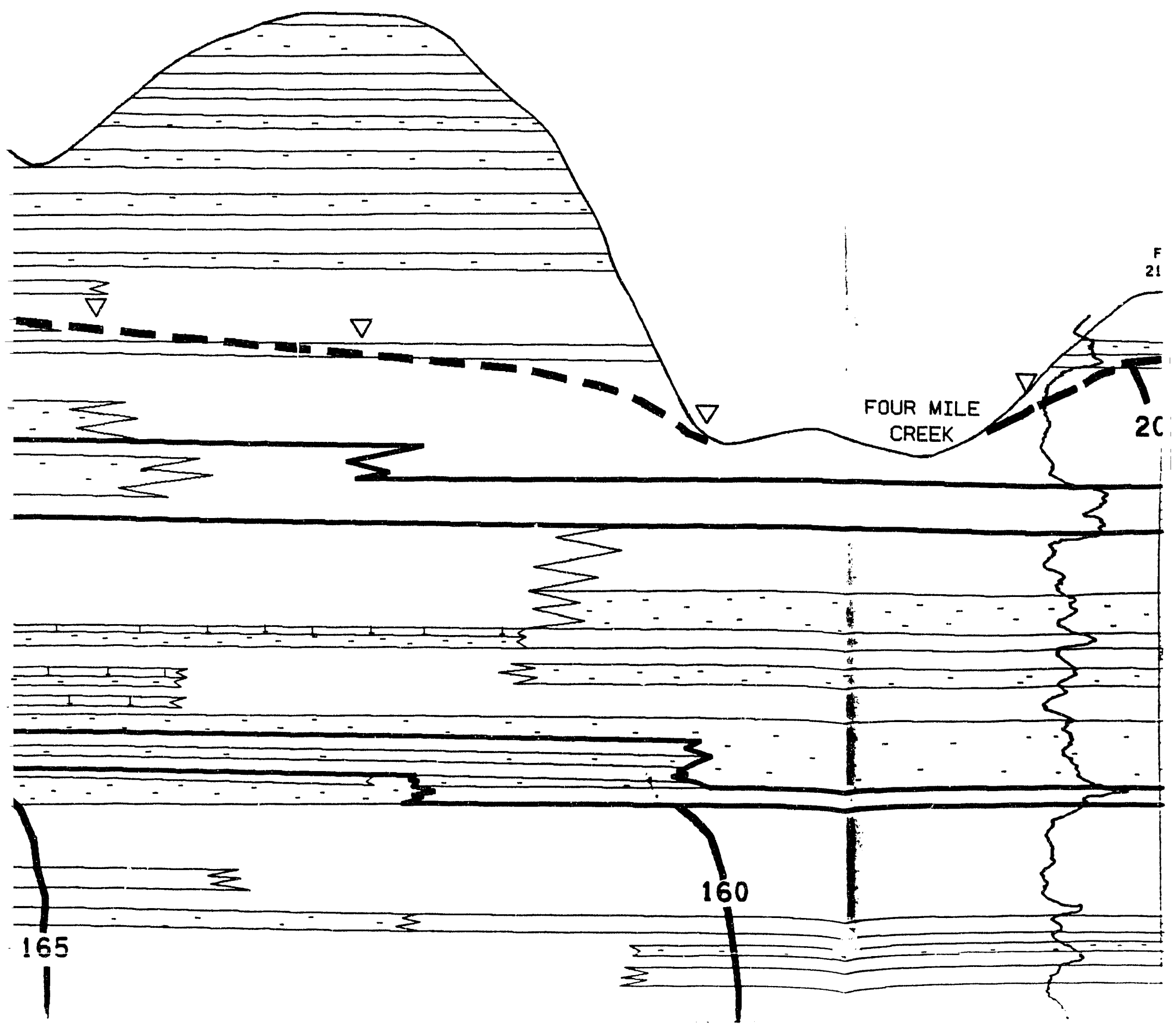




\section{ONS AREA REGIONAL HYDROSTRATIGRAPHIC}

\section{CROSS-SECTION \# 3}

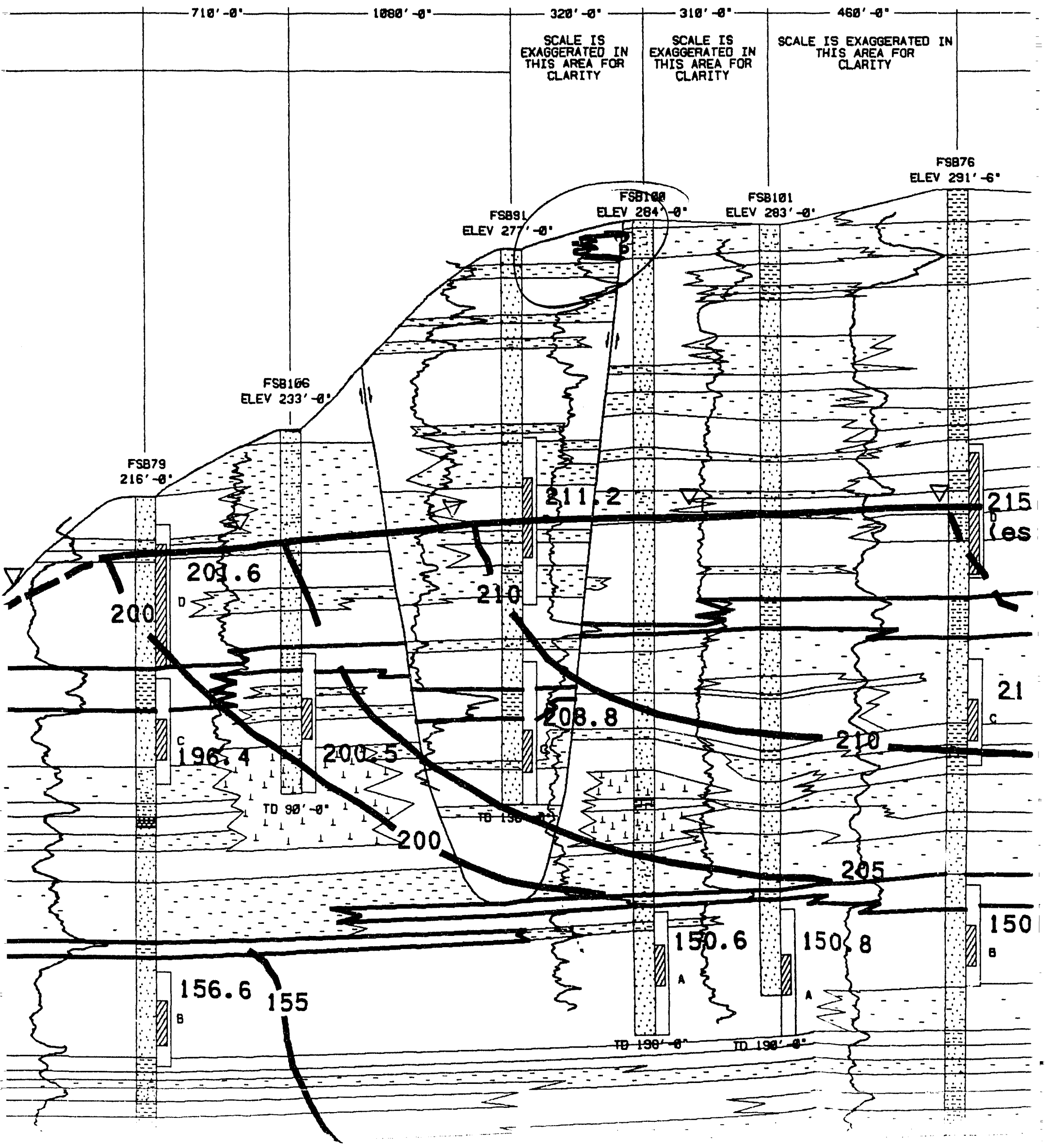




\section{APHIC}
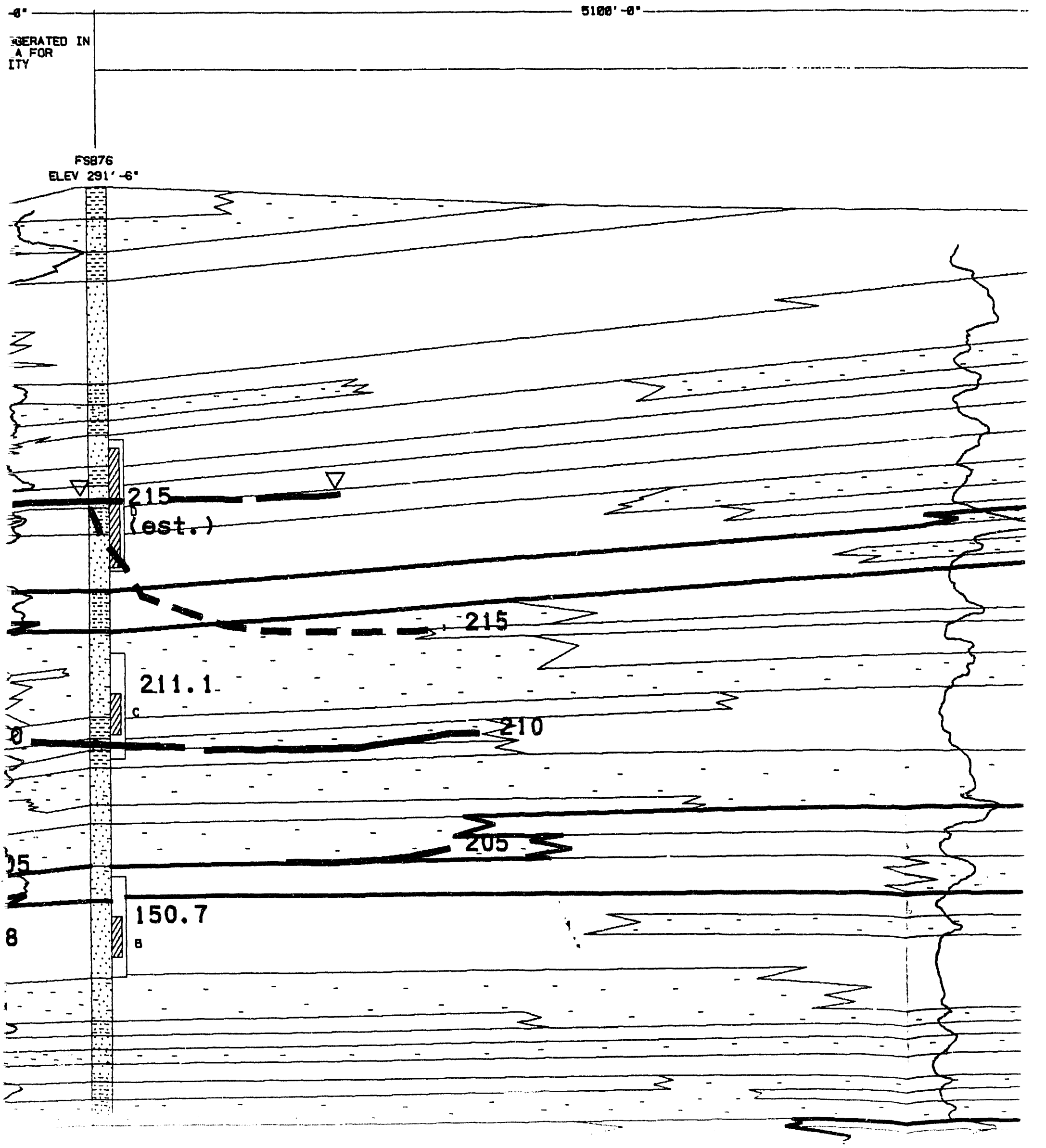


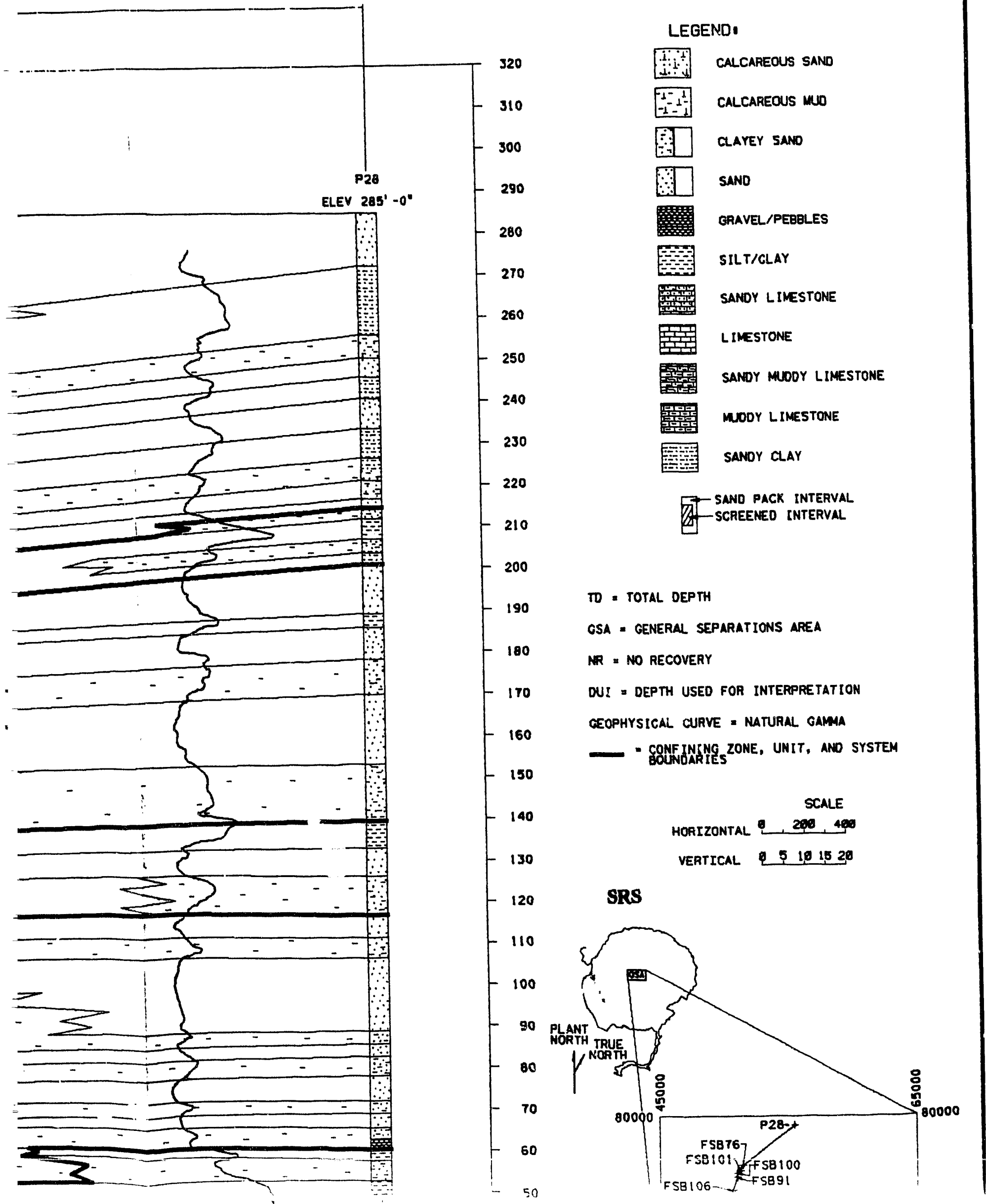




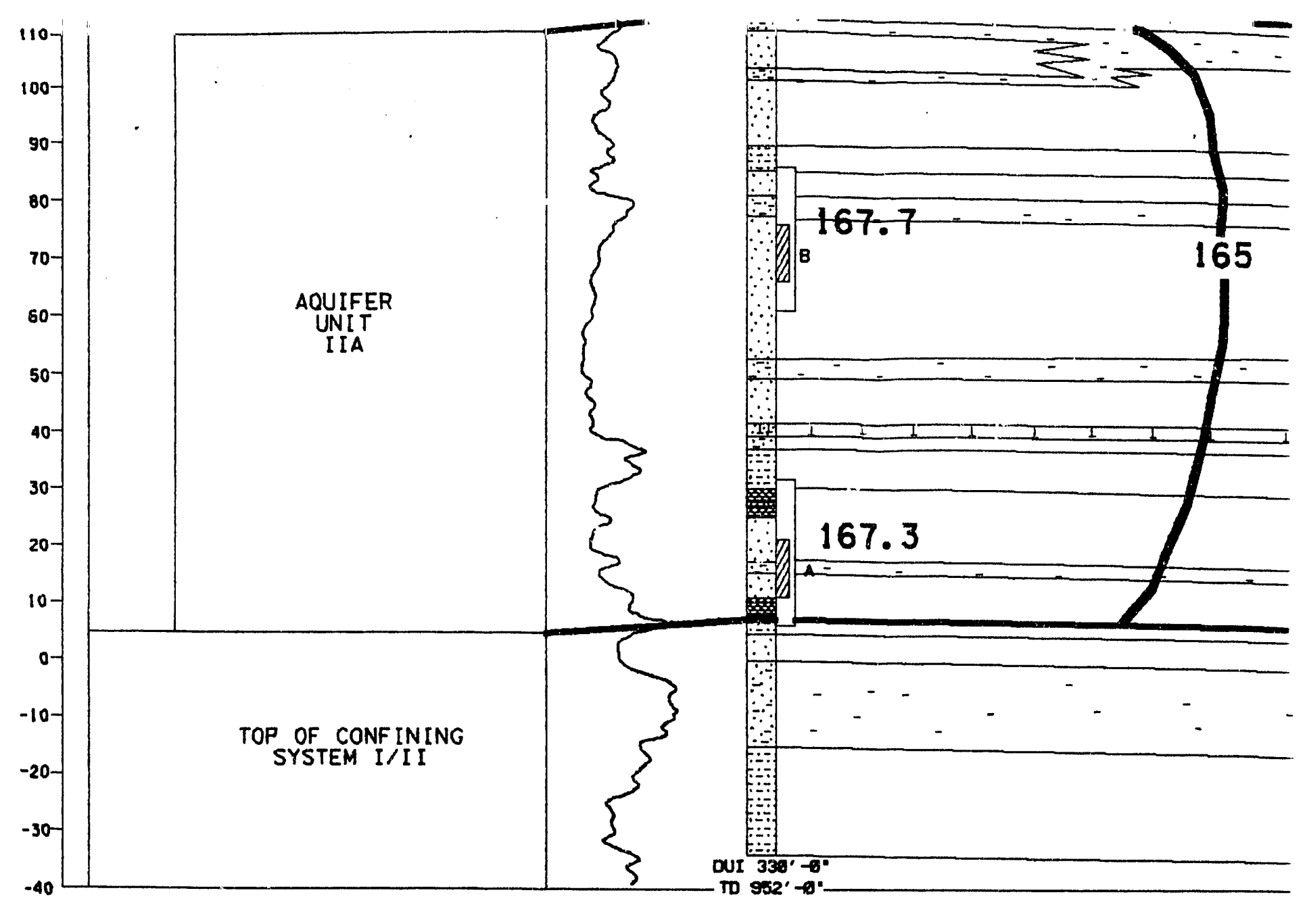




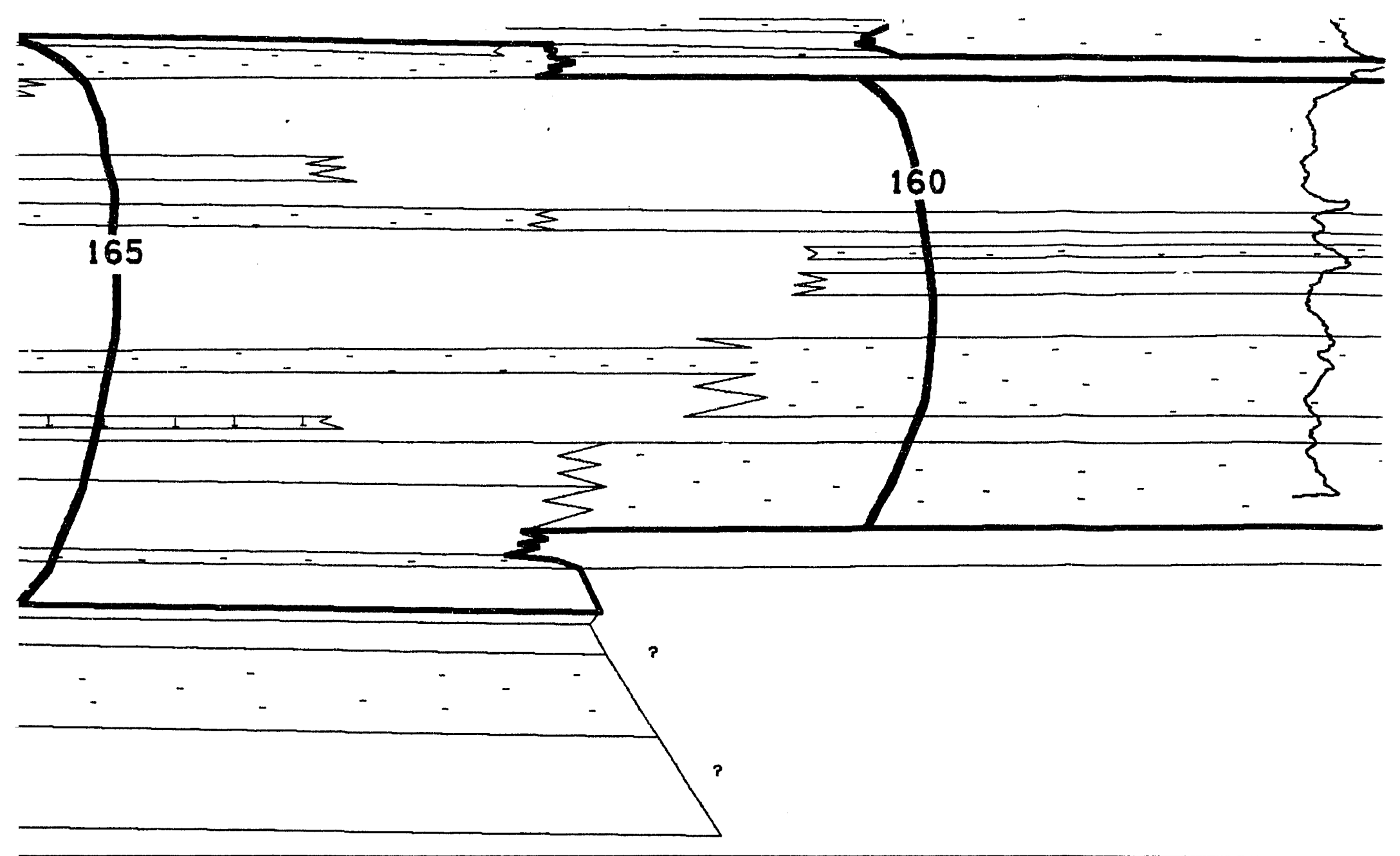




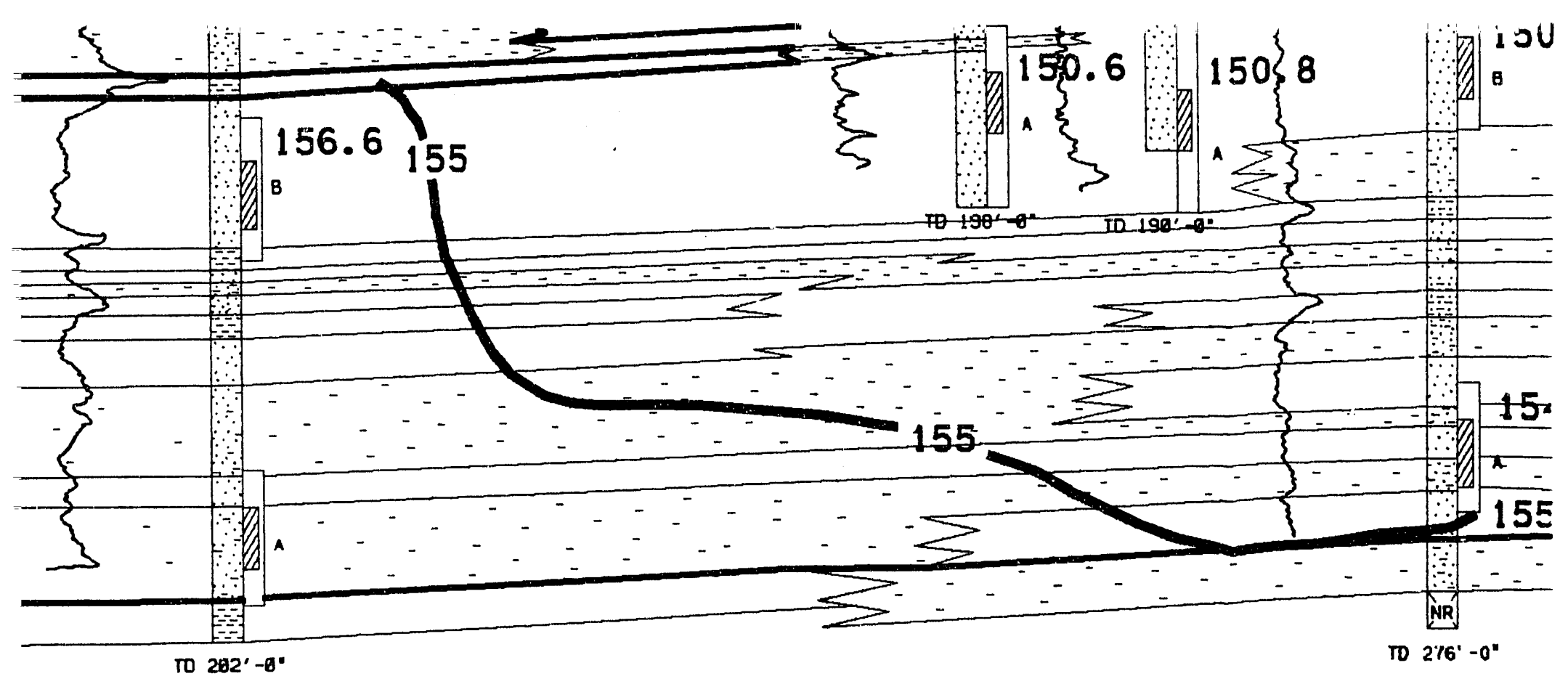




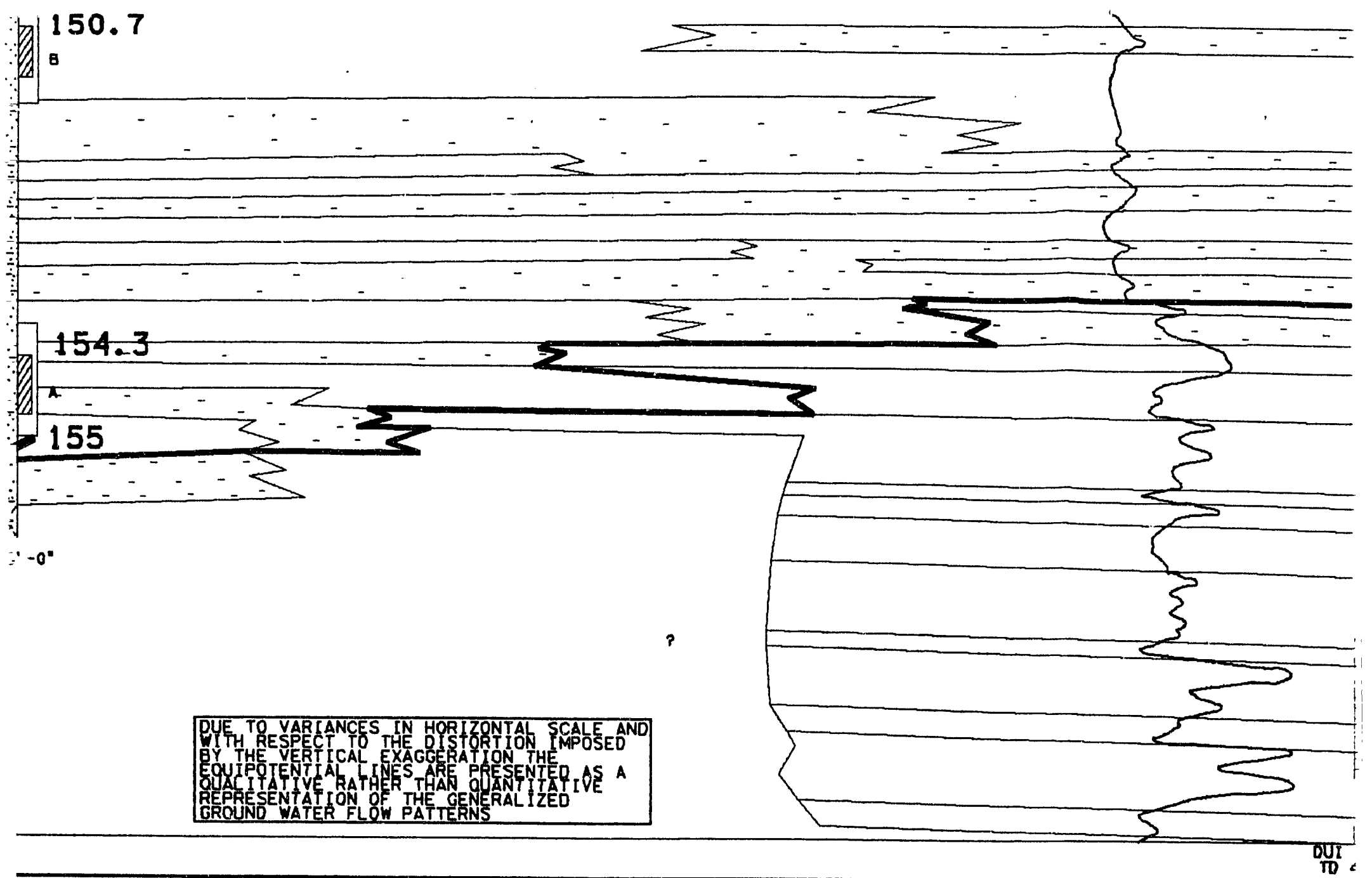




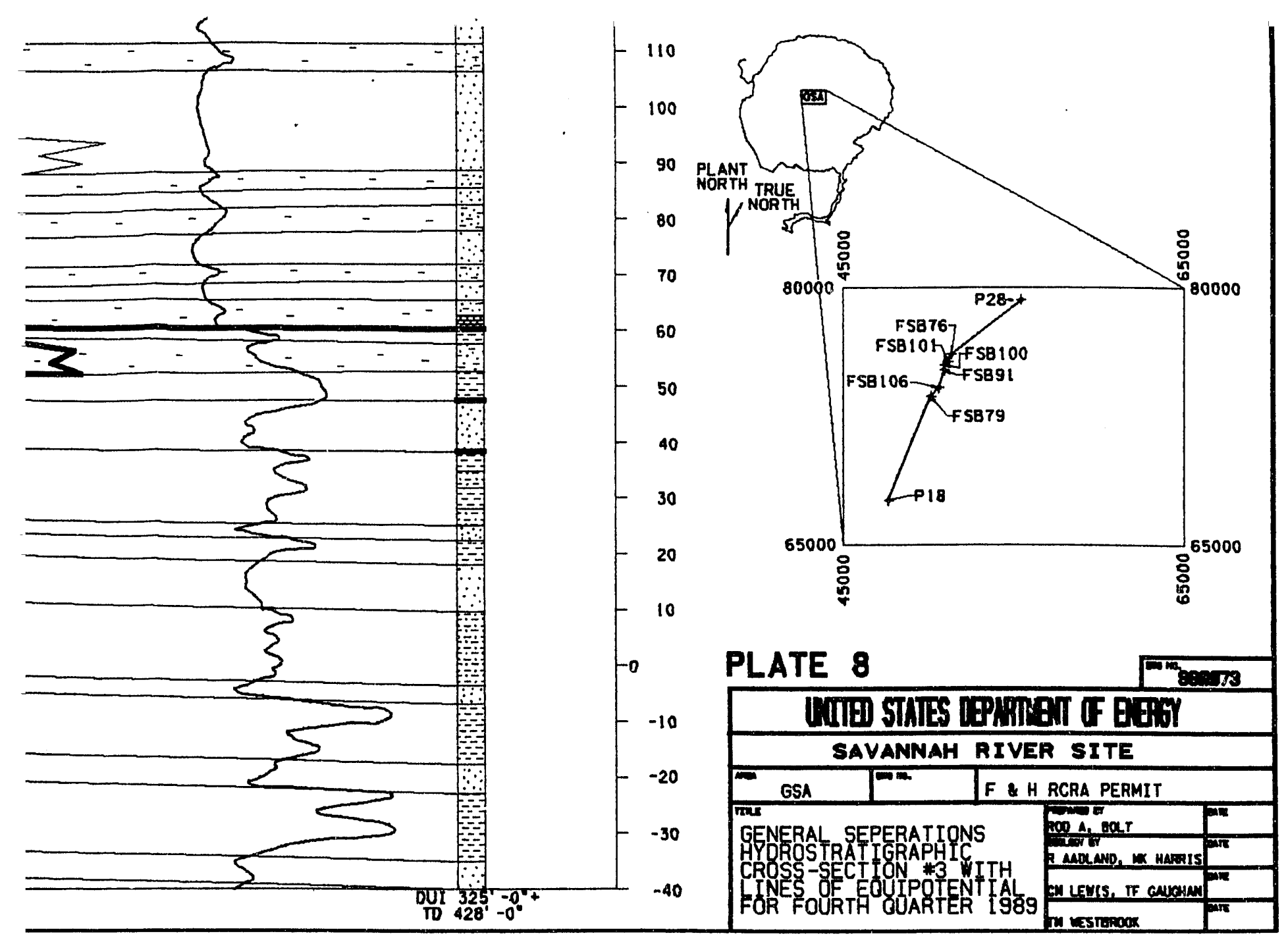




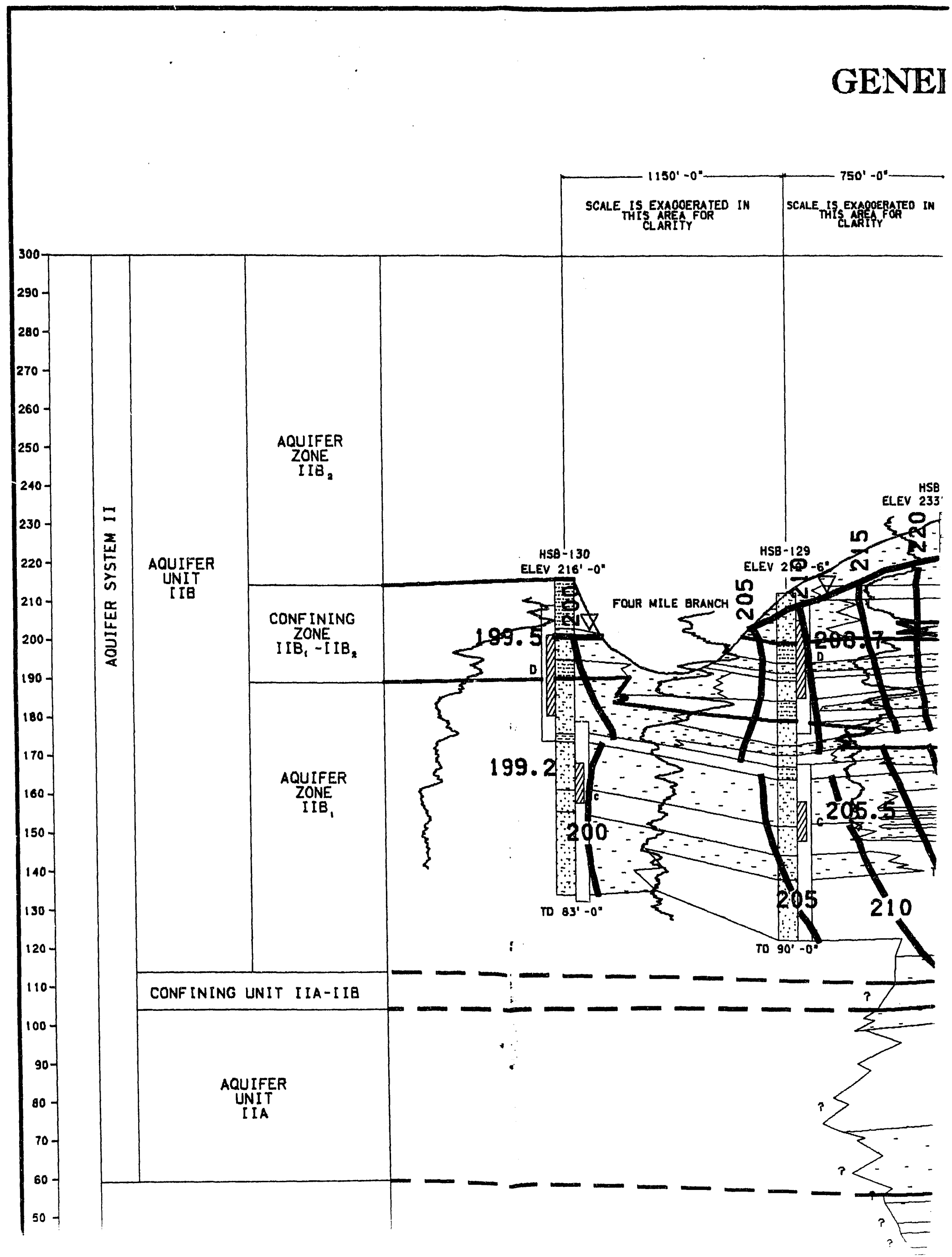


IENERAL SEPARATIONS AREA REGIONAL HYI CROSS-SECTION \# 4
$50^{\prime}-0^{\prime \prime}$
$380^{\prime}-0^{\circ}$
$140^{\prime}-0^{\circ}$
$240^{\prime}-0^{\circ}$
$230^{\prime}-0^{\prime \prime}$
$460^{\prime}-0^{\circ}-$

SCALE IS EXAGGERATED IN THIS AREATFOR
CLARITY

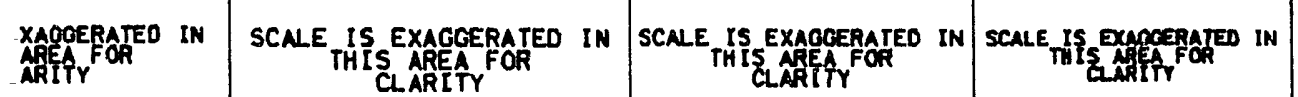

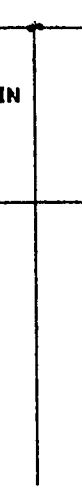

ELEV $267^{\circ}-0^{\circ}$

260' $-0^{\circ}$

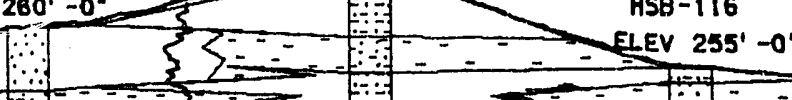

in $\xi 0^{233^{\prime}-6^{\prime}}$

(n)

3
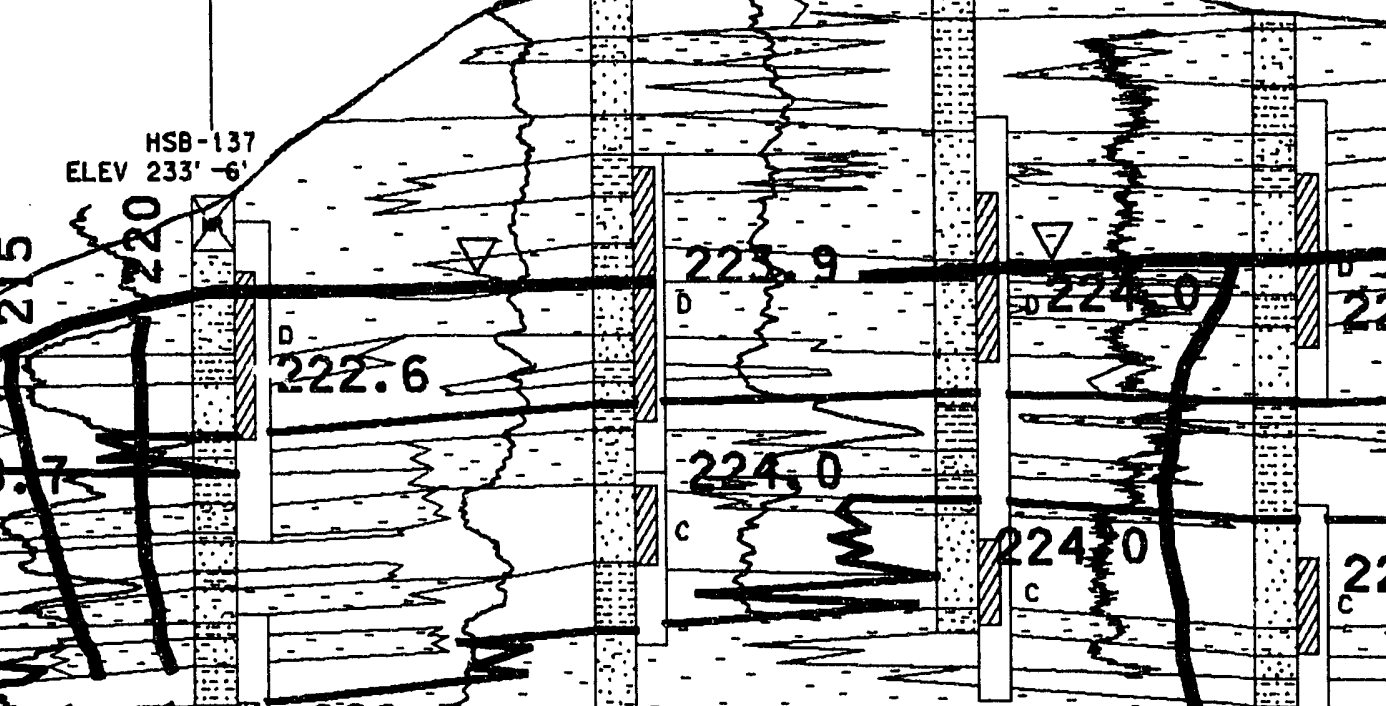

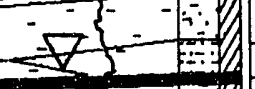
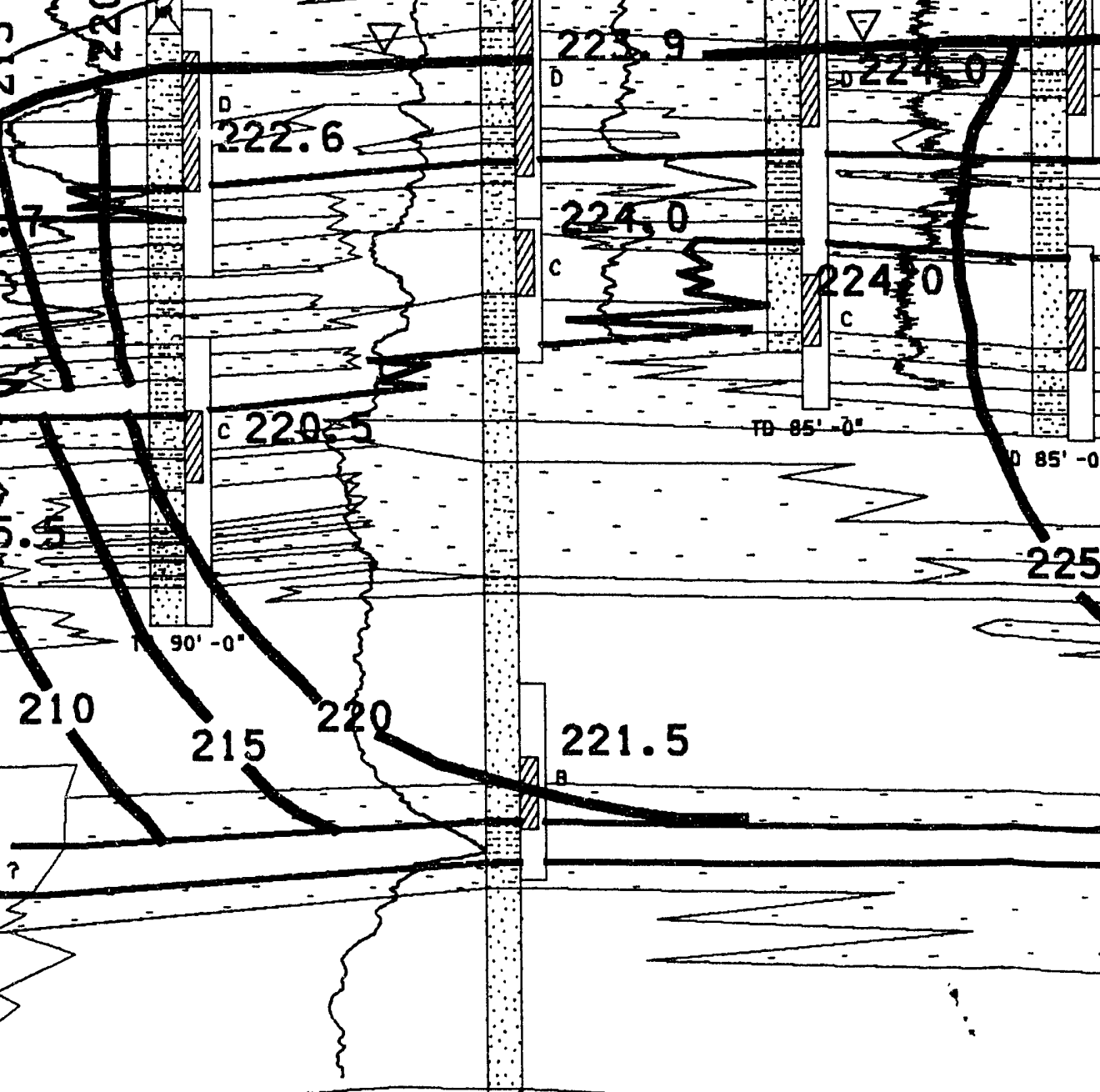

221.5

HSB -119 CALE IS EXAGGERATE
THIS AREA FOR
CLARITY

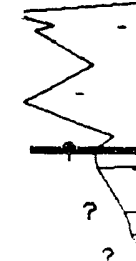

166.8 


\section{HYDROSTRATIGRAPHIC}

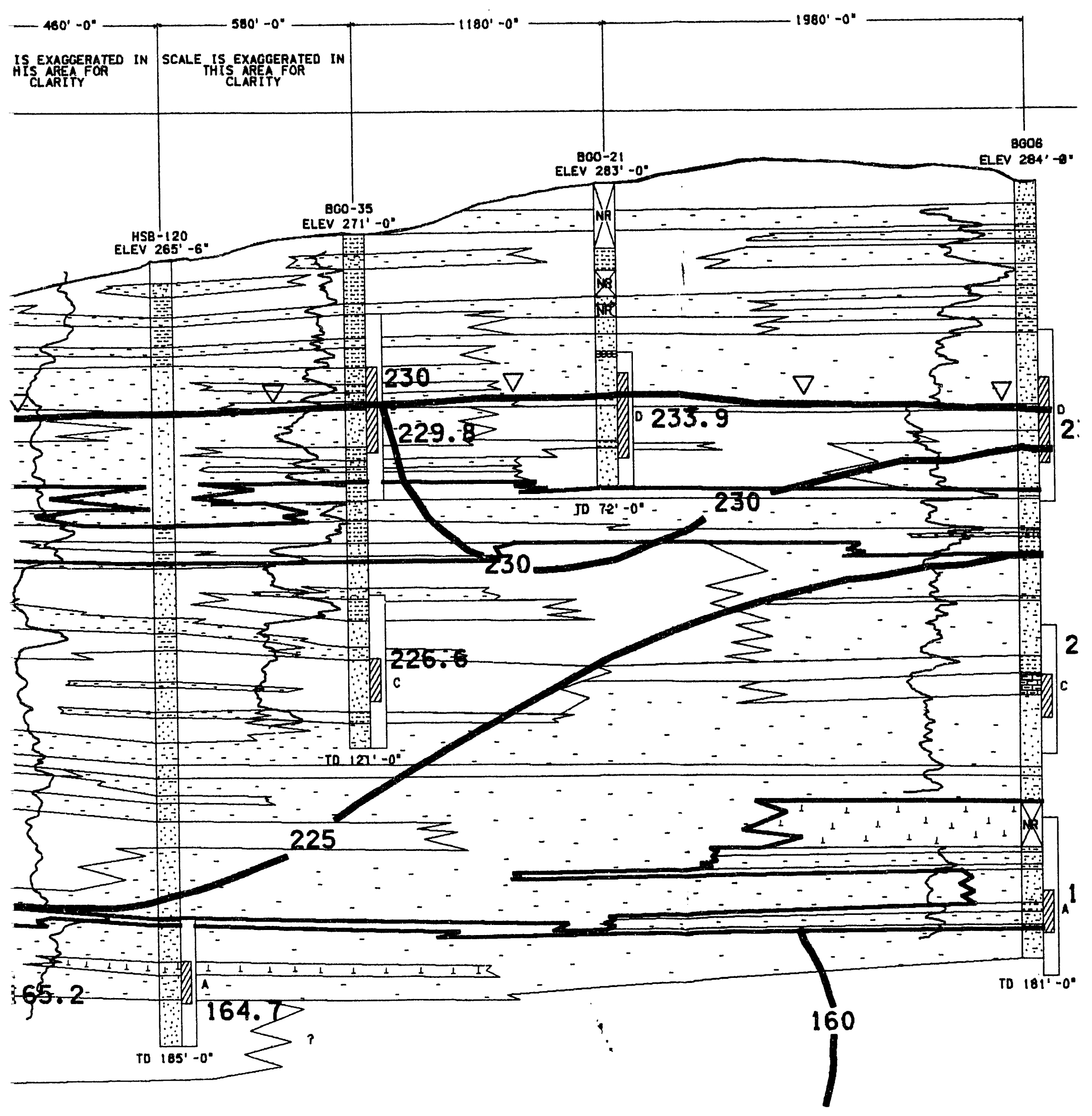




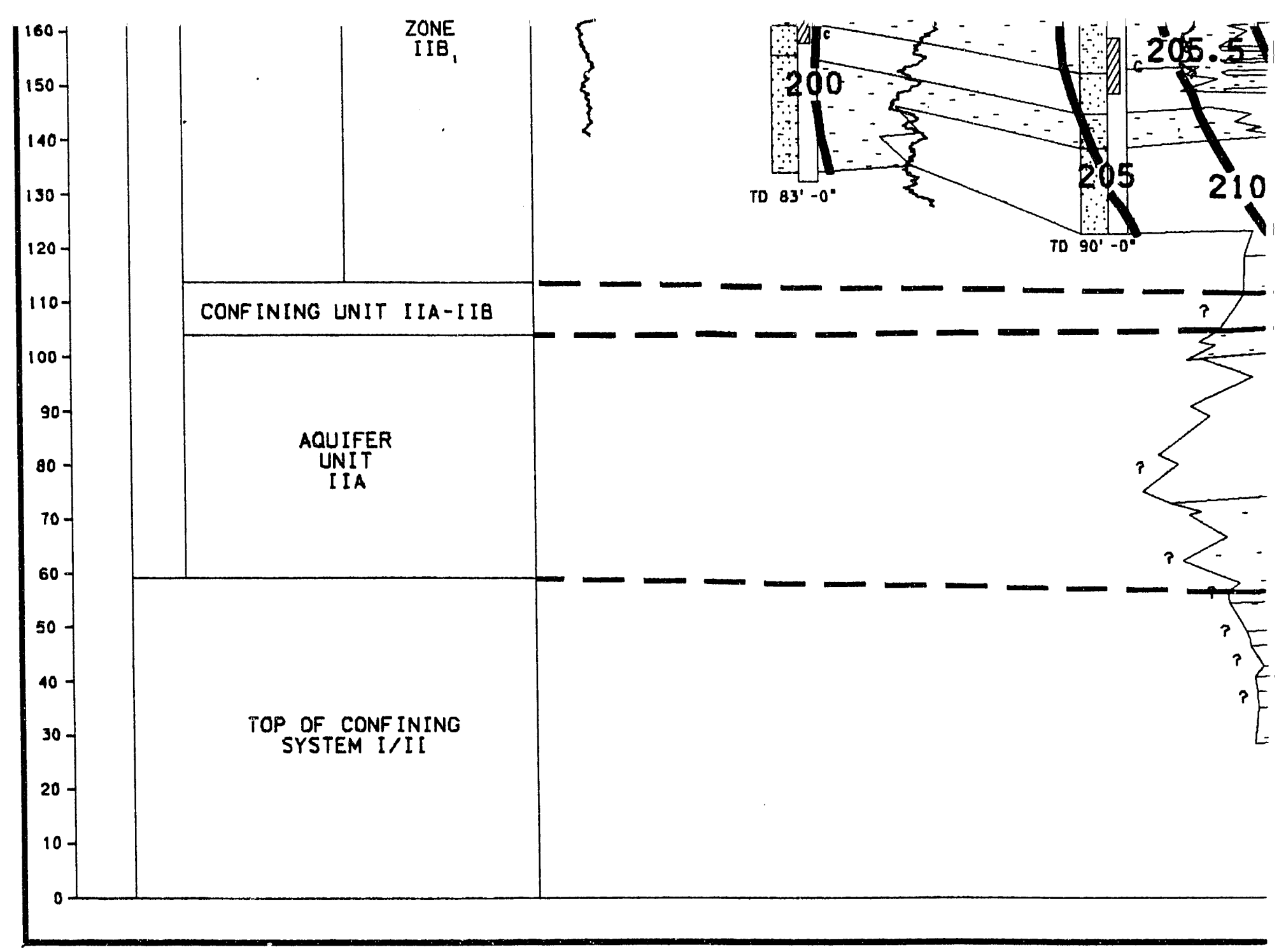



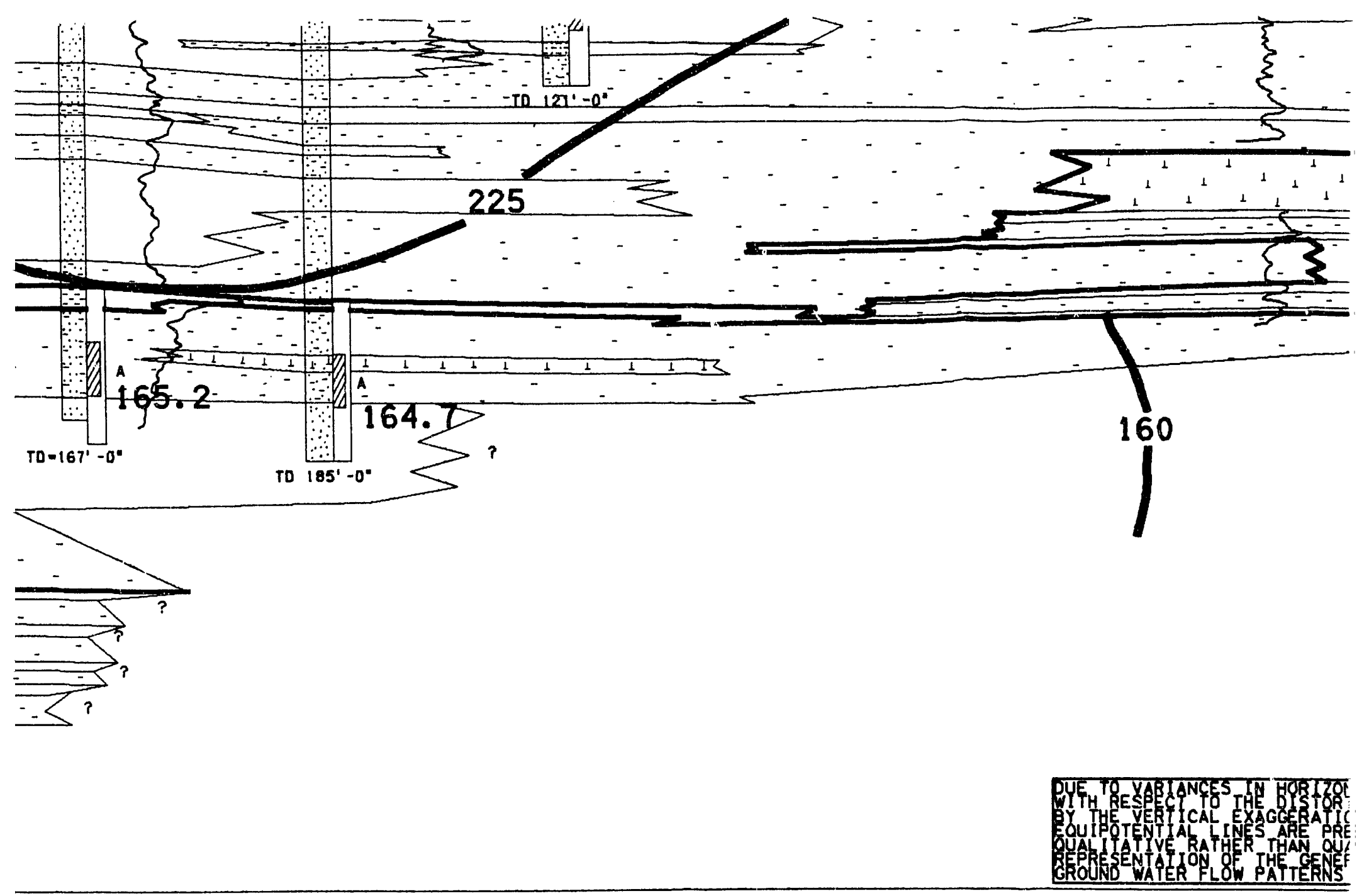


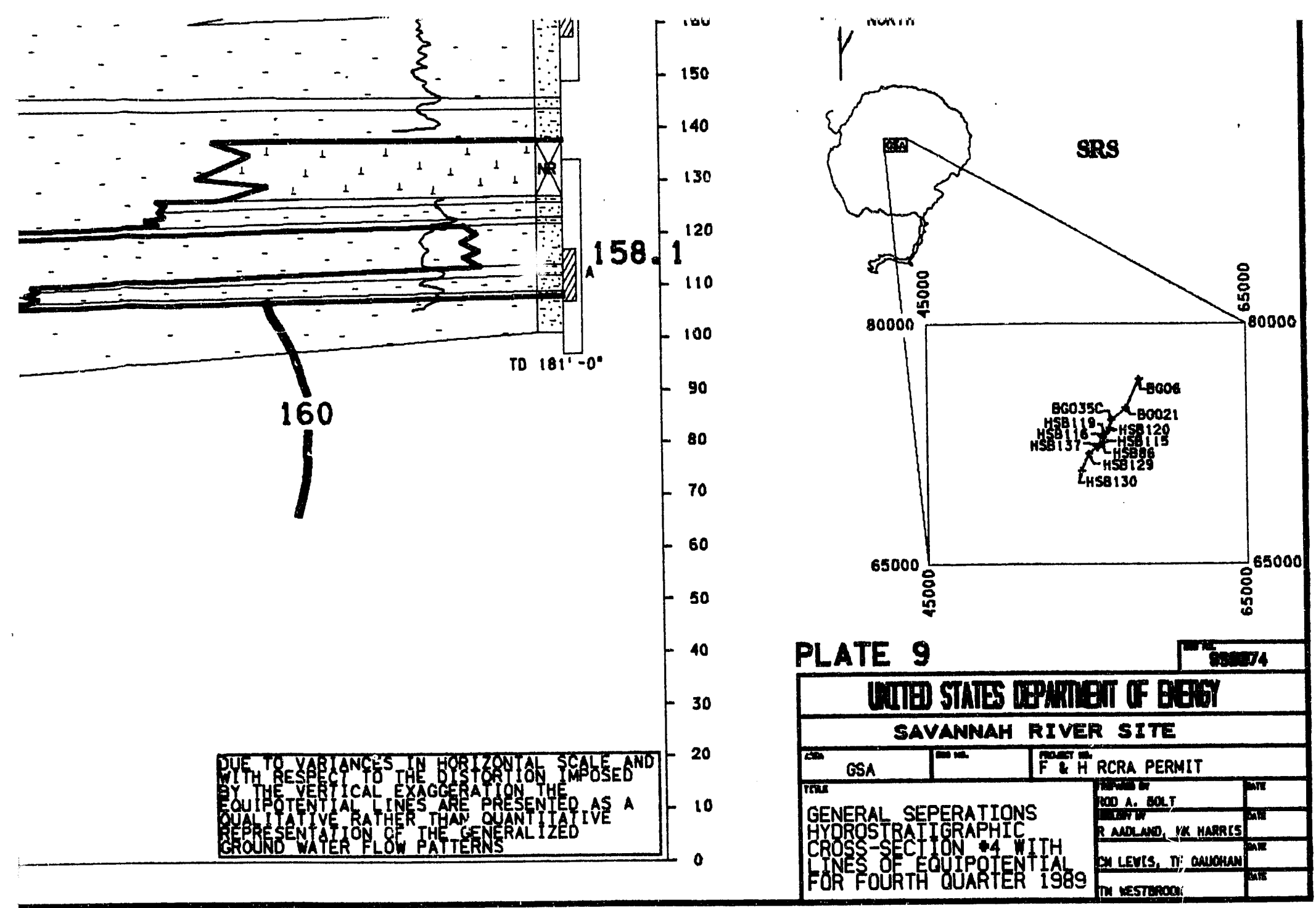




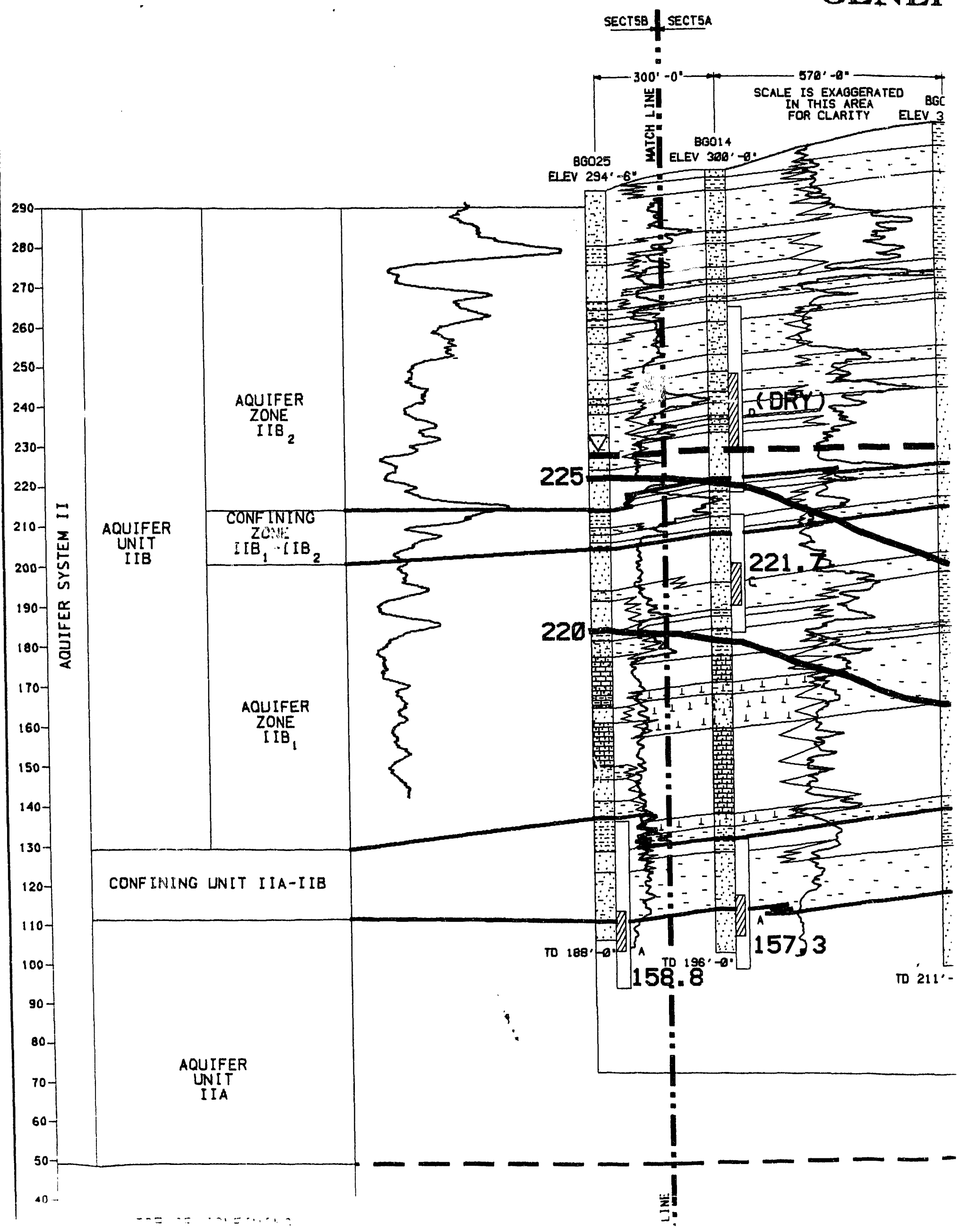




\section{RAL SEPARATIONS AREA REGIONAL HYDROS}

\section{CROSS-SECTION \# 5A}

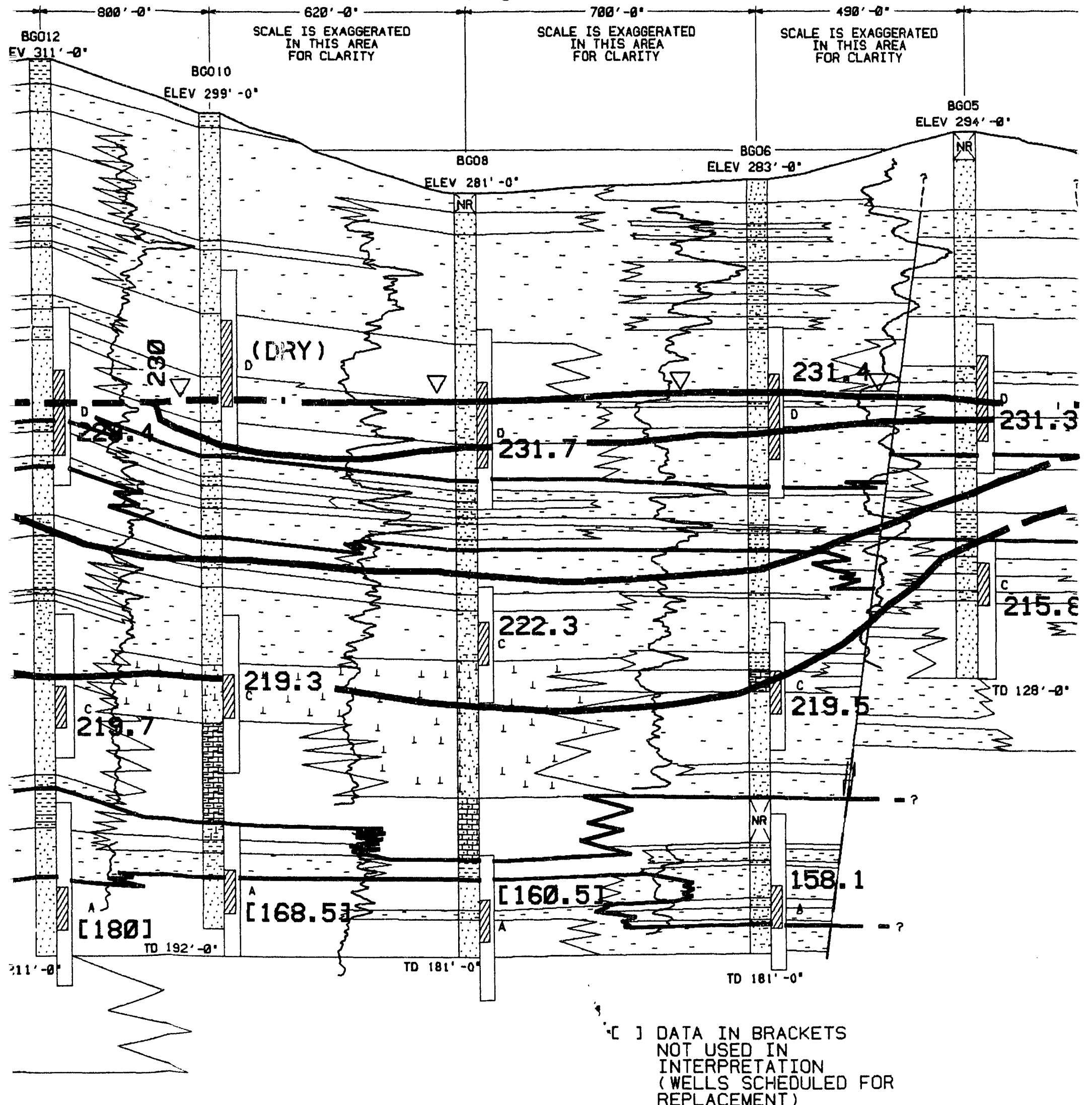




\section{YDROSTRATIGRAPHIC}

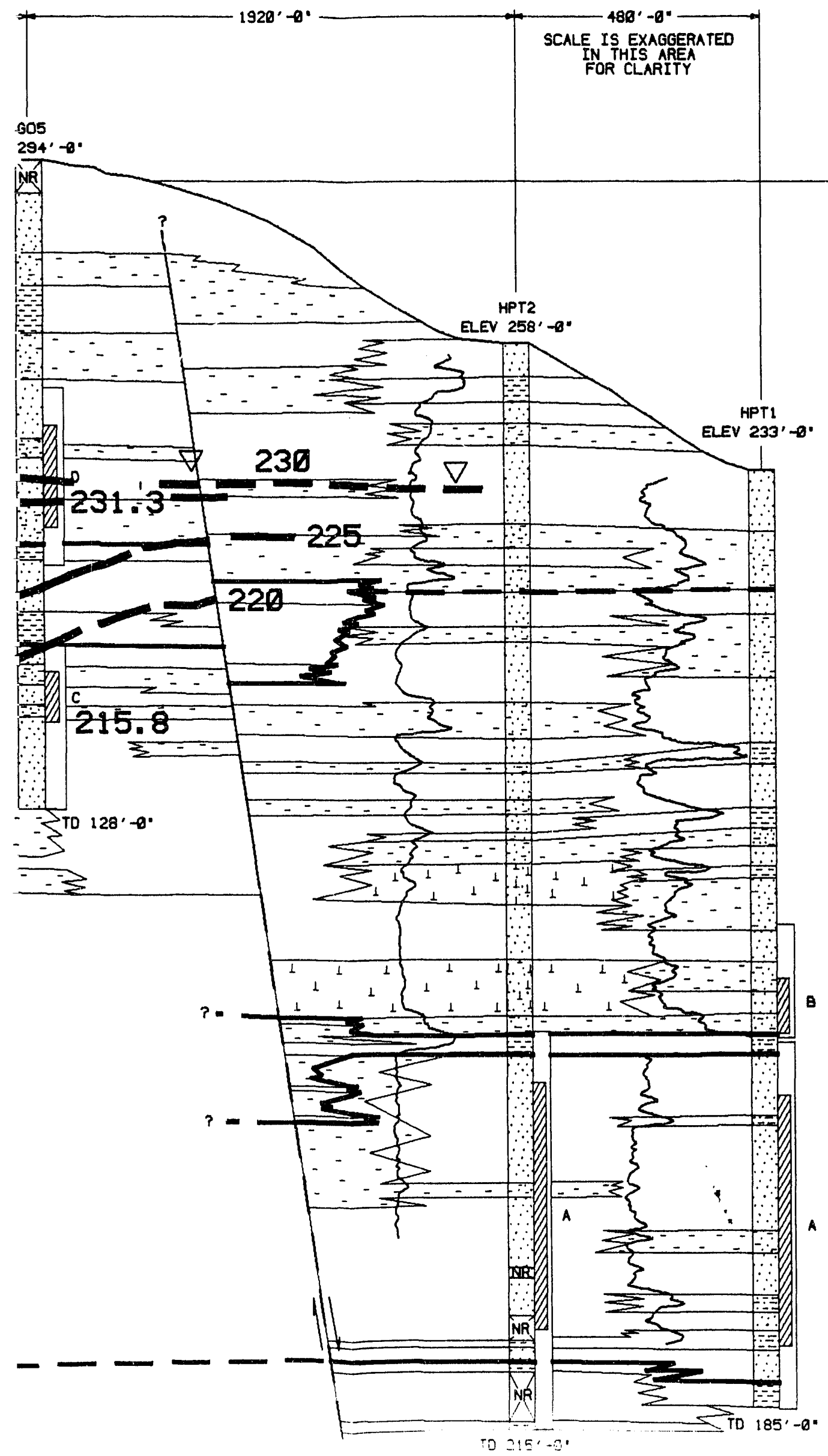

LEGEND:

i.

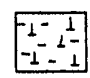

-
$\therefore$

$-290$

$-280$

$-270$

$-260$

$-250$

$-240$

$-230$

$-230$

$-220$

$-210$

$-200$

$-190$

$-180$

$-170$

$-160$

$-150$

$-140$

$-140$

$-130$

$-120$

$-110$

$-110$

$-100$

90

$-80$

$-80$

$-70$

$-60$

50

$\because$

㙎垶

$=-1$

临

证

豎望

TD = TOTAL DEPTH

NR - NO RECOVERY
CALCAREOUS SAND

CALCAREOUS MUD

CLAYEY SAND

LIMESTONE

SANDY MUDDY LIM

MUDO:' LIMESTONE

SANOY CLAY

TA SAND PACK INTERVE SCIREENED INTERVAL

GSA = GENERAL SEPARATIONS

- CONFINING ZONE, UNIT GEOPHYSICAL CURVE $=$ NATUR. DUI = DEPTH USED FOR INTEI

VERTICAL 51015 :

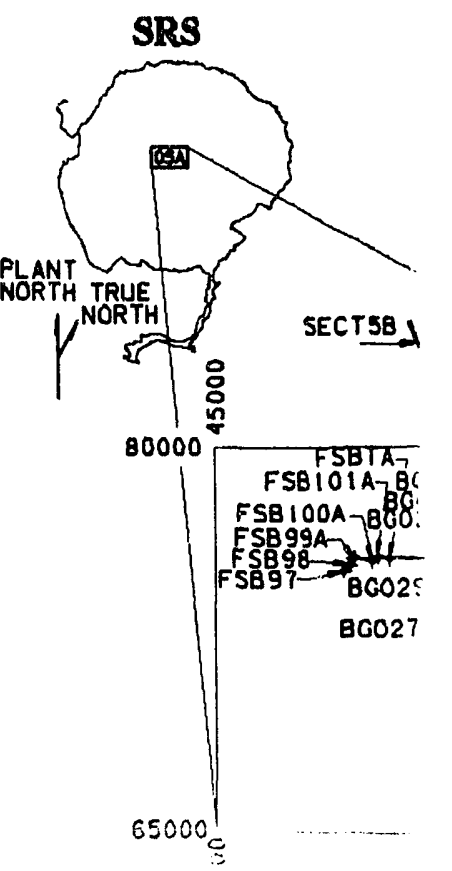




\section{IPHIC}

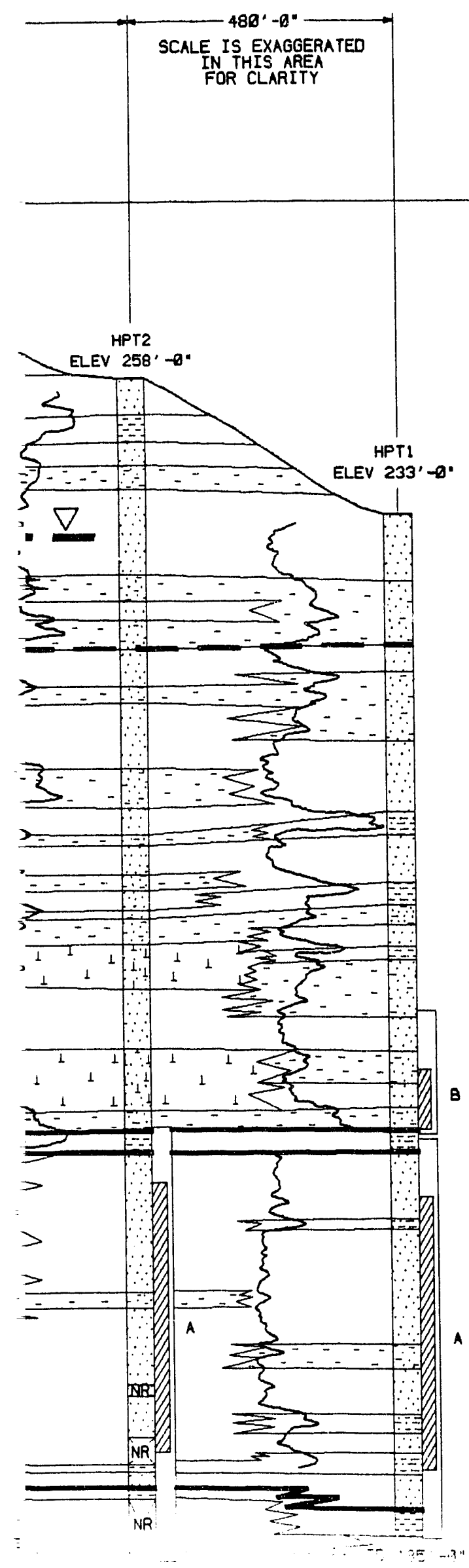

\section{LEGEND:}

i.

$\begin{array}{cc}2 & 1 \\ -2 & 2 \\ -2 & -2\end{array}$

$\therefore$

290

$-280$

$-270$

$-260$

$-250$

$-240$

240

$-230$

$-220$

$-210$

$-200$

200

$-190$

$-180$

$-170$

-160
-170

$-160$

$-150$

$-140$

$-130$

$-120$

$-110$

$-100$

$-100$

- 90

$-80$

70
$-\quad 70$

60

50
CALCAREOUS SAND

calcareous mU

CLAYEY SAND

SAND

GRAVEL/PEBBLES

SILT/CLAY

SANDY LIMESTONE

LIMESTONE

SANOY MUDDY LIMESTONE

MUDOY LIMESTONE

SANDY CLAY

- SAND PACK INTERVAL

(4) SCREENED INTERVAL

TD = TOTAL DEPTH

GSA = GENERAL SEPARATIONS AREA

NR - NO RECOVERY

- CONFINING ZONE, UNIT, AND SYSTEM BOUNDRARIES. GEOPHYSICAL CURVE = NATURAL GAMMA DUI = DEPTH USED FOR INTERPRETATION

SCALE

HORLZONTAL $0,200,480$

VERTICAL 5101520

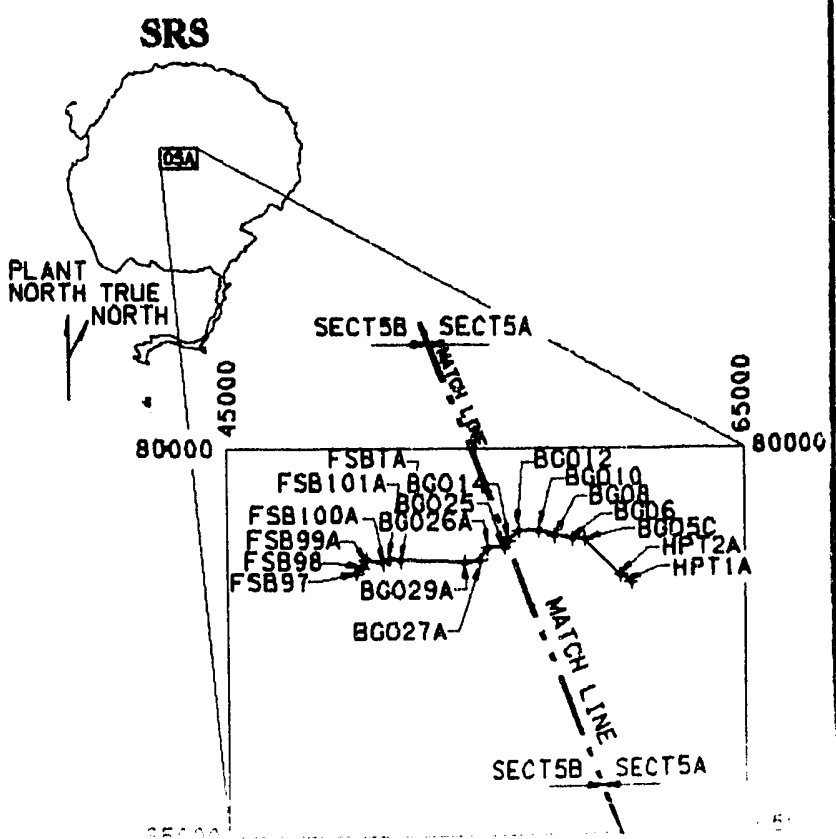



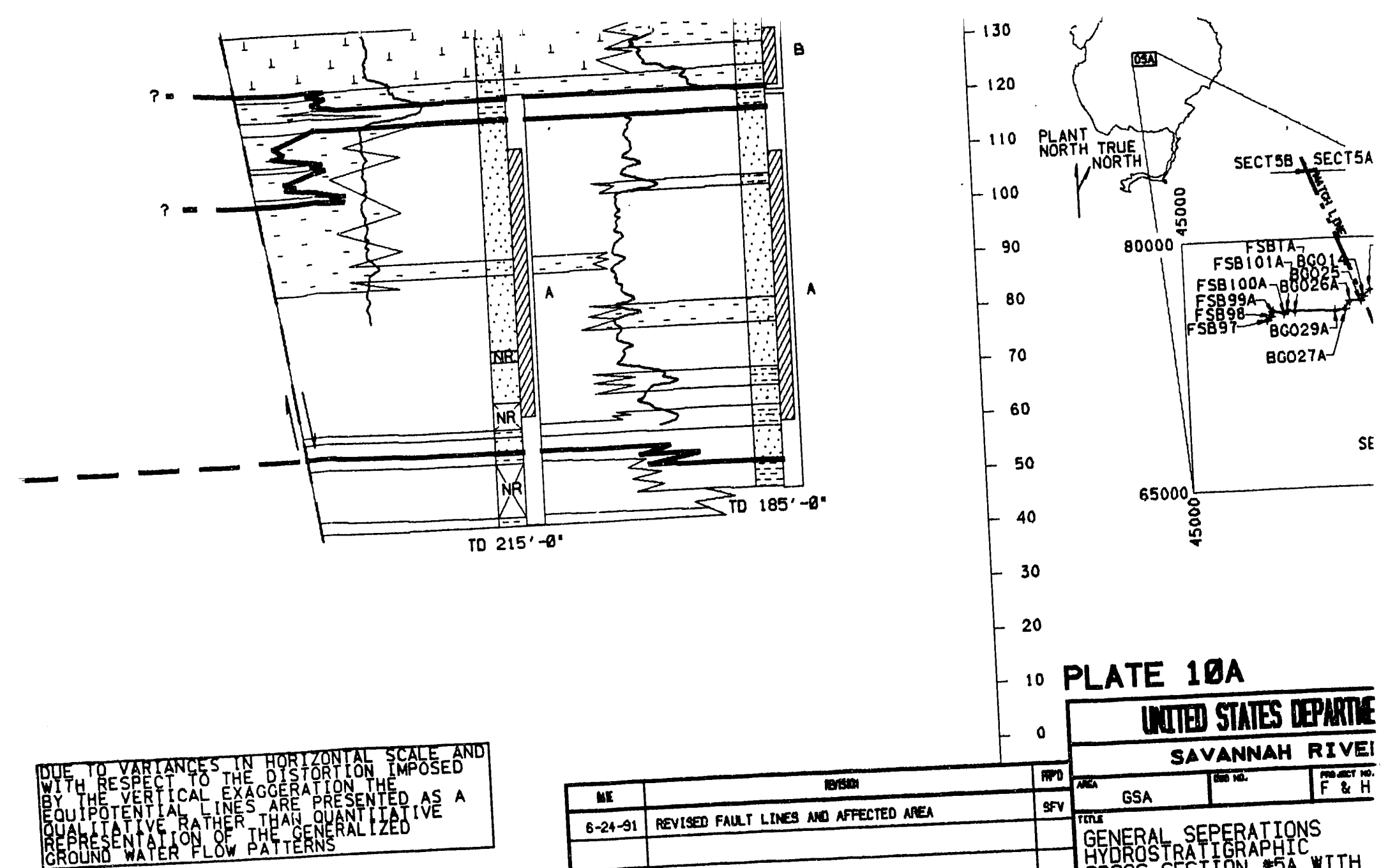

\begin{tabular}{|c|c|}
\hline$M$ & resim \\
\hline $6-24-91$ & PEVISED FAULT LINES NO AFFECTED APEA \\
\hline & \\
\hline & \\
\hline & 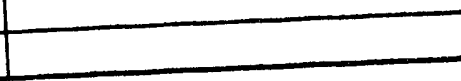 \\
\hline
\end{tabular}

Plate 10a

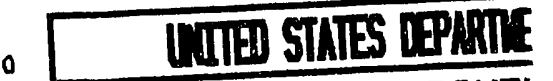

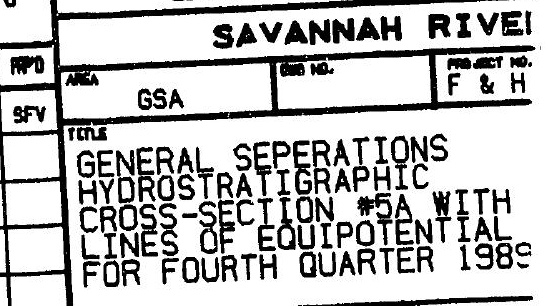




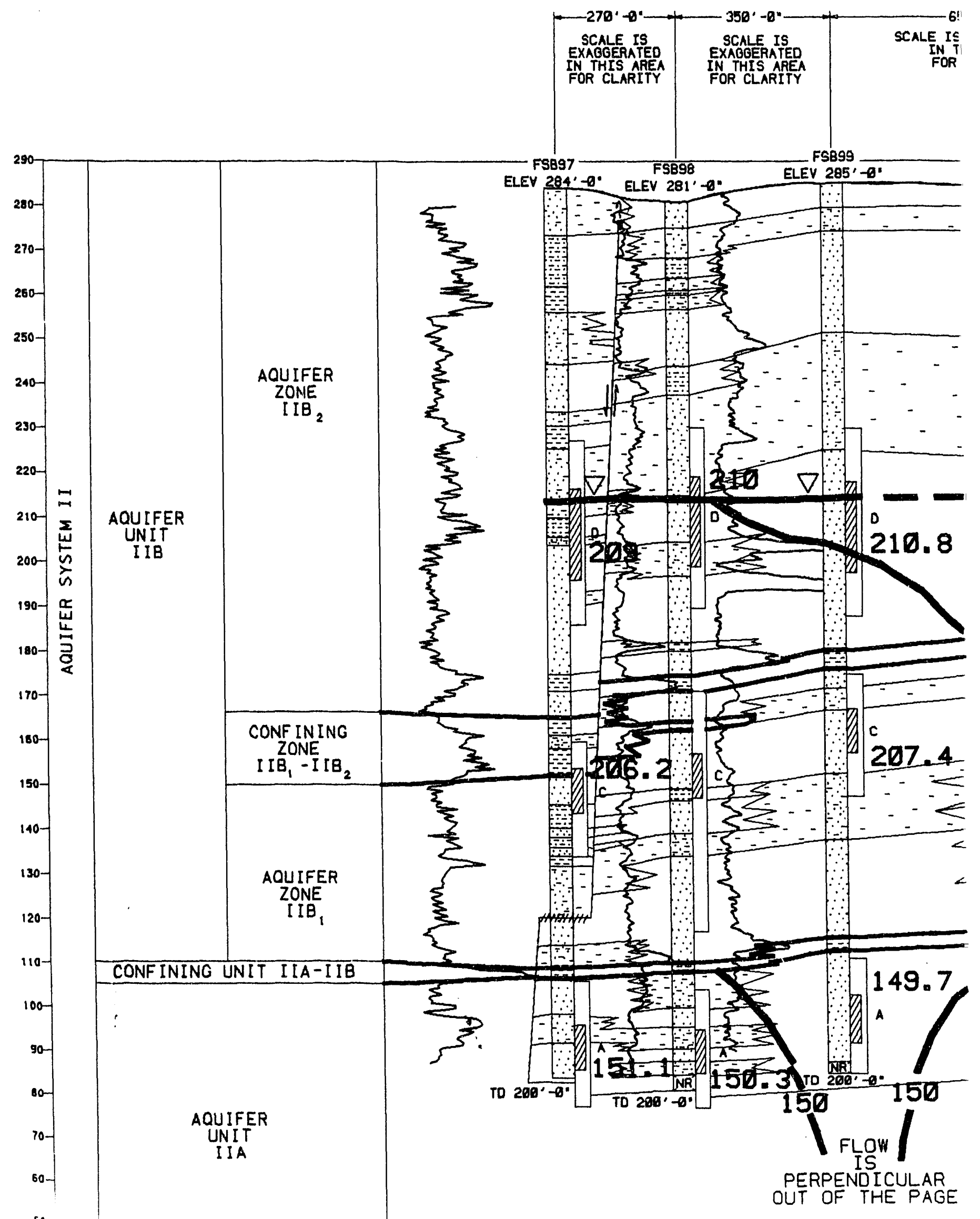


ERAL SEPARATIONS AREA REGIONAL HYDROS CROSS - SECTION \# $5 B$

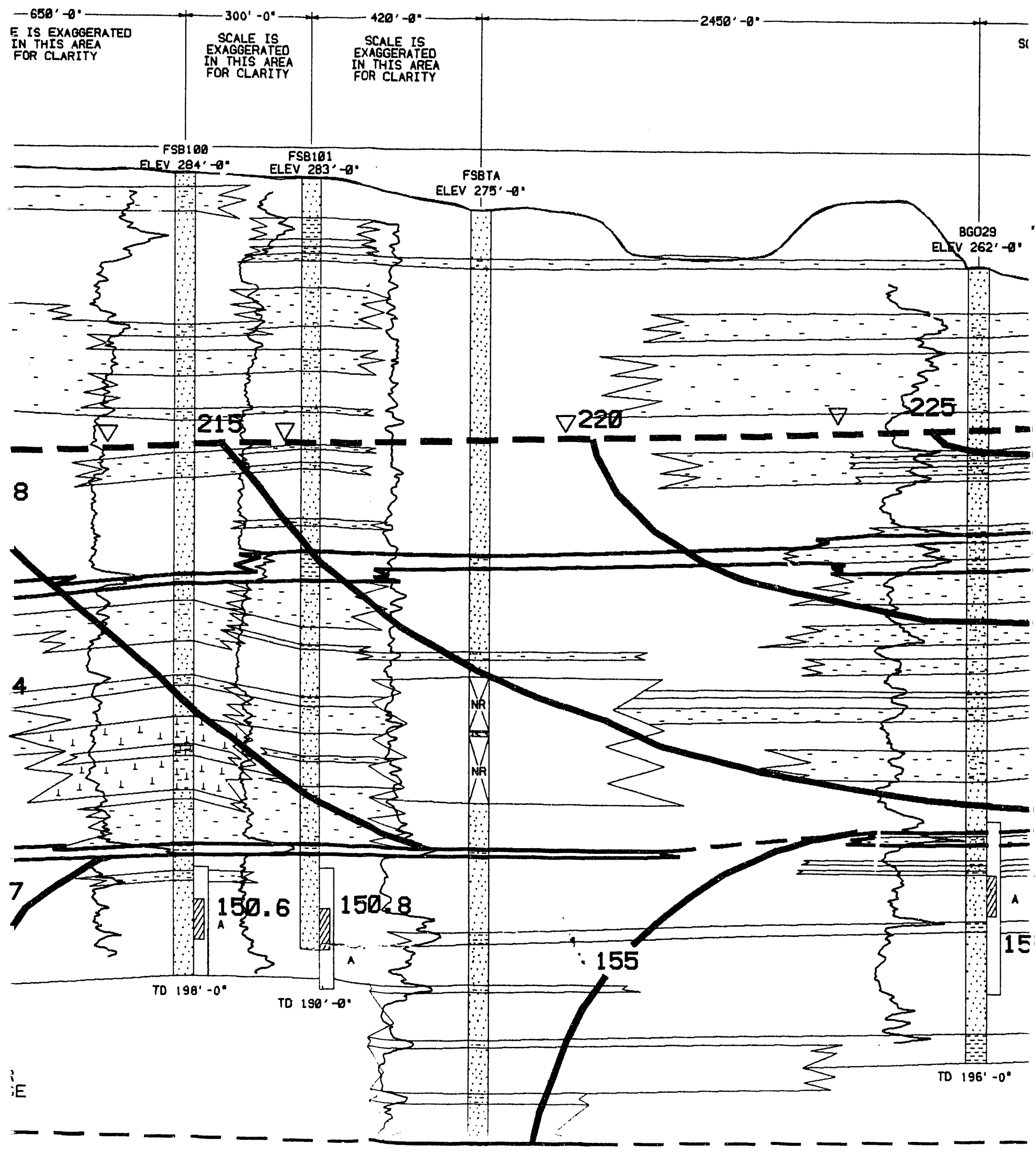



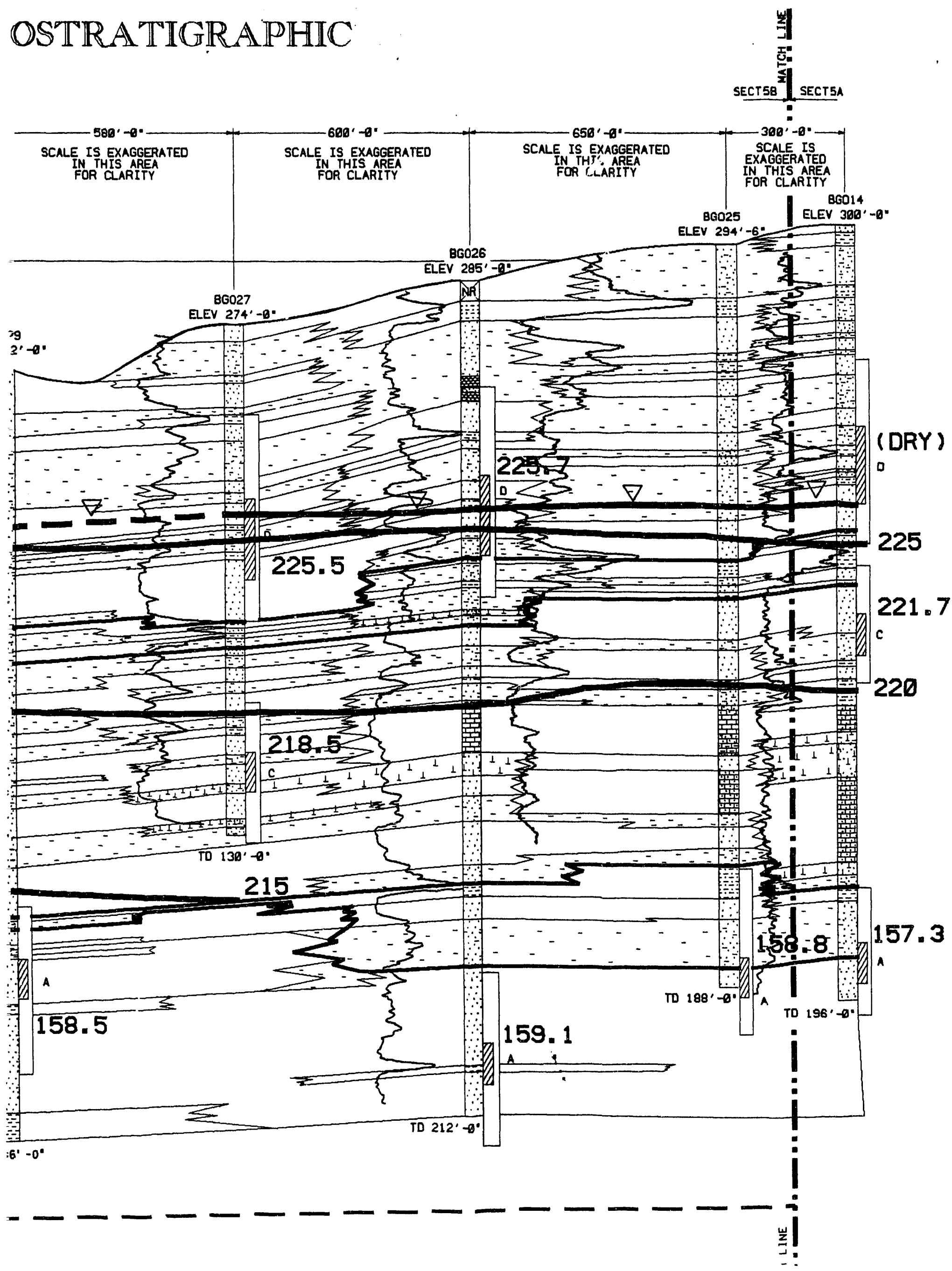


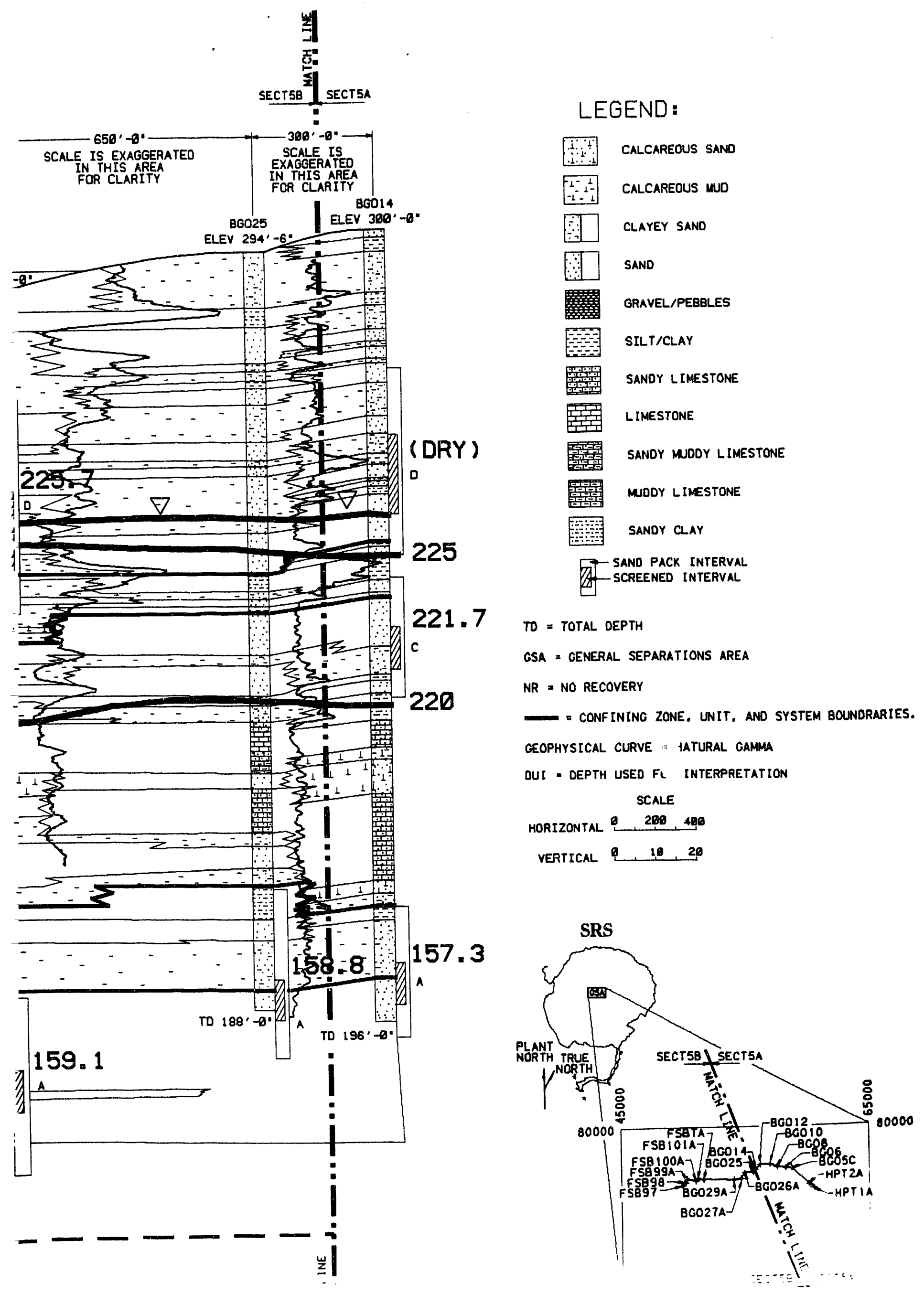




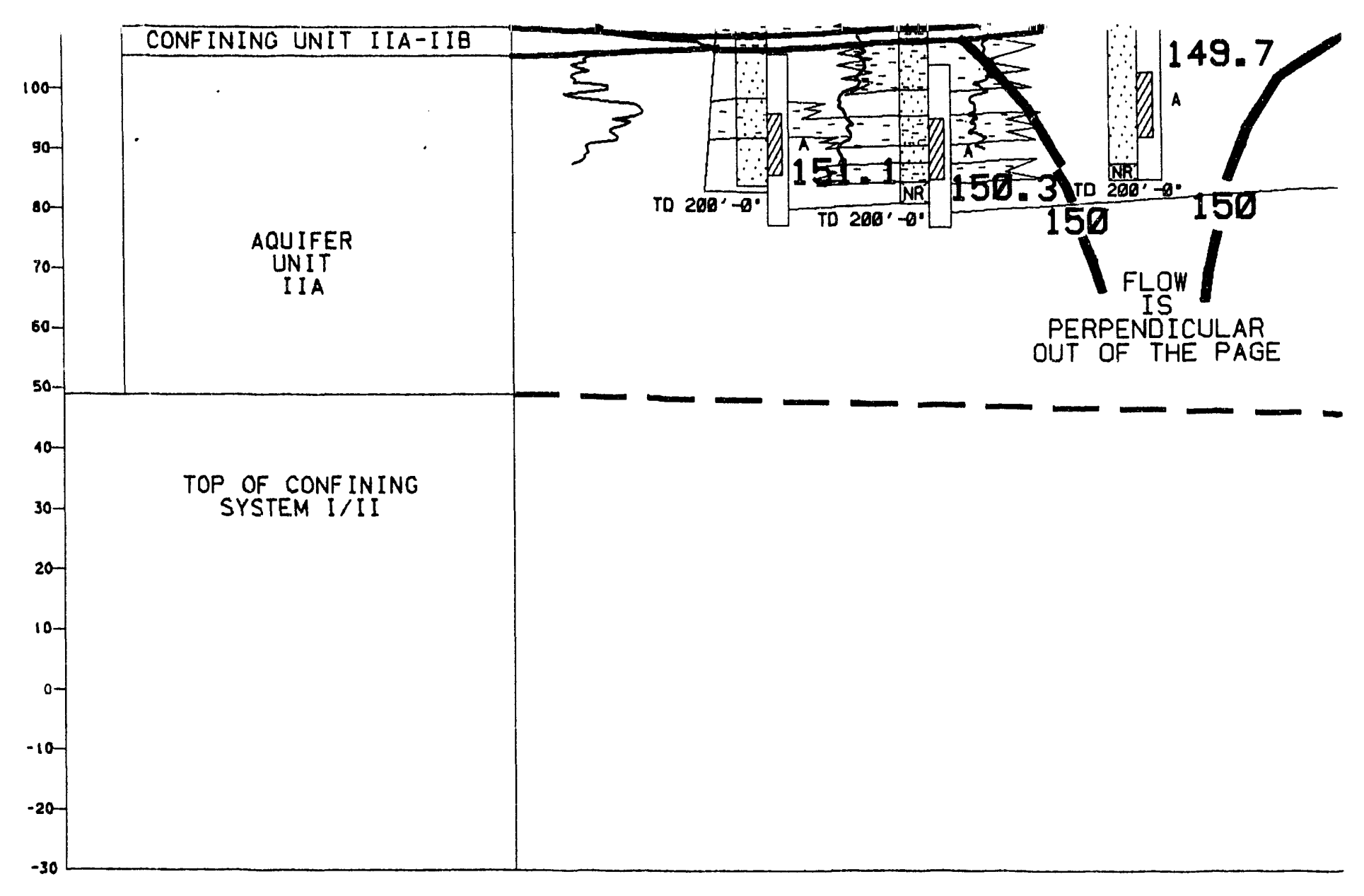




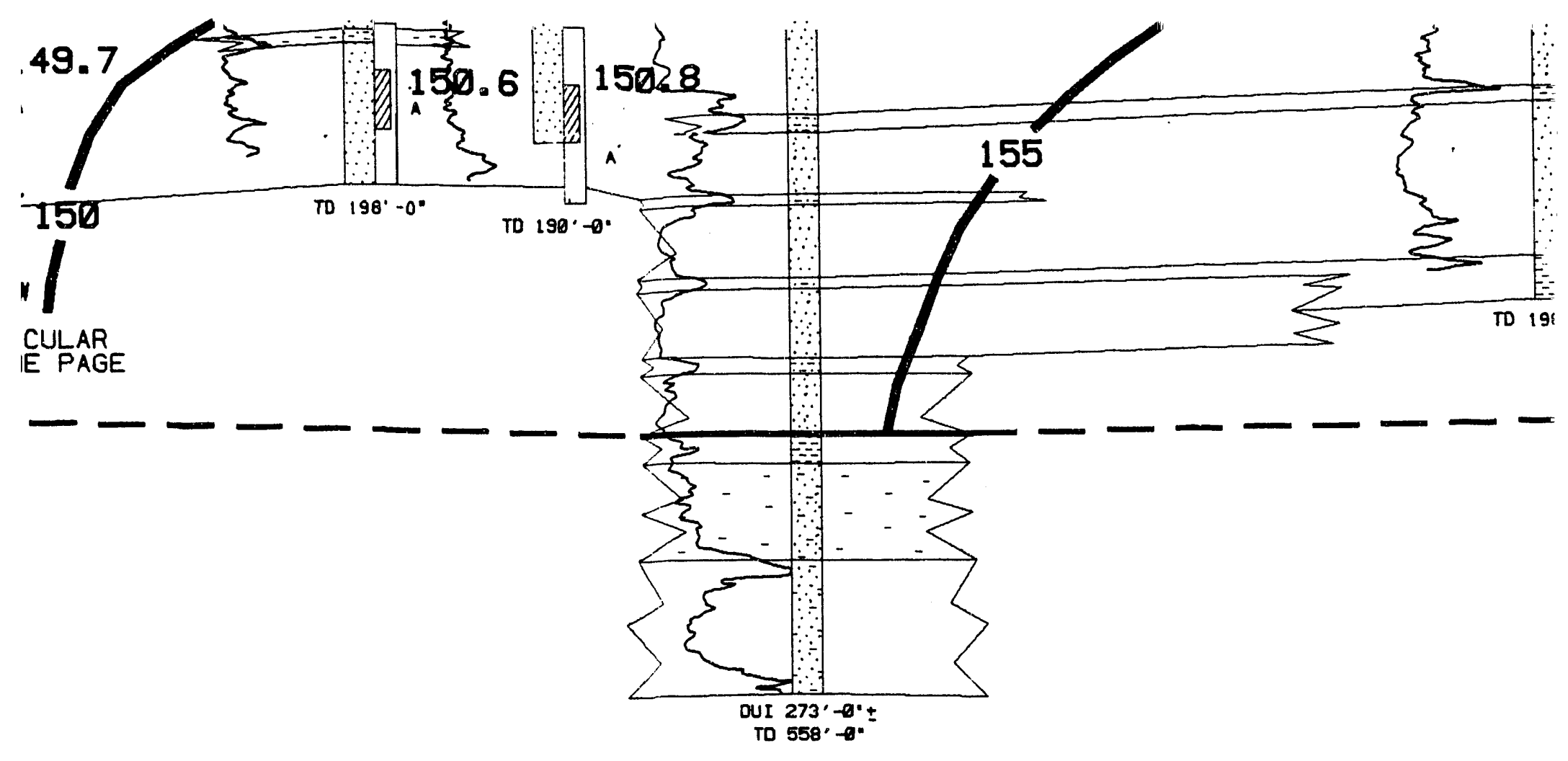


159.1

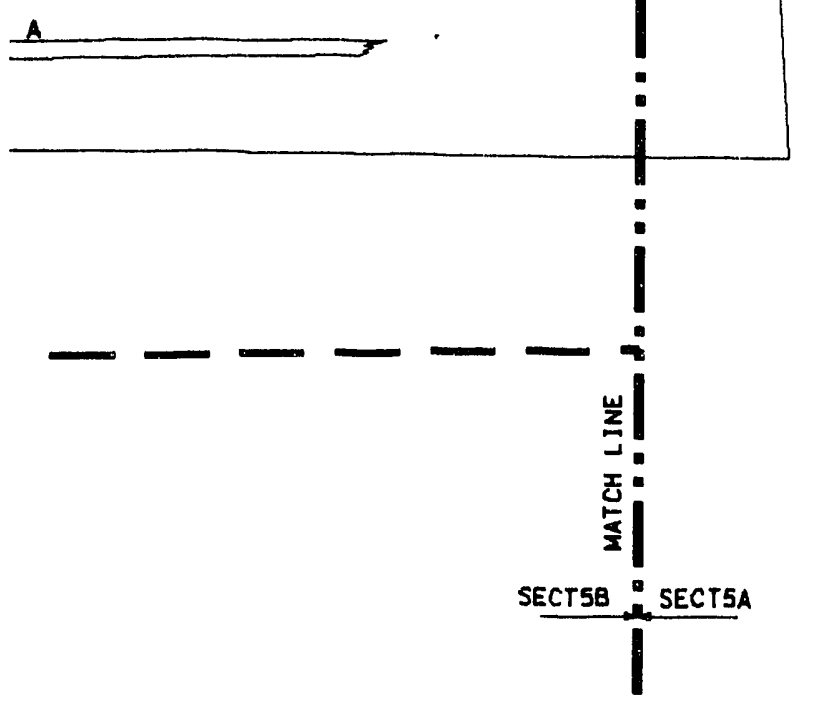

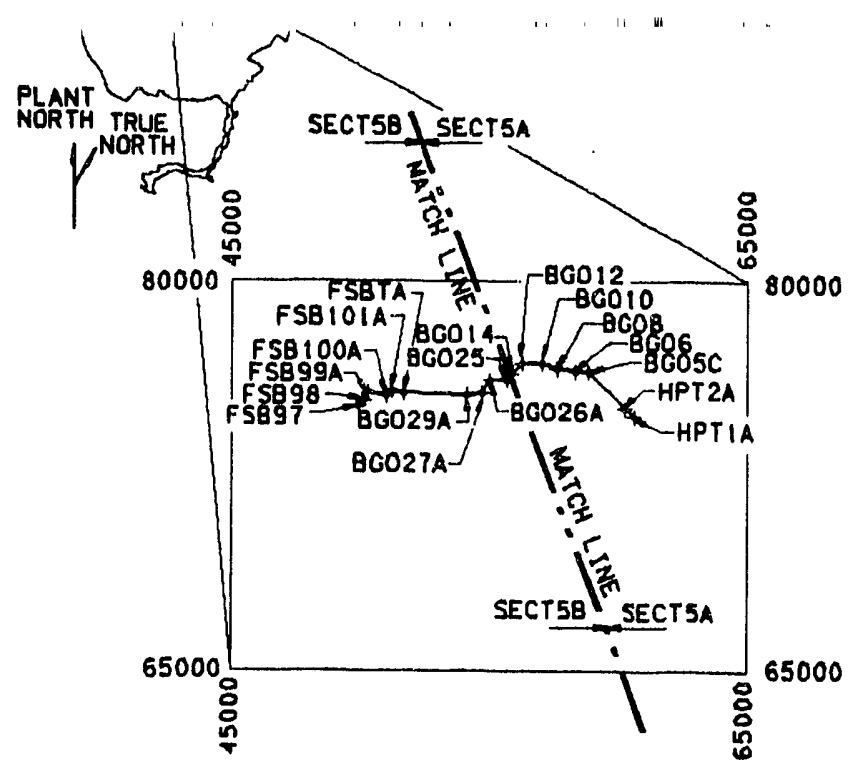

PLATE 10B

$8 \mathrm{a}, 11$

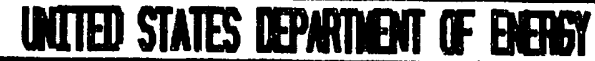
SAVANNAH RIVER SITE

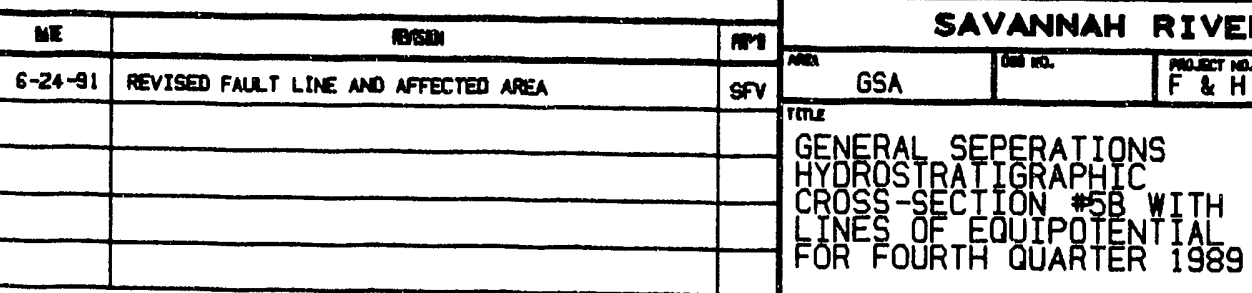

H RCRA PERMIT

R.A. BOLI/S.F. via

3 ANOLND, M HARAIS

bu LEVIS, If GANOHAN

the vestaroox 

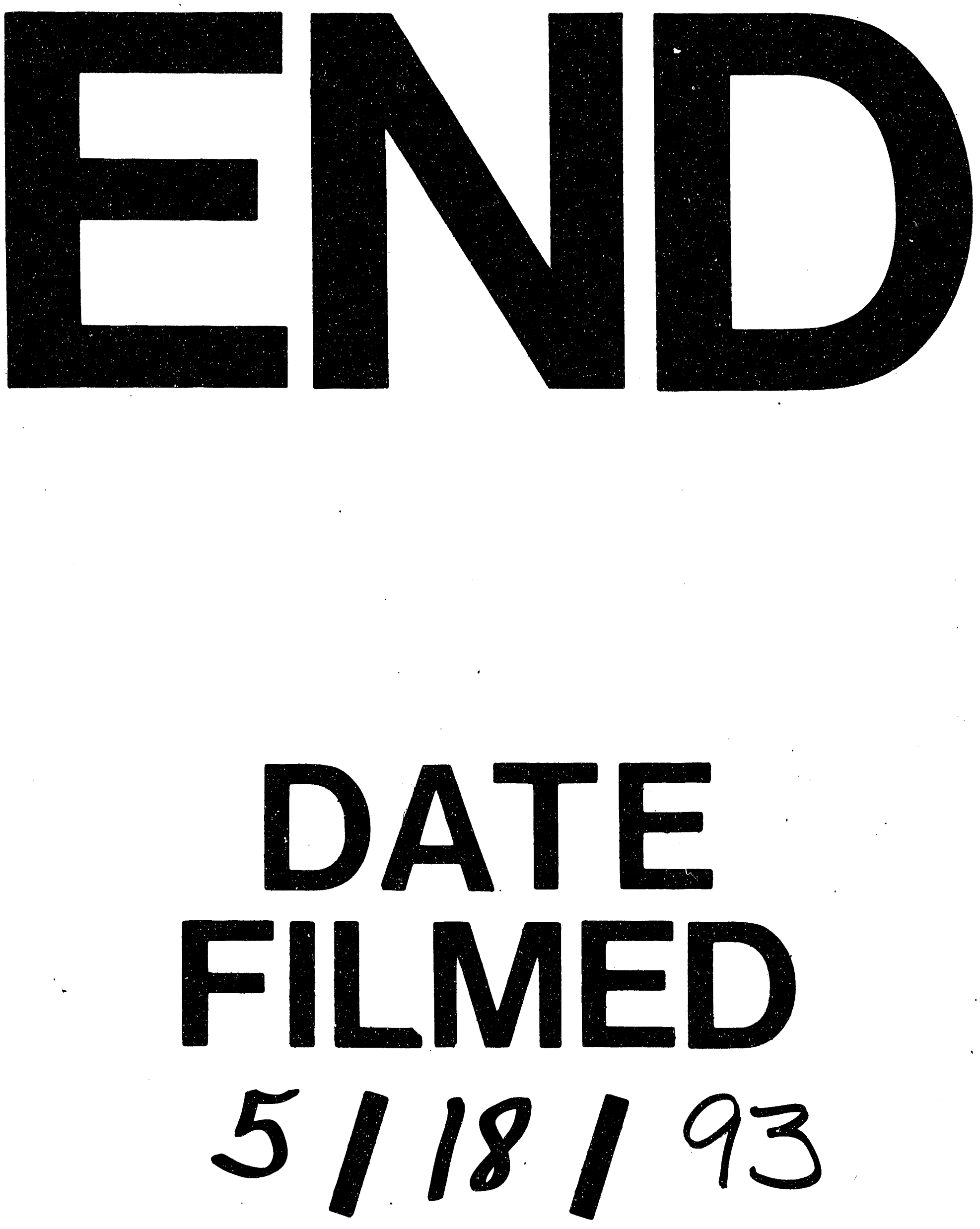

1 
